

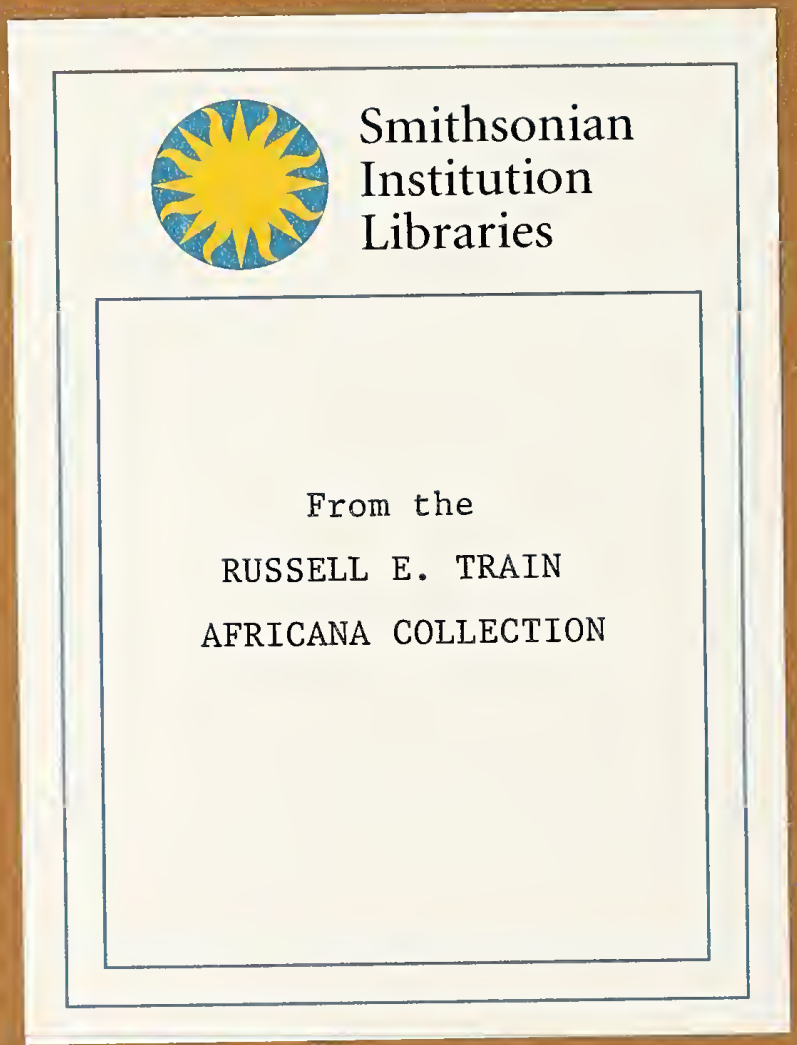




$$
\begin{aligned}
& 4 \text { volumes } \\
& \text { E225 } \\
& 189
\end{aligned}
$$

$$
1+1 e^{2} e^{8}
$$







\section{THE STORY OF AFRICA AND ITS EXPLORERS.}





\section{THE}

\section{STORY OF AFRICA \\ AND ITS EXPLORERS}

BY

ROBERT BROWN, M.A., Ph.D., F.L.S., F.R.G.S.

AUTHOR OF "THE COLNTRIES OF THE WORLD," “THE PEOPLES OF THE WORLD," "OUR EARTH AND ITS STORY"

VOL. I

THE GUinea tRaders - THE CORSAIRS OF AFRICA-THE TALE of TIMBUCTOO-THE NIGER

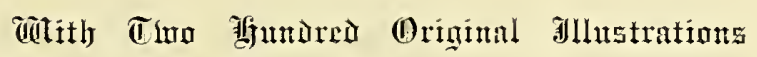

CASSELL \& COMPANY, LIMITED

LONDON, PARIS \& MELBOURNE

1892

[ALL RIGHTS RESERVED] 


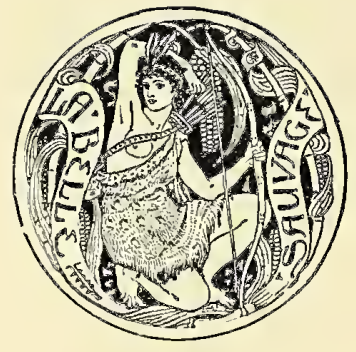




\section{CONTENTS.}

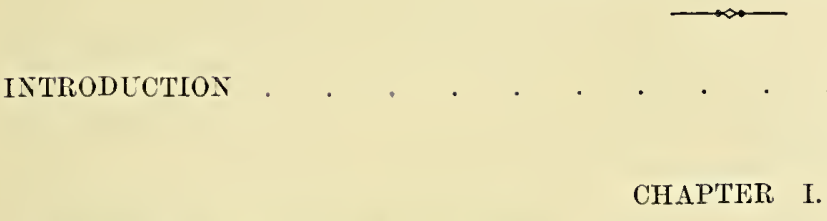

A Century of african Exploration.

CHAPTER II.

The Guinea Coast and the Old Guinea Traders . . . . . . . . . . . . 35

CHAPTER III.

Forts axd Bondmex: The Slate Trade axd the Slaje Traders . . . . . . . . 56

CHAPTER IV.

The Corsairs of Africa

CHAPTER V.

In Search of Prester John: A Paper-Chase

CHAPTER VI.

The Seekers afler Timbuctoo: Groping in the Dark

CHAPTER VII

The Travels of Axdre Brëe, Gexeral of the Royal Sexegal Compaxy

CHAPTER VIII.

The British axd the Niger: The African Associatiox .

CHAPTER IX.

The Seekers after Timbectoo: Mungo Park

CHAPTER X.

The Seekers after Timbectoo: Mujgo Park 
CHAPTER XI.

The Seekers after Thubuctoo: A Chronicle of Failures

CHAPTER XII.

ThF SeEkers After Timbuctoo: A TAle of Success

CHAPTER XIII.

The Niger Kingdoms: A Half-Told Tale

CHAPTER XIV.

The Niger Mouth: The Exp of A LoNg Story

CHAPTER XV.

The Utilisatiox of The Niger : Ax Uxisished Chapte

CHAPTER XVI.

The Last Seliers after Timbuctoo: Barth; Mordokhä̈ Abi-Serour ; Lenz . 297 


\section{LIST OF ILLUSTRATIONS.}

Speke AND Graxt at Ripon Falls, where the Nile flows out of Victoria Nyayza

Frontispiece.

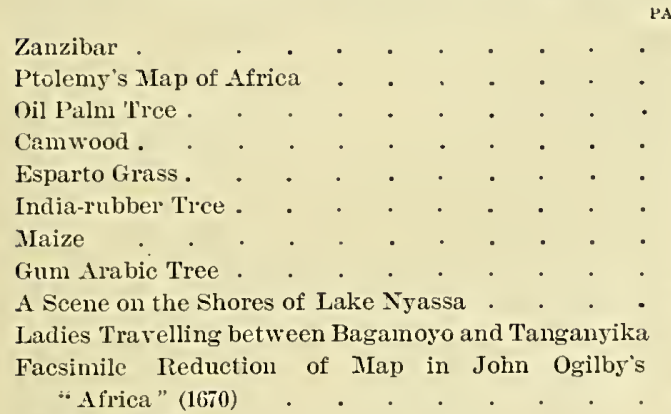

Post Runners . . . . . . . . . . 12

A Fulah, brother of the Sultan of Sokoto . . . 13

Kaffir of Damaraland . . . . . . . . 13

Native of Fernando Po $\quad$. $\quad . \quad$. $\quad . \quad$. $\quad . \quad .14$

Zulu Girl • • • • • • . . • . . 15

Zulu Chief $. \quad . \quad . \quad . \quad . \quad . \quad . \quad . \quad . \quad . \quad 15$

Native of the Lower Congo . . . . . . . 16

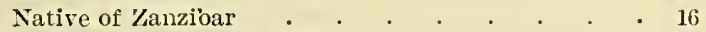

Scene on an African River . . . . . . . . 17

Storehouses and Barracks for Soldiers at Boma, on

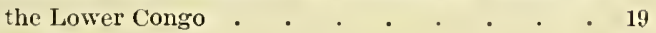

Mlungo Park . . . . . . . . . . 20

Scene at a Trading Station on the Niger . . . . 21

On the Congo, looking towards the Mouth of the River 25

Boers on the "Trek" . . . . . . . . 29

Ismail Pasha, Ex-Khedive of Egypt . . . 32

Old Hulks in the Oil Rivers . . . . . . 33

English and Dutch Forts at Accra, with a Plan of James Fort . . . . . . . . . 35

Map of Guinea . . . . . . . . $\quad$ - 36

Flat Beach on the Guinea Coast, backed by dense

Jungle . . . . . . . • • . 37

Cape Coast Castle . . . . . . . . . . 40

Lagos . . . . . . . . . . 41

Dixcove . . . . . . . . . . . 44

St. George del Mina . . . . . . . . 45

English and Dutch Forts at Kommendah . . . 45

Secondee Town . . . . . . . . . 48

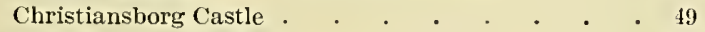

Elephant Guinea . . . . . . . . . 50

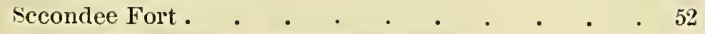

Houssa Policemen in the British Service . . . 53

Africa in 1759 . . . . . . . . . 57

Slave Barracoon . . . . . . . . . 60

Bartering for Slaves at a Fort on the Guinea Coast . 61

Capture of Christiansborg Castle by the Negroes in

Baobab, or Monkey-bread Tree . . . . . . 61

Cocoa-nut Palm . . . . . . . . . . 64

Implements in use by Slave-traders . . . . . 65

Arab Slave Raid . . . . . . to fuce page 67

Sir Thomas Fowell Buxton . . . . . . . 68

Slaver enticing Natives on Board . . . . . 69

Crest of Sir John Hawkins _ . . . . . . 71

Slaves ou the March . . . . . . . . . 72

Slaves left to Die . . . . . . . . . . 73

William Wilberforce . . . . . . . . 74

The Old French Fort at Whydah . . . . . 75

Slaver chased by Man-o'-War . . . . . . 76

Slave Market in West Africa . . . . . . 77

The Price of a Slave . . . . . . . . 78

Captain Edward England . . . . . . . . 81

Captain George Lowther . . . . . . . . 83

Death of Captain Davis at Princess Island . . . ! 85

Captain Bartholomew Roberts . . . . . . 87

Diseovery of the Madagascar Pirate Colony by Captain Woods Rogers

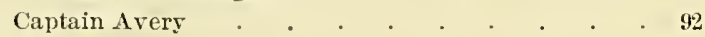

Marooned . . . . . . . . . . 93

Walking the Plank . . . . . to face puge 93

Sir Henry Morgan. . . . . . . . . . 95

'loumba, near the Isles de Los, with Pirate Craft in

the Offing . . . . . . . . . . . 97

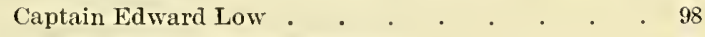

Captain Teach, alias Blackbeard . . . . . $\quad .99$

Pirate Vessel . . . . . . . . . . . 100

Merchant Ship under Convoy . . . . . . 100

Cape Spartel and Lighthouse, Moroceo . . . . 101

Tetuan, in Moroceo, and the Mountains to the South . 101

Sallee-Rabat . . . . . . . . . . 105

"Kareebs" attacking a Merchantman . . . . 105

Scene on the Niger, at Say . . . . . . . 108

Mangrove Thicket . . . . . . . . 109

Map of the River Niger . . . . . . . 112

Death of the Joloff Prince . . . . . . . 113

Portion of Fra Mauro's Map of Abyssinia . . . 116

Plantain Plantation . . . . . . . . 117

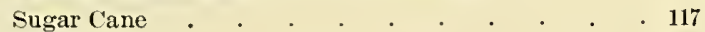

Yam . . . . . . . . . . . . 120

Timbuctoo . . . . . . . . . . . 121

Kabara, the Port of Timbuctoo . . . . . . . 121

Thompson Leaving his Vessel . . . . . . 125

Jobson's Boat Aground in the Gambia . to face page 126

"Monkeys swung themselves from the branches" . 128

Bananas . . . . . . . . . . 129

Kola Nuts. . . . . . . . . . . . . 129 
PAGE

Captain Jobson and the Pseudo-Demon . . . . 132

British Trading Post at Cape Juby : The Castle . . 133

Traders at Cape Juby-Castle and Faetory in the distanee . . . . . . . . . 133

Captain Lambert Bartering with the Natives near

Animals resorting to Lake Cayor to Drink . . . . 13

End of the Combat between the "Kamalingo" and the Lion . . . . . . . . . . 139

Goree . . . . . . . . . 140

Fort St. Louis . . . . . . . . . . 141

Native Mode of Seeuring Proteetion from Mosquitoes 144

Method of Seeuring Elephants Employed by the Natives before Brüe's Time . . . . . . 145

Ant Hill • • • • • . . . • • . 148

Removal of the Siratik's Court: The Advanee Guard

Fulah Girl

St. Mary's, Bathurst . . . . . . . . 156

Felou Falls, Upper Senegal . . . . . . . 157

Mountains in Bambuk . . . . . . . . 159

Bambarra Type . . . . . . . . . 160

Plan of James Island, in the Gambia, 1732 • . . 164

Job, Son of Solomon, Surprised by a Party of Mandingoes . . . . . to face page

Wandering Fulah . . . . . . . . . 165

General Oglethorpe . . . . . . . . 168

The King of Barsalli's Pastime . . . . . . 169

Freetown, Sierra Leone . . . . . • . 172

Sir Joseph Banks . . . . . . . . . 173

Gum Aeaeia . • . • • • . . . . 176

Mungo Park and the Afriean King . . . . . 180

Mungo Park sets out from Pisania . . . . . . 181

Medina, Cápital of Wuli . . . . . . . 184

Park Blaekmailed . . . . . . . . . 185

Fetish Tree, with Palisade to guard it ${ }^{\circ}$. . . . 188

The Returned Blaeksmith . . . . . . . 189

The West Afriean Coffee Plant . . . . . . . I91

Moorish Douar, or Eneampment . • • • 192

Seene at Dina: Park insulted by the Moors to face page 193

Map of Mungo 1'ark's Routes . . . . . . 193

Household Utensils from the West Coast of Afriea . 196

Park Lost in the Desert . . . . . . . 197

Young Girls of Bambarra . . . . . . . 200

Cowry Shells. . . . . 201

The Palaee, Sego . . . . . . . . . 204

Sego Women Entertaining Park . . . . 205

Bambarra Types . . . . . . . . 207

Timbuetoo: Distant View . . . . . . . 208

Niger River (Lokoja) Chief's Canoe . . . . . . 209

Mungo Park's Last Stand . . . . . . . 213

"The Borderers sang . . . as they gaily rode to their graves" . . . . . . . . 216

Bambarra Interior . . . . . . . . 217

Senegambian Thicket . . . . . . . . 220

Sheet of Logarithms by Mungo Park . . . . 221
Fulahs of Sokoto $\quad$ PAGE

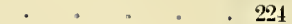

Tosque Sehool in Torth

Map of Caillie's Route . . . . . . . . 231

Sand Storm in the Sahara . . . . . . . 232

Niger River Ferry-Boat . . . . . . . 233

Toueouleurs of Senegal . . . . . . . . 236

Lake Tehad . . . . . . . . . . 237

The Town of Tripoli, in Barbary . . . . . 239

The Clapperton Expedition at Murzuk . . . . 241

Ruins at Bonjeem . . . . . . . . 243

Murzuk, in Fezzan . . . . . . . . 24

The Natron Lakes in the Ghat Country . . . . 245

Larva of the Arthemia oudneii . . . . . 247

Mail-elad Warrior from Bornu . . . . . . 248

Captain Clapperton . . . . . . . . . 249

MLajor Dixon Denham . . . . • • . . 249

Eseape of Denham from the "Kerdies" to face page 252

Ruins of Birni, or Ghasr-eggomo, the Aneient Capital of the Bornu Empire . . . . . . $\quad$. 252

Map of Oudney, Denham, and Clapperton's Routes . 253 Grass-roofed Sleeping Sheds in Mamu Forest, Yoruba, West Afriea . . . . . . . . . 256

Riehard Lander . . . . . . • . . 257

Nohammedan Sehool, Yoruba . . . . . . 260

View of Ese Ado, Yoruba . . . . . . . 261

Lander under Trial by Ordeal . . . to fuce page 262

Tanghinia Nut . . . . . . . . 263

Kano. . . . . . . . . . . . 264

The River Niger' at the Foot of the Bussa Rapids, near Rabba: "Dr. Baikie's Seat" in the distance . . 265

Map of the Landers' Route . . . , . . . 267

"They notieed some fifty large eanoes" . . . . 269

River-side Seene at Asaba, Lower Niger . . . 272

Rabba . . . . . . . . . . . 273

In the Market Place, Rabba . . . . . . 273

Calabar Bean . . . . . . . . . . 275

Snake Charmer of the Lower Congo . . . . 276

Reeeption by the King of Iddah . . . . . 277

Confluenee of the Niger and Benué Irivers . . . 280

Trading Faetory and Town of Iddah, Lower Niger' . 281

Mohammedans of the Middle Niger . . . . . 285

Guré, the Capital of Muniyo . . • . . . 288

Henry Barth . . . . . . . . . 292

Native Mode of Crossing a River by means of Calabashes . . . . . . . . . . 293

"Begged the blessing of the Syrian Pilgrim" to face page 295

Map of Dr. Barth's Route . . . . . . . 295

Top of the Main Street of Tangier, Moroeeo . . . 297

Barth met by a Crowd near Timbuetoo . . . . 301

Mordolkhaï Abi-Serour . . . . . . . 304

The Komadugu at Zengiri . . . . . . . 305

Distant View of the City of Moroeeo (Merakish), the Atlas Mountains in the distanee. . . . 308

Oskar Lenz . . . . . . . . . . 309

A Letter of Safe Conduet granted by the Sultan of Ioroeeo . . . . . . . . 309 


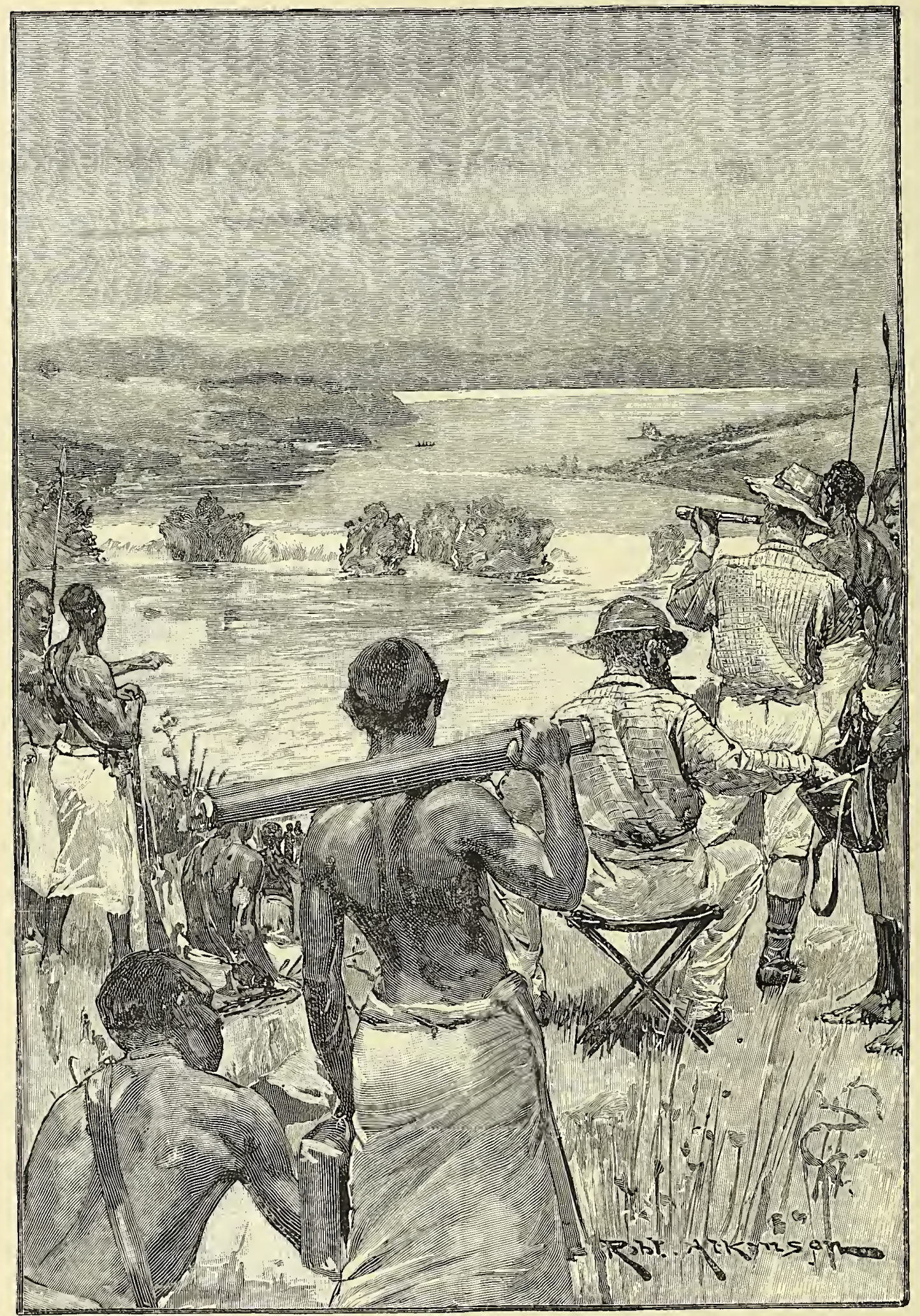

SPEKE AND GRANT AT RIPON FALLS, WHERE THE NILE FLOWS OUT OF VICTORIA NYANZA. 


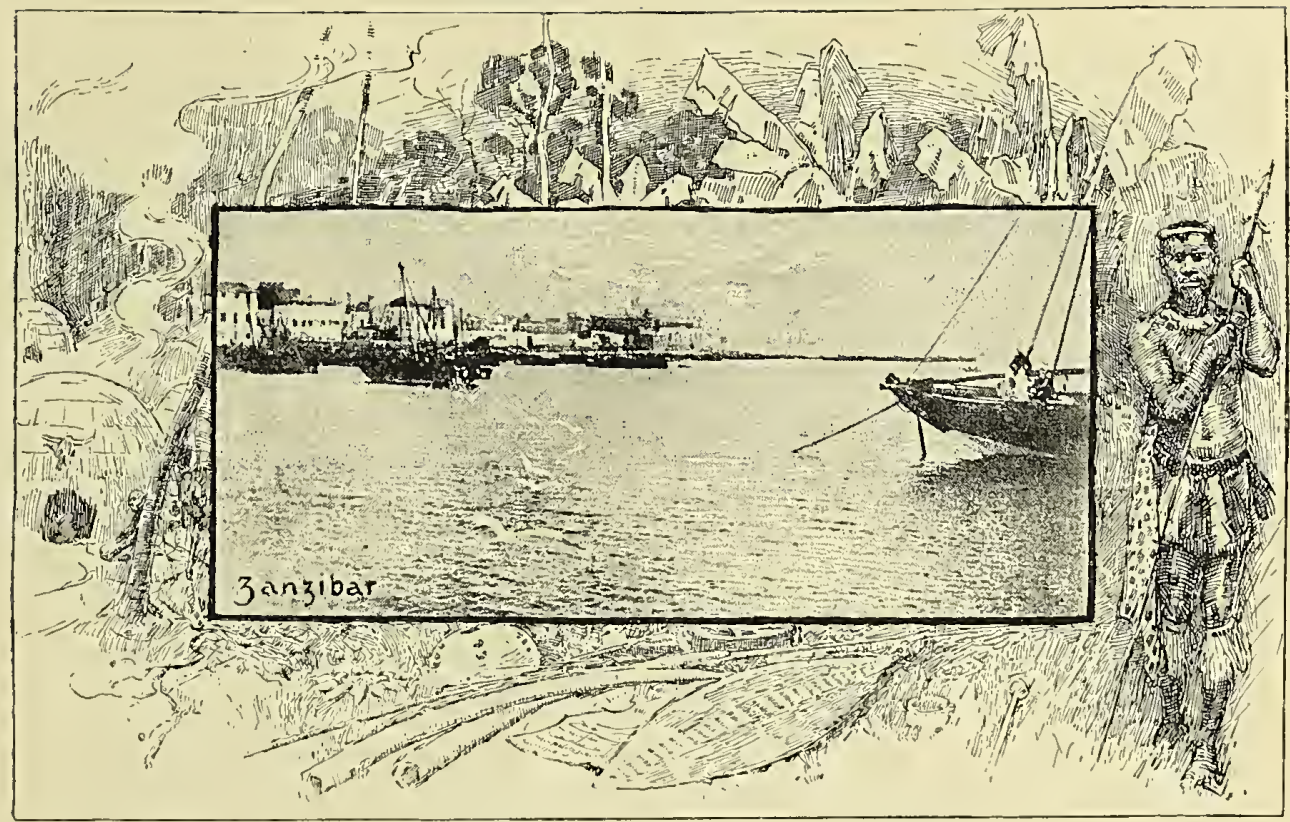

\section{THE STORY OF AFRICA.}

\section{INTRODUCTION.}

"A foutra for the world, and worldlings base:

I speak of Africa, and golden joys."

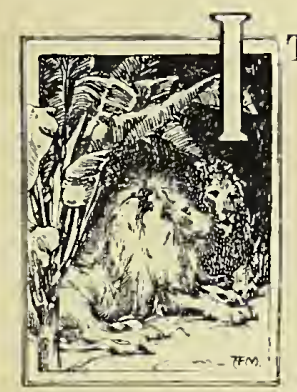

T was little that Ancient Pistol knew of the land which forms the theme of our pages. But in putting these words into his mouth, Shakespeare doubtless expressed the estimate of its riches entertained in the taverns of Eastcheap and the guard-rooms of Tower Hill. To the wassailers of thesc haunts it was emphatically a world of "golden joys." For was not this the Land of Prester John and the King of 'Tombuto, and were not the Portugals rich in the slaves and ivory and precious dust which the caravels had brought from Sicria Lcone and Senegal, and Arguin, and El Mina, and the great Congo of Diego Cain, and had not Her Grace granted the Company of Exeter merchants patents to trade to Barbary, and to Guinea, "between Sanaga and Gambra"?

Three centuries hare passed away since then, and Africa is again a name associatcd with dreams of wealth. Once more the sands of its "sunny fountains" are being searched for those yellow grains which aroused the avarice of the africa from early adventurers, and its arid uplands for the diamonds which were undreant many of in the days of Royal Hal. And better even than gold and gems, far view. bettcr than ivory of any hue, the soil is now known to be capable of growing crops 
the ultimate value of which will far outweigh the six tons of glittering pebbles which it has yielded within the last twenty years. But if we have returned, as the nineteenth eentury is closing, to much the samc opinion of Africa as the sixteenth cherished, the intervening years have witnessed a wide contrariety of belief as to its present value and its future worth. Inordinate hopes, bred of imperfect knowledge, have alternated with pessimism equally undeserved. The "golden joys" of Falstaft's lieutenant have bcen damped by the avowed opinion of one of its greatest explorers, that in all his journeys through its most fertile kingdoms he never saw anything exeept slaves and ivory which would sell for tempence a pound. Yet hundredweights of undoubted gold pass out of it every year. Ship-loarls of ivory and india-rubber, copal and gum arabie, ostrieh feathers and ebony, palm-oil and camwood, almonds and esparto grass (pp. 4, 5), wool and hides, wine and honey, leave its shores every month. Its northern area is now, with the exception of Morocco, almost entirely under European control. Its castern and westcrn eoasts have been pareelled out among the Great Powers, and the "Hinterlands," or back countries, with their kings and peoples in most eases all uneonscious of the honour foreed upon them, have eome under the "Spheres of Influence" aceorded to the sovereign companies who are the suffragan lords of these portions of the eontinent. As for South Africa, it is either a British Colony, or the seat of Dutch Republies, destined, in the fulness of time, to be part of a dominion under British protection. Nevertheless, in Cape Town and Zanzibar, in Berlin and Brussels and the City of London, there are men to whom Afriean mines and the possibility of dividends from African stoeks are a sore subject. The cheerful "Scmper novi quid ex Africa" of the Roman Proeonsul has becn succecded by the yawning complaints of blase folk that Africa is exhausted, that one black man is very like another black man, the new traveller's tale monotonously akin to the tales of all the traveller's who have preceded him, until an Emin fever or a Stanley"boom" proelaims the contrary.

At this moment Africa is the one quarter of the world whieh has not been made too mueh of for new-comers to make a little more. Asia is occupied. America is for the Americans. Europe is overflowing. Even Australia, in spite of the spaee it oeeupies upon the map, has little land fit for eultivation whieh is not already owned. But Afriea has still room for those who can develop her mines, and till her The revival soil, and hew down her forests, and it may be-though of this, warned by
of Africa. the fate of all other "provisional raees," it is as well not to be sanguineteaeh her savage millions the arts of peace. Then the "Expiring Continent" may revive, the "Dark Continent" reeeive light, the "Hopeless Continent" bceome the hope of philanthropy, and the "Last of the Continents," to use another of the many names applied to it, progress so far as to take a place worthy of the "Hinterland" of what was, once upon a time, not only the oldest, but the greatest of all the eivilisations.

For sunk though most of Afriea has always been in the grossest of barbarism, its northern shores, from a period beyond whieh the chroniele of man rumneth not, have bcen the seat of an aneient eulture. There is scareely a foot-breadth of Egypt, or of the Barbary States, without memorials of this bygone eivilisation, the rery memory of whieh has beeome a myth among the race who rumed it. From "Where Nile refleets 
the endless length of dark red colonnades," to "where Atlas swings his shadow far o'er the western foam," we stumble upon the carven stones and the lettererl tablets which bear witness to a vanished xace. High up the Nile valley we are seldom out of sight of the gigantic monuments of a people who were so far advanced in culture that, though their civilisation might not be as lofty as that of Greece and Rome, it was in many respects even more elaborate. In Tunisia-the Africa Propria of the Old World's masters-in Algeria, in Tripoli, in Morocco even, evidences are ever before us of the deathless race who are
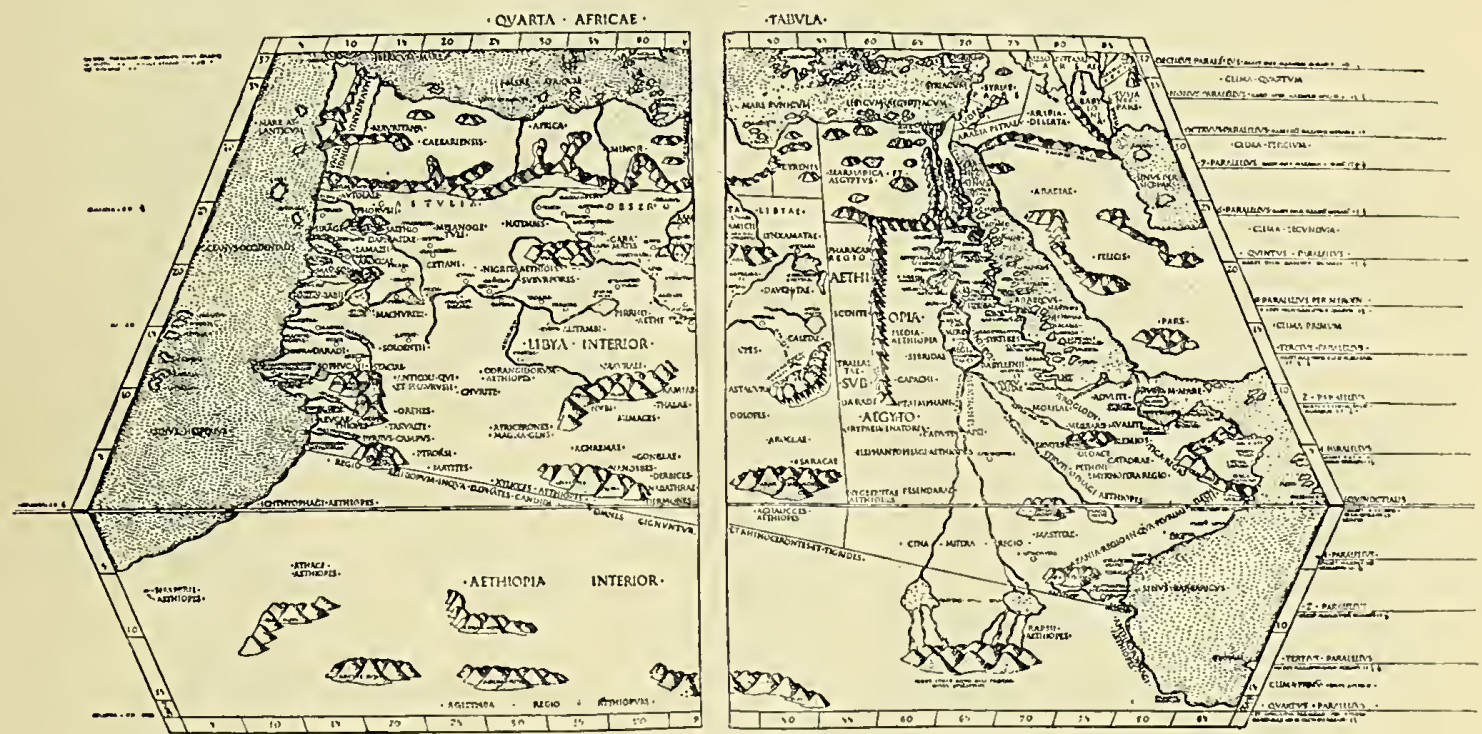

PTOLEMAUS ROME 1490

PTOLEMY'S MAP OF AFRICA.

still rememberer as the "Rumi"-or Romans. A few cisterns in which a village of wretched Arabs stable their flocks-or themselves-are about all that remain of the famous capital of Carthage. But broken arches, civilisation ruined amphitheatres, gateways worthy of the Eternal City itself, temples as well as reared to forgotten gods, tombs erected to wealthy citizens, are met with in in the any day's journey. In spots where now even the rude nomarls can find no world. subsistence for their scanty flocks, the remains of elaborate aqueducts show that less than two thousand years ago, before the Moslem fanatics poured in from Asia to destroy what they could not maintain, the region was well watered and fertile.

Africa is thus at once a continent of the newest and the most ancient civilisation. For thousands of years * before the Christian era Menes ruled over a united State and founded the city of Memphis. At that period the Assyrian Empire had not arisen. Chinese history does not even pretend to date as far back. The progenitors of the

* Two thousand three hundred and twenty, according to Gardner Wilkinson; 3892, by the calculations of Lepsius; 5004, after the computation of Mariette-Bey; 4455 , if the chronology of Brugsch-Pasha is accepted. 
Indian Aryans had not crossed the Himalayas; the ancestors of the European stoeks had not burst into the regions from which they ousted the Cave Men. Lastly, it goes

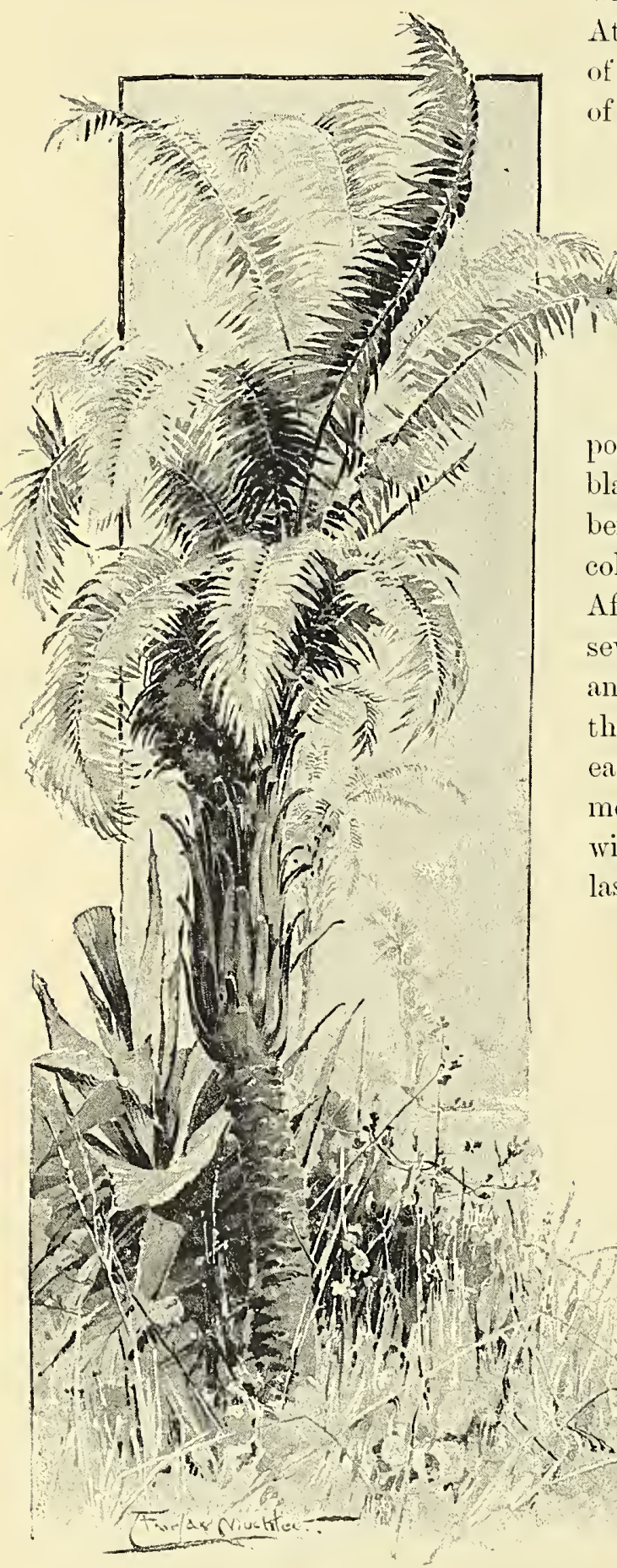

OIL PALM TREE (Elwis guineensis).

without saying that Rome was not built or Athens founded, and that the earliest chronicles of England are of yesterday compared with those of eivilised Africa.

\section{The Re-opening of Africa.}

But if Africa ean boast of the oldest of eultures, its place in the history of modern eivilisation is also If the newest. With the exception of the extreme north, it is scarcely possible to date the first attempt to reliere its blackness by the presence of white men much before the fifteenth century. But anything like colonisation, the re-settlement of Europeans in Africa as their home, did not begin until the seventeenth eentury was well adraneed, The great and systematie exploration was not explorathe lot of the continent at a period Africa all earlier than what the memory of living modern. men can reach. All the great explorations come within this century-most of them within the last thirty or forty years, while the "seramble" to 


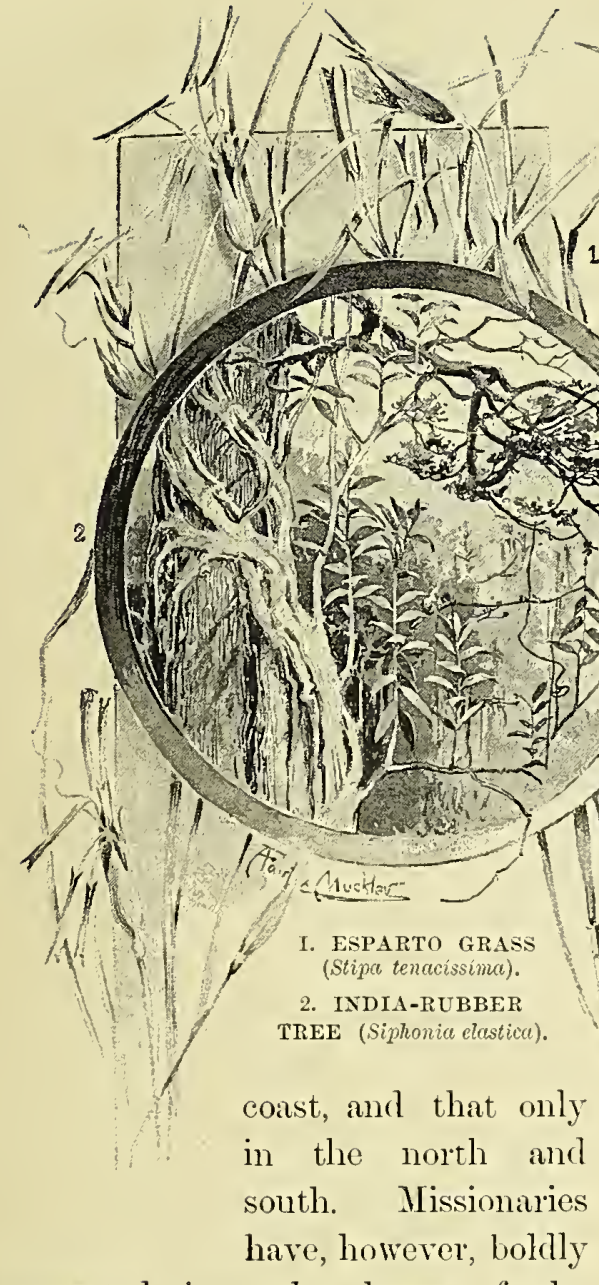

penctrated into the heart of the country, and traders are following.

But as yet all is tentative. Negro Liberia is unprogressive, and the Italian "Eritrca" an experiment. Even the Congo State, which has pushed its river-side posts half way across the continent, and the chartered commercial companies, which have extended their operations in other directions, have still to stand the test of time. The country has been divided, the boundaries are being laid down, and with railways in course of construction where a ycar or two ago there was not even a streak on the map, it may seem to sanguine men that "all is over except the shouting." But with the memory of the many native wars of South which we owe its division among a few Powers, and its systematic development by huge commercial companies, are events of our own day.

Inch has been done within that, brief span. But much more still remains to be accomplished. Ninetenths of Africa is undiluted savagedom, or barbarism so unqualificd that it is difficult to assign it to a higher gradc. The European settlements extend only a little way from the 
Africa before us, it is to be feared that there is a long interlude of a similar character before the new colonies, and territories, and "Spheres of Influence" can be considered as anything better than paper kingdoms.

Here then we have to explain the puzzle of a vast continent within sight of Europe, skirting in part the sea around which concentrated all the enterprise of the Old Workd, remaining unexplored until recent times. It was known, and

Why Africa so long left to itself.

even circumnavigated, before America was discovered, or a Briton had obtained a footing on Indian soil. It possessed European trading posts on its most pestilential shore before there were any European colonies outside the New. World. Yet it has remained ahnost to the end of the nineteenth century without attracting more than a fraction of that vast immigration which has poured into America and the distant dependencies of Great Britain. Finally, the last of all the European Power's to turn again to the Black Continent are the Italians, though they are the heirs of the enterprising race who, twenty-two centuries ago, had provinces in Africa which for eight hundred years were as prosperous as any colonies of modern times.

These anomalies seem so remarkable, that before tracing the evolution of Africa as a field for European enterprise, it may be useful to explain the cause of this neglect, more especially as it will enable us to sketch some of the more salient peculiarities of the continent which we and the reader may have to traverse in company.

Until recently, Africa was a land of legends, a continent in which certain geographical convictions were taken for granted, without anyone taking the trouble to test the iruth or the falsity of what had been transmitted to us by the

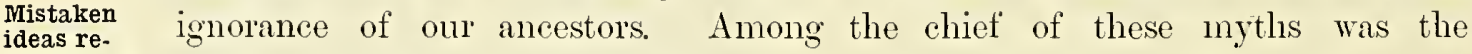
garding its widely accepted belief that the entire interior south of the Atlas was a
geography. sandy desert, with here and there an oasis or a fertile plain, or a range of mountains, yielding a little verdure, or a lake from which arose the rivers which crept into the sea through those miasmatic flats which the coaster knew too well. Yet in reality the Sahara extends for a comparatively short way into the centre of the continent, and, as the French have shown, is over a large extent of its surface perfectly reclaimable by sinking Artesian wells. Another conviction-and it is, perhaps, the least consistent of them all-was that on these "uninhabitable downs," where the geographer of Swift's day placed "elephants for want of towns," there were sultans, and kings, and kaisers rolling in riches, and cities so gorgeous that their gilded domes, studded with gems, form characteristic features of old African maps, the many open spaces in which afforded ample room for the indulgence of the chartographer's imagination (p. 9). All this is now very ancient history, in spite of old impressions dying hard. There are steamers on the river down which Stanley canoed in 1877, and Europeans of all sorts at the court of the savage king whom Speke and Grant first introduced to the outer world just thirty years ago. Post runner's and ladies in sedan-ehairs travel in perfect safety over the route between Bagamoyo and Tanganyika, which Burton first saw in 1858; railways are being surveyed between 
the east coast and the great lakes, and one is actually being built from the Portuguese colonies on the western shore; and a recent traveller tells us of a "pinkfaced baby" in the British perambulator whom he encountered on the shores of Lake Nyassa, which was not on the map of East Africa when the father of that child and the writer of these lines were "boys together" (pp. 7, 8, 12).

But even yet, as someone has remarked, few Europeans, except those who have devoted a modicum of attention to it, think of inner Africa except as a vast sandy desert, with a floating population, consisting chiefly of hungry lions, and robbers more ferocious still, the latter being in the habit of "careering orer the waste" on swift

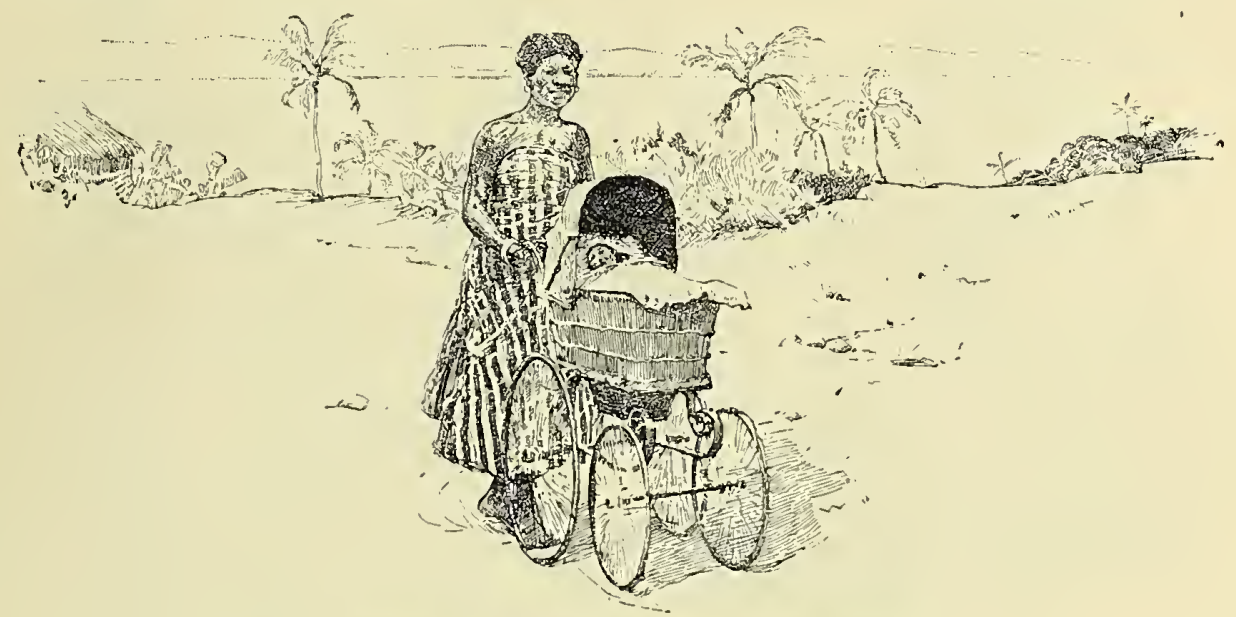

A SCENE ON THE SHORES OF LAKE MYASSA.

horses, without any obvious cause for their hurry, living comfortably when there is nothing to eat, and amassing stores of ill-gotten wealth when there is no one to rob.

\section{The Probleiss of Africa.}

Much, indeed, must be left to the depth of that inner consciousness out of which so many theories have been evolved. For once ontside the lands of ancient civilisation -and Northern Africa, physically and historically, has far more intimate relations with Europe than with the continent behind it - there is nothing on which to base any conchusions regarding its peopling and its unwitten chronicles. Nowhere in the interior is there an inscription or a house of stone, or any monument more permanent than a hut of reeds or of mud. Yet fowls and cattle are among the wealth of nearly every tribe, and their traditions afford no clue as to the period Fowis, when animals not natives of the country, or, in the case of fowls, even of cattle inthe the continent, first reached it, or by what agency. Not less extraordinary is the fact that all through Central Africa we find the rudest of the tribesmen cultivating maize, and making from it a muddy beer, with which they fuddle themselves all day long; and in this case also no legend exists regarding the beneficent race or the God-like stranger who brought to them a plant which is assuredly not a native 
of the regions enjoying its use. Maize, indeed, is by many botanists-among others by De Candolle-regarded as originally an American plant. It is the Indians' corn, so that, assuming this to be true, it must of course have reached Africa, like the rest of the Old World, after the discovery of its native continent. But even admitting, as there are good grounds for believing, that this grain was cultivated in Asia and in Africa before Columbus made it generally known in Europe-though the Arabs are

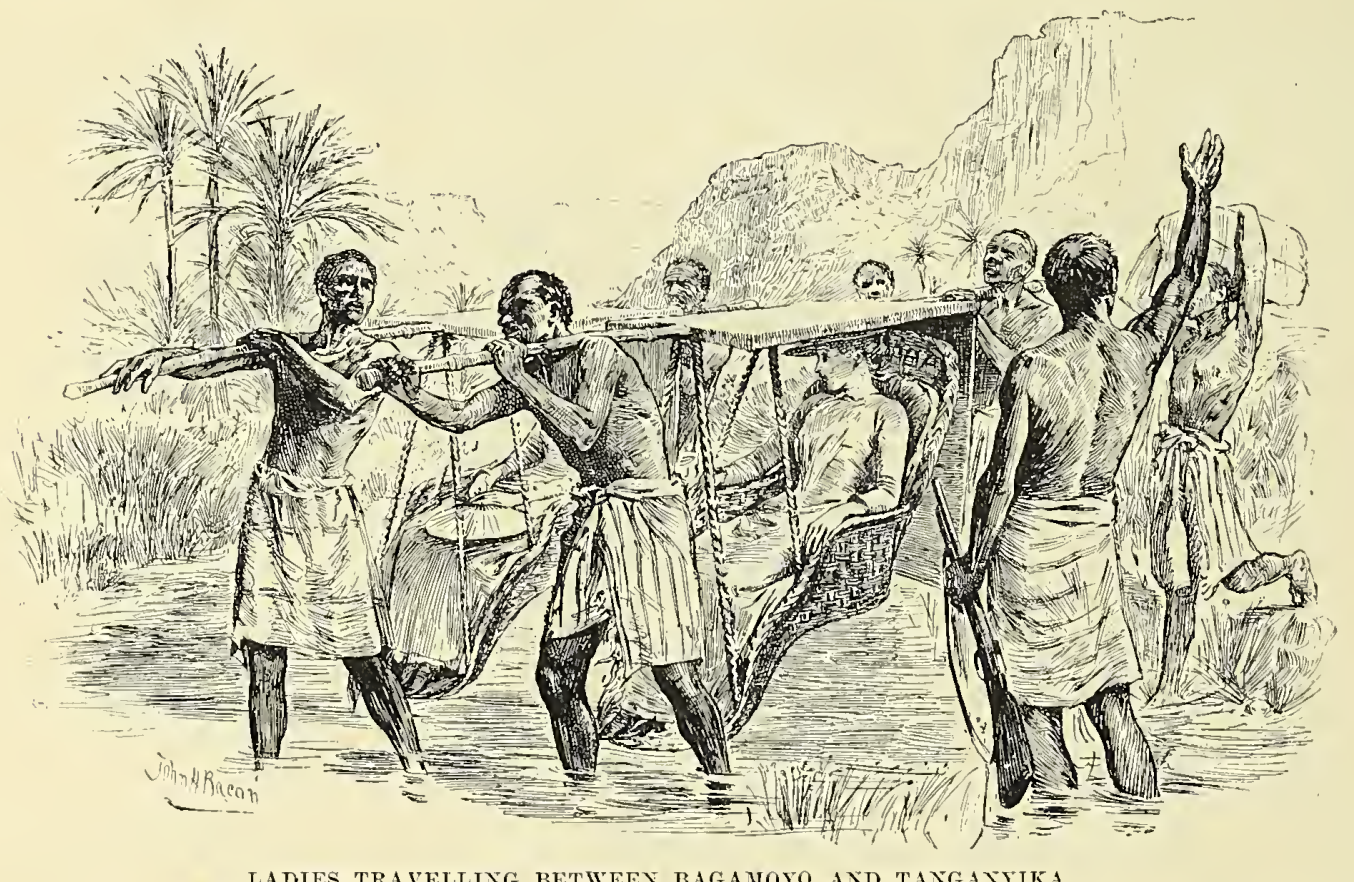

said to have brought it to Spain-it is not argued that the plant was grown out of Egypt.

Yet in Central Africa the plant was quite common before the first white men or Arabs were seen. Hence we are justified in concluding that, like fowls and cattle, it passed from coast tribe to coast tribe until it spread over the interior, or that the early civilisation of Northern Africa must have reacted on the barbarous "hinterland." It would be difficult to believe that it did not. Both Rome and Carthage had a far-reaching trade with the Black Barbarians, and we gather from Herodotus that some of his informants had an acquaintance at first-hand with raoes Ancient in-
tercourse and places the existence of which it has been left for modern explorers to with the confirm. But it must be repeated that nowhere in Inner Africa, that is, at
interior.

any distance from the coast, have Europeans left any trace of their presence which cannot, with two possible exceptions, be legitimately accounted for. These exceptions are the mysterious stone houses of Mashonaland, which were for long believed to be the work of the Portuguese, but are now known, from a narrative by Barbosa (cousin of Magellan) to have been antiquities when the Portuguese first saw 


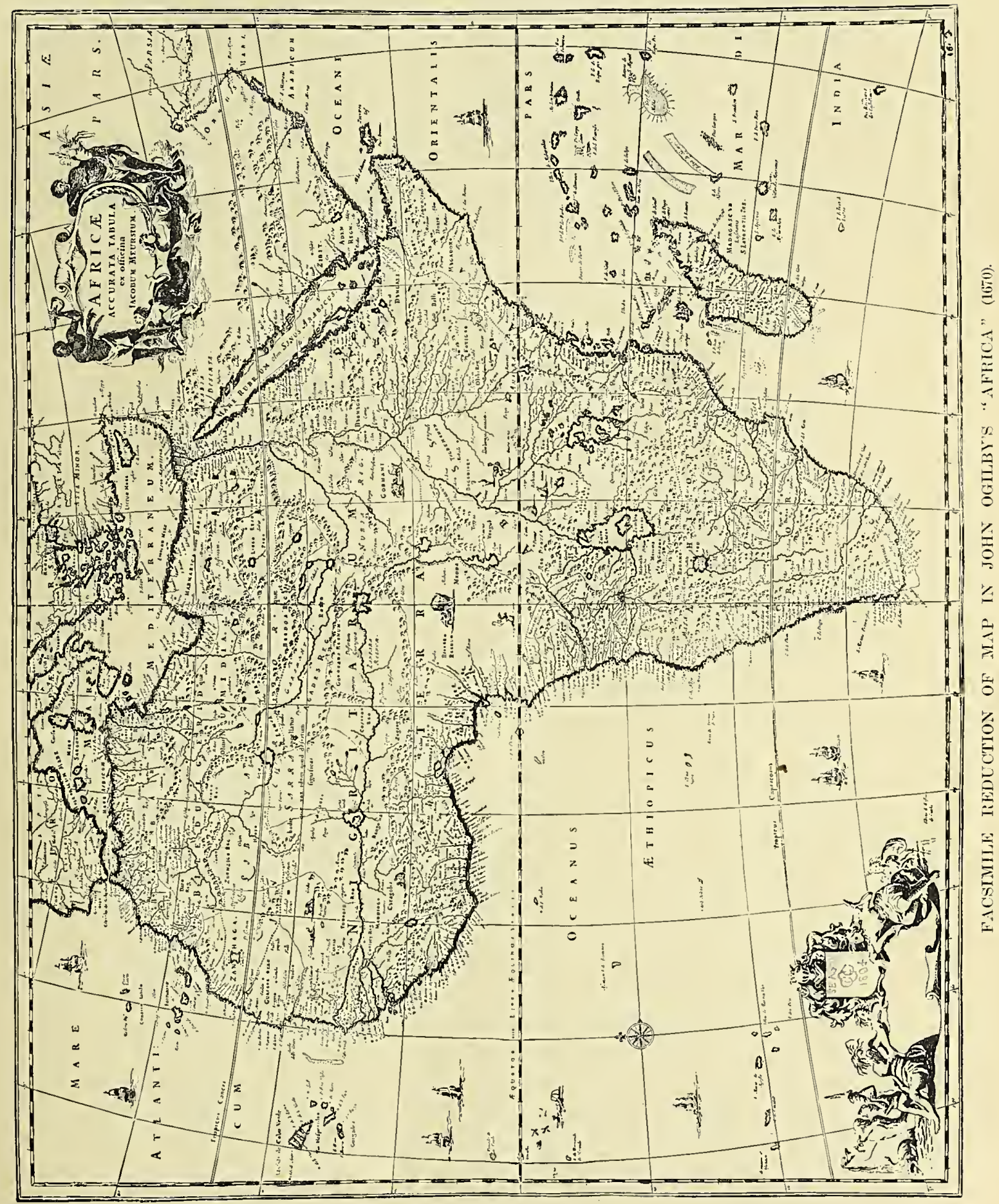


them in the early year's of the sixteenth century. By some they are thought to be Phønician, by others Persian, by a third set of theorists Moorish and by a fourth to have been erected by the early miners from whom Solomon got his supplies of gold. In other words, this region was the Ophir of the Israelitish King, which has been sought in South Arabia, in India, in Sumatra, in the West Indies, and even in Peru. One thing is certain, the buildings were evidently erected for mining purposes, and, as the country is rich in gold and other minerals, and abounds in the traces of exhausted diggings, they were likely enough the work of the same early adventurers who erected the ruined buildings near Zanzibar, which are of strictly Persian type.

But civilisation seldom takes a land journey when it can penetrate a dark land by a water-way. It is therefore scarcely possible that the lower valley of the Nile could for thousands of years have been occupied by highly civilised races, without some pioneers of these enterprising peoples pushing up the great river to the huge lakes in which its principal branches take their origin, though it is only within the last two or three decades that the regions around the Tictoria and Albert Nyanza have been reached by that natural route. Recent discoveries have, however, rendercd it probable that there existed intercourse in very ancient times between the lake districts, especially Uganda, and the civilisation of ancient Egypt. As we shall see by-and-by, though the facts in no way detract from the merits of Burton, Speke, Grant, Livingstone, Baker, and Stanley, the African lakes were known not only to the Portuguese of the sixteenth century, but to Ptolemy, the Alexandrian geographer, and even to Aristotle (pp. 3, 9).* For does not the Stagirite tell us, in a sober, matter-of-fact way, as if he was relating a piece of lnnowledge familiar "to every schoolboy" in Macedon, that "the cranes migrate as far as the lakes beyond Egypt where the Nile has its source. There dwell the pygmies: and this is no fable, but the simple truth. Both men and horses, so says report, are of small size, and live in caves;" and much the same information-which is now known to be strictly true-is vouchsafed by Eratosthenes, who lived about two hundred years before the Christian era. They also in those early days talked of those Mountains of the Moon, which Mr. Stanley thought might be the white-topped Ruwenzori, and which Dr. Peters is as positive are the Unjamwesi (as was Dr. Beke forty years before him), but which were probably founded on a vague acquaintance with Kilimanjaro, Kenia, and the other snow-capped mountains of Easterin and Central Africa. But the most curious of all the indications of the early intercourse with Central Africa by way of the Nile is that the ancient name for that river is at its source Nyiro, or Nyilo, or the same as its mouth, a name which it bore at the dawn of history. Again, Egypt and at Elgon in El Gumi Thomson discovered huge rock-cut cares, many so the Great large that they contained whole villages and herds of cattle, thus confirming
Lakes.

Aristotle, though the pygmies whom he described as inhabiting them have now been driven into the dense forests, where in time we shall ineet them. The natives

* This has been denied by Mr. Ravenstein, who thinks that the lakes on the early maps were simply those of Abyssinia, and that the great ones-Tanganyika, Victoria, Albert, and Albert Edward- ${ }^{\text {" }}$ only became known in the course of the present century, since caravans of Arabs and Swaheli penetrated the interior in search of slares and ivory," though the explorers of a later date delineated them.-Scottish Geographical Magazine, 1891, p. 310. 
affirm that these caverns were never excavated by them: "they were the work of God," and the Gods who dug them, the discoverer thinks, were in all likelihood ancient Egyptians in search of precious stones or precious metals, for which, likely enough, they will be again ransacked by the British prospector.

These are some of the African problems which still remain to be solved. There was a time when all Africa was a problem, the whole continent a region so unknown that speculation had free warren within its blank area. Imagination could rum riot in theories regarding the Fountains of the Nile and the Mountains of the Moon, as to the source and course of the Niger and the Congo and the Zambesi-all of which have, for the most part in our own day, ceased to be any longer mysteries. Geographically, there are hardly any others of prime importance.

But, ethnographically, Africa is still, and is likely always to be, one rast scientific puzzle. An Afican is in popular notions a black man-a Negro, to be more precise. Yet, though swarthiness is to a large extent the characteristic of all its races, the Negro proper-the man of the Oil Rivers-with his retreating The ethnoforehead, kinky locks, and a nose so flat that it looks as if it had been rum Africa. on the face in a liquid condition, is actually the type least frequent. Within the shores of Africa-11,277,364 square miles, exclusive of Madagascar-there are more than 600 languages and dialects spoken, and, of the $164,000,000$ people estimated to speak these tongues, it is easy to distinguish a number of families, many of them, though evidently mixed, of entirely different origin. In the dense forests and other byways of the country we find a pyginy race, which may be regarded as the aborigines driven thither by more powerful invaders; and in South Africa we come upon the decaying race of the Bushmen, whose diminutive size might stamp them as relations of the Wambatti, Batwas, Obongos, Akkas, and other diminutive Negrittos of the north. Tet they speak not one word of a language common to both; and the Bushmen, instead of being black, are in reality a reddish-brownskinned people; and in much the same region of South Africa are found the Hottentots, a tufty-haired but yellowish-hued people. Nevertheless, the Bushmen and they are really branches of one race, speaking dialects of the same language, though dialects so widely different as to be mutually unintelligible, the difference being due to the humbler race being outcasts at an early period, while the other enjoyed a comparatively easy life; and to this day there are true Hottentot septs, though few exist unmixed, who owing to the miserable condition of their existence, are barely distinguishable from Bushmen.

This leads us to ask-and at once the racial problem is thereby rendered more complicated-whether the so-called aboriginal dwarfs of the north are not degraded outcasts of other tribes, a query rendered more urgent by the fact that the languages they speak are generally those of the tribes on their border, compared with whom they are in a condition little removed from that of servitude. The great race of South Africa is, however, that known as the Kaffir, which, under the names of Basutos, Bechuanas, Zulus, and so forth, stretches far to the north, and belongs to the great Bantu stock, which, as Makuas, Mashones, Matabeles, Manganga, Mayau, Balunda, Barua, Barotso, Waswahili, Wonka, Walegga, Waganda, Wanyamwesi, Ovampo, Ovaherro, Bateki, Duello, 
and a hundred other family, tribal, or sub-tribal names, spreads in a broad band across Africa from sea to sea. They are, perhaps, the most important of the African racesand all of them speaking dialects of the same tongue, a Congoese and a Zanzibari are able to understand each other (pp. 13, 15).

These peoples are not Negroes properly: they are what the ethnologists call

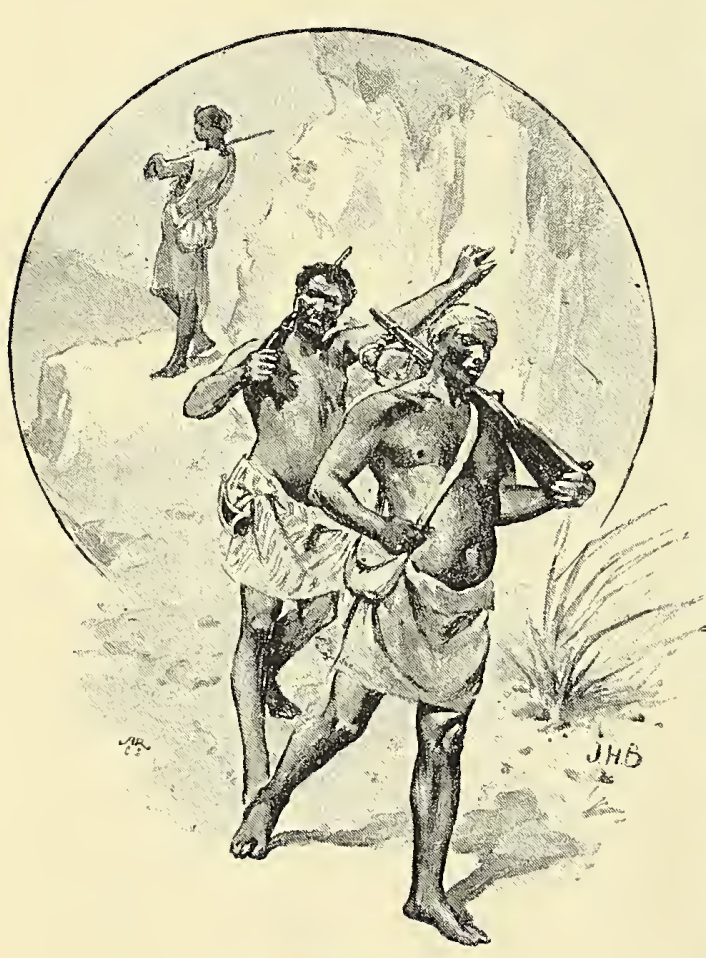

POST RUNNERS. Negroids, many of then being fine-looking people, though with certain characteristics which lend ground to the suspicion that they have at some time in their career intermarried with or amalgamated with the true Negroes who inhabited the country which they invaded. 'The latter, who, from the fact that they formed the greater part of the slaves imported into Europe and America, have led to the impression that they are the only Africans, are the Kru, Fanti, Ashanti, and Ioruba of Upper Guinea; the Joloff, Bambarra, Mandingo, Sonhrai, Haussa, Batta, Kanuri, Baghirmi, Mosku, and Kanem of the regions adjoining the Senegal and the Upper Niger ; and the Dinka, Nuba, Maba, Shilluk, Bari, Nombottu, Zandeh, and other races of the Easter'n and Central Soudan.

The African peoples, however, do not end with the black and blackish stocks (p. 16). In the north-east corner of the continent we come upon another even less Negroised group, namely, the Gallas, Somali, Afar, and Bejas, while the Berbers, under their various names of Shluh, Mzabites, Kabyles, and Touaregs, range all over Northern Africa, of which, indeed, they seem to be the ethnic substratum. The old Egyptians were probably of this stock, just as the modern Copts are, the so-called Fellaheen being Arabs very much mixed. These Berbers are in no respect Negroes. They are not even black, their ordinary complexions being as fair as that of the Arabs among whom, in the Barbary States at least, they have commingled to a large extent; while in the mountains of Algeria, and to a smaller extent of Horocco, many people with fair hair can be met with, though whether they are really aborigines, or only remnants of the old white colonists-Roman and Gothic-or of Christian slaves, is a question which admits of more opinions than one.

Another very interesting people are the Fulahs or Pulhs (p. 13), which play a wonderful part in the Western and Central Soudan; though, like the Eans of the Ogove Basin, the Tibbus of the Eastern Sahara, the Agous of Abyssinia, and the robber Masai of Masailand, in Eastern Africa, their origin and affinities are still very doubtful.

And last of all, there are the Hinyarites of Amhara, Tigre, and Shoa, who form 
a large portion of the population of Abyssinia. Yet even then we have not taken tale of all the motley races who have found a home in a continent so long despised of Europe. The Arabs pure and simple have become masters rirtually and by recognition of a large portion of it. But they are comparatively new-comers, though unquestionably from the rery earliest times there was a steady drift from Arabia, across the Red Sea and the Desert of Sinai, into the adjoining parts of Africa.

The Jews have also, through the persecutions they suffered among the Christians, become the leaders in the commercial and industrial life of Northern Africa, more particularly in the Barbary States. Yet there were Jewish colonies in Northern Africa long before the Arabs burst into that region, it is possible even before the Berbers came, and to this day, all orer the interior of Morocco, the traveller comes upon little settlements of Israelites who speak no

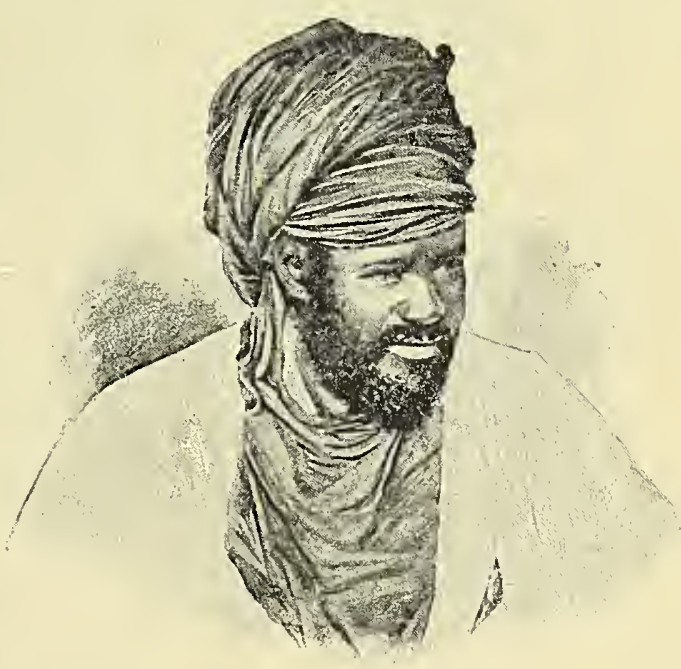

A FULAH, BROTHER OF THE SULTAN OF SOKOTO. language but Arabic or Berber, and here and there single families living under the protection of some Arab sheik, to whom they render services of value in the shape of transacting his business, and otherwise utilising that amazing commercial talent

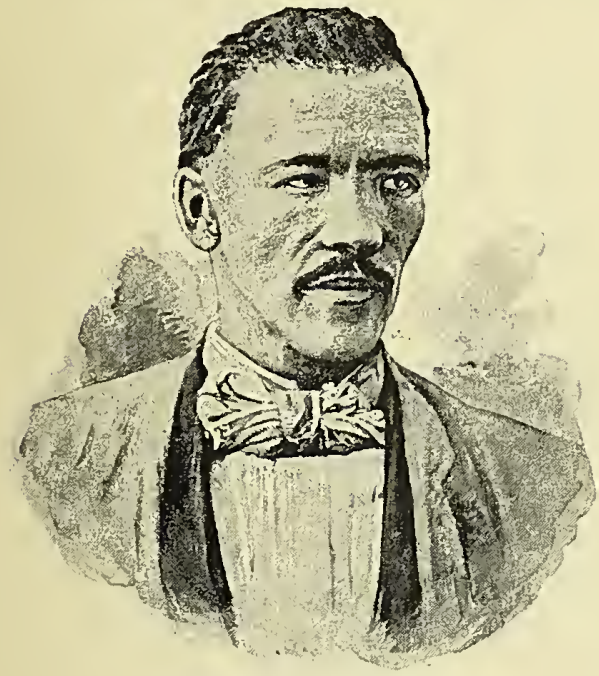

KAFFIR OF DAMARALAND. which is the birthright of that ancient section of the Semitic stock. Beyond the boundaries of Moroceo they lead a nomadic life, many of them following the oceupation of guiding cararans across the desert to Timbuctoo, where there has always been a little .Jewish colony, though whether the "Dagatta" are Jews, as the Rabbi Mordokhaï thought, or simply Pagans with a touch of Hebrew blood, is still a moot question.

of the European peoples in Africa it is not necessary to speak at length. The Greeks and Italians in Egypt are perhaps the oldest settlers. The Portuguese and the Spaniards come next. The Maltese have always been migrating from their little island to the opposite shores of Tunisia and Tripoli, where, being themselves of an Arab stock, they form as it were the link between the Arabs and the Europeans, and, with the Sicilians, are the rivals to the growing French population of Tunisia and Algeria; but as colonists the French are very moderate successes. The Danes have ceased to keep their foothold in Western 
Africa; the Belgians, except as "protectors," though virtually owners of the Congo Free State, have made no attempt to seize anything; and since their surrender of the Cape Colony, the Dutch, unless as merchants in the Congo River, have made no effort to recover their grasp of the continent. The British were among the earliest of the peoples who sought fortune in Africa, and their holding, like that of the French, is every year enlarging. The Italians also are renewing their efforts to find outlets in Africa, though except as individuals they have no longer any part in the great colonies founded by their ancestors. And last of all the Germans have begun to try their fortumes in the continent which was for centuries free to all the world, and yet until lately left to the aborigines, or to those Arabs and Turks who, strangers themselves, did almost as little for its development.

But when we come to trace these so-called aboriginal races to their origin, we plunge at once into darkness. Their original homes, like their migrations and relationOrigin of the African approach to certainty. We see in the north that the Arabs have driven the peoples. Berbers out of the fairest portion of the plains into the mountains where ships, may be speculated over, but they cannot be pronounced on with even an they now live, poor but comparatively free; though, on a snaller scale, this was also done by the Roman colonists. The Berbers are, however, immigrants themselves, and it is by many believed that they were the inhabitants of Great Britain before the Celtic wave overran our islands, and that their route across France and Spain before they passed the Strait of Gibraltar, if indeed it then existed, can be traced by the dolmens, monoliths, cromlechs, and other rude stone

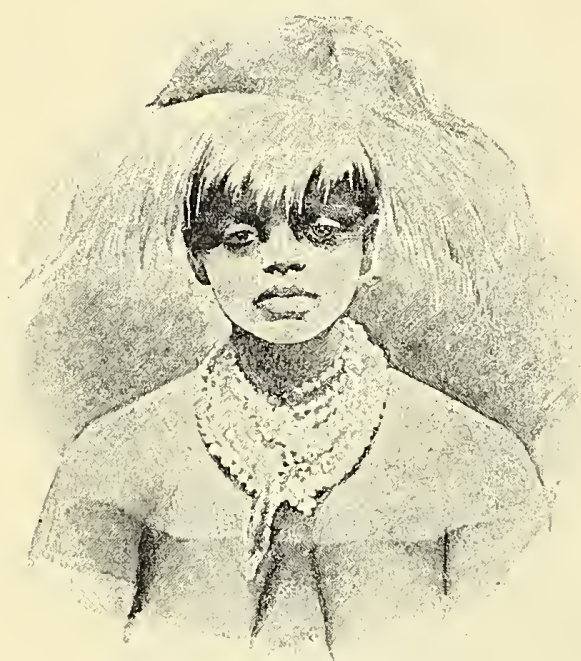

NATIVE OF FERNANEO PO. monuments which all through these countries, as well as through Northern Africa, mark the presence of some prehistoric race. These Berbers seem also to have reached the Canary Islands, for the now extinct Guanchos, or aborigines of that group, have been proved to be of the same race.

The peoples of North-East Africa may be supposed to be a mixed stock, Arabs, perhaps, amalgamated in very early times with Berbers or Bantus, or some vanished stock. But when we come to South Africa, we are puzzled to account for the Kaffir offshoot from the widespread Bantu family, who seemingly as intruders appeared in that region. Were they from Asia? This is not an impossibility, since on the island of Madagascar we see the Hovas or ruling class to be, from their language and customs, Malays. But to what origin are we to ascribe the Negroes, and the other more doubtfully distinct fanilies already noticed? Nor are the Pygmies any more free from doubt as to their relationship. For in many of the Indian islands, and in India, we meet with another set of Negrittos, which has raised the question 
whether the African continent did not at one time extend in that direction, and whether these now scattered peoples were not, at a date which it is now vain even to guess at, the inhabitants of this then unbrokeri tract?

Nowhere in Africa do we come upon any evidence of a higher civilisation among the aborigines than that which they at present possess. They vary widely in intellectual ability. But everything goes to prove that they are now more advanced in culture than at any former period of their existence. Nearly every inland tribe has, ever since the whites made their acquaintance, been familiar with the art of smelting and working iron. From whom did they learn this art, which marks so advanced a stage in culture that ercn the highly polished nations of Mcxico and Peru had

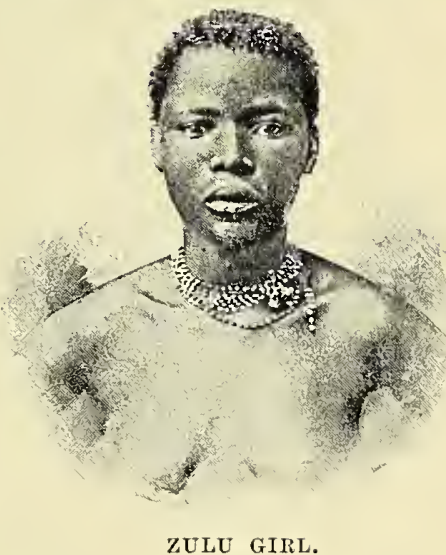

ZULU GIRL. not attained to that feat when the conquistadores first came among them? Still, the Africans did not always practise this craft. Some of the ruder septs still use flint and obsidian, and all over Africa the soil contains arrow and spcar heads, which demonstrates that the peoples of that continent passed from the stone to the iron age without any of the intermediatc bronze or copper stages which in most other countries mark the progress of civilisation.

It is therefore evident that there are many links in the history of Africa still undiscovered, and unless the caves, or the supcrficial deposits, or the refuse heaps still unexplored, contain an inkling of these, the problems thus briefly sketched may for ever remain unsolved.

\section{WHY IS AFRICA UNCTVILISED?}

These problems, however, concern men of science alonc. To no appreciable extent have they ever interfercd with the exploration or exploitation of the continent which holds them in its keeping. Accordingly, when we come to consider how Africa, though the quarter of the world nearest to that extension of Asia called Europe, has been the last to be explored and made use of, we must find other reasons than the complexity of its tribes, or even the ferocity of the majority. The latter feature has indeed never much interfered with the pioneer. Many travellers have fallen by the way, yet only a small percentage

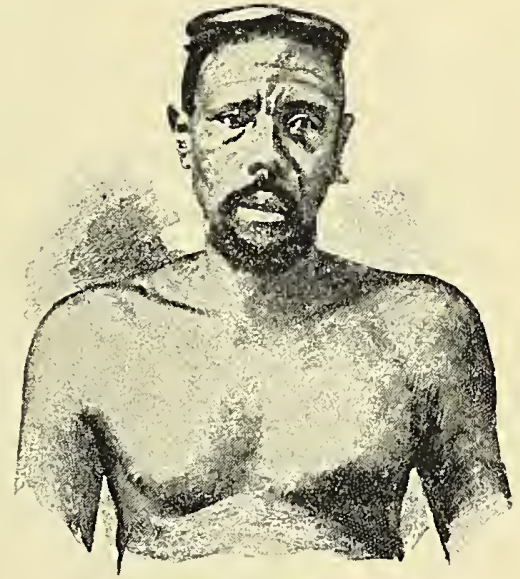

ZULU CHIEF. have perished at the hands of the people. Australia and America, on the other hand, have been rapidly ransacked, in spite of the hostility of the savages, who in a month's warfare in the New World have often killed more whites than have perished in the whole history of African travel; while Central Asia is being gradually mapped in the 
face of a scarcely less strenuous opposition from the morc civilised inhabitants of that region.

But Africa is differently shaped from any of the other continents. It is a penin-

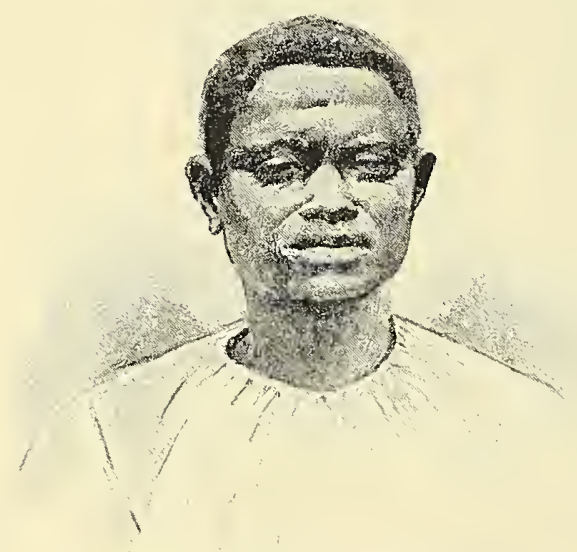

NATIVE OF THE J.OWER CONGO. sula of a form ronghly triangular, with few bays of any depth, or islands presenting a bulwark against the surf which breaks on its shores, and none of those fjords which physical intersect mole northern continents, as of Africa an if for the purpose of enticing mariners its explorato take shelter in their hospitable depths. In place of thesc inlets there are several great rivers, the Nile in the north, the Niger and the Congo in the west, and the Zambesi, the Pungwe, and the Rovuma in the east, which seem specially suitable for penetrating the continent in the directions whence they run. Yet, unlike the St. Lawrence, the Hudson, the Mississippi, the Amazon, and the Plate in America, and thc Ganges, Brahmaputra, and Irawaddi in Asia, these vast floods have until recently been little utilised for the exploration of the African continent. On the contrary, it has been pierced from Tripoli, where there is little water of any sort; from Algeria, where the streams are of small extent; and from South and East Africa, where the waterways afforded little help to the early travellers.

Actually they deterred men. For nearly all of these strcams creep to the sea through dcltas formed of the mud brought down by them in the course of unnumbered ages. Hence Africa is for the most part encircled by a strip of low land, covered with dense forest, and reeking with malaria so deadly that only the low-type tribes who have become proof against the native fever can live on thcir banks, though even they are at times infected by the dcath-dealing vapours. Through mile after mile of this monotonous flat the African rivers crecp to the sca, the immediate shore lined with slimy mangroves, among the straggling roots of which the black, muddy water oozcs, and the loathsome crocodile and clumsy hippopotamus, disturbed by the passing steamer, splash lazily (p. 17). But byand-by, invariably, to a greater or less extent,

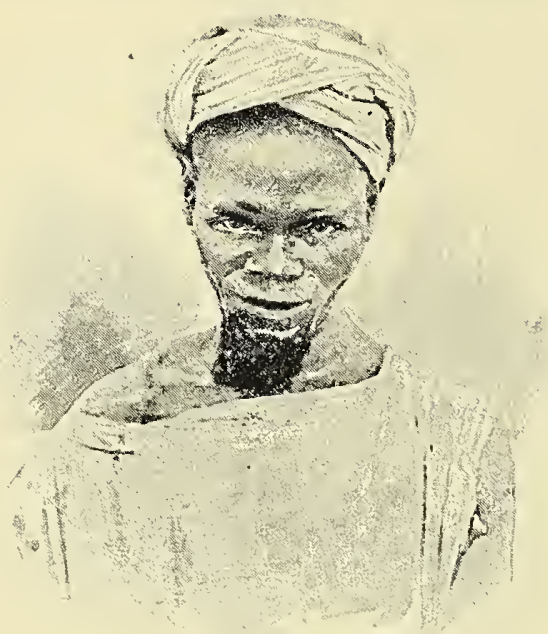

NATILE OF ZANZIBAR. the river navigation (and most of these rivers are shallow, and full of sand-banks and shoals) becomes interrupted by either falls or rapids, extending for a distance, it may be, of more than two hundred miles. This marks as it werc the old sea cliffs of the 
continent, for here the river breaks through the mountains, which slowly rise into a plateau some two thousand or three thousand feet in height. This plateau is, however, actually a mountainous region, and the one which succeeds it, though four thousand or

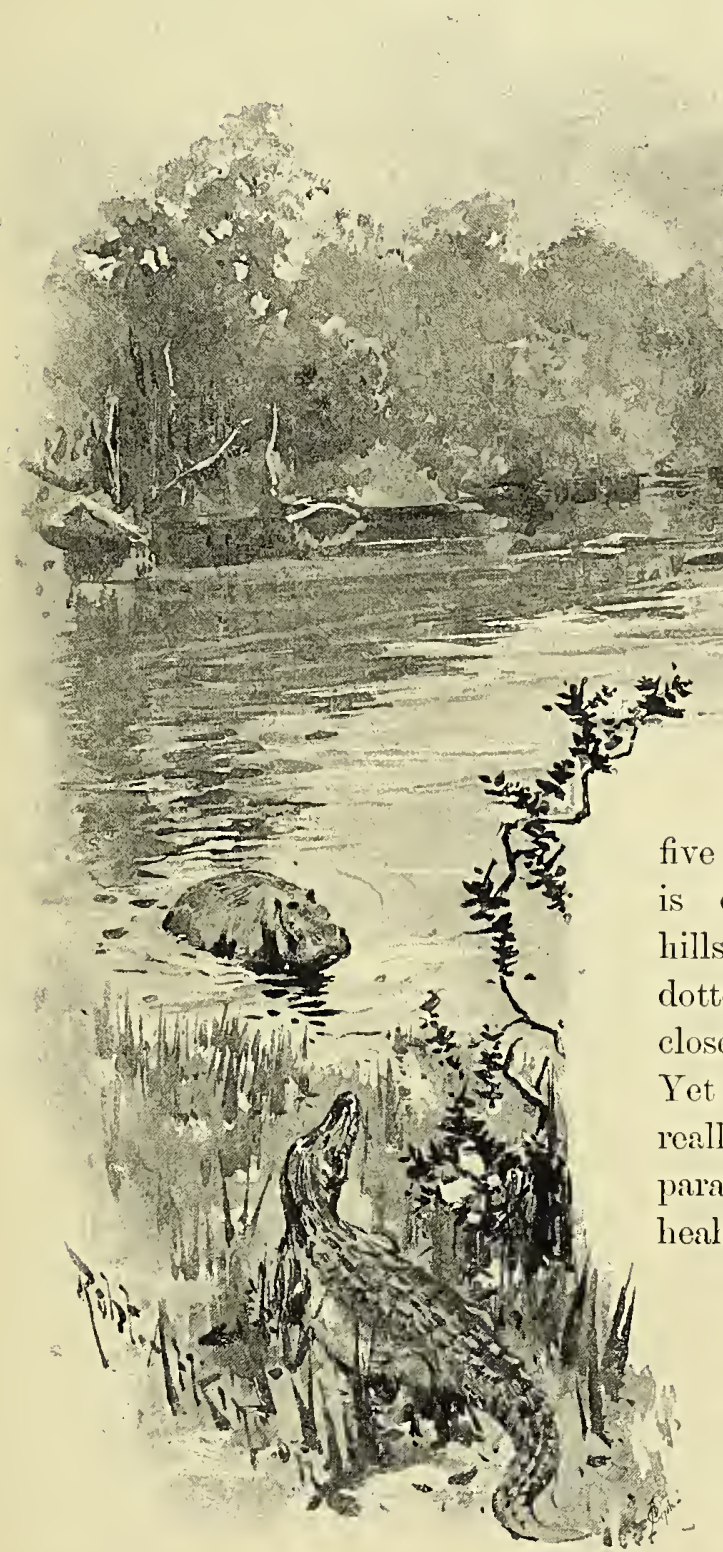

between the Indian Ocean and the pleasant uplands in which lie the great African 
lakes, until there eireulated among the seamen of every nation the wanning eouplet-

"Beware, and take eare of the Bight o' Beuin,

For one that eomes out there were forty went in."

These eireumstanees naturally impeded the exploration of the interior, while the undeniable unhealthiness of the west coast, the first reaehed, and for long the best-known portion of the country, did not suggest a more extensive aequaintance with a land the entrance to which was so uninviting. The north was fitted for the residenee of Europeans. But this region was occupied by fieree Moslems-Arabs and Turks-who held their own with the most powerful armies sent against them, and by their pirate fleets took ample reprisals against Christendom for the ports whieh, here and there, Spain, Portugal, England, and the Knights of Malta had wrenched from them. In the extreme south, no doubt, there was a fine, healthy region. But South Africa was far from Europe, and, until Bartholomew Diaz diseovered and Vasco da Gama doubled it, unknown to the nations of Christendon. Again, wherever Africa had been penetrated from the north the explorers had come upon deserts of sand. These deserts, dotted by well-watered oases, they naturally regarded as simply the beginning of a like waste extending all through the interior, instead of a mere barrier between the fertile north (the granary of Rome in the days of the Empire) and the even better-watered and richer regions which, with few intervals, stretch to the end of the continent. Accordingly, what from ignorance and what from knowledge, Afriea was repulsive to the explorer. A large part of it lies under the equator, and the heat of this belt repelled him, just as in earlier days the belief that the torrid zone increased in temperature the farther the mariner sailed south, drove back the most adventurous of the Argonauts. Most of the eountry is, moreover, surrounded by malarious swamps, and in these the pionecr adventurer found his grave; and if he essayed the interior from the only points where the circlet of unhealthy flats was broken, he perished of thirst, chasing the mirage whieh beguiled him into the arid wastes beyond, or was speared by the Touareg, whose hand is against every man.

In this way the most erroneous of generalisations grew up regarding Africa, and as a result the country remained long unexplored, and, as a consequence of this, long undeveloped. 


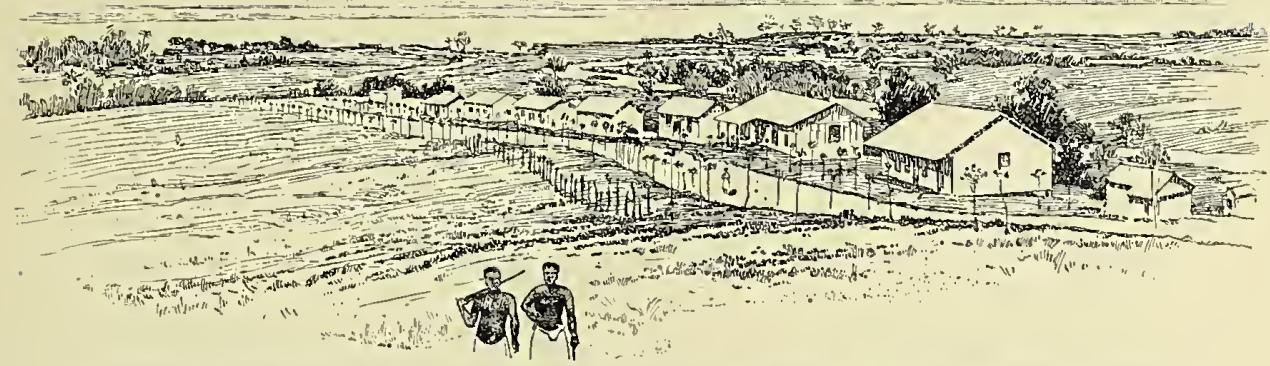

STORE-HOUSES AND BARRACKS FOR SOLDIERS AT BOMA, ON THE LOWER CONGO.

\section{CHAPTER I.}

\section{A Century of Africai Exploration.}

The Early Exploration of Africa-Some Mythical Voyages-Nediæval Voyages-The True Beginning of African Exploration dates from the Foundation of the African Association in 1788-A Sketch of the Map of Africa in 1792-Africa in 1892-Rapidity with which Exploration has Proceeded during the last Forty Years-Obstacles to African Exploration-The Climate-The Discovery of America-The "Guinea Trade" - The Evolution of Africau Exploration-The Tendencies of a Century of Exploration-Unexplored Africa - The West Coast Traders as Explorers-The Seekers after Timbuctoo and the Upper Niger-The Seekers after the Nile Sources-The East African Lakes and their Explorers-The Colonisation of Africa-What the Hunters did for making it Better Known-The Share of the Missionaries in opening up Africa-The Crossers of the Continent-The Era of International Explorers-The Founding of the Congo Free State - The Scramble for Africa-The Partition of Africa-Africa under Companies.

THE physical obstacles which have been sketched in the preceding pages all conduced to Africa being left to the Africans, while the other continents were daily receiving large accessions of population from Europe. Yet, as might have been expected from its proximity to Greece and Italy, and still more from the fact that one of the great commercial nations of antiquity had its prineipal cities on the northern shores, Africa attracted attention before America was dreamt of or the more distant parts of Asia had been reached.

The Phœenicians, who, 1,100 years before Christ, built Utica in what is now the French Protectorate of Tunisia; the Carthaginians, who laid the foundations of their metropolis 300 years later; the Greeks, who founded their colony of Cyrene 650 years before the Christian Era; the Romans, who succeeded them : and, above all, the Egyptians, who were older than any of them, must have picked up from traders and adventurers of all sorts vague notions of the lands which lay to the south of their homes: while the Arabs, who burst into Africa as the civilisation of the Roman and Byzantine Empires was falling into decay, soon spread down its shores, and in the course of their predatory and mercantile expeditions traversed vast portions of the interior which have been re-discovered only within our own day. In Africa, indeed, the ancients placed the Hesperides * and it may be that the green oases they saw in the deserts beyond Egypt and the Atlas suggested to their poets those fabled Islands of the Blest,

* One of the localities was Larache, at the mouth of the El Kus River, in Morocco: a rival site was near Bengazi, in Cyrenaica. on the modern "Garden of Osman." 
those "Insulæe Fortunatæ" which later commentators have found in the Canaries.

Herodotus, indeed, tells us of Necho, King of Egypt, sending an expedition from the Red some Sea into the Southern Ocean, which mythical after two year's' absence arrived at voyages. the Pillars of Hercules, after circumnavigating the continent. And the same historian, who had remarkably clear notions

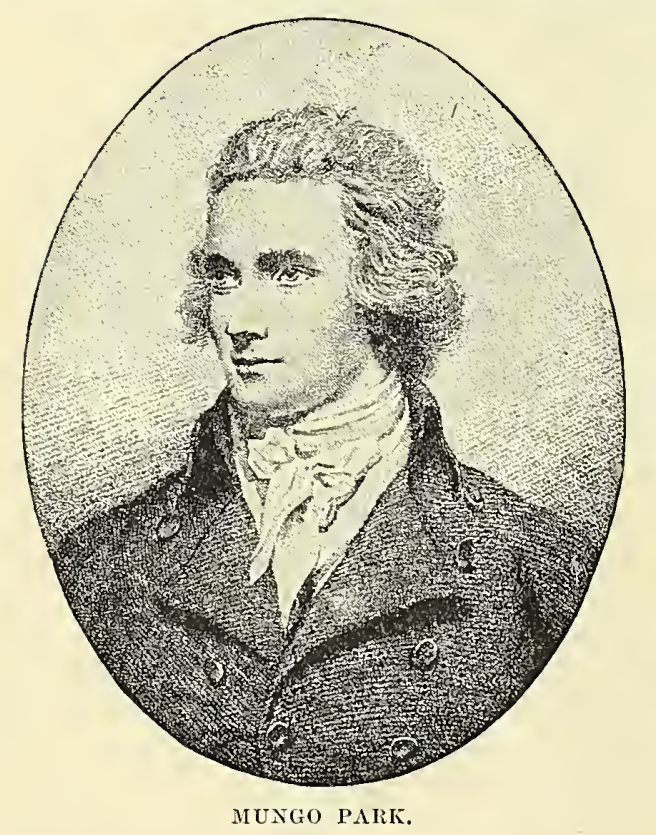

of some facts not recognised until many centuries afterwards, speaks of another voyage made along the western coast by Sataspes, a Persian nobleman, who, having offended Xerxes, had his sentence of crucifixion commuted into the venture in question. Eudoxus of Cyzicus, on his voyage to India, traded with the natives of East Africa, where he found among some wreck the prow of a vessel which had sailed from Cadiz for the west coast of the continent and never returned, a discovery which led the enterprising Greek to fit out an expedition for the same region, though what became of it. Strabo has failed to inform us.

All Africa, however, was still a land of the marvellous. Here lived not only dragons, and Amazons, and unicorns, but people without tongues, and others without mouths, so that they received their food through an orifice in the nose; so that when Harno the Carthaginian sailed southward with a fleet manned by 30,000 people of both sexes, to found the city of Thymiaterium, he might well have been expected to see all the wonders he described on his return home. For on this voyage, which extended to the Gulf of Guinea, he tells of the land being so hot that the sandalled foot could not tread upon it, of the sea being in flames-phosphorescent most likely-and of people covered with shaggy hair climbing precipices and throwing stones on their pursuers, which people we now know to have been gorillas, those gigantic apes associated with M. Du Chaillu's reputation. Many similar, though less important, explorations followed, until the arrival of the Arabs enabled their geographers tocollectmany accurate details regarding the interior. But even in the thirteenth century the map-makers were acquainted with the Nile Lakes, though it is not unlikely they took this information from the works of Ptolemy and the Greek historians, just as did the Portuguese at a later date.

But the energy of the navigators sent out by Prince Henry of Portugal soon enabled Europeans to trace not only the Mediæval west coast, but to double the Cape voyages. of Good Hope, and sail up the eastern shores of the continent. Cape Bojador was discovered in 1434, Cape Blanco seven years later, Fernando Po in 1471, the Congo in 1484, the Cape of Good Hope in 1497, and Natal, Quilimane, Mozambique, Mombasa, and Melinda in 1498.

From the colonies and trading posts established on the coast by different European nations, excursions were made here and there into the interior. These journeys were, however, rarely undertaken for geographical purposes. They were devised in pursuit of gain, in search of cheap slaves, of ivory, or gold, and those who made them were either ignorant and unable to describe and chart what they saw, or imagined that by keeping their information to themselves they would in 
some way gain an advantage over their rivals. Hence, on a map of 1670 (p. 9), a map which remained very little altered up to the close of the eighteenth century, and in its main features was not entirely transformed until less than forty years ago, three rivers, the Nile, the Congo, and the "Coanza," took their rise in the "Zaire" and "Zembre" lake, while great-almost the only-explorations of the interior have been made within the last hundred years. For the century which preceded this now ending closed with the early travels of Mungo Park (p. 20) and Frederick Horneman, just as the present one opened with the last explorations of the heroic Scot and scarcely less gallant German. How much has

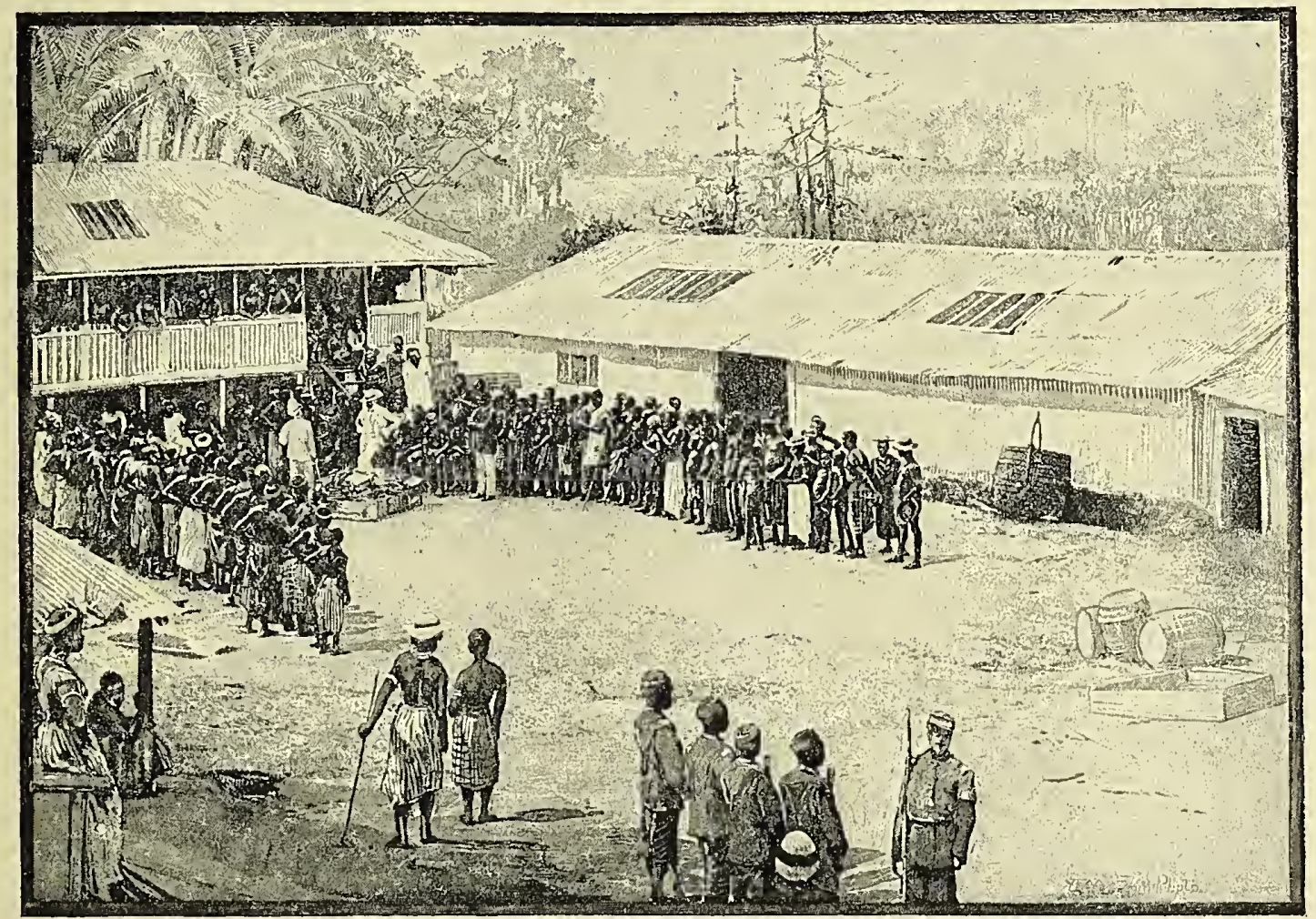

SCENE AT A TRADING STATTON ON THE NIGER.

a host of other details, mountains and rivers and deserts, could have been the children solely of the chartographer's imagination. Yet the Dutch had begun their colonisation of the The true Cape of Good Hope in 1652. But beginning until James Bruce, in 1768-73, of African
explorations. Abyssinia, and the African Association was founded in 1788 , the continent as portrayed in maps remained very much the same as it was on the maps of a century, or even two centuries, earlier. In short, all the been done in the interval may be presaged from a study of a map dating from that period and one issued in 1891.

\section{AFrica IN 1792.}

In the north we have Egypt, a Turkish province under a Pasha, at the mercy of the Mamelukes, or Janizaries, though at that moment actually held by the French. Then further to the west are Barca and Tripoli, under a "Basha," nominally the suffiragan of the Ottoman Sultan, though in reality an 
independent hereditary Sovereign of the most despotic type Tunis, next to it, is also a regency of Turkey, though the A survey of Bey is, to all intents and pur-
Africa a century poses, a king simply paying tribute ago.

to this suzerain. Algeria, in like manner, is a fief of Turkey, though for ages the Deys have been made and unmade by the insolent Janizaries, and in the interior several of the Arab chiefs owe but a slight fealty to the pirate prinees who had displaced them. Still further to the west lies the Sultanate of Moroeeo, under an independent Sovereign, who owes allegiance to no man, and, like the other rulers of Barbary, is largely dependent on the plunder brought in by his eorsairs and the labour of the Christian slaves who toil in his squalid towns. From there to Senegambia we are in no man's land. At this point, however, we enter upon a Freneh eolony, adjoining the English one of Gambia. The Portuguese have a post hard by, and at Sierra Leone we possess a station for the reeeption of manumitted slaves, the trade in black men being still as brisk, if not altogether as reputable, as of old.

As we sail south, the Grain, the Ivory, the Gold, and the Slave Coasts are passed, the shore dotted with the white faetories and castles of the different trading settlements, several of whieh belong to the Duteh and Danes. At Whydah we are in the territory of the savage King of Dahomey, and in this port are the "factories" of various nations, all more or less engaged in the traffic then pleasantly known as "the Guinea trade," and at a later date as that in "Black Ivory." But nearly all this littoral is still in the undisturbed possession of a multitude of petty negro monarchs, who sell their subjects and their prisoners to the white men, and live upon the proeeeds in a paradise of rum and gaudy ealico.

The Portuguese have St. Thomas and Prince's Islands under their flag, and somewhere south of a river ealled the Zaire or Barbela, whieh is marked as running only a short way into the interior, and suggested as "perhaps only the Nigor," the
Portuguese colony begirs. From the southern termination of Angola we pass a long expanse of shore on which is marked, "No fresh water to be found on this eoast from Fish Bay to St. Helena Bay, a distance of 900 miles," or', in other words, until we reaeh the Cape Colony, then under the Duteh rule. But it extended very little further than a strip around the eoast. A little way in the interior is marked the "Boshemen's Country," the "Country of the Booshuanas," the "Tambookies," the "Griqua Country," the "Tamakas," the "Wanketzens," and then, in the midst of a vast blank, the "Barroloos."

Up the East Coast we see a huge region marked "Caffraria"; another, further on, the region of the "Hambonaas or Mambookies," and so on, until we reach the Portuguese territories north and south of the Zambesi, though a few streams vaguely straggling through this region are about all the geography has to show after the lapse of four eenturies. As we go further north, these streams get even fewer, and the native territories more numerous, until Abyssinia and Egypt are reaehed, when naturally the details of the map, loosely though they are given, become more frequent.

In the interior, the geography is infinitely more sparse, and to a large extent mere guess-work. From the Cape Colony to five degrees north of the equator, a distanee of 2,400 miles, the ehartographer has not even attempted to place "elephants instead of towns." He contents himself with scrawling over it "Regions unexplored": and how well explored the 1,800 miles to the north were may be guessed fiom the faet that the "Jebel Kumri, or Mountains of the Moon," sprawl half aeross the continent in the same position in which they have been since the days of Ptolemy, though in reality they do not exist (p. 10), and that the eourse of the Niger is not traced, nor its termination in the Atlantie marked, the Zaire, which is now known as the Congo, being hinted as the seaward end of a river whieh we now know finds its way to the Atlantie 600 miles further to the north. 
Nor is it necessary to intimate that the Zaire is not portrayed much beyond the falls, that the sources of the Nile are not marked, and that the beginnings of the Shiré and the Zambesi are not indicated, unless, indeed, the halfdelineated "Maravi Lake" is to be accepted as Nyassa. Nor, after figuring in maps for ages, are the Nile Lakes portrayed on this map near the close of the eighteenth century. None of the other great African lakesTanganyika, Chad, and N'gami-are hinter at, while the geography of the regions south of the Nile is still largely that of Edrisi and Leo Africanus, many of whose place-names, though the places no longer exist, are marked on maps of Morocco dating less than thirty years ago. Little is stated from actual observation, but a great deal from analogy and the report of Arab and Haussa traders. Thus we are told "it is the general opinion that the Mountains of Kong unite with Jibbel Kumri, or Mountains of the Moon. In opposition to the above, the Haussa traders, in describing the difficulties attending their journey from Haussa to Lagos, on the coast of Guinea, speak of rivers, morasses, and large lakes, but make no mention of mountains." Mountains are, however, bestowed pretty freely. For opposite Zanzibar, for six hundred miles parallel to the coast, is the "Lupata" range, which seems a largish feature in African geography to be indicated as "doubtful."

\section{AFriCA IN 1892}

When we take up a map of the present day we find many changes. Egypt is still there, as it has been for nore ages than written history has taken count of But though much larger than the Egypt of 1792 , in spite of a rebellion on the upper waters of the Nile, it is no longer the country of a century ago. The Pasha has become a KheA survey of the modern map of

Africa. dive, or hereditary Viceroy, and so little hold has the Sultan of Turkey upon the country that, to prevent anarchy, the Land of the Pharaohs is administered under the protection of British bayonets. 'Tripoli is, however, more 'Turkish than ever. For the hereditary "Basha" has disappeared, and the country, no better and no worse than of old, is again an ordinary province of the Ottoman Sultan.

Tunis, diminished a little in bulk, has ceased to have any connection with Turkey; for the old regency is under that name a virtual colony of France. In Algiers the Deys are only an evil memony. Their capital, and the capitals of the native chiefs whom they displaced, are every day more and more getting French towns, with boulevards and hotels, filled with crowds of gay invalids and gayer idler's seeking here the sunshine which is denied them in the winter of their northern homes. Railways intersect it in every direction, and even the desert is being redeemed by means of deep wells sunk through the arid soil to the supply of water underground. Morocco alone remains independent. But even there, in spite of the lack of roads and railways, and all other civilised appliances, the Prince of True Believers is feeling the heary hand of the Infidel. The Spaniards still hold Ceuta and three other places on the coast, and have of late reclaimed one * which they had abandoned on the Atlantic seaboard several centuries ago, and are waiting with the French, and of late with the Germans also, for any excuse to seize at once, and with interest, the ports which they were forced to abandon in the sixteenth and seventeenth centuries. In all the coast towns Europeans are numerous and aggressive. Their envoys are no longer inclined to wink at any infraction of their rights: and though the interior is still left to the Faithful, there is a growing determination to insist on the treaty right which permits the Nazarene to go where he list and stay where he dare. They have even settled in the capitals. And there are now no Christian slaves, and no ships, pirate or otherwise.

South of the Morocco bounds-though the Sultan claims the territory when it suits his purpose, and disclaims his authority over it

* Ifini, or Santa Cruz de Mar Pequeña. 
when there is a talk of indemnity for the lawlessness of his lieges thereabouts-a British trading post at Cape Juby is the first of our outposts in North-Western Africa. From Cape Bojador to Cape Blanco the Spanish assert a protectorate, though, with the exception of a flag-post at Rio del Oro, there is little of Castile thereabouts except on the map.

From Cape Blanco to Sierra Leone there is a French colony, that of Senegal, near the coast, that of the French Soudan in the "hinterland" beyond, though the continuity of Gallic rule is broken, as of old, by the Gambia colony-now independent of Sierra Leoneand the Portuguese territory on each bank of the Rio Grande. The Bissagos Isles hereabouts are also Lusitanian, but the Los are British; and Sierra Leone has now attained the dignity of a British dependency, maintained for the profit of negroes, few of whom are natives of this part of Africa. Then comes Liberia, a republic of American freedmen.

After a short interspace of unannexed territory, the French again claim the coast and the back country to the bounds of Cape Coast, into which the old Fanti protectorate is now merged, and, for all practical purposes, the nominally independent kingdom of Ashanti also. Togoland, south of this, is German soil; and though the kingdom of Dahomey is still to be traced on the map, the British on one side, and the French on the other, are pressing his sable majesty sorely. So much, indeed, is he hemmed in that, with the exception of Whydah, his coast-line is in French hands; and even Whydah was for a time annexed by Portugal. But it is no longer a flourishing port, or rather roadstear ; its factories decayed with the slave trade, and before long it, too, will own new masters. In all the widle region drained by the lower course of the Niger and its tributaries, British influence once more asserts itself in the shape of the Royal Niger Company and the Imperial Commissioner of the Oil Rivers. Fernando Po (p. 14) is still a dismal Spanish isle. So is Annobon; and Prince's and St. Thomas Isles, perhaps because no one else cares for them, continue as of old to fly the flag of Portugal.

But from the Rio del Rey to the Campo River we now discover for the first time the German colony-without colonists-of the Cameroons, where not many years ago the British mission settlement of Victoria was the only sign of the white man's doinination. South of this is the vast territory of French Congoland. With the exception of the little Portuguese patch at Cabinda, the Free Congo State occupies the country on the south bank of the Congo River, to the Lake Tanganyika, more than halfway across Africa.

Portuguese West Africa is much as it always was, but Damaraland and Namaqualand, the waterless waste of the old maps, is all German, with the exception of a number of small islets off the coast. The Cape Colony, with its off-liers ready for absorption, is now a huge area, stretching far to the north, either as a self-governing dependency, a Crown Colony like part of Bechuanaland, a protectorate like the rest of it and so many other native territories, or, as a "British sphere of influence," under the rule of the British South African Company, whose proper territories are Matabele and Mashonaland. But two "whole cantles" cut out of this area of South Africa are the Boer (Dutch) Republic of the Orange Free State and the South African or Transvaal Republic, both more or less under British influence or control, and between which and the Indian Ocean lie the colony of Natal and Zululand.

The coast north of this country is under Portugal. Some of the islands in the Mozambique Channel are, however, French, and all the great island of Madagascar is either claimed in fee or is a protectorate of the same Power. At Cape Delgado Cerman East Africa begins, and ends at the River Umba, but extends internally to Victoria Nyanza and the eastern side of Lake Tanganyika. Zanzibar, an Arab Sultanate, is, with Pemba Isle, a British protectorate, and up to the River Juba, where the supposed Italian sphere of influence begins, the Imperial East African Company 
claims the country as far east as Uganda, the headwater of the Nile, Darfur, and the Egyptian Soudan. Sokotra Isle is, however, British, and on the northern shore of Somaliland to Obock, where the French have a foothold, the British flag waves once more. but the European Powers who have parcelled out Africa amongst them claim The "Hinthe back country also. Hence terland." Algeria and Tunis have a "hinterland"-the word has become naturalised in the language of diplomacy - stretching to within fifteen

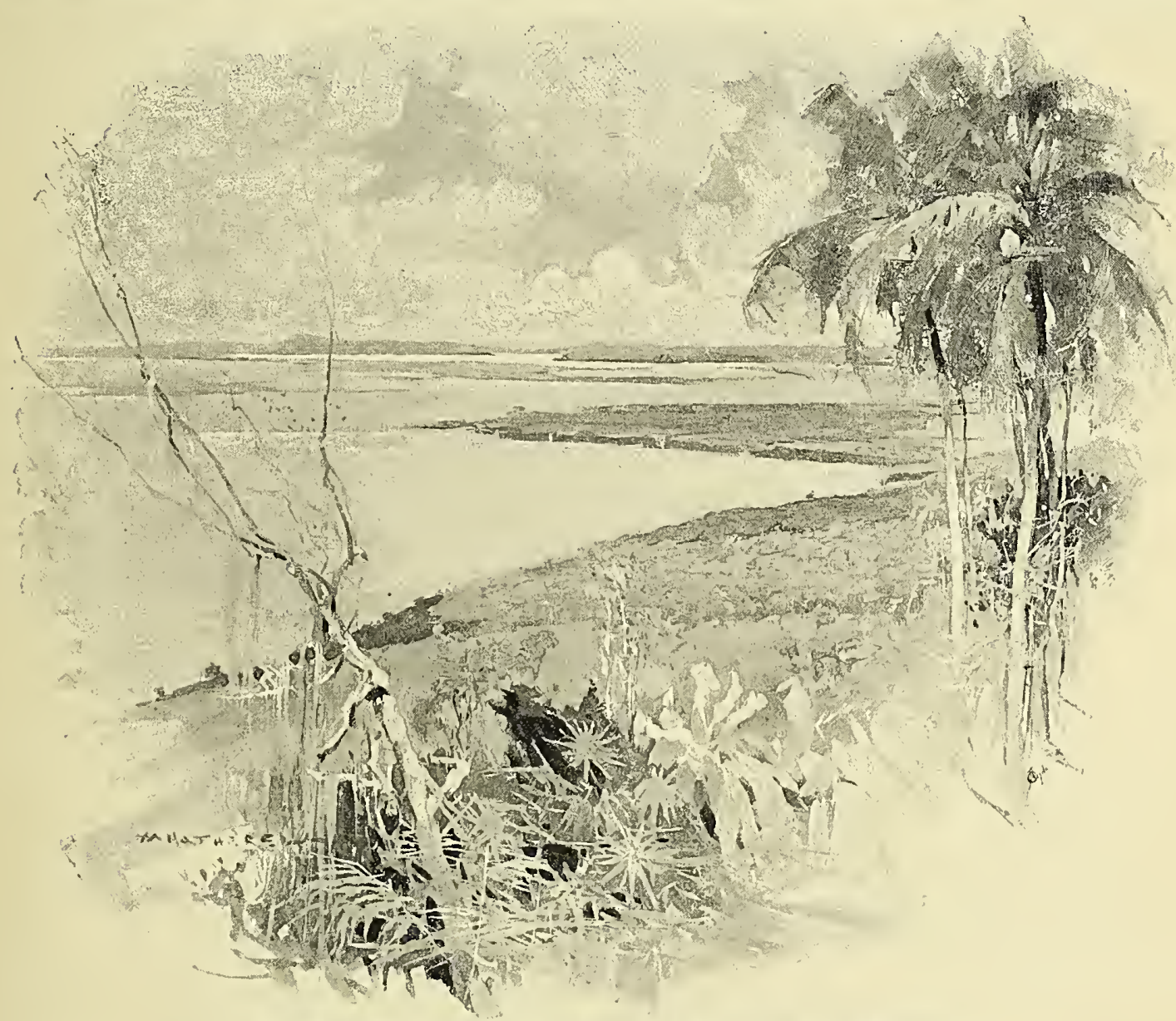

ON THE CONGO, LOOKIXG TOWARDS THE MOUTH OF THE RIVER.

Abyssinia is an Italian protectorate, and Massowah an Italian town, though Perim, an island at the entrance to the Red Sea, is, like Aden on the opposite Arabian coast, a dependency of Great Britain. Beyond this, Egypt is regarded as the rightful lord, though perhaps it would be more correct to regard the protectors of Egypt as the true masters. For if the Nile Delta is still under the Khedive, it is likely to long remain within Britain's "sphere of influence." So much for the coast ; degrees of the equator, "marching," as the Scots say, with the northern limits of the British "hinterland" in the Niger region; while the other nations have been so liberal in dividing the black man's lands amongst them, that out of the $11,514,300$ square miles, which is the latest estimate * of the African area, not more than 2,021,583 remain unappropriated,

* By Mr. Ravenstein. 'This estimate, however, includes all of the African islands, including St. Helena, Ascension, and Tristan da Cunha, far in the Atlantic. 
though of course only a small portion of the remainder can be described as effectively occupied. But the interior, which, much less Rapidity than half a century ago, had nevcr

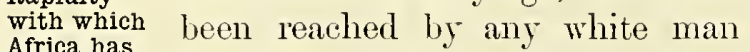
Africa has plored durforty years. been penetrated from the east and from the west, from the north and from the south, while the continent has been so often crossed from sea to sea that a new journey of this sort fails to arouse more than a languid interest in a world grown very blasé since Livingstone's day.

The sources of the great river of Egypt are no more a secret. "Honor e Nilo" is no longer to be sought, and the lakes which the old geographer's had heard of are now laid down on the naps with more accuracy than were many European shcets of water a century ago. The Congo (p. 25) has been traced to its source, and nost of its great tributaries followed far into the primeval forest. The Niger course is known with almost equal accuracy, and Timbuctoo is so familiar a city that a French gunboat has anchored off its port, and a French railway is likely before long to divert its trade to a Frencl colony.

From Tripoli, and from Algeria sonthward, endless route-maps have enabled all the chief areas of the Sahara to be charted, and the negro kingdoms of the interior to be describer so carefully that Bornu, and Kianem, and Wadu, and Baghirmi, and Iake Chad, around which they lie, are to-day far better known than were Ashanti and Dahomey in the days when Barth and Nachtigal werc not. British colonists are at home in lands which were blanks on the maps of less than a century since, and on Lake Nyassa, discorered, or re-discovered, by Livingstone, there are not only mission stations, but steamers, and the trading posts of a large commercial company, and of several private adventurers, using the term in its older and better sense. The Victoria Nyanza, Tanganyika, and the Albcrt Nyanza are already, or will soon be, quite as inuch the ccntres of an incipient civilisation.
For the merchant and the missionary are there, and they are far up the Niger, and the Congo, and the Shiré, and Cardinal Lavigerie's militant order of nonks are advancing fron oasis to oasis into the very heart of the northern desert. The Congo and the Zambesi, the Rovuma and the Pungwe, are almost every day becoming more and more the high-roads of commcree. In short, Africa is waking up. 'The forcign slave trade is at an end, and though it is scarcely possible ever to entirely abolish that carried on in the interior, the efforts of the European Powers are likely to reduce it to a mininum. 'Twenty years ago, to use the words of Mr. Stanley in April, 1891, "England held sway over but. 330,000 miles. To-day her power extends over two and three-quarter millions of miles. Four hundred European officers are engaged in Westel'n Africa, 200 in Eastern Africa, and in South-Eastcrn Africa thcre are as many morc. They have flotillas of steamers on the lakes now ; even railways are rumning towards the spot where I found David Livingstone. Africa is six times larger than the continent of Europe, and it is time that its lands were explored and exploited for the benefit of civilisation. I saw, sixteen years ago, that the inhabitants themselves would never be able to bring their land to the state of civilisation which it ought to be brought to, and I felt then, when speaking for the first time to a powerful chief, like St. Augustine when he landed in Britain and told King Ethelbert of the truths he might find in the Gospcl. There are now fifty missionary stations in Africa sowing the seeds to which David Livingstone gave his life, and I doubt not that there are children listening to me who will live to hear the goor news that thcre are millions of Central Africans who have learned that stirring anthem, "Glory to God in the highest, peace on earth, and goodwill to men." ",

\section{Obsticles to African Colonisation.}

It will therefore be seen from the preceding pages that African exploration and settle- 
ment have suffered from climate and from ignorance rather than from poverty of the soil or from hostility of the natives. The north was already occupied by a valorous people, who resisted every attempt to share the land with any stranger. The middle region was hot and sickly. 'The south was far away, and the cooler plateans of the interior were unknown. The rivers were, for the tirst part of their course, bounded by malarious country fatal to the European constitution, and, when they began to drain healthier regions, were found to be impeded by cataracts which stopped navigation; while the unfriendly character of the natives increased as the sea was left behind.

But Australia, for most of the summer, is as hot as any part of Africa, and is infinitely poorer in resources, and much more distant from Europe, besides being without any great navigable rivers. Yet this remote country, the soil of which in 1792 claimed only a few hundred free settlers, is now the home of more than 4,000,000 people, and dotted with cities far superior to any in Africa.

North America was not colonised along the banks of its rivers, any more than South America owed much to the Orinoco, the Amazon, and the La Plata: and the savages disputed every foot-breadth of the soil with the advancing tide of immigration. Yet the United States, which in 1792 had not over five millions of whites, has now thirteen times as many. Central America is, over a large extent of its area, as pestilential as any part of Africa. Yct the progress of these feverravaged, volcano-harassed, earthquake-riven States has, in spite of civil war and bad government, bcen steady so far as population is concerned. Nevertheless, until well into this century, and, over a large area of its habitable portion, until very recently, Africa was almost left to itself, so far as European immigrants were concerned, a few traders on the coast and a few colonists in the south being the only white men within its bounds.

The truth seems to be that, just at the period when the longing eyes of Europe were being devoted to Africa, the vast discoveries in another part of the world withdrew in that direction the enterprise, the capital, and the courage which would doubtless have otherwise been bestowed on a continent nearer home. Spain and Portugal had been eagerly aggressive in Northern
The discovery of America the leading obstacle to the development of Africa.
Africa, and meditating great things on the eastern and western sides of the continent, when news came that a Genoese mariner had lit upon a fairer world on the other side of the Atlantic. At first the tidings aroused comparatively little attention. Even in Spain, the islands which were supposed to be the westcrn limits of India had so few attractions for the Lacklands of the Peninsula that the second expedition of Columbus had to be manned by galley-slaves. But this apathy was of short duration, as, year after year, every home-coming ship brought news, strange in itself, and stranger still as it passed in an exaggerated form from mouth to mouth, of the wealth of the country north and south of Hispaniola-of Mexico and Venezuela, Quito and Guiana, and the Golden City of Manoa, of the Pampas bordering the River of Silver, of the inconceivable riches of Peru-and by-and-by, in more sober language, of the good farminglands in Virginia and New England. Everything was novel, everything wonderful; nothing dull, nothing trite from long familiarity.

With these rivals to face, Africa and its "golden joys" ceased to attract the adventurers. America was now the field of fortune to which hied the soldudos and the swashbucklers, the condottieri who had survived the hangman, the mercenarics who had learned their trade under Sforza of Milan or har inherited the traditions of Fra Moreale and Francis of Carmagnola, with a swarm of ne'erdo-wells in peril of axe and rope, the Grand Inquisitor, or the debtors' prison. 'The gallants who a few years before had been dreaming of looting Fez with Dom Sebastian, or colonising Mozambique with Albuquerque, could think of nothing less than the golden sun of Cuzco or the turquoise masks of 
Mexico. Even the pirates, who had hitherto found Africa and the India-bound ships their richest prey, turned their prows to the West. 'Thus for ages the Black Continent was left to those not bold enough for the Indies or not fortunate enough to share in their plunder. Trade with it no doubt gradually grew up. Portuguese colonists (of a kind) were enticed to Angola and the opposite shore, and the mercantile settlements of various Powers, under the names of forts and factories, sweltered along the sultry shore of the Gulf of Guinea or braved malaria a little way up its ruvers.

But the Guinea Trade was for three centuries the shame and the ruin of Africa. For whatever else might be bought from or sold to the dusky folk, the staple merchandise was black men and women, dragged from their homes to toil as slaves in the plantations of the New World. Hence, the discovery of America had a double effect upon Afica, since it first attracted the enterprise of the colonists that would most likely have found an outlet there, and then, by raising tribe against tribe, turned the country into a desert, and prevented anything like legitimate trade. Most of the early physical olstacles to the colonisation of Africa have vanished, or have been diminished by the resources of science or by the progress of discovery. But thongh the European and American slave trade is now a thing of the past, the lounting and sale of men still continues for the supply of the native markets, and until this ceases Africa will not settle down to the arts of peace.

It was only when America no longer afforded an easy road to fortune, when hostile tariffis and rivals, where of old there had been customers, forced Europe to find new fields for her growing population and her surplus manufactures, that Africa began to receive the attention which four centuries ago it had first attracted.

What shape this assumed, what agencies were at work in the former development of the continent, what likelihood there is of their becoming important factors in the future, will be the theme of these volumes. We shall narrate this chequered tale sometimes by the hand of the explorers themselves, at other times from information supplied and revised by themselves or by those who took part in the work, and at all times from the most authentic materials.

\section{The Evolution of African Exploration.}

At first sight it might seem as if the exploration of Africa had been conducted without plan or system-that it was taken up and dropped, begun again at some new part, and as suddenly tried once more in cireumstances which appeared entirely unrelated to those which preceded it. To a certain extent this is true. The explorers who penetrated the continent in early days had no programme before them. They did not, like those under the auspices of the international scheme of recent years, work in co-operation, or with any mutual understanding. But in all history there is a motive at work, even when event follows event with the least semblance of law. And it is found that the universal law of evolution applies to the acts of men and nations quite as much as it does to the growth of plants and animals and the development of civilisation. Hence, in tracing the influences at work in opening up Africa, it is not difficult, for the purpose of study, to throw these into great groups.

An attempt has been made to classify the periods of African exploration * during the last century or so into two great The tendenepochs. The first of these is from cies of a 1788 to 1850 , when (ip to 1830) $\begin{aligned} & \text { century of } \\ & \text { African ex- }\end{aligned}$ the Niger problem was being solved plorations. by individual exploration, and the time after that date devoted to minor work in the Nile territories and in South Africa. The second epoch extends from 1850 to the present period, during which the explorations in Northern and Southern Equatorial Africa were connected with one another. Thus from 1850 to 1862 the Nile and Zambesi

\footnotetext{
* Supan's "Ein Jahrhundert der Afrika-Forschung" ; Petermann's Geographische Mittheilungen, vol. xxxiv.; and Silva White, "Development of Africa" (1890).
} 


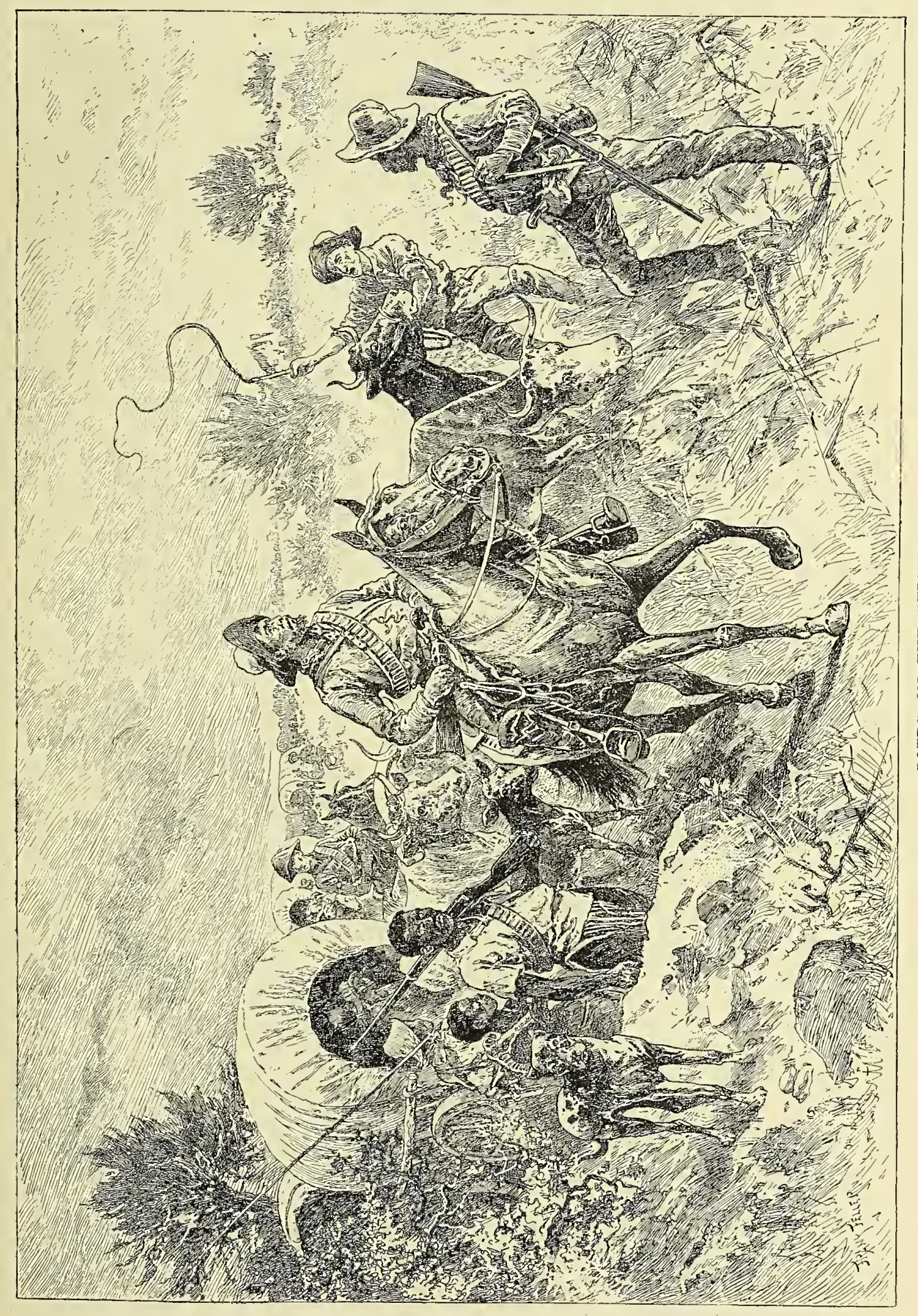


problems, and the geography of the Soudan and the Sahara, occupied a number of travellers. From 1862 to 1877 the Congo problem was the one which engrossed niost attention, and in the course of the journeys with that object in view the unknown lands between the eastern and western sides of Equatorial Africa were ransacked. Fronl the latter of these dates, all that has been left in the way of exploration has been to fill in details and extend colonisation in tropical and subtropical Africa.

Compared with what the men of twenty or thirty years ago had before them, there is now little actual new country to be mapped.

Still the African explorer need not sit down and weep, for if he has not a new world to Unexplored conquer, he has a widler expanse of Africa. unknown regions to bring within the ken of the chartographer than the men of last century thought fit to lay down upon their blank maps. 'The Sahara, for example; has never been systematically explored, our knowledge of it being obtained sinply from routes taken in various directions; so that there are still vast regions contiguous to the Soudan about which we know little, though it is not to be expected that such arid land has many secrets in store. Much of Morocco and the Marrocan Atlas is still not laid down on our maps. Back from the West Coast there are still many unvisited lands, and numbers of the Congo, and even of the Niger, tributaries, with the country between them, have still to be traced. The Liberians have done little to explore their "hinterland"; but before long the back countries of the French Congo and the German provinces in West Africa will be examined as completely as any in a continent where few regions are surveyed by any nieans more accurate than a rough reconnaissance. Even then, between the lines paced by travellers, much remains to be filled in ; while anything like an exhaustive inquiry into the resources or natural history of any area outside of Egypt, Algeria, Tunis, and the British colonies is unknown. This is the heritage of the Coming Man.
But the development of Africa lias not quite proceeded on the lines laid down by Dr. Supan. It has never been systematically explored, as might be inferrerl from his classification of the periods during, which speciai regions were ransacked, or particular geographical problems solver. Nor were those who opened it up always explorers by calling; they became so, in niany instmees, by accident. They were slavers, or pirates, or visionaries looking for Prester John. Yet if we study the story of the evolution of Africa from darkness to daylight, it will be seen that though one motive often overlaid another, and all of them were at times actively in operation, there have been from time to time certain great influences at work in opening up the continent. Occasionally one has been dropped in order to take up a second, and again resumed. Tet on the whole it will be found convenient to throw the history of African discovery under certain great heads or tendencies, these tendencies being, in not a few cases, not geographical at all, and set in action by traders who never stirred far from the coast, cared little for learning, and even, in some instances, kept the knowledge of its resources as much as possible to themselves.

The traders who established the earliest "factories" along the West African shore had, we may take it, as a class, little co coastdesire to add to geographical know- traders as ledge. But in search of gold, and explorers. ivory, and dye-woods, and of barbaric sultans, to whom, like Marlowe's wealthy Moor, pearls were like pebble-stones, some of them penetrated the rivers on the banks of which they had stationed themselves; or the necessity for their making friends with the black kings with whom they dealt led to embassies which added considerably to the knowledge of inner Africa. But these early pioneers were generally unlettered men, who did not think of preserving the records of their journeys, or if they did, reporter only to their principals in Europe, who generally carefully concealed the journals of which they became possessed, lest their rivals might profit by the information. 
To this day the same system holds good. The Oil River merchants kept what they knew out of print until concealment was no longer possible, and until Du Chaillu's time the Gaboon traders added little to the knowledge of African geography beyond the limits of their settlement.

But by-and-by competition on the coast abridged profits so severely that the more The seekers after Timbuctoo and the Upper Niger. enterprising merchants bethought them of tapping the interior by other means than through the middlemen by whom the produce of inner Africa reached the sea. Then came that longing to reach the Upper Niger and the city of Timbuctoo, about the magnitude and riches of which exaggerated tales had for ages been filtering to Europe through native reports. This longing led to a host of expeditions, first from the west, and then, when the feverish character of the rivermouths became notorious, from the healthier north. These expeditions became very earnest affairs about a century ago, when the African Association was founded, and have continued at intervals to our own day, though the original motive has ceased to operate in the same way. But the seekers after Timbuctoo and the Niger sources were the lineal descendants of the men who, in quest of slaves and ivory, plunder, and Prester John, first broke ground in West Africa. It is even permissible to believe that some of the gentlemen who sent Mungo Park on his expedition were not altogether disinterested, since several of them were directly concerned in what was then the staple branch of the "Guinea trade," and no doubt hoped that his explorations might enable them to advance that lucrative and, a century ago, most respectable line of commerce.

However, long before the Niger was heard of, and long after its headwaters had ceased

The seekers after the Nilesources. to be the primum mobile of African travel, the mystery of the Nile had aroused the attention of the workd, and led to a vast amount of exploration, which has ceased only within our own day. It was always the great African mystery.
It was directly due to these speculations that the East African lakes were discovered, and the course of African exploration diverted from the north and The East tion west to that side of the continent. lakes and For the Nile lakes of Aristotle and plorers.

Ptolemy were found in searching for a route more direct than that which followed the never-ending windings of the river of Egypt. These lakes having been discovered, and the populous native kingdoms on their banks brought to light, the ambition of Ismail Pasha (p. 32) to annex these regions was the beginning of a long train of miseries for Egypt, and a change in the fortunes of the Nile Valley, the end of which is not yet. Under the thin disguise of crushing the slave trade he established his officials far in the interior, and raised such animosities among the natives, that the insurrection of the Mahdi following rapidly upon the mutiny of the Army, due directly to discontent with the oppressive service entailed by these schemes of the Khedive, brought England into the Delta, and precipitated the lurid events which followed. To this far-reaching project of Ismail may be traced his own deposition, the death of Gordon, the loss of the Soudan, the occupation of Massowah by the Italians, and the protectorate of Abyssinia by the same power, the heroic stand of Emin Pacha, the transcontinental expedition of Stanley, which reseued him to so little purpose, and even the AngloGerman agreement, which resulted in Queen Victoria and Kaiser Wilhelm dividing up the greater part of Africa between them. This chapter, long though it has been, may not close for ages yet to come.

Meanwhile there had arrived, quietly at first, though not so peaceably afterwards, colonists to stay, instead of travellers to make a journey and return wh of Africa. whence they came, or traders intent on earning a fortume to spend anywhere than in Africa. But as long as the slave traffic was the staple business of Africa, colonisation in the strict sense of the term was unknown. The "factories" were simply forts, 
the governors of which exercised no control over the surrounding country, nor made themselves responsible either for the conduct of the natives or for their defence. But when territorial rights and Governments were established, our wars with the natives began, either in repelling the aggressions of neighbouring tribes, or in defending our colonists against the savages whom we had annexed. This

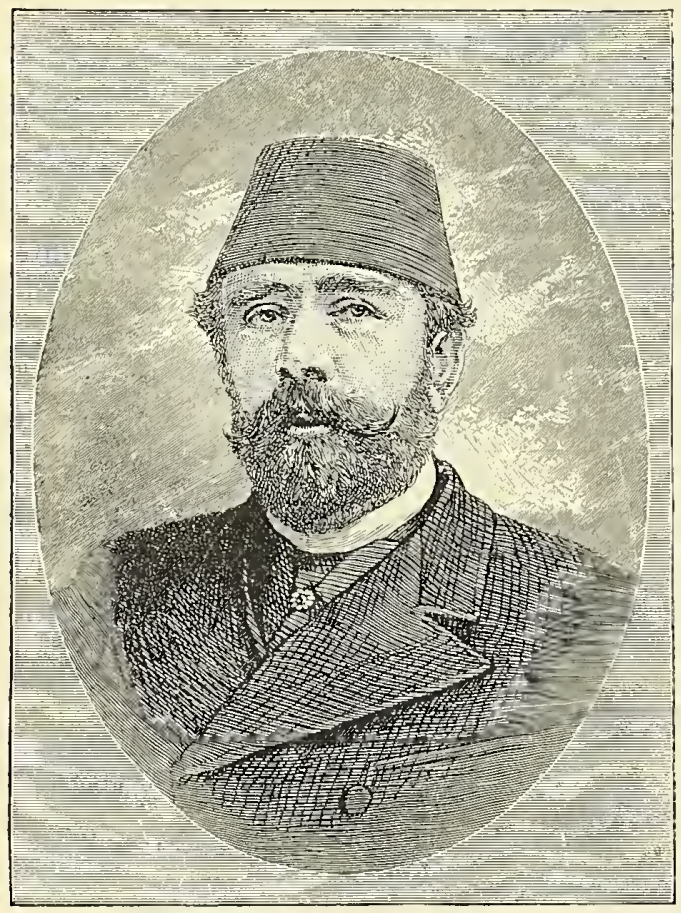

ISMAÏL PASHA, EX-KHEDIVE OF EGXPT.

introduced a long episode in the history of Africa, and led to many other developments in the opening up of the continent.

For the hunters who were attracted to South Africa by the immense swarms of elewhat the phants, lions, and other large game, hunters did pushed in pursuit of their quarry for Africa. far beyond the bounds of civilisation, and, when animals became scarce in these regions, wandered still further afield, until East Africa and the regions in the vicinity of the lakes were not unfamiliar to them. Their descriptions of these regions led colonists to venture thither, and the Boers, dissatisfied with British rule in the Cape, to found republics after their own way of thinking in what was then no man's land; their "trek," however (p. 29), was soon to be followed up by that of a more progressive race.

As Europe got ashamed of the wrong it had wrought Africa by encouraging the traffic in human beings, it endeavoured to The share make ainends by sending teachers of the misto the black people. These mission- sionaries in aries were for a long time the most Africa. active agents in adding to our knowledge of the country, one of them being the first Briton-if not the first European-to cross the continent, while his stimulus soon brought swarins of more professional explorers into the interior. 'The centres of civilisation they established attracted the better class of traders and woke up Europe to the horrors of the slave raids. "The expedition of Stanley "in search of "Livingstone-who was not "lost"drew attention to Tanganyika, and directly to the mission-fields lying ripe around that lake, while the next journey of the same explorer resulted in the missionaries going to Uganda, and to a great deal which will be best considered under succeeding sections. But while the missionaries have been important agents in opening up Africa, they have been innocent instruments in creating many of the disturbances between the whites and the natives, the Abyssinian war, among others, being traceable to the complications which their presence in the interior caused.

The crossers of the continent form a prominent class anıng African explorers. Livingstone was the tirst of them, or, at least, The the first who gave any tangible European account of his journey, and in a crossers of more or less direct manner he led tinent. to the expeditions which followed his, the wanderings of the great missionary proving the turning-point in the exploitation of the continent, just as the establishment of the African Association, in 1788, may be regarded as the initiation of African exploration in earnest. These transcontinental journeys have now ceased to be geographical wonders, 
but the results which followed their completion have been of an importance so great and so far-reaching that it is almost impossible to exaggerate them.

For they led, inter alia, to the scheme of several notable journeys were marle under its auspices, and a stimulus was imparted to the development of the continent which it has never lost during the years that have elapsed since the formation of this geographical league.

For out of this short-lived understanding arose the Congo Free State, which is still an experiinent, though one differing from that

The found. ing of the Congo Free state. which resulted in the forma- international exploration, each nation undertaking a special section, the travelThe era of international explorers. lers whom it despatched not overlapping the work of their colleagues, while the members of the Association were, theoretically at least, to be inspired by no motive less lofty than the desire to perform their task for the common good in the inost perfect manner possible. Practically dealing with a host of ambitious men, some of them incompetent, and most of them inexperienced, the result did not come quite up to the lofty standard fixed at Brussels. This Golden Age of African exploration lasted but a short period; for it left out of account that intangible entity called Human Nature. Still, tion of Liberia in so far that it is not adininistered by freed negroes, but by white men. Already, however, the decent pretence of independence has ceased; for as it was simply a philanthropic idea of the Belgian king, supported for years out of his privy purse, it has gradually become little less than a Belgian colony, governed entirely by Belgian officers. But though it is still from a commercial point of view a very moderate success, the stations that have been established on the banks of the Congo half across Africa have formed the basis from which an immense amount of exploration by its own officers and by missionaries has gone on, and is still proceeding. 
Another epoch in the history of savage Africa evolved itself out of this airy scheme, The since the jealousies which were scramble aroused by the necessities for fixing for Africa. the boundaries of the new province fired the ambition of States which had hitherto affected the rôle of disinterested philanthropists. But the self-denying clause in the compact by which the État Indépendant du Congo was established did not long interfere with the gratification of that earthhunger by which so many of the European nations were troubled. Then began that scramble for Africa which, after a sort of pandemonium of annexation, settled down quietly to a grave partition, according to mutual agreements, though not without frictions and occasionally graver misunderstandings.

The summary partition of "unappropriated" Africa-for the lords of the soil, who may The parti- yet have something to say, were tion of scantily consulted-led to the rise Africa. of the great commercial conpanies by which Africa is now to a large extent governed and exploited, if indeed the formation of these imitations of the medireval Association which acquired for England so many possessions beyond the seas did not actually necessitate the annexations in question. These joint-stock sovereigns are at this moment the most remarkable of all the modern developments of Africa, for though its earliest settlements were largely due to corporations such as these, until lately they have been regarded as abandoned in favour of direct control by the Crown. It is therefore with the formation of these guilds and their proceedings that we shall have last of all to deal. Already the diplomatic trouble africaunder they have caused, the expeditions companies. of discovery and "relief" which have been undertaken by officials acting on their behalf, the pioneer journeys by their agents, and the opening out of regions hitherto scarcely known even by name, call for a longer chapter in the history of Africa than many of those recording the events of centuries prior to 1884.

Under these headings-though possibly not always in the strict sequence indicated-it will be possible to find a place for most of the leading events which form the modern chronicles of a "continent" which is ceasing to be "dark." The narrative will, naturally, not be rigidly chronological. One series of events must at times necessarily overlap another, but, as arranged in these pages, the agencies at work in the development of a quarter of the world long left to itself will be better understood, and be less intricate, than if they were related after the usual historical fashion, as if they had occurred haphazard, without any law influencing their sequence.

And, last of all, after a table of dates in African history, we shall be in a position to cast the horoscope of the continent and its peoples, to venture as it were on some prophecy regarding the future of a land which it will take centuries to reclaim from saragedom, though the attempts made within the last fifty year's far outstrip in magnitude all that had been accomplished in the tive hundred that preceded them. 


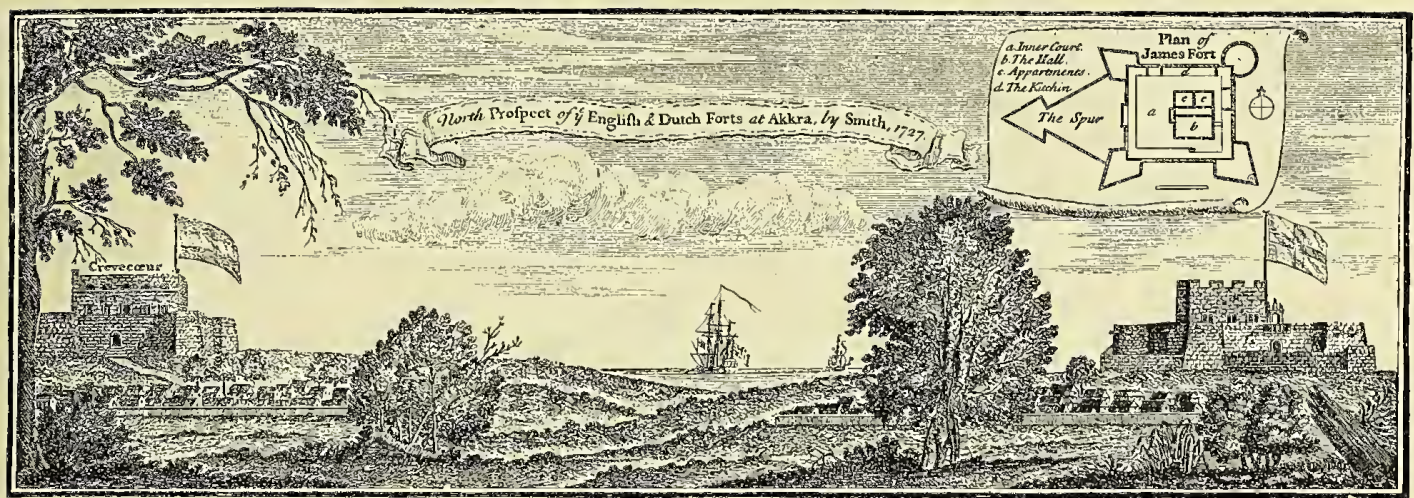

EXGLISH AXD DUTCH JORTS AT ACCRA, WITH A PLAN OF JAMES FORT. (Reduced Facsimile of an Old Print.)

CHAPTER II.

\section{The Guinea Coast and the Old Guinea Traders.}

The Rainfall of Africa Denoted by the Absence or Presence of Wcodland-The Bights and the Oil Rivers Delta-Description of its Principal Features-The Better Parts of Guinea-Climate of the Guinea CoastThe Romantic Days of Guinea-Old Divisions of the Guinea Coast-The Grain, Irory, Gold, and Slave Coasts-Their Leading Features and Productions-The Rise and Fall of the Chartered Companies of West Africa--The Normans-The Portuguese-The Dutch-The French-The English-Wars Betweel them and their Rivals-Various Companies and the Modifications in their Charters-The Danes-Their Period of Prosperity and their Forts-The Brandenburgers and the Hanseatic Merchants Try their Fortune in the Guinea-The War between the English Company and the Dutch-Its Decay-The Monopoly Thrown Open - The Imperial Government Takes Over its Posts-The Associations of West Africa-Struggle for its Trade-The Ruined Forts of the Gold Coast and what Caused their Ruin.

THE voyager who sails from the Strait of Gibraltar down the Atlantic shores of Africa The Guinea passes from a region of moderate, coast. through a zone of scant, until he comes within the tropics to a country of heavy rainfall. This is seen in the character of the vegetation. In $\mathrm{M}$ orocco, except on the scalps of the hills, and here and there in the valleys, timber is sparse, though before the Arabs cut it down there were, so Pliny tells us, great forests of oak, and of arrar,* and of argan, $\uparrow$ through which roamed herds of elephants, animals no longer found north of the Sahara. But a little farther south, in the province of Sus, for instance, there are years in which the clouds

* Callitris quadrivalvis-a cypress-like tree, the wood of which is held in such high esteem that it is not allowed to be exported.

$\uparrow$ Argania Sideroxylon, a tree confined to Morocco. An oil extracted from its nuts is extensively used in Moorish cookery. never burst, and famines are consequently frequent. The land here and for leagues beyond is parched and dry, and often desert, dotted with a few dates, and palmettocs, and prickly acacias, and roaned orer by nomadic tribesmen, half robbers, half herdsmen, whose beast of burden is the camel, and whose trade, when not reaping their scanty patches of grain, or pasturing their fat-tailed shcep, is war, or the plunder and enslavement of the hapless seamen who may be wrecked on their inhospitable coast. From the southern tcrmination of the empire of Sultan Iloulai el Hassan to close on the border of the French territory of Senegambia, the country is almost desert; it is the westward termination of that droughty Sahara which, under this or some other corresponding name, extends in one broad belt from the Atlantic to the Red Sea.

But from St. Louis southward to the Portuguese colonies we enter upon a wetter, a 
rieher, and a more unhealthy region. This is the Guinea of the old writers.* Its produets vary, like its elimates, in numerous partieulars, though, take it as a whole, the land, physieally, hygienically, and from an eeonomic point of view, is very similar. It is not attraetive at a distanee; but it is better to examine most of it from the offing than eloser at hand. All day long, as we sail and sail along it, we see little exeept a flat beach, ereeps into the sea, though even then the wooded banks and islets in its mouth eoneeal from the voyager this rift in the glistening sand and gleaming foam, whose hollow boom brings to the seaman many a memory of swamped boats and the ravenous sharks ever hovering in wait for sueh gruesome prey as frequent mishaps of this nature bring ready to their jaws. The shore is, indeed, often so low that the forest seems to rise out of the water,

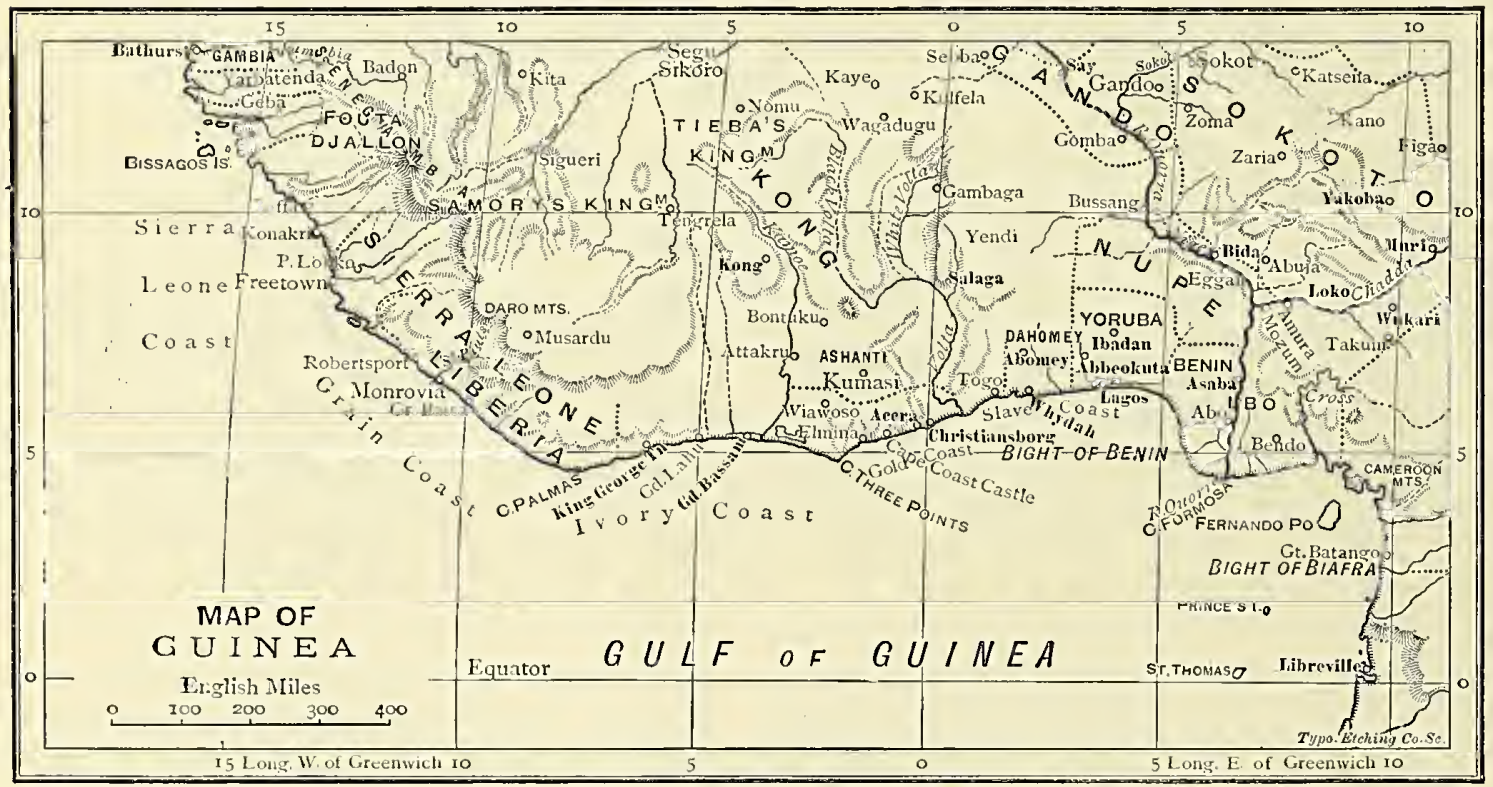

MAP OF GUINEA.

backed by a dense jungle, and still further in the interior, if the haze which hangs over it elears up a little, a mountain range whieh marks the western edge of the hilly plateaus that occupy the interior of the country. And on the yellow sand resounds the monotonous thud! thud! of the Atlantie (p. 37) breaking in a eurling wall of surf. There is seldom at gap in this long line of olive green, except where here and there a great river

\footnotetext{
* The origin of this comprehensive term is disputed. It may be from Ginahoa, the first negro region visited by the Portuguese ; from Ghana, the modern Kano; from the kingdom of Jennah, or Jenne, on the Upper Niger, or from Jenna, a coast town once of note, governed by a deputy of the "King " of Gambialand.
}

the tops of the trees being, at a little distance, the first indieations of the approach of land.

Here and there a solitary palm or eottonwood, a native village, or a whitewashed "faetory," a spot too poor even for the rank tropieal regetation, or a headland, marking, like Cape Verd, the point where a mountain spur reaches the oeean, relieves the sameness of the long leagues of woodland between the "Great Desert" to the north and the "Great Thirst Land" to the south of it. There are better bits and there are worse bits: and annong the latter are and the oi "the Bights," the insalubrity of whieh is celebrated in the doleful ditty already quoted (p. 18). For here the Niger and other 
rivers crawl seaward through a huge series of forest-covered deltas, formed by the mud brought down by their own waters. This area is either swamp or plain, the former predomin- beautiful disguise. It "hicles its foul breath with the sweetest of perfumes, and wears the smile of sunlight ever on its lips." But in the Delta, death, as if sure of its victims, throws
FLAT BEACH ON THE GUINEA COAST BACKED BY DEXSE JUX(†LE.

ating, and the soil a sticky black mud, extending over a region about as large as Ireland, intersected in every direction by lagoons and creeks and back-waters. Of all the sickly Bights these "Oil Rivers" are the most pestilent. In no part is fever to be avoided; but in some the malaria, as at Sierra Leone, puts on what a poetical traveller has called a

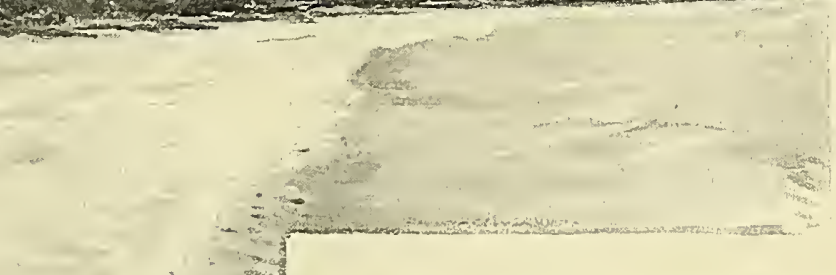

off the mask. "Once enter that gloomy land"-I am quoting the late Mr. Winwood Reade, a man whose great abilities the world is only now beginning to recognise - " and the impression can never be effaced. The rivers filthy as sewers; the slimy mud stinking in the sun; the loathsome crocodiles lying prone upon it, and showing their white bellies as they sullenly plunge into the stream; the foany, sharkhaunted bars; the hideous aspect of the people, whose bodies are usually covered with sores; the traders with their corpselike faces-all these can be remembered, but cannot be described." 
So mhealthy is this region that the English traders never live ashore, but in the hulks of old East Indiamen or Atlantic liners anchored in the rivers, and thatched over to serve at once for dwelling and shop and warehouse until "the owners" ships arrive from Liverpool to carry home the produee of their traffic with the natives (p. 33). There are, or were, whole hamlets of these hulks, the captains and oeeupants of whieh punished thieves and mutineers, appealing when need be to the British Commissioner, or his Tiee-Consuls, under whom the Oil Rivers were placed when they beeame a proteetorate of Great Britain, or to a gunboat when the negro "kings" intestine quarrels or proceedings grew intolerable. On every river there is one of these trader's' courts of arbitration: and, as the outlets of the Niger are numerous, there is no lack or justice of a kind. But the kind is not ehoiee, for the type of men who take up their homes in this depressing region are not the pick of their native land. It has been called "a refuge of reekless and despairing" Britons.

The mortality is large, no doubt, yet some seem to enjoy the life, such as it is. Wherever any dry land is found on the banks of the rivers there are established native towns, each with its "ling," who speaks broken English with a bad roeabulary, and is generally at loggerheads with some swamp sovereign farther up the stream, who has been interfering with his trade in palm-oil or kernels or canwood or ivory, blowing up his store of gumpowder, or helping himself to his rival's supply of wives. Opposite these villages the hulks are moored. Existence is monotonous in the extreme. There is little to go ashore for, nothing to stay on board for if business is not. brisk. A feeling of wearisomeness and depression takes possession of the oceupants, varied by bouts of fever, and sometimes of delirium tremens, whieh the muddy river and the banks of reeking ooze, and the interminable slimy mangrove swamps that fringe them, are not calculated to remove. The air is hot and foetid, and at night the deadly miasma " ereeps up from every creek, and gradually enfolds all objects in a damp white shroud; while the croaking of the bull-frogs, the ery of a night-bird, or the lapping of the restless tide against the side of the hulk, are the only sounds that break the oppressive silenee." Without work and the afternoon sea-breeze, and the hope inspired by the arrival of a mail, the Bonny or Old Calabar or Brass River trader would die of exhaustion. "If ever a man was justified in seeking consolation in the flowing bowl, it would be in these rivers, whieh used to be the haunt of the Palm Oil Ruffian, a ereature that would not have been tolerated even in Alsatia; but the genus is now rapidly dying out, and soon bids fair to be elassed with the Plesiosaurus and other extinct reptiles." So mueh for Colonel Ellis, on whom I prefer to put the responsibility of this uneomplimentary verdict, since it is understood there are optimists who have a good word to say even for Bonny and the Brass River and the "P. O. R."

Business here is largely done on eredit, and bad debts are so frequent that by the law of the Delta any member of a tribe is responsible for the liabilities of any other. Aecordingly, if the trader grows impatient, all he has to do is to seize the oil puneheons passing his hulk, and permit the owner to settle matters with the recalcitrant debtor. The coast tribes, a degraded but numerous race, are, for the most part, middlemen, aeting as intermediaries between the whites and the interior natives, though little by little this system has broken down, and will soon be permitted only when the convenience of the trader renders it advisable. For, in spite of its unhealthiness - an unhealthiness whieh only affects the whites - the Oil Rivers are among the most thickly populated and wealthiest parts of Western Africa. Many of the chiefs have beeome rieh men out of direet traffie, eommissions on the transactions of their people, and the presents or "dashes" of the traders who live amongst them-there being a regular series of gifts or this kind payable to the potentate in question. All of the Delta is a vast natural plantation 
of oil-paln!s, " from which is extracted some 60,000 tons of the yellow grease used in making the best qualities of English soaps, candles, and pomades, just as the French ones are compounded of the oil of the ground nut, $\uparrow$ which, in like manner, is the chief export of the countries bordering the Senegal and Gambia farther north. And from it also, there is no scandal in remarking, a good deal of the "finest salad oil" is extracted, though, as a substitute for the olive, this humble vegetable, the "pea-nut" of America, is being' run very closely by cotton-seed. So enormous, indeed, is the trade in palm-oil that the amount exported from the Niger Delta equals, if it does not surpass, in value, all the other commodities sent to the civilised world from the British, French, and Portuguese settlements. Yet at the beginning of the century the entire export of it from Africa did not exceed two hundred tons; for at that date little except slaves was shipped from this region, which came to be called the Oil Rivers. At that time Bonny, which now contributes 16,000 tons, exported 16,000 slaves.

All Guinea is, however, not so barl as the Niger Delta. Some portions of it are even

\section{The better} parts of Guinea. moderately enjoyable to those who do not find the "seasoning fevers" unbearable. Gambia is little better than the region described; but Senegambia is reasonably healthy, and St. Louis, for West Africa, is a pleasant town. Sierra Leone bears an evil name among those who know only Sierra Tueone. All manner of facetious tales are current regarding the fatal atmosphere " of the white man's grave"-how it takes three governors "to work it," one dead, one acting, and a third on his way out; how when a fresh official inquired as to his pension, he was told by the Colonial Office clerks that there was no precedent for any retiring allowance, "no one having ever lived to claim it," $\ddagger$ and so forth.

* Ela is guincensis, a species peculiar to West Africa, from whence it has been introduced into the West Indies. + Arachis hypogaca.

This tale attaches also to the Consulate of the Bights, and, no doubt, to many other places besides.
And undeniably the cemetery of Freetown, and, still more patently, the Whitehall records, are painfully suggestive of there being some substratum of truth in these well-worn legends of the " charnel-house."

Lagos also is not accounted quite a sanatorium (p.41). But Lagos, in spite of its terrible bar, inpassable for weeks at a time, is almost an approach to a European town. Even some of the native towns are passable so far as pestilence is concerned. Between Accra and the Niger the country, like that on the Upper Gambia and Senegal, is open, with busy villages, large markets, and plains waving with corn and cotton. Abbeokuta is indeed a walled "city," twenty miles round; and Whydah, the port of Dahomey, though now a decaying place, its quondam importance being due to the slave trade, bears the remains of former briskness in the different forts and warehouses belonging to merchants of many nationalities. Cape Coast Castle (p. 40), Anamaboe, Dixcove, Accra (p. 35), Elmina, and a number of smaller stations, are, or were, places of commercial importance, and, of course, vastly superior to the Delta of the Nile; for they are villages with, in several instances, substantially built forts, and in most cases a permanent garrison of the West India Regiments.

But though they differ in degrees of grandeur, as well as in degree of unhealthiness, none of them are desirable places of residence from a sanitary point the Guinea of view. Everywhere the day is Coast. extremely hot, but the nights are cool, and the decaying regetation and stagnant water render nalarious fever of constant occurrence. The year on the windward coast is divicled into rainy and dry seasons. The rain, when it does fall, pours for from twelve to thirty hours without ceasing, while the pervading wet lasts at Sierra Leone for about four months, between the end of May and the beginning of September. But the rains advance from south to north, not leginning at Sierra Leone until they are over in the Bights, and not reaching Senegal until six or eight weeks after they have been deluging Sierra 
Leone. Tornadoes are frequent during four or five months in the year; yet, except for the damage they do, are not prejudicial to health. The harmattan- "the doctor" of the parboiled European-is a dry, cool, north-east wind, which withers trees, kills tender plants, splits doors and window-shutters, removes the veneer on furniture, and bends back the boards of books as if they had been exposed to the fire. The body is also affected. The eyes, lips, nostrils, and throat feel dry and uneasy, and by-and-by the skin begins to peel off. Nevertheless, as the thermometer falls ten or twelve degrees, Europeans welcome it with all these disadvantages; and even the natives, ,who complain of its coolness, admit that it cures old ulcers and skin diseases, interrupts the progress of epidemics, such as dysentery, small-pox, and ague, and renders the body less susceptible to infection. As long as it of living in the vapour-bath known as the Guinea Coast.

Of this abundance of vapour any book which has done service on the well-marked region here sketched (p. 36) bears ample proof. No part of the continent is good for literature. Even Northern Africa is for some months in the year apt to be wettish, and the Sahara, like the droughts common to the south of the Portuguese territory, destroys a volume by reason of the dry heat to which it is subjected. But in Guinea the covers soon fall off, cracked and shrivelled by the harmattan, mildewed by the rains, nibbled by cockroaches or devoured by white ants. It is even said-so Mr. Reade affirms-that the leaves become depositories of disease germs, infecting the reader as he turns them over like the poisoned manuscripts of the "Arabian Nights." A musty smell arises from books or

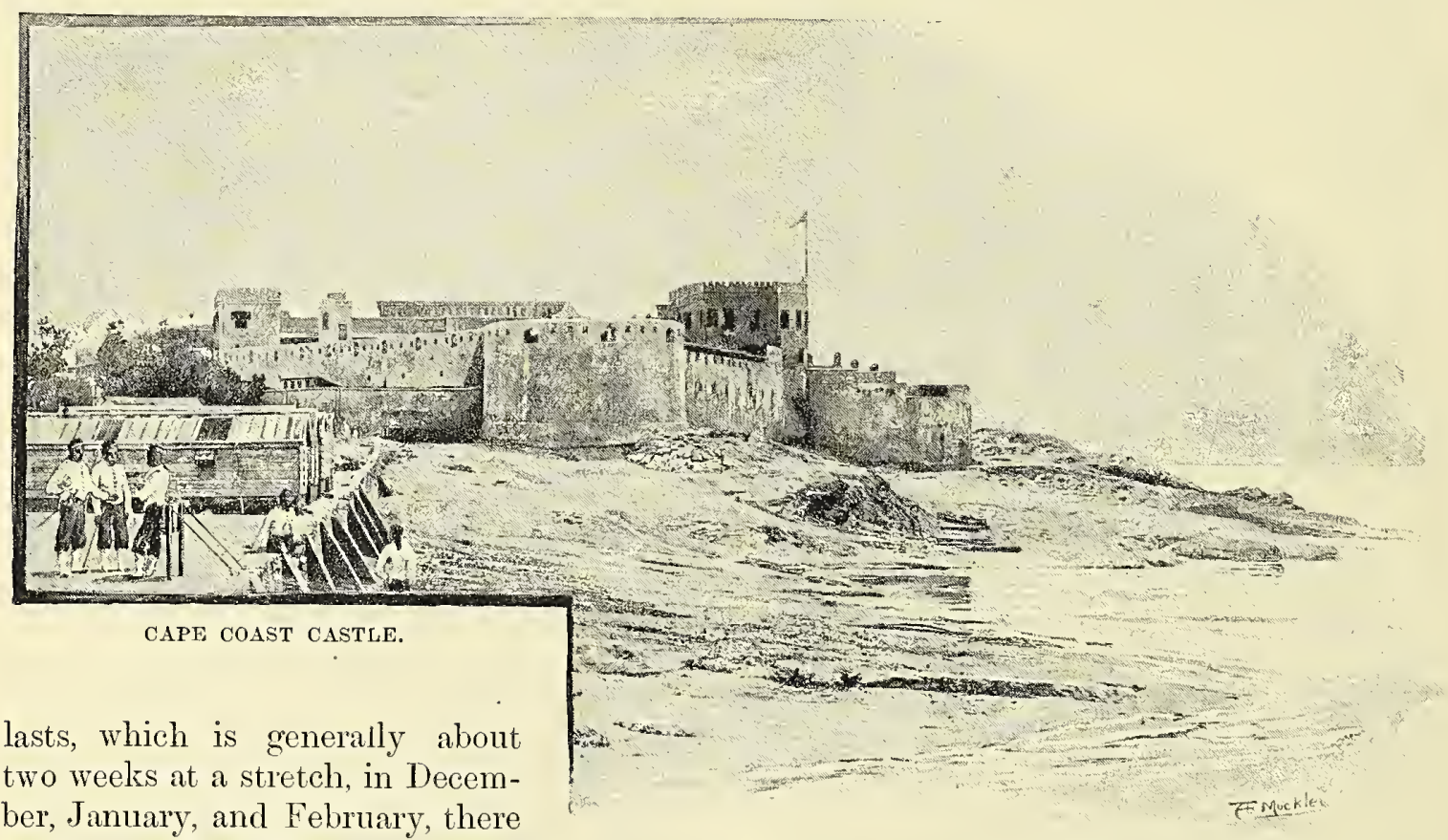
is not the least dew or moisture in the air, though a kind of haze, obscuring the sun, moon, and stars, accompanies it, this atmospheric condition being in marked contrast to the copious dampness which at other periods of the year adds to the discomforts

clothes that have been long in the tropics. This, say the theorists, is due to the invisible fungus spores that produce the swamp fever. In like manner, a room long unopened, or a bed not recently aired, or the virgin soil 


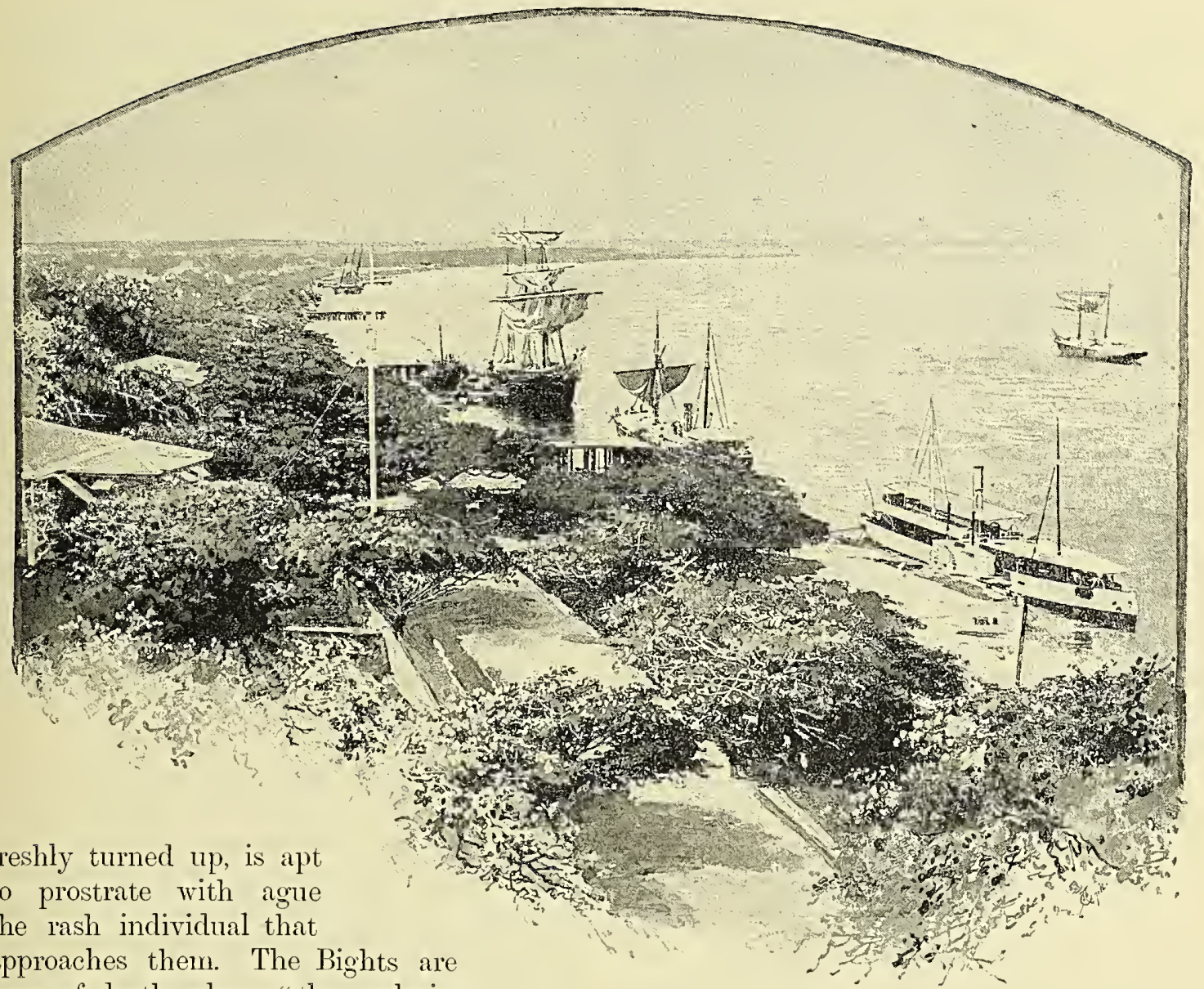

dens of death where "the malaria,

like a wild beast, slceps through the

LAGOS.

day. But when night descends, and

the bright sun has disappeared, it arises from its secret places and steals along the river-shore, and floats on the land-breeze to the vessels that arc lying in the roads, and winds its way up the mountain, and creeps into the town, and through the windows that are open, to many a swinging hammock, to many a bedside. Sleep, sweet sleep, in England the restorer, is in Africa a peril and a snare."

For no matter how Guinea differs-and its tribes are varied in their habits, their tongues, their customs, their faiths, their degrees of faithlessness, and their origin, just as their products are not the same throughout the enormous stretch of coast which goes under that name-it has this characteristic in common. It is all malarious. It is a traveller tells us, who has been "down" again and again with fever in almost every portion of it, uniformly bad; though there are, no doubt, districts in other tropical and semi-tropical countries quite as unhealthy as any part of Western Africa. From the Senegal River to Jittle Fish Bay, from the Desert of the Hoors to the Desert of the Hottentots, from latitude $15^{\circ} \mathrm{N}$. to latitude $15^{\circ}$ S. $-a$ sinuous coastline of several thousand miles-there is not a cubic inch of air which is not in the nighttime impregnated with malaria. No European resident escapes the fever, and even the natives suffer from it, though in a less degree. For a time he may imagine he is to be the favoured exception to the gencral rule. He may for days, and possibly weeks, feel. 
perfectly well, and even be charmed with the elimate. But one day, when he is least expecting the visitation, it arrives, first in the eold, then in the hot, stage, until a burst of perspiration relieves him, and, it may be, "cuts" the fever: However, the chances are it will eome back again and again; when, if the patient or his friends be wise, he will leave "the coast," to save the little life the demon has left within him. For every repetition of this exaggerated form of ague leaves the body weaker, and more liable to other diseases, if it does not, as it sometimes does, create eomplaints of its own. No regularity of life ean savc the most provident of men from it. Temperanee is essential, but total abstinence is no safeguard. Busy men, with plenty of work to do and plenty of internal resourees to fall baek upon, enjoy the nearest approach to immunity, and, eontrary to the general impression, fair men, men of what is called the sanguine temperament, are usually better able to bear up against it and the lassitude, lack of elastieity and buoyaney that eat into the vitals of every individual who lives long enough to enjoy the humble distinction of being an "old coaster." None, however, eseape-not even at Aeera, now eomparatively healthy. Few white women, happily, live on this shore. To them maternity is too often death, and they are peeuliarly constituted if they long retain their beauty, and their ehildren are exceptional if they do not wither and die like the tender bud under the blast of the desert siroceo.

West Africa is prosaic enough now. It is all divided into eolonies, to which no eolonists The roman- eome, ruled by regulation govertic days of nors, and the common type of Guinea. Colonial Office clerks, who issue ycarly reports, and squabble with the black Britons for whose benefit this machinery is kept going, and at intervals appear at the Colonial Institute with papers descriptive of the "boundless resources" of the swamps for which they are officially bound to do the best. They have even been known to say something for the climate, ${ }^{*}$ and there is a ease on record in whieh an Irish governor served two terms by choiee at Sierra Leone, and would have taken a third had not a post been found for him to whieh the suspicion of bureaueratie homicide might not so readily attach.

There are now no fortunes to be made here, either honestly or, as some of the earlier ones were earned. not quite so honestly. The official can hope to save little money, and promotion, beyond a eertain point, is slow. For "if a man can bear the elimate and the Liberated Africans, the Colonial Office appreciates these rare and rhinoceros-like qualities too well to transfer them to another sphere." The days of mercantile venturing also arc past. Fortunes are more readily lost than won upon the coast; the trade is regular, the competition is severe, and the profits are depressingly small.

How the traders live, and the plaeemen work, how the eolonies took their modern shape, and what their value is to their present possessors, will form the theme of a later section of this book. We have in the meantime to deal with an earlier, a more romantic, a more stirring, and, it must be admitted, a less respeetable period in the history of the colmtry.

For vile though this region is, "the spirit of man "ineluded, dread though the pests of fever and mosquitoes are at all times-the worm, whieh bores under the skin when the wayfarer least suspeets mischief, ring-worm, elephantiasis, eraw-eraw, and the million insect plagues that make life barely worth living-this portion of the eontinent was the seene of the earliest of African explorations.

* On the 13th of May, 1874, Lord Carnarvon, on the strength of some such minute as this, informed the House of Lords that the Gold Coast was as healthy as London, and more so than many English towns. His august audience took this astounding statement very placidly. But the region in question has not yet quite recovered this cer. tificate of character. Yet the invalid who, after his tenth or twelfth fever, is carried on board the homeward-bound steamer, feels that official flattery and Colonia! Office ignolance are no guarantee against malaria. 
Here the first African voyagers touched. On this shore the pioneers of the mediæval African traders settled. It was in Guinea where the Europeans took their first grasp of the soil of Africa south of the Atlas, where they obtained those crude ideas of the continent which for three centuries they con1municated to their countrymen in the shape that Lieuteriant Pistol enunciated them to Justice Shallow and his guests.

For the soil, fatal though it is in places, and sickly everywhere, is rich in all the vegetable products of the tropics. It is so amazingly fertile that Sierra Leone ought to supply all England with tropical products. The baobab, the palm, the cocoanut, the orange, the lemon, the locust-tree, the shea or butter-tree, the coffee-shrub, the nutmeg, and the cimnanion, are easily grown. Maize and millet, and rice and yams, liola nuts ard earth nuts, are abundant. The oil-pahn yields its welcome grease along almost the entire coast, and down the rivers that intersect its dark forests come ebony and canl-wood, gum-arabic from the interior, ivory tusks hewn out of the skulls of elephants slain in the jungles around their head-waters, and the still more precious gold-dust, from which were coined the pieces that for nearly two centuries circulated under the name of "guineas," this title and the elephant stamped upon them denoting the region whence the metal of which they were Divisions of made had come (p.50). The names Guinea.
The Grain applied to the different parts of the coast. country expressed roughly the products for which each portion was most notable. Thus the northern portion is known as the Grain Coast. For here was traded the Attare, Malaguetta pepper, or Grains of Paradise, the pungent aromatic seeds of a plant belonging to the ginger order.* Until the better condiment of the East drove it out of the market,

* Amomum Grana Paradisi. The name Guinea pepper is, however, also applied to the berries of the capsicum, to the dried fruits of Cubebs, and to the seeds of IIcbzelia athiopica. Malaguetta is a corruption of the native "Emaneghetha"; Grains of Paradise is the name given to the first specimens brought to Italy by the Moors. towards the close of the eighteenth century, it was extensively used, under the name of Guinea pepper, to flavour food. It is still employed in veterinary practice, and at one time was still more widely in demand to increase the pungency of fermented liquors, bad gin being made drinkable by virtue of the Grains of Paradise infused into it.

South of this region is the Irory Coast, the Tand Kust, or Tooth Coast, of the Dutch, which extended beyond the Rio da The Ivory Sueirio Costa of the Portuguese. Coast. The Dutch furthermore divided it into the country of the good and the country of the bad people, the boundary between them being the Boutry River. But in reality none of them were anything but indifferent, a verdict admitted by the fact that all the trade was carried on on board the ships, or if on shorc, with great precaution, the natives, after the Normans quitted the land, objecting to have any European settlements in their country. Farther south is the Gold Coast, rne Gold being the best-known and the most coast. affected by Europeans of any part of Guinea, and south of this, on the other side The slave of the Tolta, lies the Slave Coast, Coast. But whether grain, or ivory, or gold, or negroes were the staple of these regions, which still bear the old names, slaves were the most lucrative of the commodities obtained from all of them. It was mainly for the convenience of purchasing "servants," at first for any part of the world, and latterly altogether for the plantations in America, that the coast became dotted with the forts and factories of different European nations. These merchants were in no way Government officials. All the recognition given them by the Home Powers was a charter of incorporation, certain privileges in the way of exclusive trading, and occasionally remission of duties upon their imported goods and exported stores. It was an age of private enterprise, when one company of merchants laid hold of India, and another became the owners of a large section of North America. In time, the authority passed out of the hands of the African 
merchants just as it passed out of those of the Indian and the Hudson Bay Companies, and the factories became the Government Houses of colonies, and the trader's who gathered into the growing towns around them merely artisans and shopkeepers, payers of rates and taxes.

That, however, was not the notion when the merchants of Dieppe and Rouen established

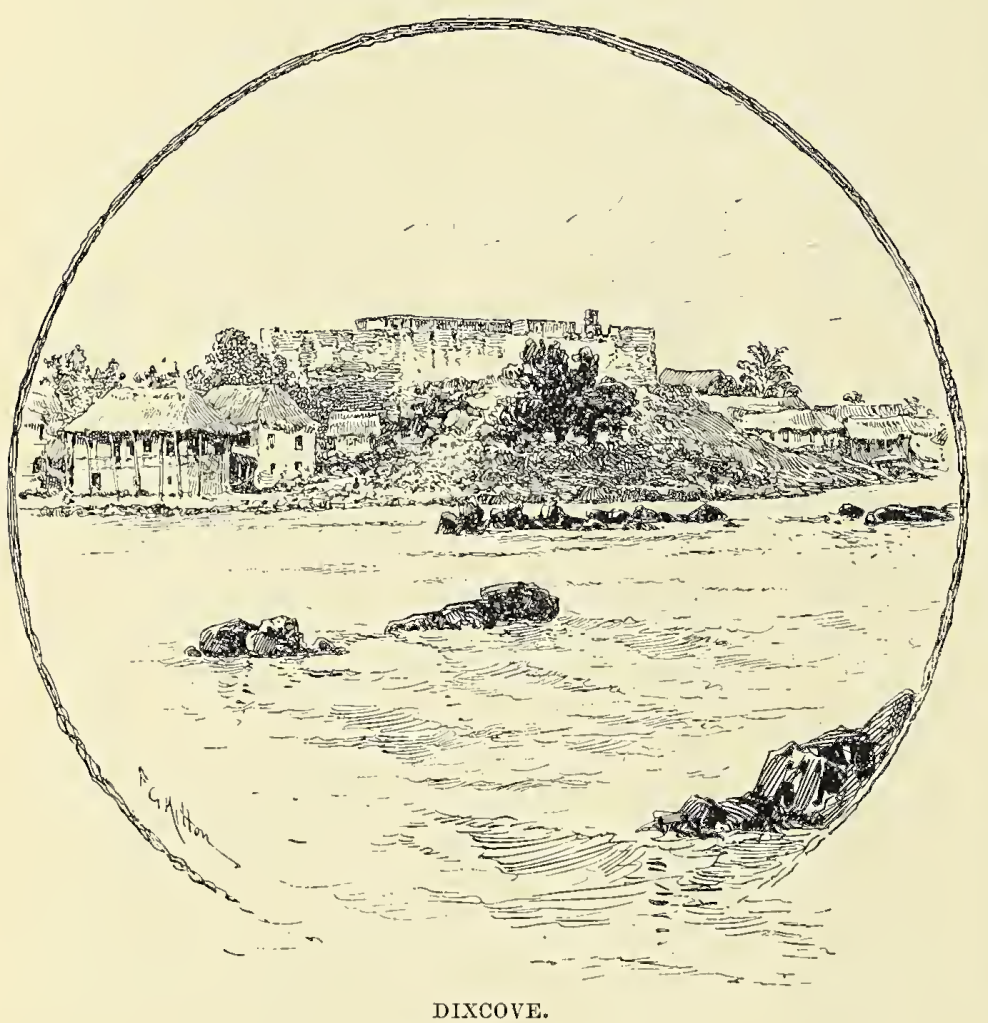

DIXCOVE.

themselves early in the fourteenth century on the Senegal River and along the shores of West Africa as far as Sierra The rise fall of Leone, built Littlc Paris and Little the chartered Dieppe on the Grain Coast, exWest Africa. tended their posts to La Nine The Normans. d'Or in 1382, and to Accra, Kormantin, and elsewhere as trade grew brisker, until they became wcalthy out of honest traffic in gold and ivory and Guinea pepper. But the part the Dukes of Normandy took in the civil wars of France succeeding the unhappy death of Charles VI. in 14.22 fell so heavily on the commerce of Africa that from that day it began to decline, until at the end of the sixteenth century none of the many Norman forts remained, except that in the Senegal, which afterwards became the nucleus of the town of St. Louis. Meanwhile the Portuguese, Dutch, English, and Spaniards took advantage of the failing energies of their rivals to push their own business in the same region. The first-named, had, indeed, never abandoned their clain to be the dis. coverers of this coast, and they were undoubtedly the first people who ever attempted to found in Western Africa anything worthy the name of colonies.

The earliest appearance of the "Portugals" in that capacity was in 1465. The PortuIn the coursc of guess.

a few years they built one fort on the island of Arguin, another on the site of the old Norman settlement (remains of which can still be traced), re-named St. George del Mina, and extended their posts southwards until they founded Saó Paolo de Loango, in what is still the colony of Angola, where by-andby we shall visit, them, if, peradventure, Angola by that time still owns Dom Carlos for its lord. Under the favour of Pope Martin V., who granted to the Portuguese the right of seizing and confiscating all the property. of infidels for the good of their souls, according at the samc time a plenary indulgence for the benefit of all who might perish in such pious cnterprises, the Lusitanians throve amazingly until a chartered company was formed with a monopoly of all the trade on the Gold Coast. Axim was speedily the site of a fort, and then 


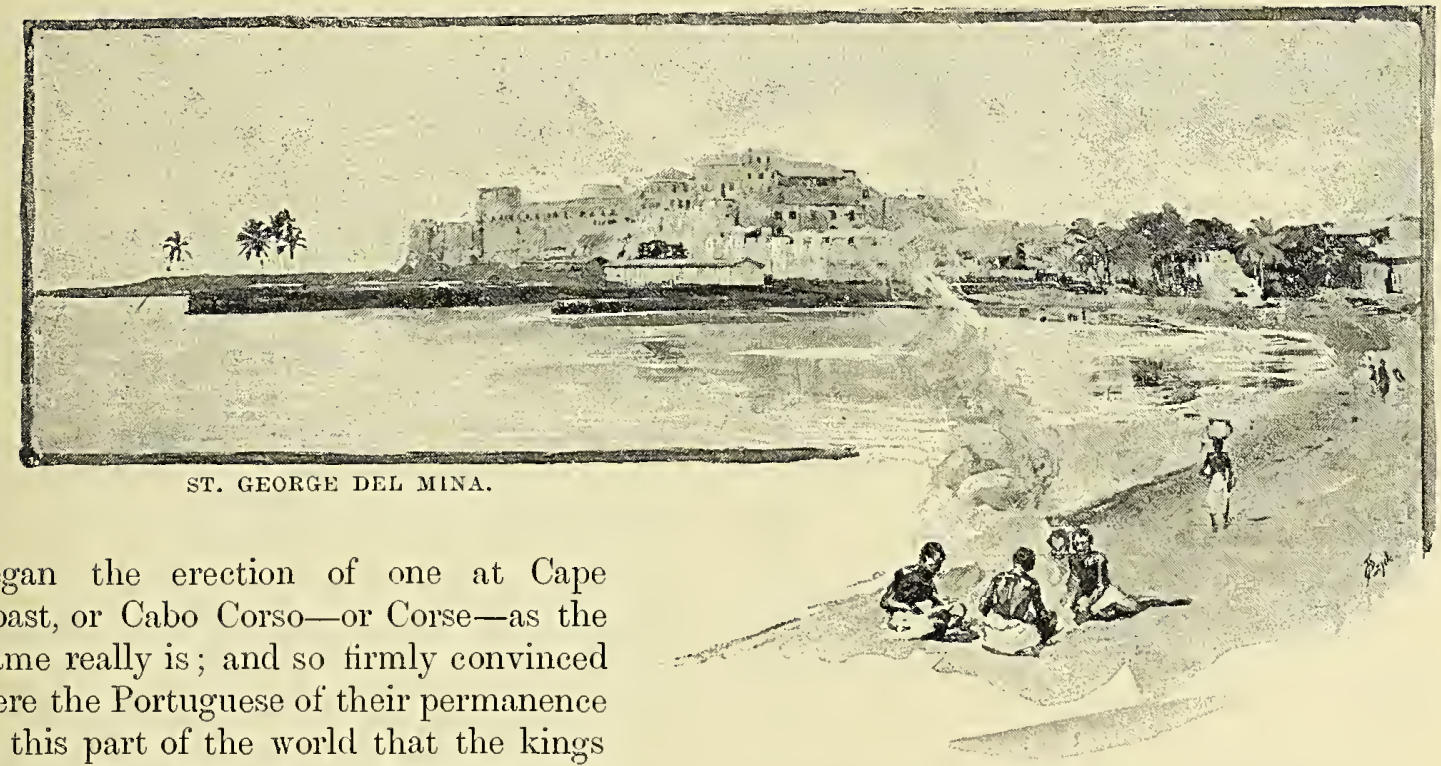
in this part of the work that the kings of " Lords of Guinea and of the navigation and commerce of Ethiopia."

But Nemesis was waiting them in the shape of the Dutch, who, in spite of every effort to The Dutch. displace them, built a fort at "Cabo Corso," and, aided by the natives, whom the cruelty and avarice of the Portuguese had outraged, ousted the latter from the Castle of St. George, which is now more familiarly known as Cape Coast. The latter then retired to the island of St. Thomas, and soon began to take a secondary place on the shores of Guinea. But from that day until 1871, when they ceded to Britain the last of their posts, the Hollanders were one of the chief peoples in that part of the world.
Meanwhile the French had again begun to assert themselves and regain possession of some of their old posts. The merchants of Dieppe and Rouen, finding, for the reasons already noted, their trade The French. no longer so profitable, sold their last remaining establishment to what was called the West India Company, who, however, used this privilege so badly that in 1673 the king was forced to assign their charter to a new association confined in its operations to the country between Cape Blanco and Sierra Leone, the monopoly of trading southwards to the Cape of Good Hope being accorded to another company. But their affairs soon falling into disorder, a fourth African or Sanaga (Senegal) Company

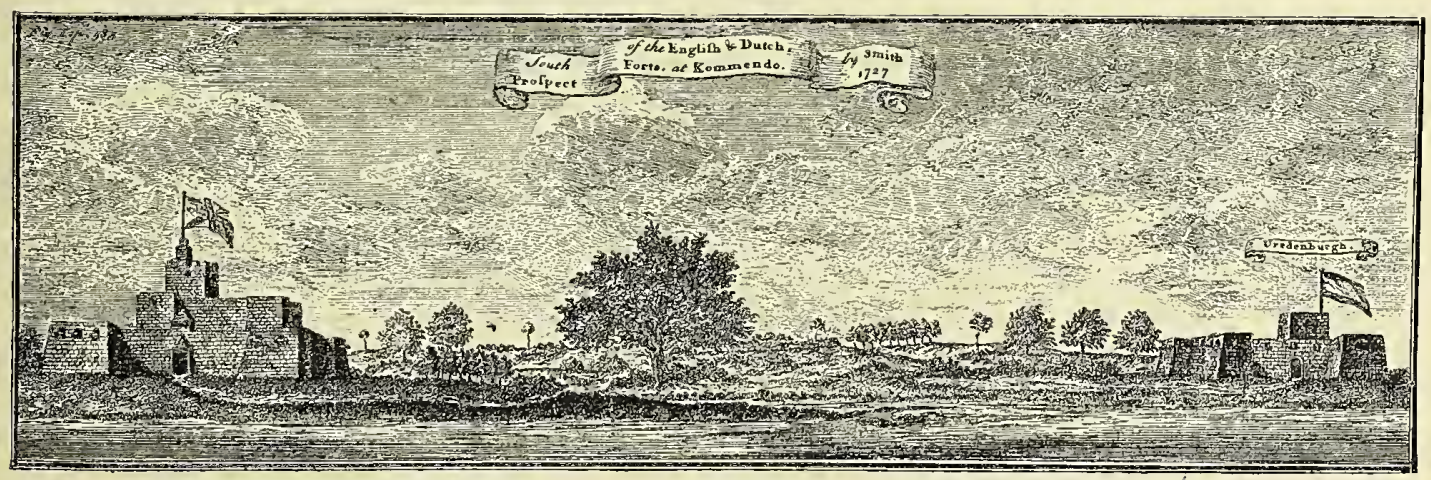

EXGLISH AND DUTCH FORTS AT KOMMEXDAH. (Reduced Facsimile of an oul Print.) 
took over their enterprise. This society, in its turn being no more successful than its predeeessor's, was in 1709 reconstructed by certain Rouen merchants as the Fifth Sanaga Company, which eight years later disposed of their possessions to the New West India or Mississippi Company, one of the many sehemes emanating from the fertile brain of John Law. After various other ehanges, the British captured St. Louis and Senegal in 1758, and liept possession of them for twenty years, until by the peaee of 1783 they were confirmed in the ownership, though at a later date they were again made over to their former owners. The Gum Company and the Senegal Company were two others of the French Proprietary Associations, though in 1791 , being badly organised, the last of them was abolished by a deeree of the Constituent Assembly, and the country gradually put under the direet control of the Central Government, though during the wars that followed the Freneh forts frequently ehanged hands. Thus Gorce was captured by the British in 1800, and was wrested from them in 1804; it again fell into their possession, but was restored at the general peaee in 1815 . Sinee that date it has been permitted to remain undisturbed, and is now a St. Louis on a small seale. Its citadel is mueh stronger than anything of the kind that Britain has on the West Coast: but its elimate is infamous-yellow fever and smallpox being almost yearly visitants, plus the ordinary maladies of the country. Worse still, the establishment of Dakar on the mainland (Goree is an island) is threatening the prosperity of the place. It may be added that it was during the temporary British ownership (in 1782) that Governor Wall caused three soldiers of the Royal Afriean Corps (many of whom were bad eharaeters drafted from other regiments) to be flogged to death-an excess of discipline, earried out without a eourtmartial, or acquainting the Home Government, for whieh he was executed in 1802 .

'The English trade with the Guinea Coast was, like all these great enterprises, begun by independent merehant adventurers, sailing out of English and other ports at their own risk and charges. We know that they were so engaged in the reigns of Edward TI., Mary, and Elizabeth, and, the The English. British Colonies having as yet no need of negro labour, the ships bartered only for gold, ivory, Guinea pepper, and the like, though, as the Portuguese captured them when they could, eonfiscating the vessels and cargoes without the least ground for redress, the masterful merchants ran no small peril in playing the part of "interlopers." However, their ehanee came by-and-by. War breaking out between England and Spain and Portugal, Queen Elizabeth granted a eharter to a eompany of merchants to trade to this region; this eharter, as usual, prohibiting all of her subjects not included in it from sharing in the monopoly thus deereed. In 1585 and 1588 she issued two patents. The first was to eertain London adventurers traffieking to Moroeco and the other Barbary States, and the seeond to the English merehants who had on their own account been trying to obtain some of the profit made by the traffie along the African shore "between the Sanaga and the Ganbra" (p. ]).* In 1592 their efforts had proved so sneeessful that she chartered a new association for exploiting the coast from "the River Nonnieat to the south of Sierra Leone."

But either the trade had deeayed or the traders had proved unequal to the tasks they undertook: for in the sixteenth year of James I.'s reign a new monopoly was decreed to Sir Robert Rieh and other eitizens of London, to take up and extend the commerce dropped by their predecessors. But this company were so injured by interlopers-private individuals, who defied them and their charter, and sold more eheaply than could the faetors of the eharterers, with their heavy expenses in the way of forts and garrisons, and, we may be sure, in "gratifications" to greedy courtiers - which in time grew to be known as "palm-oil"- that they soon abandoned the privileges aceorded them. However, about

\footnotetext{
* The Senegal and the Gambia.

† Nunez or Nougnos.
} 
this period the Dutch success in cutting out the Portuguese fired the enterprising traders of the Thames with hopes of undermining both, so that in the seventh year of Charles I.'s reign he was induced to accord to Nicholas Crisp and his associates a new charter of the same nature as those which had preceded it. Under the Commonwealth this monopoly was renewed, though, in the confusion of the times, the Dutch (and the Danes also, who had by this time entered upon the scene) had taken the opportunity to recover much of their lost ground, and to enlarge and strengthen their forts, so that the Englishmen-both those concerned in the monopolyand the private traders, or interlopers-fell upon evil days. Their factories were taken and burnt, their goods pillaged, and their ships seized so frequently by the enemy, that in the course of a few years

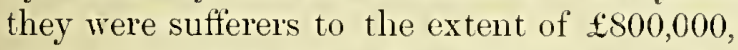
an enormous sum when the value of money at that date is taken into consideration.

Parliament, thereupon, in 1664, addressed Charles II., begging him to support the African trade, and "check the insolence of the Dutch." His remonstrances at the Hague having no effect, the first Dutch $\mathrm{W}_{\text {ar }}$ followed as a final protest against this and other wrongs suffered at the Hollanders' hands. But the hostilities that ensued did little for the Guinea inen generally, and least of all for the new "Company of Royal Adventurers of England Trading to Africa," which the king had chartered two years after his restoration, with power to do their best fron the Strait of Gibraltar, in the north, to the Cape of Good Hope, in the south. For the infant association had to settle accounts with De Ruyter, whose fleet took Kormantin Castle and Takorary Fort, ${ }^{*}$ and seized the Company's vessels and effects to the value of

* This place often changed hands; English, Dutch, Brandenburgers. Swedes (during a faint attempt to gain a footing on the coast), and Danes having had their turns of it. The English, according to the Dutch. obtained possession of it in 1665 by clandestine means (which is likely enough), though even after De Ruyter had recaptured it, its old masters suffered reverses. At the date of Bosman's narrative (1700) it had been abandoned. and the town burnt by the Adomese.
$£ 200,000$. The English, on their part, captured, among other places, Forts Witsen, Secondee and Cape Coast Castle, though they were not long permitted to retain these posts, Cape Coast Castle being the only stronghold that successfully resisted the attack of De Ruyter. The London Adventurers, nevertheless, kept their footing in Africa, and when peace came in 1667 each side, it was stipulated, was to be restored to the places it possessed before the war. By virtue of this article the Dutch West India Company kept possession of the British fort at Kommantin and the British Cape Coast Castle, which they had retaken from the Dutch before the war actually broke out. During the irregular hostilities that preceded that first arbitrament of arms, Kormantin had, in like manner, been captured by De Ruyter, "by the assistance of the natives of one of the adjacent countries, who had been bribed by the Dutch general at Elmina," though their power to effect this was a fatal knowledge to impart to the natives, for some years later it was carried by assault from the Ashantis.

The stipulation as to recession, nevertheless, came too late to be of much use to the British. The three years had crippled them beyond the power of any treaty to heal the wounds inflicted. Accordingly, they were glad enough, in the hope of saving further loss, to accept a sum of money in consideration of their surrendering into the hands of the Crown their briefly enjoyed charter. This was duly made over by letters patent to the Royal African Company, which for seventy-eight years, $\uparrow$ greatly to their own profit, and not a little to the benefit of England, were virtual rulers of the parts of West Africa not held by any other Power, though then, as subsequently, the Crown accepted no responsibility for the acts of its subjects, permitting them to make their own bargains with the native chiefs. From the piratical port of Sallee in Northern Morocco to the southern part of the continent this new association of adventurers had all the privileges which their charter + Namely, from 1672 to 1750 . 
could grant and their rivals allow, and carried on their operations with such vigour, so far as Guinea was concerned, that, beginning with Cape Coast Castle, the only portion of their predecessors' possessions left them to buy,* they had forts or factories at Accra, Dixcove, Winnebah, Secondee, Kommendah, and Anamaboe-all on the Gold Coast, and three of them within musketshot of the Dutch strongholds. The Danes The Danes. had by this time Christiansborg, Fredericksborg, and Quittah along the same shore. Then the new company purchased and built a fort at Whydah, now the seaport of the King of Dahomey, but at that time a part of the Savi territory, so that very speedily the British trade on the Guinea Coast was superior to that of every other nation except the Dutch.

The traders of that nation lost no oppor- goodwill of the natives for permission to make the settlements mentioned, as well as for transporting from England the soldiers, mechanics, provisions, arms, ammunition, and other necessaries for holding and protecting these fortified settlements, difficulties not rendered any the less by the long war which ensued with France.

Yet, in spite of all this hazard and anxiety, the Company followed up their projects so energetically that they were soon regarded as the only rivals of the Dutch, and, so far as the volume of their trade was concerned, their equals in every respect. Every year they inported some seventy thousand pounds' worth of woollen goods, and other British manufactures, and the slave trade having by this time grown to vast dimensions, they supplied the Amcrican colonies with great numbers of negroes, at a moderate rate, and in so

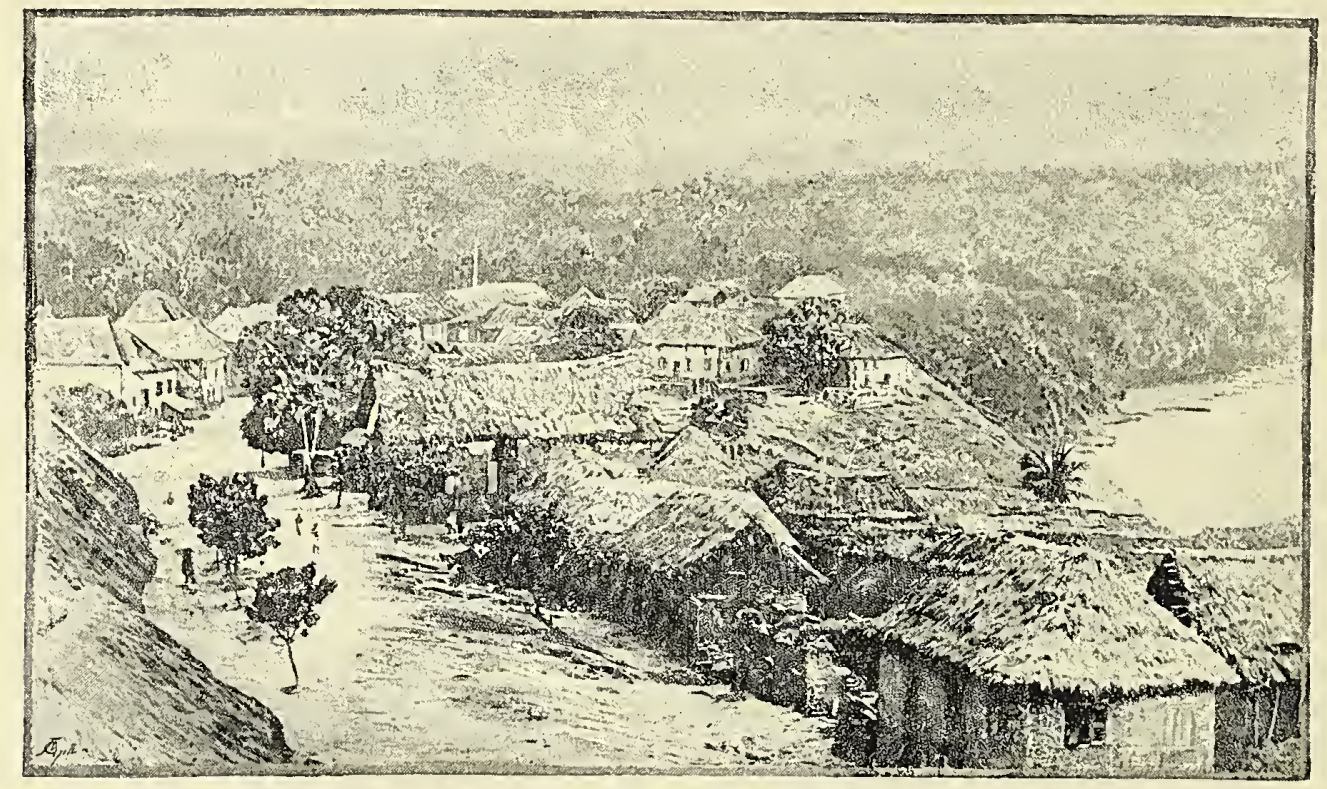

SECONDEE TOWN.

tunity of annoying the new-comers. Indeed, open hostilities often ensued, and ended not without bloodshed on each side. Tast expenses were incurred in purchasing the

\footnotetext{
* -They paid $\$ 34,000$ for it, and made it six times larger, stronger, and more commodious than before.
}

encouraging a manner, that they sometimes trusted the planters to the vahue of one hundred thousand pounds, and upwards, till they could conveniently pay it. Then they also exported vast quantities of red wood, elephants' tusks, and the like, besides such a 
quantity of gold-dust that they frequently coined* from thirty to forty thousand guineas at a time, which pieces, from the elephant below the king's head, were-and are still_ known as "elephant guineas" (p. 50).

On the north eoast, where opposition was
Hope; the Senegal Company, whieh had hitherto enjoyed a monopoly of the whole of West Afriea, as has been seen (p. 45), being: eonfined to the region between the river

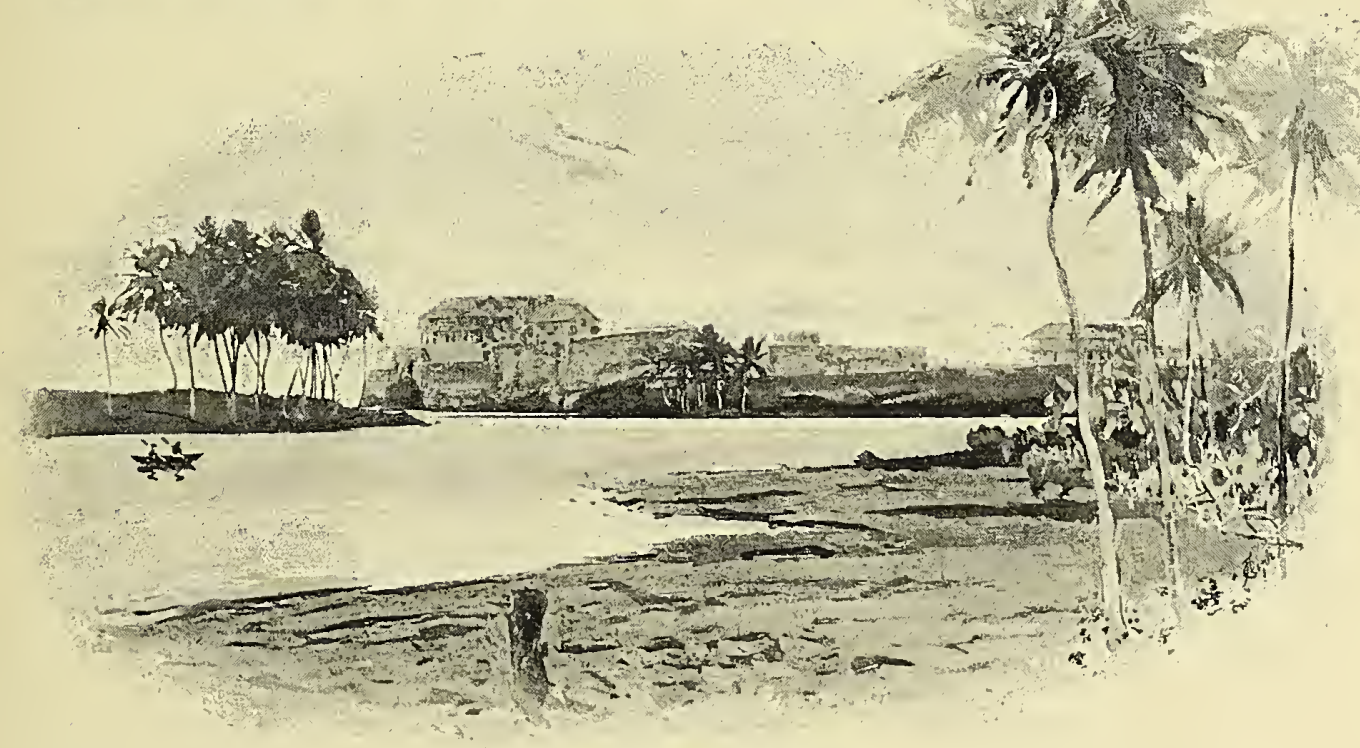

CHRISTIANSBORG CASTLE.

less keen, the Company, it might have been imagined, would have met with even more sueeess. But this was not the case. The Duteh were in possession of Arguin and Goree; the Senegal Company-a French monopoly established in 1673-held the sunall fort of St. Louis, on an island within the bar of the Senegal River; and the Royal Afriean Company had one establishment (St. James Fort) in the Gambia River and another on the River Sierra Leone. For some years the stutus quo was permitted to remam undisturbed-the companies of each nation trading freely to all the places on the coast not in the aetual provinee of the other. But in 1677 and 1678 the Freneh eaptured the Dutch forts of Arguin and Goree, and had their ownership eonfiseated by the Treaty of Nimeguen. About the same period a French Guinea Company was given the trade of the coast from Sierra Leone to the Cape of Good mentioned and Cape Blaneo. The contrat for supplying slaves to the Spanish West Indies being transferred to Great Britain, this new company got into such finaneial diffieulties that their monopoly was withdrawn, and the trade of that part of Africa hitherto in their hands was laid open to all the French king's subjeets. This eontinued from 1716 to 1720 .

The Senegal Company were inore aggressive, claiming the sole privilege of trading from Cape Blaneo to the River Gambia, a distance of about five hundred miles, and they rhe Brandwould fain, as early as 1681, have enburgers. prevented the English company from doing business on that part of the coast. But not then being strong enough to contest this point, they eontented theinselves with merely seizing and confiseating ships belonging to the Portuguese, Duteh, and Prussians, or "Brandenburgers," the latter of whom had begun to ereep out of the Baltie in the hope 
of picking up a few of the crumbs of this lucrative branch of commerce. Then, in 1685, they renewed their claims against the English company, and continued to harass them at all points until, as we have seen, war broke out between the two countries in the year 1690. This war, which seriously hampered the Senegal Company, almost ruined its rivals. Ship after ship, fort after fort, had been captured and destroyed, and the worst of all its calamity was that in 1695 a squadron of French privateers plundered the English post in the Gambia, and then razed it to the ground. To add to these misfortumes, when piping times of peace arriver the hapless

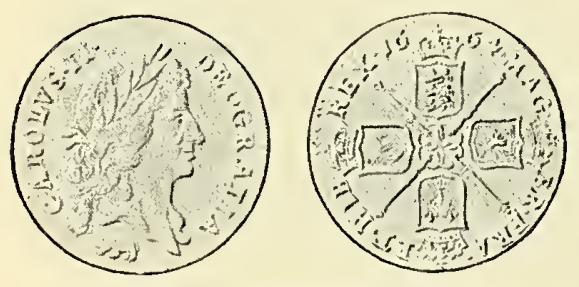

ELEPHANT GUINEA.

Royal African Company found the French settled in that river and claining an equal share with themselves of the trade which had hitherto been theirs alone.

Finally, Parliament decreed that, in order the better to extend the African trade, it should for fourteen years-from the 24 th of June, 1698, to the 24th of June, 1712 -be thrown open to all comers, the Royal African Company, in consideration of their keeping up the forts and castles on the coast, being permitted to exact ten per cent. duty on all goods imported into the country throughout which they had up to that date a commercial monopoly. On the expiration of this Act it was renewed, though the Company still continued the chief traders in the country, the situation of their posts giving them an arlvantage over the private traders. Yet the latter, being able to work at less expense, undersold them in the Anerican slave trade, and were in consequence unscrupulously opposed by those who were still the virtual ruler's of the region.
The African Company, on the other hand, complained loudly that the import duties dir not cover one half of the cost they had been put to in maintaining the forts and their garrisons. Then the gold trade decayed, and the price of slaves rose to so extravagant a figure that the Company wereoften in such financial difficulties that the directors obtained from Parliament, in $1730, £ 10,000$ to enable them to pay their way, which subsidy, ostensibly for the support of the forts and factories deened essential for the protection of the trade, was, with a few exceptions, continued every year until 1752, when the corporation was dissolved and their possessions were rested in a new company.

Henceforward the trade was declared free and open, and, in compensation for the loss of the import duties of ten per cent., Parliament agreed to an amnual grant of $£ 10,000$ for the maintenance of the castles which figure so frequently in this narrative, and still bulk so largely on the Guinea Coast. The African Company as merchants carried on their business after the old fashion. They were not monopolists, but, like the Hudson Bay Company when their charter was taken away, or the East India Company when interlopers were permitted, they managed to make a very fair profit out of their bargain with the Government. At that time they had about a dozen forts, castles, and settlements scattered along the coast, or rather more than all other European nations had amongst them. But their rivalry with their neighbours continued as bitter as ever, and fighting was not unfrequent with the Dutch, the English as a rule having the best of the contests, which lasted until peace was restored in 1782. Meanwhile, under various pretexts, the Company had been continuous in its applications for Government money. From 1750 to 1807 it received on an average $£ 1: 3,500$ a year, and from the latter year to 1821 this subsidy rose to an annulal giant of about $£ 23,000$.

But in the interval the association was expiring. Competition had abridged its gains, and the impossibility of the slave trade being any longer openly pursued, without other 
sources of gain being developed, made it only too willing to retire from so profitless a shore.

And so it came to pass, in 1821, that the Imperial Government took over the Company's forts and settlements, only Cape Coast, Anamaboe, Dixcove, and Accra being retained as fortified places. The rest were permitted to fall into decay. Then came the colonial era of the Guinea Coast, the story of which will afford material for a future chapter in the history of the development of Africa. In course of time the Dutch and the English forts had got rather mixed up--so many had been captured and deserted and repossessed, and so many more had been built in the course of the hot rivalry of former years to intercept each other's trade or to share in it. Thus in Accra (p. 35) there were actually two Governments: the Dutch in what is now called Ussher Town, and the English in James Town, each Government having its own fort. And as the English levied duties upon imported goods, and the Dutch did not, the squabbles over smuggling were as frequent as they were wellfounded. Meanwhile the Dutch and Danes abandoned their hold on this part of the world with patriotic reluctance. Little by little, and occasionally, as in the case of the Cape of Good Hope, in huge lumps at a time, their territories beyond the sea had been leaving them. But in 1868 the Hollanders agreed to all places to the east of a line drawn from the Sweet River (near Ehnina) to the Ashanti frontier being abandoned to Great Britain, while all to the west of that boundary were to be handed over to Holland. What these were need not be recalled. It was a bad arrangement at best, and was not carried out without hostile demonstrations by the natives, instigated, it is believed, by the officials whose occupation was gone when the pestilential spots which they had administered on the slenderest of salaries were surrendered to England. Accordingly, it did not work well, and in 1872 came to an end, when all the remaining Dutch posts and lands in West Africa were bartered to Great Britain for certain equivalents in the Malay Archipelago.
As for the Danes, they had recognised the inevitable long before that year ; for in 1850 , Christiansbor'g at Accra, and the fort of Quittah, which they had held for the best part of two centuries, were sold to Great Britain, who then-for the Brandenburgers, like the Hanseatic merchants and the fainthearted Swedes, had long given up the attempt to keep their footing-divided with France and Portugal in a small way the ownership of that intertropical region of which the Lusitanian sovereigns still describe themselves as the lords. All the Gold Coast was England'sshe had ousted or bartered ont every rival.

Whether so feverish a land was, even in the era of its greatest prosperity, worth struggling for, or is, now that its best days are gone, worth retaining, are questions the consideration of which must be reserved until a later period. What we are at present interested in learning is that it was here that Europe first laid hold of Africa, and as the Portuguese territories on the east coast never were anything but colonies in name, and even in Lisbon were not mentioned with pricle, it was from this region that Europe first obtained its ideas of Africa, ideas which have mischievously influenced the civilisation of the continent for three centuries, and even yet are not eradicater from the popular corpus of inherited impressions.

It was from this death-rlealing shore that the earliest of African explorations started, and the shore to which so many travellers never returned. Hence tions of it was accepted as a typical, instead WestAfrica. of an exceptional portion of the continent. This reason alone ought to be our excuse for dwelling at some length upon the early traders of this shore. But it is impossible to underderstand much of what followed without being aware of the beginnings of African exploitation and exploration, the struggles of the rival nations for a share of Pistol's "golden joys," the evil deeds wrought by the traffic in ivory and men, and the courage, the enterprise, the persistency with which English merchants clung to the establishments which they had 
for'ned in one of the least inviting parts of the world. For it was in this way-in good and in evil, but always by self-reliance and foresight-that Englishmen did their country's business in far-away lands. The Afriean traders on a small seale, though the beginnings of the one were as large as those of the others, were simply what the East India Company and the Hudson Bay Company were in other parts of the globe. And it is not a little curious to see that, so far as Africa is eoncerned, Englishmen are returning after three eenturies to the fashion in whieh they began. They are developing it by eompanies, ehartered, eneouraged, protected no doubt, supported, it may be, by the Imperial Government, but still simply, in their initiative, assoeiations of traders who venture their money for the glory of their native land, it is to be hoped, but primarily, we may take it, for the filling of their own poekets.

The history of the Guinea eompanies, whieh

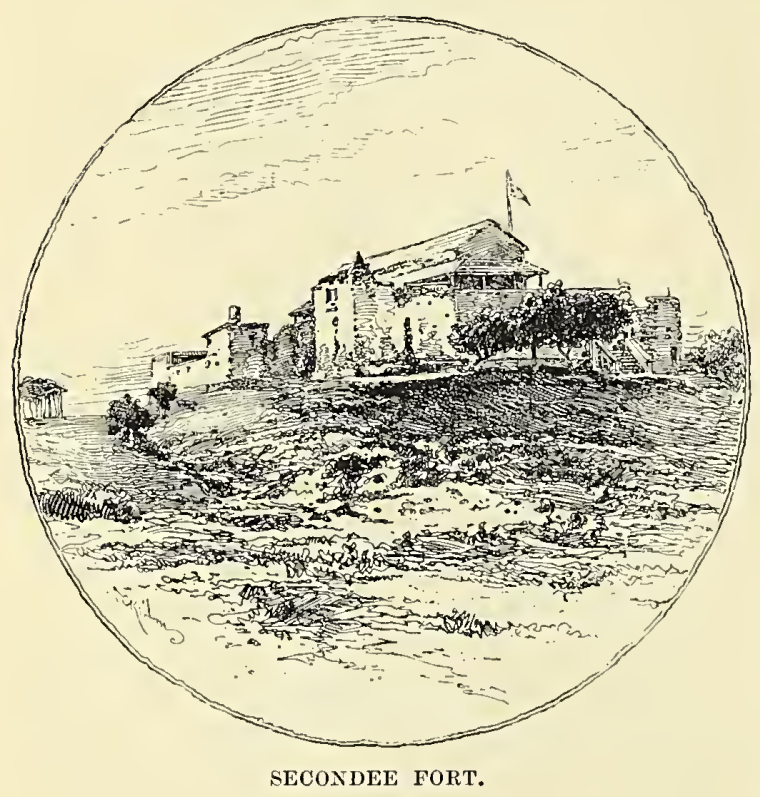

we have traced, affords preeedents for what The pre- has been done and is doing. It cedents of
the Guinea the Guinea roeks upon whieh some of its sueeessor's, separated by so many ages, may split.
It is, indeed, almost pathetie to read of the eagerness with which different nations struggled for the trade of Guinea. Up to the time of the Revolution,* the French Afriean Company was allowed an exemption from all duties on merehandise exported to Afriea, and from half the customs on all goods imported from Africa, and on all American produets bought with the priee given for African negroes sold there. The Guinea traders, moreover, were freed from tolls of any kind on their goods passing through France, were entitled to a bounty of thirteen livres on every bondman carried across the Atlantic, and a bounty of twenty livres on every eight ounces of gold-dust brought into Franee.

In like manner, the thriftier States-General of Holland allowed the Dutch West India Company (for so the African assoeiation was called) the following "extraordinary aids and immunities. It was entitled to a subsidy of thirty-eight thousand florins per annum, a duty of three per cent. on all merehandise exported to and imported from any place between Newfoundland and Florida, a duty of two per cent. on goods exported to or imported from any place on the continent of America, from Florida to the Orinoco River, inelud. ing Curaçoa-these pereentages amounting to something like one hundred thousand florins per annum. The patient Dutchmen were moreover entitled to a duty of five guelders per last on all ships trading to Cuba, Hispaniola, Jamaiea, Puerto Rieo, and the other West India Islands, or to any plaee from the Orinoco to the Straits of Magellan, and "from thenee to the Straits of Annian," + computed at thrce thousand florins a year. Then there were the "clear profits of the

* Actually up to the year 1786 , when the Senegal Company, by a decree in Council, were ordered to pay $260, \pi 4$ ? livres in defrayment of the colonial expenses, though, in addition to many other privileges, they were granted the exclusive right of the slave trade.

+ A mythical strait connecting the Atlantic and Pacific, said to have been discovered in about the 58th or 60 th parallel of $\mathrm{S}$. latitude by Gaspar de Cortereal. It was in reality an exaggerated account of the Strait of Juan de Fuca, explored nearly three centuries later. 


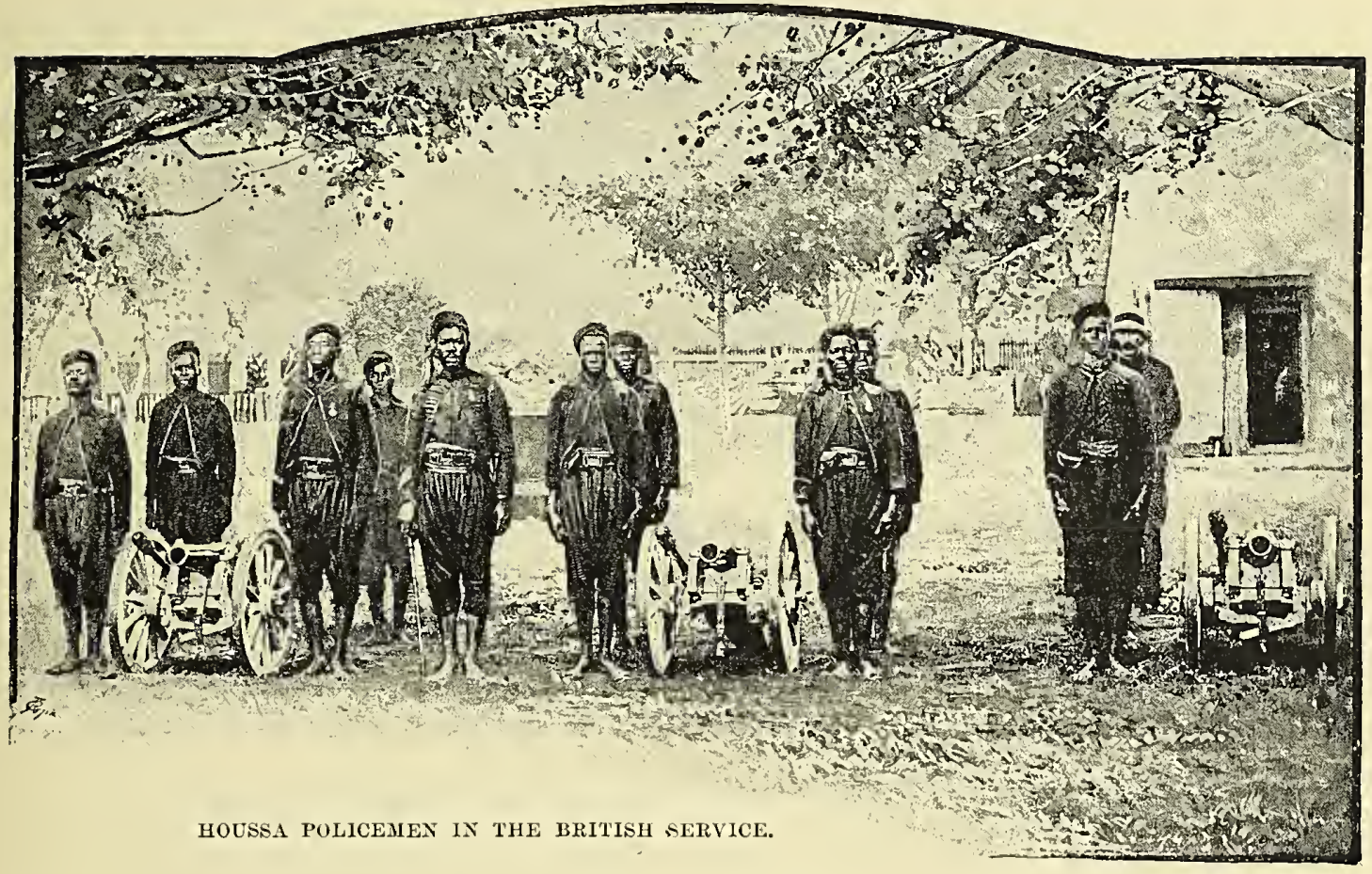

colony of Isscape," considered equal to twenty thousand florins; one-third of the net income of the colony of Surinam, estimated at six thousand florins, and all the profits arising from the captures and licences which they were authorised to make upon or grant to such Portuguese ships as came for slaves, a perquisite worth at least ten thousand florins per annum. In short, the Dutch Company received as subsidies-one year with another -two hundred and seventy-one thousand six

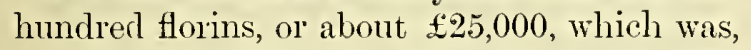
of course, in addition to the enormous profits which were for many years made out of their trading operations. Hence, the Parliamentary grants made to the English companies, over which econonists now wax indignant, were absolutely necessary to prevent England's tentative hold of the West African shore from being prematurely released.

All this is, however, a tale of the past. The ruined There are still plenty of traders forts of the in West Afica, some the agents Gold Coast. of firms, some on their own account, and many the representatives of companies. But they have no special privileges, and no forts, or castles, or factories which can in the remotest manner claim this lofty title. Yet the strong places of the old trader's were, in many instances, lordly dwelling-places. They were no mere switch-anddaub huts with a feeble stockade, or $\log$ shanties, surrounded by a picket of trees, like -so many of the Hudson's Bay posts. As any nan who visits the Gold Const can see for himself, most of them were substantial buildings, fortified after the most approved system, equal to a siege of some duration and the assaults of artillery more powerful than the trade muskets of Ashanti or of Fanti.

Cape Coast Castle is not a fortress which could give a creditable account of itself in an encounter with a modern war-ship, but it is not likely to fall before any native force ever likely to be brought against it. Moree, five miles to the eastward, boasts of another fortress in ruins, ${ }^{*}$ and every nine or ten miles

* Fort Nassau, built by the Dutch. and their chief post when the Portuguese had Elmina. It was provided with eighteen pieces of ordnance, mounted on four batteries, and garrisoned by seventy or eighty men. 
along the coast one comes upon massive strongholds, now crumbling into dust-their very names no longer remembered-though to have reared them must have taxed the energies and resources of their architects. Some are still the residences of District Commissioners and other minor colonial officials, but most of them are little better than qualified ruins, shorn of almost every shred or their pristine glory. All of them are built in naturally strong positions, where there are good landing-places, sheltered from the surf, and look as if they had been intended to repel aggression by sea, as well as the less formidable onslaughts of the natives from the landward side (Pp. 35, 40, 44, 45, 49, 52, etc.).

Between Elmina and Apollonia, a distance of ninety miles, there are nine uninhabited forts of this description-Vredenborg, Kommendah Fort, Channa Fort, Fort Batenstein at Boutry, Fort Dorothea at Aquidah, Fort Brandenburg at Cape Three Points, Prince's Castle, Fort Elise Carthage at the mouth of the Ankobra River, and Apollonia Fortand three inhabited ones, Secondee, Dixcove, and Axim.

Tredenborg was a Dutch fort at Kommendah, built in 1688 (p. 45), with batteries mounting twenty-three camnon, though these proved none too many to repulse the attack made upon it by the natives in 1695 , which attempt was the origin of the Coomassian War. Close by was an English fort, also with four batteries, and so strong that a Dutch trader, writing in 1700 , regrets that it will be impossible to displace these rivals, who were floing much injury to the trade, even had he at his disposal the five thousand pounds' worth of black mercenaries employed in the Coomassian campaign. Chama was another of the Batavian strongholds, known as St. Sebastian to the Portuguese, from whom it was captured; but though it was at the time only walled in by palisades, the English, with their allies the Jabishians, were unable to take it. At Insuma, which the Dutch knew as Dikjeschoptt, the English built a small fort in 1691, after they had several times disputed the land with the Brandenburgers, who had set up the Elector's flag there. But the natives swindled them so scandalously with sophisticated gold, and were so apt to besiege the residents, that they made little out of it until-so writes Mynheer Bosman, Chief Factor of the Dutch at Ehmina -the white men and the black agreed jointly to cheat all the ships that came to trade by putting what in California is known as "bogus dust" upon them. One ressel was in this way defrauded of $£ 1,700$, and the trick grew so common that Insuma became "the false mint of Guinea"-the price of the article being about a crown in good gold for forty shillings' worth of false. It was vain to complain to the English chief governor of the coast. For "to complain to him was to go to the devil to be confessed," since this honest gentleman, "participating in the fraud, would by no means help" the swindled captains-a statement that affords a striking picture of the commercial morality of Wrest Africa two centuries ago. Batenstein Fort, at Boutry, was for several years a drain on the Dutchrnen's pockets. Dorothea, like Fredericksborg near Pokquesoe and the "fort-house" at Tacrana, belonged to the Prussian (Brandenburg) Company of Embden, which, though chiefly officered by Dutchmen, never did much good on the coast, owing to bad luck and baci management, some of the fuctors, like "Jan van Laar, an Anabaptist," having "a much better talent at drinking of brandy than at business." But Boutry bore the reputation of being the healthiest place on the coast, just as Chama had the character, up to the date of its surrender by the Dutch, of being the most deadly spot in all that region. Prince's Castle, once a fine place, is now scarcely known, even by name, to residents at places only a few miles away: like so many other places-and several of the forts were destroyed in the wars, never to be rebuilt-it is no longer of use. These castles, built at enormous cost, all the materials, as well as the workmen employed on them, having been brought from Europe, 
were garrisoned by trained soldiers, so that, at the most modest calculation, there must, in the palmy days of the Guinea Coast, have been thousands of white men where to-day it would be difticult to number a couple of hundred, or perhaps even a single white soldier, the fow troops employed being either men of the so-called West India Regiments, or Houssa policemen, a much more capable set of peacemakers (p. 53).

Everything in that part of the world seems to have been steadily going backward for the last eentury. The trade routes which the Dutch and Portuguese opened up have been forgotten, or been negleeted. Ten miles in the interior is a terma incomita to the modern "coaster," and we are only now beginning to re-discover the places out of which every year so much gold was obtained that it is caleulated Europe has first and last imported some thirty or forty millions from West A frica alone, while the explorations made in searoh of slaves and other treasures have been sedulously concealed, and so apathetically followerl up that, in spite of all that has been done in the past, West Africa is still a region quite virgin in parts for the explorer anxious to break fresh ground.

And the reason why these lordly oastles fell into deeay, why whites and negroes have alike deserted the coast, why trade is languishing and fortunes the rarest of acquisitions, is that the chief artieles of eommeree on the eoast were not dye-woods and ivory, or even golddust, but black men and women. The forts were erected for the convenience of the slave trade, and its abolition was the death-knell of this once flourishing region. In short, just as Rome was built by robbers, and the origin of the Australian colonies was a penal settlement, so the first step in the regeneration of Africa was depopulating it by European adventurers, who, whatever else they were, must be pronouneed the resetters of stolen fiesh and blood.*

\footnotetext{
* From amid the plethora of literature regarding the operations and trading of the old African companies, the following may be selected: "Reflections and Considera. tions upon the Constitution and Management of the Trade to A frick from 1600 to 1709 offered to the House of Cominons by the Royal African Company" : Appendix to Barbot's "Description of Guinea"; "Answer of the Company of Royal Adventurers Trading in to Africa to the Petition of Sir P. Painter, concerning H.MI. Plantations in America" (1667); Wilkinson's "Treatise on the Intrigues and Arbitrary Proceedings of the Guiney Company. also how prejudicial they are to the American Planters" (1690); "View of the State of the Trade to Africa" (1708); "Case of Royal African Company, with Supplement" (1730); "Observations on the Trade to Africa" (17+8); "African Trade the Pillar and Support of the British Trade in America" (1745); "Importance of the African Company's Forts and Settlements" (17ti) : "Reasons for Settling the Trade to Africa" (n.d.); Astley's "Collection of Voyages and Travels" (1i+3), vol. ii., p. 158; Bosınan's "Guinea" (1720); Ellis"s "African Sketches" (1881) and "Land of Fetish" (1883); Reade's "African SketchBook" (1873), etc. etc.
} 


\section{CHAPTER III.}

\section{Forts and Bondmex: The Slaye Trade and the Slave Traders.}

A Nodern West African Factory-The Bristol-Barque Traders-The Old Fort Traders-Life in Fort James in the Early Part of the Eighteenth Century--What now Remains of the Once Busy Place-The Dangers of the old Fort Traders-The Dutch Forts and the Way they were Conducted-Slaves Latterly the Chief Commerce of West Africa-_Rise and Culmination of this Trade-Numbers of Human Beings Exported-KidnappingHow Brought from the Interior-The Profits of the Slave Trade-The Slave Merchants-A Picture of a Lordly Trader of the Nineteenth Century-The Middle Passage-Humanity in Private Life not Incompatible with Brutality in this Branch of Commerce-Its "Respectability"-How it was Defended from a Political, Economical, and even Moral Point of View-Its Gradual Decline, and Disappearance as a Branch of Foreign Traffic-Reasons for this-Captain Snelgrave Regards it of Benefit to all Concerned, the Slaves Included-Talk in the House of Commons-Dr. Johnson's Hatred of Slavery and the Slave Traffic-Gradual Restrictions upon it Consequent upon an Outery in Europe-History of this Agitation.

The West African fort of the early and the palnier days of the Guinea trade was, we have seen, a more important affair than the modern "factory"- the old name, both in this region and in America, for a trading-post. But such a place is very different from what the modern use of the term would imply. In an African factory there are no tall chimneys, no five-storeyed rows of windows, no "hands," no sereech of steam-whistles, no whirr of treadles, no eternal sough of engines. It is a solitary place of one, or at most two, floors, sulrounded by a verandah, and standing in the middle of an inclosure (p. 21). Nothing is manufactured on the place, but everything is sold, from a suit of cast-off uniform to a gill of Hamburg gin; and as the business is done almost entirely by barter-in which the "merchant" (for he would scorn to be called a shopkeeper) prices his trade goods at onc hundred per cent. over what he paid, and buys the palm-oil, or kcrnels, or camwood, in exchange at one half of what they will fetch in Liverpool-trade, when there is any doing and competition is not of the "cut-throat" order, is quite profitable enough to be eagerly contended for.

But nobody is in a hurry. The climate and the abundance of time forbid haste. When customers are reported, Kroo boys-a labouring tribe from Cape Palmas and its vicinity, who are about the only freemen in West Africa who do any work at all-roll the puncheons into the sheds, and the trader or his clerks leisurably turn out of the hammocks in which they have been dozing under the verandah, or in their rooms over the shop, to inspect the oil which the black meı have been gauging, or to " dash " -that is, to "tip "-the owners who, if rivalry is lieen, have perhaps been brought in by touts, seattered in his interest along the beach or up the rivers, and to put everybody in a generous mood by free libations of very ardent spirits.

There is also still a good deal of the old "Bristol-barque" trade flourishing on the coast between Cape Palmas and Grand Bassam. Ships are loaded with trade goods, which are calculated to last for a round voyage of from twelve to fifteen months. They are actually floating warehouses, and, during the time they anchor off a part of the coast without factories, barter for whatever is saleable, and send the result home by the mail-steamer, returning themselves when their cargo of cloth and beads, rum and gin, salt, tobaceo, and gunpowder is sold out. At one time this way of doing business was more common than now. But it is less frequent than of old, and only profitable under conditions not found on the cntire coast of Guinca.

\section{The Old Fort Traders.}

Last century, or perhaps a little earlier, competition was undoubtedly keen enough. But the traders ashore werc altogether a more lordly set of gentlcmen than their successors in these duller days. Profits were good, in spite of rivalry, and the men who made money 


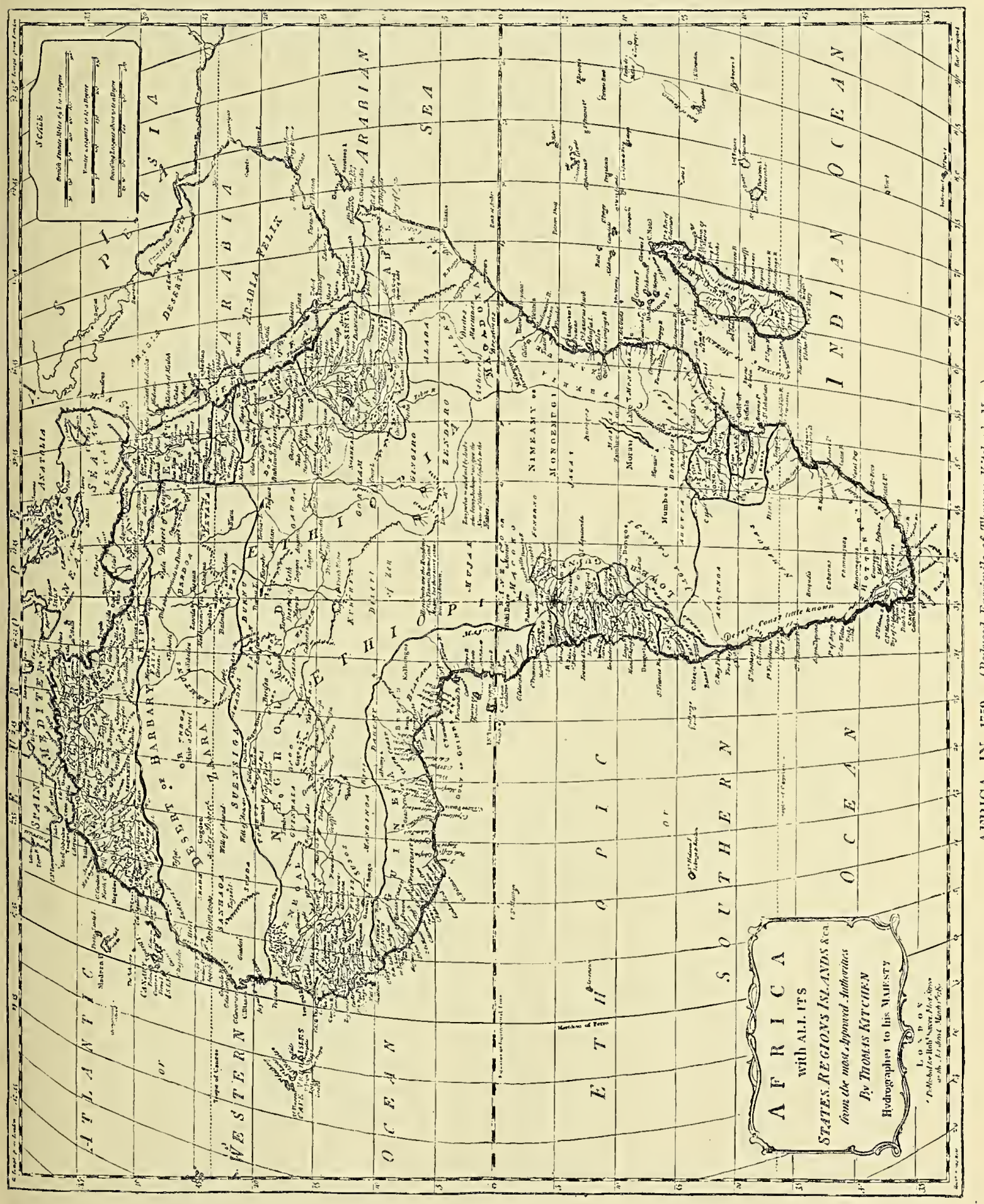


for the merchants of London or Bristol, of Embrlen, Anrsterdam, or liarseilles, insisted on being lodged after a more sumptuous fashion than serves the less handsomely though still liberally paid inheritors of their trade and traditions. It was an age of corporations, so that whether the factor's and writers, or by whatever name they were called, were Britons or Brandenburgers, Danes or Dutchmen, in the employ of the Hanseatic merchants, or of the French, or of the Swerles, they were all in the pay of a great association, who lored to do business after a grandiose fashion. At some forts there was a better, at others a worse, table. But at none of them were the staff badly fed or badly drunken, and, as occasion served, they had all the luxuries that the country could supply.

One instance will afford an idea of the kind of garrison a trading factory of those times supported. The date is the beginning of last century, and the post is Fort James, in the Gambia River, which, after various changes of fortune, ended its days of profitableness in the hands of the English. It was built on James' Island in mirl-stream, here three or four miles broad, and seems to have been a strong place, as strong places were looked upon in 1730 , when Francis Mloore, Writer in the selvice of the Royal African Company, having nothing better to pass away the time, wrote a description of it-such description not being, however, a part of the duties he had to perform for a yearly wage of thirty pounds and "the run or his teeth." There were three chief merchants - the first of whom acted as governor, the second as warehouse-keeper, and the third as accountant-eight factors, thirteen writers or clerks, a wax-refiner, a tanner, a surgeon, three surgeon's mates, a surveyor, two gardeners, two masons, an interpreter or " linguister," a steward, an armourer, a " bombay,"* two coopers, a joiner, a carpenter, a purveyor, and a gunner. In addition, there was a garrison, consisting of a captain, a sergeant, a drummer, and thirty-three private soldiers, though a few years earlier, when the Dutch

\footnotetext{
* Bombardier.
}

were making themselves disagreeable, the military inmates of the fort numbered from sixty to seventy whites, beside "groomettoes," or free black Sepoys. Then to wait on all this company of Europeans, or people passing as such, there were thirty-two "castle slaves."

Besides the establishment described, there were sloops, shallops, canoes, and boats, with their crews, and eight out-factories with black servants belonging to them, besides the white factors, writers, and "linguisters." These included Joar and Jilifri, where a large business was done in beads, beeswax, ivory, slaves, and gold. The gold was brought to the forts and factories, not usually in gold-dust as elsewhere, but in small bars, big in the middle and turned round into rings, worth from ten to forty shillings each. This commodity was traded by Mandingo merchants known as .Joncoes, who, however, were extremely reticent as to the countly from which they came. The same people brought down the ivor'y, the slaves, and the heeswax, derived from domestic bees, which is still an article of commerce in that part of the country. The method of bartering was then, as it is practically still, by " bars," a bar being a certain quantity of goods of any lind equal in value to a bar of iron when the traders first came to the Gambia, for iron being the article most esteemed became the standard by which everything else was appraised. Thus a pound of fringe, two pounds of gunpowder, an ounce of silver, and a hundred gun-flints were each worth a bar. Again, twenty leares of tobacco were considered a bar of tobacco, and a gallon of well-watered spirits a bar of rum, a bar being reckoned, about the close of the last century, at an average of two shillings. Thus a slave priced at $\mathfrak{£ 1 5}$ was said to be worth 150 bars. Hence every species of trading goods was reckoned in this currency, which rose or fell in money value "according to the goods asked for:" "Spread-eagle dollars," crystal beads, iron bars, brass pans, and "arrongoes" were called the "heads of the goods," because they were the dearest. Thus, when the factors in the forts made their bargains with the 
native dealers, they always agreed how many of the heads of the goods they would give for eaeh slave. This might be three or four if the slave were worth forty or fifty, but when this article was dearer-worth, say, eighty bars apieee-then the faetor had to gire five, and sometimes six, of the heads for every slave, when an assortment of the goods by bars of different kinds whieh came up to the price was made out.

The factor's of the old companies were rather fond of writing their experiences, How the old and of exposing the conduct and How the old character of their rivals: so that
traders lived. we possess a tolerably clear account of the life of those pioneei's of African eolonisation, or at lcast, of Afriean eommerce. The larger forts were ordered with great regularity, though naturally the steadiness of the offieials depended a good deal upon the eharacter of their superiors. In Fort James there were several tables, the writers dining at what was known as the Second. They had fresh beef in plenty, an ox being killed every day; and as the natives brought in hosts of fowls for sale, those who did not care for beef could have chickens at their choice. All the tables were freely supplied with regetables out of the Company's garden at Jilitri ; flour bread was made freshly every day; and those who liked oysters - in West Africa a muddy mollusc at best-could pick what he pleased off the shore at low water "at the north-north-west" part of the island. Everybody had wine and brandy by paying for them, and a reasonable share of beer when there was sufficient among the stores, so that, the climate and the isolation apart, the Royal African Company's people were not in such evil ease as many colonial offieials at the present hour.

In the days of its prosperity, Fort Jameswhich was named after the Duke of York, afterwards James II.-was indeed a much more stately establishment than the woebegone capital of the present colony of the Gainbia, to which the remnant of its officials were transferred when the old Company expired in bankruptcy. For when the trade of the Gambia was thrown open, the business done here was every year less and less. By the time Mungo Park visited it (1795), its gross exports amounted to no more than $£ 20,000$; and twenty-five years later, the rights of the Company having been transferred to the Crown, Fort .James ceased to be oceupied, Bathurst being considered a better site for the eolonial eapital. Thus a plaee whieh had been taken and retaken, battered down and rebuilt, was permitted to fall a prey to time and the African raees.

The curjous pilgrim who visits it nowadays sees little evidence of its former grandeur, except in the solid lime and as!lar masomry, eraeked and fissured by the rank tropical regetation which has insinuated itself into every ereviee. Walls have fallen here and there, other's have tumbled into dust, and everywhere huge pieces have been riven asunder in search of those treasures which for no reason in the world are so persistently believed to be hidden in every old building along the Afriean eoast. But the great quadrangle ean still be tracerl, and the lozengeshaped bastions, eaeh of them liner with good briekwork, were still standing when Captains Burton and Cameron examined the spot some years ago. The horse-shoe redoubts, three in number, "with batteries along the palisades from one to another," deseribed by Francis Moore, were there, with four old iron canion out of the sixty or serenty whiel once upon a time presented so formidable a front to Monsieur de Gennes, who destroyed it in 1695; to Captain de la Roque, who captured it in 1702 , and paid for his victory with his life; and to the squadron of privateers under II. Parent, who attacked it for the last time in 1709. But the ancient slave-barracoons, the dwelling-houses, the barracks, the stores, the salt-house, * the "linguister's room," the cotton-house, the powder magazine, and the rest of the plaees marked on Moore's plan, are all more or less in ruins, striking monuments of the rise, eulmination, and decline of

* Salt was a-great article of trade with the interior tribes. 
the old commerce of the region in which England made her first attempt to gain a footing on the African continent (p. 35).

In the smaller forts there was less dignity, and possibly more dissipation. Indeed, on the the fermented juice of the palm, which, by the exercise of some perseverance, is quite capable of intoxicating, though it requires a longer training than most white men are capable of undergoing to acquire a taste for a liquor so like soapsuds as this much vaunted "palm - wine." Indeed, the outspoken Bosman affirms that the larger the salary on the Guinea Coast, the greater the thirst was in his day, and, consequently, the less the regard for that wholesome food without which it is impossible to preserve health in the tropies; and as the officials were deeply in debt, their coming pay was so mortgaged that they were

SLAVE BARRACOON.

Gambia we read more than once in the records of factors dying of drinking, accounted heavy even in an age very prone to look upon the wine when it was red, and of offences against the canons of conventionality openly committed. Drinking was indeed the bane of those old traders. 'The factors drank freely, and the soldiers and many members of the staff often laid out their pay the moment it was received either in brandy or in compelled to live and die on the Guinea Coast. But, according to the soldier's maxim, that a "bloody war and a sickly season" are his best firiends, the factor did not object to the unhealthiness of the region, since it kept up the steady flow of promotion among those who survired, while the dead were, of course, beyond the reach of any anxiety touching a rise in place and pay. For, so argues the old Dutch factor, "if men 


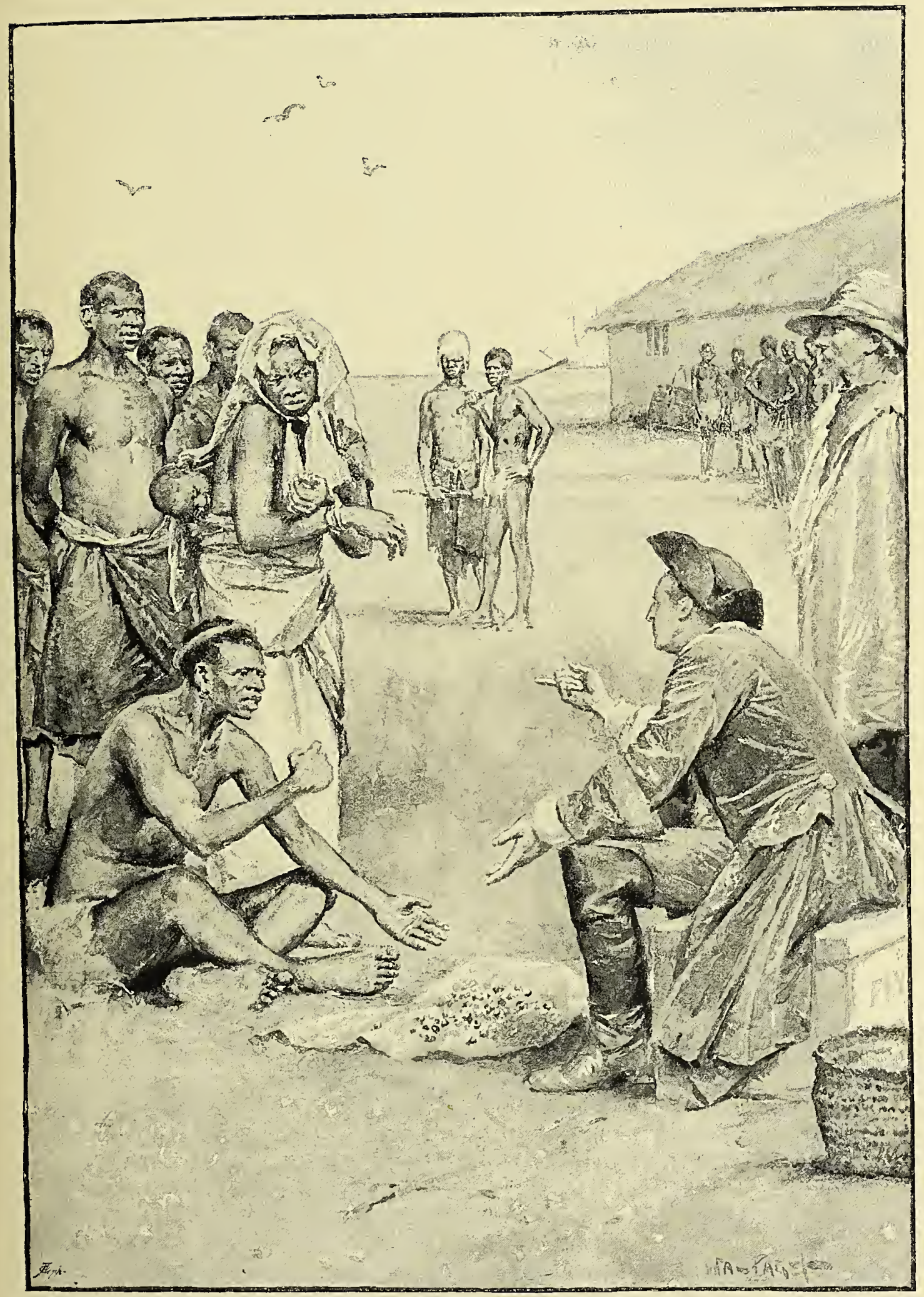

BARTERING FOR SLAVES AT A FORT ON THE GUINEA COAST 
lived here as long as in Europe, it would not be worth while to come hither, and a man would be obliged to wait too long before he got a good post, without which nobody will return rich from Guinea, the chief persons there being the only people who can lay up anything." The English forts were, aecording to eontemporary opinion, the worst of all the European posts for indulgenee in drunkenness, and the most slovenly. When Dutch posts were in their vieinity, the Englishmen were apt, in spite of all agreements to the contrary, to "greedily entertain" all the deserters from their rivals, so that in time many of the British posts were manned by the scum of a class at no time the most desirable members of any sort of society. These soldiers were permitted to drink to any extent, as their officers had an interest in the protits derived from the sale of a "liquor made of brandy, water, lime-juice, and sugar," for which the men paid twiee its value. "And those who spend but little money that way are sure to be very well beaten, they taking no eare whether the soldier at pay-day saves gold enough to buy victuals, for it is sufficient if he have but spent it in punch; by whieh exeessive tippling and sorry feeding most or the garrison look as if they were hag-ridden."

It is likely enough that this tale was quite true ; for during our oeeupation of Tangier, Captain Kirk is affirmed to have paid his "lambs" in liquor, out of whieh he had a heavy profit, and, in consequenee, had to parade them very early in the morning, since at a later hour in the day they were too drunk to be diseiplined. So besotted, indeed, were the English traders by devotion to Baechus, combined with an equally inordinate addietion to flesh, that not a year passed without a superior officer dying, while the mortality among the factors was too great to be kept count of. Most of the traders were addicted to other weaknesses than the bottle. Sone lived pretty mueh after the native fashion, so far as polygamy was eoncerned. A certain Edward Barter, a mulatto, more powerful on the Guinea coast than any three white men, pretended to be a Christian, and could read and write. But though lawfully married in England, he had eight wives " in the country" ; and, our informant adds, this compromising fact in no way detracted from the esteen in which $\mathrm{Nr}$. Barter's moral charaeter was held by his English associates, "since most of their ehief offieer's or governours follow the mulatto's example pretty close; for I believe most of their present agents have about six." This was at Cabo Corso-that is, Cape Coast-upon the Danish Mount (p. 40).

But the old faetors had something more to do than to drink pumeh, eat beef, and marry " country wives," as the phrase is, to express a somewhat similar praetice still in vogue, or even to buy wax The dangers of the old and ivory, and gold, and "negro servants" ; for they had often to defend their forts, and their own lives and their employers' property, against hostile onsets by the warlike tribes of the interior, or even of their own immediate neighbourhood. Thus the Anteans captured the English post at Zakonde. Christiansborg, the Danish fort at Accra (p. 49), a square building mounting twenty guns, was in 1693 , owing to the garrison being weakened by death, captured by the natives. For a few days the negroes rioted in plunder, and the old ehief, dressed in the Danish commandant's uniform, and addressed by his name, mimieked to the best of his ability the language and acts of his prototype. "He thundered at all the English and Zealandish interlopers, by way of salute, with his eannon, as if there could never be an end to the powder." Then two Danish menof-war, aided by gifts and the intereession of the Dutch, suceeeded in regaining the plaee. Such mishaps did not, however, always end so happily. There is, for example, a tragical tradition eonneeted with Fort Elise Carthago, a deserted post at the mouth of the Ankobra River. This plaee was in Dutch hands when it was besieged by the natives of the surrounding country, who faneied that the commandant had a large quantity of gold ready for shipment. Knowing, probably from sad experienee, of some similar mishaps elsewhere, 



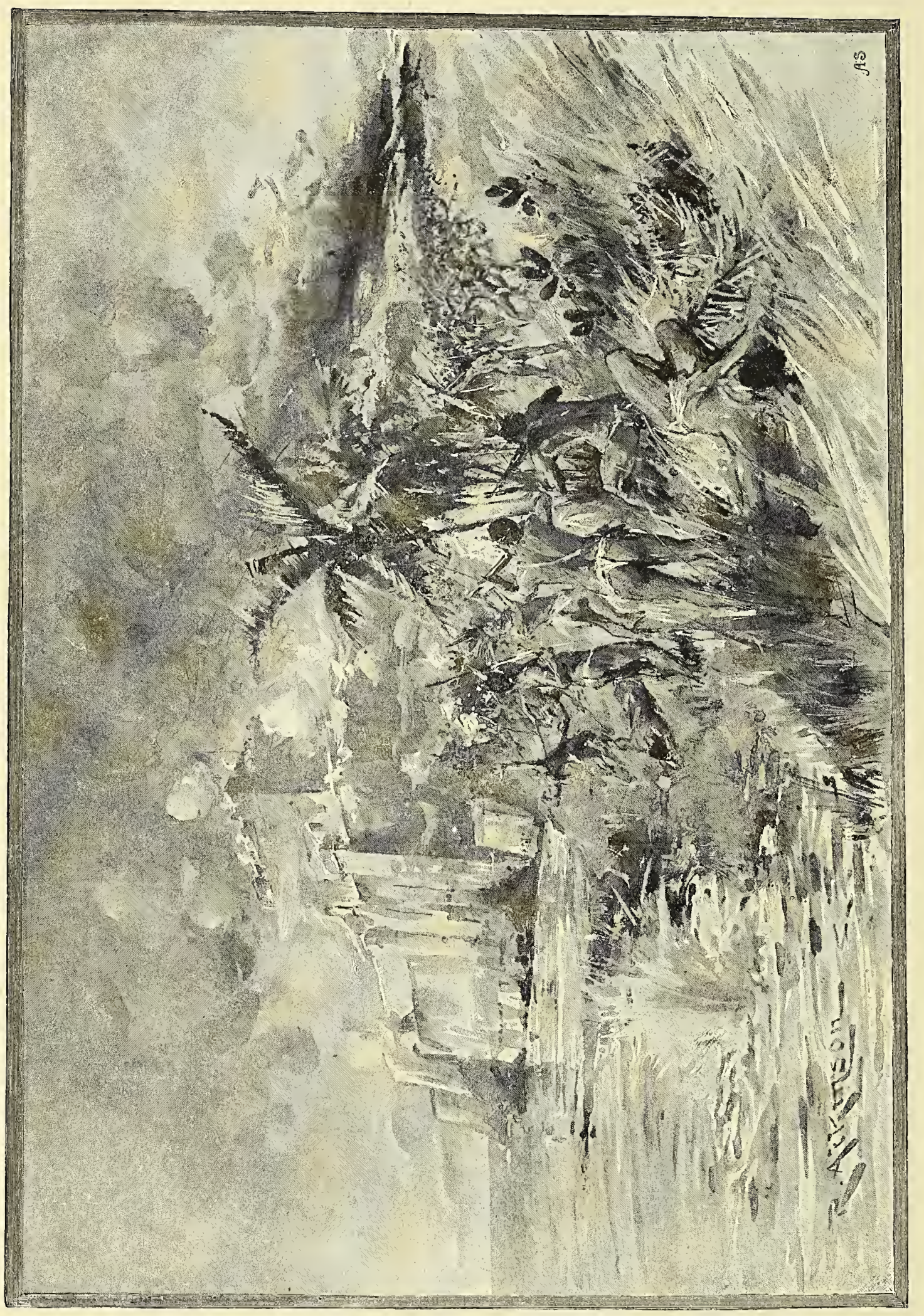


the fate which would await them, the stouthearted Hollander fought until all his lead was expended and his garrison shot down one by one. Seeing that he could hold out no longer, and could expect no mercy from his savage enemies, he determined, as many a desperate man in like case has doù before, to sell his life dearly. With that intention he utilised the last hours at his disposal by placing sereral barrels of gunpowder under the "palaver," or audience-hall, of the fort, and lighting a slow match, which he placed in communication with the powder. He then surrendered at discretion, and invited the eager negroes to come into the hall to receive the gold supposed to be there. Scarcely, however, had the place been filled before the mine exploded, blowing the fort and all within it into atonis. This story is told by Colonel Ellis, and is, no doubt, historical; for the place was never rebuilt, and its ruined walls, now almost covered with bush, alone remain to commenorate this tragedy of the Guinea trade.

Those old Dutch forts were on quite as lordly a scale as their English rivals, and, if we The Dutch are to believe the Dutch, much torts. del Nina, their principal place on the Gold Coast (p. 45), there was a general, or chief governor, a chief factor, and chief tiscal, with very fine warehouses for storing the goods brought from Europe, and "the trade" which they carried off in return. Gold was the chief article bartered for here, and in those days nulst have been a profitable affair for all concerned, since it was reckoned that, early in the last century, as much as $£ 230,000$ of the precious metal was every year exported from the Gold Coast. This was brought down by the negroes, who, after it was weighed, assayed, and purified-and, as sham dust was very common, it was most carefully examined-received the stipulated value in goods. No credit was given except at the factor's own risk. These negroes were usually the slaves of their masters; but, for policy's sake, the head of the caravan was always treated by the white traders not as a serf, but as a great merchant, in case he might take offence, and go to the English, Danes, or Brandenburgers.

In addition to the dignitaries mentioned, the Dutch had in the forts a garrison of soldiers, out of whose ranks, when qualified, clerks and other assistants were sometimes chosen. The assistant received sixteen gulden a nonth, and twenty gulden more for board wages, so that their pay was pretty much the same as that of the English. His first step in promotion was to be an under-factor, with twenty gulden a month, and, his chief business being to buy gold, he required to exercise much shrewdness, not to say honesty. Accordingly, when a subfactor was noticed to be inclined to extravagance, he was apt to be watched very closely, since the factor was responsible to the company for his intronissions. If, however, he behaved well, and the season was reasonably umhealthy, the under-factor would soon become a factor, and be sent to take charge of an outpost, at a salary of thirty-six gulden a montl, and an allowance of ten gulden for a servant or two, besides the nsual twenty gulden for his food. If provided with good interest, he might eren rise to command one of the minor forts, with double this salary, or become chief factor at Elmina, an official who was the second person on the coast, with a stipend of one hundred guklen a 1nonth and allowances; though the governor-general, with three hundred gulden a month and corresponding perquisites, was a dignitary the appointment of whom the directors in Holland usually reserved to themselves.

Then there was the chief fiscal, with fifty gulden a month, and ten gulden for a servant, besides the liberty of the general's table, and one-third of all the gold seized from unlawful traders or interloper's, whether whites or negroes, and one-third of the fines imposed upon them, or upon offending officials of the company. The bookkeeper-general at Elınina was also a person of considerable consequence, with enoluments amounting to one hundred and five gulden per month. Under him were an assistant, or secretary, and the garrison book- 
kecper, who though not paid a high salary, had the privilege of selling by auction the effects of all persons who died upon the coast, at a

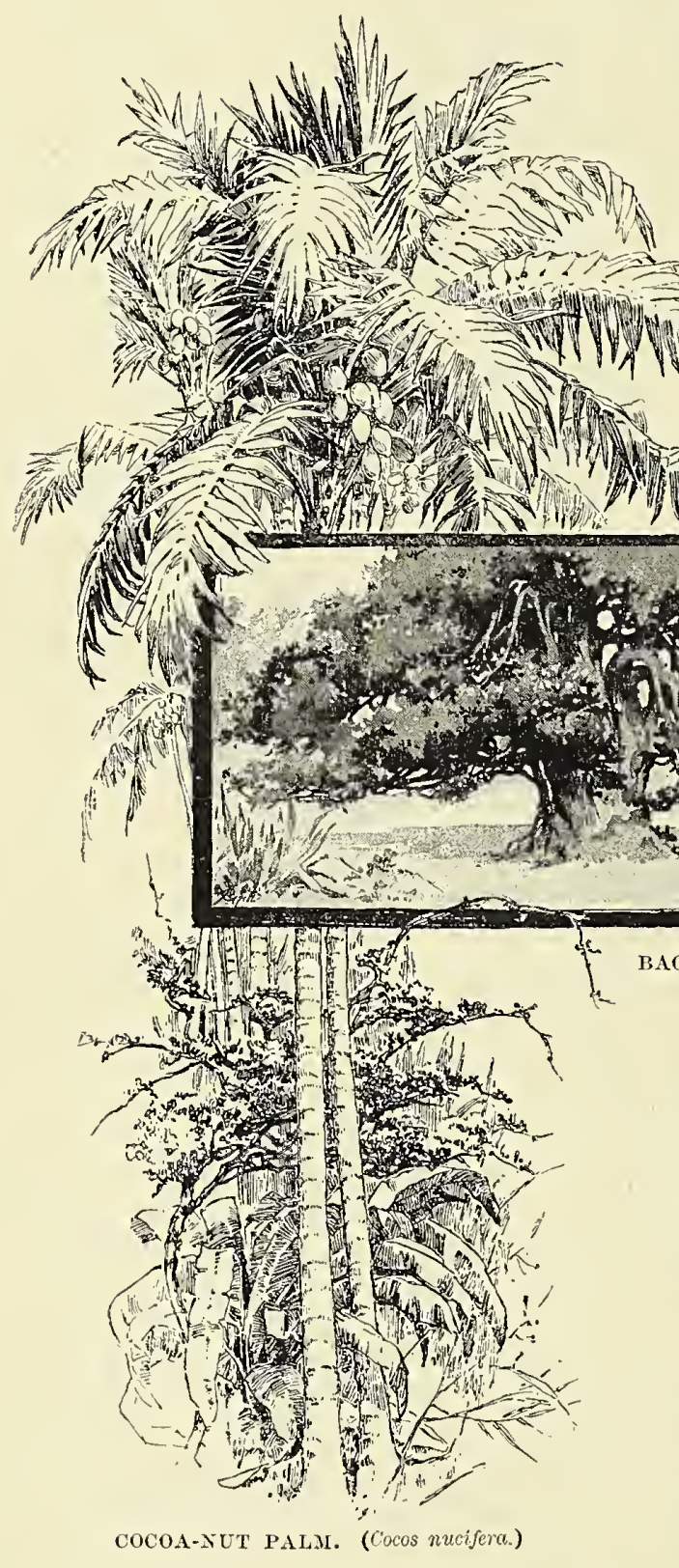

commission of four per cent. on the sum they brought. The officer held in least estcem in the Dutch forts was the under-fiscal, auditor, or actually inforner, who recciving, besides his salary of twenty gulden, the tenth of all fines, did his best to enlarge the number of them by spying on the other officials for the purpose of detecting any breach of the rules, and was held in contempt accordingly.

Lastly, there was a chaplain, with a monthly stipend of one hundred gulden, and a clerk, at a fifth of the salary; the first having, in addition, an allowance of ten gulden for a servant, and a place at the governor's table. The StatesGencral of Holland of those days, as Dugald Dalgetty remembered with a wry face, were strict disciplinarians as regards the outward observances of morality. And, if the Gold Coast officials were licentious, it was not the blame of their masters, who paid the parson the same salary as the chief factor of Elmina. Every man capablc of getting out of bed had, on pain of bcing fined twenty - five (Adansonia digituta.)

stivers, to attend church every day, except on Sundays and Thursdays, when the smart-money for absence was doubled. In all, Ehnina possessed in its palmy days a director-general, a chaplain, a fiscal, a chief factor-and somctimes two or three in addition-seven or eight factors, nine or ten sub-factors, eighteen or twenty assistants, a warehouse-kecper, an accountant-gencral, the under-bookkecper, the garrison accountant, the clerk of the Church, the auditor or "informer," besides the soldiers and their officers. The supreme control of the coast was in the hands of the dircctor-general, who, in cases of emergency, asked the advice of the Council, which consisted of himself, the fiscal, the chief factor, the ensign or banncrman (in command of the garrison), and sometimes the accomntantgencral, though, as a rule, the only result of 
their meetings was to register the opinion of the supreine ruler, on whose goodwill all the members were dependent, and to divide amongst them the responsibility of acts often arbitrary, and sometimes perilous for him to do alone.

\section{The Slave Trade.}

But whatcrer' were the commodities bartered on the Guinea Coast, the one which latterly threw all others into the shade was slaves. Slavery has always existed in Africa. Bondage was invariably the lot of prisoners captured in war who were not sacrificed or eaten, and long before the whites tracked to Africa the negro kings trafficked with the Mloors of the Barbary States in the surplus of their own subjects who had committed crimles, or in those of their neighbours who had fallen into their hands in the course of those inter-tribal hostilities which then, as now, werc a common feature of savage life. But the bondage of black man to black man, or even of the negroes to the Arabs, was mild compared to that which was the lot of the sons of Ham when the American planters, finding that white inen could not, and red men would not, cultivate their cane and cotton fields, deported them to labour in the New World.

In Africa they were at home, among men of a kindred race, with the possibility of obtaining their freedom by some turn of fortune, or, in any case, not regarded as so infinitely inferior to their mastcrs that there were ethmologists ready to pronounce the swart labourers who arrived by the ship-load from Bonny and Whydah and the Congo to be only a superior species of chimpanzee. In Africa the slave of one day might be the master

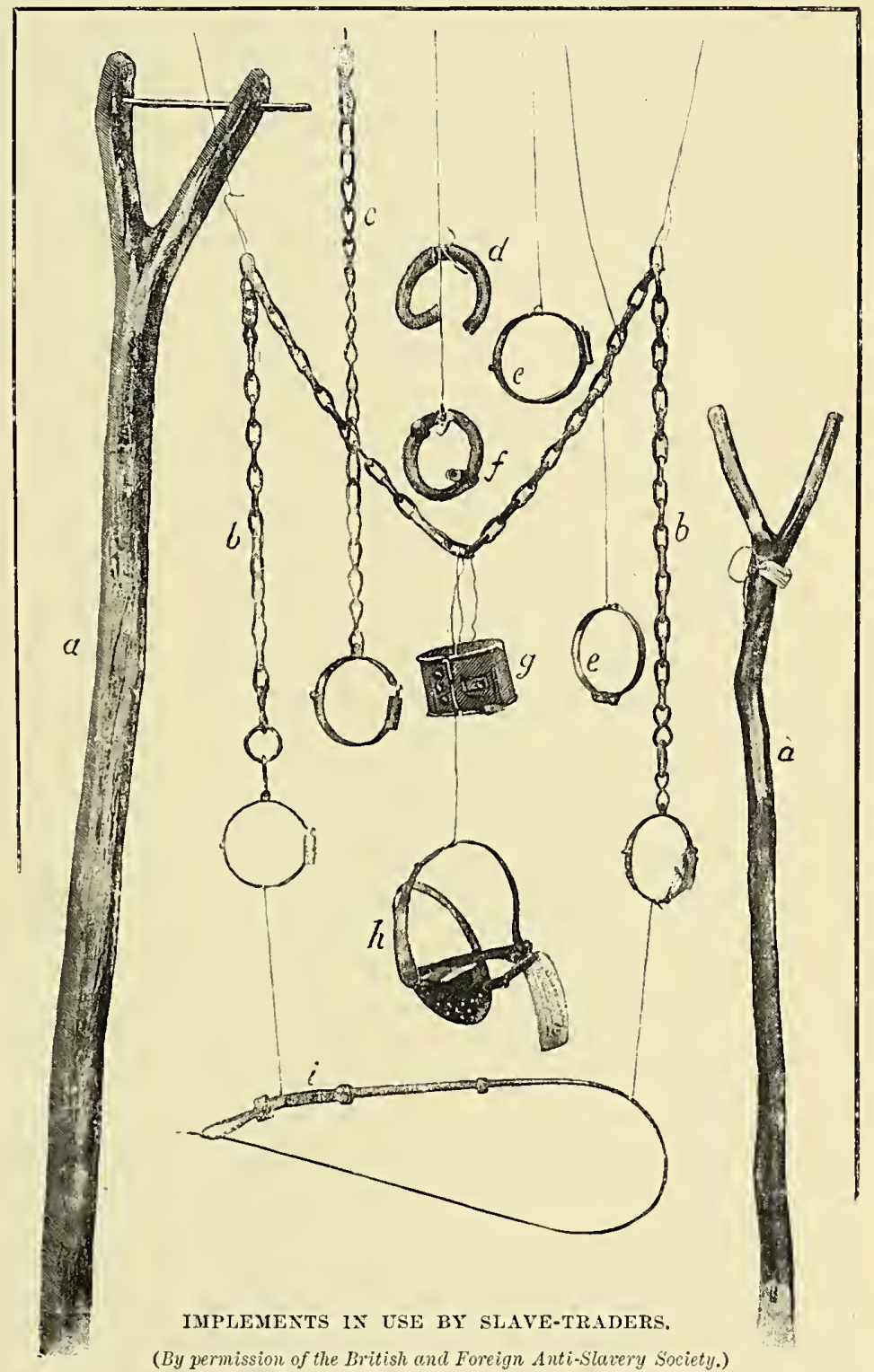

$a, a$, The Yoke or Goree ; $b, c$, Chains used to fasten slaves ; $d$, Iron ring welded on to limb of a slave, which has to be severed by a chisel in order to be removed; $e$, Fetters $f$, Rope used to bind slaves; $a$, Iron Collar ; $h$. I Ielmet used for gagging slaves, with piece of iron to force tongue down; $i$, Corbash or whip made of rhinoceros hide. of another, as in Morocco, to this hour, the black bondwoman may become the mother of an Emperor, and the black bondman the commander of an army, the governor of 
a province, or the head of a religious sect, as influential as the Sultan himself. In America, on the contrary, it was seldom that the slave could attain freedom, even under the most degrading conditions.

Among the many crimes that history lays to the charge of the British nation is the circumstance that an Englishman The rise and
growth of was the first individual who saw growth of slave trade. Africans a source of gain greater than the traftic in gold-dust and ivory. This personage was the celebrated Sir John Hawkins, who, in 1562, "ran" the first English cargo of slaves to the West Indies, an offence against humanity which he scarcely expiated by lis doughty deeds in after days, when, with Drake, he fought against the Armada at home, and perished off Puerto Rico in an unsuccessful expedition against the Spaniards abroad. But, in reality, the Portuguese and Spaniards set the example, which Hawkins merely imitated. As early as 1503, African slaves were working in the mines of Hispaniola, Mexico, and Peru, or cultivating the soil, a capacity in which they were found more manageable than as toilers underground. But it was lot until 1517 that the commerce in human beings was fully established, Charles T. having granted to Lebresa, a Fleming, the exclusive privilege of importing 4,000 slaves every year, a monopoly which the concessionnaire disposed of for 25,000 ducats to the Genoese merchants. The Portuguese and Spaniards never intermitted their activity in this dreadful traftic, though other nations soon ran rivalry with them; among these the English were not long' in taking the lead, and they continued, until the trade was abolished, to be the principal dealers in human beings between Africa and America.

From 1680 to 1786 fully 2,130,000 negroes were imported into English colonies, Jamaica in the course of eighty years absorbing 610,000 . In one year, 1793-and it was not an exceptional one-the different European Powers landed in the New World 74,000 slaves, those brought by the Britisl being 38,000 ; while in 1771 there sailed from England to Africa 192 ships provided with accommodation for 47,146 negroes. At a later date the traffic rather. increased than diminished. Soon Brazil alone took an average of 78,000 and Cuba 60,000 per annum, though this did not include those rescued by cruisers after the trade had been declared illegal, those thrown into the sea to avoid capture, or those who died during the passage. As late as 1830, 150,000 human beings were carried every year across the Atlantic and sold as bondmen, in spite of the fact that all nations cxcept Spain, Portugal and Brazil had made the tradle penal. This was Sir Fowell Buxton's estimate. Captain Maclean - the husband of the hapless "L. E. L." - who as Governor of the Gold Coast in 1834 was in a good position to ascertain the truth, estimated the number carried off in that year fiom the Bights of Benin and Biafra at 140,000 . Four years later there were on that coast, under Portuguese colour's, 200 slave-vessels: and ny late friend, the venerable James McQueen, who for unany years was the link between the old and the modern students of African geography, estinuated from personal observations marle in $18: 37$ that $\mathbf{1 9 6 , 1 4 6}$ nien and women were carried from their homes to a lifelong slavery in Brazil and the Spanish colonies. Again, if the value of the Manchester goods exclusively manufactured for the most reprehensible branch of "the Guinea trade" is made the basis of the calculation, allowing $\mathfrak{f} 4$ as the average cost-price of each slave, less than sixty years ago, exclusive of the thousands sent to Persia, Turkey, Arabia, and the Mohammedan States of Africa, or owned by the negro potentates, 250,000 is not too high an estimate of the enforced emigration by which every twelve months Africa-and ahnost solely the region now under consideration - was drained.

The wonder was not that Africa did not progress in civilisation, or that it was, over vast fertile regions, thinly populated, but that it was not turned into a desert. In reality, nothing shows the recuperative character of 
the negro races, their enormous vitality, compared with the American Indians and other savage peoples, more than the fact that in a few years the country recovered-as it will recover still more rapidly in the near futurethis ceaseless bleeding in the shape of the deportation of its youngest and strongest inhabitants. For there was no market for old men and women, weaklings, or young children. In the slave raids the able-bodied alone were taken; the rest were knocked on the head. And it was by such murderous raids that most of the slaves sold to the white men were obtained. It was not often that the latter themselves stole the negroes, though even of that, in earlier times at least, they were inuch less innocent than the excellent $\mathrm{Mr}$. Norris* would have us believe.

For Herr Wadström, who in 1787 and 1788 made a journey to the Coast of Gninea, affirms How slaves in the most positive manner that How slaves in places where there were no settle-
were obtained.

ments Europeans often layin ambush for the natives, seized them and kept them in confinement until they could be shipper off to the colonies.t This knavery, therefore, seldom canie to the notice of their honest countrymen, who would have regarded with indignation "private pillage," while ready enough to profit by that undertaken in a public way. Such dishonourable traders seem to have becn the forerunners of the South Sea "blackbirders"; for penetrating up the great river in search of business, they either invitcd the natives on board on the pretence of buying, or insisted on hostages being delivered up as sccurity for their good behaviour-black traders or black hostages rumning a parlously small chance of ever seeing the village again if, peradventure, the wind served when these transactions were approaching a close. Such an "interloper" naturally never visited that river or that part of the coast again, though the next ressel

* "Memoirs of the Reign of Bossa Ahádee, King of Dahomy, an inland country of Guiney, to which are added the author's journey to Abomey, the capital, and a short account of the African slave trade" (1789); p. 172.

$\uparrow$ "Observations on the Slave Trade, and a Description of some part of the Coast of Guinea" (1789), p. 18. which arrived without suspicion of the villainy of its predecessor was apt to pay the penalty of his crime (p. 60). But no scruple was entertained regarding the natives kidnapping each other. Such stolen goods were legitimate merchandise. It was, indeed, an everyday occurrence for blacks to be entrapped into slavery, even by the people with whom they and their tribe were on terms of great cordiality.

But it took a long time for a negro chief to "fill an invoice" for four or five hundred slaves with such petty pilferings of human merchandise. He had to resort to stronger measures and to theft on a more wholesale scale. In the first place, all the prisoners and all the criminals in the tribe were sold into this kind of penal scrvitude for life, and it is certain that offences multiplied in a direct ratio to the demand for saleable offenders of this sort. It might also occasionally happen, as has happened in Horocco in our own day, that during times of famine the wretched natives would barter their freedom for the certainty of having something to eat, and, as is still the case in most parts of Africa, an insolvent debtor became the property of his creditor. But the very chance of obtaining prisoncrs encouraged quarrels among the slavery kings; and when no cause for hostilities existed, except that there wcre several slave-ships waiting for a cargo, a royal broker (and the chief was generally the principal merchant) would, without hesitation, fall upon a neighbouring tribe in orker to supply the number of "servants" whom he had agreed to furnish. Latterly, such raids became the regular mode of obtaining prisoners, with the result that the internecine quarrels for which Africa has ever been notorious grew more and more truculent and continuous, and anything like legitimate commerce was impossible. To this day-or' at least, until very recently-on the frontier bchind Sierra Leone, Mendis or Kossais men may be often met with, armed with swords and spears, going about in couples hunting for slaves. If asked what they are doing, they answer, without hesitation, Coloncl 
Ellis tells us, that they are wanting to try to catch somebody, and they hold up the roll of braided cord which they carry to bind their captives as a proof that they are not common agriculturists, but bona fide slave-hunters. The slaves thus secured are, of course, not exported-for there being no market for them across the sea, there are now no purchasers on the African side-but carried across British territory and sold in the Sherbro country, whence they are finally disposed of to the Mohammedan rice-growers of the rivers between Sierra Leone and the Gambia.*

Comparatively few slaves were drawn from the coast itself. The shore tribes were the middlemen, who obtained them from the

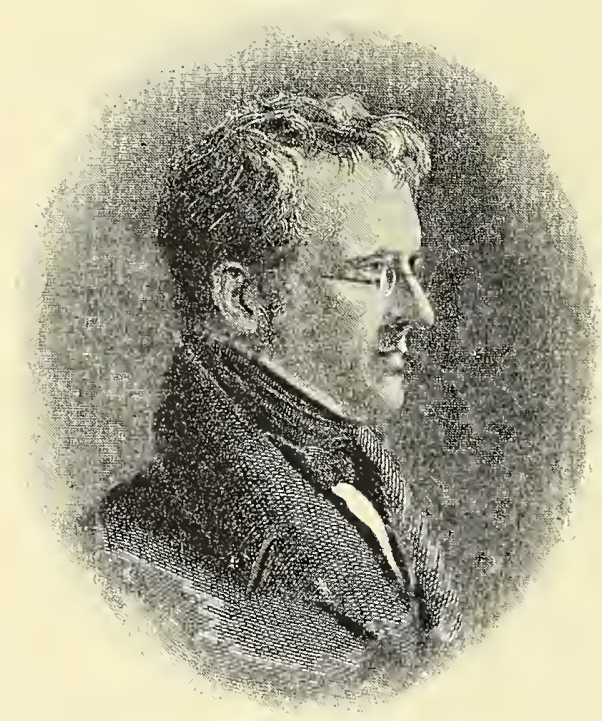

SIR T. FOWELL BUXTON.

(From the Portrait by Sir George Hayter.)

interior people, and found their profit in selling them to the whites. Higher up the rivers, and wherever there were fortified trading-posts, the slave-merchants dealt directly with the agents of the chiefs and caravans who brought them from the East, though it was rare for the white merchants to penetrate far up the water-ways, and when they did so it was either to scan the resources of the country or to open up friendly

* "West African Islands" (1885), p. 119. negotiations with the tribes so as to secure their custom in the near future.

Yet these journeys, made for the advancement of the least commendable object, helped directly to open up Africa, and by publishing to the world, through the agency of the explorers who followed, some of the horrors of this traffic in flesh and blood, conduced to its total abolition.

The agents who brought them to the coast were known as "slatees," and the gangs in which they travelled as "coffles." Both were infamous - so infamous, indeed, that though one might have imagined that it would have been to the interest of the owner to take care of his merchandise, the hardships of the journey were so great for years that the routes of the slavegangs were marked by whitened skeletons of wretched captives, badly fed, heavily manacled, and cruelly treated, who had dropped by the way and been left where they fell to die or be eaten alive by wild beasts (pp. 65, 72, 73).

After reading the voluminous narratives of early travellers who were familiar with the slave trade, the evidence laid before the various Committees of Parliament which sat on the subject, and many facts obtained from later journeys with the Arabs in an opposite direction, it seems to us that there is no exaggeration in affirming that thirty-six per cent. of every "coffle" of slaves perished on the march to the coast, not to mention the horrors the survivors endured during the period they were shut up in barracoons waiting the arrival of a ship (p. 60), or the still more terrible agonies they had to bear when packed in the hold during the "middle passage" from Africa to America.

Yet it must not be supposed for a moment that the men who were engaged in this traffic were accounted anything but highly The slaverespectable merchants. It was in merchants. the first place extremely lucrative. Bristol and Liverpool fattened on it. Most of the "warmest" merchants were interested in it, and it is safe to say that only the most active, courageous, and enterprising skipper had a chance of commanding a ship fitted 


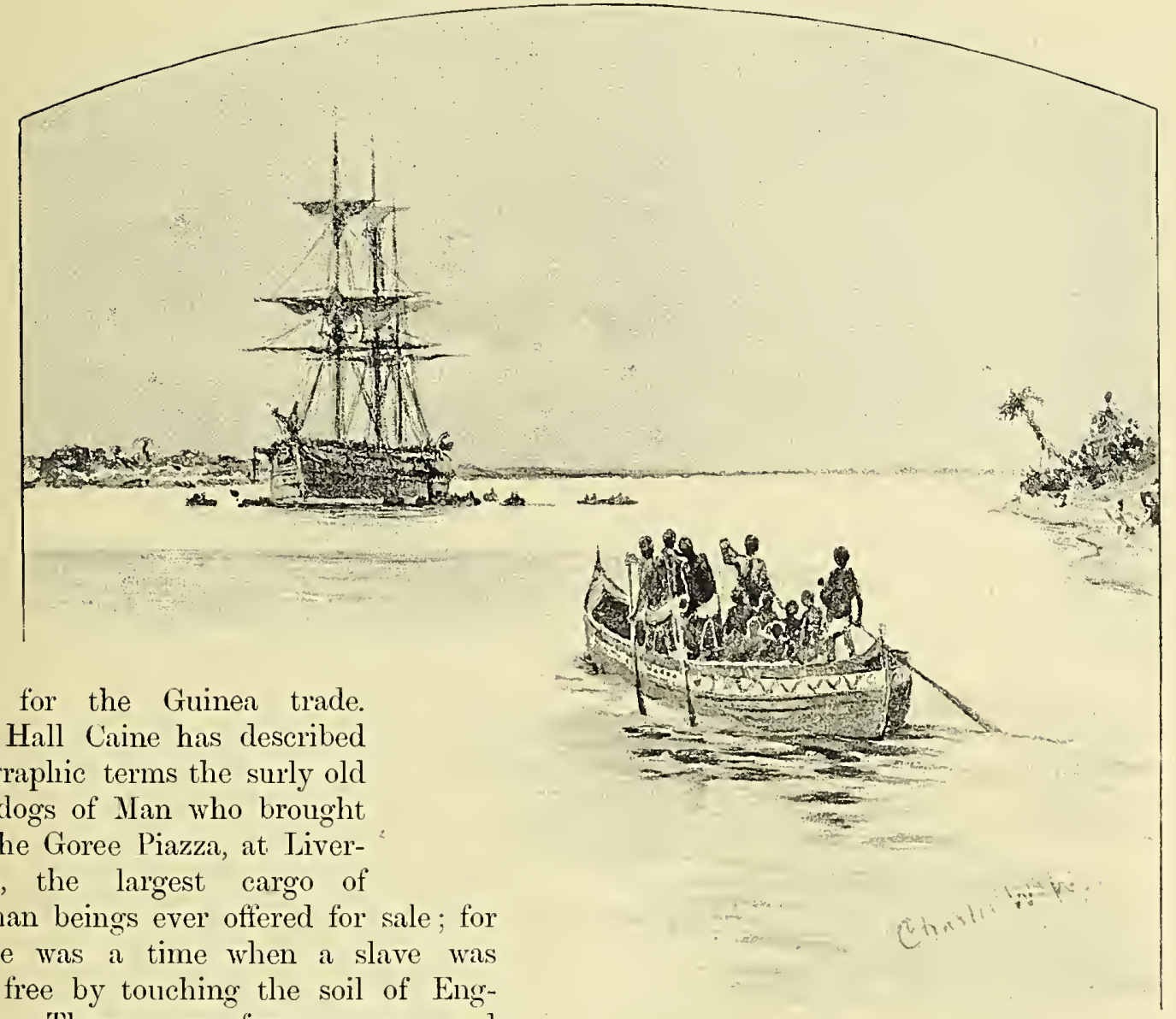

out for the Guinea trade. Mr. Hall Caine has described in graphic terms the surly old sea-dogs of Man who brought to the Goree Piazza, at Liverpool, the largest cargo of human beings ever offered for sale; for there was a time when a slave was not free by touching the soil of England. There were four men-a sad quartet. One of them had only one arm and an iron hook, another had only one arm and one eye, a third had only one arm and a stump, a fourth was covered with scars from the iron of the chains which a slave had worn for twelve months at Barbadoes. "Just about enough humanity in the four to make one complete man, but with vigour enough, fire enough, heart enough-I daren't say soul enough-in their dismembered old trunks to make ten men apiece; born searovers, true sons of Orry, their blood half brine." Some of them, indeed, were-in their way-very excellent men; it was only when - the trade became disreputable that the captain and crew shared in the infamy attaching to it, though-we venture to think - at no time were they very pleasant-mannered gentlemen. "Is this the great Mr. Pope?" was the exclamation

of one on being presented to the weazened little author of the "Dunciad." " Kounds! I have bought better men, body and soul, in the Bight of Benin for fifteen pieces of eight."

But the blacks were to be obtained in early days, before competition had become so keen, for a great deal less than that. When M. Dancourt made his voyage in 1682, ${ }^{*}$ the price for a prime slave was ten francs, and, as the chattel was saleable in a Christian country for a hundred crowns, $\uparrow$ the profit was considerably

* "Voyage to the Canaries, Cape Verd, and the Coast of Africa, under the command of M. Dancourt." Translated from the French of M. le Nacre by Edmund Goldsmid (1887). p. 35 .

† The crown, or "Ecu," varied in value from six francs or livres to three francs, the average worth of it about that period. 
more than the 200 per ecnt. at which it was estimated at its worst-paying cra. A fairindeed, a very good-slave was then to be purchased for four or five jars of brandy, though the cxpense of transporting the merchandise to the auction-blocks in Virginia, or Louisiana, or Rio, or the West Indies, or even to smug New York, which in those days har not quite eschewed the "peculiar institution," any more than had the Mother Country, was greater than his first cost on the shores of Senegal. At the Isle of St. Louis the ordinary articles gircn in exchange for hides, ivory, gum, and, we presume, for negroes, werc linen, cotton, copper, pewter, iron, brandy, and "trifles of glass," which resulted in a protit of 800 per cent., the cost and risk of carrying. homc the stuff being less than in the case of slaves. In 1859 the Portuguese, who dealt surreptitiously in slaves from the Congo region, we learn from a memorandum prepared by an Anerican who aided that year in landing a cargo on the coast of Cuba, though he is mistaken in thinking that his was "the last slaveship," paid for men and women after something like the following tariff:-The trader had in the first place to "dash" the chief of the tribe among whom he settled for the privilege of erecting a barracoon, which, being built, was carefully protected by the members of the tribe constituting themselves its selfappointed guardians. A scale of prices was then agrced upon for negroes, according to age and scx. This averaged four yards of calico, one flint-lock musket, one six-pound keg of coarse gunpowder, one two-gallon keg of rum, some beads, and brass wire; in all, goods worth about thirty-four shillings for cach black captured and lander in the barracoon by the tribe from their weaker neighbours. 'The tariff' had been lower until within a few years prior to 1859 , "when competition increased then " to the rates mentioncd, a cynical commentary on the efficiency of the blockading squadron.

Numbers dicd on the way to the const, many more while waiting a customer in the barracoons, and a large percentage while packed in the hold of the slave-ships making "the middle passage." As soon as they arrived from the intcrior the slaves were cxamined as to their physical condition by the surgeon attached to the factories, who arranged them in classes according to their state. Each serf was then branded with the name or arms of the owner, in order to prevent the "slatees" from exchanging them for worse, and also as a certificate of good quality, certain dealers or compranics being noted for the grade of negroes whom they exported. Women were always one-fourth cheaper than men, though by dint of long practice there was never any difficulty in arriving at the valuc of the different lots (p. 61).

To save the expense of keeping them, at a charge of about twopence a day, they werc usually sent on board at the The Middie carliest possible moment, stark Passage. naked, thc owner having stripped them of every rag they possesserl, and in this condition they made the voyage, unless, indecd, the captain was charitable enough to supply some garment for cach of them. As six or seven humdred were often shipped in one vessel, careful stowage was imperative: and assuredly no space was lost.

The Dutch boasted that their slavers were always cleancr than those of other nations. But none of them had much of which to boast. The stench in all was frightful when the hatches were taken off and the slave-decks aired. As the belief of the captives was that they were being taken to the white man's country to be eaten, with such a prospect before them mutiny was common among a people naturally ferocious and reckless of their lives. Not unfrequently ships have been captured, the crew murdered, and the craft run ashore by the slaves, while the cases in which revolts, sometimes causcd by the sailors ill-using the wrotched people under their control, were suppressed after a sanguinary struggle fill a large portion of every slaver's log-book. They were fed twice a day, and in fair weather allowed to come on deck, and on some ships they were served with pipes and tobacco, it being the object of the captain to 
land his cargo in as good order as possible, every negro being credited to him at a commission of so nuch a head, the officer's and crew also sharing in the profits of the enterprise.

It was only when the trade became an offence against the law of nations that the sufferings of the slaves grew atrocious. For the aim of the master was to pack as many as possible on board his ressel, the peril of making one rum being only half of what was entailed in making two. In case the cruiser ran the slaver hard, and a prison cell or the yardarm began to look perilously near, the captain never hesitated to save his own life by throwing the negroes overboard. This has been denied; but it happened within the memory of men still living. Thus, in 1831 the Black Jolie and Fair Rosamond chased two slavers into the Bonny River ; but finding it impracticable to escape in this direction, the slavers ran into a creek and began deliberately to toss their living cargo to the sharks, and before the cruisers could reach them had thus disposed of the greater number. A Spanish slaver, when captured, had made every preparation for blowing up the three hundred and twenty-five captives lying in the hold; and during another chase of a Spanish slaver by an English ship, the crew of the former noticed the other busily dropping casks overboard. Each cask was found to contain from one to two slaves. Instances of abouninable cruelties, alnost incredible were the stories not fully authenticated, might be quoted had these any direct bearing on the theme of our volumes, and the harder run was the slaver the more heartless was the harshness with which the rictims were treated (p. 76).

It would, however, be a mistake to suppose that the captains engaged in the slave trade were monsters of iniquity any more than their employers were men of low commercial standing. On the contrary, many of them were much respected in private life: and as none but extremely smart men were, engaged for a service which demanded great courage, shrewdness, and resource, it is certain that the riff-raff of Liverpool and Bristol were not shipped for the Guinea trade. They followed a lawful branch of industry, and their owners and consignees were among the greatest folk in the ports whence they sailed or on the plantations to which they were bound.

Sir John Hawkins during his trips to the Canaries "by his tenderness and humanity had nuade himself much beloved," and was so little ashaned of his business that when he was dubbed a knight he chose for his crest a "demi-Moor in his proper" colour, bound with a cord." On board the Portuguese brig Teloz, captured in 1837 , was found a charming correspondence. The agent of the Pernambuco Slave Importing Company, to which she belonged, writes to his principals that, in spite

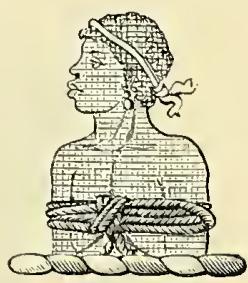

CRES'T OF SIR JOHN HAWKINS. of the kindness of the Queen of Benin in giving him forty-eight pairs, he was badly in need of leg-irons; and to his wife:- "Dear Spouse of my heart, I send you three fine mats and two parrots, one ram-goat for iny little son .John to play with, and three seahorse teeth for our little daughter Henrietta, also a little girl, very pretty"-for whom this humane parent had paid two rolls of tobacco, twelve yards of flannel, and one piece of calico- "and a little black boy for Johnny. They have the mark $O$ on the right arm"; and so forth, the cruel scars left by the branding iron being described with a professional callousness that suggests curious reflections regarding the composite condition of the mind of man.

A traffic so profitable, so lawful, and pursued by such humane men as the Portuguese factor whose epistle has just been A defence fender's. Captain Snelgrave (as slave trade. worthy a inan as ever ran negroes from Whydah to the Sugar Islands) was very sad to think that the "traffic in human creatures" might be accounted barbarous. But it had 
this to be pleaded as its exeuse, that the trade was to the advantage of both merehants and slaves, for the latter would be killed were they not sold, and on the plantations they lived better than they did at home. As many of the negroes were criminals, their absence was good for Afriea; and as the tropies

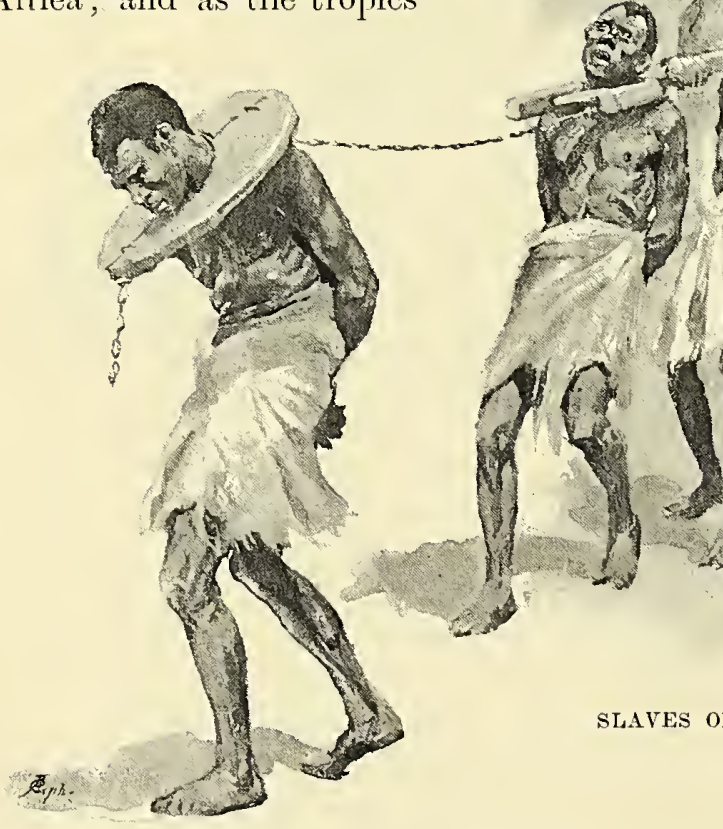

eould not be eultivated without them, their presenee there was exeellent for the planters. And, finally, it goes without saying that the trade was good for the people who sold, bought, transported, and sold again the very peeuliar goods in which the exeellent gentleman mentioned dealt. But there were greater folk than master mariners to defend this traffic. Did it not, it was triumphantly asked, employ a large fleet of ships and absorb a vast amount of British manufaetures; and find work for a host of seamen, mechanies, brokers, elerks, and the like, not to mention the millions of produee whieh the labour of these bondsmen reared in America and the West Indies?

As to the morality of the matter there surely eould not be any loubt on the subject, since the Soeiety for Propagating Christianity, ineluding half the episcopal bench, derived, as masters, from the labour of their slaves in the West Indies, an income which it spent in teaehing the religion of peaee and goodwill to men. That it was approved of by all sound patriots was evident from divers Acts of Parliament and utteranees having all the foree of a Royal deeree. For did not a Statute of King William of pious memory affirm "that the trade was highly benefieial to the kingdom," and another of George II. that it was not only "very adrantageous to Great Britain," but " necessary to the plantations," whieh Act, remarks $\mathrm{Mr}$. Norris, with some acrimony, was made by "a Whig King and a Whig Parliament, who, when they dissolved the late African Company, granted a large sum 
of money as a compensation for their rights, in order that a trade that was necessary and advantageous might be carried on with greater energy and success." In short-to parody another piece of optimism - the negro kings liked the slave trade; the Bristol merchants liked it; the captains liked it; the planters liked it; and it was the belief of some people whose utterances are not quite so remote as the days of Wilberforce and Buxton that the slaves liked it too.

Logic as feeble used to be heard night after night in the House of Commons when it was proposed to do away with the traffic, and a century later, when the aftermath of the trade was a huge civil war in the land to which the negroes had been carried. With quite as much reason highway robbery might have been defended on the plea that it stimulated the breeding of swift roadsters; that burglary helped the ironmongery trade by encouraging the manufacture of good locks and superior window-fastenings; or that pocket-picking was a branch of industry that provided employment for many sharp-fingered youths, a host of policemen to look after them, a legion of lawyers to put them into prison, and a battalion of turnkeys to see that they did not get out.

But all these arguments did not prevent an ever increasing number of people from doubting. that, however serviceable the black labourers were in the sugar, tobacco, of the and cotton fields, the capture and slave trade. carrying them across the Atlantic were bad for Africa and bad for Europe. Even so severe a Tory as Dr. Johnson was fond of toasting "The next rebellion of the Jamaica blacks." Vested interests were, however, strong enough to prevent the advocates of abolition from

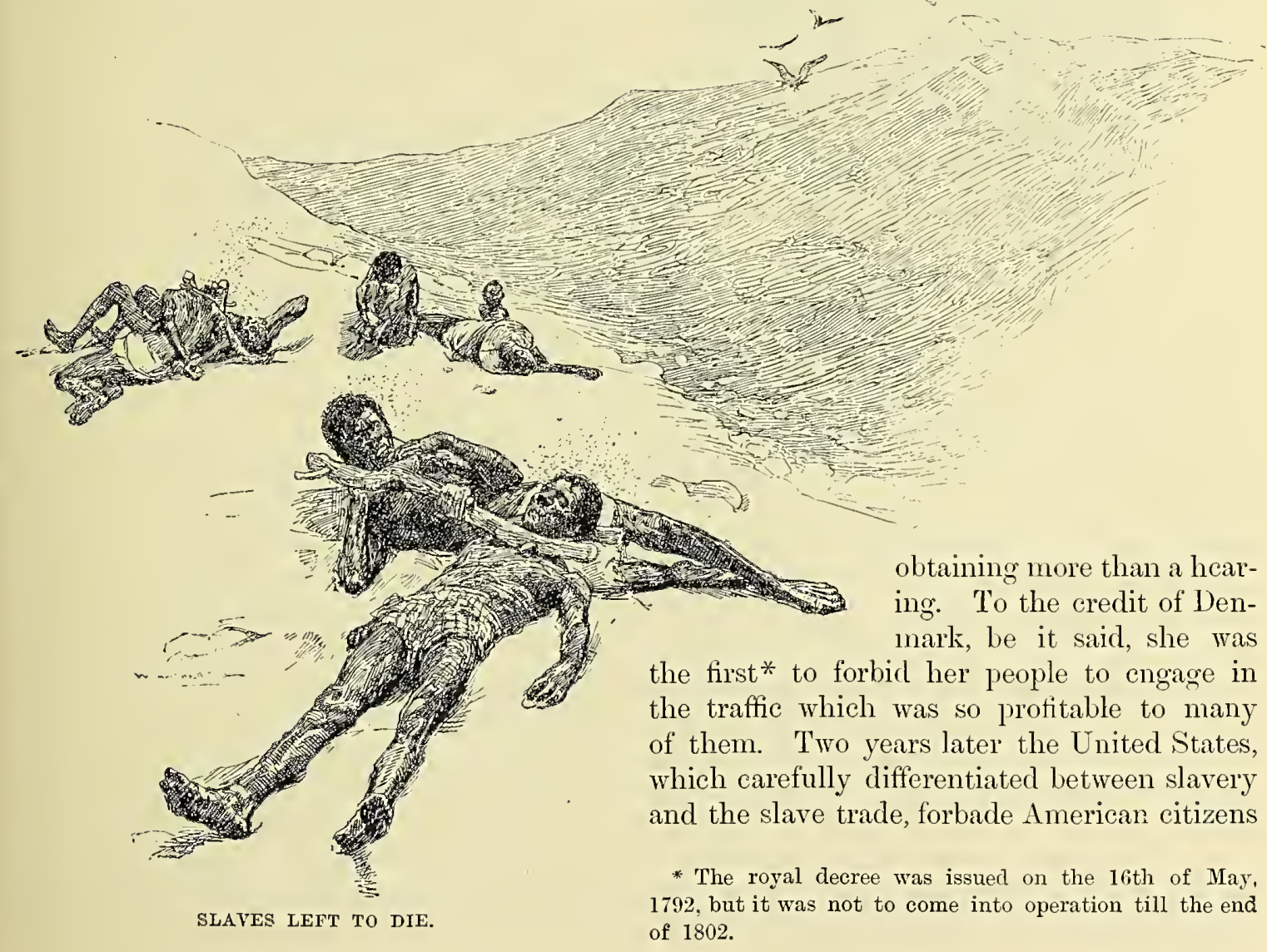


to participate in the exportation of negroes to foreign countries, and in 1794-the Act to come into operation in 1804-prohibited the introduetion of Afrieans into their own dominions. Great Britain, which had bcen the carliest and most strenuous opponent of this commerce, was able in 1807, aftcr a stout struggle in Parliament and out of it, to abolish the slave trade so far as she was coneerned. The Bourbons never made any

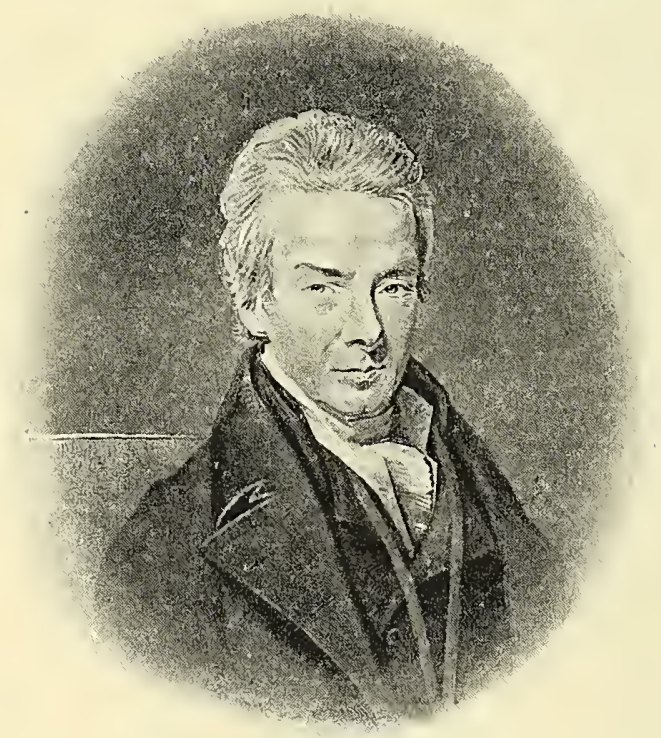

WILLIAM WILBERFORCE.

(After the portrait by Sir Joseph Slater.)

advanees to what thcy regarded as a revolutionary reform. But at the Congress of Viemna, in 1814, Franee agreed in prineiple that the slave trade should be done away with as soon as possible, entcring at the same time into a treaty with Grcat Britain whieh provided that no foreigners should in future import slaves into the French colonies, and that aftcr the 1st of June, 1819, the traffic should be entirely stopped, this postponement bcing dictated by a wish to introduce a fresh stock of slaves into Hayti should that island bc reeovered. During Napoleon's brief reign, in 1815, a decree was issued whieh ended the trade for good and all, an Act which was confirmed at the second Pcace of Paris, in Norcmber of that year. though it was not effeetually earried out until
March, 1818. In 1815 Portuguese subjeets wcre forbidden to carry on the slave trade north of the Equator, and the year 1823 was fixed as the date beyond whieh it should be everywhere unlawful, though the time was subsequently extended to 1830 ; and on England paying the Portuguese a eompensation of $£ 300,000$, a royal edict was issued in 1836 prohibiting the cxport of slaves from any of the Portuguese possessions. In like manncr England paid $£ 400,000$ to the Spaniards in 1820 , on condition that they too should ceasc to buy Afriean negroes. But though the Governments of both eountries concerned carried out the eontract, it is notorious that the bargain was violated again and again by Portugucse and Spanish subjects, and that in too many instanees the loeal officials in Afriea openly connived at this infringement of a compaet of which they disapproved, in so far that it robbed them and thcir friends of a great deal of unholy profit. The Duteh trade was elosed in 1814, on the Swcdes ending theirs a ycar earlier ; and by the Peaec of Ghent, in 1814, the United States and England mutually bound themselves to do what lay in their power to extinguish a traffic which had by this time been recognised as infamous, whether earried on as prior to 1788 , in an cntircly unrestrieted manner, or, as after that date until its abolition, under regulations ordained by various Aets of Parliament. It was at once prohibitcd in several of the South American States when they shook off the yoke of Spain, though othcrs, like Brazil (on separating from Portugal) continued to countenanee a trade which her planter's eonsidered essential to their prosperity. In 1831 and 1833 most of the Powcrs agreed to a right of inutual seareh, a proviso which rendered the traffie much more diffieult than before, and by the Ashburton Treaty (1842) Great Britain and the United States arranged for the joint maintenanee of squadrons for preventing the exportation of slaves from the Guinea Coast.

In this way, officially at least, the slave trade, so far as it eould be earricd on under the flags of European nations, beeame a perilous 
occupation. But it did not cease. There were Brazil and Cuba eager for more black people, and the Southern United States in no way inimical to a cargo of negroes being quietly run into one of the Carolina creeks, and no questions asked. Hence, for many years the cruisers seldom had their anchors down, and Sierra Leone, which had been founded for the reception of captured slaves, had no reason to complain of a lack of fresh colonists. Portugal and Brazil—or, at least, Portuguese and Brazilian subjects-scarcely made any secret of continuing to carry on the traffic: only they had to look out for the cruisers. Whydah was the chief port, and here the Da Souzas and Medeiros lorded it like kings on the profits they made out of the thousands of blacks whom the King of Dahomey poured into their barracoons. The founder of the Da Souza family-old Francesco Felles of that ilk-was a Brazilian farmer who in 1810 came to the Guinea Coast, and for nearly forty years was in rank and influence only second to the King of Dahomey, and in wealth far superior to him. He died in 1849, leaving more than a hundred children, the tawny descendants of whom now form quite a caste in Whydah, declining to intermarry with any of the natives, though in morals they are in no way their superiors. Iavish hospitality was, however, the rule with old Da Souza, and Senhor Medeiros, who in days not very distant exported an enormous number of slares, kept open house for all comers.

But the "forts" of Whydah are now in decay, and the cntire place bcars the impress of fallen fortunes. Incomes, once upon a time reckoned by tens of thousands, are barely countable by as many hundreds: and though the gold-inlaid bedsteads, the musical-boxes, arms, silk, and other costly articles purchased at exorbitant prices in the days of reckless extravagance, are still there, the huckstering of palm-oil is a poor business compared with the lucrative trade of an era never to return.

Pedro Blanco, a well-educated Spaniard of a good Malaga family, whose "factory" was at the mouth of the Gallenas River, rivalled the
Whydah magnates in the extent of his operations in "black ivory." All the approaches

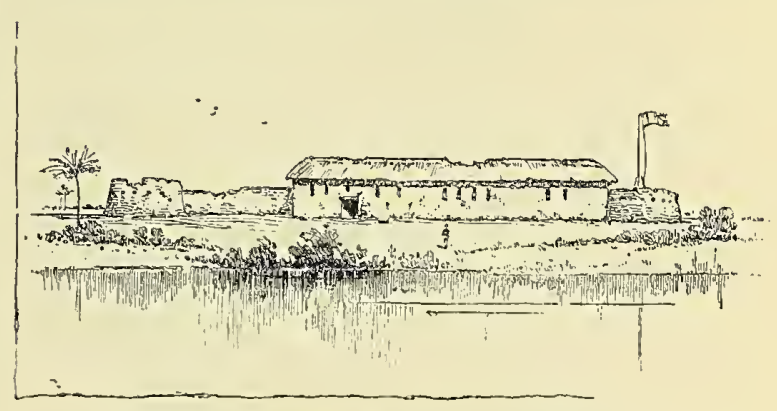

THE OLD FRENCH FORT AT WHXDAH.

to his establishment were carefully guarded by watch-towers, in which were men constantly sweeping the horizon with powerful telescopes to give timely warning to his slave flects of any cruisers being in sight. At the first sign of danger, warnings were signalled to the barracoons for miles up the river, so that when the war-ships arrived nothing except a few bales of harmless merchandise were to be seen, while the notorions slaver was ready to receive the officers with the utmost kindness, assuring them that he had long ago abandoned the business which had brought them to his humble abode. Then, after the cruisers had left, suspicious that they had been outwitted, the two or three thousand negroes Señor Blanco had in stock would be brought from the jungle and the mangrove swamps where they had been hurriedly concealed. Up to the year 1839 the sunburnt little Rothschild of the Guinea Coast, whose paper was freely accepted in all the money markets of Europe, lived on the Gallenas River, his commercial cares being latterly shared by his sister. Then, finding the business declining, he returned to Havannah with his enormous fortune, dying in that city within the inemory of the present writer. He was amazingly successful in his evil trade, seldom losing a vessel, and so fortunate in the prices he obtained in Cuba and South America that he could well afford an occasional capture by the oft-disappointed war-ships. His establishment is described by 
those who visited it in the days of its prosperity as quite princely in its barbaric splendour. He had depôts on the islands at the mouth of the river. Higher up, on another island, was his private residence, an establishment of the most luxurious decription; and still farther up were his savage seraglio, and twelve barracoons, each of them eontaining from 100 to 500 slaves ready for transhipment when required. All this is, however, a tale of the past. Nowadays there is little on the Gallenas River to remind the visitor that Pedro Blaneo ever lived, exeept the ruins of his depôts, or of speculation. And they found the profits quite equal to the risks. Vessels were specially built for the trade, and thus, so long as the slavers eould outsail the cruisers, with the experienced spies the former had in their pay all along the African shore, the ehance of the latter overhauling the man-thief was not great enough to cheek a good many trying their luek in the venture. Sauey brigs lay in the fever-infested mouths of the West African rivers, waiting their ehanee to elude the warships, and then, when a favourable opportunity oeeurred, the white sails were spread to the

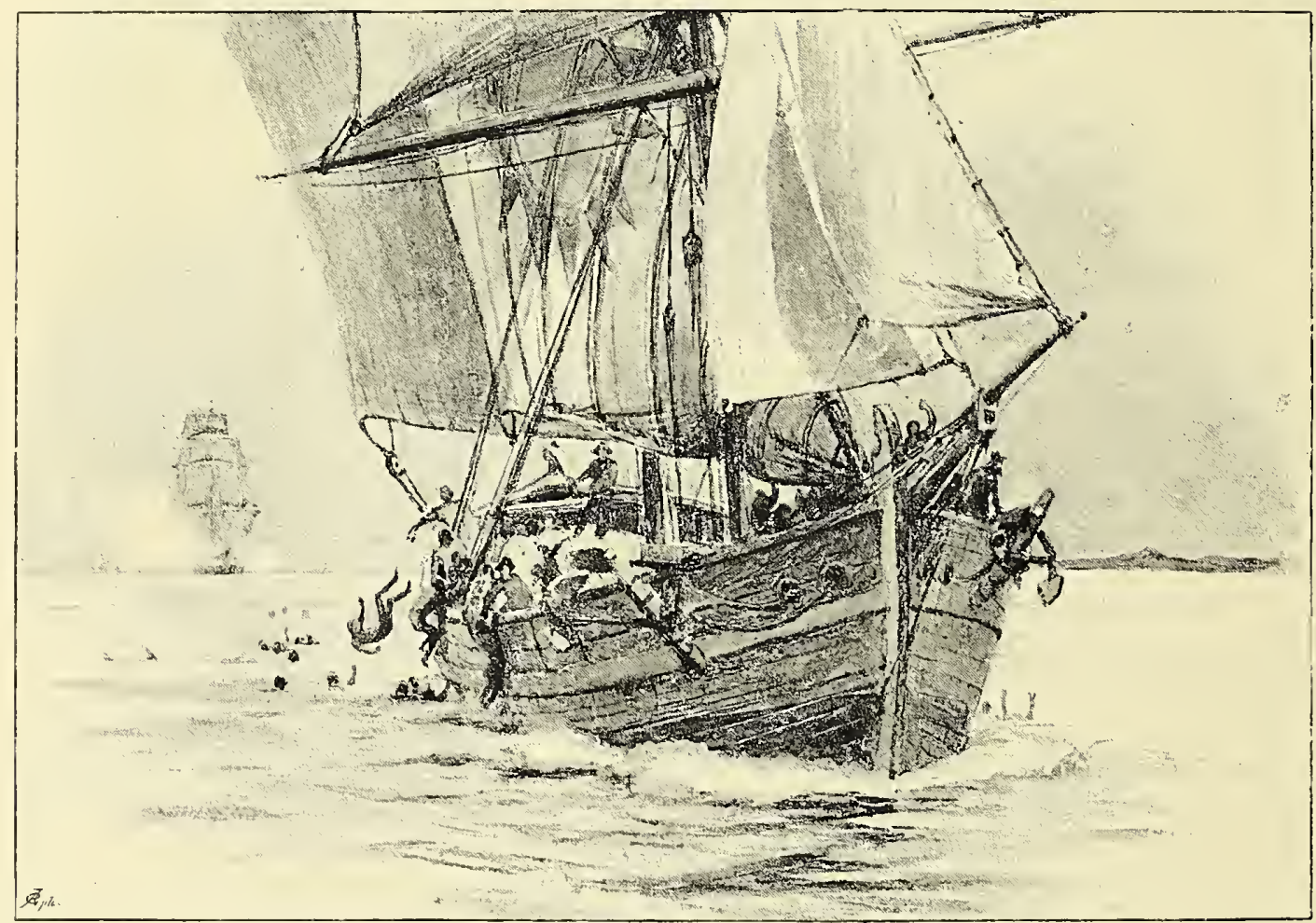

SLAVER CHASED BY MAN-O'-WAR.

the little palaee in which he dispensed sueh regal hospitality.

Naturally when the laws of nations frowned on the slave trade the price of slaves

What

followed rose, but this fact rendered the prohibition. business of "rumning" them all the more attractive to the reckless men engaged in risking their neeks in the breeze, and then, hey! for Cuba or Carolina. For there is no doubt but that eargoes of slaves were every now and then "rum" on the southern shores of the United States up to the date of the Civil War, and on those of Cuba and Brazil close to the period when by the abolition of slavery in these eountries sueh merehandise had no marketable value. A 


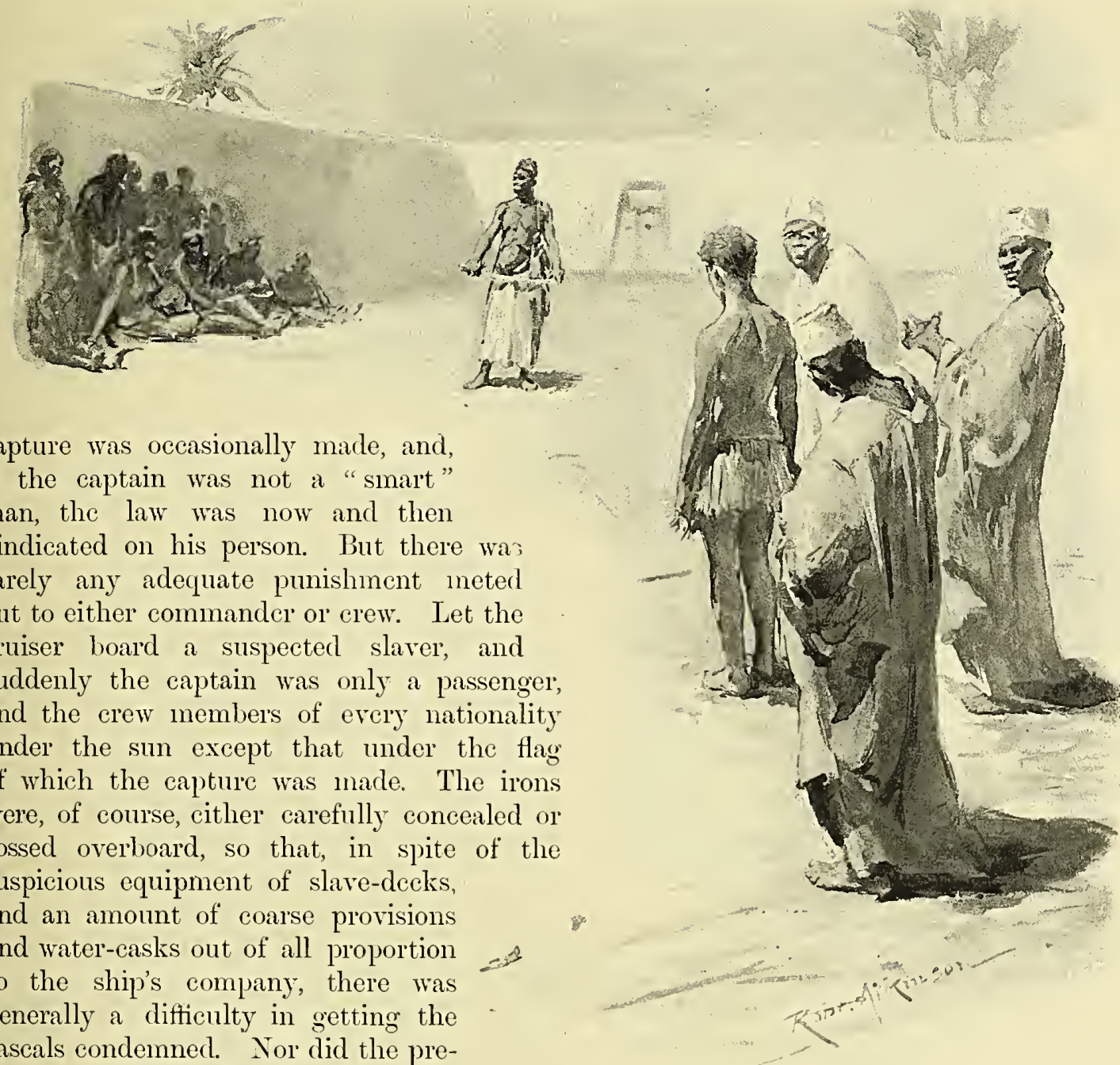
sence of negroes always sccure a conviction: for they might only be labourers. The result was that in most cases the blacks were, at worst, landed on the Seychelles, at Sierra Leone, or in Liberia, and the captain and erew at the nearest port, the value of the ship being divided among the efficers and seamen of the cruiser that had made the capture. All that the preventive squadron did was to confinc the trade to fewcr speculators, and, having rendered it more risky, compel men to cram a larger cargo into a smaller space, and to pursue it with greater barbarity than ever. Steam made the business still more perilous, for the cruisers could then out-chase them,

since a steain-slaver afforded, unless very large, too little car'go-room.

But what ended the export of negroes from Africa was not the war-ships or the treaties under which they pursued their unhealthy work, or the smiting of the callous public conscience, but the fact that, by the abolition of slavery in countries which were formerly ready to purchase the contraband article, there were no more customers for the slaves. Then it stopped. Yet, were slavery to be again decreed lawful, it is perfeetly certain that plenty of slaves would cross the Atlantic. 
However, though the exportation of the people of Africa is now at an end, slavery and

The end of the slave the slave trade are still flourishing, trade. and will continue to flourish until slaves are no longer marketable. The Arabs hunit them from the East Coast to all around the great lakes and the head-waters of the Nile, the Niger, and the Congo, for the home demand. Every year thousands are sold in Morocco, and it is believed in the remoter parts of Tripoli and Tunis, and even

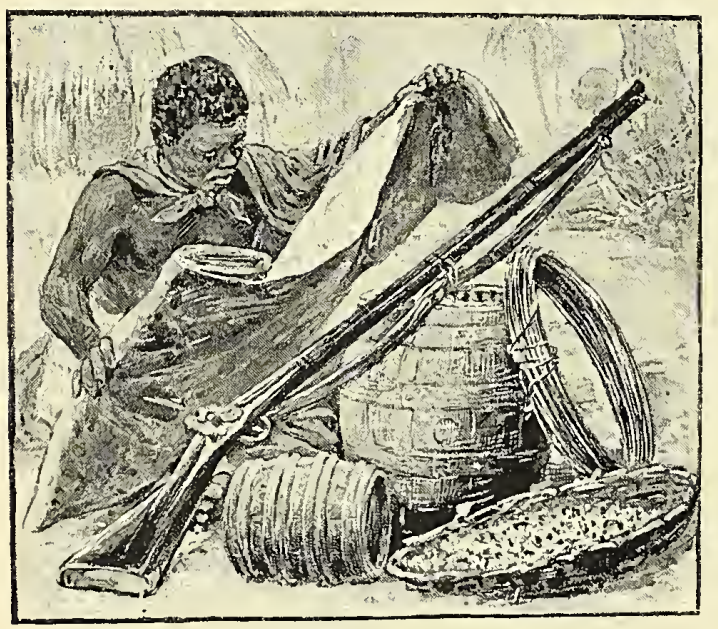

THE PRICE OF A SLAVE,

on the frontier of Southern Algeria; and in spite of the East African cruisers and the prohibition of the trade in the Sultan of Zanzibar's dominions (Zanzibar being at one time a great slave mart), and, of course, in those of the European Powers who have divided this coast anongst them, numbers, it is believed, find their way into Arabia and Abyssinia, while many are disposed of to the Central African potentates who may not have opportunities of capturing them in their own intertribal raids and robberies. This infamy we shall have occasion to come across very frequently before we are done with Africa. For the present we have only to do with the
Guinea trade, and eren there merely in so far as it aided in the development of Africa by calling attention to its unexplored parts, or retarded its progress by preventing merchants or the people from thinking of any resources other than the hucrative one which came to an end when Brazil, in 1888, abolished stavery. From that day a new life began for África. For so long as this South American inarket was open to illicit merchandise in the shape of human beings from Africa, so long would there be a chance of someone trying to profit by their sale. If any proof nore circumstantial than a knowledge of human greed were required, it is supplied by the fact that though in 1830 a trattic which four years previously had been "abolished" was declared piracy by the Emperor of Brazil, up to 1850, by the connivance of the local authorities, 54,000 Africans continued to be annually imported. In Africa the slave trade was an unmitigated misery - a crime unredeened by one extenuating circumstance. It caused war, bloodshed, and every kind of wretchedness, and it impeded, or rather, destroyed, all honest industry. Wherever slavery has been stopped, it has been found that a greater export of ivory, gold-dust, ebony, palm-oil, and other products of legitimate African coninerce, has followed, and that the natives become more industrious and less brutal than before. On the other hand, it is questionable whether many parts of America could have been settled, or some parts of it cultivated, to this day, without negro aid. To the "Guinea trade" we owe the earliest impulse to African exploration and commerce, and it must never be forgotten that to it we are indebted for the writings of such doughty menand such gallant seamen and historians as Dampier, Hawkins, Bosman, Jannequin, Barbot, and others. It may, nevertheless, be a moot question whether we have not purchased the heritage of their works at far too dear a rate. 


\section{CHAP'TER IV.}

\section{The Corsairs of AFrica.}

Piracy as an Agent in the Non-development of Africa-- Some Notorious African Pirates - Davis, England, Lowther, Massey, Roberts, Avery-The Madagascar Pirate Colony-The Pirate Princes-Congdon, Claydon, Taylor, White-John Plantain-Audacity of the Pirates-The Ways of Pirates-The Pirate of Fact and of Fiction Two Different Personages-The Decadence of Piracy as a Profession-The Experiences of Captain William Snelgrave, of the Bird Galley--The Laws of the Lawless-The Legends of Buried I'reasure - Baselessness of these Tales-The Pirates' Friends and Resetters-The Isles de Los and their Memories-The End of Piracy, and how it was brought about-The Barbary Pirates-The Rovers of Tripoli, Tunis, and Algiers-The Morocco Pirates-The Sallee Rovers-The Riff Pirates-The Last of their Order.

But if there were thieves on land there were also thieves on sea, and the sea wolf, contrary to the proverb, ate the land wolf whenever an opportunity occurred. The Guinea ships were, indeed, for a long time the favourite prey of the pirates, the gold-dust on board of them being the principal attraction. And as the sea between Africa and America was the highway of vessels doubling the Cape of Good Hope, or on the way round Cape Horn or through the Magellan Strait, this coast had more than enough of these gentry. Slaves were, however, not despised, and cases are known in which, long after the slave trade was accounted piratical, robbers waited until a vessel laden with negroes had run the blockade of cruisers, then quietly overhauled her, transferred her crew, and sailed for the destined port. The Guinea-bound vessels were likewise worthy of attention, since they contained bales of cloth and ammunition, and, after the negro kings took a liking to Maria Theresa dollars, a store of specie, which the pirates preferred to goods of any description. Accordingly any account of the early struggles of the African trade, and of the obstacles which lay in the way of African development, would be incomplete without a sketch of the rovers who, for a long period, played so uncomfortable a part towards the more or less legitimate traders on the Guinea sea-board. Few of the latter-day corsairs were not familiar with this region. Some of them, indeed, had, before joining the pirates' ranks, been engaged in the service of one of the companies which at different times ruled this coast, and, in one instance at least, a notable member of the fratemity of sea-thieves was the officer in command of a Gambia fort.

Among the most notorious of the pirates plying their trade on the African coast was Howel Davis, a Welshman, who had the boted had the boldness to anchor under African the gums of Fort James, on the pirates. Gambia, and land between files of musqueteers, in the guise of a merchant bound from Liverpool for the Senegal, but forced to take refuge in the river to escape the pursuit of two French men-of-war. The governor credited the tale, and, prior to "slaving him to the full extent of " the supposed cargo of iron and plate on board the pseudo-merchant's vessel, entertained the pirates hospitably. Neanwhile, the latter had been maturing their plans, and, when the garrison were off their guard, seized the place without sherlding a drop of blood. Many of the soldiers joined Davis; those who did not were confined in one of his ships, and then, no fear of a recapture being apprehended, the pirates proceeded to ransack the castle, after a prolonged carouse, which was the preface and the end of every act of these ruffians' lives. The contents of the fort, however, disappointed them. A large suun of money having been despatched a few days before, they found no more than $£ 2,000$ in bar gold to divide, in addition to various articles of value, which they duly 
carried on ooard, after dismounting the guns, demolishing the fortifications, and doing all the harm they could. Strengthened by the alliance of two French cut-throats, Cochelyn and La Boise, he next drove the garrison out of the Sierra Leone fort. Three of a trade never agreeing, especially when in strong arink, as the devotees of sea-robbery generally were, they parted company, each continuing his course, seizing, and plundering, and scuttling when the merchantmen were weak, or fighting with might and main when they were strong. This fell out to be the case with a Dutchman of thirty guns and ninety men, which struck after an engagenrent off Cape Apollonia which lasted from one o'clock in the afternoon until next morning. Equipping the captured ship, Davis set sail for the Bay of Anamaboe, where he took several vessels waiting to take on board slaves, gold, and ivory. One of them he made a present of to the Dutch captain and his crew, and allowed them to depart in quest of what fortune might have still in store for them. All this time the fort ashore (p. 48) was puzzled at these somewhat peculiar proceedings, only firing at Davis's vessel when it dawned upon the commandant that the latest arrivals were pirates. "Davis fircd also, and hoisted the black colours," but, adds the historian from whom we obtain these particulars, not receiving any damage, "deemed it prudent to depart." Still in luck, he was so fortunate the day after leaving this spot as to make a prize of a Dutch ship conveying the governor of Accra to Holland, and, what was much more to the point, $£ 15,000$, "besides a large quantity of merchant goods and other valuable articles." At Princess Isle, however, Davis's fortune deserted him. For here, finding that his vessel had sprung a leak, he entered the port under English colours, pretending to be a man-of-war' sent out in scarch of some pirates who had becn heard of in that quarter. The Portuguese governor affected great delight at seeing so distinguished a visitor-in those days uniform was not worn in the Navy--and insisted on escorting him to the fort with a guard of honour. Davis kept up the character of a nava captain by being rowed ashore by nine men, and, furthermore, to combine business with pleasure, seized a French ship which happened to arrive, on the plea that she had on board some articles which he knew belonged to pirates. All this time, whatever might have been the governor's suspicions, the corsair was not molested. He cleaned his arms, caulked his ship, mended his sails, and generally put everything into trim for another voyage, meditating, meanwhile, to play the fort here the same trick that he had played the Gambia one-or to scize the chief personages while dining in his cabin, and not release them without the payment of a heavy ransom. Fortunately for them, however, a negro who had got wind of the plot, swam ashore in the night and gave information to the governor of what was in store for them. The result was that when the pirate came ashore next morning to invite and convey on board the selected guests, he was received with a salvo of musketry, so well-rirected that every man of the party fell, except one who escaped to the boat. Davis died with the rest-in his agony, firing his pistols at the people who approached him. This is the usual tale (p. 85). But two Capuchin Friars told Captain Snelgrave another version not so creditable to the governor. For, according to these cye-witnesses, that functionary was well aware who Davis was, but winked at his proceedings, "out of the great gain he and his chief people made out of the pirates." It was only when he got afraid of the King of Portugal hearing of his conduct that he plotted their destruction. If we may believe these Friars, Davis had no intention of holding the officials to ransom.

England was another notorious scourer of the West African coast about the beginning of last century (p. 81). But though he had a certain success between the Gambia and Cape Coast Castle, his infamy is more associated with the East Indies than with the Dark Continent. $\mathrm{He}$ is described by some of his contenporaries as too amiable for a piratc. That also was the opinion of his crew, who displaced 
him in favour of Taylor, a ferocious miscreant who tortured prisoners to extract information. This villain-one of the worst of an evil tribe-had originally served in the Royal Navy, and cnded his career by commanding a Spanish war-ship engaged in harassing the English logwood-cutters in the Bay of Honduras.

George Lowther (p. 83) was another of the rascals that kept merchant captains awake during their watch. He sailed from the Thames as second mate of the Gambra Custle, an armed vessel belonging to the Royal African Company. On board was Major Massey and a troop of soldiers intended to re-garrison Fort James, recently sacked and dismantled by Captain Daris. Quarrelling with the nerchants over the provisioning of his men, Massey joined Lowther, who also har taken umbrage at his commander, and seizing tho ship, started out on a course of piracy. The partnership was, however, not of long duration. Lowther was a thief, and not too bold a one either. His ain was to plunder merchantmen with as little risk and as great a protit as possible, and then to make for Madagascar or other safe spot in which to enjoy it. Massey had beconie a robber more by force of circumstances than by inclination. At heart, he remained a soldier, and, after the first flush of lawlessness was over, seenied anxious to appear in his military character, and, by redeenring the past, save his neck on returning to England. He accordingly proposed to land with fifty or sixty men, and raid the French settlements about Senegal. The vote of the majority was, howerer, against what they regarded as rashness without any compensation in the shape of gain. The minority, nevertheless, remained unconvinced, and were on the eve of trying conclusions with the other side when a sail was reported. A few hands and a supply of necessaries was the most that was got out of her, and Lowther proposed to scuttle the ship with her passengers; to this the more humane Massey objected, which course of action broadened the gulf between the two factions on board. The next day, a small sloop being taken, the military captain announced his intention to part company with the pirates, and, his men following him, he sailed for Jannica, and there telling a plausible tale, made his peace with the governor, and was despatched in search of his late associate. Not finding him, he returned to England and again told his tale to the African Company. But these men of business, less easily convinced than the governor,

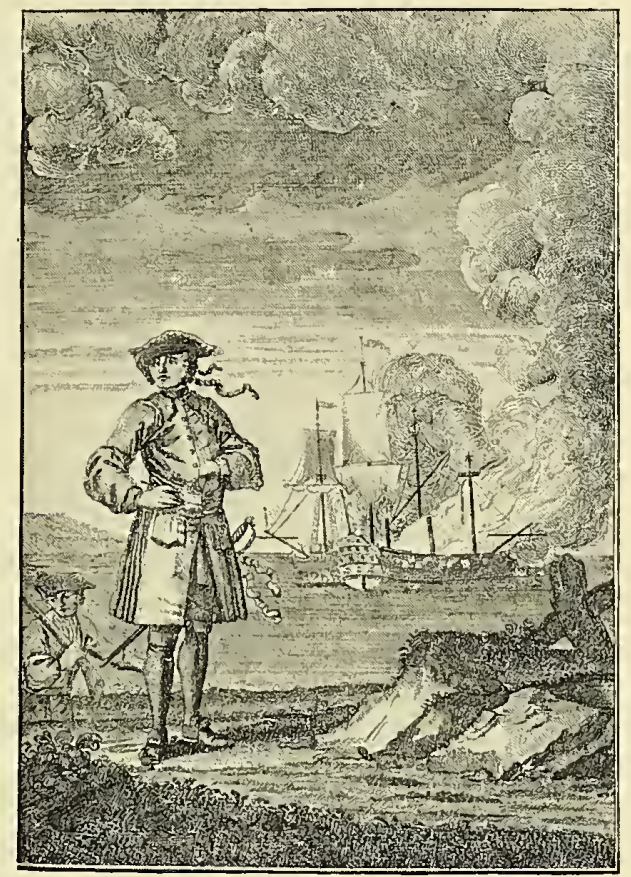

CAPTAIS EDIVARD ENGLAND.*

returned him for answer "that he should be fairly hanged": the which he duly was, upon the evidence of his own letters and the witnesses of his proceedings on the Gambia River. Lowther, finding the African coast too hot for him, forthwith confined his operations to the West Indies, where, having becn forced to take refuge in the woods by the crew of a ship that proved too strong for him, he shot himself in respair of any death more

* The portraits of Pirates in this chapter have been reproduced, on a smaller scale, from the plates in Captain Charles Johnson's "General History of the Lives an'? Advertures . . . of the most famous Pyrates" (1734). 
honourable than the gibbet or more agreeable than starvation.

Bartholomew Roberts (p. 87) was an honest sailor until Davis took his ship on the Guinea Coast, when he was induced to adopt the career in which he gained so evil an cmincnce that, on the death of the captain, he was elected, by the crew, commander in his place. This dignity he accepted with the remark, that, "since he had dipped his hands in muddy water, and must be a pirate, it was better being a commander than a private man." And, forthwith, to justify the choice of his associates, the new captain landed thirty men, who, under cover of a cannonade from the ship, drove the Portuguesc who had killed Davis out of their fort. The robbers then tumbled the guns into the sea, fired the place, and, after battering down a few houses and taking all they could lay hands on,* sailed again for the Guinea Coast and took prizes galore, the crews of several of them-as was not unconmonly the case-joining their captors, and preying on others in their turn. After a cruise in the West Indies and along the American coast, Roberts returned to Guinea, and, single-handed, overpowered two well-armed French ships, with which he sailed for Sierra Lcone, where the robbers remained unmolested for seven weeks, "enjoying themselves in all the splendour and luxury of a piratical life," bartering their plunder to the honest traders ashore. The supply of canary, or the wherewithal to provide it, growing short, the pirates put to sea again and soon captured several vessels. On board one of these was a clergyman whom they tried to persuade to join them as chaplain, assuring him that he "should want for nothing, and his only work would be to make punch and pray." But the parson dechining this tempting plurality, they let him go with all his property, and, to "banish care and sober reflection," they rctired, for a time, into a convenient harbour at Old Calabar, where they

* A Portuguese account affirms that he never landed, contenting himself with bombarding the town from a raft, the water being too shallow for the ship to get near enough, though in the end doing little damage. "cleaned, refitted, divided their booty, and for a considerable time caroused," a period of festivity and mirth, "according to their usual custom, prolonged until the want of means recalled them to reason and existence." But this was the last cruise of Bartholomew Roberts, of Pembrokeshire. For rum not having conduced to sober reflection, he permitted himsclf to be decoyed into a fight by the Swullow man-of-war, Captain, Sir Chaloner Ogle, and died fighting, clothed in his best, his pistols slung over his shoulders, and a gold chain about his neck, just as his crew cried for quarter. Being duly tried, "according to the different Acts of Parliament," his men were promptly hanged at Cape Coast Castle.

Arery (p. 92) was another of the pirates. whose cvil reputation has descended to us. The mate of an English ressel commissioned by the Spanish Govermment to prevent the French trading with South America from Martinique, he persuaded the crew to seize the ship and do business on their own account. It was, however, not on the West but on the East Coast of Africa that Arery, from his stronghold in Madagascar, carried on his piracies, and his place in the Newgate Pantheon is mainly due to the fact that early in his career he captured a ship of the Great. Mogul, engaged in conveying one of his daughters and her retinue to Ljeddah, for the Necca pilgrimage. Some very undiplomatic correspondence which the incident precipitated between the then powerful Mohammedan Empcror of Hindostan and the comparatively feeble East India Company obtained for this pirate captain a greater celebrity than his personal abilities deserved, and an absurdly exaggerated report of his wealth. But out of this, mainly diamonds and other jewels, he was cheated by some worthy Bristol merchants, fitting agents for the robber who had swindled his comrarles out of their share of the plunder which they had stolen from the dusky mariners. Then at Bideford, skulking under a false name, wretchedly poor, in vain trying to extract from the knaves who had him 
in thcir power a few of the guineas for which he had risked his life, the pirate dier. Some of his inmediate companions lay hidden in Ireland until they obtained King Willian's pardon, and were thus enabled to begin afresh as honest men, or, more likcly, to start on another bout of piracy when a likely chief marle his appearance. The rest of Avery's companionsthose to whom he harl given the slip with the Mogul's diamond-made their way to

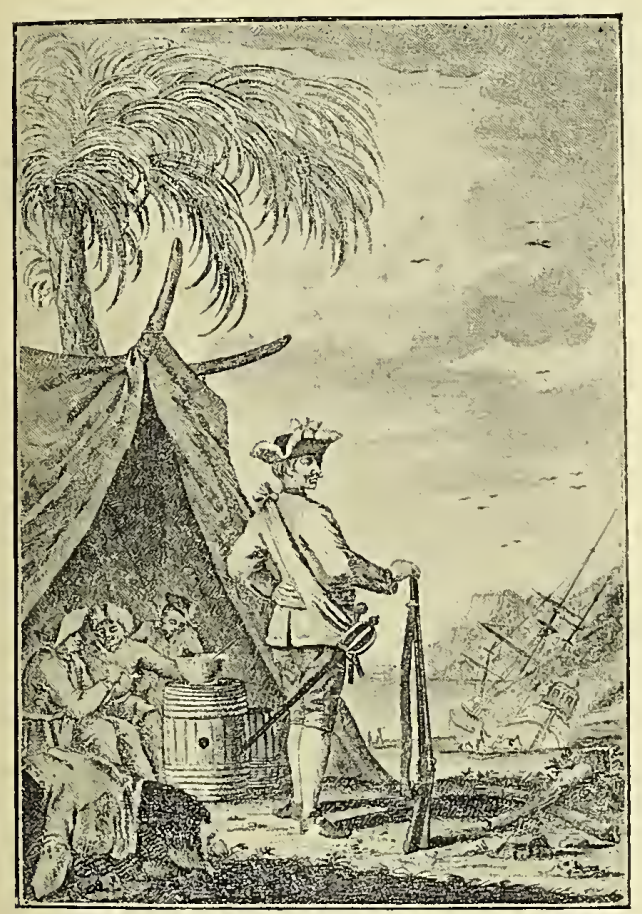

CAPTAIN GEORGE LOTTHER.

Nadagascar, where they found plenty of their own sort.

For many years, crer since the brothers Tew, instead of sailing for the Gambia under

The

pirate

colony. a commission from the Governor of with their plunder on the Marlagascar coast, this island harl becn a favourite haunt of the bascr order of sea-robbers. At the time referred to, the island was in quite a savage condition, and on the Sakkalava coast, where the Hova authority was feeble, the country was divided up among numerous rival chiefs, each anxious for the assistance that the new-comers could render him. The pirates and their fire-arms, until then unknown, were therefore weleome allies, and soon became so drearled that their appearance in the ranks of the enemy was enough to put the opposing army to flight. It is, perhaps, unnecessary to add that the reward they exacted for thcir services was enormous. Each pirate became a little prince, with a retimue of slaves cultivating the soil for him, and a harem, the extent of which was limited solely by the conveniences which the uxorious white pagan had for provisioning it. By-and-by, these petty kings fell to warring among themselves, and in the civil war that ensued their number was considerably reduced. Although these, with few exceptions, were men of the lowest origin, they spectily developed a fine aptitude for tyranny, revenging on the Sakkalara blacks years of rough usage in the fo'c's'le. Their power over their dependents was exercised in the most wanton manncr, the punishment for the least offence being a shot through the head. A conspiracy was then formed to destroy them root and branch, and would have been suecessful had not a native woman, who was partial to the pirates, run twenty miles in three hours to warn her friends of their danger, so that when the conspirators arrived the pirates were ready to receive them. This narrow escape marle them inore cautious. No longer relying on terrorism, they resolved on the policy of clivide et impere, though possibly they knew it by another name. Fomenting jealousies among the native tribes without themselves taking part in the feurls, they shcltered the vanquished, and thus increaserl their strength until no onc dared oppose them in open warfare, though, in order more effectually to guard against surprise, either from the exasperated Malagasics or from each other, they vied as to who should possess the strongest retreat in the most retired spot in the middle of his petty principality. 
Living in this manner, dreading and dreaded by all, they were found by the famous Captain Woods Rogers, the privateer (whose mate was in after years Alexander Selkirk), when he cane to Madagascar in search of slaves. He touched upon a part of the coast where no ship had been for seven or eight years before, and here he met with pirates who had been on the island for a quarter of a century. There were only eleven of the original stoek left, but they were represented by a numerous oftspring of children and grandehildren. At first they were struek with terror at the sight of Rogers's ressel, dreading that it was a warship sent to seize them. Reassured, however, by a short conversation with some of the crew-in whom they doubtless reeognised kindred spirits - the old pirates crept out of their secret abodes, and by-and-by ventured on board attended like princes, albeit, having been so long without aecess to the stores from which they had been in the habit of supplying their" wants, their majesties were, so far as garments were concerned, extremely out at elbows. They were not exactly ragged, for they wore the skins of wild beasts in their natural condition, without stockings or shoes on their feet, "so that they resembled the pieture of Hereules in the lion's skin; and being orergrown with beards and hair upon their bodies, they appeared the most savage figures that the human imagination could well coneeive" (1. 89). The slaves that they disposed of to the privateer soon provided inore suitable clothing, and the necessaries of which they were sadly in need. Meanwhile they becane very familiar, though they do not seem to have had intelligence enough to feel any interest in what had been going on in the workd since they deserted it, in this respect resembling the "squawmen," "beach-combers," and other modern adopters of a savage life. If they had originally cared nuch for the ways of civilised men, they would not have so long abandoned then.

But the old passion for other men's goods soon began to revive within them. They exanined, with suspieious interest, every part of the ressel, making friends with the men and inviting them on shore with a manimity which convinced the eaptain that, had it not been for the strong guard he kept, these seoundrels would have carried out their intention of seizing the vessel. They had, indeed, aheady attempted tocorrupt the sailors, and, as the privateer's men were largely recruited from the same class as the pirates, might have been suecessful-for they had several boats-had not the wary eommander prohibited the erew, except the agent employed to purehase the slaves, from having any intercour'se with them. Woods Roger's tells us that one of these Madagasear kinglets had been a Thames wateman, who, having committed a murder, fled to the West Indies, where he tumed pirate. The rest of them had been before the mast, and not one of them was able to read or write.

A few years later-namely, in 1721-we have another glimpse of the Madagascar pirates. This time it is not by a slaver-and in those days there was not mueh to choose between the resetter of stolen men and the footpad of the high seas-but by a naval officer who, in the diseharge of his professional duties, had to conne in contact with these ruffians. At that period, Charnoek Point, on St. Mary's Island, showed that it had been mueh frequented by "pyrates" for many years previous to the visit in question. The remains of Captain Avery's fortifications were to be seen, as well as part of the eargoes of several merchant ships that had been destroyed by the freebooter's and left to rot on the beach, the natives not appreciating the articles of which they had been composed. There were in that year inany Europeans settled about Madagascar, all of them nore or less connected with piracy. Congdon, Claydon, Taylor (p. S1), and White were men of note among these "esehatoi andron," and Robert Drury, whose narrative was probably edited by Defoe, was, in spite of his efforts to eonceal the faet, no doubt during his pretended fifteen year's captivity on this island mixed up with then, if not actually a nember of the fraternity; 


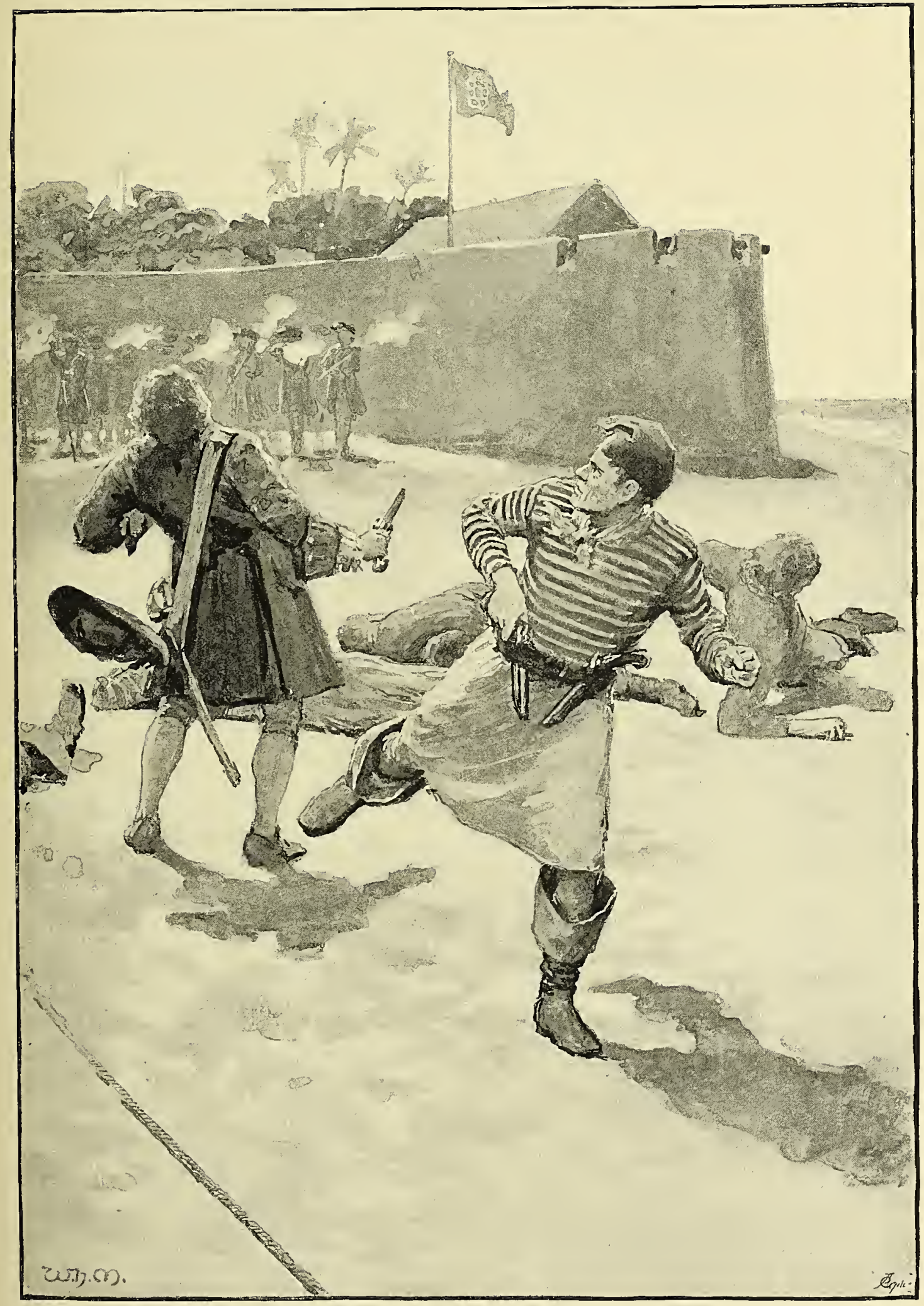

DEATH OF CAPTAIN DAVIS AT PRINCESS ISLAND. 
for we know that he sailed with White, who was in after years one of the most notorious of the Madagascar gang. But in 1721 John Plantain was the chief of the kinglets already described. This individual was a native of Chocolate Hole, in Janaica, though of English parentage, and before settling down in Ranter Bay had been an associate of Roberts, England, and other well-known corsairs. At Ranter Bay he was surmounded by a crowd of native serfs and English and mulatto hangers-on, who helped him in his enterprises, shared in his plunder, and composed in his pritise songs of which the refiain was "Plantain, King of Ranter Bay." At one time he ownerl a thousand slaves, and, after a series of civil wars with native chiets and white "princes" orer a certain Eleanora Brown, the mulatto daughter of a slaver, who, in addition to being rery pretty, was ralued by her husband for her piety, he meditated the eonquest of the entire island. At that date many of the natives spoke a little English, so frequent had their intercourse been with pirates, and, as might have been expected from the kind of example set them, were about as vile a set of lascals as the African islands had to exhibit. Howerer, Plantain seems to have gradually tired of being a Sakkalava kinglet, for we find him, soon afterwards, leaving Madagascar to join Angria, the Indian pirate prince against whom the East India Company had to despatch so many expeditions. To this day there are numerous traces of the old freebooters who had their retreat in Madagascar. But they seem to have gradually died out. Either they were murdered by the natives, or murdered each other, which might, in the circumstances, be caller a natural death; $\mathrm{Or}^{\circ}$ they left on another cruise and ended their carcer on the Dry Tortugas, or in the Execution Dock, or at Gallows Point, not far from Kingston, in Jamaica, where the remnants of the gibbets on which they hung in chains can still be seen; or they accepted one of those "Acts of Grace" which did more to encourage piracy than anything in the world except greed, cruel captains, and a love of laziness.
For at the period when the story of African exploration began in earnest the Madagascar inen play little or no part in the tale of its seas.

The audacity of some of these gentry was enormous. They would not hesitate to attack a fort if it was weakly garrisoned, or, as we have seen, a war-ship if it carried not too heavy an armament. In 1693 they captured, in sight of the coast, two Danish men-of-war that had weakened their crew in order to garrison Christiansborg (p. (j2). Now and then, howerer, they were meted out a treatment not much better than that with which they serred others. Thus, we read how some French pirates, being stranded on the island of San Thomé, agreed with the captain of an English ship, "in consideration of a part of their prey," to carry them and their booty of gold, slaves, and irory to the French islands. But the skipper played them false; for, after getting the plunder on board, he hauled up his anchor and paid the pirates for the cargo with what is known in sea-faring parlance as the "flying jib."

\section{The Ways of Prrates.}

These were the pirates of fact; and though it is no business of ours to study the American pirates, those of that continent were not a whit better, their ways and life being identical. Those of fiction are not quite according to the live model of which some specimens have been sketched. Indeed, the attraction which these freebooters have invariably possessed for the writers of story-books is difficult to pirate to understand. A housebreaker is of fact and seldom a romantic personage, but a of fiction. sea-robber seems, in the eyes of the boys' novelist, to possess every attribute of the picturesque. It must be admitted that the picturesqueness is a recent addition to his character, for the earlier writers knew too much of the real corsair to palm off upon their reader's anything so absurd as their successors have pictured with such acceptance. There has, in truth, grown up to be a pirate of fiction and a pirate of fact, though by the long conventionalism which the latter has enjoyed in print and on the stage he has been received as the reritable 
corsair whom steam and the telcgraph, rather than improved morals or the dread of the yard-arm, drove from the high seas. Every boy knows and too many admire him. He is always dark, often good-looking, and has, in nine cases out of ten, a redundancy of glossy curls. A brace of pistols, a cutlass, and a belt with a big buckle are indispensable. His language is spiced with maritime expletives, and is strictly grammatical, which is explained by the fact of the pirate captain having been a man of high degree, driven to evil courses by oppression, a lawyer, or a cross in love. A lady, always young, very beautiful, and generally dark, is usually seen peeping out of his cabin ports, and the robber, though he never fails to order his male captives to walk the plank, is chivalrous to an embarrassing degree when female passengers fall into his hands. And, above all, the piratc is invariably rich beyond the dreams of ararice. His craft is ballasted with dollars and pieces of eight, golden candlesticks and silver chalices wrenched from Peruvian churches, pearl necklaces torn from the necks of Spanish donnas, emerald rings stripped from the brown fingers of Indian kings, diamonds never seen out of the valley where Sindbad found them, and bars of the precious metals numerous enough to pave such a road as that over which La Palata rode his goldenshoed horse into the capital of Peru.

But instead of turning this loot into current coin at the earliest date, and either retiring: from business lest a worse fate overtake him in Execution Dock or at Gallows Point, or at least spending it in riotous living, the pirate of fiction is aftlicted with a craving for burying it on some desert island, and has a trick of dying without digging it up again. Finally, the secret is revealed on his death-bed by the sole survivor of the corsair crew, though even he never manages to explain why he has all

* As late as the beginning of this century, Michael Scott describes in "Tom Cringle's Log," still the most graphic account of Jamaica in existence, twenty-five Cuban pirates strung up one morning-the "John Crow" buzzards hovering around for the feast that awaited them. these years been shipping at "three pound ten and his victuals," and finally taking shelter in the workhouse, with the wealth of Potosi for the taking away.

This is the pirate of Mr. Stevenson, of Mr. Besant, of Mr. Knight, and of other ingenious gentlcmen, not omitting Sir Walter Scott and Lord Byron, who have evolved him

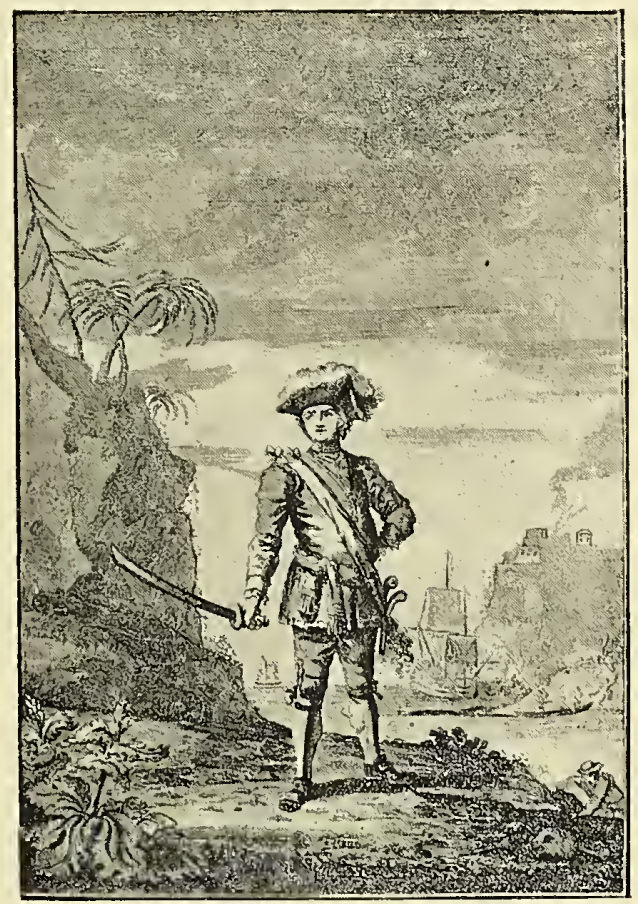

CAPTAIN BARTHOLOMEW ROBERTS.

from the depths of their inner consciousness. But this romantic creation of the stage, who risks his neck never to get any good out of the venture, is not at all like the sea-robbers of Captain William Snelgrave, who, in the month of April, 1719, trading for negroes to "the River Sieraleon," in the Bird Galley, was "taken" by them, hard by that pestilential stream. $\dagger$ Nor do we read anything corresponding to the novelist's picture of the pirates in the volume of Clement Downing, ${ }_{\uparrow}^{+}$lieutenant

+ An Account of Guinea and the Slave Trade. . . . A Relation of the Author being taken by Pirates, and the many dangers he underwent" (1754), pp. 193-288.

+ " A Compendious History of the Indian Wars; with an Account of the rise, progress, strength, and forces of Angria, the Pirate, etc." (1737.) 
of the Revenge grab, who sailed against Angria and John Plantain, who, as we have seen, after plundering for eight years on his own account, left the Madagascar settlement to become chicf admiral of the Indian corsair. In vain do we search Captain Johnson's History* of thesc scamps for the prototype of the rover of fiction; and Defoe, who had scen scores of them dangling in chains, and listened to the narratives of hosts of scafaring men who knew more about these folk than they cared to proclain at St. Paul's Cross, was too realistic ever to make Captain Singleton, or Captain Avery (whose history he wrote), or the scoundrels with whom Captain Gcorge Robcrts had so uncommonly bad a time off the Azores, the romantic personages of the modem story-books. Finally, the real pirate, in all his brutality, treachery, and greed, may be scen in that curious book + written by Aaron Snith, "who was himself aftcrwards tried at the Old Bailey as a pirate, and acquitted," though, it must be admitted, the very peculiar proceedings of Aaron while avowedly mate of a West Indian piratc scarccly warranted the jury in taking so lenient a view of his case. And if anyone cares to study the ways of the vulgar, unromantic sea-robber, he will find ample matcrials in the "Newgate Calcndar," in the trial of Benito Soto, one of the old-fashioned sort, who was duly hanged at Gibraltar, on the 25 th of January, 1830, as the reward of his dceds in the brig El Defensor de Pedro, + and in a host of printed documents and manuscript journals that have passed through the hands of the writer of these pages.

The student of social history with a clinging

The belief in the trade not bcing withdecadence out some redecming features is of piracy. fain to confess that piracy is one of the callings which, likc prize-fighting and

* "History of the Lives and Adventures. . . . with an account of the Voyages and Plunders, of the most famous Pyrates." (1734.)

† "The Atrocities of the Pirates, etc." (1824.)

¥ "A Narrative of the Atrocities committed by the Crew of the Piratical Brig El Defensor de Pedro, etc." (1830.) professional parriotism, has suffered so gradual a deterioration that when it died of inanition and the hangman scarcely a decent blackguard died with it. Yet, it was not always so. The Phocreans of Greece and the Vikings of Scandinavia were driven to the sea owing to the sterility of the land, and the Cilicians, against whom Pompcy sailed with a mighty fleet and army, were, in common with the Etruscans and Carthaginians (who received peace from the Romans on the condition that they did not sail, cither for the purpose of peace or piracy, beyond Cape Faro), rovers of a character not to be compared with the scoundrels who kept the executioner so busy in the serenteenth and cightecnth centuries.

The medieval pirate represented by Hugh Despenser and the corsairs against whose depredations in the Baltic the Hanseatic League was formed were decidedly on a lower level than their predecessors. Yct, cren some of the rovers who infested the Europcan seas at the close of the sixteenth and the beginning of the seventeenth century were, in their way, notable folk. Some of them had evcn a dash of patriotism. They had been privateersmen and scamen of the Queen's Nary, who found, aftcr the stormy days of Elizabeth were over, nothing to do in their line of life. For years they had been employed in enriching themsclves by robbing the Spaniards along the Spanish main, and it was sometimes difficult to say whether Drake, and Hawkins, and Ralcigh, and the worthies whose names are bracketed with theirs, were not morc pirates than patriots. Indced, for a long time afterwards the masterless men who plied their trade under the name of buccaneers-among the most notable of whom was Sir Henry Morgan, ViceGovernor of Jamaica (p. 95)-made a pretence of waging private war only on the enemies of their country, though, even at the best of times, they were not over-particular as. to the flag which their intended victim flew.

Still, the worst of them had their picturesque points. Even when driven from the British scas and compclled to settle on the Barbary coast, where they werc men of consequence 
until the Moors had learned the pirates' business from them, several displayed thriftiness, and even a tawdry ambition. Ward, a "poor English sailor," retired from business, and when William Lithgow, the Scottish traveller, visited Tunis in the early years of James the First's reign, he found him a Cieneral, who,
Cellis were so unfortunate as to be hanged by Queen Elizabeth of blessed memory, the historian must not forget that the "gallant merchant ship" which brought the first news of the Spanish Armada to Plymouth was, in reality, a pirate, commanded by a good fellow named Flemming on whose head a price had

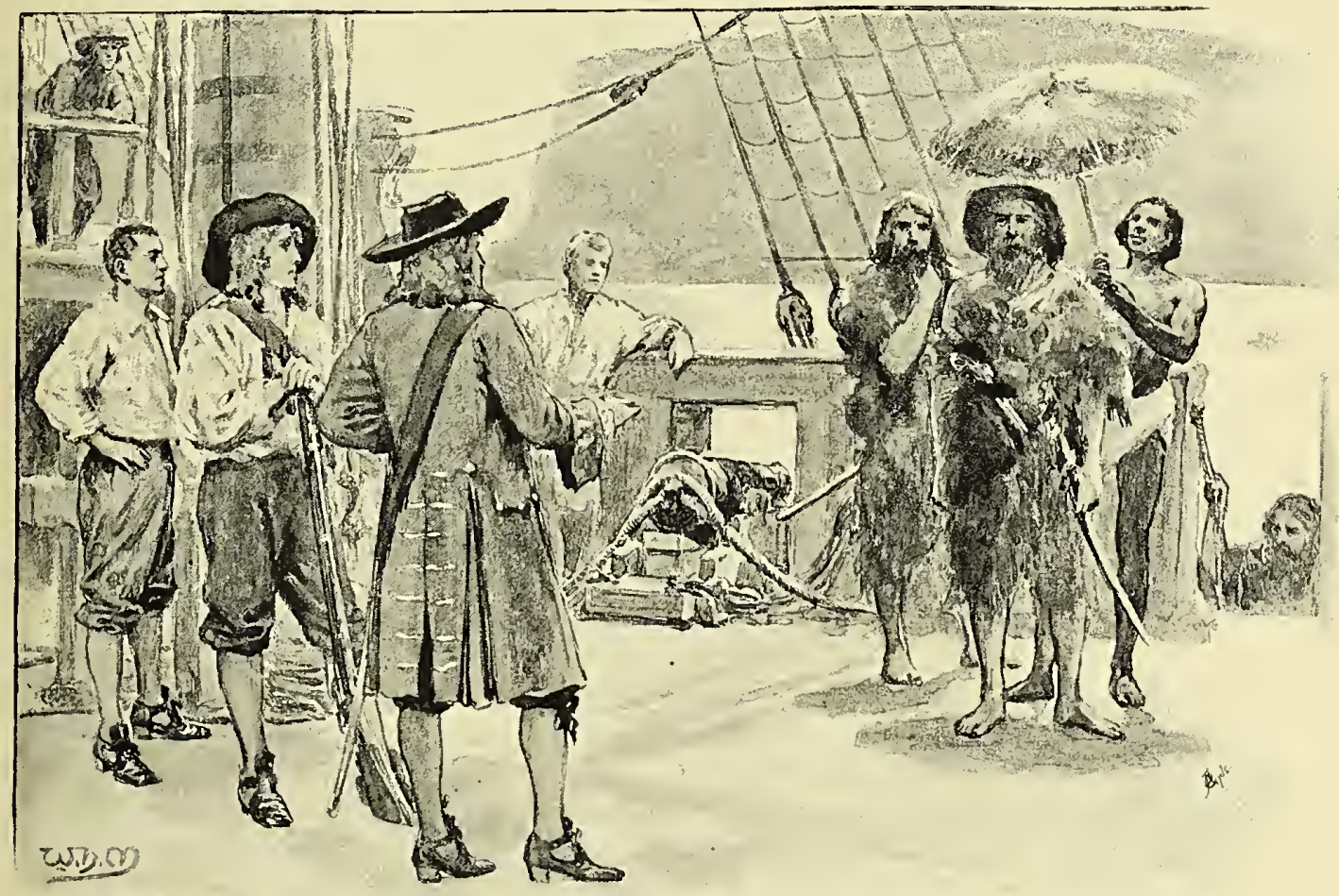

DISCOVERT OF THE MADAGASCAR PIRATE COLONY BY CAPTAIX TOODS ROGERS.

"in despite of his denied acceptance in England, had turnerl Turk, and built there a fair palace, beautified with rich marble and alabaster stones." With him were living " fifteen English renegadoes, "whose lives and countenances were both alike, even as desperate as disdainful." However, the old Bashaw was what Lithgow calls "placable," and not only gave his countryman a safe conduct to Algiers, but, at various times, invited him to dine. Easton, another English pirate of Elizabethan days, saveri enough of his ill-gotten gains to buy a Marquisate in Savoy, and though Clinton, Pursser, and long been set. In short, as Scaliger puts it, in a strain of doubtful compliment, "Nulli melius piraticam exercent quam Angli." And, no doubt, if so evil a trade could be exercised in a goodly fashion, the Errglish, at the worst period of its history-namely, towards the close of last century-exercised it in a less sordid manner than the mulattoes, Brazilians, and the scum of the West Inclies and the Spanish main to whom it was latterly abandoned, just as the Chinese and Malays, who are now the sole followers of this ancient craft, are, if possible, even viler than the mongrel rapscallions in question. 
At the time we make their acquaintanee, about a century or so ago, the typical "rover of the sea" appears as a more or less mmitigated ruffian, ignorant, nurderous, seldom relieved by a spark of generosity, without foresight, or any thought except for his immerliate enjoyment. It is rare that one comes upon a pirate captain of decent origin. Ilost of the fratcrnity seem to have been mutineers who distinguished themselves by stealing ships from their owncrs, or natives of West Indian islands and other haunts of pirates who had never been engaged in any other trade. It is certain that none of them ever eane honestly by the ressel with which they first began business, and, so far from these thieves displaying that honour which, aecording to the proverb, exists anong men of the same kidney, from Morgan who swindled his comrades out of the plunder of Porto Bello, and Avery who gave his associates the slip (p. 82), down to the meanest robber who ever stole the eargo of a eoastcr, the eaptain was always suspected, and in most cases was guilty, of trying to cheat his crew of their just share of what they had helped to win.

In a volume on the subjeet, Mr. Howard Pyle mixes up buecaneers, privateers, and pirates as all belonging to one class. This is erroneous. No doubt the bueeancers latterly fell from the moderate anount of virtue with which they began; but at first thcy were simply traders in eattle, and to the end affected to prey upon the Spaniards alone. In like nanner, the privateers were private war-ships bearing the King's commission, and though at present not recognised, will, we may be sure, in case of another great naval war breaking out, be again in demand. But when peace came, many privatcersmen turned pirates-the ehange, except that it carried with it the risk of the yard-arm, being searcely notieeable-just as Captain John Sinith, of Virginia, tells us, many masterless men, with nothing to do, or out of revenge at the way they had been treated, took to the high seas, soon after the peaee with Spain, in James the First's reign, had inundated the country with idle sailors. Captain Kidd, indeed, was the commander of a privatcer who, finding little lawful prey, attacked any craft whieh eane in his way in order to find means to satisfy the rapacity of his owners. And, as the master was, so were the crew, only, if possible, a little worse. How far the idealisation of a pirate chief can be carried may be seen by comparing Scott's glorifieation of John smith Gow (who, with seven of his fellows, was hanged at Exeeution Dock in 1725) with the true tale of his fiendish depredations in the Orkney Islands.

Here and there we come upon one not quite so bad as the others, and mere brute courage was a trait which, on the prineiple of natural selection and the survival of the fittest, was never laeking in any of them. Roberts, when quartermaster of Davis, more than onee saved eaptured erews and passengers from barbarity, and, a ruthless ruffian in other respeets, throughout his carecr never compelled anyone to join him. He took to piracy from ehoiee, not from want of erruloyment, but "from a roving, wild, and boisterous turn of mind." It was his usual deelaration that " in an honest serviee, there was commonly low wages and hard labour: in this, plenty, satiety, pleasure and ease, liberty and power; and who would not balance creditor on this side when all the hazard that is run for it at worst is only a sour look or two at choeking?" And his courage was evinced by the crews of twoand-twenty ressels scuttling before him when he swaggered into the Newfoundland harbour of Trepassi, with the "Jolly Roger" at his mast-head, drums beating, and trunpets sounding, and soon afterwards destroyed ten French ships on the Banks, except one of twenty-six guns, which he seized and earried offi. A score of cren more eourageous aets might be recorded; several have becn already mentioned. But if their bull-dog pluck was unquestionable, their ferocity was equally indubitable. Lolonais is said to have split the breast of a Spanish prisoner, plucked the heart out, and gnawed it. Low lopped off the ears of an English nuerchant skipper and made him eat thcul with salt and pepper, or, 
as others say, broiled his lips before him; and Teach (p. 99), the "Black Beard" of a hundred legends, whose chief ambition was to be thought in league with the Devil, was an unmitigated savage, who did his best to earn the reputation after which he hankered. Even Davis, though not quite so umredeemed a ruffian-he is praised for his generosity by those who might have experienced his malignity - was wont to declare, when asked where his money was, that only he and the Devil knew, and that the longest liver was to have it. Yet though Hades, and their likelihood of soon reaehing it, was a constant theme of eonversation with these abandoned miscreants, in a way they were permeated by religious superstition. They were anxious to have a ehaplain "to pray and make the puneh" on board Roberts's eraft, and when there was an eleetion of a new eaptain, after Davis's death, it was earnestly stipulated that the chosen personage "should not be a papist."

As an illustration of the squalid life of a West Afriean pirate, it may be useful to give

The

experience

of Captain

William

Snelgrave. others in an open boat which was never afterwards heard of; but as Moody was in the habit of cheating his men, the morality of the pirate world rose a trifle by his disappearance.

Mr. Snelgrave having, as in duty bound, defended his vessel firom the night attack in which she was taken, mainly by his crew, under the influence of a mate who turned traitor, calling for quarter before they had struck a decisive blow, was worse used than was wont. One ruffian shot at him, and another tried to eleave his skull with a eutlass, the few men who stood by being served with about equal atrocity. Everything he had about him was taken by the pirates, and as the vessel was laden with liquor all of them were soon riotously drunk. Anything like order was impossible, and the eaptain and quartermaster, who on board a pirate ship had almost control of the master, never tried to keep discipline anong the cut-throats on board, nost of whom were either forced men or the erews of captured ships who had willingly thrown in their lot with their eaptors. Poor Snelgrave, as a loyal subject of King George, was, however, less grieved at seeing his owner's cargo pillaged, and his own chest and private venture made free with, than at hearing the Pretender toasted by the name of King James the Third. For this proved them "doubly on the side of the gallows, both as traitors and pirates." Seafaring men, worthy Master Snelgrave admits, are consumedly given to profane language; but sueh a pandemonium of oaths and blasphemy as went on all night, while he in vain attempted to sleep in his hammoek, had not hitherto come within his experience. Wanton waste and destruction were the order of the day. Bales of valuable goods and all the books were tossed overboard, the bales because they had no use for the woollens they contained, and the books in ease they "might breed mischief enough to prevent some of their comrades from" proceeding on the eourse they had entered upon; and though the pillaged seamen who had remained faithful to the eaptain begged for them, several casks of
* The Rokel, Rokèlle, Tagrin, or Mitomba River; the Rohung Dakell, or Stream of Scales, of the Timni tribe, possibly the "flumen Bambotum crocodilis et hippopotamis refertum" of Pliny. 
"Irish beef" met the same fate, the pirates preferring the English "junk." Webs of tine linen were spread on the dirty decks for the drunken crew to lie on. and then, when they were sleeping off the fumes of the liquor; which they drank out of the bottles, by simply "nicking" the neek with cutlasses, their courrades, masquerading in embroidered coats and periwigs, woukd, as a bit of playfulness, throw buckets of claret over them.

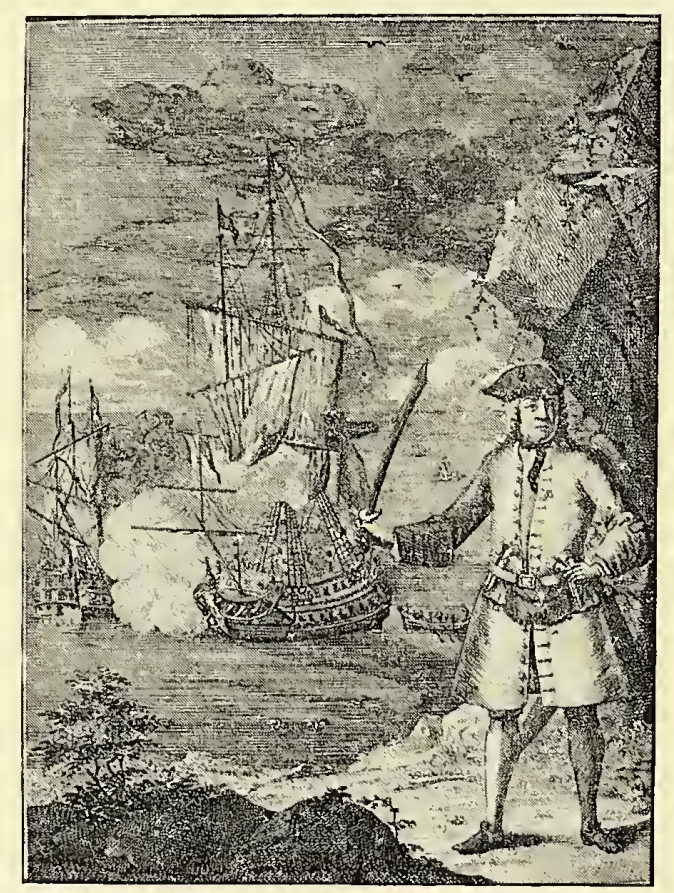

CAPTAIX AYERY.

Now and then Captain Snelgrave met with exceptional civility from some of his captors who had known him of old, and ascertainer that his men spoke well of him. As a rule, however, he was in daily danger of his life from the brutes, who were rarely sober, and, worst of all, ten of his own men and his mate "entered with the pirates," the mate, it appears, having had all along hankerings after this life. Ashore were several merchants, who seem, either out of fear or for the sake of profit, to have been on the friendliest terms with the pirates, receiving presents from them, and acting as resetters of the stolen goors, though at times befriending as best they could the unfortunate mariners. The profusion of the thieves with their plunder made them courted everywhere, men and women, black and white, giving them an equally warm welcome the moment they landed. About this period, indeed, the fact of a party of sailors spending money lavishly in any por't always lairl them open to the suspicion of not having come honestly by it, a suspicion usually strengthened by their truculent conduct in the alehouses in which they caroused.

The ruffians, who were seldom sober, were all the time quarrelling with each other over lreaches of " the rules," accusing a comrade of keeping some "stuff" for himself, instead of putting it into the common chest to be sold at the foremast, or of meditating treachery in some other fashion. The Devil and the Bottomless Pit were eternally in their inouths, and the probability of their reaching the latter goal at an early rlate and in a sudden fashion the commonplaces of their blasphemous conversation. Once they set the ship on fire by their carelessness, and on another occasion, by the merest good-luck, missed blowing up the powder magazine. Yet amid their debauchery there were some who were anxious to abandon the lives they were leading, and the quarterinaster, though he died yelling the most lurid profanity, displayed before his career closed a dreadful terror at the thought of neeting the ally whose name he har so often invoked. When re-naming the ressel which they had stolen, the scomndrels-all of whon were robbers, and most of them murderers, hardened in every form of crime-were careful to offer up a prayer that "God would bless the Windleam galley"-in the piratical course upon which she was entering.

All the officers of a pirate ship were elective, but of the captains especially, and their en(leavours to assume greater power The laws of than "the rules" gave then au- the lawless. thority to exercise, the men were very jealous. No vice was strange to them. Few atrocities marle then hesitate. But, though there were ahways plenty of Delilahs in the pirate ports, 


\section{-}




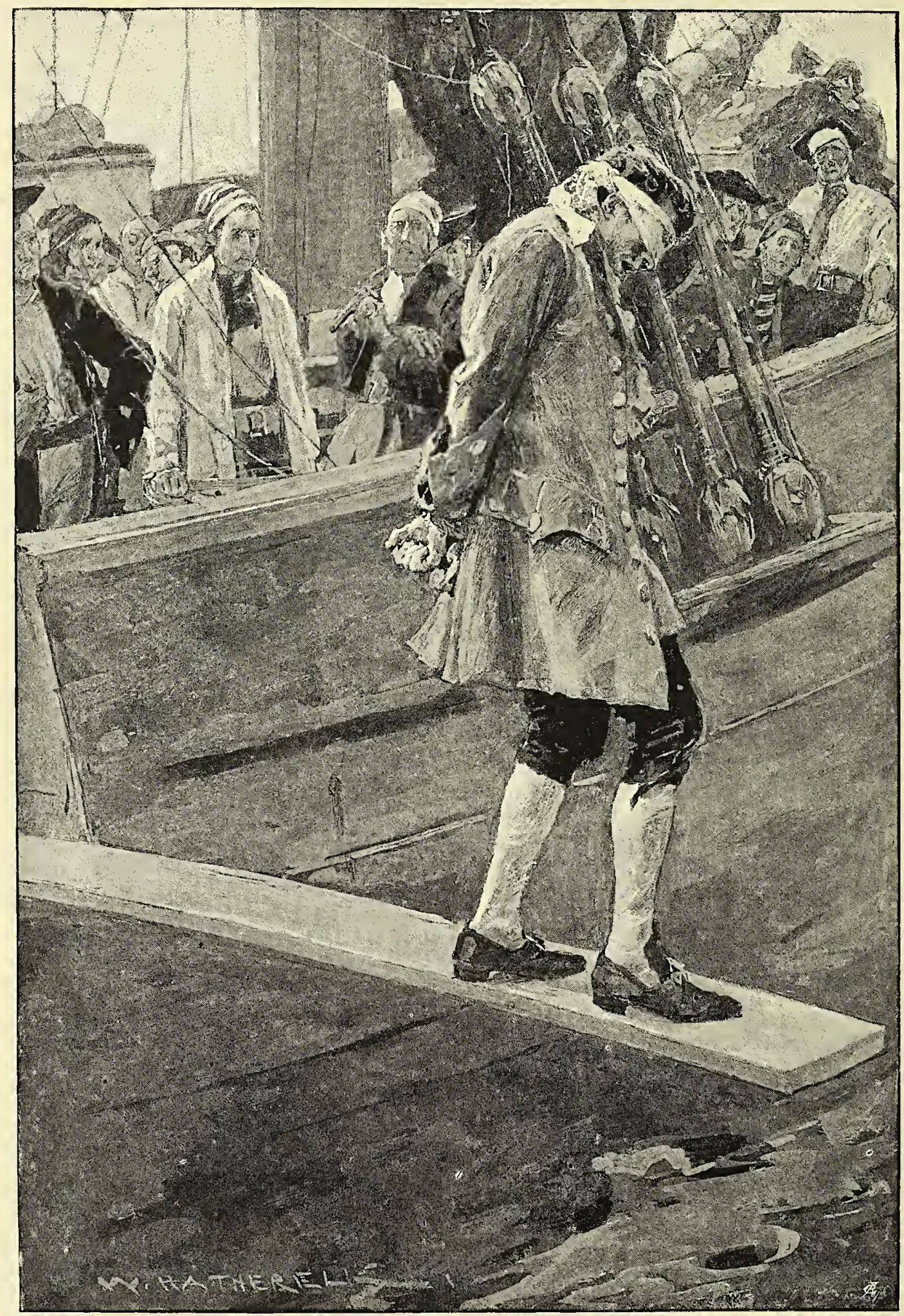

WALKING THE PLANK (p, 93) 
the fair lady with the raven locks peering out of the stern windows was a fiction; for one of the strictest laws of pirates was that, in order to prevent jealousy and the trouble it would bring, no woman should on any condition be pernitted on board, and, as the captain was the creature of the crew who the rule was the contrary. The pirates bore no ill-will towards the seamen, who belongerl to their own class. The "King's ships" weie, of course, disliked by them. So were many of the merchant captains. Their excuse for pirating was, indeed, to take revenge upon "cruel merchant captains, with hearts as

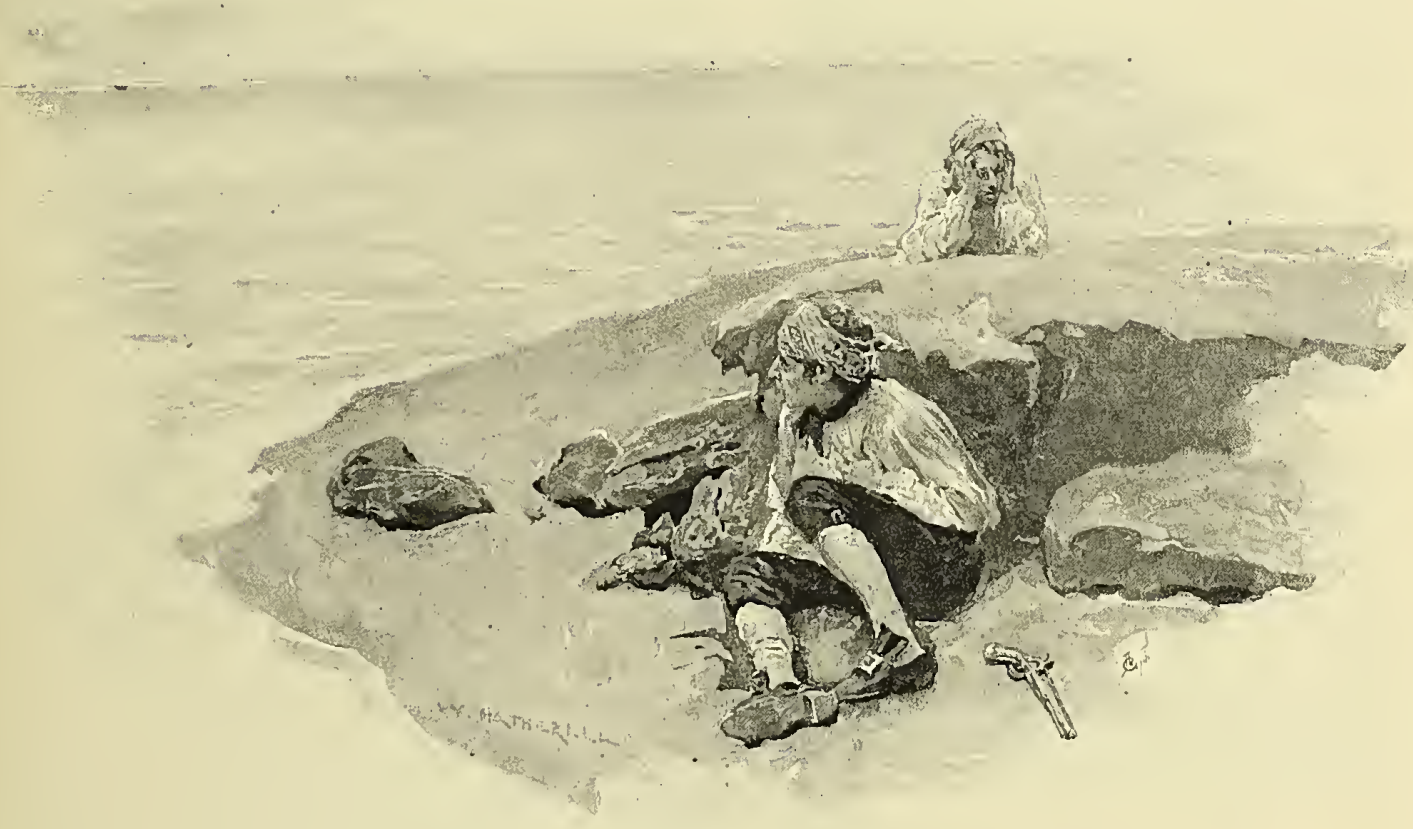

MAROONED.

elected him, it is certain that he would never be permitted to infringe this regulation. Hence such undesirable passengers were aiways lander as soon as possible, and, whatever might have been the case in individual instances, it was one of the most stringent articles in their code that injury to any female captive was to be punished by death.

Nor is there a much firmer basis for the legend of "walking the plank." Cases of this have occurred, and there are instances of torture being applied to captives, and of vessels being scuttled with all on board; but hard as stone, who keelhaul men and flog them and starve them to the bone." And all capitalists were fair prey to these early socialists, who, it may be noted, were, during the Revolution, almost to a man adherents of the Pretender: some, indeed, took the trouble of carrying his commission, in the hope that it would be respected by foreign Powers, just as one Bartholomew Sharp, a "Brother of the Coast," escaped the gallows because he produced a warrant signed by an Indian chief who was styled the "King of 1)arien." Accordingly, the worst fate that usually befell 
the crew of a captured ship was to be robbed and landed on some island, unless they chose to join the captors. And this, we regret to add, they did very frequently.

If the attacked vessel offered resistance, there was often severity displayed in revenge. Thus, we read of the captain of a French ship which was "taken" by the same pirates that so despitefully used Mr. Snelgrave, being hoisted up and down several times to the main-yard arm, with a rope about his neck, till he was almost dead, because he did not strike on the first firing. Again, we read that when an obnoxious captain was captured by a pirate commanded by lis old boatswain, the wretched man was first pelted with broken bottles, then whipped round the deck, and finally shot, in repayment for the treatment his enemies had received in former days when their positions were reversed. But by "the articles" it was death to ill-use a prisoner "after quarter given." On the other hand, if the men gave the captain a good character, he was generally fairly treated, and even, as in the case of Mr. Snelgrave, offered part of the cargoes of captured ships, some stolen slaves, and an old ressel to set him up in business again. In reality, it was quite common simply to pillage a ship of what the pirates required, take a few men they were in need of, and then let her go. There was, also, another reason for using their captives without needless harshness-leaving out of account private vengeance in the case of a hard taskmaster falling into the grip of his quondan mate, or boatswain, or sailors, who had deserted his ship through his hard discipline-and this was the hope that, if they fell upon evil days, the clemency they had displayed might save their necks, and, in case no murder had been committed, might go far in securing them the benefit of those Acts of Clemency which, we shall see, did more to perpetuate piracy than any other agency at work.

All of them had "their rules," and these every pirate agreed to by signing the articles. Some of these were common to all ships, though we may take it each captain had some peculiar to his own craft. Thus, the master had a double rote and a double share of the plunder, and if there was any difference of opinion as to the course the vessel was to sail, the captain-in cases where the decision was not left to him-settled the matter by vote. The officers had a share and a half, or a share and a quarter, and the sailor's one share each, of all booty. Any attempt to embezzle was punished by "marooning"-i.e., being set ashore on some island where the offender could do little harm (p. 93); but desertion of the ship or arrant cowardice in battle was punished by death. Arms had always to be ready for action, and, if the compensation for disabling wounds differed on different ships, there was invariably a regular tarift for the loss of limbs - Lowther, for example, paying $£ 150$ as compensation for an arm or a leg put hors-de-combat. The man who first sighted a sail received the best pair of pistols on board, a reward so highly valued that they were sometimes sold for a large sum of money. In battle there was no appeal from the captain: but the quartermaster was an officer, a salt-water tribune, whose duty was to exercise a kind of control over the commander in the direct interest of the men. If such a thing as honour could be expected among thieves, it existed among the pirates; for theft from each other was so bitterly resented that slitting of the ears and nose was a common punishment for this offence. However, as the captain was generally selected as the most capable man in the ship, he could not long remain undeposerl did he exhibit any weakness, so that the quartermaster ran a perilous risk when he tried to infringe on his authority.

But the legend about burying their "treasure" is one of the most unsubstantial of all the myths concerning the pirates of fiction. How it originated we of buried have never been able to fathom. treasure. Most probably the notion had its beginning in the fact that, though many pirates had been captured, and all were supposed to have 
wrung vast riches from their unfortunate victims, it was seldom that they had anything on board which made the captors very wealthy in prize-money. The truth is that, though now and then - as in the rare cases of Davis, Kidd, Avery, England, and 'Taylor-a haul in the shape of jewcls or money was made, the pirates seldom landed much specie. Nowadays, merchants do not sail with bags of gold; they pay in bills or in goods. And a hundred or two hundred years ago they took remarkably good care to limit their com and bank-notes to the smallest possible dimensions. When they had plate to carry home they sailed under convoy; or the merchants took the opportunity of a war-ship visiting their port to despatch such treasure in a craft not at all likely to be meddled with by a sea-robber. The result was that the pirates rarely got any great amount of portable valuables. That they obtained was merchandise_silks, velvets, lace, cloth, wine, spices, and other goods; and these it is certain they did not bury, any more than they buried what bullion they now and then managed to find in the captain's strong box or in the seamen's chests. Why should they? If they managed to get into port, they required the "stuff" to cnable them to indulge in one of those prolonged debauches of drinking, gambling, and worse, which so regularly alternated with their cruises, while, if captured, they were safe to swing, so that it was useless hiding their ill-gotten gains. What was more, considering the kind of crews on board pirates, it would have been extremely unsafe to let any amount of treasure lie perdu in Trinidad, or the Salvages, or elscwhere: for the chances were that, at the very next place the ship put in at, one or more of the hiders would decamp and make it to their profit to inform another thief of the place where the booty lay. Teach, according to information given Clement Downing, buried several "chests well clamp'd with iron plates," at the upper end of a small sandy cove near "Mulberry Island, in York River, in Maryland." But if so, it was, we may be sure, soon disinterred, as he was on excellent terms with the Governor of North Carolina. Captain Kidd did deposit in certain places a good deal of the jewels and plunder he picked up in the Eastern seas. But these hiding-places were alnost always the houses of friends and accomplices, and the memorandum which he kept of them having been found in his desk, the whole was

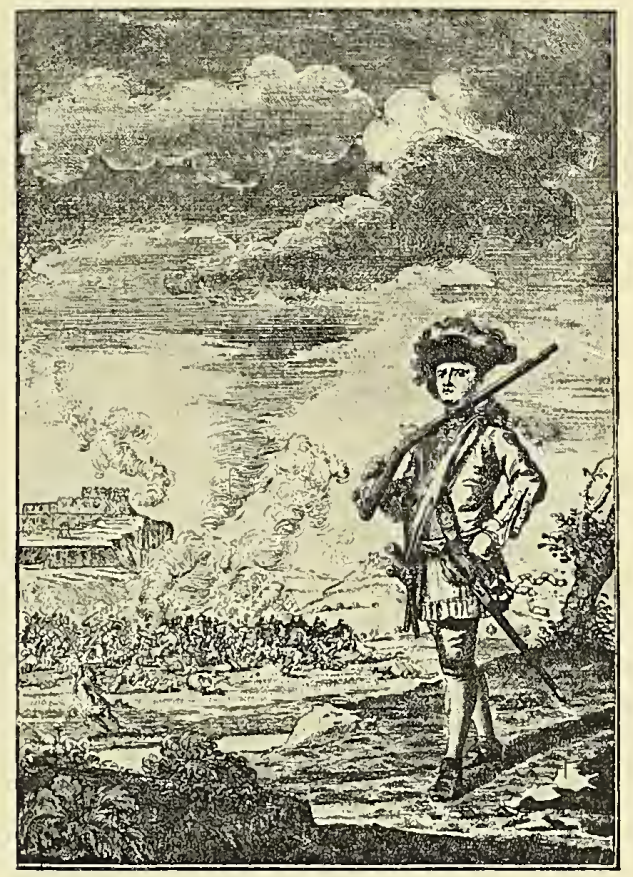

SIR HEXRY MORGAN.

recorered, though it did not amount to

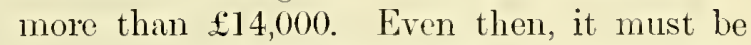
remembered, Kidd acted thus at a time when he was so certain of immunity from seizure that he entcred Boston harbour. Hence, the probability is, he was trying to make away with some of his plunder to aroid the exactions of his secret partncrs.

On the contrary, whenercr a pirate managed, in ordinary circumstances, to "nuake anything like a voyage," the unruly crew always insisted on getting ashore to spend their shares; and a pirate had no more trouble in disposing of his plunder at a price than a burglar has in finding a resetter to buy his "swag." When Captain snelgrave met with an old school- 
fellow among the Guinca pirates, he affected not to know him, "having formerly heard it had proved fatal to some who had been taken by pirates to own knowledge of them." But in many a port there were plenty of people who made much profit of "owning knowledge" of the sea-robbers. There was a sort of republic of them in "the pleasant Isle of Aves," anent which Charles Kingsley has a charming song, and another, we have seen, on even a greater scale in Madagascar. But on every coast haunted by them there were plenty of ports open to all comers, and no questions asked. Kidd had good friends on Gardiner's Island, near New Tork, albeit the owner of it was by patent permitted to bear the title of "lord." Desirous of risiting Boston, without too much cargo on board, he left part of his spare plunder with this gentleman, and his wife was quite willing to accept two pieces of rare Bengal muslin firom the thriving desperado. At another time cloth of gold and a bag of sugar were amongst his gifts, and a bundle of quilts, four bales of goods, and some jewellery the articles left in charge of "Lord John." The Earl of Bellamont, at that time Governor of New York and Massachusetts, wrote home-as can be read in the State papers in Fetter Lanethat Long Island was a "receptacle of pirates, who are so cherished by the inhabitants that not a man of them is taken up." And no wonder that they were liked, for goods could be bought from them for next to nothing, while they paid bumper prices for everything they required. Yet it does not seem that his lordship ever brought any of the offenders to justice-a fact which may be explained by the circumstance that he was one of the adventurers who originally fitted out Kidd, and to that end, there is good reason for believing-as a large minority of the House of Peers believed one hundred and nimety-four years ago,received bribes from him and other pirates for winking at their malpractices. New Providence was another pirate haunt, and there was a large settlement of them and their friends at Cape Fear. Rhode Island was well-affected towards them. New York, even, was pronounced a regular rendezvous of theirs, on the excellent atuthority of Lord Bellamont: and his predecessor, Governor Fletcher, had gone so far as to fix the immunity to pirate seamen at $£ 20$ a head, thongh now and then it could be cheapened a little. "Rerl Sea men" spent money so freely that they debauched the courts of justice and public sentiment in South Carolina, and their resetter's, well known as such, sat at the Council Board, while "Blackbeard" actually stored his booty in the Provincial Secretary's barn, and had the Gorcrnor of North Carolina for an accomplice. He brought his prizes into Bathtown, and by order of the Governor, who shared in the plunder, had his captured ships condemmed by a Court of Vice-Arlminalty as lawful prizes taken from the Spaniards, though it was well known that most of them belonged to English merchants. This infamous Proconsul had to submit to the open insolence of his partner, and when it pleased "Blackbeard" to take to himself a fourteenth wife, though he had twelve still alive, the obsequious Governor performed the marriage ceremony.

It was needless for such men to bury their treasures. The truth is that the lavish expenditure of the pirates sapper the morality of the entire community. In London and Bristol and Liverpool, in New Tork and Boston and New Orleans, hosts of well-known buccanecrs lived opulently, and in many a quiet English town there were well-to-do gentlemen, of seafaring antecedents and full-bodied conversation, who were strongly suspected of having received the slash on their cheek while in command of a crait not quite so reputable as a King's ship or a Letter of Marque. Fortunes were made out of buying from and selling to the pirates. The people of Bourbon were on very friendly terms with the British and Dutch forbans who frequented Maragascar and sold slaves to the French, and it required the pressure of the East India Company to induce the French colony to drop all intercourse with the pirates. Dr. Camplbell, a 
most respectable tenant of the best-rented part of Grub Street, bewails, in one of his publications, the hanging of Captain Green and his worthy mate, Mr. Mather; his sympathy, like that of the Duke of Argyll, being evidently more on the side of the criminal than on that of his victims.

The amnesty granted in 1721 to the pirates who chose to become colonists of Bourbon did not prevent them from attacking ships, even in the roadstead of St. Denis. The Viceroy of Goa had scarcely brought his ressel to anchor in that haven before a pirate and Taylor were at Cochin, the fort exchanged salutes with them, and the Dutch Governor and his daughter not only sent and accepted gifts, but gave the pirates information of a useful character regarding likely vessels to be met with.

Yet the tradition that the pirates buried their ill-gotten gains, in spite of none having ever been found, is ineradicable. There have been scores of expeditions in search of these treasures, and only lately Mr. Knight's was one of the many parties that have ranged the Salvages and Trinidad in the hope of disinterring

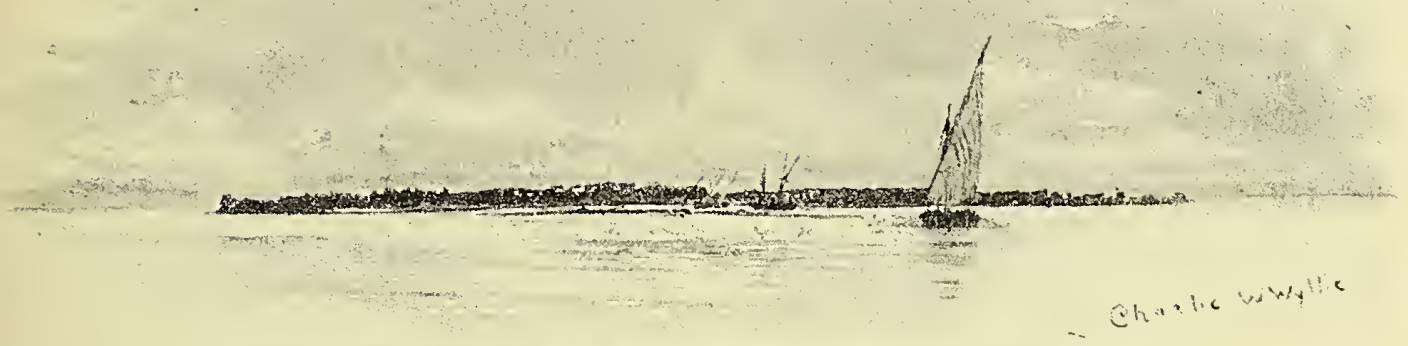

TOUMBo, NEAR THE ISLES DE LOS, WITH PIRATE CRAFT IN THE OFFING.

brigantine of fifty guns captured her.* The corsair was immediately invited to dine with the Governor, seating himself between His Excellency and the Portuguese Viceroy, then and there arranging for the latter's ransom, and, in spite of the pleasant tale told by Bernardin de St. Pierre of his refusing to take anything for the release of so agreeable a gentlentan, actually carrying off the ship in default of getting the two thousand dollars demanded, for which misconduct Capitaine Olivier Levasseur was hanged at Bourbon on the 17th July, 1730, having failed to get himself included in the Act of Grace.t When England

* Johnson attributes the adventure to England and Taylor, and declares that the vessel was disabled. This writer-erroneously, no doubt-also affirms that there were four million dollars' worth of diamonds on board of her.

† Introduction to "Robert Drury's Journal," etc., by Captain Oliver, R.A. (1890), pp. 24, 25. gold, which never existed, save in the imagination of the authors of galley tales. There is scarcely an islet off the American coast but has been ransacked for Captain Kidd's buried dollars, in spite of the historical fact that his hiding-places were all cleared out by official hands more than 190 years ago. Oak Island, in Nova Scotia, was searched in 1891, and another rummage of the same kind was made on Wood Island, at the mouth of the Saco River, in Maine; but the seekers were scared away by "spirits," and have not yet resumed their futile labours. This kind of passion takes possession of certain men like a fever. Everyone has his "clue," and not one of the clues has the faintest streak of truth in it. There is a regular pirate-treasure mythology, which appeals to the imagination, regardless of the veracities; for the pirate of fiction is an individual so much more attractive than the 
pirate of fact that it is vain to try and clisestablish him in popular esteem.

Africa is also not without these treasure

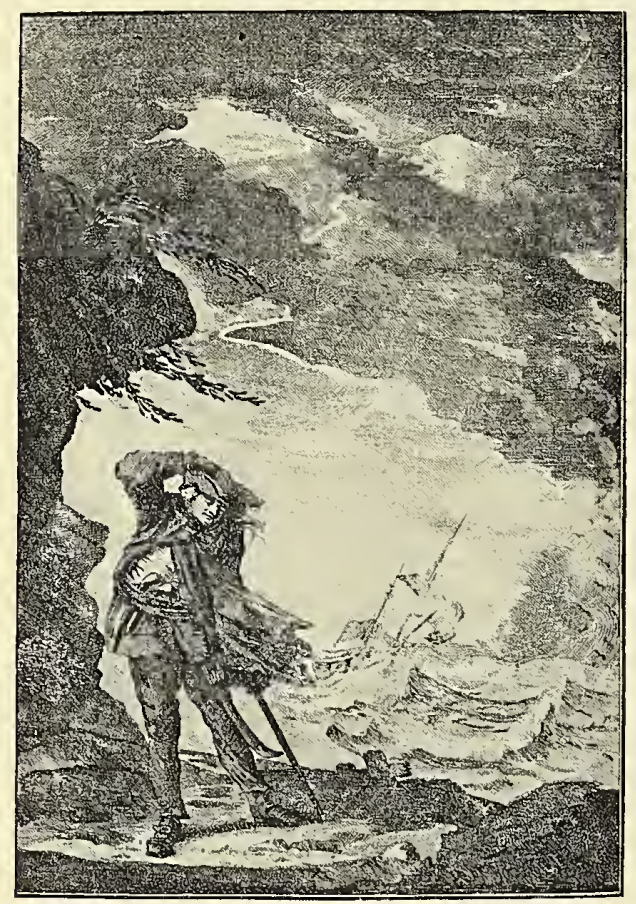

CAPTAIN EDWARD LOW.

tales. Ail the old forts were, we have seen (p. 59), pulled to pieces in search of slavers' and pirates' gold, and the Isles de Los* (p. 9ז) are still believed to be the hiding-place of the gold, etc., deposited, in the least secure of banks, by Bartholomew Roberts. These islands were, however, in the bad old days, favourite haunts both of pirates and slavers, for vessels of light draught could lie under the shelter of the land, where a war-ship could not venture, and even if it did, unless it sent boats out in search, would have some difficulty in detecting the lurking craft. These freebooters were bold to the point of aggression, and in some instances they did not get the worst of the encounter with the menof-war. The Cumperdown, a brig of sixteen guns, destroyed the British sloops Rambler and Trial; the Paz, which was under American colours, beat off the Princess

* Properly, "Dos Idolos" (of the Idols).
Charlotte, and killed several of her crew; and the crew of the Vengunza resisted the boats sent to take her until the last extremity, when, being boarded, they blew themselves up with their assailants. The Sierra Leone brig was so constantly roving about the Isles de Los and the adjacent rivers that she became an object of the greatest antipathy to the slavers and their kindred knaves, and two vessels-the Dolores and the Temerariowere avowedly fitted out for her destruction, but, happily, were captured before those follower's of private warfare could compass. their purpose. Even during recent years, long, low, piratical-looking craft, decked over the stern, and with raking masts carrying large lug-sails (p. 100), have been observed rumning cargoes of domestic slaves from Sherbro and other localities, into the rivers which here discharge into the sea, for sale, it is said, to the Mohammedan rice-growers on the banks of the great streams between Sierra Leone and the Gambia. If boarded by a Government. vessel, the headman of the boat immediately declares that the women are his wives and daughters, and the men his sons or servants; and so apathetic are the slaves, that frequently they not only do not claim their freedom from the eruisers, but actually corroborate the lies of the dealer. Hence, it is difficult to stop the traffic, either here or on other parts of the coast, for it is hard to prove anything, unless, indeed, the cargo is manacled. Then the officials are easy in their minds as to the risks of making an illegal seizure, for the courts of law are pretty safe to give them a good deliverance. On Crawford Island a detachment of European troops - the Royal African Colonial Corpswas stationed in 1812 and 1813 , to stop the slave trade and piracy combined which went. on in and about the Isles de Los. But the men sickened and died of old habits, new rum, and the unhealthiness of the station, and here, as elsewhere in Africa, the export trade in human beings expired of the lack of customers. $\dagger$

† Ellis: "Test African Islands" (1885), pp. 113, 11 . 
African piracy, like the export African slave trade, is a thing of the past. It died, not, The end of as some optimists have imagined, piracy. of "improved public morality, as the mouse dics under the exhausted receiver of the air'-pump," but of steam, telegraphs, and improved postal communication. When these came into action, the pirates ran so slender a chance of escape that they found the business did not pay, and, their haunts being broken up, the foul birds who nested there drifted into other pursuits. What remained of the old trade fell into the hands of the mongrels of the Spanish Main, though to a comparatively late date the Lafittes of New Orleans were more than suspected of clearing the Gulf of Mexico of slow-sailing craft. For a little longer, a few scoundrels of the "Bully Hayes" type-more

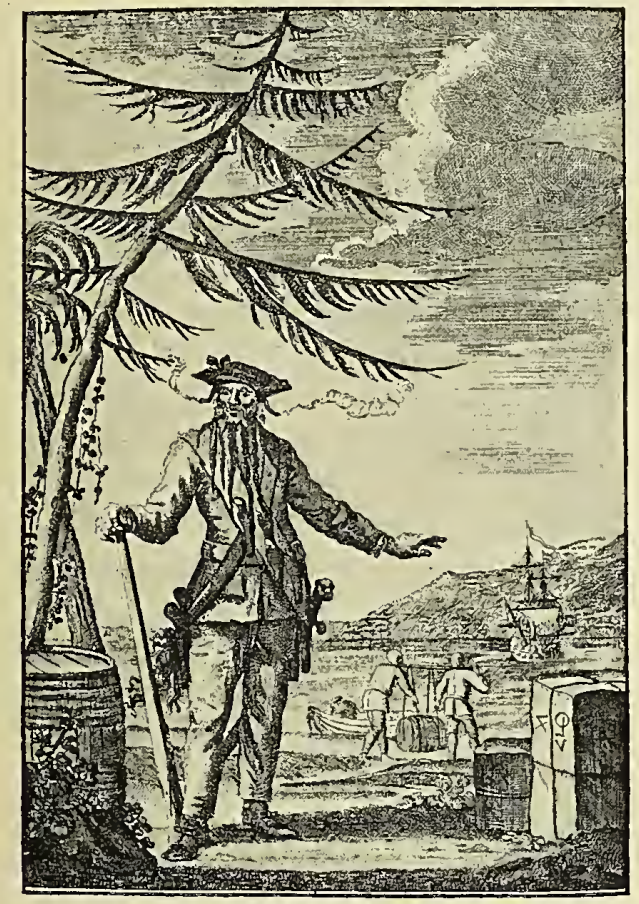

CAPTAIN TEACH, ALIAS BLACKBEARD.

ship-stealers than pirates of the old sortkept the Pacific Islands in subjects for conversation; but submarinc cables and the ubiquitous gun-boats were soon too much for them. The general use of stean also all but ended the career of the Malay prau-men, and though we hear cvery now and then of a Chinese act of piracy, it is rarely by means of junks, but by the more cowardly trick of a number of pirates entering themsclves on board the mail-steamers as passengers, and then rising and falling upon the rest of the ship's company. In European seas, piracy is dead, for the so-called pirates of the Flowery Land and the Lennie were simply mutincers, who, whilst rearly cnough to rob their own ship after nutrdering the officers, made no attcmpt to cxtend their operations.

European piracy, though it occupies a large place in the history of the carly relations of Africa and the whites, did little for the development of that continent. It helper, no doubt, to bring about the rapid cinployment of steam as a motive-power, of tclegraphs between the centres of commerce, of better mail communication, and of banking facilities. It aided, also, in banding merchants into leagues like that of the Hansa, and in manning the navy and the privateers with sailors skilled in the use of wcapons, since no merchant-ship, unless commanded by a Quaker, left port without being "well-found in small-arms and cannon round about." But in a much more direct manner it retarded the progress of trade and civilisation. It checked the enterprise of merchants, and, by the system of demoralisation which it wronght among seamen and their employers, made slaver, buccaneer, pirate, and privateer too frequently little better than convertible terms; for the one was, after all, only the other writ small. Tet the historian must not forget that, if piracy did little for the world, it tumbled up England a great deal. For the first levy of ship-money, in 1635, was made for the suppression of "pyrats," and we all know to what this most commendable of imposts (imposed in the wrong way) led King Charles and his subjects.

\section{The Barbari Pirates.}

But long before white men had begun to harry ships on the high sea, and some time after they had ceased that calling, there was 
a form of African piracy nore persistent, more blatant, and in its effeets more far-reaehing than any ever praetised off the coast of whieh sheltered them, and if they were by no means partieular as to the flag flown by Guinea. For all along the eoast of North Afriea, but partieularly from the towns of Tripoli, Tunis (La Goletta), Algiel's, and Sallee-Rabat, there were, until well into this century, nests of pirates pursuing their victims, nominally, at least, they attaeked

(n)
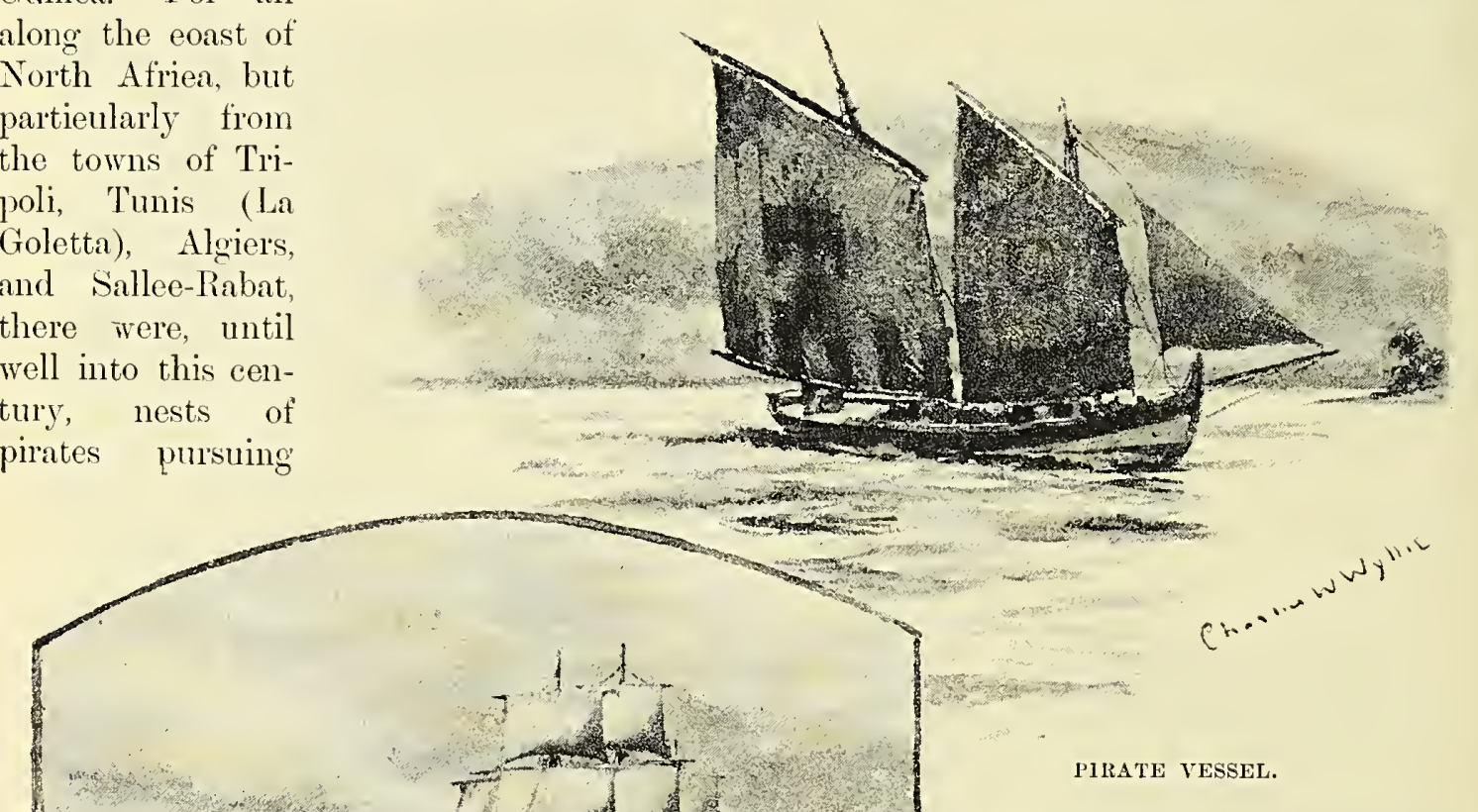

only the vessels of eountries the sovereigns of which had not treaties with their masters. As a matter of fact, they followed too strietly the Koranic injunetion to "war" against infidels," and interpreted the term enemy as meaning everyone who was not avowedly a friend. But the worst feature of Barbary piraey was that the seamen and passengers captured were one and all redueed to a hopeless slavery, unless they turned Moslems MERCHANT-SHIP UNDER CONVOY.

(whieh many of them did), their nefarious business openly under the auspiees of, and, indeed, in most eases with the help of, the Powers under which they lived.

Perhaps, however, to apply the term pirates The Tripoli, to these people is unfair. They The Tripoli, giers rovers. though fitted out solely to prey on eommeree, were the fleets of the regeneies or eseaped, or were ransomed by their relatives, their sovereign, or the religious brotherhoods who spent their lives colleeting money for that purpose. It is only right to add that, when the Moors were eaught, they had much the same measure meted out to thein by the Christians; only the Moors were, as usual, a eentury or two behind Europe, since they 
carried on the practice long after "the Christians" had abandoned it.

These habits of theirs, however, led to many changes in the political geography of that portion of Africa north of the Atlas and west of Egypt-a country which, we have the Knights of Malta, but many greater Powers that at one time or another laid siege to it. At this hour, however, Europe proper-for the Turks are not Europeans, only partially residents in Europe-has no part in the government of Tripoli, Barca, and

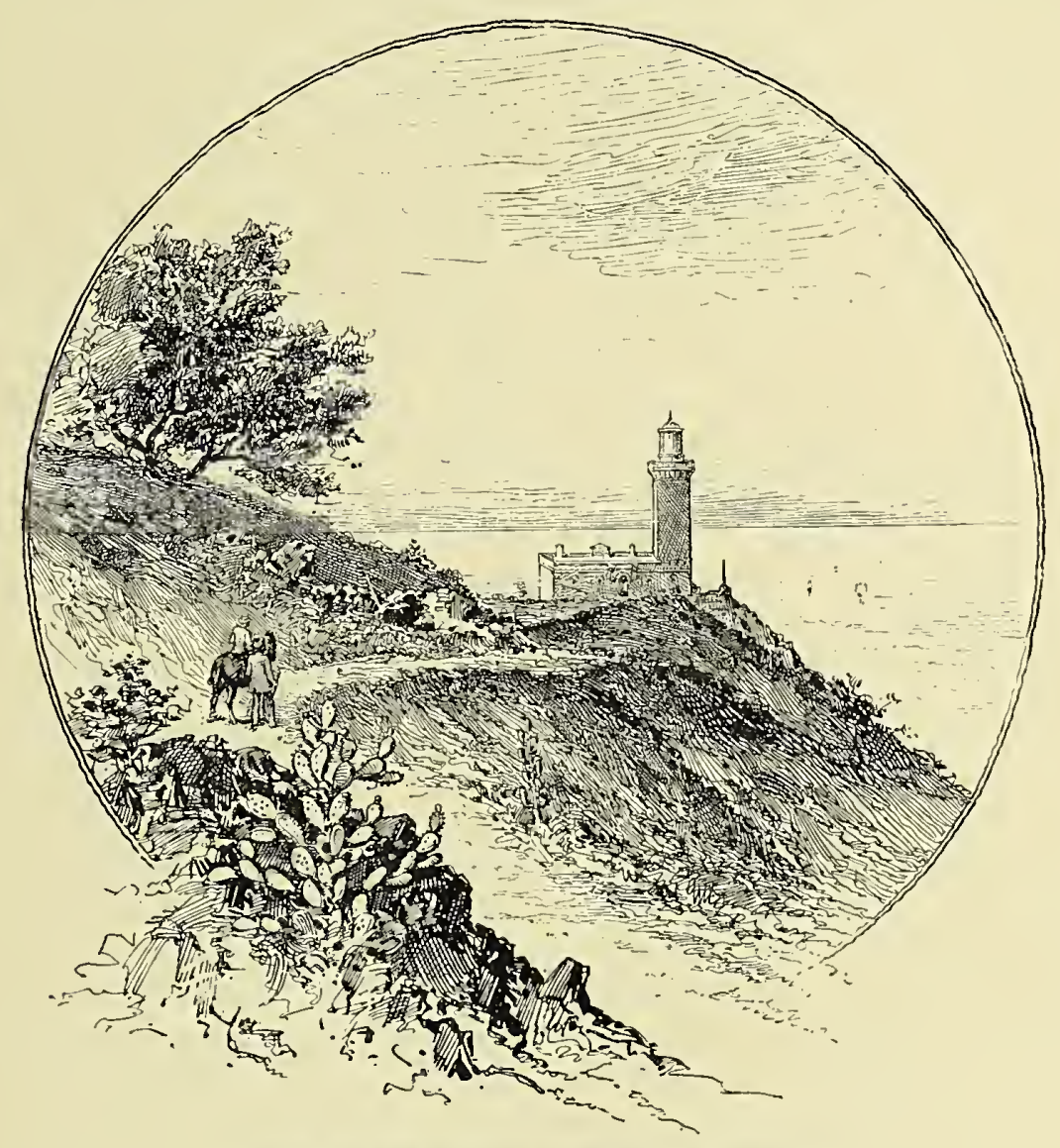

CAPE SPARTEL AND LIGHTHOUSE, MOROCCO.

seen, was the earliest part of the continent to be colonised by Europeans, though eruptions of the Arabs utterly effaced those settlements for more than twelve centuries. Tet it was owing to the malpractices of the new inhabitants of Barbary that European colonisation began afresh. Tripoli is still Turkish, but its piratical proceedings led to its more than once changing masters, and to a long chapter in its history which touches not only
Cyrenaica. Tunisia, in like manner, again and again brought upon it the heavy hand of Europe, and the capital has more than once been occupied by an eneny incensed beyond the limits of patience by the wrongs done by its "pirate" fleets. Its final occupation"protection" is the official term-by France was not directly brought about by piracy, since piracy was by 1881 at an end; yet it would not be difficult to tracc the encroachments 
that led to the Franks becoming the virtual masters of what was formerly a regency of Turkey (though, in reality, an independent Power in everything but the name) to the ravages of its old corsairs. For it sprang out of the French conquest of Algeria, which originated in 1839 in the quarrels precipitated by the faithlessness of the Dey and his piratical subjects. This act led to many other developments, and is likely to be the parent of many more, besides the exploitation of this portion of North Africa and the Sahara, as far as Timbuctoo, as we shall have occasion to discuss more fully when the colonisation of Africa is traced.

To the piracy of Moroceo are due many hostile relations with Europe-the occupaThe pirates tion for long of its littoral, a of Morocco. host of invasions, blockades, and bombardments, and in our own day the Spanish war of 1859-60, which, though it led to no territorial shanges, was a distinct landmark in those tireless efforts of Europe to obtain a more liberal commcrcial footing with the last and most backward of the independent Barbary States. Piracy and Christian slavery are now only inemories of the Empire of Itulai el Hassan. He has nowadays no fleet, peaceful or piratical, and though he resents every effort to amend his ways after the European model, and keeps his crumbling towns in much the same fashion that they have been these thousand years or more, his all-pervading fear is to embroil himself with the infidel dogs whom, once upon a time, his fathers captured and enslaved.*

Though piracy was formally cnded by treaty in 1819, there were still occasional

\footnotetext{
* The fullest history of Barbary piracy will be found (for Algeria, Tripoli, and Tunisia) in Mr. Lane-Poole's "Barbary Corsairs" (1890), Sir Lambert Playfair's "Scourge of Christendom" (188t), Admiral Jurien de la Gravière's "Les Corsaires Barbaresque" (1887), Count de Mas Latrie's "Les Relations et Commerce de L'Afrique Septentrionale ou Magreb avec les Nations Chrétiennes au Moyen Age" (1886), and (for Moroce) in the present writer's Introduction and Notes to "The Adventures of Thomas Pellow, of Penryn, Mariner" (1890).
}

outbreaks of it until a later date. In 1829 , a boat party, that had landed from a ressel becalmed off Cape Spartel, only a few miles from Tangier (p. 101), were seized and never seen again; and in 1831, Sir Arthur Brooke tells us that "the country Moors on all parts of the const are constantly on the look-out for Christians, and instantly make prisoners of all who have either landed accidentally or have been shipwrecked," a fact confirmed by the wife of the British Vice-Consul being seized at Cape Spartel, and escaping solely by her escort happily appearing in time. In 1828 the British had to blockade the Moorish coast, in retaliation for some lamage done by the corsairs of his Shereefian Majesty, and next ycar the capture of an Austrian ship led to the bombardment of Tetuan, Azila, and SalleeRabat. In the same year Sir Arthur Brooke noticed the departure from Tangier, a town in sight of Gibraltar, of two Moorish brigs, "in the hope of pouncing upon some hapless Bremen or Hamburg merchantman," and mentions that Sweden and other States, to save themselves the expense of maintaining squadrons in the Mediterranean, actually paid the Sultan Mulai Abd-er-Rahman good round subsidies by way of propitiation. Still more recently, any scamen who were wrecked, or who incautiously landed on the Sus coast and the country on the southern frontier of Morocco, were certain to be seized. We possess numerous narratives of these captivities, the latest of which was that of Camille Donls, who, after severe hardships, was brought to the eity of Moroceo in 1887, and liberated by the British Minister, who happened just then to be on an embassy to that capital. But the most notorious pirates were the Riffians. It was they who, in 1859, after endless bickerings with Spain, compelled the latter Powerno way loth for an excuse-to invade the country, and, after defeating the Moorish troops, to occupy Tetuan for two years, and exact a heary indemnity. 'These people are Berbers, the inhabitants of the country before the Arabs-or, for the matter of that, anyone else-came, and, secure in their still 
unexplored mountain fastnesses of Er Riff, at which the geographer sailing down the Mediterranean looks with such longing, remain unchanged through the centuries. Nominally, they are subjects of the Sultan of Morocco. Practically, they are their own masters, and it fares badly with the tax-collector who is rash enough to enter the gorges on the sides of which are perched their fortified villages. Indeed, he seldom troubles them, permitting these refractory folk - whose country, though not five days' steam from London, is less known than many parts of the centre of Africa-to live ummolested. Some years ago, they quietly murdered the Bashaw whom the Sultan had scnt to rule over Chechaulan; and the two or three Europcan travcllers who have venturcd into that town have done so only in disguise and at the risk of their lives - a fact that is not difficult of belief by those who have seen these independent tribesmen swaggering about Tetuan, musket on shoulder and knife in belt; ready to dispute the narrow way with any more chastened pedestrian. Their Mohammedanism is also more fanatical than orthodox; for, though the ground on which an infidel treads is to them unholy, the Riffians have no more compunction in eating the wild boar than they have in drinking the juice of their own grapes.

They were the last of the Sultan's subjects to abandon the capture of Christian ships and the enslarement of Christian sailors, and even yet it is clear, as recent incidents indicate, they are by no nieans averse from a bit of piracy, even in so awkward a spot for corsairs as the two Spanish Presidios of Alhucemas and Melilla. In reality, though the latter have a number of Hispanised Moors in their garrisons, the wild Arabs and Berbers have never paid more regard to the Unbeliever than to the Moslem, and, unless sharply looked after, are apt to indulge in the playful jest of taking a pot-shot at the Spanish sentry pacing his rounds. The veneer of civilisation that has been spread over the town Noors by long contact with
Europeans has not reached the Riffians, and, like the other mountaineers of Norocco, they know little of, and have less regard for, the might of the "Kafirs who fear not God."

Among thesc bold mountaineers-men who, with all their savagery, are infinitely preferable to the double-dealing, painfully polite, semi-cultured town Arab - the people of the village of Beni-boo-Gaffir, near Cape Ras ed Din, a few miles to the westward of Melilla, are the most notorious for their piratical habits. Steamers, of course, they never meddle with. But the sinall merchantmen who still form the bulk of the Mediterranean coasters used to dread being becahned in the ricinity of this corsair haunt; for the chances were that the natives would immediately launch their large "kareebs," hidden in nooks or buried under sand, and make for the doomed craft, firing volleys to frighten the crew, who, if they did not escape in their boat, were certain to be either permanently enslaved or held to ransom (p. 105). However, provided they made no resistance, they were, though badly fed and hard worked, gencrally treated fairly well. But their ressel, after being stripped of every article of value, was burnt, even the clothes on the seamen's backs being replaced by old "djellabs," or garments of less elegance. It happened now and then that the becalmed craft managed to give its assailants more than they had bargained for. But this was a very rare occurrence, and only when the vessel carried guns ; for the Rifirans' "kareebs" were each manned by thirty or forty men, all armed with long muskets, pistols, and swords, and apt to exact a cruel retribution from those who failed to beat them off. Things went on in this way up to the year 1856, when Sir John Drummond Hay, for many years British Minister to the Shcreefian Court, succeeded in rescuing some British prisoners, and exacting a promise that such conduct should not occur again. This vow, he maintains, has been faithfully observed, and, provided the outrages of 1889 and 
1890 arc explained as nothing more than a rude way of protesting against being supplied with contraband arms and other European goods, Sir John's claim is not unjustifiable. Still, when the Riffians' loose ideas on such subjects, and the old-fashioned Moslem's creed touching the violability of Kafir wealth, are considcred, the merchant captain had better avoid the "Tres Forcas,"
Sallce and Mamorà were ports of far less importance than Tunis and Algiers, and the evil instincts of Tangier and Tetuan were kept in check by Gibraltar on one side and Ceuta on the other, they were long the scourges of small ships entering the Mediterranean. Sallee-Rabat (p. 105), on the Atlantic, was the strongest of thesc pirate dens, and its vessels -often owned, and always countenanced, by

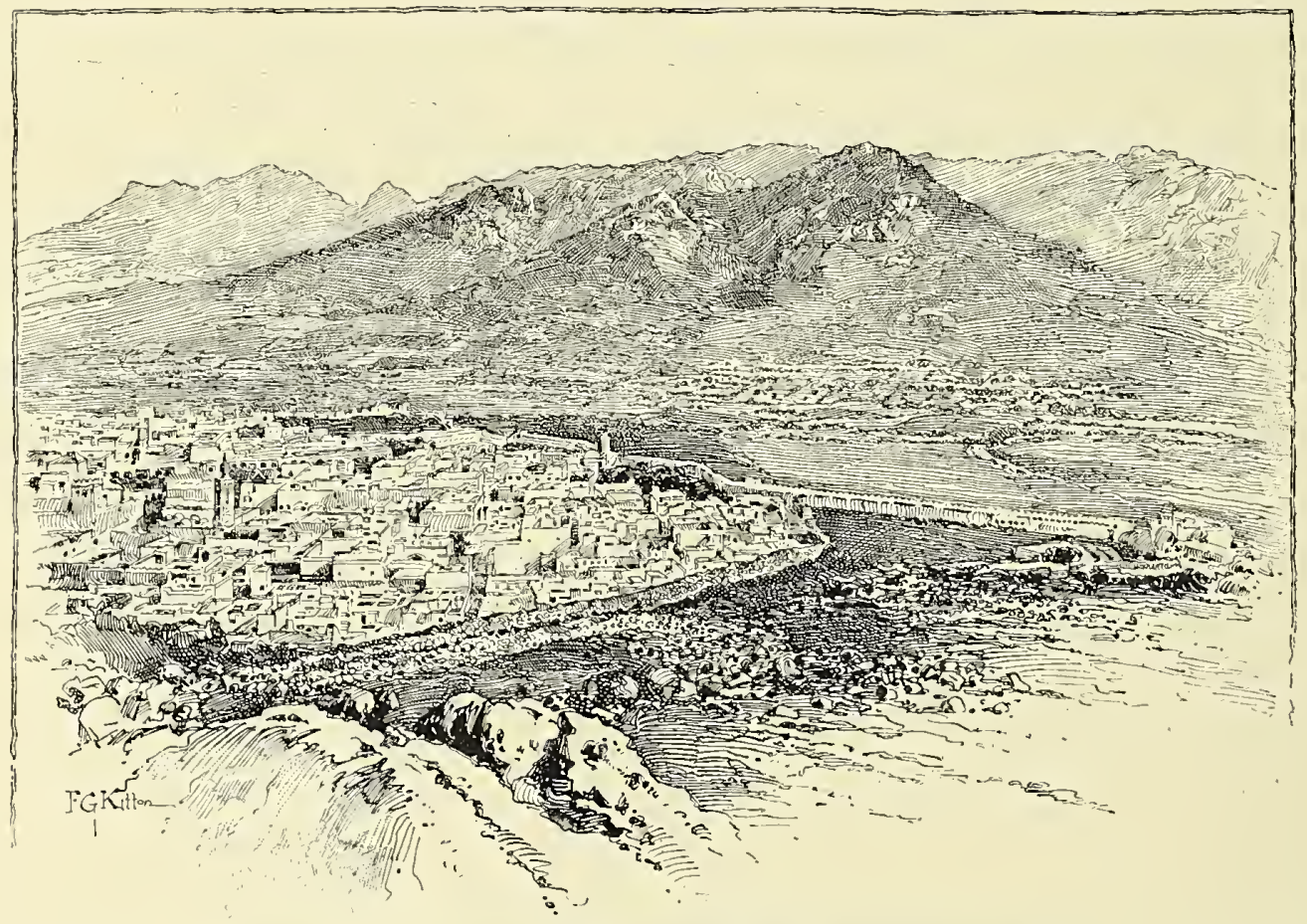

TETUAN, IN IOROCCO, AND THE MOUNTAINS TO THE SOUTH.

unlcss he is sure of a wind, of his crew, and of his gunpowder.

The Riffians are, in short, "survivals," and, as such, interesting to the historian who is in no danger of falling into their hands. But there was a time when the mariner who approached "the gut of Gibraltar" began to scan the sea warily, so as to give a wide berth to the "Sallee Rovers" who, two centuries ago, so despitefully used one Robinson Crusoc, of York, marincr. In those days piracy was the trade of a score of what are now crumbling ports along the Barbary shore. And though the Sultan, who shared the profits-would sometimes have the boldness to lie under Lundy Island, to pounce upon merchantmen sailing out of Bristol, just as the Algerian rovers had the audacity to attack Baltimore, in Ircland. At that time not a year passed but hundreds of British and other sailors-not to speak of an occasional passenger-were marched into the interior. At Fez and Mequinez, and, to a smaller extent, at other inland citics, thesc ill-starred people were enslaved, beaten, and half starved. They were cngaged in building houses and walls, 
and in other occupations, until, through the bounty of the King, or the pity. of the Redemptorist Fathers, or the self-sacrifice of relatives, their ransom arrived. Sometimes it never came. Then, unless they managed to escape, a life of slavery was their certain lot. Their only chance of avoiding it was to "turn Moor," and this many a despairing Briton did. Henceforward, his native land knew him and, under new names, the John Smiths and Thomas Pellows of Pemryn or of Plymouth sometimes rose high in the military service of the Sultan. In 1780,

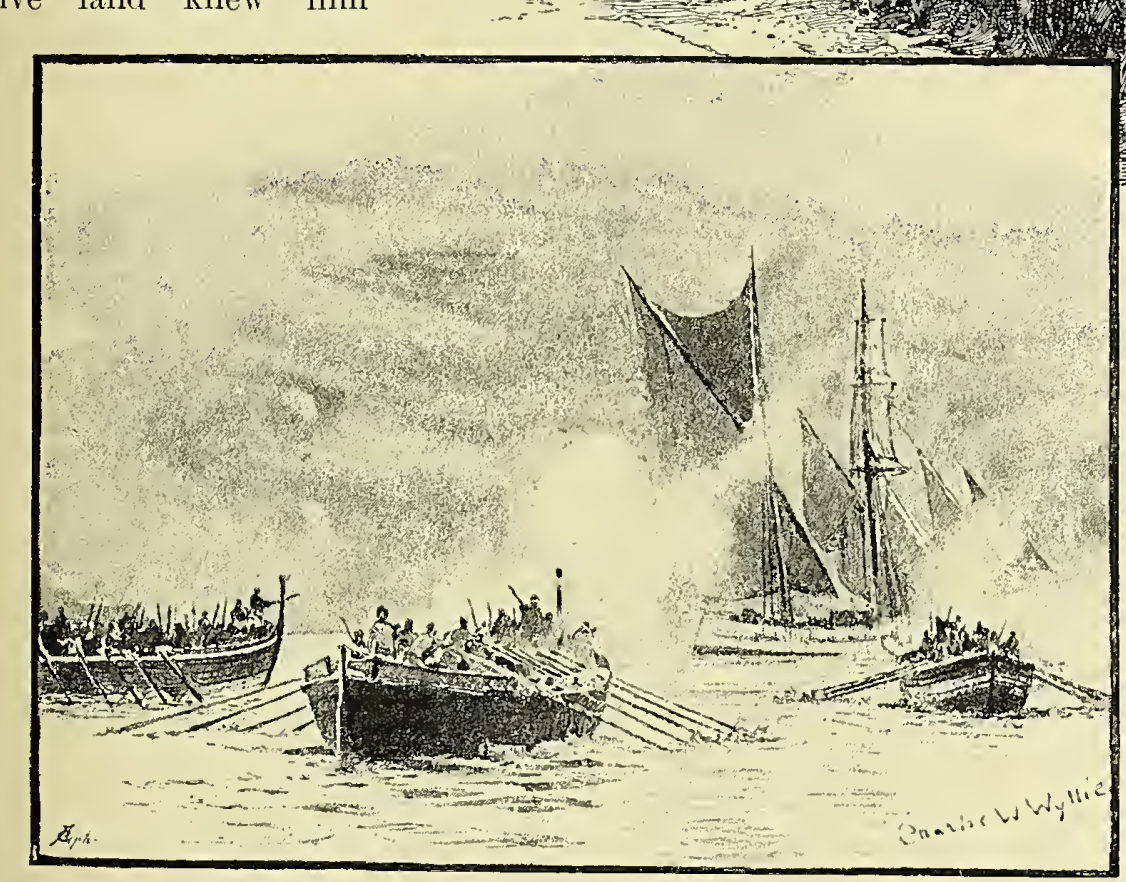

"KAREEBS" ATTACKING A MERCHANTMAN.

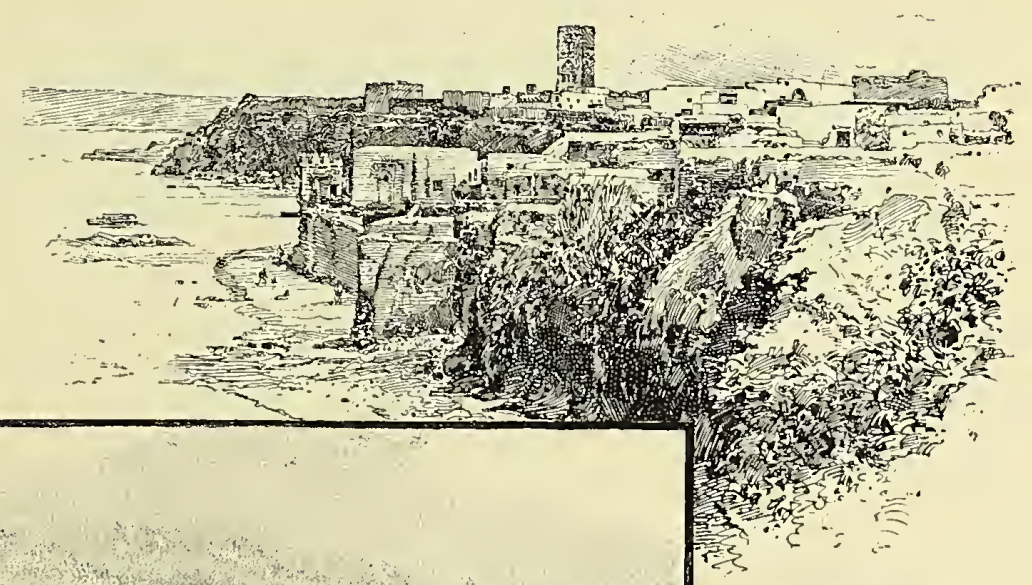

SALLEE-RABAT.

"Omar, a Scotchman," was captain of a "zebek" of sixteen guns and one hundred and twenty-four men, and, at an earlier date, Pillet, a former French merchant, was for a twelvemonth the Governor of Sallee, the gates of which, however, his head ornamented soon

no more; for, as a subject of the Sultan, he was excluded from ransom, and was so closely watched that escape was seldom possible. But he was freed from the degraded position he formerly occupied, afterwards. "One Carr" was, in 1727 , Kaiid of the Jews, and in Mulai el Yezeed's reign Mogador was garrisoned by two hundred and fifty French renegades, commanded by Boisselin, the son of a Parisian hatter. 


\section{CHAPTER V. \\ In Search of Prester Johx : A Paper-chase.}

The Course of the Niger-Early Tales of the Niger-Edrisi-Ibn Batuta-Leo Africanus-Timbuctoo and the Upper Niger Cities-The Renaissance of Geographical Exploration under the Portuguese-The Strange Myth of Prester John-Its Influence on African Exploration--Nunez Tristĩo's Hapless Attempt to Penetrate the Interior-The Joloff Prince and what came of his Story of Prester John's KingdomEmbassies to the Niger Princes-What Sultan Mohammed thought of His Very Faithful Majesty-First Journeys into the Interior-What Truth is in Them-The Story of Andrew Battell of Leigh-Zebras, Gorillas, and Pygmies described by him-How Far he Anticipated Later Discoveries-The Last of Prester John as a Stimulus to the Exploration of Africa.

Afric a within the last hundred years has been so ransacked in all its main features, so mapped and geologised and botanised and described, that we are apt to forget that there was a time within the memory of men still living when the features with which we are now so familiar were hotly discussed as non-existent. The Niger is, for example, a river so large that it might seem scarcely possible for anyone to miss the rast delta through which it enters the Atlantic. Still less would it appear possible for more than twenty centuries to elapse before travellers could agree as to its course to the sea, or, indeed, whether it was not the Nile, which flows into the Mediterranean, with the entire breadth of the continent between it and the flood with which it was conformded. Rising in the region now known as the States of Samori, inland from Sierra Leone and The course Liberia, the Loma Mountain, which of the Niger. is the source of the Tembi, its earliest fountain-head, is not far distant from the beginnings of the Senegal and the Gambia, for which also it was for long mistaken. But the Niger (p. 112), though taking origin in the springs of this mountain, if weaccept the Tembi as its chief stream, soon attracts other rivulets, which, uniting, form a goodly river, rolling north-easterly, as if it would follow the Nile by finding its outlet in the Mediterranean. But near Kabara, the port of the famous city of Timbuctoo, it takes a more easterly course for a couple of hundred miles. Before arriving at, this point it has received the Mahel-Balevel and swollen into a broad torrent, with, however, a tendency to split up into narrow channels, with back-waters, cross-creeks, and swamps.

Soon, however, collecting its force again, it turns sharply to the south-east, cutting its way through a rocky country, more picturesque than any of the low-banked, grain-bordered region which had been the main features of its banks from Samoriland to far beyond Kabara. Negro villages dot its banks in rapid succession. But Gogo, Say, Gompa, Bussa, Rabba, and Egga almost deserve the name of cities. At the last-named, the river, having forced its way through the Rennell Range of mountains, its even flow broken by many rapids, like those of Ansongo, takes a more southerly and westerly course, until the Benue, or Mother of Waters, joins it from the east, and swells the river which, though known for convenience' sake as the Niger, bears in every stretch of its long course a different name. *

Before this confluence, though a broad river from the European point of view, it had not received many large tributaries. But the Benue, $\uparrow$ before losing its identity in the Niger, has coursed for 860 miles, fed throughout

* Joliba, Kworra, Mayo, and Kakinruwa are a few of its many designations. The word Niger or Nighir has nothing to do with the Latin Niger, black. It is most likely derived from the same root as the Berber Ghir, to this day applied to various streams in North Africa. The word is, however, very old, for Ptolemy and Pliny both use it.

$\dagger$ Also called the Shary and Tchadda. 
its entire extent by rivers which, like the Mayo-Kebbi, are themselves of considerable dimensions, and their banks the home of populous nations, though explorations made only recently show that it has no connection with the basin of Lake Tchad, to the north of it. * At the confluence of the two streams the Niger is about three-fourths of a mile wide, and the Benue rather larger, though they vary at different periods of the year, since the two rivers, having different gathering grounds, are not in flood at the same time. Their united current is, nevertheless, at any pcriod of the year so broad that it looks like a lake, two miles in width, dotted with islands and sand-banks.

This rast river now leaves the sandstone plateau through which it had for many miles been winding its way among rapids and rocky islets, to enter a narrow gorge, by which it passes through a series of bold, picturesque hills, the limits-we may take it-of the old Atlantic shore before the flat coast formed by the mud brought down by the rivers had been formed. This delta, of which we have ahready spoken (p. 37), begins soon after learing Onitsha, and stretches for about 120 miles along the coast, and for 140 or 150 miles inland. Through this flat, densely covered with bush, the great river, which for 2,500 miles has flowed along so majestically, through more than twelve degrees of latitucle, crawls so secretly into the ocean that it took many centuries of exploration to establish so simple a fact. In the delta formed by the mud brought down by it through unnumbered ages, the river divides and subdivides, the different branches crossing and intercrossing with each other and with the lower courscs of other rivers which, in like manner, creep seaward in this direction, until so intricate a network is formed that even were the delta accurately surveyed it would be impossible to say which was the Niger and which one of the many

* Macdonald: "Exploration of the Benue and its Northern Tributary, the Kebbi," Proceedings of the Royal Georraphical Society, 1891, pp. 449-17\%. other fetid floods collectively known as the Oil Rivcrs (p. 37). For in one direction the plain of mul extends to the Old Calabar or Cross River, and in the other to the lagoons around the colony of Lagos, though the channel chiefly used by vessels ascending the Niger is the Nun, which may be regarded as the most marked continuation of the river before it begins to divide.

On the drier part of the delta the river has low but regular banks, and where the "region of mud and miasma" has not begun the villages are embosomed anid plantations of plantains and sugar-cane (p. 117). By-and-by the ground is less raiscd above the gurgling current, though even here rast forests of oil-palms and other trees grow luxuriantly. Then the division between land and water is scarcely marked at high water. It is only when the tide goes out that the long, straggling roots of the swampy mangroves mark the first beginnings of soil, formed by the brown clay washed down by the river and strained through the rough sieve made by the network of these amphibious plants (p. 109). But, in time, as the delta widens seaward, the mangrove swamps will become dry land, and palm-trees take possession of the ground. Here, however, and for twenty miles inland, as far as the influence of the tide is felt in the dry season, these dense thickets shut out the view on every side. The voyager, as he stcams to Sunday Island, sces little save the dark grcen wall on each side, the sluggish river underneath and the strip of blue sky overhead. From the deck of a ship sailing along the coast he sights barely that much. For, except a break here and there in the long line of dark green, there is little to indicate that among these sliny mangroves, rising to forty or fifty feet above the water, there rolls into the Gulf of Guinea the river which shares with the Nile the dignity of having attracted more explorers than any other in Africa, and which has cost more lives than any other part of this death-dealing continent.

All this is now the common heritage of 
geography. A century ago we knew about as little as we did in the days of Edrisi Early tales and Ibn-Batuta and Leo Africanus. of the Niger. Mnch was vague, and nearly everything speculative. It was known, or suspected

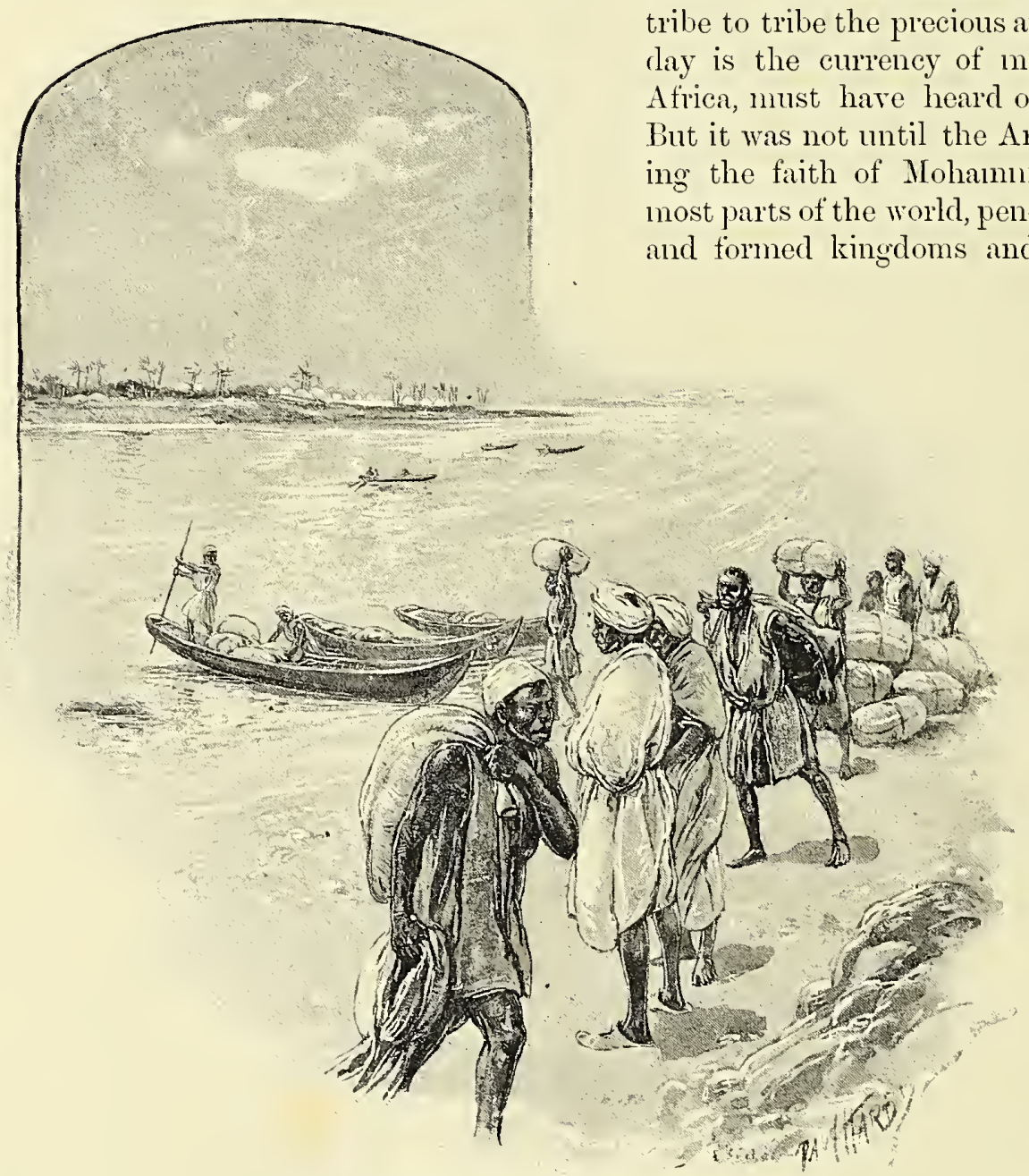

SCENE ON THE NIGER, AT SAY.

the country to the south-west of Egypt, had, after a thirsty journey over a sandy desert, reached a land of pygmies, watered by lakes and marshes, abounding with fruit-trees, and through which ran, from west to east, a great river. The salt-traders, who carried from tribe to tribe the precious article which to this day is the currency of many parts of inner Africa, must have heard of the same stream. But it was not until the Arabs, bent on carrying the faith of Mohammed into the uttermost parts of the world, penetrated the Soudan, and formed kingdoms and eren empires on the upper waters of the Niger, that the noise of the turmoil to which they gave rise began in these nodern times to reach the ears of civilised men. And when the echo of their doings did find a place in the rude chronicles then beginning to be written, every fact was exaggerated, every little village enlarged into a town,every town of whitewashed huts roofed with reeds a city of so much wealth and splendour

- and the reputation of such a river could scarcely remain long concealed-that through the land of the Black Men flowed a mighty stream, which, if not the Nile, was quite as large. Herorlotus, patiently jotting down on his tablets of wood the tales that he collected of far-away lands, had heard in Egypt of five young Nasamones who, setting out from that alongside of them even the capitals of the old world sank into insignificance. With such eagerness did these Asiatic fanatics press forward on their self-appointed mission of proselytism and, it must be admitted, of cirilisation, that within less than a hundred years after the death of the Prophet there were schools and mosques in the 
kingdom of Ghana, while we know from the statcments made in the works of Arab historians that by 893 , i.e., two hundred and seventy years after the flight of Nohammed from Mecca, the Arabs, who by this time had overrun Northern Africa, and overthrown the stately monuments of Roman civilisation, were regularly sending caravans into the country between Tunis and the Upper Niger, just as they have been doing all the thousand years subsequently, and are doing at this very moment after much

the same fashion that thcir govermment. It was under one of thesc that Timbuctoo* was founded as a trading station, which in time dercloped into the meetingplace of cararans from Morocco, Tripoli, Tunis, Egypt, the oases of the Sahara, and the Soudan. It was at no time a great political capital. Its wealth and importance depended upon its trade, and when the course of Central 
the eontinent from the west and from the north. They struek the great river here, or they eame upon it there. Their wanderings led them to regions often far away from the Niger; but the goal after whieh they all aimed, from Mungo Park to Oskar Lenz-or, perhaps, it would be more eorreet to say from George Thompson, who aseender the Gambia under the belief that it was the Niger, to Lieutenant Caron, who two hundred and seventy years later anchored in front of its port-was this alnost mythieal eity of Niger-land. Like the ambition of eertain folk to reaeh the North Pole, or to follow Leiehhardt, or to diseover the North-West Passage, or to find Franklin's log-books, the eagerness to share in the wealth or the glory to be won by being the first to enter this negro metropolis beeame a sort of passion. Every slave who eame from the interior was questioned regarding it, and answered in exaet aeeordance with the wishes of his interrogator, and a "Slatee" who eould give, or pretend to give, any information regarding 'Timbuetoo was sure of a rearly listener at any post from the Gaboon River to the Senegal.

Meanwhile, there were hot disputes about the river on which this mueh-talked-of eity was built. Many geographers regarded the Niger and the Nile as identieal,* while other's held by the Senegal as the seaward eontinuation of the river of whose upper waters the inland traders brought tales, and regarding whieh Edrisi and Leo the Afriean had written in their volumes, which until well into this eentury were our prineipal authorities coneerning the geography of the eontinent. Other's insisted as stoutly on the Gambia, while a few followers of a short-lived faith fought for the Congo being the mouth of the river. Some even affirmed that it flowed into an inland basin. The only outlets to the Atlantie whieh nobody seems to have thought worthy

* Up to well into this century there were geographers who held with the Arabs that the "Nil of the Negroes" was the upper portion of the Nile, and, considering the fact that the lower part of the former and the higher part of the latter were both unknown, the theory was by no means so absurd as we are now apt to consider it. of notiee were those breaks in the delta up whieh there is now some ground for believing that the Portuguese had penetrated in the sixteenth eentury, when they sent embassies to the Kings of Mlelli and Mosi, and even-so it is elaimed-to the ruler of Songhai, on the Upper Niger. The wonderful revival of geographieal exploration whieh began in the fifteenth eentury was led by the Portuguese. Their ships and their settlements were the first to diseover and to take possession of the many new lands that were then not known eren by name. Strange tales reached Europe of a Christian of Prester sovereign, very rieh, very pious, John. and very powerful, who lived in the interior of Afriea, and was known by the name of "Prester John." This phantom potentate is one of the strangest myths of the Middle Ages. At first he was rumoured to be the sovereign and priest of some great realm in the Far East. 'Then, after' seeking him in Central Afrien, Abyssinia was assigned as the land of Prester John, though not unlikely the eonfusion of Ethiopia with India, whieh is as old as Virgil, might be the eause of his home having been transferred, in the popular imagination, from Afriea to $A$ sia. Be that as it may, Abyssinia, until the myth died away, eontinued to be regarded as the true kingdom of this eeelesiastieal monareh. Letter's were sent to the sovereign of Abyssinia in that eapaeity, though, not improbably, the story of Prester John originated long before the people of that eountry had fully aeeepted the Christian faith.

At all events, when the Portuguese first began their voyages, whieh in a few years brought half the world to the knowledge of Europe, Abyssinia was not quite taken for granted as the seat of this sovereign. On Fra Mauro's map of $\mathbf{1 4 5 9}$ there is a fine eity figured as "the prineipal residenee" of "Preste Jamni" (p. 116), and forty years later Vaseo da Gama heard-or thought that he heardwhile proseeuting his voyage from Mozambique northward, of the same personage reigning in the interior: So firmly established was the 
belief in the existence of this pope-king, that among the customary instructions received by the commanders of the expeditions, then so frequently setting out for Africa and India, was the order to inquire diligently of the inhabitants regarding Prester John,* and whenever news of any likely monarch came to their ears, to lose no opportunity of penetrating inland in search of him. For if the close of the fifteenth century was full of commercial enterprise, it was also intensely tinctured with religious fervour, and the Church, as the custodian of all the learning of the period, took carc that their side of the great Portugucse expeditions, which Prince Henry the Navigator was despatching hither and thither, should not be neglected. The long, drcary cxpanse of havenless sandy shore between Horocco and Upper Guinea offered little chance of landing. But when the marmers saw the fertile shores of the Senegal and the Gambia, and wcre offered gold and ivory from the interior, then they remembered Prester John, just as their successors thought of Timbuetoo and the Moslem kings of the Upper Niger. Nunez 'Tristão's first essay in that direction was unfortunate, for he and a number of his men were killed in attempting to ascend a sinall river near the Rio Grande, without anyone cver hearing of Prester John and his cmpirc.

But one day $\dagger$ there came to the settlcment on Arguin island a Joloff Prince, who had much to tell of Timbuctoo and Jenné, of the vast trade carried on with these cities, and of a land bevond Timbuctoo in which dwelt a people who were neither Moors nor pagans, and must therefore be Christians, and if Christian, surely the subjects of the longsought-for Prester John. How far this wily black, who had becn exiled by his relatives, and was anxious to obtain the white man's aid in recovering his throne, was playing on the credulity of the Portnguese, of whose anxicty to

* Oppert: "Der Presbyter Johannes in Sage und Geschichte" (2nd Ed., 1870); Zarnecke: "Der Prester Johannes" (1876-79); Yule: "Cathay and the Way Thither," pp. 173 et seq., and "Marco Polo," 2nd Ed., vol. i., pp. 229-233. vol. ii., pp. 539-5 43 .

+ In 1489-three years before the Discovery of America. hear of a Christian land in the interior he was, of course, well aware, is an open question. At Lisbon, however, he clung to his tale, and professing no reluctance to be baptized, the pagan was duly admitted into the pale of Christendom, receiving at the same time-fit cmblem of what was to follow-a coat of arms, consisting of a crown of gold on a vermilion field, with the quarters of Portugal in the border. He then did homage to the King as his Liege Lord, and to the Pope, in the person of his commissary, according to the forms usually adopted by Catholic princes. Meanwhile, at the tourneys of the Court the Joloff Prince exhibited some wonderful feats of horsemanship. His negro attendants ran alongside a galloping charger, lcaped on while it was running its swiftest, and then sprang off again with the same promptitude as if it had been stopped for their convenience. These performances, like the horses on which they werc learned, had doubtless beenimported from the Arabs in the intcrior, or from those who had penetrated south from Norocco. By-and-by a flect of twenty caravcls was equipped under the command of Pero Taz da Cunha, with a body of Dominican monks, under the orders of a brother of that order-the one for the subjection, the other for the conversion, of the natives. The Senegal was the river they selected for ascending, and here a fort was begun. But before it had procecded far the Joloft Prince, sceing that the Portugucse wcre more intent on establishing themsclves in the country than in re-scating him in power, quarrelled with his protectors, and being suspected of plotting with his kinsfolk against them, was, in the heat of a squabble, stabbed to death by the sullen commander of the expedition. Abont the same time, a pestilence broke out among the troops, with such fatal results that, though the flect did not leave the river, the building of the fort was stopped. During this delay enbassies were sent to the inland princes, several of the envoys being accredited to the King of Timbuctoo, though, unfortunately, no record has becn kept of a visit which, wcre it confirmed, would give the 
Portugucse the credit of anticipating by more than three centuries the first entry of any European into that city.

Still seeking for Prester John-and perhaps also for gold and slaves-the Portuguese touched the coast here and there, sending messages to this "Prince" and that "Emperor," full of inflated compliments to them somewhere in the Niger country. Sultan Mohammed was, however, in no way inclined to bandy compliments with the Portuguese envoys, for he dismissed them promptly with the remark that he understood nothing of all this palaver about magnificent kings in the Infidel country. There were to his knowledge only four who answered that description-the

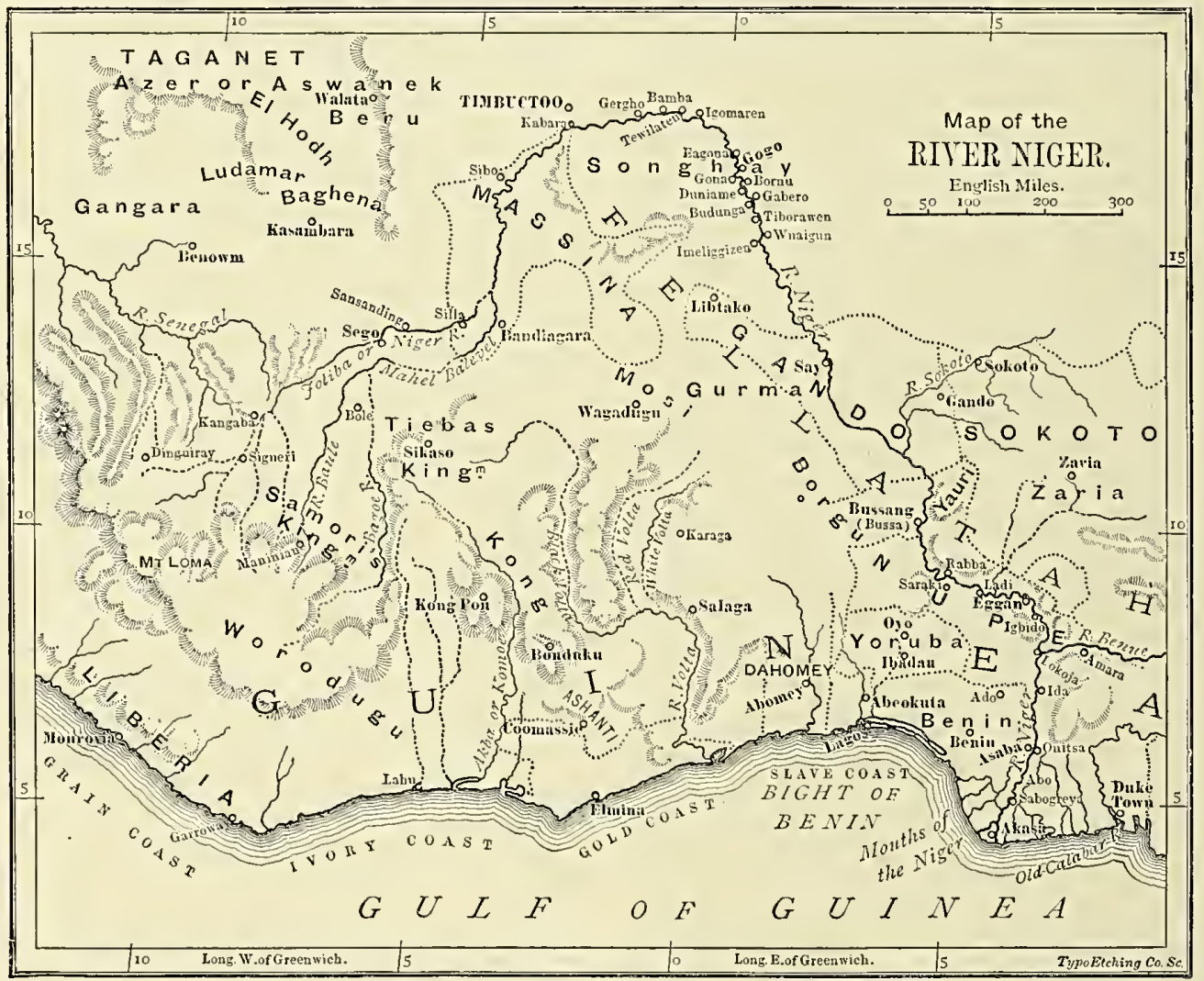

MAP OF THE RIVER NIGER.

and grandiose descriptions of the might and puissance of his Lusitanian Majesty. Among the black potentates to whom these early envoys were sent was a "Moorish" monarch with the not uncommon name of Mohammed, who ruled a country about 500 miles in the interior behind Cape Palmas, and therefore

* In the earlier writers this term is used very vaguely. It meant at most only a Mohammedan in faith, though the name was not unfrequently applied to any dark folk-Pagan or Moslem, Berber, Arab, Negro, or Fulah.
King of Cairo, the King of Alimæm, the King of Baldac, and the King of Tucurol. And, he added, of the "four thousand four hundred and four kings" of which he was the lineal descendant, not one had received or sent an embassy to any Christian prince ; that he had no intention of introducing any such innovation on the wisdom of his ancestors; and that the envoys would be pleased to depart forthwith. Whereupon, adds the old chronicler, they lost no time in taking their departure. 


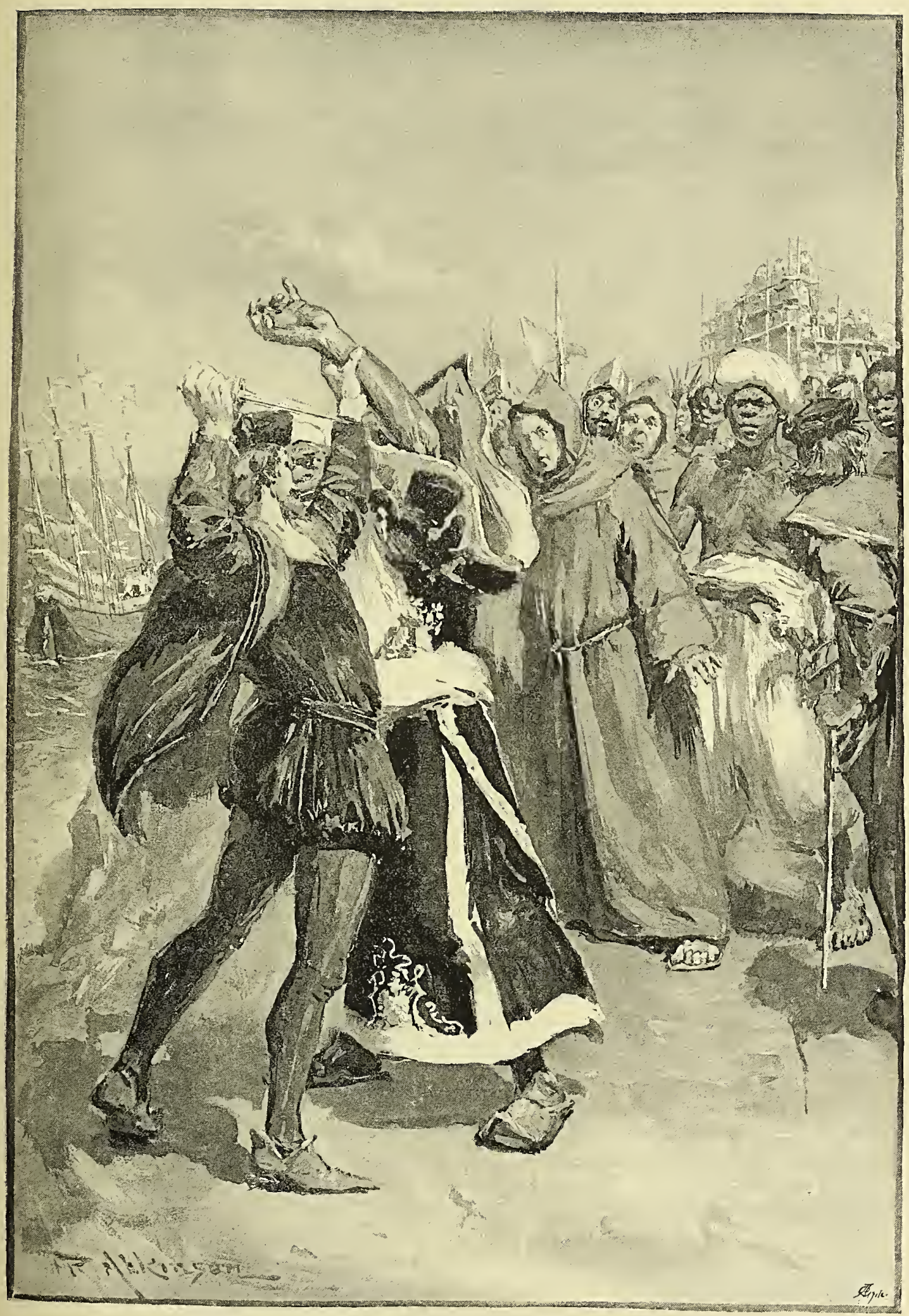


But the ardour of His Very Faithful Majesty in search of Prester John was not to be damped by the boorish

First journeys into the interior. curtness of Sultan Mohammed. Accordingly, another embassy was despatched from the Island of Arguin, where the Portuguese had built a fort and founded a factory, into the Hodem country, more than two hundred miles in the interior, on the headwater of the Niger. But though the Bambarrans and Iudanar people, whose home was in those parts, were quite willing for the white men to found a factory, and promised to make all needful inquiry about him, they, like everybody else consulted, had never heard of Prester John. And so the envoys came back again, as little successful in their errand as the seekers after the North Pole at a later day, though, like them, not without hopes of being able to find the long-sought-for goal.

Leaving out of all account the Latin braggadocio from which the Portuguese of those days, like their cousins in Spain, were not exempt, there cannot be any doubt that these early adventurers did penetrate far into the interior, and were acquainted with much of the Niger country long before the world at large knew anything about it. When the French and English came to the Scnegal and Gambia, they found a considerable mixed Portugucse population established on these rivers; and even at Bambuk, when the French reached it, as they thought, for the first tine, there were-as there are still all along the $\Lambda$ frican coast-many words in the native language which attest the former presence of the enterprising people whose explorations, from jcalousy of other nations, or from the ignorance or carelessness of those taking part in them, were permittcd to pass out of memory without being committed to writing. It is possible that the few facts which remain would have becn lost altogether had not the industrious De Barros collected them before they had vanished from the memory of man. From these records we learn that, though they knew much of the countries traversed by the Gambia, the Senegal, and the Niger, they had no idea of the two latter being separate rivers, or of the fact of the Niger flowing for a certain portion of its course almost due eastward; but they must have had some idea of the length of that river, for De Barros expresses surprise that so long a stream did not pour more water into the ocean. They describe the populous towns and the fertile country on its banks. The ravages of the slave trade had not then begun ; but the tribal wars were brisk long before the white man had been scen, and there was always a local traftic in serfs, which, however, was more than satisfied by the sale of criminals or prisoners taken in the campaign of onc little king against another still smaller. Timbuctoo, where the merchants from Cairo, Tunis, Tlemçen, Fez, and Morocco met those from all other parts of Northern and Equatorial Africa, and Jenné farther to the west, which was a rendezvous for the traders nearer to the coast, were among the places which came within the knowledge of these Portuguese pioncers. They not only visited them, but they bought at El Vina (p. 44) and their other forts the gold which the natives of these lands brought to the coast. They were eye-witnesses of the dismal desert between IIorocco and Cape Blanco, thongh, like the ancients, they had heard of the green "abeses," or oases, which werc not only centres of population, but stepping-stoncs by which the rolling sands could be crossed by caravans; and in their writings we read names now part of the everyday vocabulary of the whites in Northern Africa-of the "Sahel," of the "Sahara," and the "Azagar"--to cxpress the relative richness and poverty of the region in question, though the terms are not now applied in exactly the same way that the Portuguese imagined they were four hundred years ago. But small though the land which actually owned the rulc of Portugal was, it was enough for her sovereigns to style themselves Lords of Guinca. As such the explorers crected pillars on those parts of the coast at which they touched, some of them remaining 
to this day, discovered and tried to explore the Congo, and failing to find the land of Prester John among its swamps, establisher in the Congo country, south of the river of that name, Christian missions, the renmants of which, among crumbling cities and rumed churches, we shall have occasion to describe when the story of the share which the Church soon took in the civilisation of Africa comes to be the subject of a later portion of this work. From the Congo country the Portuguese sent expcdition after expedition either along the coast or up the rivers, founding colonies and missions and trarling-posts, under stern soldiers and stout-hearted priests, and huxters whose courage was equal to that of either friar or musketeer.

It was a golden age for discovery which we are sketching. Half the world knew little The story of of the other half. Not a ship came Andrew into port but she brought tidings Battell, of Leigh, Mariner. of lands, and peoples, and products, all strange to the most learned of our countrymen, or to the books which existed in such small numbers that it was quite possible to remember them all by name. In every tavern, ear-ringed men, clad in watchet cloth, talked of regions the ver'y whereabouts of which puzzled the oldest nariner in the company, and the little lads playing about the shore and the wharves could, by approaching a group of sailors come ashore, hear of realms and fights, goodly cities and fair havens, of which the wisest clerk in "Powl's Schoole " could not tell the position.

Portugal and Spain, it is true, had by the Pope's grace the monopoly of these outlandish voyages. But no priest or potentate, no bull or Tatican decree, could, or, for the nuatter of that, did, bar the valiant seamen of the Tudors long out of any ocean over which they wished to sail. Twenty years before Queen Elizabeth had ended her reign, Thomas Stevens, an English .Jesuit, had reached India by way of the Cape of Good Hope, on board a Portuguese ship, and not long afterwards, John

* Most of them have, however, been removed to museums.
Newbery and Ralph Fitch, "with six or seven other London merchants," had, first of their race, travelled overland through Aleppo, Bagdad, Bussorah, and Ornuz. Even the jealousy of the Spaniards could not keep the Briton out of the new world which the conquests of Cortes laad just ardled to the Empire of the Indies. For Robert Tomson, of Andover, found his way to Mexico in the year 1554, and abode there with "many ancient men that were of the Conquerors," until, giving utterance to sentiments that smacked of heresy, the Englishman found it prudent to put the sea between him and New Spain. Yet, even this was not the first British venture to Mexico. This distinction must be reserved for "one Thomas Blake, a S'cottisman," who had dwelt in the city for twenty years. Ten years later, Roger Bodenham, another Englishman, being unsuccessful in his trade with $\mathrm{Fe}$, in Norocco, a fanatical town long subsequently closed to infidel merchants, stayed nine months in the city of Montezuna, and lid so well that he brought back to Seville a cargo worth, in the money of that day, about $£ 36,000$.

We need not, therefore, be surprised to hear that in 1520, Andrew Battell, a tisherman of Leigh, in Essex, having a soul above the cockles and flounders of that Thames-nouth village, or even the salmon that ascender the then unfouled river, was exploring the coast of Africa on board a Portuguese ship which was looking out for a cargo of slaves, though, no doubt, the captain had strict orders also to be keeping an ear open for tales of Prester John. It is true that Andrew was nominally a prisoner on board "the Portugall," which, like most of its flag, was half-trader, halfprivateer, with perhaps a dash of the pirate all through. They had rescued him from captivity among the Indians of Brazil, which possibly the wayward mariner found less agreeable than the fo'c's'le of a ship. At all events, he was by no means depressed by reason of his lot, and to this accident the world is indebted for a very curious discovery. Cruising up and down the coast in search of 
slaves whom they might buy, or possibly of free-lances had no land of their own. freemen whom they might kidnap, the Por- They were outlaws who lived by plunder tuguese fell in near the Morro, or Cliff,* and murder, and in pursuit of their calling on the coast of Benguela, with a host of had reached the coast with a multitude of freebooters called Gagas or Giagas, who had captives whom they were glad to get quit of

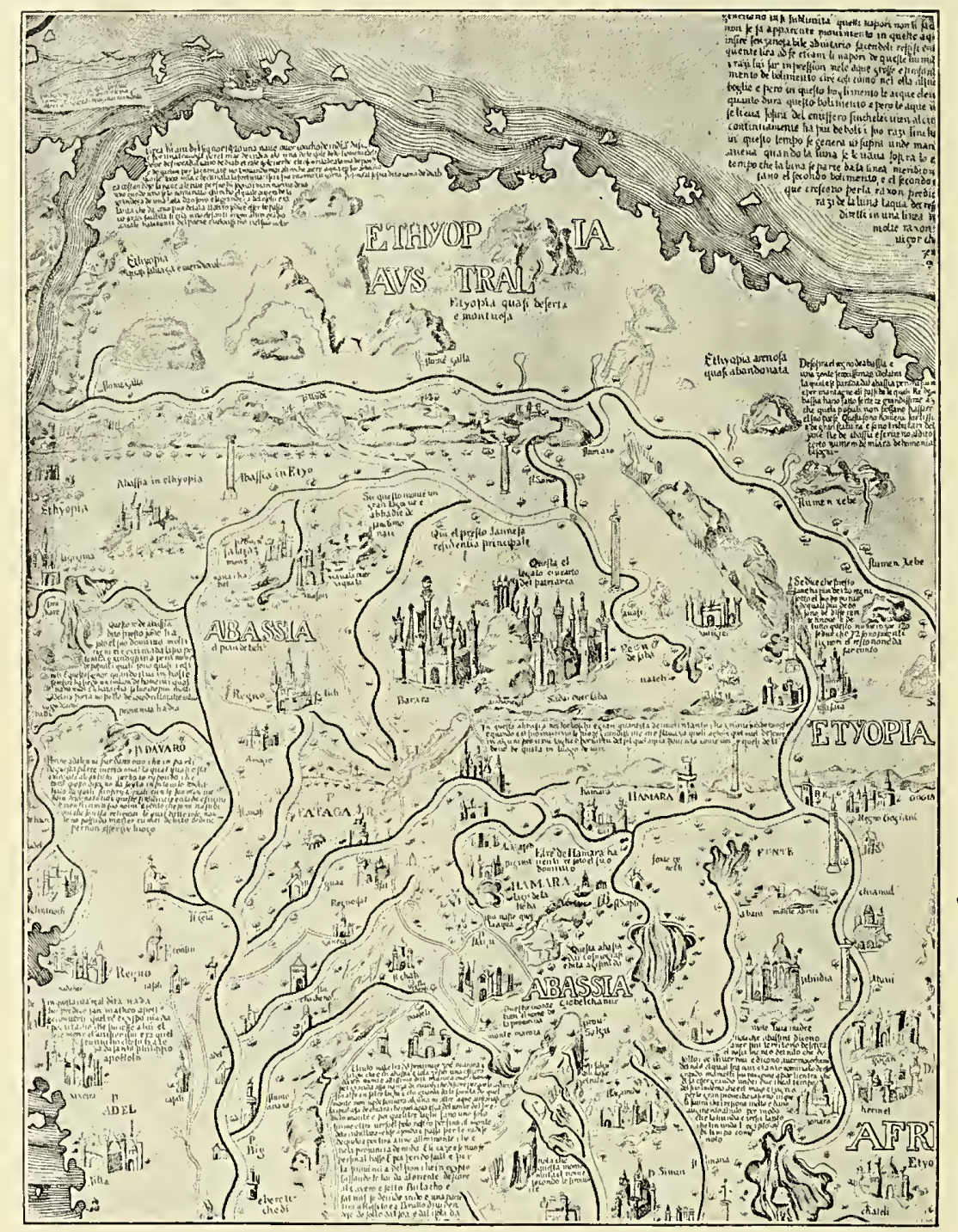

PORTION OF FRA MAURO'S MAP OF ABYSSINIA.

(The white star shows representation of Preste Janni's principal residence.)

come through the Congo country and Angola from a region somewhat near the headwaters of the great river that Mr. Stanley's exploration rendered so famous nigh four hundred year's afterwards. But this wandering tribe * Cape Morro. for a few pence apiece. Never had a slaver met with such a bargain before, and naturally, when the robbers expressed a wish to be ferried over the Cona, $t$ in order to harry the

+ Probably the Quanza, or perhaps the Curo, a little south of Cape Morro. 
Benguela people on the other side, the honest traders in human flesh were only too ready to oblige allies from whose depredations they expected still further profit. By eighties at a time they were accordingly carried over the river, and their landing covered by a discharge of musketry from the ships hard by. With such powerful assistance, the Benguelas, as might have been expected, were routed, their chief slain, and his borly, with that of many of his tribesmen, devoured by the cannibal victors, while the survivors were huddled into the holds of the inhuman scoundrels who had constituted theinselves partners with the savage Giagas.

For five months the black robbers continued to ravage Benguela, and the white ones to buy from them the produce of their raids. Loading and discharging, they passed to and fro between Africa and Brazil during that period, supplying the wherewithal for their allies ashore to steal, and then, as they filled up, hurrying off to a port with their cargo of men, women, and children. Such a business was too good to desert: for in all their evil dealings the Portuguese had never met with a people so ready to rob or so easy to defraud. But, returning one day to ship the usual freight, they found that the Giagas had left. Determined, however, not to lose such profitable customers, the Portuguese sent a party in search of them, and after several days' tramp overtook "the army," marching under the command of a new chief called Mofarigosat, who was just then ineditating a fresh expedition against a neighbouring tribe. Finding, however, the white men in his power, the wily negro intimated that it was now their turn to do a little fighting, and, seeing that there was no alternative, they had to consent.

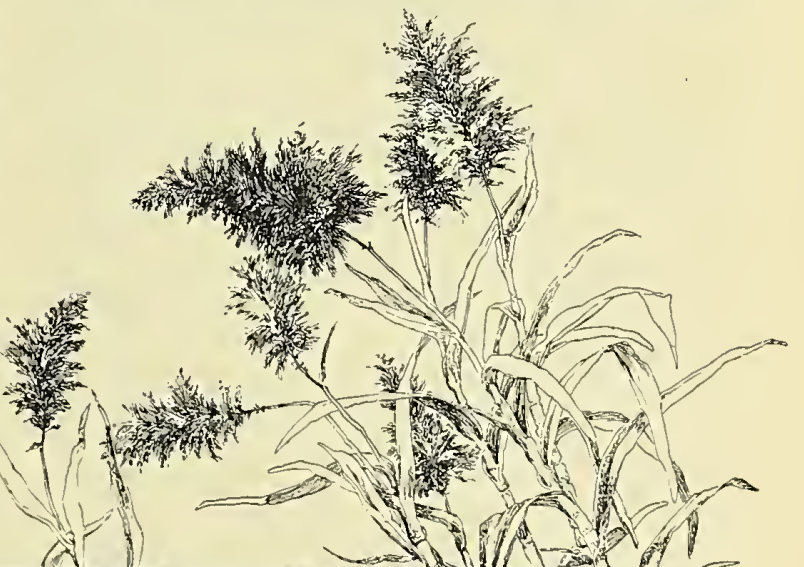


and a heretic, he was chosen as this perilous pawn

For a time the hostage was treated reasonably well. It was only when it became evident that his companions had left for good that the Giagas began to ill-treat him, and finally to discuss the advisability of putting him to death. But the chief, though in the minority, was strong enough to protect him and in the end to secure his freedom. Freedom in the African bush is, howerer, as Battell found it, a poor boon, and so, after wandering about half starved, and in hourly danger from wild beasts and prowling savages, he was fain, as the lesser of two evils, to return to his old friends the Ciagas. Flattered apparently by his confidence in their amiability, they now looked upon Andrew as one of themselves, and during the four months longer he had to stay with them indulged in one wild orgie of "triumphing, drinking, dancing, and eating men's flesh," though the last-named habit he does not admit to have contracted. At length their roamings brought then near a Portuguese port, and their fetish-men, or "wizards" as the narrator calls them, having announced that it was the Devil's pleasure that the white man should depart, the hapless Essex seaman was glad enough to ship on board a slaver which just then was on the eve of sailing.

This at least is the tale told by Andrew Battell, of Leigh, to Richard Hakluyt, Prebendary of Westminster, and printed many years afterwards, by Master Purchas, in " His Pilgrimes." How far it is true, we have, of course, now no means of ascertaining, though there is no reason to doubt its substantial accuracy. The Giagas-by that name at all events-are not known to modem ethnologists. But that is not renarkable. Such a race of maraulers, kept up as they were by the adoption of boys and girls from the tribes they conquered, all their own children being killed at birth, were not likely to last long as an independent organisation, even if the anger of their neighbours permitted the existence of a race who depended "on war for a supply of all they wanted," who sowed without reaping, and cut down the palnu-trees to extract the juice, instead of carefully tapping them after the ordinary fashion of a stationary people. But their customs, their cannibalism, their devil-worship and devil dances, their wizards or fetishmen, and the occasional human sacrifices, all agree with the general traits of the people at the headwaters of the Congo, where, according to Lopez, who also mentions them, they lived "particularly about a lake which gives rise" to that river. This, we may infer, is either Lake Noero or Lake Bongweolo, in which it is almost certain that the Lualaba, its chief tributary, or indeed its continuation, arises.* Once upon a time they swept into the Lower Congo country, compelling the " King," whom this old Portuguese writer calls "Don Alvaro," to take refuge on an island in the river, until the Giagas, having consumed everything, were constrained to seek for further booty in another country. Merolla-Padre da Sorrento -was also familiar with these marauders, for he relates how he saw outside the Congo capital shambles in which hmuan flesh had been sold by them while they occupied that place. They offered it liberally to the Portuguese who came to trade with then, but the latter were more desirous of buying living men "than to have their bellies filled with such barbarous food" as the corpses of dead ones. $\dagger$

This, at least, supports one statement of Andrew Battell, and another fully as interesting has been confirmed by the discoveries of very recent years. For among the information picked up by him was a report that "to the north-east of Mani-Kesock are a kind of little people, called Matimbas, which are no bigger than Boyes of twelve yeares olde, but verie thicke, and live onely upon fleshe, which they kill in the woods with their Bowes and Darts. They pay tribute to Mani-Kesock, and bring all their Elephants' teeth and tayles to him.

* “Relazione del reaume di Congo c delle vicini contrade di Odoardo Lopez Portogheso, per Philippo Pigafetta, etc." (1591), Book I., ch. i.

$\uparrow$ Merolla: "Relazione fatta nel regno di Congo" (1692). 
'They will not enter into any of the Marombos' houses, nor will they suffer any to come where they dwell. And if by chance any Marombo or people of Loango passe where they dwell, then they will forsake that place, and go to another. The women carry Bow and Arrowes as well as the men. And one of them will walk in the Woods alone, and kill the Pongos with their poysoned Arrowes." *

Then Battell gocs on to give excellent descriptions of animals, such as the zebra, now well known, but at that date new to Europeans, and the pongo and gorilla, which were unquestionably the hairy men and women whose skins Hanno the Carthaginian (p. 20) hung up in the Temple of Juno, where they still remained at the taking of Carthage by the Romans. Yet when, more than 2,300 years afterwards, an African trader from the Gaboon -of whom we shall have something to say by-and-by-brought to London several specimens of the same animal, a great many people, who had never heard of Hanno, and a great many more who, having had the advantage of a classical education, ought to have been familiar with the "Periplus," imagined that some great zoological discovery had been made, though, it may be added, several travellers had in the interval between five hundred years before the Christian Era and eighteen hundred and sixty after it brought numbers of skulls and skeletons to Europe and America. Prester John was not found, but it was something to have seen the gorilla and the pigmy folk. For the latter were undoubtedly the same pcople whom Dr. Touchard described in 1861 in the country to the back of the Gaboon. They were also those from whose poisoned arrows Mr. Stanley's expedition suffered so nuch during their march through the great forest which covers so much of equatorial

* "The Strange Adventures of Andrew Battell, of Leigh, in Essex. sent by the Portugals prisoner to Angola, who lived there and in the adjoining regions near eighteen years." [1589-1607.] ("Purchas, His Pilgrimes," 1625, lib. vii., chap. iii., p. 983.)
Africa, and whose relatives Schweinfurth and others have described in various other parts of the Continent as living at the beck of the more powerful tribes around them, who have apparently at some early period invaded the land once held by these ancient lords of the soil. $†$ But unless Aristotle and Herodotus are to be credited with giving us the first inkling of them, Andrew Battell, of Lcigh, deserves the honour of bringing back from his captivity among Indians in Brazil, and Portuguese in Angola, and negroes in Africa, the earliest information about these curious little folk no bigger than "boyes of twelve yeares."

However, if Andrew Battell's pilgrimage is the first in which we learn anything of the Pigmies, it is the last in which we hear anything of Prester John. The world was getting too prosaic or too greedy for any such mythical hero. Amcrica had been discovered, and vast lands and strange peoples had to be conquered and brought into the bosom of the Chureh. The new route to the Indies had changed the course of commerce, and so from the close of the sixteenth century Prester John ccased to be the stimulus for any explorer, or a personage who figured in the instructions for any expedition, whether fitted out for the purchase of slaves, or to seek for the golkien city of Manoa, of which Raleigh went in scarch, or for those Fountains of Perpetual Youth which Ponce de Lcon so long sought in vain. For it so happened that just as the fabled king of a Christian land in Inner Africa vanished into the limbo of "working hypotheses," the tales of Timbuctoo, garish with gold-dust and ivory and ostrichfeathers, took his place, and for many a year were the primum mobile of African exploration, which, until there was little more to learn about it, concentrated in or about the Niger river:

+ The history of these pigmy races is fully described by Dr. Flower in the .Jommal of the Authropologieal Institute, vol. xviii., p. 73 ; by M. Quatrefages in his work, "Jues Pygmées" (1887); and, among others, by Miss A. Werner in the Gentleman's Magazine, 1890, p. 556. 

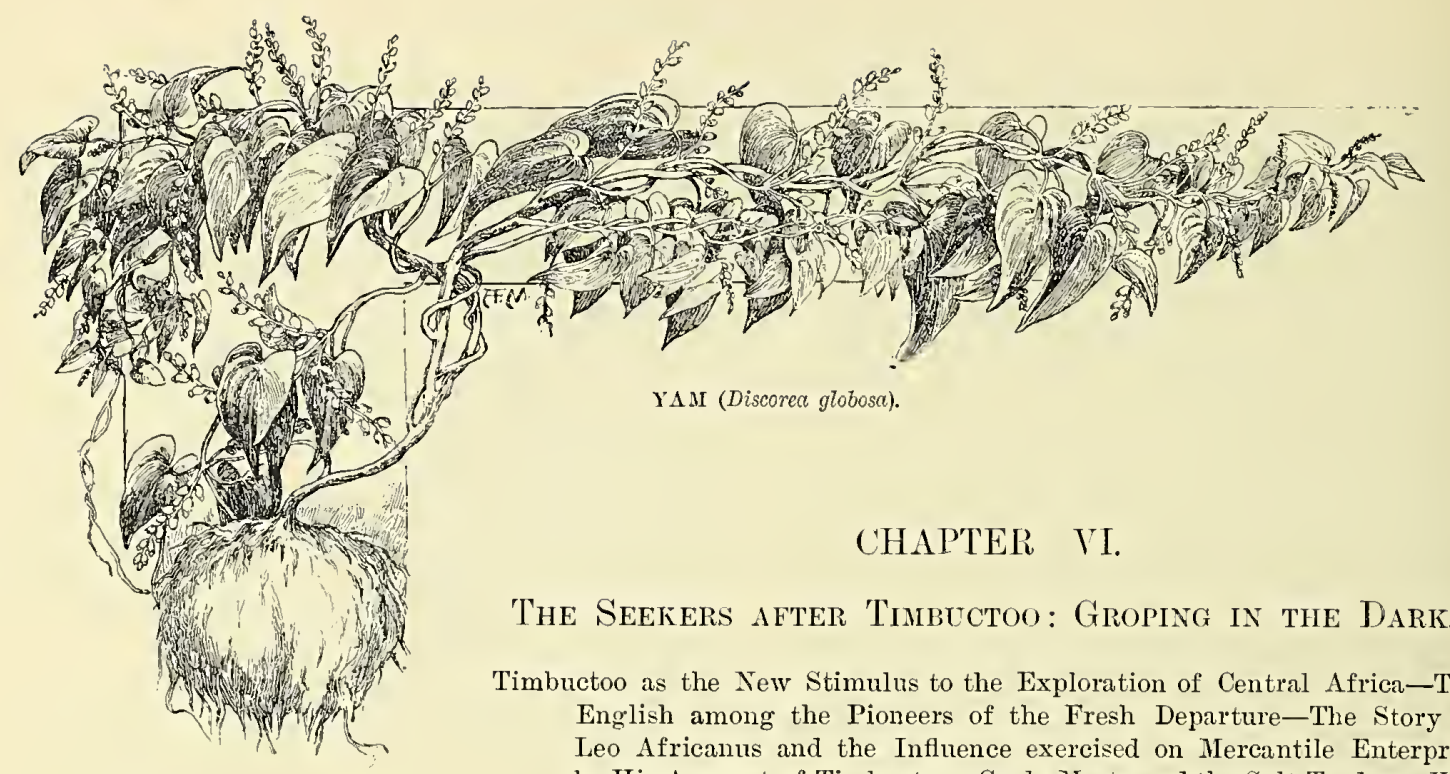

CHAPTER VI.

The Seekers after Thibectoo: Groping in the Dark.

Timbuctoo as the New Stimulus to the Exploration of Central Africa-The English among the Pioneers of the Fresh Departure-The Story of Leo Africanus and the Influence exercised on Mereantile Enterprise by His Account of Timbuetoo-Ca da Mosto and the Salt Traders-Was the Water reached by them Lake Chad?-A Similar Mode of doing Business in the Yoruba Country-What the English Merchants Detcrmined to do-A Tale which came from Morocco regarding the Conquest of Timbuctoo by Sultan Ahmed II. and of the Enormous Quantity of Gold brought back by the Conquerors-What befell George Thompson in the ship Catherine of London-The Voyage of Richard Jobson up the Gambia-A Wondrous Tale of Gold-The Adventures of Claude Jannequin, Sieur de Rochefort, and other Frenchmen-Bartholomew Stibbs and his Doings-The Romantic Story of Job, Son of Solomon-The Foundation of the African Association-The Dawning of the Day.

Aт no time did the Fnglish ever worry themselves over Prester John and his kingdom. They were prosaic folk, who searched after something more substantial than a sovereign who was at onec priest and king, a combination for which the mariners who were winning for us the mastery of the sca in the days of the first Stuart and his predecessor had no stomach whatever. For, apart from some painful experiences that werc still fresh in men's memories, the ehanees were that this Christian prinee, even were he diseovered, would be a Papist, and hence, as not a few sea-going folk had good reason to remember, hercties such as they would be apt to suffer in the inquisitions of countrics professing that partieular form of Christianity. It is true that, three years before Qucen Elizabeth of blissful memory was laid among her fathers, John Pory, "lately of Goneuille and Caius what was College in Cambrilge," had pubtold by John lished, in his quaint version of the Leo a More. "Geographical Historie of Africa, by John Leo a ILore," a long aecount of the "Empire of Prete Janni," eompiled from the writings of Malugueei and De Barros. But by this time Abyssinia had been fixed upon as the abode of the "Empcrour," and nobody seemed to faney that in this corner of Northern Afriea there were great riches, though in "Annara castel" he "layde not up so mueh golde, because thcy knew not how to purifie it, but rather jewcls and wcdges of gold."

If, however, the English merchants read this story, mueh disappointment had rendered them eallous to such tales. And, moreover, in an earlicr portion of the work in question John Leo the Hoor had to relate from his own knowledge how on the Upper Niger were the realms of many Moslem princes-Ghana, Wangara, Bornu, Cassina, Jenné, Melli, Guber, Zanfara, Walct, and, above all, the kingdom and eity whieh he ealled Tombuto, and is now known under the name of Timbuetoo (p. 121). Other travellers, we have seen, had heard of this from seeoni-hand deseription, and some, though they have left no reeords, might even have visited it. The Arab historians had told what had been told them, and Messer Ahrise da Ca Da Mosto, "Gentleman of 
Venice," related in 1504 how every year rocksalt was carried from a place called Tegazza to Timbuctoo and Melli, where it was sold for three hundred ducats the load, since the country was so hot that unkess the people ate this mineral their blood would putrefy. From Timbuctoo the salt was carried to another still more interior country where there was a river or lakc, but whether fresh or not he could not learn, though probably fresh,
This story evidently refers to Lake Tchad, and even now a like custom is followed in the intercourse between the negroes and Arabs in some districts; and I have heard almost the same talc told by Moorish traders to the Soudan of the manner in which business is done betwcen them and some of the remoter tribes, justly suspicious of the Moslems' good faith in the matter of life and liberty. It was the way strangers not in the best of repute had to deal with the tribesmen of the Saharan coast not long ago, and to this day a somewhat similar 1ncthod of buying and selling is, though from a different reason, the
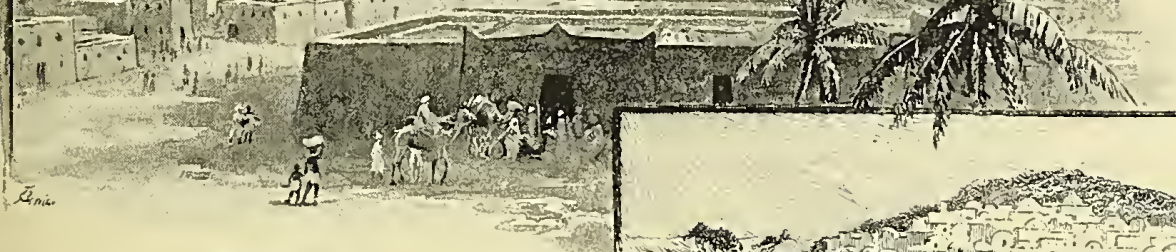

TIMBUCTEO.

otherwise there would have been no need of salt. Having rcached the water, the salt-carriers made piles of it in a row, each marking his own, and having made sand-piles, they all turned back. "Then comes another generation of negroes who do not wish themsclves to be seen or spoken to. They come with large barques that appear to issuc from certain islands, and land, and having seen the salt, place a quantity of gold opposite each pile, and then return, leaving the gold and the salt; and when they are gonc the salt negroes come, and if the quantity of gold pleases them, take the gold and leave the salt; and in this manner they make their trade without seeing each other, by a long and ancient custom;" and, adds Signor Ca da Mosto, "though it appear a hard thing to believe, I certify having had this information from many merchants, Arabs and Azanaghi, and likcwise from persons worthy of credit."

custom in the Yoruba country, behind Lagos in West Africa. In this still primitive region a passing traveller may stop at any ficld or farm, and cook sufficient food from the standing crops for one meal, but it is considcred a very heinous offence for him to carry any away. On the road-sides it is a conmon practice for maize-flour, starch, or bean bread, or cooked yams (p. 120), or akara (a ball of beans and pepper fried in palm-oil), to be carefully arranged on a mat for salc, while near at hand a broken calabash is placed for the receipt of cowries, the little shells that are the currency of the country. In passing by, Mr. Alvan Millson tells us his men would 
choose what they wanted and put a number of cowries into the calabash, after consulting among themselves as to the exact price whieh they had paid at the last town or marketshed. For forty cowries (less than a halfpenny) a man could fully satisfy his hungerand the hunger of a negro marching from fifteen to twenty miles a day, with a heavy load on his head, is not easily appeased. "Though I had among my carriers men who were probably not unacquainted with leisured retircment within the walls of Lagos gaol, it never occurred to them to under-pay or take that of which they did not know the price. The owner of the articles would probably be a mile or two away, working placidly at home, while the inats did business for her at the roadside. Even an automatic postagestamp machine would have no difficulty in realising a dividend in such a conmunity." * It is at the same tine to be remembered that dishonesty in other forms-so much are morals a matter of conventionality-is as prevalcnt in Toruba as elsewhere.

But to return to Timbuctoo. All the stories about it had hitherto been vague, tincturcel with obvious falsehood even to the credulous minds of the men of 1600, and in all cases strained through many mouths ere reaching Europe. Joln Leo had, however, actually secn the city which he described. A Spanish Hoor, born in Granada when that city was a Moslen capital, he had crossed into Africa with his family while a child, and after receiving the best education that Fez could supply, had been employed in various public offices which led him to travel over most of Northern Africa and Persia (though of this country he has not left any rccord), and to accompany his uncle on an embassy from the King of Fez to the Sultan of Timbuctoo. All throughout, his journeys he kept a careful record of what he saw and heard, which served him in good stead in after years. For on a voyage to or from Egypt he was captured by a Venetian corsair, who presented him as a

*Proceedings of the Roy. Geog. Soc., 1891, p. 583. slave to Pope Leo X. This enlightened pontiff, perceiving the manner of man the Moor was, converted him to Christianity (of a kind), gave him freedom, and encouraged him to remain in Rome by the bestowal of a liberal pension. Here he, occupied himsclf in many learned labours, onc of which was the expansion and transtation into Italian of his Arabic nanuscript. Published at a later date by the famous Ramusio, Secretary of the Venetian Council of Ten, the work of Leo Africanus, or Johannes Leo (for the Pope was his godfather), has been issucd in many languages. For long it was the chief-almost the sole-authority on Africa, and to this day may be profitably studied for the description it gives of regions still imperfectly known to Europeans, and for its graphic picture of Northern Africa and the Niger regions four centuries ago

Time has only confirmed the truth of Leo's descriptions, and among his most attractive sketches is that of Timbuctoo, which he says abounded in all the necessaries of hife except —as Ca da Mosto tells us-salt, which was dear owing to its being brought from Tegazza, 500 miles distant. Horses were not bred, but, as is still the case, were brought from Morocco, from which eountry also-as is the custom to this day-many manuscripts were imported. All other goods were saleable at a fine price; and as were the people, so was the king, rich and liberal to such. a degree that he had inarried his daughters to two of the merchants of the town. The circulating medium, in addition to little shells (cowries), was unstamped pieces of gold, and, among other cmblems of wealth, the precious inetal was so plentiful that the king had many plates and sceptres of it, "some whereof weighed 1,300 pounds." $\dagger$ When to this fact was added the information that the inhabitants were mild and gentle, and-as the fashion of Africa is-

$\uparrow$ This statement has been doubted. However, without vouching for Leo's exactitude, his words are plain enough - "Il re possiede gran ricchezza in piastre e verghe d'oro, delle quali alcuna e di peso di mille trecento libbre "-each Italian pound being twelve ounces. 
spent a large portion of the night in singing and dancing, it may be certain that not a few gentlemen of England who read Master Pory's version, as it issued in 1600 from George Bishop's press in London, determined to try their fortunes in so promising a market. And, as we shall see presently, not a few cavaliers in France had come to a like conclusion when the same information had been put at their disposal by the version which Jean Temporal had issued at Lyons in 1556, and dedicated, in a curious preface, in which he talks of " our republic," to the first husband of Mary, Queen of Scots. The entire account does not occupy many lines, or the description of the Niger sorereignties many pages. Yet it is perhaps not too much to say that in the whole annals of literature there is not another passage which has conduced more materially to the progress of geography. For while the vague stories of wealthy realins in the interior which had for a century or more before been floating around among the African trader's and slavers and pirates contributed little compared with the dream of Prester .John and his realm to stimulate journeys into the interior of Africa, the two centuries or nore of Niger exploration which followed nay be directly credited to the brief narrative of this old Moorish traveller. Nor, indeed, has its effect eren yet entirely ranished.

It was in those days of stay-at-home geographers, when one party was all for Ptolemy and the Ancients, and another all for Leo and the Moderns, that certain merchants of London town, into whose minds the words of the latter had sunk, determined, insteal of wrangling orer the matter in the Thames-side taverns, to find out the facts of the case for themselves. Not that Africa, and especially the Guinea coast of it, was strange to the English trader, even at that early date. For as we have seen (p. 46), certain merchants of Exeter had for twenty years been trading with the Gambia and the Senegal, with such effect that they had driven all but a solitary Portuguese out of the latter river, though in the former the Portuguese were so numerous

and so jealous of the new arrivals that they formed a conspiracy to seize their ships and massacre the crews. It is satisfactory to know that, even at a time when ascetic virtue was not a feature in the Guinea trader, the Englishmen had so far ingratiated themselves with the natives that they were told one bar of iron from them would be more welconie than forty from the "Portugals." In those days there were English merchants in Morocco, then far more liberal in sentiment than it became at a later period when piracy and the wrongs of their countrymen from Spain had aroused all the fanaticism of the Moors.

And from one of them we learn that other people besides the English and French had got ambitious of reaching Tinbuctoo. For this gentleman writes to a correspondent in Jondon in 1594 that there had just arrived from Gago a caravan of Moors witl thirty inules laden with gold,

The Sultan of Morocco's Captain takes Timbuctoo and brings back great store of gold. though the merchant adds that of serenteen hundred men who left for Timbuctoo onethird perished in the desert from lack of water. Arrived there, the negroes tried to defend themselves with the assegais and poisoned arrows of which Leo speaks; but their courage was of little avail against the firelocks of the Moors, who took the town, and from thence proceeded to Gago, where the inhabitants were slain so fast that they were fain to yield, and "to pay tribute by the yere." That for Timbuctoo was "sixty quintals * by the yere, the goodness whereof you know. The report is that Mahomet; brought with him such an infinite treasure as I never heard of. It doth appear that they have more gold than any other part of the world beside. The King of Morocco is like to the greatest prince in the world for money if he keep this country" - which, it may be added, he did not do for long, except in name.

This is the first account we have of the overthrow of the Songhai dynasty by Jouder ou Zergon, "a Cahia of the Andalouzes," or"

* Taking the quintal at 112 lbs, avoirdupois-about 6,720 lbs. 
Spanish Moors, who had marched against the Soudan princes under the orders of Ahmed II., El-Manssur, who, on account of the wealth he won by the plunder of their cities, obtained in his later years the name of El-Dehebi, or "the Golden," a title bestowed more than 130 years later on another Sultan of Morocco. The account is, no doubt, substantially correct; for in those days Timbuctoo and Jenné were the centres to which much of the alluvial gold of West Africa converged.

It was with the echo of these stories re. sounding among the warehouses of Wapping and the counting-houses of LomWhat befell bard Street that certain merchants Master George

Thompson in the good ship "Catherine" of London, forming themselves into a "Company of Adventurers," despatched George Thompson, a Barbary merchant, on an errand which, hapless though it was, will for ever remain memorable as the first of the many to which it gave birth. It was a notable journey for geography. Yet commercially the Catherine, a vessel of one hundred and twenty tons, with a cargo valued at less than $£ 1,860$, was a humble enough beginning for an enterprise which two and a half centuries later culminated in the Royal Niger Company. The Gambia was the river selected for exploration, Thompson's employers evidently inclining to the thcory that this was the seaward end of the river known so long under the name of Nigcr. For this stream, thcrefore, he set sail ir. 1618 , with instructions that as soon as the watcr became too shallow he was to leave the ship and continue his inland voyage in boats. Accordingly, leaving his vessel (p. 125) at a place called Kasson, he rowed up stream for a long distance, finding the natives very friendly, much inclined for trade. and anxious for a factory being established in their country. Meanwhile news of a sad misfortunc reached him. For, during his absence, the Catherine had been seized, and the crew murdered, by some Portuguese and mulattoes whom they had admitted on board.

It may be remembcred that the former had becn for more than a century settled in this part of Africa, and had begun to regard themselves as the rightful owners of the country, though the English and other traders had never recognised any such claim. In no way discouraged by the loss of his vessel, Thompson despatched some of his people to England to inform the Company of his bad luck, and, at the same time, to ask for further remittances. The London merchants were valiant men, for immediately the St. Joln, a craft of fifty tons, set sail, though unfortunately arriving short-handed, owing to several men having been washed overboard, and at the worst season for trade. Thompson sent her back "with letters of further hope," in the meantime ascending the river with the eight men he had with him and what goods had been brought by the last arrival.

This was the last seen of the first explorer of the Gambia. For on a third vessel, larger and better-found than any of its predecessors, reaching the river next year, the first news which the commander received was that Thompson had been inurdered early in the spring. Rowing up the river with two white men and several negroes, he reached as high as Tenda, ${ }^{*}$ some seventy or eighty miles above, where he wished to confer with a salt-trader, widely known in those times by the name of Buckar Sano. At Tenda, which was far beyond any point reached hitherto, he found the merchant from home, having gone with a train of 300 salt-laden donkeys into the interior, though he learned that caravans from Barbary frequented the district. Whether this circumstance unduly elatcd Thompson, who, being a Barbary merchant, was therefore likely to do good business with these people, or the climate had affected his brain, we know not. The reports that reached his countrymen were that he had treated, not only the natives, but his own party, with such intolerable hauteur that quarrels broke out with the latter, and in one of them he was slain. The true facts were, however, never known, for the survivors kept their own counsel, and Thompson, like so many other

\footnotetext{
* Koba Tenda of Park.
} 
traders, had committed nothing to writing, so that in case of his effects being seized by rivals they should not benefit by his discoreries. All his talk before his death was, same manner that they had treated their predecessors.

The captain of the last ressel sent to succour George Thompson was Richard

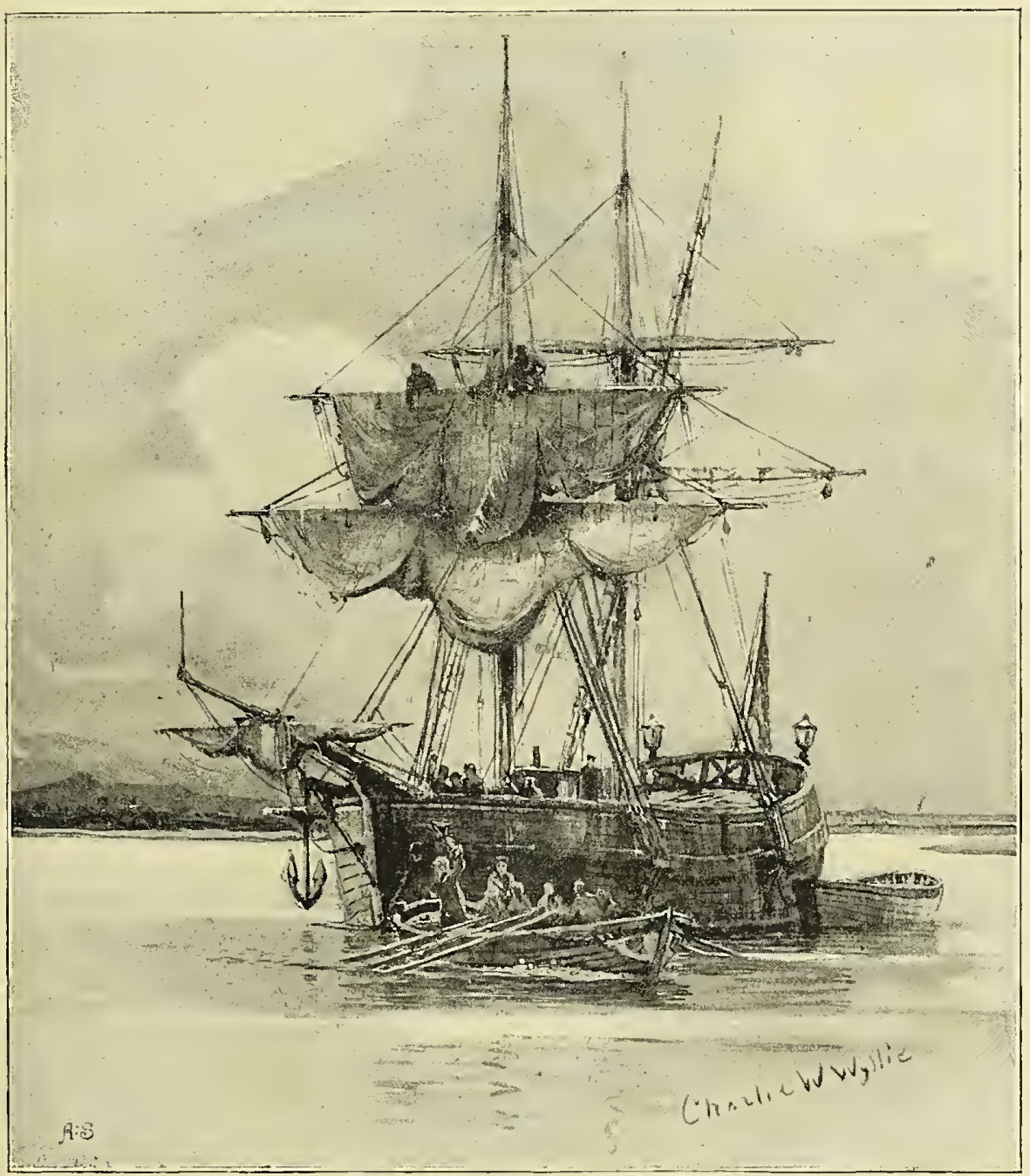

TILOMPSUN LEAVING HIS VESSEL (p. 124).

indeed, how best to fortify the river, build castles and factories, and bar the upper part of the stream against anyone who might wish to follow in his track. And that these precautions were not uncalled for is proved by the fact that the Portuguese mongrels on the river had been bribing some of the natives to waylay and murder these pioneers after the
Jobson. We have no further particulars regarding this famous name in the annals of West African discovery, voyage of except that he was a native of Lon- Captain Richard don, but whether he had been Jobson. already in the Guinea trade is not readily to be ascertained from the narratives to which his name is attached. His first voyage was a 
failure; for though he went up the river as far as Tenda, and seized a boat containing the effects of Hector Nuncz, who was considered the ringleader in the destruction of the Catherine, his efforts were thwarted by the jealousy of certain persons on board who were in the interest of a faction among his employers at home. 'These latter, permeated with the Guild jealousy of the time, were, it seems, annoyed that any adventurers save ordinary traders should have been admitted into the Company, and so, to discourage the newcomers, they managed to man the vessel with their own creatures, and to conjoin with them as supereargo "one Low," who by his spite and meddlesomeness rendered the voyage a loss instead of the success it might have been.

However, the story which Jobson has to tell is one of the most interesting in those early tales of adventure, and, as the first earnest attempt to reach the gold countries of the Upper Niger and the famous city of 'Timbuctoo, is worthy of being re-told. Leaving' Gravesend in 1620 with two vessels, one of 200 and the other of 50 tons, he sailed up the Gambia, arriving at the place called Kasson, governed by a Portuguese, and inhabited by a large warlike population. But as soon as the vessel heaved in sight the Portuguese fled, after offering high bribes to the negroes to entrap and destroy this expedition in the same way that they had fallen upon that in the Cutherine. Procceding still farther up the river, the English adventurers arrived at Jerakonda, where two of Thompson's men were met with. At Oranto the factory which his predecessor had built was reached. And here the cxpedition was visited by Summa 'Tumba, a blind chief subject to the King of Kantara. This magnate was profuse in his compliments, and, the object of his flattery being produced, proceeded without further loss of time to "drown his wits in the aqua vitce we brought him." Brandy, indeed, even at that early date, as, unfortunately, to a very recent period, was one of the prime articles of trade along the Guinea Coast, and even as far into the interior as the trader-explorers had reached. It was the first thing that the people who crowded round Jobson's party asked for in exchange for produce, and those who had nothing to sell begged for it as a gift: But the people from the interior always asked for salt. It was their currency, their standard of luxury, a rich man being one who "ate salt with his food," and hence without this commodity the "golden joys" which filled Captain Jobson's imagination were not capable of realisation. For among the cargo there was not enough, which shows how blindly the carly traders were groping in the dark the moment they left the coast. But even this circumstance did not deter those stout-hearted pioneers of African exploration. . Pilots, it is not necessary to add, were in those days as little known as charts, and soon after leaving Oranto the dangers of the rapidly shoaling river were increased by the difficulty of obtaining provisions, and of doing business in a barren country where villages were few and wild animals proportionately numerous. The flat regions had now long been left behind, and a mountainous country is mentioned as among the features seen from the deck. Hippopotami were so common that the places where they canne ashore to feed were "beaten with tracks as large as a London highway." At Barrakonda, the first plateau which indicates the old sea-coast (p. 16) was marked by cataracts that prevented a free passage into the interior. However, by winding through narrow side-ways they passed round the rocks, and though the tide was no longer with them, and they had to stem the increasing current of the river, they managed to make some headway with their cratt. Owing to the rocks, nevertheless, they could not sail during the night, while the terrible heat of the sum prevented them from dragging the boat except for a few hours in the cool of the morning and the crening. Shoals and sand-banks now became more and more frequent, and as it was often necessary to enter the water to ease off the craft from places on which it grounded, the men were in momentary fear of being seized 


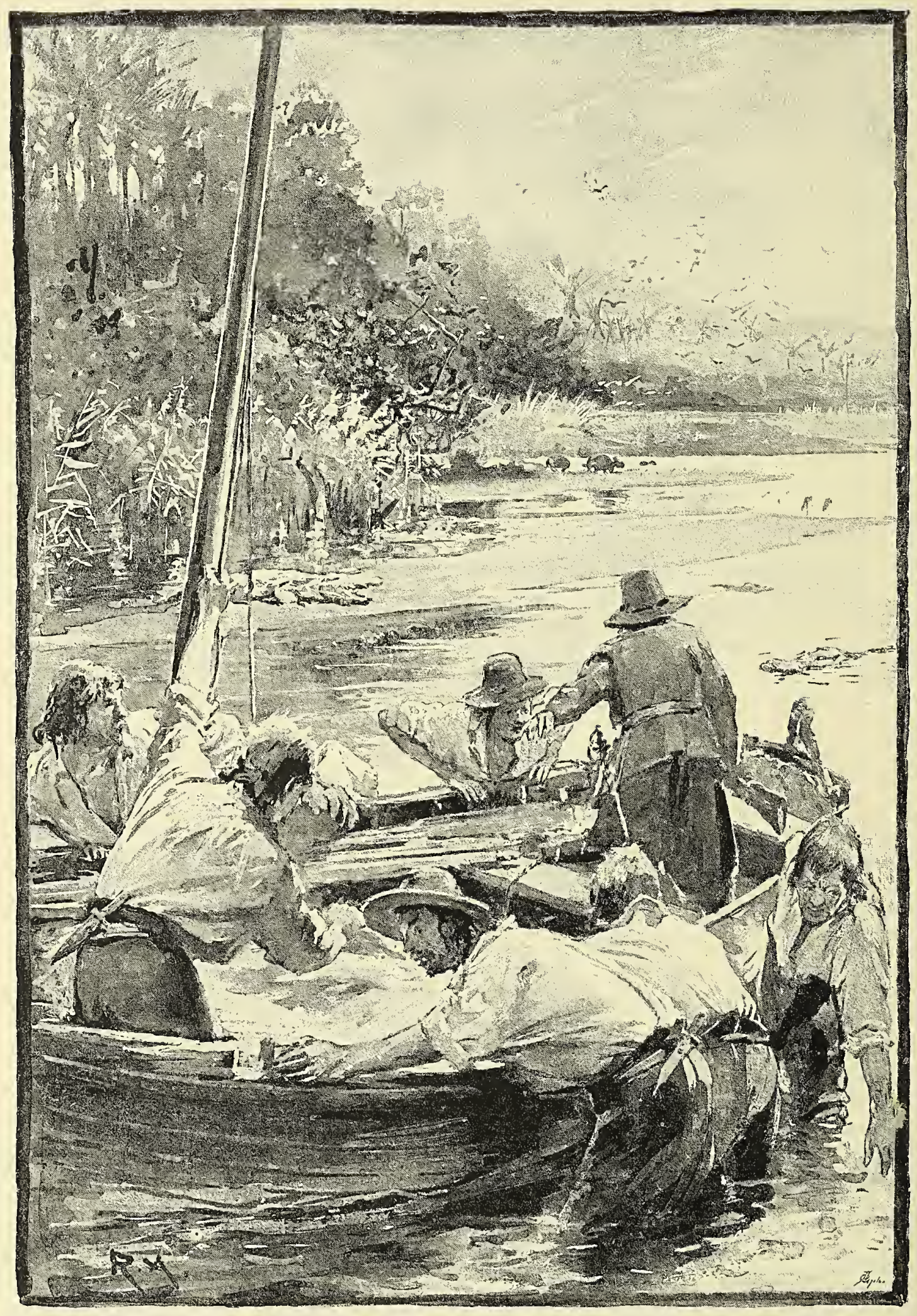


by the swarms of crocodiles that lurked under the banks or swam about in the open stream.

Myriads of mosquitoes added to their torments, and evcry night they were kept awake with roaring of lions and other wild animals in a land where, even at that period, "beast was more and nore and man was less and less." Everything was new to them, as it was new to the rest of the world-the dense jungle, the insects that hummed through it, the gaudy-hued parrots, which the noise of the firelocks sent in swarming flocks out of the glossy-hued foliage. Monkeys, then little known in Europe, swung themselves from the branches to stare at the unwonted sight of white nen rowing wearily against the stream, while huge flocks of baboons arc described by them as trooping through the underbrush, filling the air with strange cries, except when "one great voice would exalt itself and the rest were hushed." Even at night, as they lay awake in fear of the wild beasts that had come out of their lairs, the myriads of fire-flies sparkling among the trees were to them as strange as the iridescent bectles and the gaudy-winged buttertlies that met their eyes during the day, wcaried with the monotony of date-pahn, silk-, cotton-, indiarubber- and baobab-trees. One day, walking along the bank, Jobson came upon "sixteen great elephants hard by him." He discharged his piece at them, but, fortunately for him, did not wound any, otherwise, instcar of the frightencd animals rushing off in terror, the bold mariner might not have lived to tell his tale.

Crocodiles, in knots of twenty or thirty, would glare at the voyagers with grcedy eyes, greatly to the terror of the negroes in the party. Towards break of day these reptilessome of which "were thirty feet" long-"would call one to another, much resenbling the sound of a deep well, and might be easily heard a league." Against these brutes the firelocks of the inexperienced sailors would, in any case, have been of little avail. But the rnuskets of those daring venturers into the wilds of Africa were in such bad condition that they were useless for obtaining even a sufficient supply of food, though deer and birds were plentiful in the woods, missing fire just as frequently as not. What made matters worse, the natives from whom they had hitherto been able to buy, or to obtain as gifts, supplies of elephanis' flesh, yams, no doubt, and other country produce, were nowhere to be seen. In vain did the explorers ascend a high mountain in hope of seeing some village. But "descrts replenished with wild beasts" were the burden of the reports brought back to the indefatigable commander of this chase after wealth.

At last, nearly eight weeks after boginning the river voyage, first by ship, then by pinnace, and finally by shallop, the hill of Tenda appearcd in sight, and a request was despatched to the Mandingo ling and to Buckar Sano, the black merchant, that they would come with a supply of provisions. The merchant soon appearerl, not only with the provisions, but with one of his wives and daughters and a troop of forty attendants. Brandy being one of the articles which had not been given out, the native trader was regaled with it in such immodcration that he lay for the whole night "dead drunk" on board the boat. Warned, however, by this result of his inexperienced toping, he never permitted hinself to transgress again, mainly because it enabled the white man to make the best of a bargain. Beef, mutton, and poultry were now cheap and abundant, and a brisk traffic began. Salt, however, was the only European coinmodity at all in demand, while slaves were "the trade" upon which the natives sct the highest price. But just then Captain Jobson was more concerned about gold than serfs, though he affected indifference on the subject that was uppermost in his mind. A small quantity was produced, and then when the natives sawwhat they wcre doubtless on the watch for-that the white man valued it, they launched into inflated rescriptions of the abundance in which it existed and of the 


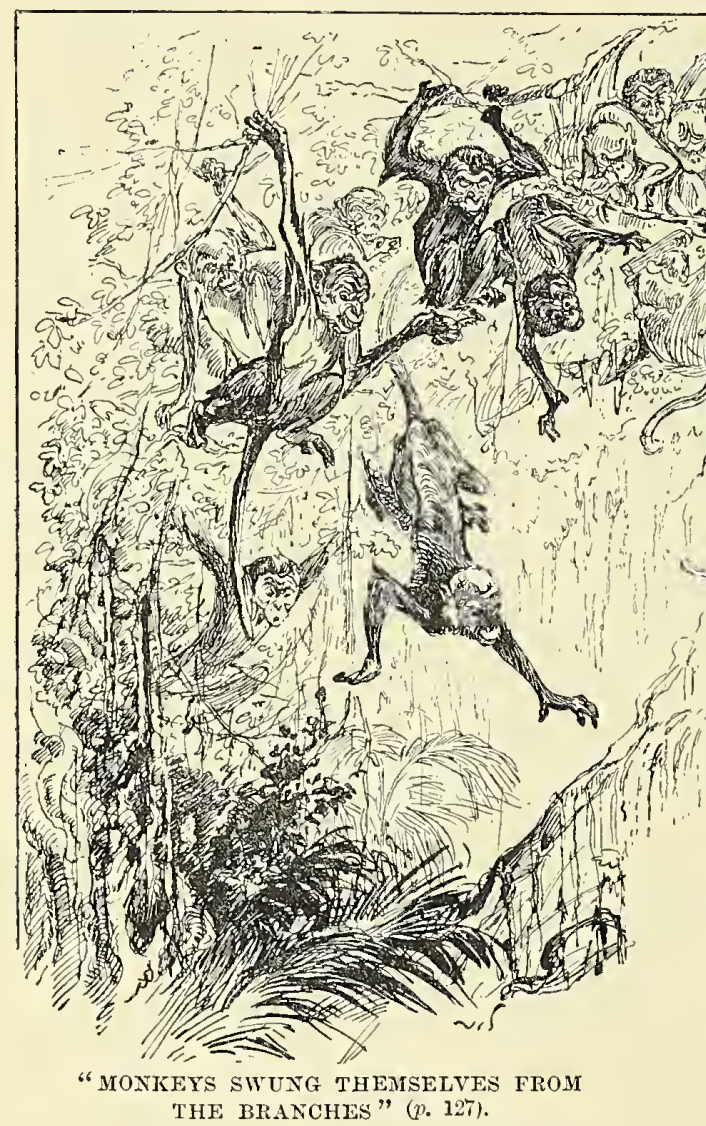

splendour of the countries from which it was brought.

Buckar Sano was even ready to affirm that he had been in a city the roof's of A city with which were covered with gold, but golden roofs
and other wonders. distance of four moons. A four months' journey to men who had already had a two months' struggle with hunger, toil, the current, mosquitoes, and the heat, was not readily to be executed, though on second thoughts, considering the slow rate at which Africans travel, Jobson began to think that not improbably this El Dorado might be much nearer than the cunning middleinan would fain make him believe. Meanwhile, the news of whites having arrived spread far and near, until in a few days the village was filled with vast crowds of people impelled thither either by curiosity or by the desire of bartering with the strangers. Many of them had never

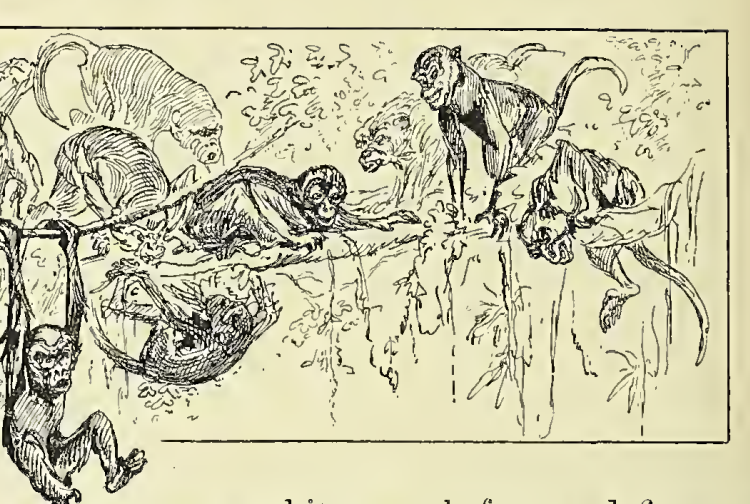

seen a white man before, and firearms being equally novel to them, the news flew abroad that the strangers could kill game, and possibly human beings also, with thunder. In a few days a little town of booths, built of branches, grew up around Jobson's camp, until the place, which before his arrival had been a lonely waste, was noisy with the din and the chatter, the drumming and dancing, of a negro town. Among the latest arrivals were some five hundred people from the opposite bank of the river. These barbarians appear to have come from a long distance, and had not hitherto had any relations with civilisation. Men and women alike were clothed only with the skins of wild animals girt about them, "the tails hanging as from the beasts." None of them were very bold in the presence of the English sailors, and the women, until they gained confidence enough to deal with them, ran and hid themselves in the bushes on the approach of any of the whites. But by-andby that eagerness for traffic which is the most hopeful of all the negro characteristics that tend towards the ultimate civilisation of Africa, impelled them to.ask for salt

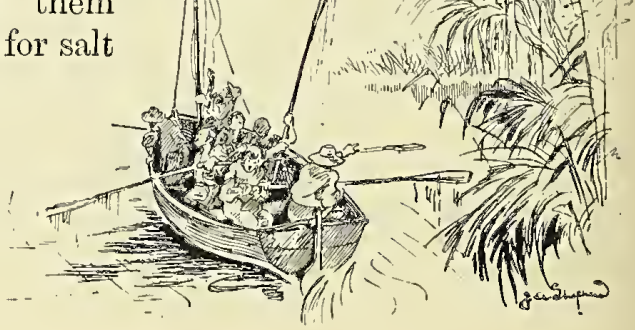




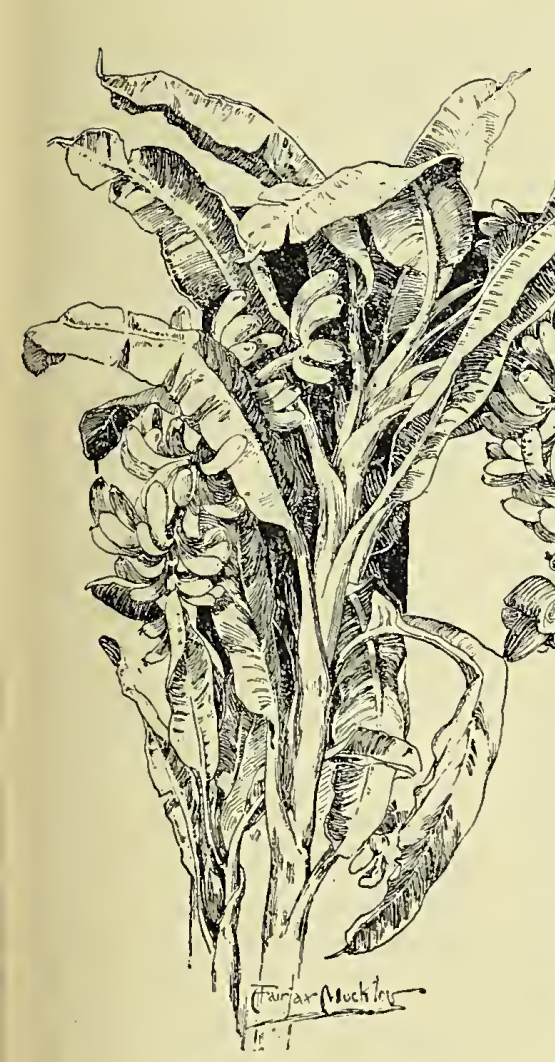

BANANAS (Musa sapientum).

much more important contingent under the King of Jallakotta, now a walled town of 250 huts, but then evidently a much more intportant place, tributary to the "great King of Wali," a Moslem potentate whose capitalMedina, or "the City"-lay some distance to the south. This chief was surrounded by "his juddies, or fiddlers," musicians, or minstrels, who follow great folk for the purpose of celebrating their achievements, or amusing them by singing songs, to the accompaninent of instruments, in praise of themselves or their ancestors. Falling in with the humour of the ceremonious folk around him, Jobson now proceeded to invest Buckar Sano with the style and dignity of "white man's alcahade* and merchant," putting a string of crystal beads round

* Al Kaïd, or officer, a title picked up from the Hoors. his neck and a silver chain across his breast, while a cup of brandy was the material proof of the office being not without its advantages in the way of solace, and a salvo of five muskets the final confirmation of the new dignity. Among the varied arrivals were some people from Tombakunda, which Jobson supposed was 'limbuktu, though in reality it is a place not far from the Gambia. A marabout, or holy man, who had known Thompson also arrived, offering to conduct the Englishmen to Monbar and Jaye, of which he was a native, if only they could get past that part of the river, the system of middlemen-one district exacting from those above it the right of doing business with those lower down-being then, as now, one of the principal obstacles in the way of the trader and explorer. For it is the fear of the white luan reaching the interior countries, and thus trafficking directly with the people in that quarter, that has again and again prevented the jealous races nearer the coast fron pernitting them a free passage to the eastward.

Buckar Sano did not, however, intermit his attentions or his cordiality. Indeed, his cordiality was increased since he had been appointed "English merchant" with a percentage on every transaction, and now, after he had for the present picked the mariners pretty clean, he invited them to the king's residence to witness a peculiar ceremony. They found his sable majesty seated before a fire of 
reeds with his grandees about him. Buekar Sano joined the eircle, but in a strange guise. For he stripped himself naked and lay down at full length on the ground before his sovereign, whereupon "divers Marybouts"-or, as we would say, marabouts-collected earth and covered him entirely over. Sano, while in this position, took up a quantity of earth and threw it into Jobscn's lap, after which he arose and, stepping a little aside, dressed himself in his best elothes. Then he and his attendants, after making a pretenee of shooting with a bow and arrow, came and laid their weapons before the Englishmen, explaining after all was over that the purport of these formalities was to signify that the King had made over to Jobson, Tenda and the entire eountry round about, at the priee of a gallon of the best brandy, which the mariner paid, not without some doubt in his own mind whether his new dominion would ever return to him in hard eoin as much as the strong water had eost in London town; though, in sooth, the sites of a good many eities of the New World have been purchased from the Indians for an even smaller equivalent in ardent spirits. But land was not what Captain Jobson hungered after. He longed for gold, and for Gogo and Timbuctoo, of whieh he had read in Master Pory's translation of Leo the Afriean, and in the letter sent to Anthony Dassel, of London, by Laurenee Madoe, the English merehant in IIoroeeo. He had every day on his voyage up the Gambia-whieh, like so many others, he took to be the Nigerexpected to see the glittering minarets, and perhaps the golden roofs, of Timbuctoo, though, had he paid proper attention to Leo's words, he would have known that the houses in that eity were, as many of them are still, simply thatehed with reeds.

But the season was now getting late. He was out of goods fit for trade, and had all along been short of salt, which was what the natives were nost in need of. Moreover, the river was getting no longer easily navigable. Roeks, and shoals, and sand-banks were beeoming disagreeably frequent, as many a navigator sinee his day has learnt to his eost. For beyond the part to whieh he reached, namely, what is now linown as the mouth of the Nerico River, vessels drawing more than three feet of water eamnot proeeed, "shallows, sands, and rapid currents oeeurring in every reaeh, and navigation being extrenely diffieult."* Beyond Yarbutenda the infinence of the tide ceases, and even at that part it is seareely noticeable. Accordingly deelining, very reluctantly, the marabou ts' offer to eonduet him to the golden cities of the further interior, Jobson took advantage of the eurrent to return to Barrakonda, whieh he reached in six days, or about half the time it had taken him to ascend, though part of the way was by land, ehasing and wounding an elephant as they passed through the woods, and witnessing, as they loitered in the villages by the banks, many curious eustoms now quite familiar to the world, but at that time not so nuch as heard of by Europeans.

Fires were lighted under every large tree, and in those days as in ours, the noise of "shouts and drums, and country inusic, the roaring, shouting, and daneing, " dinned the travellers' ears all night long. Mumbo Jumbo appeared to terrify evil-doers, mueh to the indignation of honest Jobson, who intimated his intention to diseharge his musket at the first " horey," or devil, who might try his pranks in his presence, a threat that had so salutary effect that the pseudo-demon fell down in terror, speeehless even to beg for merey, though on being stripped he turned out to be a stout negro (p. 132). "The devil" was not ungrateful for the Briton's elemeney. For on ariving at a place called Pompetane, to whieh he had sent no message, Jobson found a dinner provided for him, the hostess having obtained her information that the travellers were on the road from the "horey," who, no doubt, had r'm swiftly ahead by paths unknown to strangers. But Jobson, who, in spite of his bluff courage, was not above the superstitions

\footnotetext{
* "Correspondence relating to the Recent Expedition to the Upper Gambia, under Administrator V. Gouldsbury, II.D." (Parliamentary Blue Book), with maps, 1881.
} 
of his class, was rather staggered by what he regarded as a display of supernatural power on the part of an impostor whom he had so recently been ridiculing.

At Setico he met many Mohammedan merchants. This, at that time, was the highest point to which the Portuguese had carried their trade in slaves, salt, and gold. Here he witnessed the funeral of a leading marabout-much gold was buried with him, for use in Paradise-and had a proof about the same time of the rigidity with which the black Mohammedans obeyed the tenets of their faith. One of them was nearly drowned in a whirlpool, and taken out in a state apparently of total insensibility. Yet on brandy being applied as a restorative he closed his lips firmly against its entrance, and on recovering the first words which he eagerly asked, were whether he had swallowed any portion of the detestable hiquor forbidden by the Prophet, declaring that he would rather have died than that the smallest drop of it should have passed his throat. This circumstance satisfied the voyagers, who had so recently witnessed drunken orgies on the upper river among the heathen, that even the creed of "false Mahound " was not without its elevating influence on the people who had adopted it.

Recovering the pinnace which they had left here, the party then sailed down the river. But before doing so, they were in inminent peril from hippopotami, swarms of which still abounded to such an extent, that one stove in the boat so badly that it was with difficulty the leak could be stopped in time for the crew to reach the bank.

At Kassan, where the ship had been left, they found a sad tale of misfortunes awaiting them. The master and the greater part of the crew had died of the country fever, and of the remainder not more than four remained in a condition fit for work. Knowing, therefore, apart from the fact that he was imperfectly supplied with articles of barter, that it would be impossible for him to remain any longer in the Gambia with profit to his einployers, Jobson utilised what strength still remained to hoist the anchor and sail with all speed for England.

In London he seems not to have met with the warmest reception. He had to tell of cheap slaves and abundant ivory, gold in the interior, which he did not reach, elephants as "fearefull as forest stagges" and much more numnerous, strange grains, bananas, lemons and oranges, pahm-trees and pahm-wine, Kola nuts,* which, though bitter in themselves, made water "taste like white wine or sugar," and so valuable that fifty would buy a slave. Then Captain Jobson piled up his periods on the subject of hons and ounces, of civet cats and baboons, which travelled, he said, in herds of three and four thousand under the leadership of the largest, like an army on the march, with vanguard and rearguard, the chattering of inany voices hushed when "one great voice exalts itself," and which formed an arbour in the woods "for their dancing and disport," so cunningly fashioned that it looked as if made by the hands of man. But neither these, nor wild bulls nor wild boars, and antelopes, not to speak of " beasts unknown" and trees not one of which he could call "by an English name," charmed the merchants on Sir Thomas Gresham's bourse, who had every day in that dawning of a new age the opportunity of listening to mariners who had come from the Indies and Africa and from America with tales quite as strange.

The smiths, who were held next in esteem to the makers of gewgaws and charms and horse-gear, looked more promising. They might be utilised in connection with commerce. And then for the first time London heard a

* Also called Guru nuts, the seeds of Sterculia acuminata. They contain an alkaloid akin to that in tea and coffee, and are still so highly valued in the Soudan that no gift is more acceptable. In times of scarcity one will buy a slave. The natives profess to be able to withstand hunger, thirst, sleep, and exliaustion by chewing them, though their power of clarifying water is not more than that of any other mucilaginous seeds. They are now imported, and made into various preparations, the value of which is doubtful. 
good deal about the Mandingoes and Fulahs or Pulhs-"a tawny people mueh like to those vagrants among us ealled Egyptians "who pastured their eattle on the mountain eirele of fires within whieh the stock were eollceted. The Mandingoes, who were negroes, which the Fulahs (p. 12) were not, worked scarcely any except during the two months

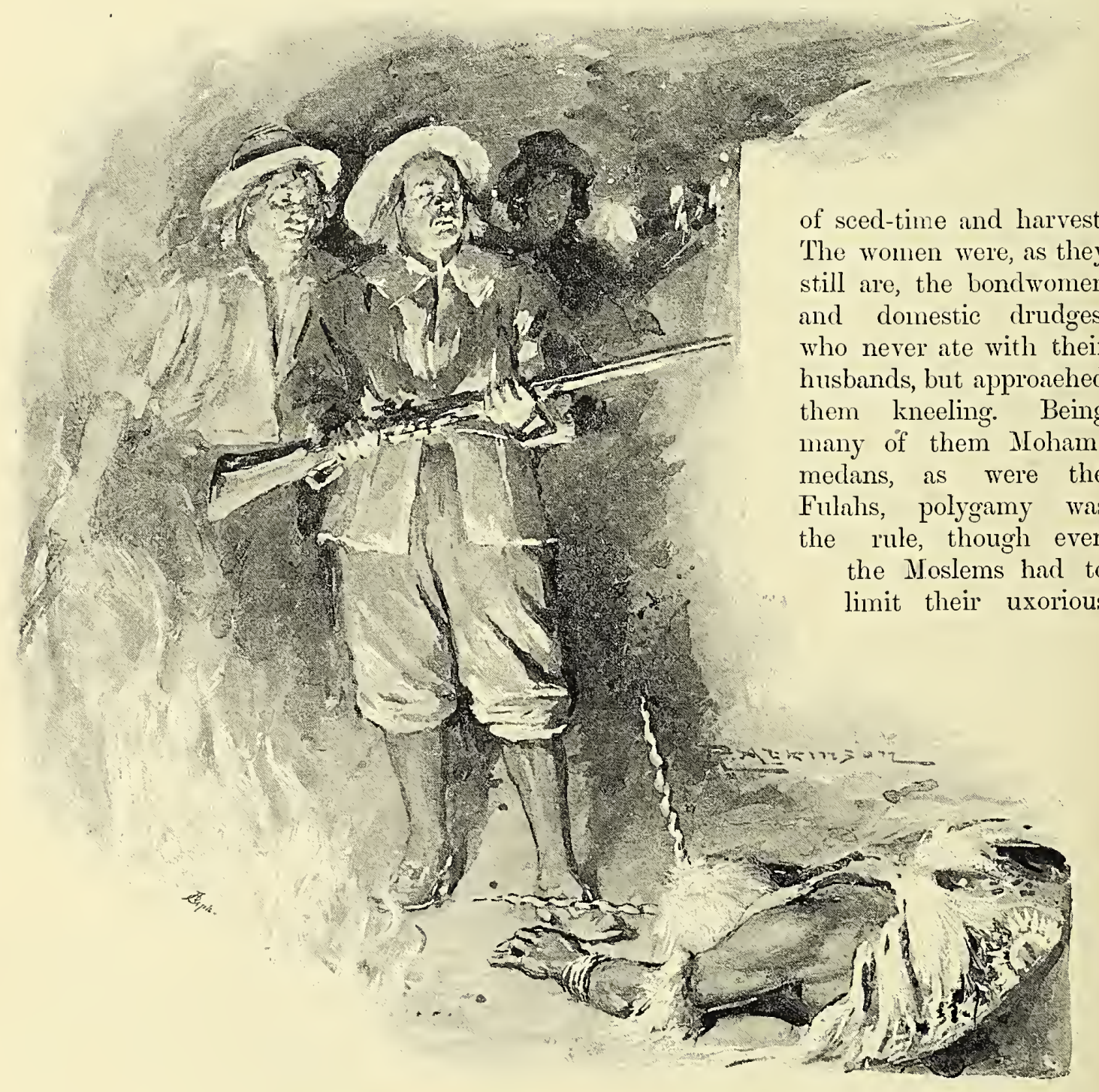

CAPTAIX JOBSON AND THE PSEUDO-DEMON (p. 130).

tops during the rainy season, and in the river valleys whon the weather was dry, fighting a hard fight against the wild beasts which, at a period beforc the natives had obtained firearms, were bold to the point of howling all night on the outside of the propensities to four wives, while the pagans' establishment was restricted solely by the power to purchase brides from their parents, and to pay the king the commission he demanded as part of his Civil list on every transaction of this kind. Marriage by force, 
which is one of the most ancient of ceremonies, and prevails to this day in an almost meaningless form even among civilised people, was then the rule. The bride was attacked by one party and stoutly defended by another, though this was a mere formality, since the former never failed to prevail in the end and carry off the wife to her husband.

All this, however, did not interest the keen jealous of people from the Court end of London prying into their mysteries, did all they could to discourage any outsiders or interlopers from trying their fortune in any similar speculation. This pioneer effort to

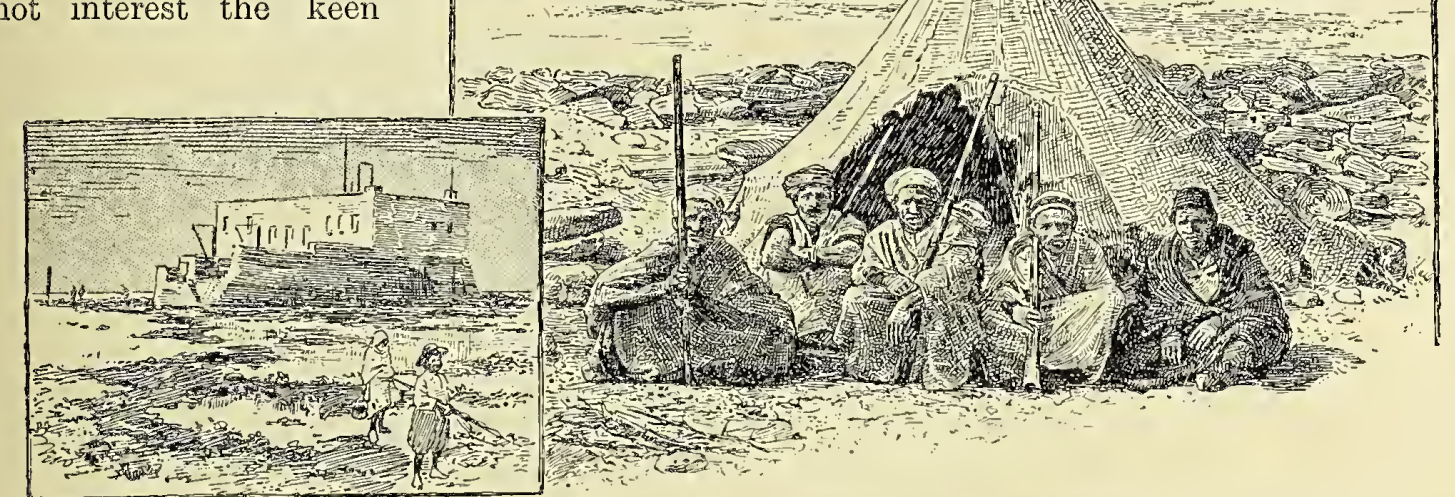

BRITISH TRADING̈ POST AT

CAPE JUBY : THE CASTLE.
TRADERS AT CAPE JUBY.

CASTLE AND FACTORY IN THE DISTANCE.
London merchants. They were more concerned when he told of the salt which was brought from the coast, carried into the interior on donkeys, and exchanged for gold, slaves, and Kola nuts, in much the same way that had been described more than a hundred years before. But, unfortunately, Richard Jobson brought back little gold or ivory, and no slaves; and Kola nuts, which nowadays are articles of commerce, were in the reign of King James I. nothing more than natural curiosities. They were not saleable, and the merchants not having despatched him simply to bring back the materials for a pleasant tale of travel, seem to have lost heart. Accordingly, though they numbered among them names as famous in the annals of early enterprise as Sir Thomas Button and Sir William St. John, the moneyed men despaired. The "Gentlemen Adventurers" were willing to go on; but the ordinary traders, open up Africa, therefore, cued of discouragement, and Captain Jobson's name appears no more in the annals of African discovery.*

At no period did Prester John occupy a great deal of the Frenchman's mind. 'The subjects of his Most Christian Ma- Thetale told jesty were never quite so eager to by claude propagate the Faith as those of his Jannequin, Very Faithful brother of Portug Rochfort, Very Faithful brother of Portugal, and other and, it may be added, by no means Frenchmen. so ruthless as those of His Catholic Majesty of Spain when they did send missionaries into

* "The Golden Trade; or, the Discovery of the River Gambra, and the Golden Trade of the Ethiopeans. Also the Commerce with a Great Black Merchant called Buckar Sano, and his Report of the Houses Covered with Gold, and other Strange Observations, for the Good of our own Country. Set down as they were Collected in travelling part of the years 1620 and 1621 , by Richard Jobson, Gent." (1623): "A True Relation of Mr. Richard Jobson's Voyage, employed by Sir William St. John, Knight, and others, for the Discovery of the Gambra," "Purchas his Pilgrimes," vol. ii., p. 1567. 
foreign parts. The light-hearted Celtie raee were always more inclined to fraternise with the natives of any land to whieh they came than to eonvert or exterminate, or even to kidnap them. It is, therefore, not very probable that Claude Jannequin, Sieur de Rochfort, fired one day in the year 1637 with a longing to explore Africa, by the sight of a vessel in Dieppe Harbour bound for that continent, troubled his head eoncerning the Christian Emperor. A youth of good, even aristoeratie, family, he had been what in a later day came to be called a scapegiace. He had aeeompanied the Freneh Ambassador to England, in what eapacity we are not told, but had left his serviee intending to seek his fortune abroad, and was strolling along Dieppe quay when he saw a vessel preparing to heave her anchor. Inquiring of some monks, they told hin that she was bound "for Sanega, in Africa, near Cape de Terle." Instantly he deelared that he would go. In vain the good. inen trieci to dissuade the wayward youth from his resolution, for before the sails were sprearl the Sieur de Roehfort was entered on the ship's book as a soldier, performing the duties of eaptain's elerk. It was not a lofty post from which to write his name on the blank places of the earth. But Providenee does its work by strange agents. Cortes, he remembered, was a briefless barrister, Balboa a bankruy, huxter, and the world was still ringing with the fame of a Spanish swineherd who had conquered Peru. It might, perchanee, be that a like future was in store for the lad who was leaving Franee on one of the many missions that the still untrodden world had then in keeping for the adrenturous.

The destination of the ship was the Senegal River, and, in order to build some small bark suiter for ascending it beyond the limits or what had then been the ordinary navigation, they landed on the eoast of the Sahara, to the north of Cape Blaneo. What, except extreme ignorance, eould have tempted them to seleet this part of Afriea for sueh a purpose it is hard to imagine. A broad belt between the fertile North and the tropical South, it is the sandiest, the driest, most barren region in all Afriea, though with well-watered valleys here and there, inhabited by wandering tribes, pasturing floeks, cultivating a little grain, or living on the produce of the datetrees round their white-washed villages. But there are no harbours worthy of the name, and the people bear so invidious a reputation for seizing and keeping in slavery those who land or are driven on their eoast, that traders give this treacherous shore a wide berth. Even yet there are only two settlements on it, the British trading-post on a ridge of roeks off Cape Juby (p. 133) and the rival one built by the Spaniards at Rio del Oro, which was intended to checkmate it. But the latter is a forlorn establishment, virtually abandoned since the people were attacked and some of them inurdered by the predatory Arab and Berber nomads, while that at Cape Juby, though more fortunate, has more than once had to bear the brunt of a like hostility on the part of those who regard themselves as the rightful lords of the soil, and look upon the Infidel with theabhorrence bred of twelvecenturies of ignoranee and fanaticism. It was on this treeless, havenless eoast that Captain Lambert, of the Dieppe Expedition, landed in the winter of 1637 , for the purpose of building river-craft, a eonvenienee for which, of all others, it was the worst suited. This impression the mariners were not long in imbibing; anything more desolate than the country about Cape Blaneo it is hard to eoneeive. The soil is sand, and the sand everywhere so soft that it is impossible to flounder through it for fifty paces without being exhausted. Wood and water there are none, and in vain did they sink wells in the loose drifts in search of the latter. 'The appearanee of a handful of natives who, impelled by curiosity or the desire for plunder, crept out from beyond the sandhills bore unmistakable testimony in their wild, lean, woebegone appearanee to the poverty of the land. It was, however, impossible to induee them to approaeh, fearing, no doubt, and with reason, the good faith of the whites, with 
whom their relations had hitherto been that of stcaling or being stolen, kidnapping or being kidnapped. But as they were ready to barter the fish which they shot with arrows for the brandy, tobacco, and biscuit of the sailors, the articles offered in cxchange were laic down at a safe distance between the contracting parties ; the natives, on their part, taking them up and learing fish in their place, decamped to a distance (p. 136). A long stay here proving unprofitable, as no timber was to be had, and no provisions except dried fish and maize, one bark only was built of wood brought from France. The ressel, which had all the time being rolling in the offing, the men landing with difficulty through the wall of surf that is continually breaking on this coast, then bore up for the Senegal.

This river disputed at that date with the Gambia for the distinction of being the The Senegal seaward end of the Niger. We and its now know that all these rivers course.

arise in common with some of Sierra Leone in a hilly country not far from each other. But in those days all was vague for more than a few miles from their mouths. Formed by the union of two streams so large that at their confluence at Bafulabé, the Bafing, or Black River, is 1,475 feet broad, and the Bakhoy, or White River, 800 feet, this united stream, receiving many important tributaries, flows for a thousand miles through what is known as the French colony of Senegal and the region of Senegambia, more or less navigable for the greater part of its course, until below Medina it presents a series of great reaches that continue to the sea. Unlike the Niger and the southern rivers, it does not creep into the Atlantic through a rast mud-formed delta, but is now deflected along the coast by the drifting sand-dunes that form a narrow barrier between it and the sea.

But navigation on the Senegal is always precarious. In the rainy season there is too much water and the plains of the lower river are for miles nothing but immense marshes that, when the hot weather comes, breathe forth malaria. Then Lake Cayor, on the right bank of the Lower Senegal, and Lake Panieful on the left, receive the overflow of the river, constituting, as did Lake Mœris in ancient times for the Nilc, and the Lake of Cambodia at the present day for the Mekong, vast reserve basins from which a supply is drawn in the long period of drought. For months in succession Lake Cayor forms the only drinking-pond for the wild beasts of the surrounding country. Thither they resortor dicl resort-in crowds, and it is a sight that docs a hunter's heart good to see lions, elephants, leopards, panthers, ounces, cheetahs, hyenas, lynxes, giraffes, gazclles, antelopes, monkeys, and jackals, all impelled by thirst, hieing to its erlge to drink, just as during the season of flood they take refuge in the same tree, a common danger rendering them, if not "wondrous kind," at least tolerant of each other's society (p. 137).

The river itself and its tributaries during the rainless months, owing to the scantiness of its sources and the steepness of its upper course, combined with the rapid evaporation that sets in as soon as the torrential rains cease to fall, would speedily dry up in the inland parts of Senegal were it not for the natural dams. Sand ridges and rock barriers cross its bed, and behind these ledges the watcr accumulates in deep reaches, so that though troublesome transhipments are necessary between reach and reach-some of these difficulties being overcome by the railway now in course of construction between Khayes and the Niger-it is quite possible for vessels of very light draught to navigate the river even at the driest period. But it is only from the 1 st of August to the 1st of October that the river is open as far as Medina to ressels not drawing more than eight feet. At Bakel, below the confluence of the Falemé-which flows through Bambuk-the river is navigable till the 1 st of December, from Bakel to Saldé between the 15th of July and the 15th of December, and from Mafu to the sea, a distance of 215 miles, ships sail all the year round.*

*Henriques: "Les Colonies françaises," vol v., pp. 63-71. 
But in 1637, and for many a year afterwards, little of this was known. The facts accumulated gradually, and were often acquired at a cost of life, and suffering, and
Dieppe (p. 44) were said to have discovered the river in $\mathbf{1 3 6 0}$, and the Portuguese had some trading-posts on its lower reaches in the fifteenth century, when the Sieur de

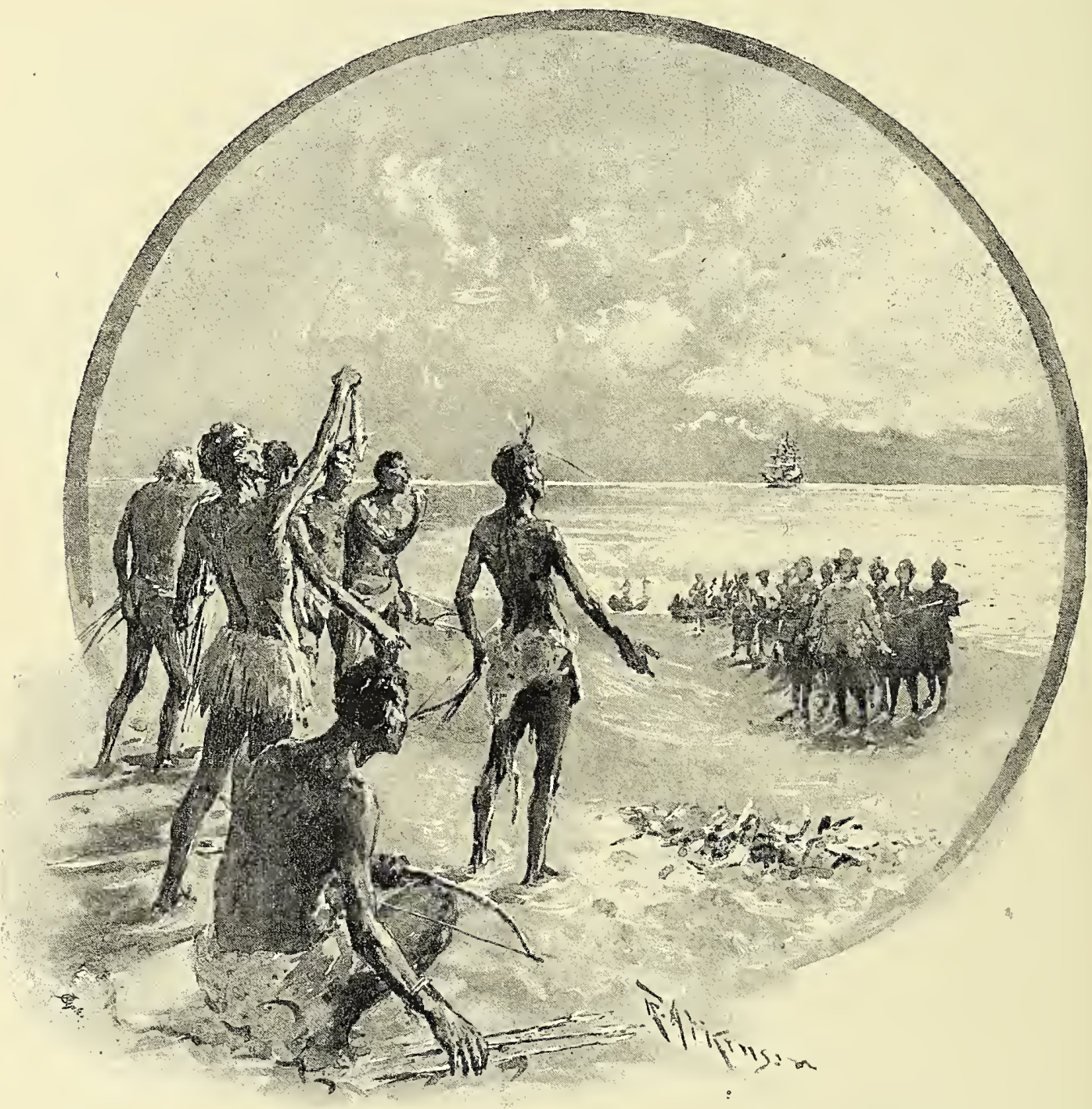

CAPTAIN LAMBERT BARTERIYG WITH THE NATIVES NEAR CAPE BLANCO (p. 135$)$.

money, and the disappointments that make the hearts of men bitter, hard to be understood by the reader who has lightly skimmed the few lines into which the result of two centuries and a half of toil has been compressed. Yet though the navigators of
Rochfort and his companions entered it there were no white men either to welcome or to oppose them. All was strange and new-plants and animals and peoples. They, or some of them, had read Leo s account of the river, and might have wondered, if this 
was the Niger, that more water did not pour seaward from a river that drained such a broad area of Africa. However, even this form of doubt did not come to more scientific geographers for generations afterwards. They were buoyed up by expecting at every could have helped business, to vouch for the gables also being built of the same attractive metal.

As they ascended the river between the walls of forest that came down to the water's edge, they were struck with admiration

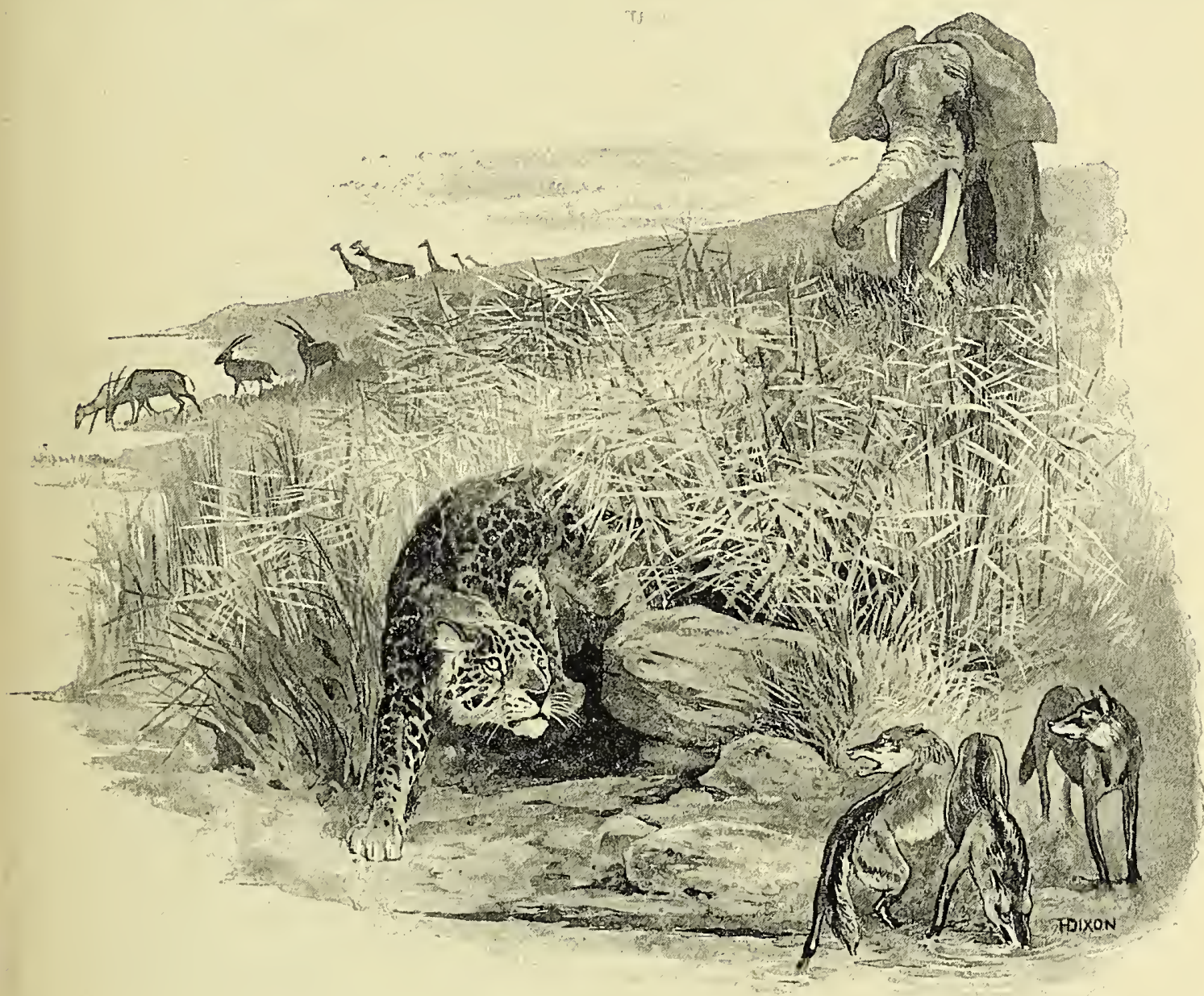

ANIMALS RESORTING TO LAKE CAYOR TO DRINK ( $p .135)$.

bend of the current to see Timbuctoo and Gogo, or some of the golden-roofed houses that the black merchant had described to Richard Jobson ; and no doubt the ambassadors from "the Damel and the Brak,"* who arrived almost as soon as they had crossed the bar, were ready, if their affirmation

* The supreme sovereign and his deputy. at the perpetual verdure of the tropical jungle, and at the beautiful birds, unknown to naturalists, $\uparrow$ that disported themselves

+ Adanson was the first naturalist to break the soil in this virgin ground. He visited the river banks, a little way from the sea, during 1749-53. His "Hístoire Naturelle du Senegal" (1757) has not been displaced from its eminence as an original authority by the many researches that have been made since. 
among the branehes of the strange trees. All the woorls echoed with unwonted noises. A virgin Every sound was heard with distinetriver. ness in the vast solitude. Nothing but weleome greeted them, the ehiefs and the people vying with eaeh other in their eagerness to traffic with the white men. Jalofits, and Fulahs, and Mohammedan negroes were alike ready to do business with them or to exhibit the national sports for their amusement. One of the most notable of these was performed by a potentate whom the navigators deseribe as the "Kamalingo," or "King of the Moors of Barbary"- -a Moslem sovereign from the Upper River no doubt, or possibly the leader of the caravans from Moroceo-who undertook to vanquish a lion in single combat. On the day appointed the Frenehmen, in order to be out of 'harm's way, took their plaees in the trees surrounding the extemporised eircus. This Kamalingo then mounted on horsebaek and, armed only with three javelins and a Moorish sword, actually slew the savage brute without sustaining more damage than a slight wound in his $\operatorname{leg}$.

Most of the people with whom they eame in eontaet seem to have been Mohammedans, terribly in awe of the marabouts, who sold them grisgris, or eharms, eonsisting of an ineantation or prayer written in Arabie on bits of paper, but otherwise not very strict observers of the Koran. But their Mohammedanism was marked in one respeet. Unlike the Gambia people, they did not demand brandy either as a gift or as an artiele of barter. Iron bars, Rouen linen, red and blue frieze, sugar, silver braeelets, eombs, lookingglasses, knives, beads, crystal and paper, with just a little grog if the reeeiver were not one of the Faithful, were the usual articles in demand, while ox-hides, the skins of wild beasts, ivory, gum-arabic, ostrich feathers, ambergris, and gold were what was mainly given in exehange. The heat was, however, very trying and, sleeping or waking; the mosquitoes, whieh they ealled "marignons," tortured the voyagers both on the water and when they landed to streteh their legs in the many-eehoed woods. The dews were, moreover, so heavy that "whoever sleeps overnight with his stomach bare would infallibly die next day." The ship's company were busily employed in making and burning bricks to build a house, unloading the goods to pay the eustoms or "dash" to the four kings who controlled the tracle of the river, or in making a raft on which to receive "the trade" that was arriving from the up-river eountry. Others were sent into the woods to hunt stags and wild boars, while a sixth party were occupied in digging the foundation of the faetory that is so notable a landmark in the history of Freneh eolonisation. For this house formed the first permanent settlement of the Freneh, and it may, therefore, be regarded as the rude beginning of the eolony of Senegal. Finally, as the ship was anehored outside the bar, the remainder of the men were busily at work taking the eargo to her in their little Sahara-built bark. In the meantine, good water was hard to obtain, and while the masons were striving to find a foundation in the oozy soil, the deadly elimate of the river mouth was beginning to play havoc with their health, so that they were glad to begin the inland voyage in the bark, trading as they sailed up the stream. At Terrier Rouge, 210 miles above where St. Louis now stands, the Frenehmen found it difficult to proeeed any farther. Then the mariners returned, pleased to eseape out of a land where the people were either Iloslems or pagans, who believed in charms, and credited the devil with helping them to write Arabie. For Jannequin, thongh a roving blade, was a good Catholie, and saw all men and all things through the speetacles of his creed. Nor was his geography mueh more enlightened, sinee he relates little regarding the interior with whieh 'we were not already aequainted, or whieh was better than a réchauffé of what he had rcad. But the expedition in whieh he took part irust for ever remain famous in the annals of Afriean exploration 
in so far that it was the first to reach the limits of unimpeded navigation in the Senegal, or Sanaga, as it was then called, which was regarded by him as a branch of the Niger.

Their voyage home was more eventful than their stay in Africa. For on the island of St. Vincent, then uninhabited, they rescued the crew of a French ship, who had for weeks been living on tortoises: and they themselves fared so badly that, before they reached Dieppe, what with contrary winds and fear of the Dunkerkers, who were harrying the coast, which made them wait until they could find consorts to share the danger of the passage, they were so reduced by hunger as to sell the clothes off their backs in order to buy food for their stomachs.*

* Jannequin: "Voyage de Lybie au Royaume de Senega le long du Niger, description des habitants qui sont le lon de ce flcuve, leur coutumes, etc." (16-13.)

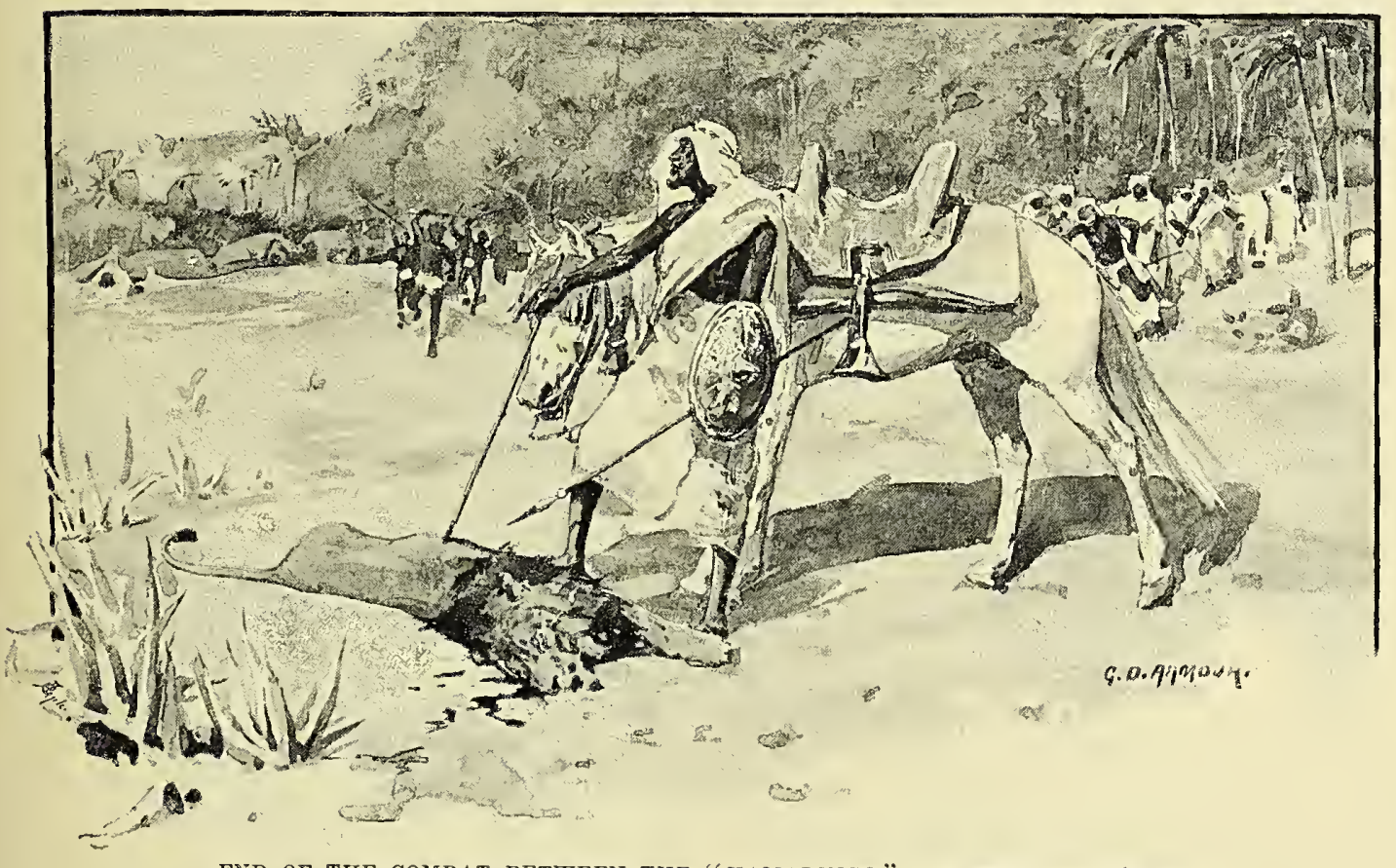

END OF THE COMBAT BETWEEN THE "KAMALINGO" AND THE LION (p. 138). 


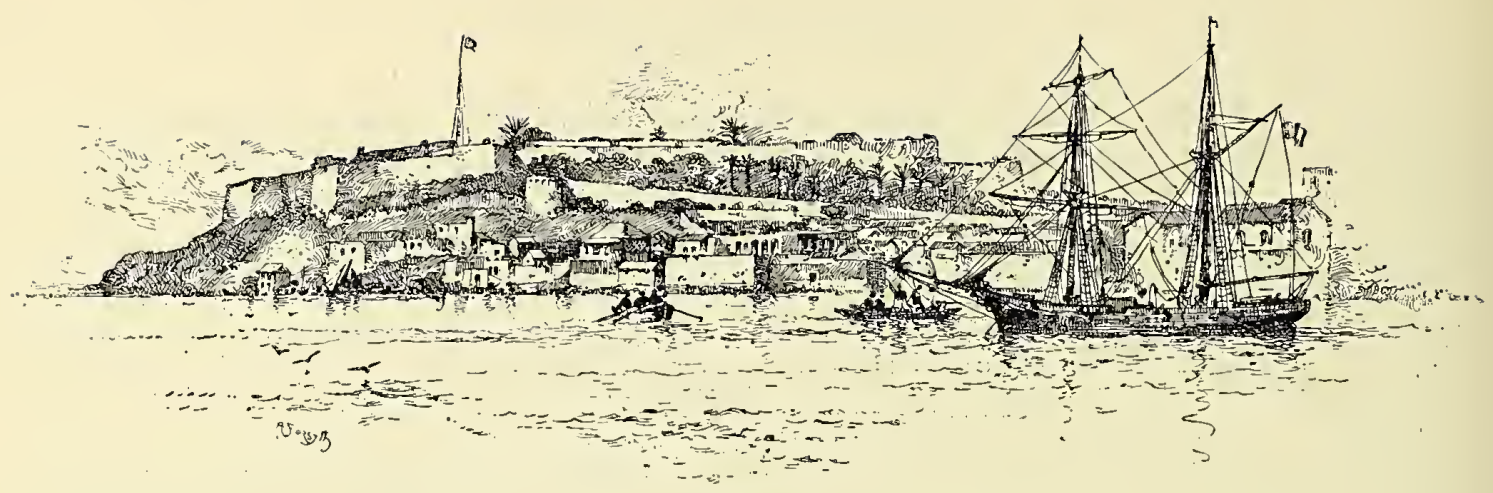

GOREE

\section{CHAPTER VII.}

\section{The Travels of Andre Brue, General of the Royal Senegal Company.}

The Arrival of André Brüe as Director of the Royal Senegal Company-His Character-Begins to Ascend the Senegal-Morfil Island and its Swarms of Elephants, Lions, Monkeys, Crocodiles, and Hippopotami-The Fulahs-The Siratik's Court-A Voyage towards Galam-A Man-eating Lion-A Flight of Locusts-A Congress of Monkeys-A Bee King-A Civil War and a Surly Sovereign-Loose-living MohammedansThe Felu Cataract-News of Timbuctoo-Changes in the Country since this Early Voyage-Alterations in the Character of the People since Jannequin's Visit-Lust for Brandy-Begging- Costly Gifts-A Curious Traffic in Bilge-water-An Overland Journey to Cachao-Jews in Disguise-Society at Vintain-A Trader-missionary-A Spanish Gentleman with Negro Morals-The Flûps-Cachao and its MannersPresent Condition of the Country-Other Explorations of Brüe-The Discovery of Bambuk by the Sieur Campagnon.

For long little more was attempted in the way of exploration from this time. The Norman Company, in whose service the Sieur de Rochfort was, had, in 1664, sold its trading rights to the West India Company, finding that even the favour of Riehelieu, ever eager to extend the eommeree of his country, was not suffieient to enable them to make headway against the Dutch at Arguin, Goree (p. 140), and Rufisque. Even the new assoeiation had in turn to yield to the Senegal Company in 1672 , whieh seven years later, ruined by the war with Holland, eeded its privileges to another union of merehants, who again, in 1696, made over their rights to the association that took the title of the Royal Company-facts already hinted at in our ehapter on the early Guinea traders. But these short-lived mercantile unions were eontent to build forts, to buy slaves and ivory, and, like the adventurers of the other European Powers, to try to seizesometimes with good and just as often with bad fortune-a share of the Guinea trade. The interior seemed to have lost charms for them, or they found it more profitable and less troublesome to barter for what was brought down the river, instead of going up stream themselves.

An exeeption to this rule was the Sieur André Briue, who arrived as Direetor, or General, of the Royal Senegal Company, with his head-quarters at Fort St. Louis, at the mouth of the Senegal (p. 141). This remarkable man was an admirable eombination of the merchant and the explorer, and, in spite of the apathy of his employers in Franee, made his labours in both eapacities pay in a manner which later travellers must regard with something like envy. In 1697 he sailed up the stream to Morfil, a great island formed by the bifureation a pioneer of the river. This name means voyage to Isle of Ivory; for in those days senegal. the elephants, whieh have long ago retreated 
to Ferlo, the sources of the river, and the high country of the interior, went in herds of forty or fifty, and were quite harmless unless molested. As the negroes, until a few years before Briie's visit, had no weajons except bows and arrows and spears, thcy captured them in pits covered with leaves and branches of trees (p. 145). Great numbers of lions also roamed through the valleys by the river-side, hippopotami reared their heads above the surface of the water, and every now and again a crocodile snapped up a wild duck, flocks of which swarmed in the quieter reaches. These brutes are still numerous in the Senegal, and must be very sharply looked after, as they often wander for miles back from the river in search of anything that they can snatch up, be it pig or dog, fowl or child.

But few lions are now seen, and the herds of elephants that then frequented Morfil Moril Island have long ago been killed off. Island. Much of it was, indeed, clcared to grow millct, rice, indigo, and cotton, though, renomoins insccts are still as fierce as ever. During the worst season the wealthier natives remove to higher grounds to avoid them, while the poorer ones sleep in the open air on a raised platform, beneath which a little sinoky fire has been lighted (p. 144) - a custom adopted even in the houses of the Upper Niger country, though there the ague and not the insects is what it is intended to drive away. These clearings have, however, in part, at least, scared the leopards, once so numerous, and even the hyenas that haunt the abodes of man are less numerous than when the Sieur Briie described the Senegal banks. Giuineafowls and partridges are still abundant, and the great conical ant hills (p. 148) form as in his day striking objects in the landscape, while the aponogeton and other river weeds that block up the channel swarm with myriads of leeches, for which, since the change of fashion in surgical sciencc, there is no longer a market. But the monkeys are as numerous as ever they werc in the days when the

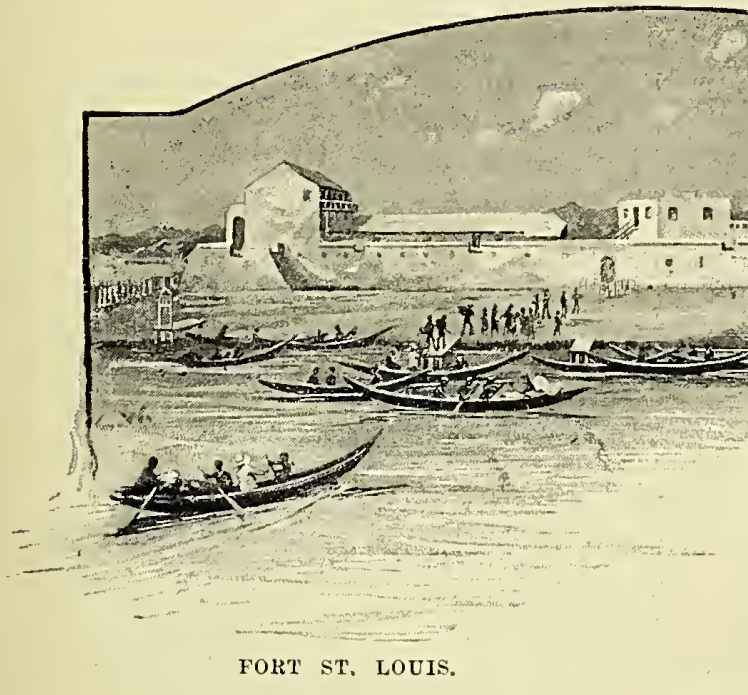

negrocs, amazed that anyone would buy such creatures, brought the voyagers rats also, under the idea that any living. creature would be quite as welcome to these strange people. At Tcrrier Rougewhich is a district near the western extremity of this island, on the north side of owing to the partial exhaustion of the soil and the low rates that most of these crops now bring, the plantations are again lapsing into the virgin forest from which they were reclaimed. But the mosquitocs and other the river, and the limit of Jannequin's journey-there was a great trade in gumarabic carried on by the Moors, who collected it from the forests north of the river, 
and the borders of the Sahara. Here the meadows were still rich, and vast herds of cattle pastured on them, though during the rainy season, when the country around was flooded, they had to be driven to higher ground. Still continuing up the river, Brủe passed Hovalada and Kahayda, both places of considerable trade, until, reaching Ghiorel, a message arrived from the Fulah "Siratik," or king, earnestly begging the favour of a visit in order that some trade matters in dispute should be settled without further loss of time.

As one of the objects that had brought Briue up the Senegal was to see this potentate, he now set out for his country, lying at some distance from the river. The region through which they travelled for two days was flat, cultivated, and full of villages, and in places so covered with cattle that it was difficult for the French trader and his retinue of six factors, two interpreters, four trumpeters, and a host of negroes, bond and free, to make The Siratik's rapid progress. At the Siratik's court. Court the party were received with a barbaric welcome, though in truth the palace and its surroundings were more primitive than some of the abodes of those minor African princes whom the slave trade had begun to enrich. For it was simply a few thatched huts surrounded by a hedge of thorns, situated a littlc way from Gumel, the principal village of the little realm. His majesty's throne was a bed, on which he sat surrounded by his wives and daughtcrs, squatted on mats upon the bare ground. The king, delighted with the gifts he had received, not only granted all that the factor asked for, but offered him the honour of an alliance in the shape of a princess of seventeen, his respectful refusal on the plea of his faith allowing of only one wife at a time (and that one he had already in France) arousing many speculations as to the kind of religion that admitted of that nonsense, and some speculation as to the morals of the white folk professing such a creed.

The king's forces, cavalry and infantry, were, however, not despicable for an African sovereign, and the mode in which justice was administered was, on the whole, worthy of approval. The ten Privy Councillors by whom the sovereign was always surrounded examined the accused persons, or litigants, separately, and then furnished their report to the fountain-head of mercy. No advocate was allowed to interfere. Every man pleaded his own case, and whatever the sentence it was always executed without a inoment's delay. Tet, few crimes were punished with death; the Siratik had found a better use for men than killing them. He compelled them to expiate their offences in what he was pleased to describe as "banishment," but which in reality meant sending them down the river to St. Louis for sale to the French Company. As for the insolvent debtor-in accordance with a custon of almost world-wide usagewhen he could not pay what he owed, he and his whole family were sold into servitude, the king exacting as his contribution towards a Civil List one-third of the price.

However, M. Brie's opportunities for observation were soon eut short by the pest of mosquitoes and other venomous flies compelling the king to remove to another part of his doninions, the advance guard-consisting of 160 horsemen-blaring trumpets and timbrels in an exceedingly inharmonious inanner. After these came the female members of the royal family, mounted by twos on camels, though so completely enclosed in wicker baskets that no part of the ladies was to be seen except their heads. And, unlike most Mohammedans-the rural folk, perhaps, excepted-they made no pretence of veiling their faces from the admiring gazc of the stranger. Feinale attendants, riding donkeys, jogged by the side of their mistresses, endeavouring by constant chatter to keep them amused: and in the rear came the sovereign, his court, his belongings, and the mob of slaves and soldiers who follow in the train of even the humblest African potentate. For though it is often troublesome to take them along with him, it is decidedly dangerous 
to leave them behind with the ehanees of their being bought over to the interest of a rival, and the certainty of plundering as a diversion for their too many idle hours. Then, last of all, more eavalry brought up the rear (p. 149).

Next year the Sieur Briie made another royage up the Senegal, reaehing on this

A voyage towards Galam. oceasion as high as the kingdom of Galam, which is situated oll or about the confluence of the two rivers whieh, united, form the main strean (p. 135). On the way he visited the Siratik again, and was reeeived in quite as friendly a manner as before. In the interval, however, the Dutch had been endeavouring to win him over to their side by means of an embassy sent from one of their forts on the coast (p. 45). But whether the Batavians had been sueeessful or not did not appear, sinee just at that moment the Fulah sovereign had what is known in the familiar metaphor of the West as "an axe to grind." In short, he wanted the white man's help in killing a ferocious lion that for weeks past had been the terror of the district. Four negroes, daring hunters, were aeeordingly sent to attaek it. But, skilful though these men were, two were torn to pieees by it, a third was wounded, while the fourtl would have shared the fate of his eompanions had he not by a happy chanee given it the death-thrust with his lanee.

At Embakane the air suddenly grew dark by reason of a vast army of locusts that Lions, covered the sky. For two hours locusts,
monkeys, they eontinued flying aeross the and bees. river, in whieh, of course, the boats were blaekened by them. Happily, however, for the seaward eountry, a south-west wind began to blow, and as the inseets were unable to bear up against it, they were speedily wafted into the desert, there to die of hunger amid the sands in whieh they were originally hatched. At Bietel he found poultry abundant, and, what it seldom is in Afriea, good also. A fat pullet eould be bought for a sheet of paper, and eggs at a proportionately low figure.
At Tuabo, on the Galam frontier, a swarm of red monkeys erowded the branehes of the trees to have a view of the white-faeed folk rowing up the river. The sight seemed to anaze them. All the time they ehattered ineessantly, evidently eomparing notes regarding the eurious people underneath, and then, as eaeh detaehment satisfied its euriosity, another took its plaee, with the utmost regularity and good-nature. By-and-by, however, the misehievous disposition of these animals began to exhibit itself in their tossing down dry branches and stieks into the ressel - a faeetiousness that was answered by a diseharge of musketry. Then, as the dead and wounded tumbled into the water, a mighty tumult arose. Loud eries resounded on every side, while others, sparing their grief for another oeeasion, rushed to colleet stones and other missiles to hurl at the invaders--an unequal eombat whieh went on for some time, until, worsted, the monkeys retreated in " angry parl" to the depths of their native forests. Wax was in their days, as in ours, a common product of the Senegal district, and at every village the natives kept swarms of bees for the sake of their honey. A person announeing himself as the "King of the Bees" eame on board the shallop at one of the halting-places. He was covered with them from head to foot, and thousands more hovered around without doing him any injury, the man claiming to have sueh perfeet control over them that he eould even prevent his protégés from stinging anyone whom he took under his protection.

As Briie proeeeded up the river, news cane that there had been a revolution in Galam whieh had resulted in the unseating of the old king by a rival, who sent to the Frenehman a eurt intimation that, if he did not reeeive the customary dues, he would prevent him from ascending farther. No notice being taken of this threat, except an intimation that the white men would proeeed, and be stopped at the peril of the new sovereign having his territory laid waste, the banks began to be erowded with exeiterl negroes, 
menacing destruction to the whites. In those days, however, traders werc not so easily frightened as they arc in a time of telegraphs and philanthropic societies whose business in life it is to make. the way of the aborigines' oppressors extremely hard. So, firing a round of cannon without ball, and blowing his trumpets and beating his drums as if preparing for action, the irate Galances that it contained neither pig's flesh nor wine.

For by this time the travellers had passed out of the region of loose-living Mohammedans into a land whcre the tenets of the Koran were more strictly observed. It may, however, be added, that the Prophet having said nothing about brandy, his majesty, like a good many of his casuistical co-religionists, drank all that was put before him without any visible compunction of conscience. An income not having as yet been provided for the parvenu prince whom the rebellious chicfs had

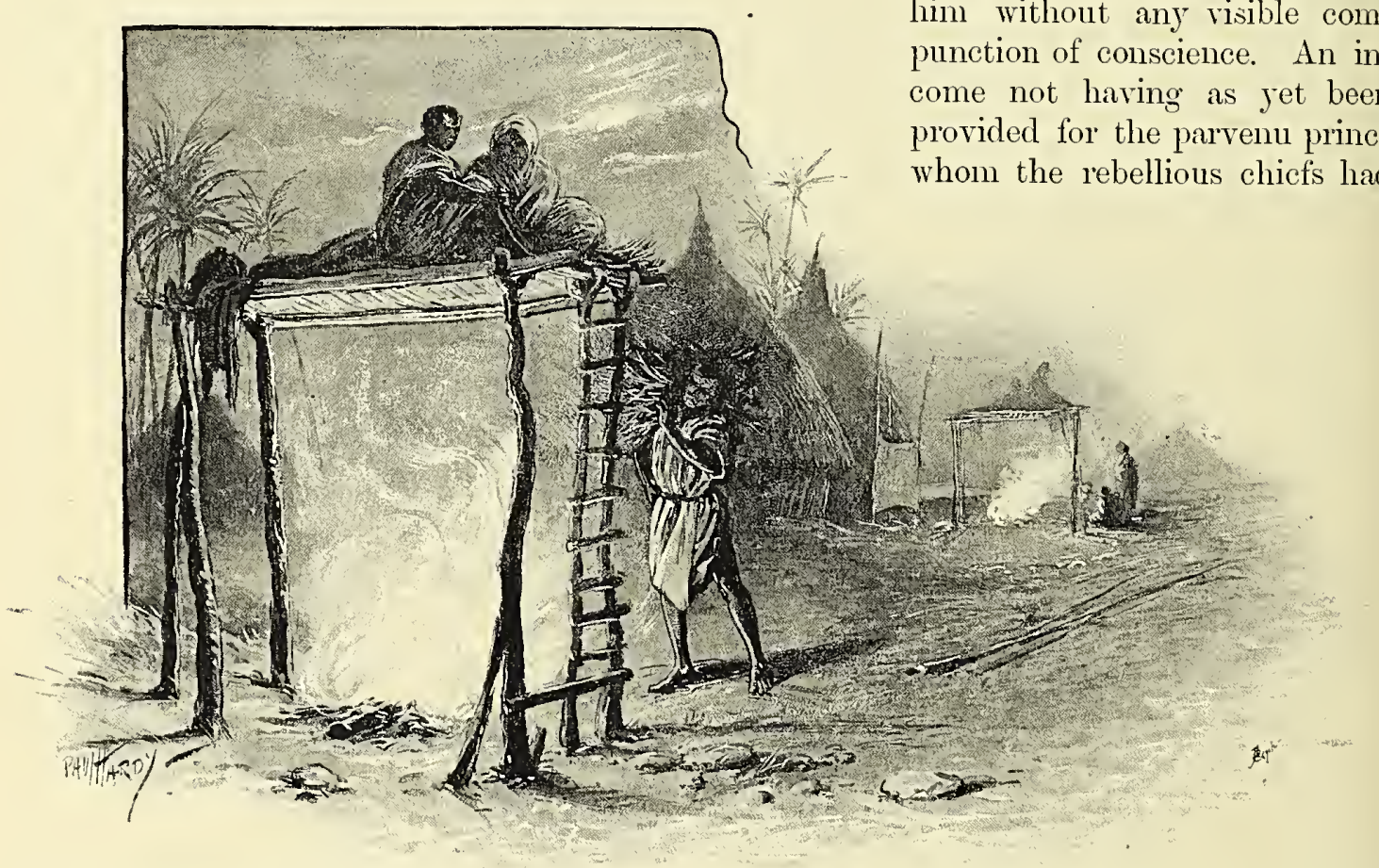

NATIVE MODE OF SECURING PROTECTION FROM MOSQUITOES. (See p. 141.)

as promptly dispersed as thcy had assembled. At Burnaghi, finding that the revolutionary party were the actual power with which he had to treat, Monsieur Brie, having no concern in the politics of Galam, paid his respects to the new king, and in time also paid him the "dues" that by now were exacted by cvery African chief as his right of every trader passing through his territory or doing business with his subjects. On a visit from the sovereign in person, cattle and poultry wcre presented by him, and a cup of chocolate was drunk, the host passing his word called to reign over them, the king's hut was in no way diffcrent, either in dirt or in the absence of riches, from that of the meanest of his subjects, so that, except the few fowls and cows already given, hc could make no return for the handsome gifts he had received. The west winds having begun to blow, the voyagers left the poverty-stricken king, and soon arrived at Baba Seghalie. Here the deposed monarch had taken refugc with a number of faithful followers, and, as he assured his visitors, he was still the lawful sovereign to whom the dues 
ought and must be paid, otherwise, the African Bourbon declared, all trade should be stopped and the voyagers made prisoners on their return journey. The only reply to this threat was an announcement that, unless the monarch who did not know when he was
Timbuctoo, for it professed to do a large trade with that city, importing from it gold and ivory, while slaves were brought mainly from Bambarra, a region described as barren, but very populous, and therefore a fitting hunting-ground for dealers in flesh and blood.

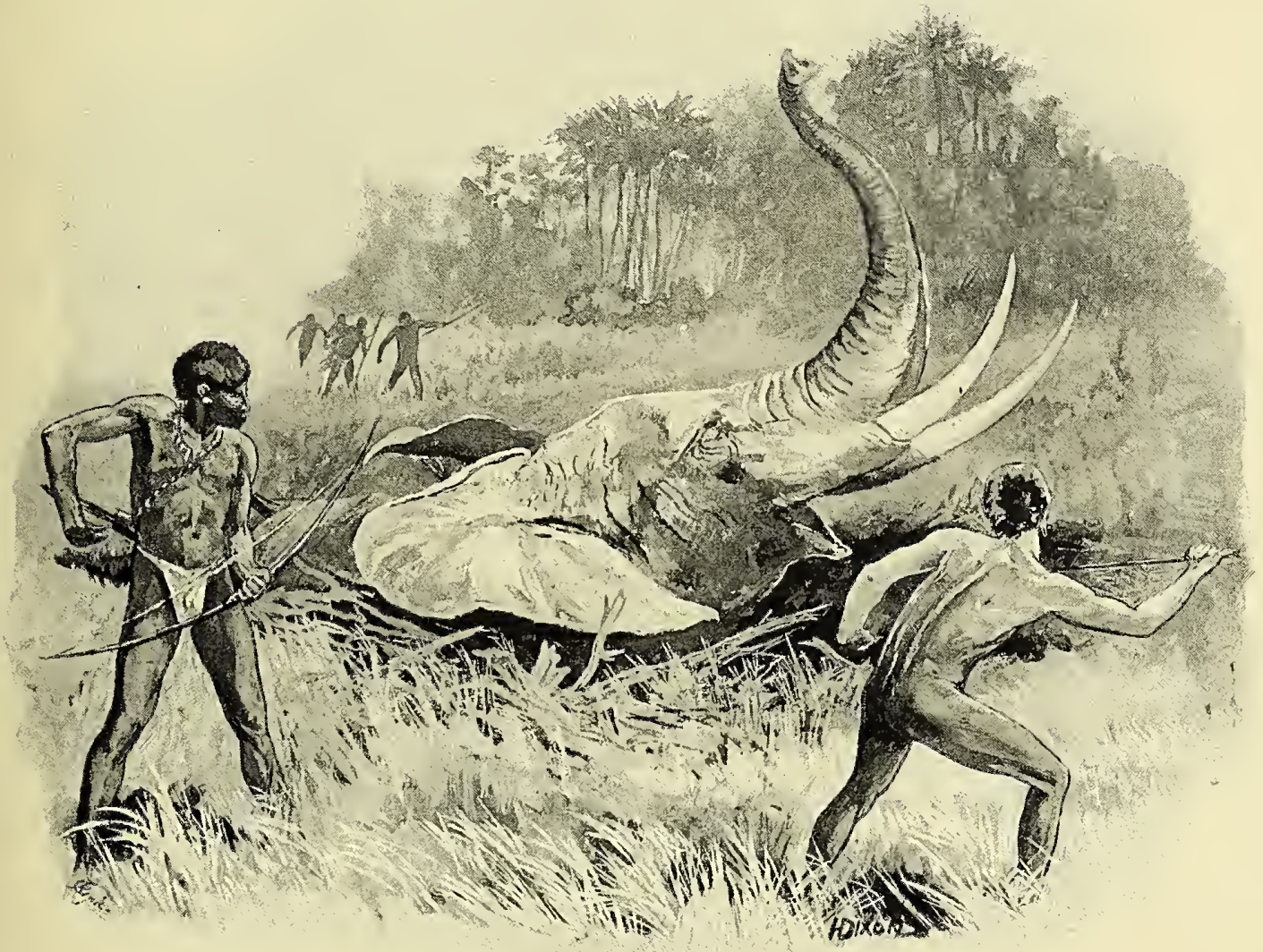

METHOD OF CAPTURING ELEPHANTS EMPLOYED BY THE NEGROES BEFORE BRËE'S TIME. (See $p$. 141.)

beaten decamped without further palaver, he and his son-who had delivered the message -would be seized as slaves, and forthwith deported as such to the American plantations. After this King ("Tonka") Mouka practised that discretion which even in Africa is the better part of valour. At Dramanet, a Mohammedan town of 4,000 inhabitants, the voyagers came into appreciable touch with
Hitherto, they had been accustomed to send their commodities to the English on the Gambia ; but, now that there was a prospect of being able to sell them to traders on the spot, they eagerly crowded to the Frenchman's camp with these wares. In the meantime, while traffic was busily proceeding, a hostile army heaved in sight, and, the people of Dramanet not expecting any such unbidden. 
guests, managed to gain entrance to the city. It turned out to be the deposed Galam king, in high dudgeon at his contemptuous treatment by the French, and still determined to exact the dues paid to his successful rival and refused to him. But the townsmen speedily seizing their arms, the prudent invarler beat a retreat, on the plea, which in the circumstances might be accepted as sincere, that rather than come to blows with the white folk he would abandon his lawful rights.

At Felu they reached the cataract that had hitherto formed the extreme limit of the Frenchman's knowledge of the river. Briie, however, leaving his boats below it, passed by land to the falls, and was on his way to those of Govina, 120 miles farther up, when noticing that the Senegal was falling, he determined to return, in case he might be unable to pass some shoals lower down. Arriving at Dramanet, he fixed on a position for a fort which was to be the centre of French trade in this region, and in due time renched Fort St. Louis without any notable ardventure.

This early royage-the first, indeed, so far up the Senegal of which any record has Changes in descended to us-was a notable one the country in the annals of the opening up day. of Africa. It is still easy to follow it, for all the places he describes inay be traced, though most of them have changed greatly for the worse since the Sieur Brie first saw them. The country so high up the river is still largely self-governed, the French influence being seen more in the occasional ribbon of the Legrion of Honour on the white robe of a native chief than in the actual insignia of authority; and even after a railway runs across the country, so wild a region will be a long time in feeling its influence. The little kings and chiefs still fight, every man for his own hand. It is only a general rlanger that compels them to sink their jealousies for the common weal. At the station where the Felu rocks form the cataract that impeded the voyage of Brie, there is a fort where the French were in 1854 besieged by the "Moors," who in the end were defeated with the loss of 600 men, though to this day the people of the Medina and Bambuk districts are sorely troubled by these warlike people from the interior seizing their cattle, and driving them away captive into the desert. But the slave trade, so far as the coast is concerned, is at an end, and perhaps the last monument of its existence is the ruins of the factory at Medina village, which was built about 1830 for the purpose of trafficking in gold and "black ivory." To the north-north-west of Galam there is still a vast, lone land where nomads wander in search of pasture, and, still farther away, the country of the desert-living "Moors," who, as of old, compensate for the poverty of their land by making raids on the flocks and herds of their more sedentary neighbours. A few hippopotami still disport themselves in the river, and travellers have not ceased to keep a sharp look-out both for lions and leopards. Buffaloes and antelopes are also plentiful, though elephants are every day getting rarer and rarer, if, indeed, there can be said to be any trade whatever in ivory brought from Senegambia proper. Salt is still the article most in demand, though greater familiarity with the white man and his ways has established a desire for superfluities unknown to the people in Brie's time, when the chiefs, owing to the slave tracle, were richer and the people poorer than nowadays, though golden chains, coral beads, and amber balls are no uncommon ornaments to see around the necks of ladies of high degree who squat reiled on the rich carpets of Fernagha, near Timbuctoo, with which the people of the Upper Senegal and Gambia continue to trade in spite of the greater accessibility of St. Louis and Bathurst and Sierra Leone.

Regiments of mandril monkeys may still be met with, gnashing their teeth as their rich relations approach, or fiercely aining sticks at them as they did at Brie's party 
more than two hundred years ago. Civilisation has not affected thein, and the troops of obscene hyenas obtain a sort of protection from the superstitious contempt of the natives. "Kill a bouki," so r'uns the adage, "and defile your gun!" Still, as of old, the caravans pay their dues to the chiefs or "kings," and the white men, though more feared than in Brie's time, are not more respected, as might well be imagined after examining the infamous muskets and other goods which they scll to the confiding natives. Gold is found all through the country and is mined by the people in a rude way. Yet in French hands the business has not been successful, and all down the Falemé branch of the river may be seen ruincd factories from which much was expected in the way of exploiting the wealth buried in the soil of the Bambuk country lying between this and the other tributary of the Senegal (p. 135). Most of the business is now transacted by Mandingo agents of European houses, who buy from the traders at Medina, and from caravans passing on their way to Bakel, and during the rainy season down the main tributary as far as the coast. Moors, Fulahs, the mixed race of Toucouleurs, Joloffs, and Sousous, still divide the country among them, and leave little undone in the way of mutual jealousy. 'The Mandingocs are, however, the great objects of dislikc. Yet, curiously, these people, who are at once the commercial travellers, the priests, and the schoolmasters of the Senegal and all the Mohammedan country in that region, are not natives of the lands in which so many of them are settled. They come from Manding, in the interior, and are for the most part strict Mohammedans of fine commercial ability. Yet though republicans in their native land, their colonies are all monarchical. In Barra, for example, they form, as in many other places, a majority of the inhabitants, and the king and all his great folk are of the race. But they are not liked. They are "malinko" - "lazy $\operatorname{dogs} "$ - a word which it is said is the origin of the English "malingerer," the term applied to a skulker who affects illness to avoid work. That, however, is not the Mandingo excuse: they set their wives to do the vulgar toil, reserving to themselves the nore ornamental department of trading and talking and getting the best of the white man. Yet no region in Africa is better fitted to support a large population.

The endless waterways by which the upper sources of the Scnegal, the Gambia, the Sierra Leone Rivers, and the Niger are so connected that in some cases the overflow of the one falls into the other, will in future days render this vast area a busy home for a higher civilisation than that which at present finds a scanty subsistence from its resources. The country is now safe, and Ouddoarin, the spot where formerly so many European vessels were plundered, and Saldé, opposite Morfil Island, where the Fulah King once levied customs duties, amounting to as much as sixty pounds upon large vessels, are now surrounded by rich plantations, this monarch's power, like that of the many petty chiefs on the river who mulcted traders heavily, bcing now almost at an end.

It is, therefore, intcresting to read the pioneer voyage of the Sieur Bric. Yet cver since Jannequin's visit to the Senegal, people had bcen altering. They the phes in had bcen imbibing those "vices of between the civilisation" that are the first and Jannequin too often the last benefits that and Brüe. savages gain by intercourse witl Europeans. In the first place, the slave trade, with its evil influence in setting tribe against tribe in order to supply a greater quantity of the peculiar merchandise in demand than the ordinary aftermath of local wars and tribal crime could afford, harl attained full vigour. Then no longer did all good Mohammedans look with horror on brandy. On the contrary, M. Bric recommends cognac as always the most acceptable and profitable merchandise that can be carried into $\Delta$ frica. Curiously enough, the negroes in his dayas some of them do to a certain extent still-refused any bottle from which the 
smallest quantity had been taken. They would even prefer a sinall vessel full to a barrel of which even an inch from the bunghole was empty. This curious notion may be compared with another still in full vigour on the Guinea Coast. Even at Cape Coast Castle, where experience ought to have taught them differently, the Fanti will not accept any coin

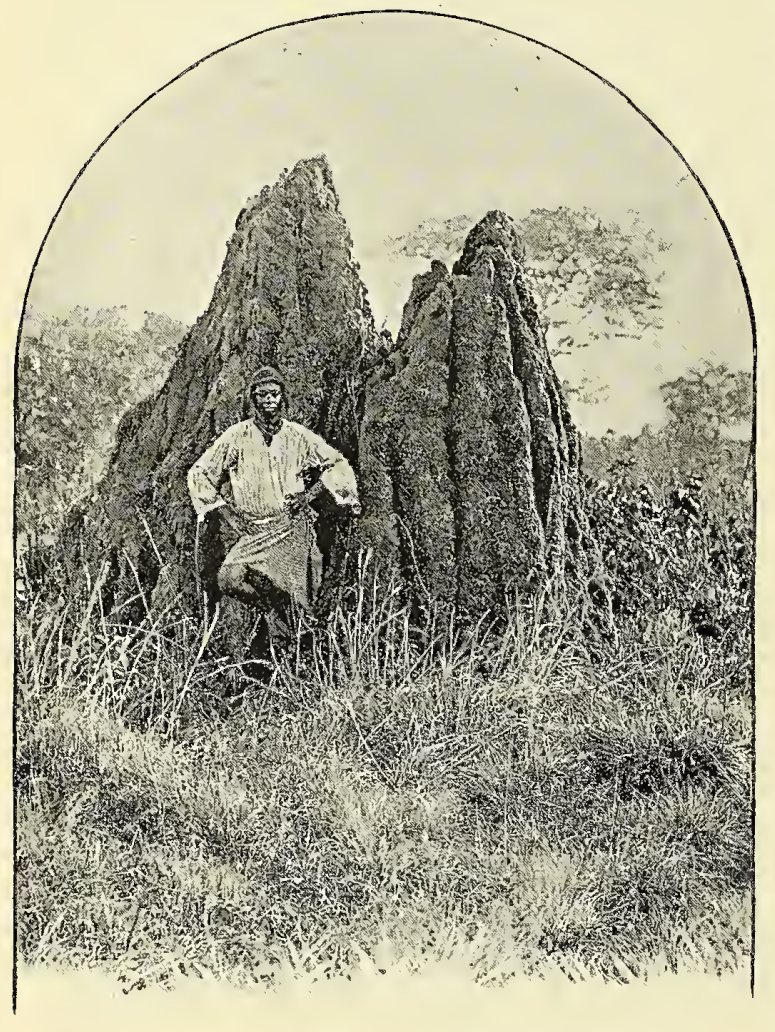

ANT HILL (11 FEET HIGH). [ $p$. 131.]

that has not the head of the reigning sovereign : "for him dead and no good, sah." Again, in Abyssinia, and other parts of Africa, no silver coins except those bearing the image and superscription of Maria Theresa have currency. So much was this the case that the Austrian Government permitted to be struck for the use of Lord Napier's Abyssinian expedition, in 1868-9, a quantity of these thalers from the old dies in the Tienna Mint - the mere fact of pieces bright and unused being dated more than a century ago arousing in the minds of the recipients no suspicion as to their genuineness.

Begging, which had early become an offensive feature in the African character, was, by the time of Brie's visit to the Senegal, an ingrained practice among all classes. Whatever the effrontery of European beggars-and, in spite of rope and branding-iron, stocks, whipping-post and pillory, mendicancy in 1697 was by no means the most unfrequent sight in Dieppe and Paris-they were, this voyagcr assures us, modest, even retiring, compared with an African monarch. Everything was asked for, and every gift bestowed, instead of appeasing his greed, was considered simply as an opening for further demands. Then the wives and daughters, the queen, princesses, and princes, were set to bleed the hapless white man, and finally, after everything that interest or good-nature, generosity or fear, could extort from the newcomer was given, the begging began anew in the shape of an attempt to borrow without any intention of paying, or of obtaining goods on a credit that was not intended to be wiped out during the lifetime of the debtor. At last, when every expedient for plundering the merchant had been exhausted, or the latest demand refused, the invariable expedient was either to prohibit commerce or to load it with new imposts. And the worst of having any dealings with an African king, writes this shrewd trader, was that if any of them sent a trumpery present, he expected double or triple in return, and, the next time the stranger made his appearance, demanded as a right what had thitherto been given as a gratuity. Hence, in even the most disadvantageous market, the dearest article that could be procured was bought more cheaply than being received as a present. And as it was at the close of the seventeenth century, so is it when the nine. teenth is coming to an end. Arms seem by this time to have been plentiful, silver-mounted pistols and silver-hilted swords being among the ordinary gauds of the chiefs, and the items in the "annual presents" that were 


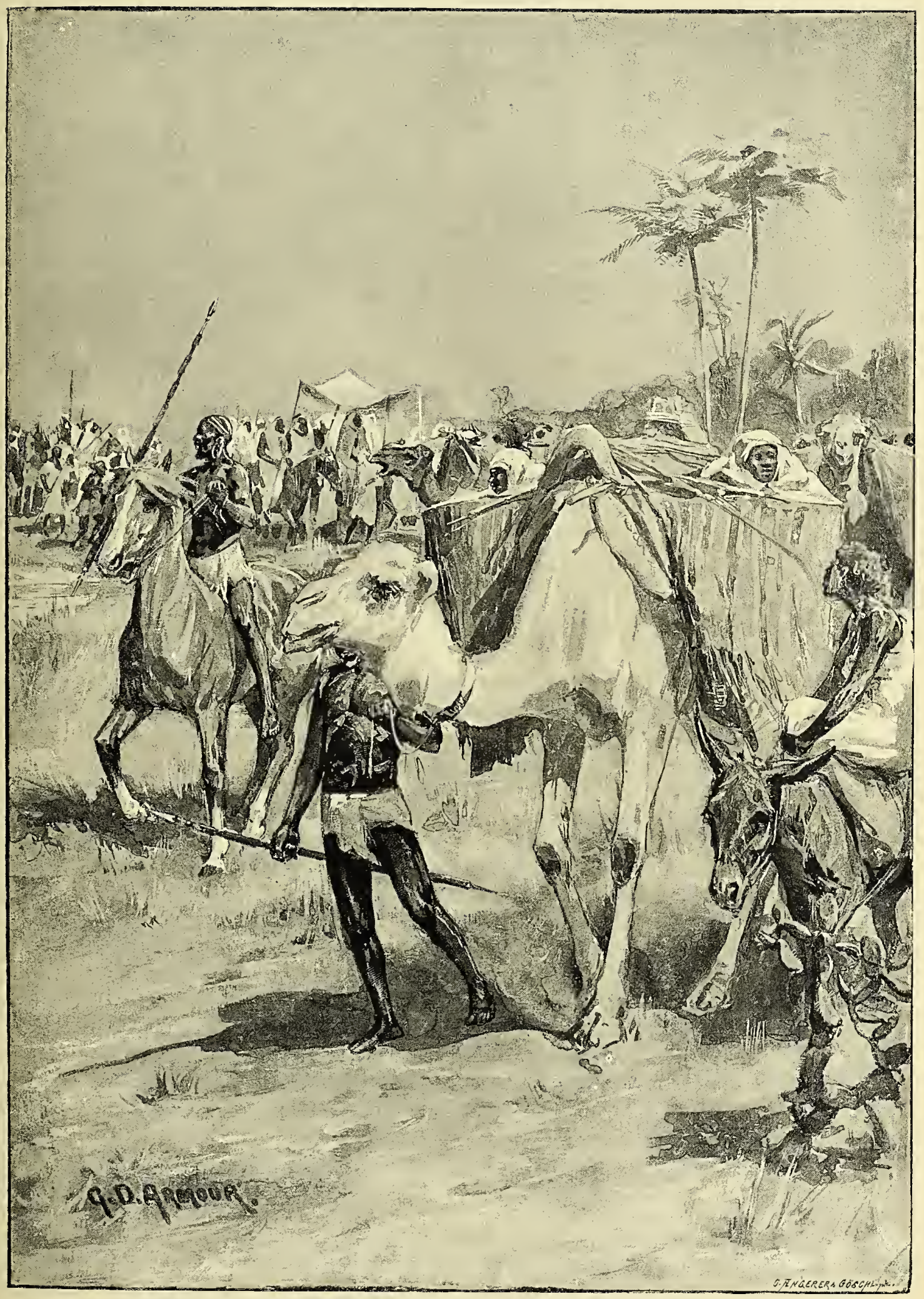

REMOVAL OF THE SIRATIK'S COURT: THE ADVANCE GUARD (p. 142). 
extorted as tributc from the factors and captains who came to buy gum and gold and men and women. So cagerly indeed were the benefits-material not moral-derived from the presence of the traders appreciated, that the jealousy usually entertained regarding the building of forts was either feebler than of old or, at all events, not so openly displayed. For liberty to establish factories on the river was readily enough granted, no doubt with the inward reserve that the white man should pay dearly for the privilege of selling his goods at his own time.

Yet, though the simplicity of former days was rapidly disappearing, a certain ludicrous sophistication still held its own among those who only by a courteous conventionality could be called the fair sex. At Ghoriel the latter opened a somewhat peculiar trade with the seamen of Briie's vessel. For some inexplicable rcason-founded, perhaps, on the same basis as that which attributes virtue to any substance in a dircet ratio to its nastiness-the women came to the conclusion that the bilge-water of the ship's hold was a sovereign remedy for toothache. Once this conclusion was arrived at, sufferers arrived from far and near to barter large quantities of milk for this evilsmelling liquid. The sailors naturally did not baulk the ladies in their wishes and, having fixed the price of this valuable commodity, would permit no abatement, gravely replacing the bilge-watcr in the pump when the amount of milk offered did not come up to their stipulated tariff.

Briie stayed for eighteen years longer in Africa, making many voyages along the coast and a little way into the interior.

Thus, in 1700, being at the French factory at Albreda, on the north bank of the Gambia, An overland he crossed that river to the English journey to fort that was afterwards called Cachao. Jannes's, but at that date bore the name of King William, where he was entertained by the Governor, with whon in former years he had had many discussions resarding the rights of their respective nations to the trade of that region. Sailing up the Vintain, or Vintang, tributary, which flows into the Gambia on the south sidc, the Frenchman came to a town of the same name, where again the English traders bccame his hosts. Here he was visited by the native chief, who went away very well pleased with the customary bottles of brandy. At that time many Portuguese lived in the village, and among the public buildings belonging to them was a church handsomer even than that at Jcllefiri, then the principal place on the Gambia, Bathurst, the present capital (p. 156), not having then come into existence. Some of these gentlemen paid the French party a statcly visit of ceremony. They were dressed in long black cloaks, with spados, or long swords, "thrust up behind." 'They had also "poniards long enough for swords, and long chaplets of beads on their left hands and hanging over the pommels of their swords. They wore broad Quaker hats, and long moustachios, and made their compliments with great gravity." Society in Vintain was, however, in a somewhat primitive condition, as Monsieur Briie, who was not prone to be too ascetic, soon discovered. Among the grandees whom he visitcd was a mulatto lady married to an English captain. He found her sitting, without any clothing at all, in the porch of her housc, surrounded by a number of her slaves, spinning cotton. Her husband was from home, so that the visitor had not an opportunity of making the acquaintance of this humanc gentlcman. But they heard a few months later that domestic infelicities having broken out between them-it must be admitted not without good ground on her part-he seized the black baby that had been the bone of contention, and had it "pounded in a mortar and thrown to the dogs." For a few months there was an injudicial separation between this amiable couple. After a time, however, they made up their differcnces and everything went on as smoothly as if nothing had happened to ruffle the ordinary course of life on the Vintain.

Bees in those days hived in the mangroves in such numbers that wax was to be had 
anywhere in almost ineredible quantities. At Jerefa, higher up the stream, were Freneh, English, and Portuguese factories that paid a ycarly tribute to the king. This sovereign, "a little squat man of a pleasant eountenanee," liad given his daughter in marriage to a Spaniard long settled here. Instead of, as usually happens in such ease, the spouse of the sarage wife being converted into a praetieal pagan, the husband claimed that he had argued his bride into Christianity, and that the king himself had seeretly abjured his aneient faith, a eourse of action in which it scems he had been confirmed by a miracle. For having been thrown over a precipiee by his stumbling horse, upon erying out "Jesu, my God, have merey on me!" he found himself, without knowing how, on his road again, "to the great amazement of those present." Don Juan Felipe-a slave-trader, yet withal a most religious man-had offered to be at half the charge of a missionary, which the Portuguese deelining, "it made him believe they were secretly Jews, who had only retired here from fear of the Jesuits' Inquisition. Although these gentlemen carry sueh large ehaplets of beads, it is eertain they live in no edifying manner."

From Jerefa they passed southward through a well-cultivated eountry, interseeted by earefully eonstructed eanals for riee-growing, the higher lands planted with millet, maize, peas of various kinds and water-melons of a superb quality. Excellent beef was to be had, and mutton was equally plentiful, though too fat, while poultry, eggs, and milk eould be bought at rates surprisingly low even to people aeeustomed to the moderate priees that then prevailed on the banks of the Senegal. Huge bats as large as pigeons suspended themselves from the branches of the trees, and were killed by the natives for food, after peeling off their brown skins, which were supposed to be poisonous. Large conical mounds attraeted the attention of the travellers, who supposed them to be tumuli. They were, however, only the ant hills now familiar to everyone in this region of Africa. To them, as well as to the worms, the eountry owes mueh of its perpetual fertility, for both earry to the surfaee the rieh unexhausted soil that is swept over the land by the rains.

But this fertile country had its drawbaeks. Every village was surrounded by a double row of palisades, and Brie passed one night in the house of a Spaniard, who had, at that early date, established himself thus far in the onter work, his dwelling being defended by four rows of stakes and eight cannon. This, however, was not to preserve him from attaek by the natives, for Don Juan, a native of Cuba, was on exeellent terms with his eustomers, few of whom failed to call upon him, or left without a needleful of the coloured worsted which they valued as adormment for the necks and sleeves of the shirts that they had begun to wear. Don Juan had, moreover, in the matter of polygamy, adopted the manners of the eountry. But the savage Flîps, or Felûs, were the terror of this region, and it was to grard against them that the dwellings of the richer folk were fortified in this way. These people dwelt at that time between the Gambia and the Cachao River, and gave great trouble not only to the negroes, but to the Europeans also, doing little business with the latter, preferring to live by plunder, though the more eivilised members of the raee had cattle and goats and cultivated riee and millet. But the wilder ones were reputed to be cannibals, barbarous and eruel, giving no quarter to any white man who fell into their hands. Henee the Portuguese knew them as Bravos, or savages. It was through the country of this race that Briie's route lay. As he passed along, well-armed and furnished with a suffieient escort, he saw a good deal of the Flups and their ways. In some of the many rivers and small streams that he had to cross, he notieed the natives' skill with the eanoe. With one hand the fisherman would steer his little eraft, holding in the other his bow and arrow, and instantly, when he notieed. a fish in the clear water, transfixing it with a shaft that seldom missed its aim. 
How primitive a period we are treating of may be gathered from the fiaet that though traders had been on the coast for at least two centuries, and had penetrated a considerable distance into the interior, at many villages the Flûp women crowded round the traveller, admiring his dress, arms, and above all his hair, which they would not believe to be of the Flûps. These factories, as was then the fashion-perhaps it would be more correct to say the necessity of the timewere mueh stronger structures than any force of natives could possibly capture. At one, fifteen guns were mounter on the pickets and bastions, and in all of them there were small garrisons of European troops, pallid

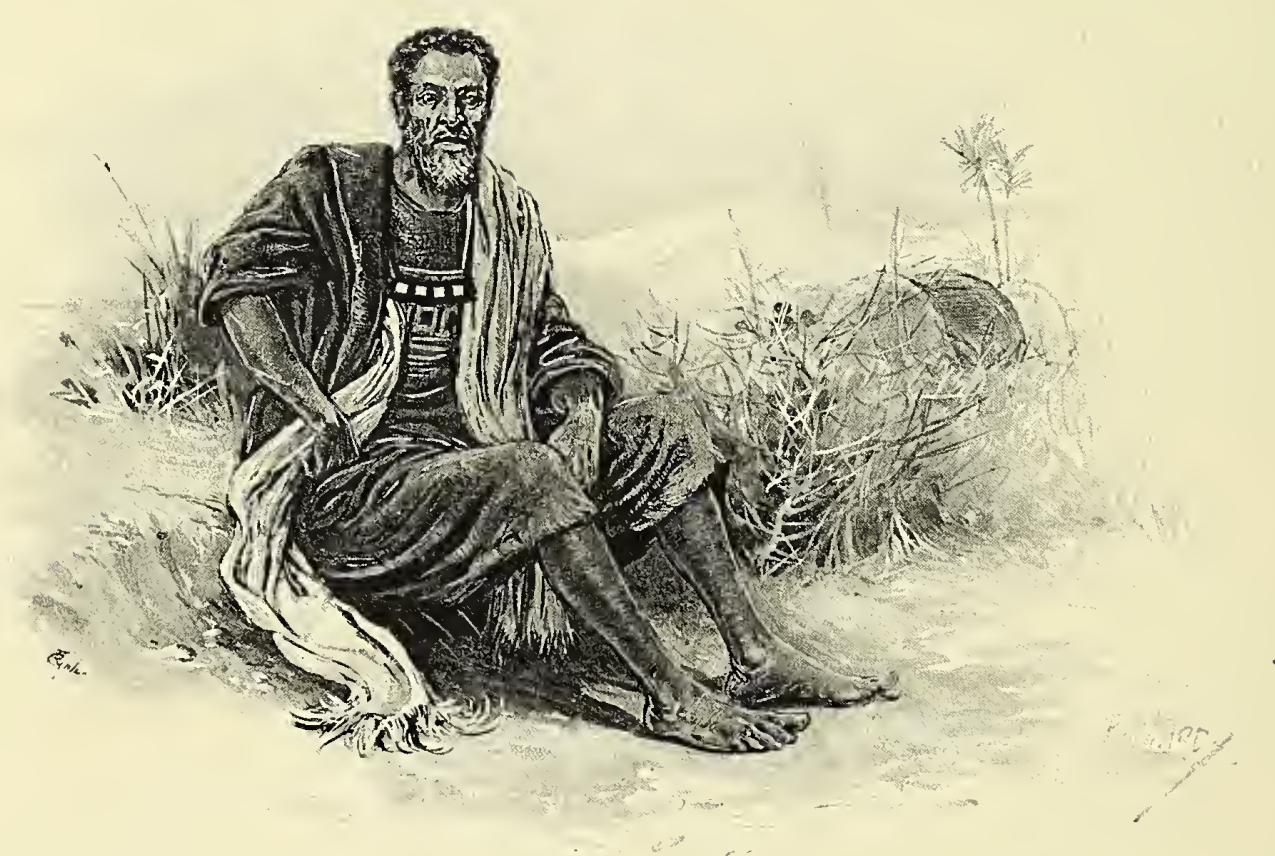

MANDINGO MARABOUT.

natural, as it hung down his baek. Few of them had seen a white man before. Wax was produced in great quantities and formed the chief article of trade with the Portuguese, who had established thenselves among then, living very much like the natives, and not more to be depended upon in a transaetion. From Jam, or Janez, he descender by canoe to Cachao, a Portuguese settlement on the San Domingo, or Cachao River, sailing part of the way down the Cassamanehe, which now flows through what is part of the French eolony of that name: but in those days it was dotted on eaeh bank with the forts of the Portuguese traders and the villages wretches who showed "by their swelled bodies and ghastly looks the unhealthy situation they were plaeed in." In fact, they had now and then to fight against pirate ships and to be prepared for the aeeident of war breaking out between Portugal and the eountry to which a passing ship belonged.

Declining the hospitality of the eommander at Boyta, the energetic Freneh trader pushed forward to reaeh a rivulet by which he might enter the San Domingo. But night overtaking him, he was soon lost amid the swamps made by the network of streams and divided months into which so many of the West African rivers split up in flowing through the delta 
formed by then just before reaching the sea. Bewildered by the geography of the country, the party were glad to take refuge in a Bagnun negro hut for the night, reaching, next evening, by the aid of horses and donkeys supplied by the King of the Bagnuns, Ghinghin (Zighinchor), a populous place, where the Portuguese had plantations worked by the "Gromettoes," or slaves, and doing a large business in wax, then naturally more valuable than in our day when gas, the electric light, and petroleum have so largely displaced candles. Bees and flowers and fruit-trees abounded, and swarms of monkeys preyed on the gardens and plantations, though with a prudence begot of long experience they avoided meddling with the bees.

Among the intricate interlacement of streams hereabouts the Flûp pirates were in those days very busy, often waylaying small ships and, if successful in their plans, murdering and robbing without the slightest compunction. So bold indeed were they-and well into the next century they practised the same manœuvres-that they did not at times hesitate to swinl after the vessels when canoes were not at hand, and endeavour to climb on board in the teeth of a murderous fire from the deck. On the way to Cachao, down a pleasant river bounded with citron-trees, Briie net with an English bark that had arrived from Lisbon with wine and fruit, by the commander of which he was received with the distinction due to his rank, and among other curiosities shown a swarm of bees that had settled on the rigging and were already busy at work.

Cachao was in those days, as it is in ours, a Portuguese town, heavily fortified against cachao and the "Papel negroes," who bore no its society. love to their masters, though except for the purpose of trade the place was of little value. Beef was scarce and dear, goats were few in number, and sheep and pigs non-existent, and, with the exception of a few patches of rice and maize, the waving fields so common a feature of the more inland country were absent from this low, swampy, miasmatic delta of river-silt. The houses-even the best of them-were poor cabins of mud, one storey high, roofed with canvas in the dry season and with fan-palm leaves in the rainy months. Every night heavy dews fell, and the clammy mist that rose from the estuary and the marshy flats when the sun went down was to the Portuguese of those times, as it is to the West Coaster of ours, the familiar harbinger of fevers and other death-dealing pests of this

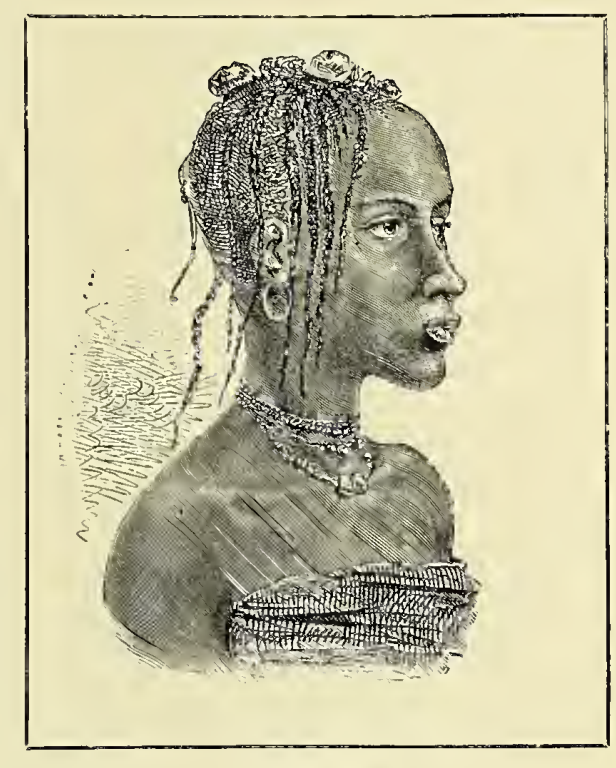

FULAH GIRL.

lovely though dangerous portion of Africa. Even the church, in a Portuguese or Spanish colony usually the most prominent building in the place, was a poor affair, and the priests, like the Convent of Capuchins with its two friars, were among the most poverty-stricken of their order.

But the excuse was that "they had so little to do." Not that their flock was particularly pious. On the contrary, from the highest to the lowest the Portuguese in this sickly port were-as they are prone to be even yet in Africa-not by any means desirable acquaintances. The garrison, which was changed every three years, was composed of 
criminals banished fron Portugal, and so wretchedly paid that, instead of being a protection to the civil population, these cut-throats were the terror of everybody with anything to steal. Fires were of frequent occurrence, most of them incendiary, and it was a common belief that they were due to the soldiers, who hoped in the confusion to benefit by annexing their neighbour's' goods. To add to the miseries of this African swamp, rain fell so frequently and in such abundance that Cachao bears even yet an evil reputation among the West African Colonies.

The picture that Briie supplies of the life of this early Portuguese settlement may be accepted as typical of many others on the coast, and explains how the people of that country, though earlier than most others in Africa, have to-day the surallest share of it, and are more retrograde than any other colonists on the continent. Indolence was the rule, industry the exception. Though every article of food was costly, nobody took the trouble to breed poultry. Accordingly, when anything was wanted-were it only water-they had to go more than a musketshot beyond their enclosure, and often with a guard to defend the slaves from their mortal enemies the Papels, many of whom lived in a quarter of the place known as the Villa Quinta. Vice of every kind was so rampant that the confessors had to take certain forms of it for granted and absolve the perpetrators without more ado. Ordinary decency was quite thrown aside, though in the matter of food the Portuguese of Cachao were, like all their race still, generally very sparing. Meat was eaten but once a day. Supper was always of fish, quantities of which of a poor quality could be obtained from the river hard by, though the abundance of alligators rendered angling a risky pastime, had the whites cared to indulge in any such exertion; and as guavas, oranges, citrons, and all kinds of tropical fruits, wild and planted, grew in great plenty, every meal began with a course of this suitable diet for a hot climate.
Slaves did all the work, though even these so mixed with the colonists that it was difficult to define where Portugal ended and Africa began. Half the so-called Portuguese were, at this early period, more blackamoor than Caucasian, and as the same miscegenation had been going on in all the other settlements along the African coast, the fact that Lisbon, Oporto, and other towns trading with Africa, have long been tinctured with negro blood need not cause amazement. For the exploitation of Africa has, among other influences upon the mother country, almost entirely transformed the city population of Portugal, the peasants in the interior and the higher classes ahmost alone escaping the general contamination of four centuries. As house-breaking was easy, owing to the walls being of mud, most people kept European dogs to bark (the native ones being usually bereft of that capacity), and a light burning all night, besides servants on the watch, who as soon as they heard any rogues moving fired upon them. A patrol paced the streets every night, though, as the inen often turned robbers and had the right to question everyone they met, it was rare for anyone to escape the professional thief or the policeman who was set to catch him "without losing your hat or cloak."

But the most extraordinary institution of Cachao in 1700 was what was known as the "Bravos," white savages or assassins, who seem to have been a very truculent imitation in Africa of the Mohawks and Scourers who at an earlier period rendered it inadvisable for any without urgent business to stir abroad at night in the streets of London. The dress of those night adventurers was peculiar. "Conceive," writes the old traveller, "a man who above his clothes hath gotten a leathern apron, with a huge flapping bib, which covers a cuirass of mail or half-suit of armour. This apron, which falls but four fingers' breadth below the waist, is full of holes, in which are stuck two or three pairs of pocketpistols and a brace of poniards. The left arm is charged with a small buckler, and the 
hip with a long sword, or spado, whose scabbard is split, and flies open with a spring, to save the time and trouble of drawing it. When they go out on business or recreation this equipage is covered with a black cloak reaching down to the calf of the leg. But when they are upon an adventure, or fight a duel after the Portuguese manner, that is to assassinate somebody, they add to all their arms a short carbine or blunderbuss with a narrow mouth, and loaded with twenty and twenty-four balls, and a quarter of a pound of powder, with a forked stick to pilot it. To complete the dress, there is a large pair of spectacles, well fastencd on the ears and affixed above the nose. When the bravo, thus equipped, arrives at the place of battle, he plants his carbine, gathers his cloak over his right hand, and in this posture bravely waits for the person who never thought of him. As soon as he sees him he bids him talie care, and fires. It is hard to miss, for these pieces scatter their balls so as to cover a gate. If the unfortunate person is not quite dead, he says a 'Jesu Maria' over him, like a good Christian, and despatches him." Sometimes, however, they met with their match, in which case the braro apologised in the grandiose fashion of his comtry, saying that it was all a mistake, but that the unfortunate mishap will teach him all the better to keep a sharp outlook for the person who was the unfortunate cause of the worshipful caballero having been subjected to the inconvenience of being shot at. This state of matters made, as the dignified General of the French Traders gravely remarks, a walk in the evening a perilous pastime in Cachao or, indeed, in any other Portuguese colony; for in all of them the same rule of ruffians prevailed. In the dark you were sure to be attacked, and if a link or a lantern were carried then every rascal had an excellent target from his hiding-place in some gloomy lane. "Smorcar! Put out your light!" was the cry, and if the order was not promptly obeyed, the chances were you would have the bullets whizzing about your ears.
Better far, thercfore, to walk in the dark, with your hand on your sword, and, whenever the sound of a guitar was heard, to take a direction as far from the serenader as possible. For the guitar-twanger, while intent on playing court to his inanmorata, had no mind to be disturbed. For as sure as the stranger passed under the window where he was engaged, the long spado was drawn, and the order "to the right" or "to the left" given in a voice which, unless the pedestrian was prepared to dispute it at the sword-point, had better be obeyed. Otherwise, "a dead man for Matins" would, as in Idaho in days not too remote for the writer to remember, be the languid gossip of next morning.

In such a sink of iniquity Portuguese women were few, and those not of the highest grade. Naturally also, no respectable dame cared to stir out of sight of her own home, in daylight or dark, or even to go to Mass, unless attended by her husband or brother as an escort. Moorish seclusion was the rule. Everybody except the negro slaves went veiled and robed so closely that only one eye and the toes could be seen-a custom still common in many parts of Spain and Portugal, and until lately the regulation dress of the ladies of Lima. So jealous were the men, that when one friend visiter the house of another it was regarder-as in a strict Mohammedan family_as a breach of etiquette to ask after the host's wife, far less to request an opportunity of paying his respects to her. "For either of these impertincnces is enough to risk a duel, or get the wife stabbed or poisoned."

Trade-as in Portuguese Africa still-was by no means "free." Nominally, it was strictly confined to the Portuguese. However, as the business done with Portugal was insufficient to make anybody rich, the "Sindiquanto," or Intendant, was quite ready-so long as it was made worth his while-to wink at this article in his instructions. "And if you do but save appearances, there is no difficulty in trading amongst them. Nay, it is said that the Company's officers themselves 


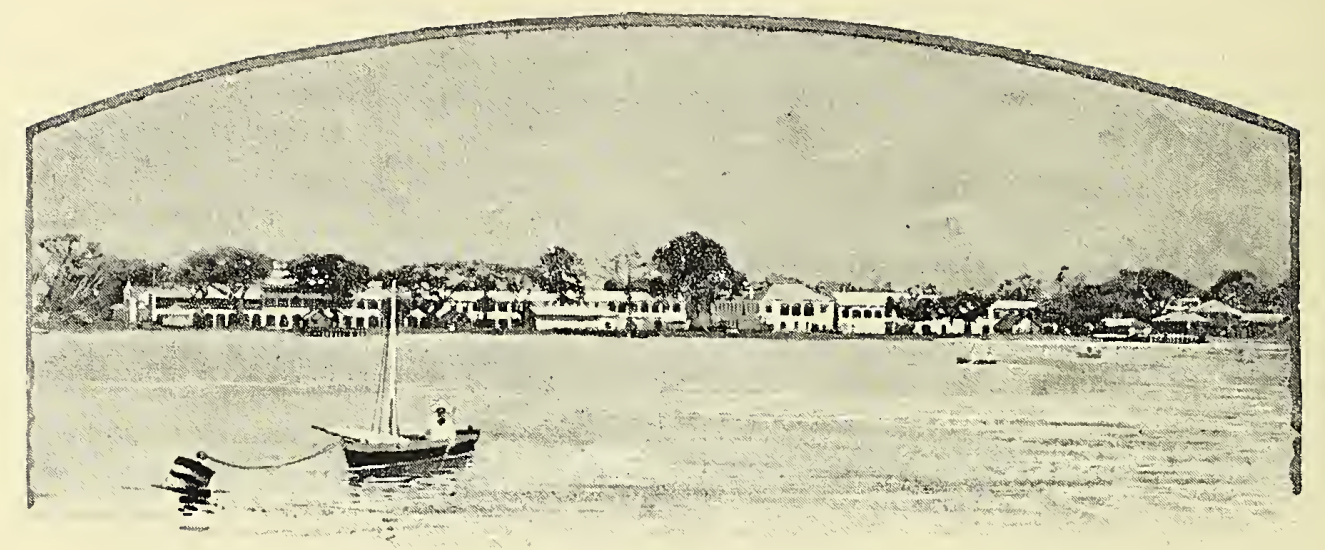

ST. MARY'S, BATHURST.

are the best-natured in this way; so that you will always find ressels of French, English, Dutch, and other nations who put in here nuder pretenee of wanting water, or some other misfortune," and bring off wax instead of water-butts.

And as it was in the days of the Siem Brie, so it is in ours. Trade, it is true, has altered Present somewhat. Ground-nuts, from

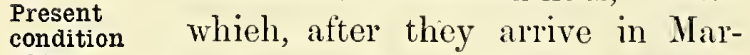
of the seilles and Lisbon, "the best salad country. oil" is expressed, and Kola nuts, with a little eotton, now form the prineipal trade of this colony and of the French possessions hard by. Maize and millet are raised in small quantities, rice in the swamps about the town, and at times some indigo has been exported. But the tapping of the palm-trees-whieh cannot be eut down to get at the tender terminal shoot, whieh forms so delieate a dish, unless by the payment of a lordly price-is the business of a large portion of the population all along the eoast. Thousands of gallons of this insipid liquor are every year carried to Bathurst and other settlements in the Gambia and Senegal eountry for the delectation of people who like a drink that, when fresh, tastes like sweet turnips, and when ferinented like soapsuds flavoured with gin, and is in no respeet wholesome, causing dysentery in Europeans and fearful evil diseases even in the more bibulous natives. The Mandingoes-that curious raee of Mohammedan negroes of whom we have already spoken-are the principal people all over this region, eompeting with the Joloffs as traders, the "nrarabouts," or priests (p. 152), being not only the teaehers of what little learning there is, and of the Koran, but, as we have seen, the commereial travellers and middlemen of the country. But the Jolas, the Flupss, and the Balingi-the Balongs of Briie's narrative-are still powers in the land, though no longer permitted to ride roughshod over their neighbours. Antelopes, gazelles, wild boars, leopards, and even lions, are still often seen, croeodiles are too frequent by far in the rivers, and the hippopotamus does not seem in all these years to have inueh diminished in number. 'The little red monkeys still toss leaves down on the traveller, and if they had the strength would toss something heavier. Pigeons eoo in the roods, and the guinea-fowl may, on any river away from the coast, be seen drinking at the water's edge. White egrets are common features of the green plains, which here take the place of the dense forests farther south, and often at night the inexperieneed traveller will be awoke by what sounds like the blast of a horn. But it is only the trumpet-bird calling to his mate. In the Mohammedan villages the order and dignity inseparable from even the least fanatieal observanee of the Prophet's law 
contrast with the squalor and open vice of the pagan settlements. The marabout intones the Koran, and at early dawn and evening the hum may be heard of a village schoolmaster seated in the centre of a circle of boys learning to read from a scrap of the holy book on a bit of board, like the horn-book of old England, or laboriously forming Arabic characters in sand or by means of a bit of charcoal. But the pagan knows no letters and cares for none. His chief business is to marry, and were it concerned-the bravos excepted-thougn, in truth, West Africa is not the region from which one expects the highest ethical lessons, as we shall learn when the story of colonisation comes to be told in these volumes.

Briie during the eighteen years he passed in "Guinea" never again travelled so far afield, nor went as high up the Senegal as Galam, not for the necessity of obtaining the wherewithal to purchase a wife or a waist-cloth, he would be loth to stretch those manly thews of his. When he acquires a comfortable matrimonial stock, like all Africans, he lives at ease. For the female members of his family do what work is to be done on his provision-patch, tap his trees for the niaterials for a mild debauch, and, when a little ready money is desired, the disposal of a daughter will supply the funds. Where the English or French hold the reins, the country is at reasonable peace. Great wars are not permitted, and fighting, beyond what is required to let off the accunulated prejudices of tribe against tribe, or pagan against Moslem, is usually put down with a strong hand, more especially when these quarrels affect the white man's interest. But, as the Portuguese settlements were in Briie's day, so they are still, so far as enterprise, and perhaps morals, are

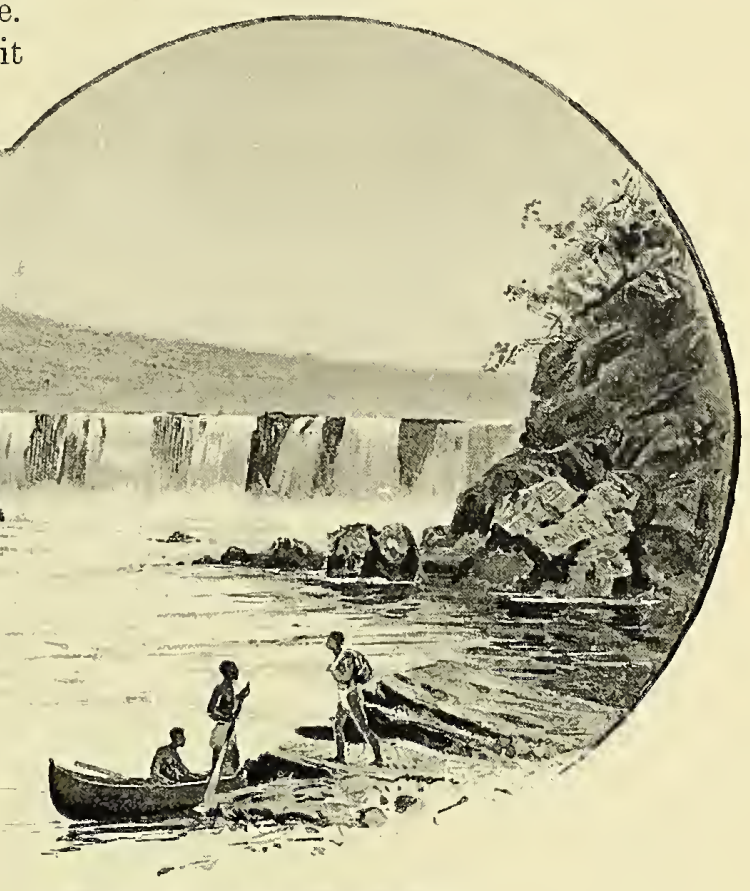

FELOU FALLS, UPPER SENEGAL.

though his agents established posts there, and carried on a prosperous trade with the natives, thus laying the foundation of the present colony in Brue's that region. He, however, visited plorations the gum forests on the north bank of the river, and had many dealings with the King of Hoval-who in those days was subject to a potentate that dubbed himself, as was the fashion then, and is yet among the African princes, the Great Brak, "King of Kings"and other dignitaries who had, as late as the beginning of the eighteenth century, mingled so little with Europeans that people of the first rank crowded from far and near 
to have a look at the white men and a share of their brandy and other good things. But with these minor joumeys we necd not conccrn ourselves : they had nothing to do with the search for Timbuctoo, though Brijc ncver ceased to make inquiries about that city, or to accumulate information on the subject of its trade and the motley races that crowded to it. Brie seems to have becn intelligent and encrgetic beyond the capacity of his superiors in France to appreciate, for he had continually to urge them to take the most necessary steps for reaping the advantage of the treaties he formed. The fort which he urged them to build near Dramanet was placed on too low a position, so that at the first flood it was swept away, and during his absence in France to justify himself before the Company, the less prudent agent left in his place managed to dissolve the good undcrstanding that Briue's adriress had cstablished between the French and the natives. The result was that, by dint of numbers, the latter cut off all supplies from the fort that replaced the onc destroyed, and thus starved the inmates into surrender, after which they razed the building to the ground. Then for a long time we hear little of the Upper Scnegal. However, in 1713, the Sicur Richebourg succeeded in re-establishing the factory at Mankanet, a little below Dramanet, and as Briie returned to the government of the Senegal trade in the course of the following year, the opcning up of the country went on again.

Factors were despatched in all directions, one of the journeys which he was very anxious to have undertaken being to Bambuk. To this country, accordingly, several of Briie's agents sct ont, but after proceeding a Campagnon's little way on the road returned, journey to terrified by the reports of the Bambuk. jealousy with which white men werc regarded. At length Campagnon, a factor of higher courage than the rest, undertook the mission, and by insinuating himself into the good graces of the Farim of Kagnure, a town some forty-five miles up the Falemé, on the frontier of Bambuk, obtained the escort of that chief's son as far as Sambanura. Here he was regarded with mingled feelings. Some wcre for killing him ; others, more moderatc, considered that the very lcast that could be done was to remove the intruder out of the country, with a warning never to return. However-such is the emollient influence of tradc-the disposition of the country suffered an entire change as soon as the traveller opened his stores and began to distribute presents to this one and to barter on what they thought excellent terms with another, until before long all Sambanura regarded the factor with such goodwill that they began to thank Heaven and the Farim of Kagnure's son for conducting him thither. Guides to other towns were speeaily forthcoming, and though at first he had invariably to ovcrconse the same prejudices that he surmounted at Sambanura, in the end the tact of the Frenchman and the attractions of his packs had the samc effect-a favourable reception was usually accorded. In a year and a half this intrepid pioncer traversed all the more important regions of Bambuk. Nevertheless, in one respect he never quite succeeded in disarming the natives' jealousy. In vain did he affect a desire to make tobacco pipes-as they did-of the "ghingan," or golden earth, for which the country is famous. The region in which this is found most copiously was regarded as sacred ground. Even those most kindly disposed towards the stranger regarded the very act of his touching the pride of the land and the source of its wealth as close akin to high treason. All his arguments failed to convince them. For, as they truly remarked, it was idle to suppose that any man in his senses would undertake so long a journey simply to obtain material for the purposc he affected.

The result was a renewal of their old suspicions as to the white man's motives, and the Mandingo traders, who had hitherto had a monopoly of acting as middlemen in collecting and selling the gold, did their best to raise in the path of Campagnen the obstacles 
that had, years before, prevented the journey of so energetic a pioneer as Brother Apollinuire, who, after serving the Royal Company in the capacity of a surgeon, had taken the habit and returned to Galan as its factor. Indeed, by this time there were nnany agencies at work against the French. The marabouts, or priests, were, of course, at no time their friends. Fanaticism and the self-interest of saints that were also traders, operated in rousing their jealousy of the newcomers, conquered, all men fit to bear arms carried into slavery, and the rest set to work in the mines. However, in spite of this jealousy, the patient Frenchman, by dint of bribes and fair words, succeeded in obtaining all he wished, and opened up a commerce that for many years yielded great wealth to all concerned, and, as we shall see when the influence of the reopening of the gold diggings of Africa by white men is described, is still an important factor in the trade of Senegal. But this was

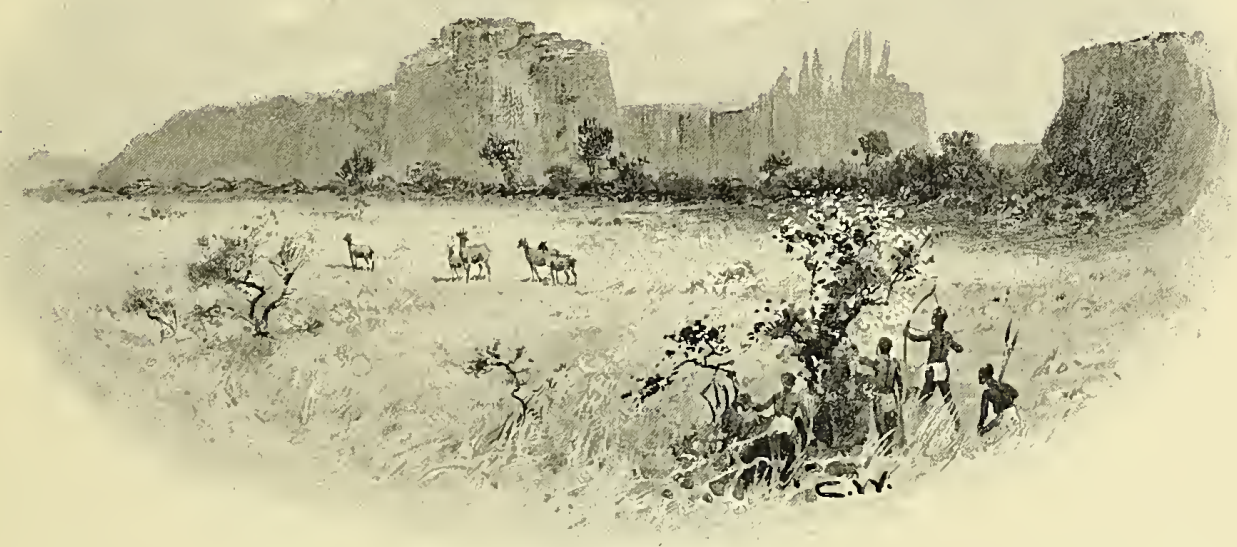

MOUNTAINS IN BAMBUK.

while from Southern Guinea came evil-disposed reports, through the caravans, that the French were dangerous folk to know, insinuating themselves by promises and presents, and, then, after they had gained the upper hand, throwing off the mask and beconning masters of the natives. Nor were the Moors, from the same motives, amicable to infidels who were their rivals in trade and inficlels in faith. For other sinister influences afloat we hear of a letter which came to Senegal, all the way from Sallee, the pirate port of Morocco (p. 105), intimating, evidently with a view to alarm the natives, that the French were to be joined by a Mloorish army, their country not in André Briie's day. All his representations regarding the ease with which Bambuk could be conquered, or the alternative policy of gradually boring into the country little by little, had no effect on the apathetic Company, too well served by agents whom they could not appreciate. Yet for many a day afterwards the French did not neglect every opportunity of making themselves familiar with this region-Levens, Pelays, Legrand, and David all visiting it long before Park's journey rendered it a familiar name in English mouths.

This was, however, a far cry from the early years of the eighteenth century when the 
Sieur Brie, after many other adventures and some petty wars, returned to enjoy in Franee the fortune he had earned in his arduous labours. His after-life is not known. He kept voluminous journals, but he printed nothing himself, and had it not been for the industry of a clerieal friend the world night have lost a eurious ehapter in the history of the early exploration of Afriea.* As for the Sieur Campagion, who shared with him in the merit of being one of the pioneers in those early diseoveries, he also returned to his native land. This little-remembered factor-for he was so unfortunate as to live in a day when every year brought forth a score of travellers with stranger tales than his to tell-had in him the makings at once of a diplomatist and a hero. Among other romantic tales told of his eonduet, it is said that one day, returning

* Labat: "Nouvelle relations de l'Afrique Occidentale," 's vols. (1728)-consisting mainly of the narrative of Brüe's travels ; Dumanet, " Nouvelle histoire de l'Afrique française," 2 vols. (176i) ; Henrique: "Les Colonies I̊rançaises," vol. v. (1891), etc. to Fort St. Louis (p. 141)-now a town of the same name- he found a lioness which had long been kept in captivity dying outside the walls. The poor animal had been seized with a distemper in the jaw, usually fatal to the species, and, unable to eat and reduced to the last extremity, had been thrown on the dunghill to perish. Campagnon, seeing some life in the sufferer, though her eyes were closed, and her gaping mouth full of ants, took pity on the creature, washed her throat with water, and poured some milk down it. This saved her life, and ever afterwards the grateful animal eoneeived sueh an affection for the person who had done her this good office that she would eat nothing but what he fed her with, and followed him up and down the Isle of St. Louis like a dog. Yet history, which would fain have had a more picturesque ending for the eareer of a man who had begun it so romantically, is forced to confess that he died many years afterwards a prosperous master mason and undertaker in Paris.

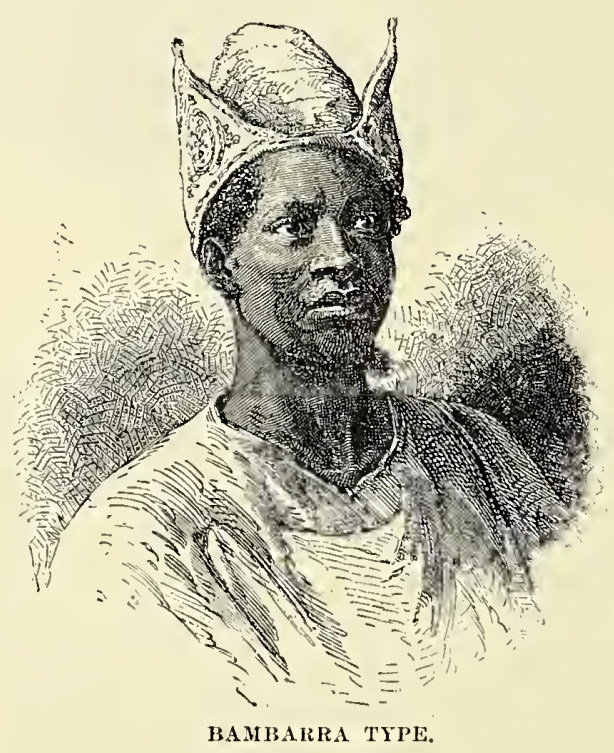




\section{CHAP'TER VIII.}

\section{The British and the Niger: the African Association.}

The Vast Profits of the African Trade-Longings of the English to Discover the Wealth of Inner Africa-The Voyage of Bartholomew Stibbs up the Gambia-Its Disappointments-His Belief that the Gambia was not the Seaward End of the Niger-Harrison's Voyage in the same direction-The Strange Tale of Job ben Solomon, the King's Son who was taken for a Slave-Its Influence upon the Renewal of African Exploration-Growing Familiarity of the Natives of the Senegal and the Gambia with White Men-Their Insolence, Drunkenness, and General Depravity-Some Specimens of "Kings in their Own Country"-The Traders and the Natives-General Decadence of even Commercial Decency in "the Rivers"-Curious Trade Customs-Numbo Jumbo-The African Association : its Founders and Early Agents-The Beginning of Exploration in Earnest by Men who were not Traders, but Travellers-Ledyard-Lucas-Watt and Winterbottom-Houghton-Hornemann-The Coming of Mungo Park.

Exploning in the days when the eighteenth century was young must have been a much more profitable occupation than in the closing years of the nineteenth. It paid its way, which, perhaps, many of the gentlemen whose tales will be told in these volumes may be ready to vouch is not the case at present. Thus, when Briie returned from his journey to the acacia forests, he had in his possession 400,000 pounds of gum, besides slaves, ivory, ostrich feathers, and anbergris washed ashore on the coast and traded from tribe to tribe as a precious flavouring substance, while the number of negroes despatched every year to America and to Enrope was, we have seen, prodigious. In two years - 1685 and 1686-1,800 were bought at the Bissao and Bissagos Islands alone, and next year nearly half as many, not, of course, taking into account the cargoes picked up in every river, north and south. Hence, even with a little loss from plunder by the natives and peculation by the factors-luxurious gentlemen who, according to the frank tales told by Brie, had slaves to wash their feet and comb their hair-the profits ought to have been great. Yet we know that company after company failed, and forts changed hands with such amazing rapidity that until we consider the story of the African colonies that began in trading-posts, the history of their ups and downs had best be left unwritten.

The English, we have already learned, had 11 not been exempt from these vicissitudes. They, too, had dreamed of Timbuctoo, and by the beginning of last century had been infected by the general longing to reach the interior from whence came the merchandise sold to them by the wily middlemen at profits altogether disproportionate to their trouble. The royages of George Thompson and Richard Jobson had not been forgotten, though, in a way, they had not been successful, and the stories brought back to London and to the Gambia factories of the enterprise of the Frenchinen fired once more the English traders to discover whether in the interior there was more wealth than had hitherto been brought to the coast. One of these tales was that of a merchant in Charles the Second's day, who we now know was called Vermuyden, though, according to his own account, he carefully concealed his name lest he should be sent by the Government on another such expedition as that which he records. From this not altogether indisputable narrative, ${ }^{*}$ this merchant, after accumulating much wealth on the Gambia, had visited some of the interior gold-mines, washing sometimes as much as fifty-seven grains of gold from ten pounds of sand, a "prospect" good enough to rejoice the heart of a Californian or Australian. The explorer, however, gives us little indication of how far he ascended the river, or any account * It was found among Dr. Hooke's Posthumous Papers. 
of the country except that while engaged in "rocking" the sands he was attacked by an incredible number of baboons, who would "listen to no oratory but guns," and who but for this species of persuasion would, he believes, have torn the party to pieces. At night a hippopotamus drove its teeth through their boat, a mishap that was avoided in future by hanging a lantern over the bows, these animals always keeping at some distance from light shining on the water. The prospectors, though provided with mercury, lead, and borax for amalgamating purposes, seem to have possessed little practical knowledge of gold-mining, a species of lore at that time difficult for any Englishman to obtain; for they would sometimes bring iron pyrites to the boat, under the notion that it was the precious metal, and were at times induced to try the divining-rod, though this instrument was never successful, possibly, the author suggests, because its virtues had dried up during the voyage from England to Africa. The entire narrative of Termuyden is, however, tinctured with suspicion. $\mathrm{He}$ is too vague for the geographer, and though he is enthusiastic over the gold, no one has since his journey discovered the deposits from which he washed what "surprised him with joy and admiration," while the names and descriptions of the places passed look as if they had been taken from Jobson. However, Bartholomew Stibbs, who seems to have read his journal, expresses no doubt as to the truth of Termuyden's story. Tet, if he did actually make the voyage he describes, he must, from the fact of his having been absent three months after passing Barrakonda, have gone far beyond any previous explorer, assuming that he did not loiter a great deal on the way, since Jobson spent no more than twclve days in covering the distance he went beyond the then bounds of European knowledge of the Gambia. Be that as it may-and, as no one lias seen Termuyden's journal except Stibbs, the doubt as to its authority must for ever remain unsolved-until the mariner just mentioned made his royage, the interior of Africa had been left undisturbed by Englishmen, who were now to enter upon that course of exploration which they have ever since pursued with such unremitting industry. The Dutch and the Danes never made any pretence of advancing knowledge. They remained in their factories on the coast, attending strictly to business, and leaving to others the task of pulling the chestnuts out of the fire for, as they hoped, the traders who had done nothing to help them. As for the Portuguese, they seem to have, at a very early date, abandoned any notion of competing with the Northerners in this region. They still kept factories and forts on the Guinea Coast and its islands (p. 45); but it was to Angola and the eastern side of the continent that their principal attention was given, and from which their journeys into the interior were directed. In these circumstances the Royal African Connpany, under the enlightened presidency of the Duke of Chandos, saw their chance. Its trade, as we have shown (p. 50), was not prospering: receipts were great, but expenditure was greater, and profits consequently were nothing. It was therefore resolved to find, after the English fashion, new markets in the interior, or, at least, new sources of gain that even the slave trade did not afford.

Accordingly, in 1723, Captain Bartholomew Stibbs was despatched on a voyage up the Gambia. At James Fort (p. 59) he found that the governor to whom he was accredited had succumbed to the clinate, and that the factor was in no way inclined to expedite a journey from which possibly he foresaw little to his advantage. Canoes, the new-comer was curtly told, were not to be had, and, just as Captain Stibbs was in hope that an indignant letter which he had despatched would arouse this gentleman from his lethargy, his dead body was brought down the river in the Company's pinnace. He, too, had perished of a mental disorder, brought on by the miasma of the Lower Gambia. A month had thus been lost, the river was falling, and some of the explorer's best men were dying or dead, before they could set out on an 
expedition that was already widely bruited abroad as a gold-hunt. Up to this date no such well-found party had ever set out on such an errand. It consisted of fifteen Europeans and thirty Africans, besides women and boys, who, not being on the payroll, did not count as members of the expedition. There were beside a "linguister," or interpreter, who, being a Christian, considered himself a white man, "though as black as coal," and a "balafeu," or native musician, to "cheer up the men and recruit them of an evening." Swarms of locusts, four or fire miles in breadth, had eaten up the country before them, but wherever they passed the tribesmen displayed the same eagerness for trade that had been their characteristic when Jobson visited the region more than a century before. So anxious, indeed, were they for traffic that at places on the banks they erected, as their countrymen still do, rude fetishes, or charms, in the shape of crossed sticks, under the notion that this would induce the strangers to come ashore. As they neared Barrakonda, the natives declared that beyond that part all was barrenness and desolation. Stibbs, however, believing that this was a falsehood simply to obtain for themselves a monopoly of the trade, pushed on. But at Barrakonda he found one of those monuments of the slave trade with which so many subsequent travellers have become too familiar. This town was a mass of blackened ruins. No people were to be seen at a spot once the centre of a flourishing market for all the surrounding country, and the spacious plain stretching for miles back from the river was no longer' grazed by cattle. All was desolation; a slave-hunting king had destroyed the place and carried the inhabitants down the river for sale to the English factories.

The sight was doubtless not a pleasant one, and to the negroes of the party seemed so suggestive of the fate that might await them that they refused to proceed farther. Beyond Barrakonda, they declared, no man had ever yet proceeded. It was the end of the world most likely, or, if there was any country farther to the east, it could only be a country, of savages, to travel among whom would be simply putting the lives of the entire party in danger. No arguments were of avail. In vain the diplonatic Stibbs tried to persuade them out of this folly. To no purpose did he endeavour to frighten them into obedience: they knew when they were well off, and had no intention eitler of being eaten or enslaved by the mythical folk beyond, or being starved to death in the desert, should this region be without inhabitants. Then the astute sailor resorted to the ultimate argument of all: he produced a brandy-bottle and told the timid Gambians to consult this oracle. The result was what he expected-all fear ranished, and in a few hours they were plying their oars, determined to go as far as the Europeans; with another bottle in their heads they would have agreed to go even farther.

The Barrakonda "cataract"- a barrier (in the dry season) formed by a ledge of rock crossing the river-bed-passed, they found that the world went a long way beyond. Not only was there country, but people living in it; and, so far from being truculent inonsters, they were a harmless folk, who supplied the travellers with plenty of fowls and other provisions. But crocodiles, baboons and hippopotami became troublesome; and, worse still, the sand-flats and shoals were so frequent that, often sticking fast in midstream half-a-dozen times a day, Stibbs was compelled to return without even reaching as far as the limits of Jobson's voyage. This was 'Tenda, still some distance ahead.

As might have been expected, Stibbs seems not to have been receired very warmly by his disappointed employers. Even The strange the traders on the lower river,* who history of were in Job. Son of outsiders from ho we to solomed outsiders from home being sent on such missions-albeit they had no wish to go on them in

\footnotetext{
* Among these was Francis Moore, of James Islanr, who published Stibbs's journal in the appendix to his "Travels into the Interior Parts of Airica" (1738), with an Introduction which in another place I have ventured to sugrgest was one of the earliest pieces of work executed by Samuel Johnson for Edward Cave, the publisher.
} 
person-accused him of "undertaking to prove that the Gambia was not the Nigcr, nor a river of long course," in both of which conclusions the explorer was perfectly correct. It would appear, however, from incidental refercnces in his narrative, that though Stibbs was the first voyager up the Gambia of whom any record has becn kept since Jobson made his attempt to reach Timbuctoo by that route, there had been other minor essays in the same direction during the interval, but, from no account having been preserved, the probability is that neither proved nor disproved the identity of these streams with the Niger, was the story told by Job, Son of Solomon, "a king in his own country," but at the time we make his acquaintance a "negro servant" in the colony of Maryland. It was so romantic, so instinct with possibilities, that it seized the popular imagination, gave a fresh start to Afican exploration, and, one would fain hope, sowed the seed of that detestation of the slave trade which in after-years produced so plentiful a crop. Job was the son of a chief of the

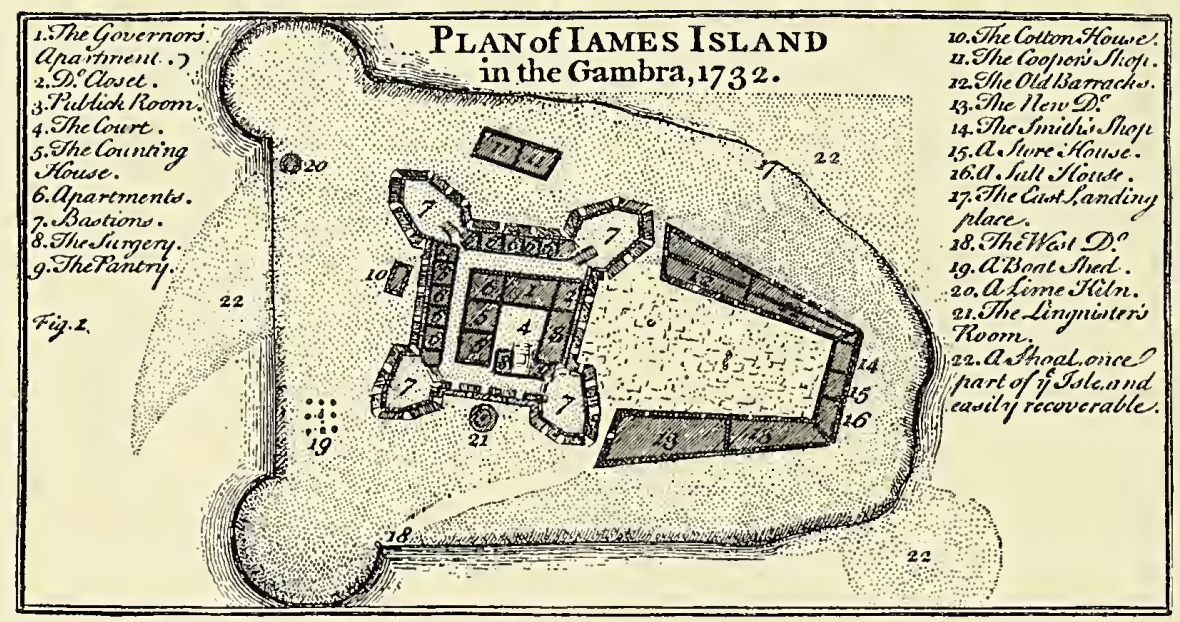

PLAX OF JAMES ISLAND, IN THE GAMBIA, 1732. (After an old Print.)

they were all failures, even more pronounced than his own. Nor was Stibbs the only explorer of English name until the era of the journeys made under the African Association set in: for in 1732, Harrison, apparently an employé of the Trading Company, reached as far as Fatatenda, when, finding that the sloop could proceed no farther, he sent Captain Leach, with boats, for over sixty miles farther, where he was stopped by what he describes as an insurmountable ledge of rocks in the river-bed.

But what did more for African cxploration than these monotonous stories of joumeys up the Senegal and the Gambia, which never got any farther, and never reached Timbuctoo, and brought back no gold, and
Fulahs who united in his person the dutics at once of prince and Moslem pontiff of the Bondu country, lying in the watershed between the Gambia and the Senegal. Having had occasion to visit the Gambia for busincss purposes, Job was strictly enjoined by his father not to cross the river, lest he should fall into the hands of the Mandingoes, who were bitter enemies of his race. But, impelled by curiosity, the young man neglected this precaution, and unattended by any of his retinue, he persuaded a negro merchant to enter the hostile tcrritory with hin as interpreter. Feeling the heat of the day oppressive, he hung his goldmounted arms in a hut by the way, and lay down to slcep away in the shade the noontide sun. Not suspecting any danger, he and his 



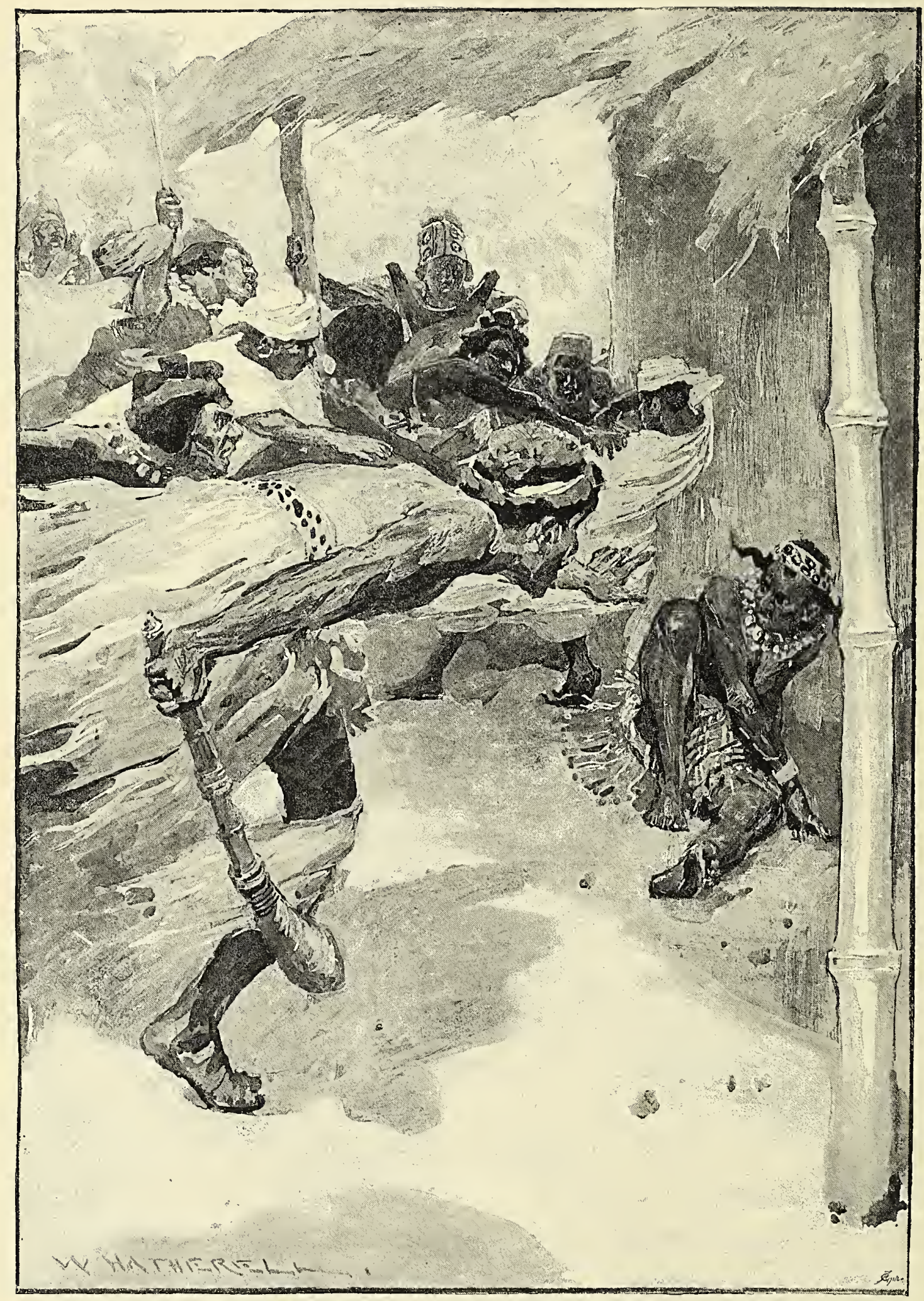

JOB, "SON OF SOLOMON," SURPRISED BY A PARTY OF MANDINGOES (p. 165). 
companion, while thus defenceless, were surprised by a party of Mandingoes, seized, chained, and brought to Joar, where he was sold to Captain Pyke, then engaged in " completing an invoice of servants" for the "American plantations." Learning the rank of his chattel, the trader permitted him to send a message to his father, so that an opportunity of ransom might be afforded. But before the messengers of King Solomon arrived with the purchase-money, Job was well on his way to the New World. In Annapolis he was sold to the owner of a tobacco-plantation, who, finding that he had not been accustomed to labour, set him to herding cows. This occupation to a Fulah was congenial enough. However, he was annoyed by being watched by a boy when he retired to the woods to pray after the Moslem manner, until, wearied with the impertinences to which he was subjected without being able to complain, he determined to seek a more sympathetic master. Wandering into the county of Kient: then part of Delaware, he was seized as a fugitive slave and thrown into prison until his owner could be found. Fortunately for him he met with a Mr. Bluet, who, hearing him pronounce the words Allah and Nohammed, saw that he was a Mohammedan, and from his affable manner and the "easy composure of his countenance" no common bondman. By-andby there came along a negro who spoke the Joloff language, as naturally many black men did in a day when every week hundreds of fresh arrivals from Africa were being poured into America. To this interpreter Job told his story, with the result that his "owner" fetched him home, and, evidently impressed by the rank of his chattel, or by the fact that the man was spirited enough to take care of himself, used him better than before his flight, allowing him a place to pray in and some conveniences calculated to render his life more tolerable.

In the meantime, Job wrote in Arabic to his father, but, owing to the vessel by which it was to reach the Upper Gambia having left England before the letter arrived, the epistle lay several months in London, where, happening to be seen by the famous Mrr, afterwards General, Oglethorpe, who occupied a high place in the African Company, that gentleman, touched by the pathetic tale of the royal captive, gave instructions to ransom and bring him to England, with the view of returning the hapless prince to his native country. This was done, and in April, 1733, Job arrived in London. The

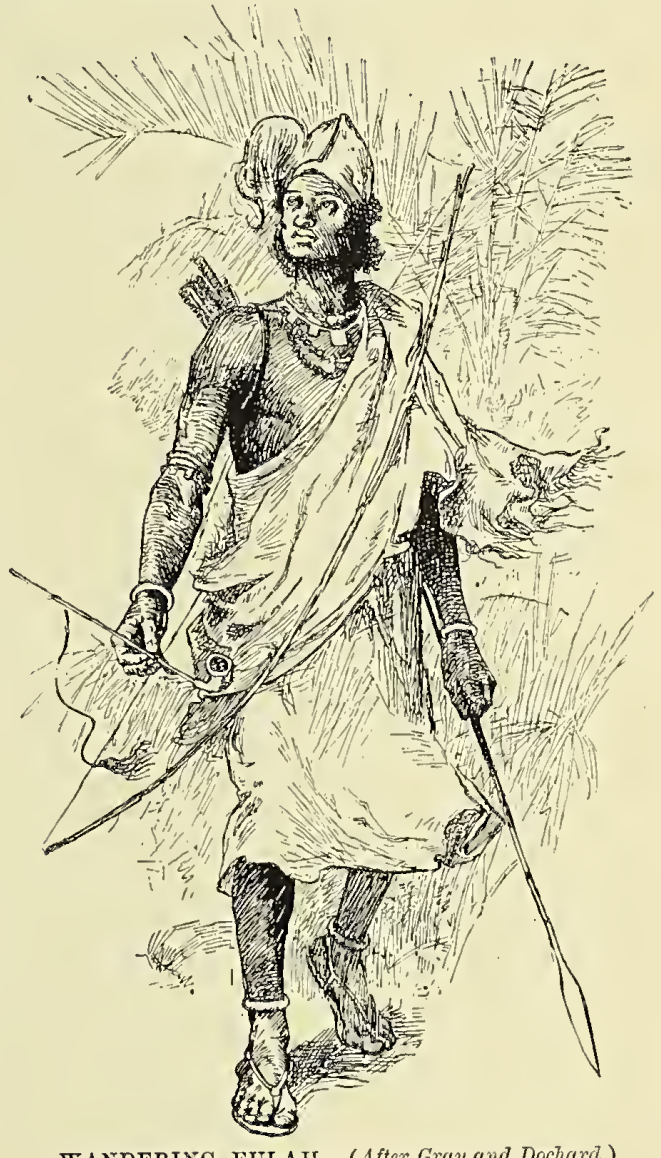

TAXDERING FULAH. (After Gray and Dochard.)

friend by whose exertions he had been rescued from slavery was James Edward Oglethorpe, the founder of Georgia, the friend of Wesley, Pope, and, in after-days, of Johnson and Boswell (p. 168). But before the African landed in Britain Oglethorpe had left on the voyage that resulted in founding the now flourishing city of Savannah. Job, however, found plenty of friends, by whom he was introduced to the King and Queen, and the royal family, 
receiving, among other attentions, a gift of a gold watch from Her Majesty. The Duke of Montagu also invited him to his house, where he inade the acquaintance of the principal personages in the capital; among them was Sir Hans Sloane, founcler of the British Yuseum, by whom, after Job had learned to speak English, he was employed to translate some of the Arabic manuscripts in his library. Endowed with a prodigious memory, he wrote out three complete copies of the Koran, with no other aid than recollection, and without using the first in preparing the other two. Nechanism of all kinds took his fancy, and, though a zealous Mohammedan, he displayed quite as much anxiety to learn about "infidel" religions as regarding more secular branches of knowledge.

After more than a ycar's stay, he set out for Africa, and arrived at James Fort in August, 1734. In England Job's disposition had been of the gentlest; on the Gambia the very sight of individuals belonging to the nation that had sold him into slavery roused in his mind such violent antipathy that it was with difficulty he could bc prevented from killing the first Mandingo whom he met. Every scrap of news he eagerly listened to; but of all the tidings which the Anglified Fulah heard, nothing delighted him so much as that the chief by whom he had been thrown into slavery was afterwards lilled by the accidental discharge of his own pistol, Job expressing an earnest hope that this fatal weapon had been the one received as part of the price of his captivity. All the tidings the returning slave obtained were not, however, so pleasant as this. For after waiting impaticntly four months for a letter which he had at once despatched to his father, messengers arrived with the information that the old king had died almost immediately on hearing that his son was again in Africa, and that his country, owing to a long war in which it was involved, was then in a very distracted condition. $\mathrm{He}$ also learned that one of his wives had married again, but that the new husband, hearing of
Job's return from a land so far away, had discreetly absconded. Determined, however, to wait no longer without seeing his friends and family, Job set off for Bondu, and in vain we search the literature of the African trade after that date for further tidings about him. He inight have been killed, for if he had been captured he would soon have been heard of ; or settling down to fight and be fought, to enslave instead of being enslaved, he, after the fashion of his pcople and his faith, soon sloughed off the veneer of civilisation obtained in the House of Bondage and in the land of the Infidels. At all events, Job, son of Solomon, Pontiff and King of Bondu, vanishes entirely from history, though, as we shall presently sec, the interest aroused by his romantic story and his stay in London did so much to advance African exploration that his capture and captivity may not unjustly be set down to the credit of a traffic that has so little to be proud of.*

By this time the Gambia and the Senegal were becoming familiar rivers. A royage to Galam or to Barrakonda was no The Galam or to Bamiliarity longer regarded as remarkable, that bred while the natives, as we can gather contempt from the journals of Francis Moore, Africa. who was trading on the former river for the African Company, had ceased to be even the moderately primitive folk they were in the days of Captain Jobson, or even in those of Captain Stibbs. Familiarity with the whites. had improved neither their manners nor their morals. Begging was the rule; insolence was frequently superadded. The King of Barsalli was an average type of the kind of potentate who had grown up under the slave trade. Tisiting Joar, he chose to reside in the factory, for no other reason than that he preferred its. accommodation to that of his own house in the town, and took posscssion of the trader's.

* The story of Ayûb ibn Suleyman ibn Ibrahim, to give him his full Arabic name, is contained in Bluet's pamphlet, "Some Memoirs of the Life of Job, the Son of Solomon, the High Priest of Boonda, in Africa" (173£), and in Moore"s "Travels," etc. (1738). 
room and bedstead simply because they were the best in the place. Finding the white man objected to so cavalier a proceeding, his sable Majesty promptly proceeded to take the keys of the store-room from him, and there and then to help himself and his courtiers to whatever took their fancy in the shape of food and drink. But "brandy was his main hank," and he applied himself so freely to an anker of it that for three days the sovereign was in a state of "royal drunkenness." This supply being exhausted, he searched the house for niore, though without effect until he came to a room where one of the servants of the Company lay ill. Espying a case that wore a promising aspect, he ordered it to be opened. In vain the owner affirmed. from his sick-bed that it contained nothing but papers, "of no value to anyone save the owner." "The King knew better than that -he was "too well acquainted with liquorcases to be fobbed off with any such story"and, to prove his discrimination, proceeded to open it and partake of the contents, which, as he expected, consisted of six gallons and a-half of excellent cognac. A fresh outburst of bacchanalian revelry followed, though, "to do the King justice," the sympathetic Moore admits, he often invited the factor whom he had robbed to take a share of his own brandy. When this supply was exhausted, and there seemed no chance of a fresh one being forthcoming, the party began to talk of taking their departure in search of a cellar better stocked. However, before doing so, they deternined to make one more scrutiny of the premises, and as they were three hundred and the white men three, the King and his courtiers ran riot among the slender furnishings of Joar factory, pocketing everything they had a mind to, and then, seeing that there was no more to be had, took an adieu as ceremonious as if they had been the most welcome of guests.

Yet, to show the degradation that had befallen the Gambia River natives in the few years that had elapsed since they would die rather than touch wine, the King of Barsalli was a zealous Mohammedan, and-when not drunk-prayed fervently. This, however, was only when nothing stronger than "A king in water was to be had, for if rum his own," was plentiful-and His Majesty was not particular so long as the beverage was intoxicating-he used to rise at night, drink till daylight, then eat, and go to sleep near sunset; then he rose, drank copiously, and went to sleep until it was time to begin his tippling again. His unquenchable thirst kept his subjects in a perpetual terror; for whenever he found his supply of brandy running low, he despatched a message to Fort James requesting a cargo to be sent in exchange for slaves-a call that the honest British merchants met with alacrity. Meantime, while the liquor was coming up the river, the King would attack a neighbouring town, set fire to three parts of it, and, stationing his guards at the fourth, seize the people as they tried to escape. These captives were usually the subjects of his neighbour-chiefs. But if he happened not to be at war with anybody in particular, then his own people had to pay with their persons the brandy-bill at James Fort; for, unlike most of the African sovereigns, this ruffian's power seems to have been absolute. His chiefs did not require to be consulted, and as their king was so were they. 'They drank and robbed, kidnapped and enslaved, and when inad with rum would join their lord and master in his favourite pastime of shooting at the canoes passing up the river, shrieking with drunken merriment when a bullet made the paddle drop from a dead man's hands (p. 169).

The factors of this time we have already sketched. They were excellent examples for the black men around them. For their business was to be the receivers of stolen property, if they did not themselves steal, and, as a list of the whites who died at the stations in the Gambia from 1730 to 1735 shows, temperance in the chief article of their trade was not any more practised among themselves than it was preached to the natives. Thus, Mr. Robert Forbes, writer, at Joar, died of hard drinking, 
and Mr. Houghton, at James Fort, of too heavy a dose of laudanum; Captain Major was killed by the natives of Kasson in revenge for an injury, and several men of Captain Williams' company by a mutiny of his slaves; Mr. Lowther, supercargo of the Bumper sloop, "was shot in the belly by his negroes," and

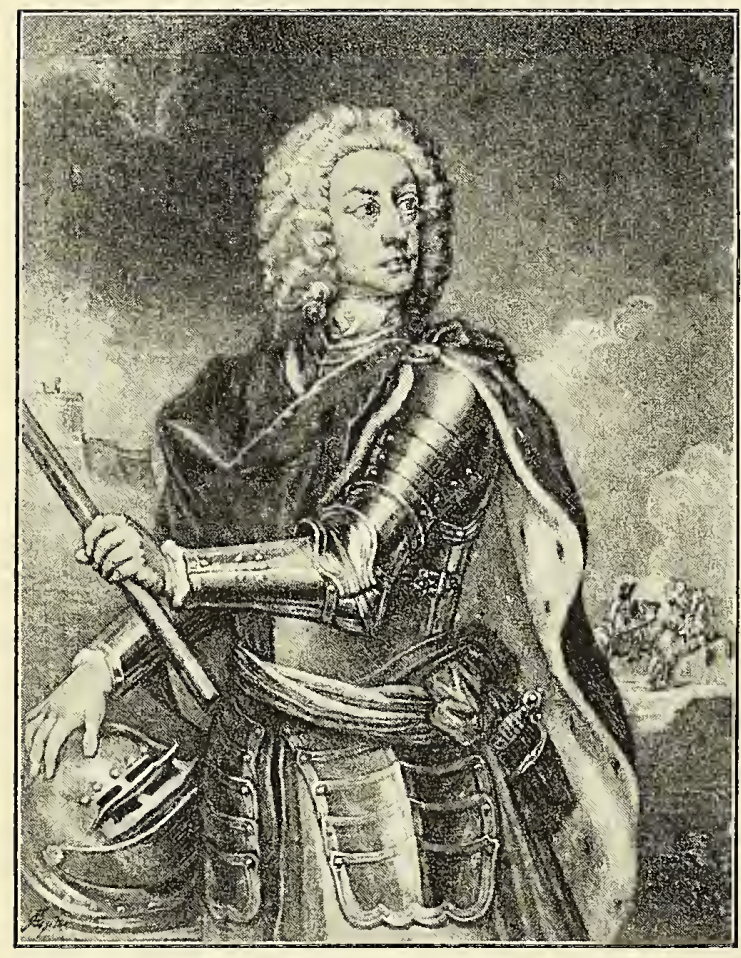

GEXERAL OGLETHORPE. (From a Print.)

Mr. Railton, factor at Brako, died from " a fall, correcting his black boy perhaps too passionately;" while Mr. James Ellis is recorded in the document from which these edifying notes are extracted to have ended his career a "martyr to rum." Such heroes deserve to be recorded quite as much as the three slares who were carried off by crocodiles in close proximity to the Company's trading-stations. 'The traders, even in the same employ, quarrelled bitterly, and sometimes carried their ill-will to each other so far that they would instigate the natives to insult and rob the white man against whom they had a grudge.

The best men of that period, no doubt, did not seek employment in Africa, any more than the pick of London are nowadays to be found on the Guinea Coast. But, of late years, everything in Africa had been steadily deteriorating. Evil communications, the infamy of the traffic in which the men were engaged, and the horrible condition of society into which the outrages necessary for keeping the market supplied had plunged the natives, corrupted more and more manners never good. Kasson had become a town noted for doing mischief. No European could pass it without the risk of being insulted, until, being taken and plundered by a neighbouring potentate, the people became, as bullies are prone to become under such treatment, "the civilest on the whole river." Factories dotted each bank of the stream, more strongly fortified than in earlier times, since the country round about was almost always in a condition of chronic war. Business was not so easy as of old, and though the up-river pcople were not quite so insolent or so corrupt as those mentioned, they had some customs that were extremely undesirable from a commercial point of riew. For instance, if a bargain were made, it could be repudiated in the course of the day on condition of the article bought being returned. This naturally led to extortion from the whites. 'Thus, a trader bought a cow, and, being a gentleman of eccentric taste, amputated its tail. This reaching the ear of the seller, he immediately saw his chance of demanding back the animal, claiming at the same time three hundred times the price originally paid, as compensation for the mutilation of his animal; and as the entire population backed up the habit and wont of the place, the trader was conpelled to pay and wait his turn. This soon occurred; for visiting the place with an armed ressel, he enticed sereral of the principal peoplc on board and clapped them in irons until restitution was made. Outwitted in this fashion, the African not being a revengeful individual, the sharpers adnitted that they had been well served out, and resumed their intercourse, on the old anicable terms, 
with the man who had collected old debts in so new a way. At Fatatenda the limits of the Company's traffic were reached. Here the Gambia is as broad as the Thames at London Bridge, the country of Kantara round about being a great plain continually echoing with the roar of wild beasts. The Company's it in a secret place at night, stealing to his hoard to partake of a "night-cap" like a miser to his hidden heaps of gold.

Everybody of any consequence was in those days, as in ours, very much married. Whole villages consisted of one man, his wives, his children, and his slaves. To keep such a pack

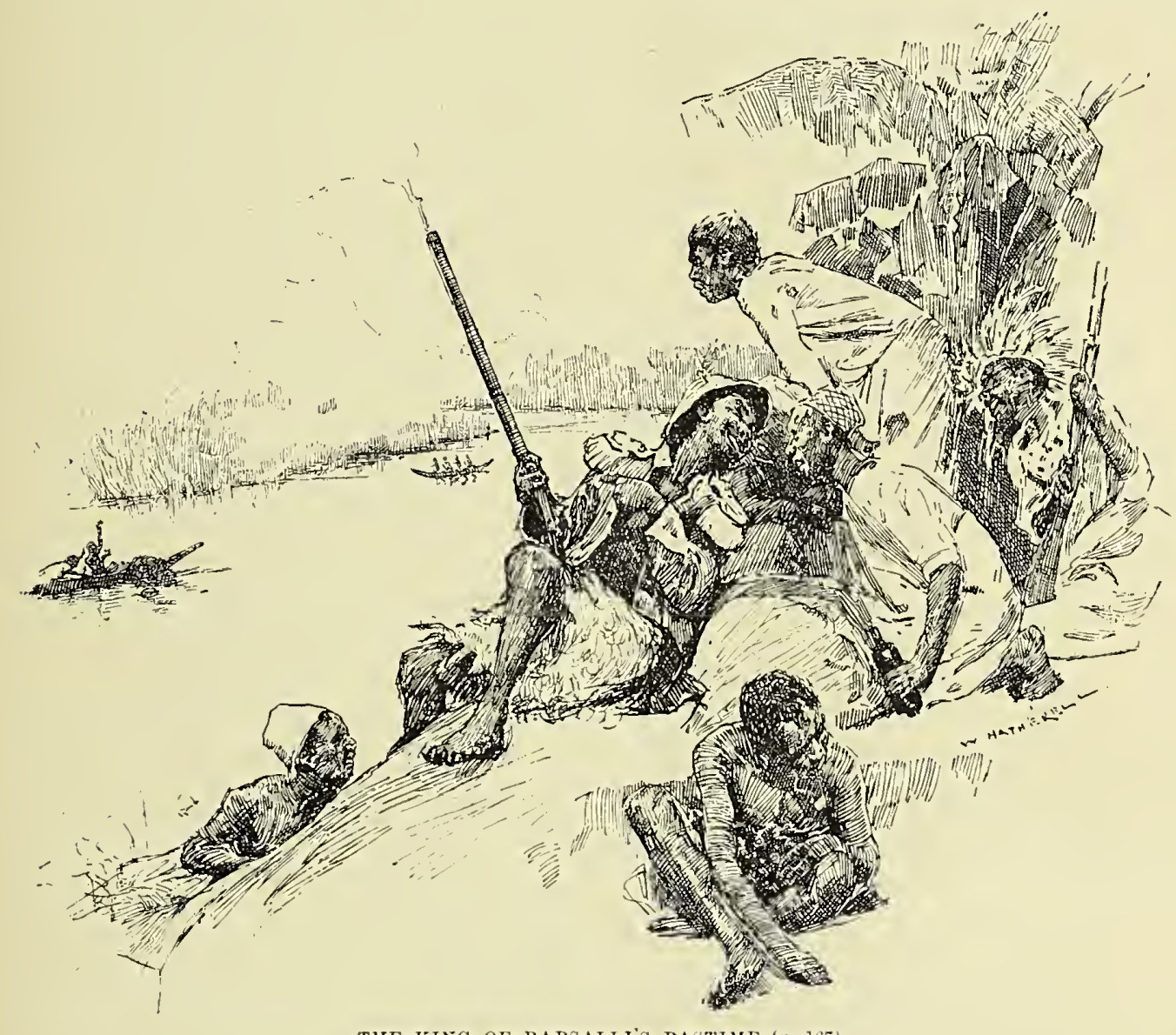

THE KING OF BARSALLI'S PASTIME ( $p .16 \pi)$.

factory was situated on a high rock near the water's edge, and the lonely agent in charge seems to have had about as agreeable a time with the king of that region as his colleague at Joar had with the bibulous sorereign of Barsalli. For brandy was what his up-river majesty lusted after on all his too numerous visits. He dirl not ask for it; he simply seized and drank it, so that the factor was compelled, if he was to hare any for his own use, to bury of termagants in order would have been difficult without the help of Mumbo Jumbo, the avenging evil spirit who arrives at intervals and inflicts dire punishment on all offenders against marital and other codes of morals, and who is possessed of an amount of local knowledge which in the minds of anyone less superstitious than the West African would raise a well-founded suspicion as to the local origin of this convenient demon-deity. 
The traders were under the protection, such as it was, of the headman, but many of them preferred to protect themselves, and not a few seem, as happens still, to have sunk pretty well to the level of the savages around them. They believed in omens, if not in Mumbo Jumbo, or "Horeys" (p. 130), and were not sure whether there was not something in the Gambia belief that everyone who dies owes his death either to witcheraft or to breaking some vow; and one white man thoroughly believed in the Mandingo method of discovering a thief, by forcing the suspected person to dip his hands into boiling water. The result was invariably satisfactory. Either he refused to do so, when, of course, no further inquiry was necessary, or if he dicl they were scalded, a circumstance that settled his guilt without further demur. This trader, who happened to be master of a vessel, proceeded to test, after this summary manner, the innocence of his crew touching the loss of a musket. Naturally, all of them were scalded. But, unfortunately for the captain, just as he was triumphing over the success of his judicial process, the missing gun was unexpectedly found in his own custody, an awkward circumstance which for a time endangered his life at the hands of the not unjustly mutinous crew, who, happening to be negroes, lay in wait for him, and before long exacted an ample compensation for their wrongs.

\section{The Africhn Association.}

All this time, though no regular exploration was going on in Africa-or at least in this part of it-Timbuctoo and the interior were not forgotten. Great quantities of African products were reaching England and other European countries every year, and the slaves despatched to the American plantations, in spite of many isolated voices raised here and there in protest against the iniquity of the traffic, were as numerous as ever. Adanson, the famous naturalist-after whom Adansonia, the Baobab-tree, or Monkey-bread (p. 64), is named-had explored the animal and vegetable life of the Senegal, and his works had familiarised the cultured men of Europe with the tribes and plants and beasts, with the dark woods, the marigots or creeks, the overflow lakes, the gum-forests, the desert, and the ostriches coursing over it, the redlegged partridges and Guinea-fowls, the grey hares and Barbary quails, the sand-grouse and snipe, the graceful antelopes, clumsy river-horses, and the pigeons that cooed by the million in the dense woods. And Saugnier, cast away on the shores of the Sahara north of the Senegal, had added to the stores of geographical knowledge much interesting information regarding that country and the wild tribes inhabiting it.

The time had now come for that systematic exploration of Africa which for more than a century has never halted. All travelling previous to the period we have now arrived at, interesting and important though it was, may be regarded as simply preliminary to the great journeys of the next century-all the explorers who had hitherto felt their way into the interior as agents in advance for the explorers whose advent was now due. In England, geographers had long been divided into two camps-those who believed that the Gambia was the Niger mouth, and the remainder who held by the Senegal as its seaward end. High words unbefitting the dignity of science were wont to be uttered by the rival combatants, though, as the Senegal belonged to France, and France therefore leaned to the first-named hypothesis, the sturdy Briton preferred to accept the Gambia as his hold-by. And there was quite as much to be said for the one assertion as for the other, and neither was right; for, as we now know, the Niger is a river perfectly distinct from either of the two so long believed to be identical with it.

In 1788, however, the mists began to clear away. An impression seized some of the best minds of England that the Niger was. not to be found and followed by expeditions up either the Gambia or the Senegal, which always ended at nearly the same place, the rivers falling just at the time when the latest: 
explorer was arriving at or getting a little beyond the farthest limits of his predecessor. Among geographers who shared this belief were Sir Joseph Banks, President of the Royal Society (p. 173), who twenty years before had accompanied Captain Cook on his famous expedition round the world, the Earl of Galloway, the Bishop of Llandaft, Lord Rawdon (afterwards Marquis of Hastings), General Conway, Sir Adam Fergusson, Mr. Beaufoy, and Major Rennell, at that period the most expert chartographer living. These gentlemen determined to form themselves into the African Association, the object of which was to send explorers to find and follow the Niger. This was on the 9th of June, 1788, and from that period until their labours were crowned with success, and the newly founded Geographical Society, with its more festive predecessor, the Raleigh Club, charged themselves with the work so long pursued by the older body, they ceased not to play a great part in the history of savage Africa.

The first emissary whom they despatched did nothing to deserve a place in this Ledyard. chronicle, except that he died on African soil. But the story or John Ledyard is so romantic that there would be a blank in the history of the seekers after Timbuctoo were he to be dismissed with so brief a notice. The son of a New England sea-captain, he soon deserted the law, to which he had been bred. But he was so little fascinated by the Missionary College for the Conversion of Red Indians which he then entered that, instead of trying to wean them from their savage ways, they managed to convert him so far that he ran away, and for a time wandered among the Six Nations to the borders of Canada. A second attempt to settle down to books was not much more successful ; for, hewing down a tree, he formed a rude "dug-out," in which, with no more elaborate equipment than a bear-skin, an Ovid and a New Testament, he floated down the Connecticut River to Hartford, a distance of 130 miles along a stream broken by rapids, in the hope that some relatives who lived there would put him in the way of something less vagabond. But the Hartford Ledyards seem to have come to the conclusion that a youth who had been lawyer, parson, and savage before he was nineteen was not the kind of person to help. For about this period, abandoning the Church and his native land, he shipped as a sailor from New London to Gibraltar; but, liking the sea no better than any of his many previous pursuits, he deserted, and when next seen was discovered by his captain among the awkward squad in red coats and black gaiter's learning the goosestep on the Alameda parade-ground. A soldier's life appears not to have charmed him any more than a sailor's, since he readily permitted himself to be bought off and to return to New England in the ship in which he had left it. Seized with a romantic passion for discovering the "rich and noble family" from which he was descended-an amusement still much in favour with his countrymenLedyard soon afterwards took passage from New York to London, where, not being received with any marked fervour by his supposed kinsfolk, he enlisted in the marines, in order to qualify himself for a post in Captain Cook's third and last voyage. He succeeded in obtaining the officc of ship's corporal, and in that capacity became known to Sir Joseph Banks. In the course of the voyage Ledyard took part in various minor explorations, and acquitted himself so well that on the return of the vessels he received his discharge, and tried to get up a furtrading expedition to Nootka Sound. Failing in this venture-which in the course of the next thirty years yielded such enormous profits to various speculators-hc endeavoured to enlist Sir Joseph Banks in a scheme for a journey across America from the Atlantic to the Pacific. The revolutionary war, which had then broken out, left England in no mood for American exploration, and so Ledyard lost the chance of anticipating Nackenzie, and Lewis, and Clark in traversing the continent from ocean to ocean. Sir Joseph, either out of charity or to get quit of the ship's corporal, 
gave him ten guineas, and with this slender capital Ledyard set out for St. Petersburg, with the intention of first crossing Siberia and then, sailing from Kamschatka to Nootka Sound, reach the Atlantic by a route he had laid out for himself. He managed to get as thence to Okzakoff. Modest assurance was one of the few equipments in which Ledyard was never deficient; or, perhaps it would be more kindly to say, the young New Englander was too much of an enthusiast ever to concern himself about the proprieties of
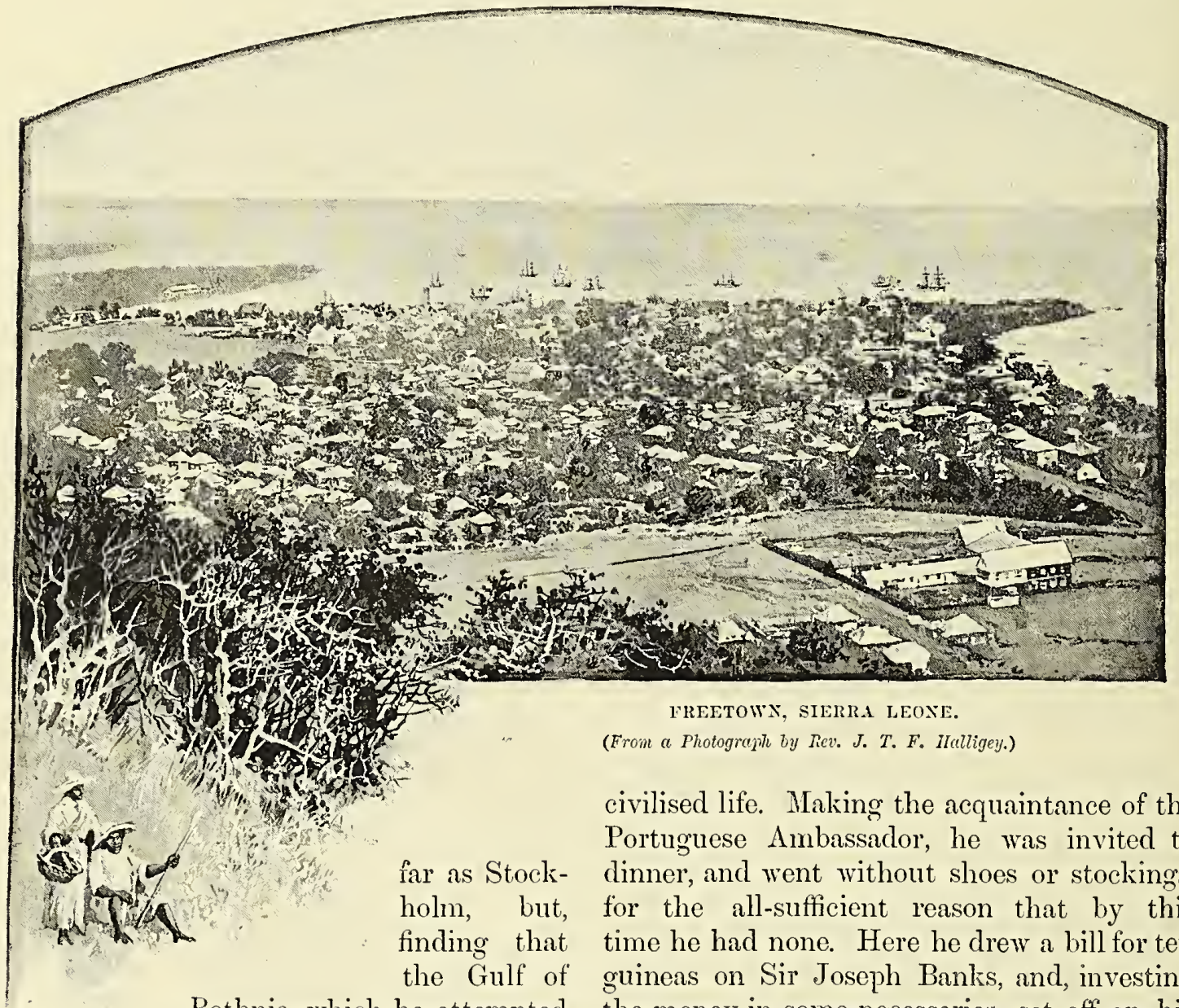

civilised life. Making the acquaintance of the Portuguese Ambassador, he was invited to far as Stockdinner, and went without shoes or stockings, holm, but, for the all-sufficient reason that by this finding that time he had none. Here he drew a bill for ten the Gulf of guineas on Sir Joseph Banks, and, investing Bothnia, which he attempted to cross on foot, was not frozen all the way over, he returned to the Swedish capital, determined to walk round the Gulf. This feat he actually accomplished in the depth of winter, reaching St. Petersburg without, we may well believe, considering the capital with which he started, the smallest amount of money in his pocket. Here, however, he made friends, and was permitted to accompany a detachment of stores to Yakutsk, and the money in some necessaries, set off on his journey of 6,000 miles, and accomplished it, when, without any explanation, he was seized in the name of the Empress Catherine, placed in a sledge between two soldiers, and conveyed, in the depth of winter, across two continents. Then, haring arrived at the Polish frontier, the traveller was discharged with the curt intimation that if he returned to Russia again he would certainly be hanged, but that, if he had a mind to go back to England,his guards wished him a pleasant journey. 
It is probable that Ledyard's name having been by this time whispered in connection with his abortive fur-company, jealousy of his supposed real object had led to this extremely autocratic proceeding. At all events, he had no recourse but to beg his way to Königsberg, where, arriving covered with rags and dirt, worn by hunger and hardship, and weakened by disease, without friends, credit, clothes, food, or the wherewithal to procure any, he was compelled to draw once more on Banksthis time for five guineas-and return to London. How could the man travel so far with so little? The answer he gave when this question was put to him by Mr. Beaufoy, Secretary of the African Association, may be useful to others. His sufferings were excessive, and, but for the compassionate temper of women, he must have perished during his long journey over a region where, even with the most ample of appliances for comfort, the hardships are exceptionally great. "I have observed anong all nations," Ledyard wrote in his note-book, "that the women ornament themselves more than the men; that wherever found they are the same kind, civil, obliging, humane, tender beings; that they are ever inclined to be gay and cheerful, timorous and modest. They do not hesitate, like a man, to perform a hospitable or generous action; not haughty, nor arrogant, nor supercilious, but full of courtesy and fond of society; industrious, economical, ingenious; more liable in general to err than man, but in general, also, more virtuous and performing more good actions than he. I never addressed myself in the language of decency and friendship to a woman, whether civilised or savage, without receiving a decent and friendly answer; with men it has been often otherwise. In wandering over the barren plains of inhospitable Denmark, through honest Sweden, frozen Lapland, rude and churlish Finland, unprincipled Russia, and the widespread regions of the wandering Tartar, if hungry, dry, cold, wet, or sick, woman has ever been friendly to me, and uniformly so; and to add to this virtue, so worthy of the appellation of benerolent, these actions have been performed in so free and kind a manner that if I was dry I' drank the sweet draught, and if hungry ate the coarse morsel, with a double relish."

The courage and physique of this man marked him out as a fitting agent of the new Association. His "open countenance" and

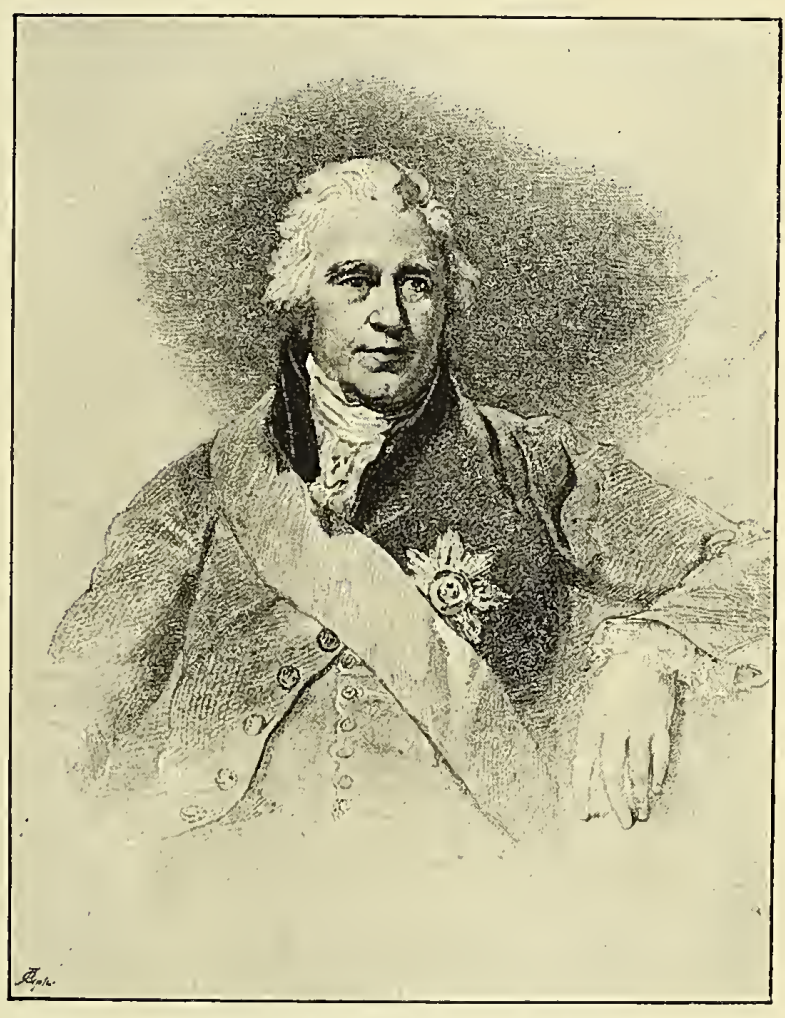

SIR JOSEPH BAXKS. (From $a$ Print.)

"unquiet eye" seem to have impressed $\mathrm{Mr}$. Beaufoy, though it may be questioned whether the two were compatible, and assuredly the explorer who professed himself in the evening ready "to start to-morrow morning" must have had a better notion of the dramatic effect of his words than of the careful preparation which a successful expedition demands. It is doubtful how far he might have redeemed his promises to do his best or perish in the attempt; for at Cairo, waiting for the 
departure of the Sennaar caravan, he contracted a bilious fever which, treated with violent medicines, proved fatal. He confessed to have endured the extremities of human suffering, to have had food given to him in charity as a madman, and at times to have sheltered himself under that disguise to avoid a heavier calamity. "My distresses," he told Mr. Beaufoy, "have been greater" than I have ever owned or will own to any man." Yet it is open to argument whether the eulogies on his fitness for the task assigned him were quite merited. Something more than mere energy without training is essential to the exploration of a new country, and the assurance that carries a man like Ledyard through Europe would not unlikely fail him in a region so widely different as Africa.

The next emissary of the Association was Mr. Lucas. Originally engaged in mercantile Lucas. affairs in Cadiz, he had been captured by a Sallee rover, and passed three years in slavery in Morocco. On receiving his freedom he was appointed Vice-Consul in that country, where he resided sixteen years, and acquired a familiar acquaintance with the Moors and the Arabic language. This secured for him the post of Oriental Interpreter to the British Court, and, on his desiring to undertake any journey in the service of the Association, he was directed to try to reach Fezzan, on the route to Timbuctoo, by the way of Tripoli, returning vick the Gambia, or the West Coast generally, as he found most convenient. A revolt of the tribes under the Turkish Government, in the province of Tripoli, delayed his journey. Meanwhile two Shereefs, or descendants of Mohammed, arriving at the coast with slaves, senna, and other articles for sale, offered to take Mr. Jucas back with them to Fezzan, the sanctity of their persons rendering them, and those under their protection, independent of the disturbed condition of the country. The Bashaw of Tripoli, then a functionary almost independent of the Sultan of Turkey, though favourable to Mr. Iucas, would fain have dissuaded him from undertaking a journey in which he might be held as a hostage by the rebel Arabs. But on the Shereefs pointing out that they had already sent a message to their king intimating the early arrival of a Christian, to preserve these holy men from suffering the indignity of having dust thrown over their heads (the only punishment which it is permitted to befall those of the Prophet's kin) should the Fezzan sovereign be angry at the disappointment, the party were perinitted to leave on the 1st of February, 1789. They took that route by Mesurata which in afterdays was so often followed, over a country dry and sandy, except where here and there among the stony tracts a little rerdure grew, and in these places the ruins of a Roman temple or monument or tomb remained as a memorial of a time when the region, now so bare, barren, and forlorn, was one of the colonies of the World's masters.

On the fifth day they arrived at Mesurata, where the traveller was politely received by the Turkish governor, who, having resided in Italy, was better acquainted with the customs of Europeans than the Stamboul officials of that day were. But all attempts to hire camels from the rebel tribes proving useless, the party were compelled to halt until better times, and Mr. Jucas to return whence he came, after collecting from traders and others much useful, and, it afterwards proved, fairly accurate, information regarding the regions between the coast and the Niger, from which Major Rennell, aided by all the existing materials, compiled a map of Africa.

The North having for the time being proved a closed route, the Association next turned their attention to the West Coast.

At Sierra Jueone a settlement had Watt and been formed for freed negroes bottom. Accordingly from this basis Messrs. Watt and li interbottom, in 1794, explored Futa Jallon, by sailing up the Rio Nunez to Kakundi, and thence for sixteen days through a country in many places barren, but in others extremely fruitful, and abounding in vast herds of cattle. This region seemed eren then to have suffered 
little at the hands of the white inan, for at every village the travellers were hospitably entertained and conducted, with their baggage, in safety another stage on their journey. Labé they reckoned to contain 5,000 people. Here they heard much about Timbuctoo from the traders who went there regularly; but the road was represented as extremely dangerous. The ruler of Labé was anxious to send one of his sons to be educated in England, and at Timbo, the capital of Futa Jallon, a town of 7,000 inhabitants, the king was equally polite. Naize and rice were everywhere cultivated by the women, and, contrary to the rule elsewhere, carried to market by the men, who were sometimes absent on their trading journeys for eight weeks at a stretch. Cattle, horses, mules, asses, sheep, and goats pastured on the hills. Iron was mined and smelted by the women, who also weaved cloth, while their husbands worked in iron, silver, wood, and leather. Schools were plentifnl; most of the people could read; books of law and theology were not uncommon, and, though the mosques were numerous, the natives were not then, any more than they are now, bigoted Mohammedans. Most of the towns were well fortified, considering the force likely to be brought against them. The reason was that the Fulahs were a warlike people, capable of placing 16,000 men in the field, and prone to hostilities against their neighbours, since " they could not obtain European goods without slaves, nor slaves without making war." However, only the young and strong were taken; the old and feeble, to avoid trouble, had their throats cut. But they excused themselves for this barbarity by declaring that the people whom they thus raided, robbed, and mirclered "never pray to God," and that, as the European factories would sell guns, powder, and cloth for no other articles except black men and women, the people whom the travellers tried to persuade into more peaceful pursuits had no alternative. Moreover, did not "the Book" (the Koran) enjoin on the Faithful to make war against the Infidel? If, however, some Europeans would settle in the country and show them how to grow produce saleable on the coast, they would gladly give up the slave trade, which, moreover, owing to European wars, was no longer profitable, few captives being bought. Finally, escorted by a strong body of Fulahs, they reached Sierra Leone (p. 172) by another route, having made a journey which, if followed up, might even then have diverted in the direction of the British colony much of the trade which, with unavailing regret, and in spite of all efforts to turn its course, now flows, and has for a long time past flowed, into the. French settlements.

Undeterred, indeed rather stimulated, by the fate of his predecessor, the Association, which hitherto had always had more applicants for employment Houghton. than it could utilise, next engaged Major Houghton to try to reach the Niger and Timbuctoo by way of the Gambia. Leaving England in 1790, news was received from him up to July, 1791, when all tidings ceased. Houghton had been Consul in Morocco, and served at Goree, then seized from the French, so that he was a more capable traveller than most whom the Association had despatched. Wisely shumning the river route up the Gambia, he started overland attended by only a few followers, and reached Medina, the capital of Wuli, where he was received with great hospitality by the king (p. 184). Unhappily, however, a fire deprived him of a large share of the goods that constitute the ready-money of an African traveller, so that at the very outset he was hampered, in passing west to the Falemé through Bambuk, where also he was received with kindness. How he fared afterwards was detailed in a note sent to Dr. Laidley, at Pisania factory: "Major Houghton's compliments: is in good health, on his way to Timbuctoo, robbed of all his goods by Fenda Bucar's son." However, either he obtained more goods or was still in possession of some, for soon after he fell into the power of the Sahara Moors, was robbed of everything, and left to die naked and alone in the desert. 
Frederiek Hornemann was another agent of the Assoeiation. He was a learned German, a pupil of Blumenbaeh, Heeren, and Hornemann. Heyne. Arriving in Egypt just
before the French had landed, he was inprisoned by the Mamelukes. But, to the eredit of Bonaparte, he freed him, offered him inoney, gave him passports, and forwarded his letters to the Assoeiation under his own seal. The object of this traveller was to reach the Niger by way of Egypt. This he did not aetually aecomplish, though he reached Fezzan by a route used before the days of Herodotus, and deseribed by the Father of History. From this point he set out on a journey to Bornu, but whether he perished in the desert, or was murdered, no man knows, for in 1800 he disappeared from view and was never heard of again.

Hitherto the ill-sueeess that had attended the efforts of the Assoeiation nilght have wearied men less earnest, and, so far as the inajority of them were eoneerned, less self- saerifieing. But if it did not deter Sir Joseph Banks and his eolleagues, it unquestionably had a depressing effect upon the zeal of wouldbe travellers. Death by thirst, by the spear, by fever, by hunger, was not an inspiriting outlook. All the unknown terrors of the desert were added to what was already too fanniliar, so that, instead of finding a dozen volunteers eoming forward to take the place of the fallen explorer, the Assoeiation, for the first time in the seven years of its eareer, had to offer substantial inducements to entiee a fresh adventurer to apply. 'They had not, however, long to wait, for in the spring of 1795 a young Seottish surgeon offered his serviees, whieh, to the lasting honour of the eomulittee, were promptly aeeepted. The new traveller was destined to win a great name in the history of Afriean exploration, and to redeem with his life the failures of his predeeessors. His work, however, requires a long ehapter to itself. For his name was Mungo Park.

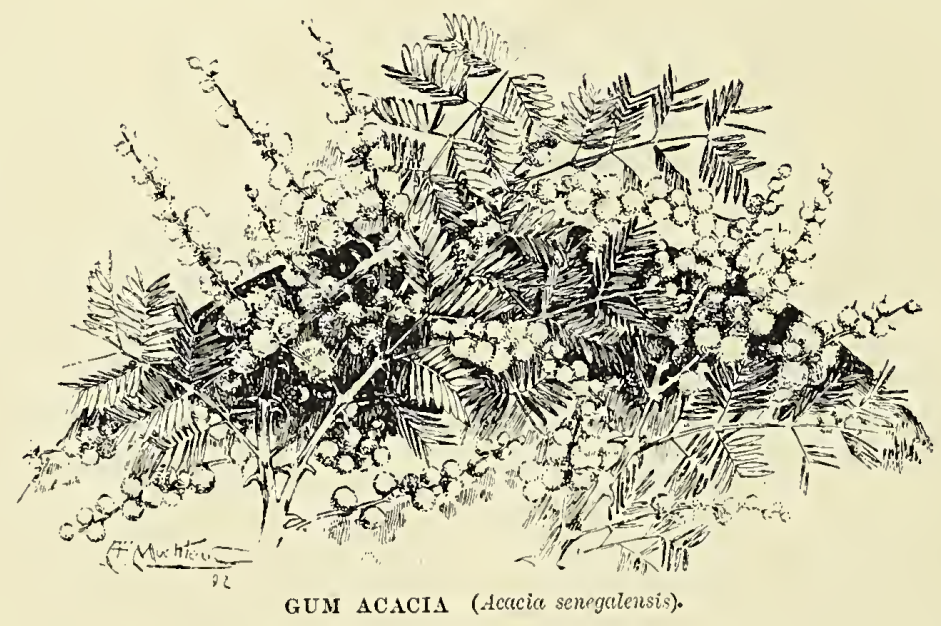




\section{CHAPTER IX.}

\section{The Seekers after Timibuctoo: Mlungo Park.}

Mungo Park-His Early Life-Leaves for the Gambia-Resides at Pisania-His Sympathy for the Slave Trade-The Natives of the Gambia since Moore's Day-Park sets out on his Journey-Its Perils-The Nature of the Country between the Gambia and the Senegal-Blackmailing Kings-Dishonest Guides - Charms-The Fulah Country-The Moral Influence of Mohammedanism-In the Senegal ValleyFrench Taste Apparent-Curious Ladies-Ain African King may be a Costly Acquaintance-A Perilous Night Journey-The King of Kajaaga and his Dues-A Friend in Need who Proves not to be a Friend Indeed-Park's Companions Begin to Lose Heart-Serawulis-Park Crosses the Senegal-Out of the Frying-pan into the Fire-Demba Sego and his Family Proceed to Business-How to Convert a Nation Wholesale-The Gratitude of the Jumbo Blacksmith-A Debt-collecting Mission-More of the Kasson Royal Family-Park Sets Out for Kaarta-War and Rumours of War-Evil Days Set In.

THE physician is perhaps the best of all travellers. His education has naturally included most of the sciences necessary for the explorer who wishes to study what he sees among the people, the animals, and the plants of the regions traversed, while the healing art. has ever been a passport to the favour of the rudest races. Hence most wanderers, even when not "qualified practitioners," have found it to their advantage to play the doctor, with results, if one may judge fron the legends bequeathed to their successors, not always successful, though undeniably better than those of the native medicine-man, whose illwill they generally manage to secure. Mungo Park was, however, one of the earliest of the explorer-surgeons of whom so many have appeared within the past century. A farmer's son, born on the 10th of September, 1771, at Fowlshiels, on the banks of the Tarrow, in Selkirkshire, the seventh child of a family of thirteen, in circumstances little raised above those of the northern crofter, he inherited no fortune, and received none, except the best education that the Selkirk Grammar School could afford. Except that he was dreamy and reserved, a great reader, and a student of the Border minstrelsy, which Scott was then collecting, there is no tradition of the future explorer being in any way distinguished above the run of the farmers' and tradesinen's boys who were his class-fellows. But, knowing that his father had to pinch and toil in order to afford him "the advantages" that he had not himself obtained, the lad studied hard, though he disappointed his family in failing to be fired with the ambition of the rural Scot"to wag his head in a pulpit." He preferred to be a doctor and, according to the country custom, was duly articled to Dr. Thomas Anderson, a medical practitioner in Selkirk, a town in which still reside some of his descendants engaged in the same profession. He was then fifteen years of age. In the next three years he acquired some routine knowledge of physic, and at the same time continued to pursue his classical and mathematical studies with a view to entering the University of Edinburgh, then in the heyday of its fame as a School of Medicine.*

In 1789 he entered the University, and in the course of three sessions obtained a surgeon's diploma, a "qualification" which in those days entailed less trouble and expense than a degree, circumstances that may perhaps account for the absence of Park's

How a Selkirk surgeon became an African explorer. name from the roll of Edinburgh Doctors of Medicine. In Edinburgh he had studied

\footnotetext{
* Many of the facts embodied in this sketch were obtained some years ago from a near relation of Park. But since then nearly everything of importance has been incorporated by $\mathrm{Mr}$. Joseph Thomson, in his admirable work on "Mungo Park and the Niger" (1890), which may be regarded as the last word on the subject. The Reports of the African Association, H. B.'s "Life of Mungo Park" (1835), Wishaw's biography prefixed to the traveller's " Journal of a Mission into the Interior of Africa in 1805" (1815), and Park's own "Trarels into the Interior Districts of Africa performed in the years 1795,1796 , and $1797, "$ exhaust the original literature of the following chapters.
} 
botany under Protessor Rutherford, uncle of Sir Walter Scott, who was born in the same year as Park, and in after-life was one of his warmest friends. His interest in this science was heightened by his intimacy with James Dickson, a scientific gardener who had married his sister, and was already a botanist of wide repute. As the discover of Diclsonia and other species he had become favourably known to Sir Joseph Banks. This accident served to obtain for the young surgeon an introduction to the then Mrecenas of Science in England, by whose influence he was elected an Associate of the Linnean Society, then in the fifth year of its existence, and in 1793 receired the post of assistantsurgeon on board the Worcester East Indiaman, on the cre of sailing on a voyage to Bencoolen, in Sumatra. A paper describing some new species of fishes that he discovered in the Malay Archipelago * recommended him still further to Sir Joseph, so that, when it appeared that there was no further prefcrment for him as a sca-going surgeon, his offer to serve as one of the African Association's agents was gladly accepted.

Park was then twenty-four, tall, robust, studious, and sanguine (p. 20). Without any experience of travel, he had many of the qualifications for an explorer. His mind was naturally romantic, though this cast given it by the reading of many Border ballads was sobered by a taste for Scotch metaphysies of so pronounced a character that, instead of taking on his Sumatran voyage the last romance of Laurence Sterne or of Henry Mackenzie, the work which the young surgeon chose to "amuse him at sea" was Dugald Stewart's "Philosophy." He had, moreover, a fair knowledge of science, was imbued with deep piety, troubled with the demon of umrest and an ardent ambition to distinguish himself. He had in addition the advantages of being poor, a Scotsman, and of haring nothing to do. As he wrote to his brother, "if I succeer, I shall acquire a greater

* Transactions of the Linnean Society, vol. iii., p. 33 (November 4 th, 1794). name than any ever did." This, indeed, was not difficult. For, as we have seen, everything had gone wrong with the African Association. Their agents had died on the threshold of their labours, or had done little after entering the field. Volunteers were not forthcoming, and, to make matters nore discouraging for those who followed, news had just been received of the murder of Major Houghton, who alone had managed to reach anyway near the goal at which the Association aimed. There was therefore a chance for a fresh explorer who set a light value on his life, or, like Park, was not too well-informed concerning the perils of the way. And when a youth of twenty-four writes from London to Scotland that the expedition on which he was about to start would be a short one, for he was to have a trader to go "with him to Timbuctoo and back again," it is clear that he had the blessed advantage of ignorance to befriend hinn.

As Park's instructions were to start from the Gambia in search of the Niger and the city which had been the goal of so many previous half-hearted at- journey of tempts, and was to be the spot at Mungo Park which so many more were to aim, he started on the 22nd of May, 1795, on board a trader bound for Pisania (now destroyed), on a part of the river above Macarthy's Island. Dr. Laidley, a Scotsman who had been the friend of Houghton, was still doing business there, and in him his young countryman found a warm friend and comsellor during the months he stayed therc studying the Mandingo language and othcrwise qualifying himself for a task so novel as that which he was sent to undertake. Determined to be independent of interpreters, who are apt to interpret as best suits their own interest, he spent several hours a day trying to master an intclligible acquaintance with the commercial tongue of this region, in picking up all the information that he could regarding the interior, and in amassing statistics on the subject of the Gambia trade, which, it may be added, was then, as fornerly, almost 
solely in slaves. Gold-dust and gum, Kola nuts and dye-woods, were mere incidents of the commerce of the river and of the interior from which it formed a highway to the coast.

Yet, though the explorer, fresh from the braes of Yarrow, saw every day men and women in manacles, it is in vain we search his journals for any expression condemnatory of the traffic. Even when he accompanies a caravan, or "coffle," of slaves he seems unconscious of the iniquity of the scenes which, as a traveller, he describes-of the long marches under the burning sun, of the chains, the loads, and the crack of the whip applied to the laggard, or the knife mercifully drawn across the throats of the dying or exhausted. Park was a man of genuine lindheartedness, unaffected piety, and great family affection. But he had grown up to regard slavery as one of the institutions of his native country, and so essential to the prosperity of her colonies that he expressly declares that "a discontinuance of that conmmerce" would by no means be so beneficial as "many wisc and worthy persons fondly expect." Why should he? His host, Dr. Laidley, was in the thick of it, and a better man than the hospitable Scot did not cxist on the Tweed or the Gambia. And, yet, in Pisania factory barracoons (p. 60), he saw almost daily " the poor wretches, while waiting shipment, kept constantly fettered two and two together, and employed in the labours of the field, and, I am sorry to add, very scantily fed, as well as horribly treated." And finally, as Park must have known, at least one leading member of the African Association, namely, Mr. Bryan Edwards, with whom he lived on terms of intimacy, was a large slave-owner, directly concerned in this infamous traftic. It has, indeed, been more than once hinted that the interest of some members in African exploration was not entirely disinterested-that they looked to new fields to tap for negroes to export, and that Park's journals had been carefully edited by Edwards in order to weed them of any passages reflecting on the merchandise in which he dealt. But of this there is no proof; otherwise he would unquestionably have deleted many harrowing pictures of the brutalities of the barracoons and the caravans. Yet, unconsciously, Park was an agent of the slave-traders, as was, more or less, crery man who in those days touched the African shore. In the meantime he had to learn something of the continent less agreeable than its languages and natural history, for the rainy season arrived, and one night imprudently exposing himself to the heary dews, he had his first "seasoning fever."

At Pisania, a small village in the King of Iani's territory, there were no white people except Dr. Laidley and two brothers of the name of Ainsley, Life at with their dependents and black

servants. Being higher up the river than most of the factories, the climate was better. The dense mangrove swamps characteristic of the seaward reaches of the West African floods, the fetid mud exhaling a sickening mist under the hot sun, was absent, and instead of an isolated clump of cocoa-nuts, or a silkcotton tree here and there, the country, when not open, was a luxuriant forest. But when the tropical rains began to fall, Pisania, a hundred years ago, was no more lively a spot than any other Gambia tradingpost. "Suffocating heats oppress by day, and the night is spent by the terrified traveller in listening to the croaking of frogs, of which the numbers are beyond imagination, the shrill cry of the jackal, and the deep howling of the hyena-a dismal concert interrupted only by the roar of such tremendous thunder as no person can form a conception of but those who have heard it."

The natives since last we have taken note of their ways had been rapidly sinking in onc direction and rising in another. They were, Park tells us, at the date of his visit divided into two great classes, the "Sonakies," or spirit-drinkers, and the "Bushreens," or Mohammedans. The first were the pagans, with whom the chief article of trade was rum or its 


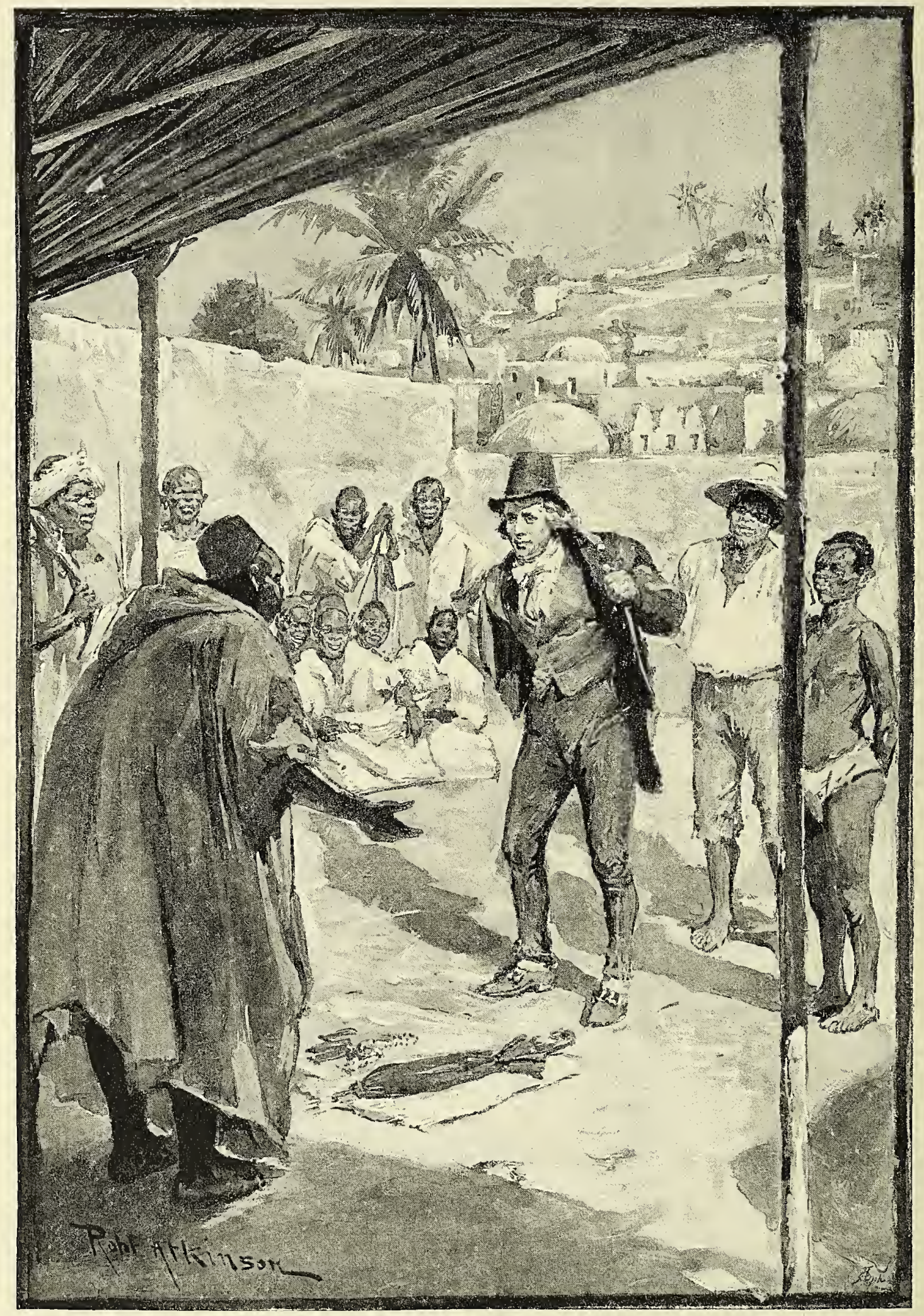

MUNGO PARK AND THE AFRICAN KING (\%, 186). 
equivalent, and after that the gunpowder necessary for the slave-raids. The Moslems, on the other hand, were rapidly extending their influence from the Upper Niger region, hospitable to the stranger-possessed of a knowledge of reading and writing, living under established laws, and respecting a code of morals which, if far from being perfect, is infinitely superior to any rule of life known in aboriginal Africa. Even drunkenness, which we have seen had begun to take hold of the IIoslems in earlier days, seemed to have

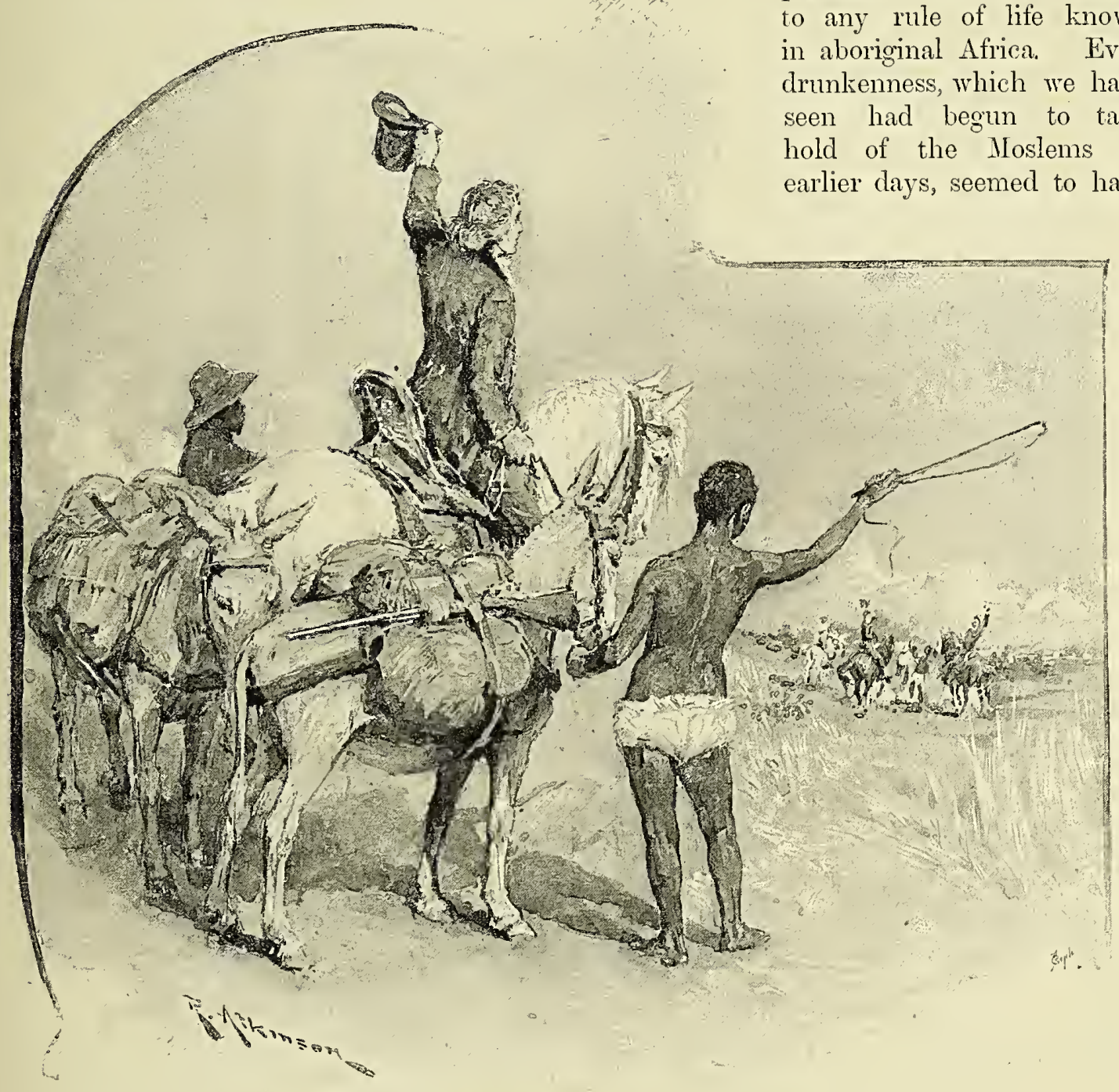

MUNGO PARK SETS OUT FROM PISANIA (p. 182).

which was their headquarters, to the Lower Senegal and Gambia, where their outer border was ever extending, greatly to the benefit of the country. Wherever the Mohammedan appears, the squalid pagan becomes a selfrespecting man, decently clothed, dignified in his behaviour-often, though not always, been abandoned by all save the viler of Bushreens and the half-pagan Johars. In those days no attempt had been made to stem the proselytism of Mohammedanism by Christianity; the African missions were yet to come. The Koran was the only book heard of on the Gambia of 1794, for 
the priests or chaplains of the trading-posts -when any such provision was made for the spiritual wants of the dealers in flesh and blood-eonsidered their duty done when the-stipulated number of masses had been said or the regulation number of sermons preaehed to the white men. But, as the law of the Koran spread, reference to written documents became necessary, and as this knowledge, hitherto strange to the negroes, was contined to a few people, a race of professional advocates, dexterous as any of their brethren in other lands at making the worse seem the better cause, had arisen on the river banks. An ass belonging to a Serawuli, a negro people of the Upper Senegal, had broken into and destroyed a great part of a corn-patch belonging to a Mandingo, and the irate farmer, eatching the offender, settled matters so far by cutting the donkey's throat. Thereupon the Serawuli "ealled a palaver," or, in other words, brought an action, and the lawyers proeeeded to argue it out. For three days the talk went on. The owner of the ass pleaded that it was a most valuable beast. This the Nandingo admitted, but, as a set-off;, affirmed that it had eaten more corn than it was worth. Thereupon experts in grain and in donkeys were summoned, and the court was favoured with some very hard swearing of the kind that we are accustomed to assoeiate with scientifie evidenee. Yet, in the end, no agreement could be arrived at, and the palaver broke up, to be resumed at some future day when the litigants could agree upon some common basis of value.

But by-and-by the rains stopped, and, the travelling season having now begun, it was

Park sets

forth on

his great adventure. time for the traveller to try his fortune in the interior, then so mysterious, now so fantiliar to a score of traders and explorers. His outfit was modest in the extreme. The modern caravan-leader who impresses a dozen porters to carry his personal effects, his European wardrobe, his ehina and his plate, his boxes from the Jondon dealer in delicacies, and his patent medicine-chest will read, with scorn at the simple ways of a eentury ago, that the pioneer of African explorers bought a horse and two donkeys - the steed, a sprightly beast, whieh cost $£ 710$ s. - and loaded them with provisions for two days, and some beads, amber, and tobacco for the purchase of a fresh supply. A few changes of linen and other necessary apparel, an umbrella, a compass, a sextant, a thermometer, two fowling-piees, two pairs of pistols-all flint-loeks be it rememberedand some other small articles, formed the total personal outfit, while Johnson, a free negro who spoke English, and Demba, a lively negro boy owned by Dr. Laidley, were the explorer's companions. Four chanee travellers who were going part of the way joined the party, so that when Dr. Laidley and the two Ainsleys, with a number of their domestics, accompanied him for two days on his journey, no doubt never expecting to see him again, Mungo Park, it is clear from the pride with whieh the honest man relates these partieulars, left for the unknown, in his opinion, after a fashion. rather magnifieent than otherwise.

On the afternoon of the 3rd of December his Pisania friends bade him good-bye (p. 181), and then for the first time he realised the "deserts of vast eternity" that lay ahead. To the explorer of these days, who crosses Africa without the world losing its head and tramps half the way back again to get the clean shirts he has forgotten, the journey on whieh the Scot had entered would be regarded as of little monent. But in 1795 Africa was a blanker land than now. All was unknown, and omne ignotum pro magnifico-or at least terribili-was the rule. No man knew what a day's journey was to bring forth; on rising up in the morning he could buy himself up with the thought that before evening he might see the golden-roofed houses or sleep in the famous city of Timbuetoo. Immediately ahead of Park lay what seemed a boundless forest eovering a eountry the inhabitants of which were strangers to civilised life, and to most of whom a white man was still an object of curiosity and of plunder. He had for the first time in 
his life parted entirely from European society, and might, from the hints he received on the way, share before long the fate that befell his predecessor. The country into which he was penetrating was ruled by a host of independent chiefs, who, like the barons of the Middle Ages, earned a precarious livelihood by plunder, either openly when they dared, or by exacting, on the ground of customs duties, blackmail from the caravans of native traders on their way to the coast with ivory, nuts, slaves, gum, or gold-dust, or returning with salt, cotton, gunpowder, rum, and muskets. Everything had to be paid for, food and shelter, wood if possible, and water always, the right of way, and the privilege of crossing a strean by swinging-bridge or rude ferry. A regular tariff was in force where the traffic was great. But more frequently the kinglet exacted a present, large or small, in proportion to the real or supposed wealth of the traveller. If he had nothing to give, or declined to be bled, his goods were seized, or his slaves compelled to change hands, and the well was locked, until the wayfarer, driven by thirst, made up his mind to yield to the extortion of the predatory despot. At the best of times, the endless stoppages to pay this "hongo," as it is called farther south, remind the elderly tourist of Germany before the Zollverein, or of Europe as it is depicted in the diaries of merchants and pilgrims when the douanier exacted his dues with an even more irritating power. As a white man, Park was naturally supposed to be rich beyond the dreams of avarice: the idea of anyone travelling so far from home for any other purpose than to win wealth was an idea too ridiculous for the African mind to grasp. If he had not quite realised this now familiar aspect of African travel, he was soon made aware of it; for as he was riding along, musing it may be on Border ballads, or on the qualitative nature of knowledge, he was awakened from his reverie by several men stopping his asses, and giving him to understand that he imust go with them to Peckaba, to pay custom to the King of Wuli (p. 185). It was in vain that he pleaded poverty, that he was not a merchant, and therefore ought not to be subject to dues. $\mathrm{He}$ might as well have talked of his impecuniosity to a Thames tide-waiter, and so he had to pay in the shape of four bars of tobacco for his majesty's private enjoyment. And as this species of plunder went on at irregular but rapid intervals, the two donkeys had before long an easy load to carry. Indeed, by the time he arrived at Kaarta, on the Upper Senegal, he was in the happy condition of having little of which he could be plundered.

Until he reached that kingdom his journey had, nevertheless, been comparatively pleasant, when the primitive appliances of African travel in 1795 are borne in mind. The coarse food, the rude surroundings, the lack of companionship, were soon scarcely drawbacks, while the road was beguiled by hourly observations of the then little-known habits of the natives. Now it was a Mlohammedan village, orderly and outwardly decent, through which he passed, then a pagan wetween the one, squalid and dirty, with Mumbo Gambia and Jumbo keeping order after the the Senegal. fashion that amused the earlier visitor's to the Gambia country, while the pleasantly rolling country, diversified by woods and cultivated fields, and green with the herbage that had sprung up after the rains, was pleasant for the eye to survey, The crops had been reared, food was cheap, and, as Dr. Laidley had friends and customers all through the country, the traveller's credit was good, and the reception he received more friendly than was his after-lot. In the kingdom of Wuli he was hospitably entertained at Medina, ${ }^{*}$ the capital, though the aged king strenuously urged him not to accept what he had as yet seen of the people as types of those with

* "Medina" is the Arabic word for "a city." The term is not uncommonly used among the negroes. Thus there is another Medina (Medine) on the Senegal, the people having evidently borrowed the name from the Moors on the frontier of this country. Sometimes, as in Morocco, the "Medina" is the residential quarter, as distinguished from the "Mellah," or Jewish district, and the "Kasbah," or section of the place occupied by the Governor and garrison. 
whom he would soon come into contact. $\mathrm{He}$ was then in the region between the Gambia and the Senegal, for the latter of which rivers he was making in a northeasterly direction. Here most of the people, and all of the chiefs, were acquainted with white men and respected them. But to the east most of them had no such knowledge. In after-dlays he had good reason to renember this advice.

Between Wuli and Bondu he marched for two days across a waterless desert, and here the guides sent by the old king who counselled him to stay at home gave place to three hunters of the elephant, still numerous in this region. At this point the curiosity with which the traveller was examined indicated that he was passing into a country that the traders had not traversed to any extent, though, as one of the elephanthunters took an early opportunity of absconding with the money he had received in advance, it would not seem that the native

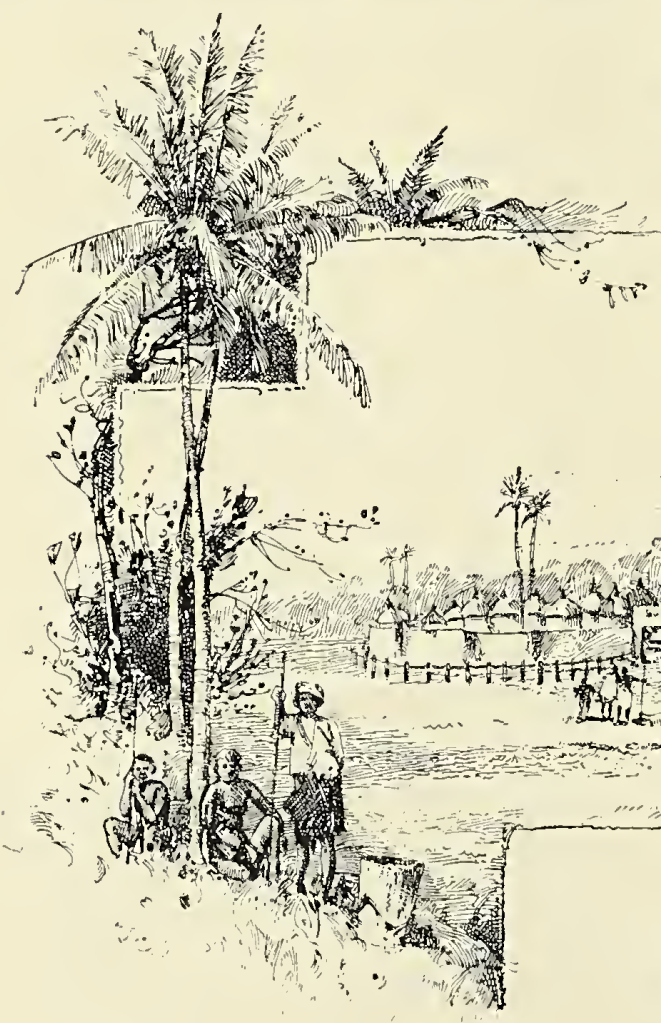

minds had been improved by lack of those evil communications which we have seen had long ago corrupted the manners of the people nearer the coast. The other two, however, kept their courage up after preparing a "saphie," grisgris, or charm, to avert misfortume. This consisted of little more than muttering a few sentences over a stone, which was afterwards spat upon and thrown three times in the direction the party intended to travel. By-and-by they reachea a tree to which were fastened innumerable scraps of cloth, the votive offerings of the many travellers who had in this manner tried to propitiate Fortune-or by whatever name the evil spirit presiding over life and death was called,-before departing from this spot, which had been originally a watering-place. In order to keep up the courage of his little caravan, Park followed his predecessor's example. Signs of robbers now became suspiciously frequent and to guard against an attack the party had to keep watch all night.

In Bondu, however, the old fertility of the land returned. Ridges, and even ranges of hills, showed they were on the divide between the Gambia and the Senegal, and for the first 


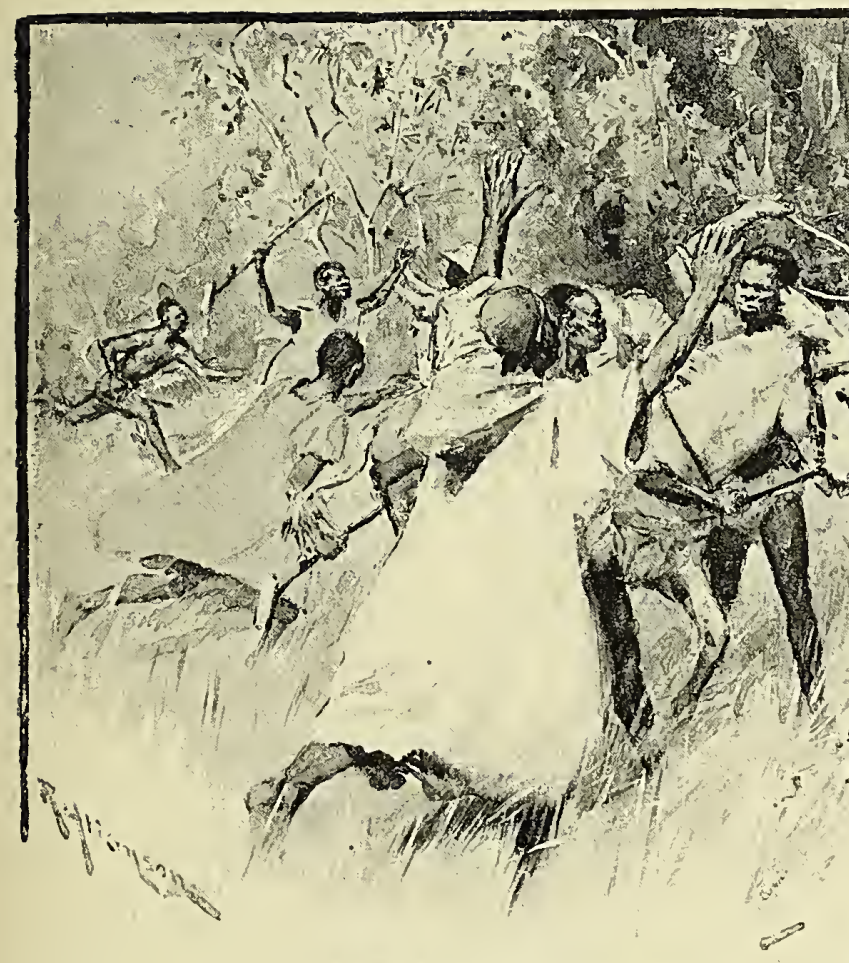

PARK BLACKMAILED (p. 183).

yielded. The latter process consisted in pounding them in a mortar while fresh, and then drying the fragments in the sun into large cakcs or loaves, These people* are strict Mohammedans, tawnycomplexioned, keen traders in anything, and of so warlike a character that they have sarried their conquests from Lake Tchad to the Atlantic, and are a remarkable factor in the history of North-Western Africa. Shepherds, cattle-owners, slavers, and farmers, their villages exhibited a prospcrity unknown to the purely pagan hamlets, and, instead of Numbo Jumbo and fetish-trees, the visitor was pleased with the sight of neat mosques, from the little minarets of which the mueddin called five times a day the Faithful to prayer: by the turbaned schoolmaster, with his circle of urchins around him intoning the Koran or inscribing its Arabic characters in the sand; and among the objects that the marabouts exhibited to the visitor were various religious manuscripts, bought, no doubt, as they still are, from the Moorish traders who cross the Great Desert from Morocco on their way to

* Also called. among other names, Peulhs, Fulbies, Fellatah, and Fillani. which, after being moistened with boiling water, are mixed with the kous-kousoo, the favourite Moorish dish of steamed farina and meat. These black fish-loaves are carried into the dry country to the eastward, forming a favourite article of commerce among the people where such food is almost unknown.

The party were now in the Valley of the Scnegal, and the thin French gauzcs and other tasteful articles of dress in $\begin{array}{ll}\text { which the women were clothed pro- } & \text { In the } \\ \text { Senegal } & \text { Valley. }\end{array}$ claimed the influence of a people who were still-in spite of the decay of the old régime - the arbiters of fashion in Africa as well as in Europe. But with Gallic taste the ladies had not acquired Gallic politeness. Yore importunate beggars, in truth, never existcd. They begged for anything, for everything-for amber and for beads, for calico and for physic; and then, having torn his cloak and cut the buttons from his servant's coat, and pilfered a few sheets of writing-paper which they could not make use 
of, they one and all begged for "that great African specific, blood-letting." Nor were the ladies of the king, or Almami, of a bashful type, for they insisted that the white man's skin was artificial-his mother had dipped him in milk-while his nose had been pinched from its natural flatness into its unsightly elevation. His majesty was also every whit an African monarch. He did not bear the best of reputations, having, it was reported, pillaged Major Houghton most unmercifully while resident in Fatticonda, the town in which Park had now arrived. This incident he did not, however, refer to, and expressed surprise that the new-comer cared to purchase neither gold nor slaves, a circumstance that seemed to trouble the king, as a trick to avoid payment of the customary tribute. In this country when a stranger arrives it is usual for him to stand at the "Bentang"- a sort of covered stage that serves the purpose of a town-hall or "palaver" house-or" other: public place until someone invites him to become his guest. On this occasion Park lived in the house of a slatee, or slave-merchant; but the Almami, as the easiest way of bleeding the traveller, ordered him to come to the palace in the evcning for a supply of provisions. Knowing what to expect, Park put on his best blue coat-scarlet and the like had gone out with the French Revolution-and carried with him his umbrella and a few other articles as a present for his majesty. The gift was welcome enough, and received with a due eulogy on the wcalth and benevolence of the white men. But, added the sovereign, all that he had yet seen was poor in comparison with the brass-buttoned coat, which, were it his, should be wom on all public occasions, with a full acknowledgment of the donor's generosity. The only reply to such an exAn African tremely broad hint was to strip off

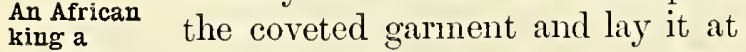
costly ac- the Almami's fect (p. 180). The quaintance. cautious Scot had in reality put it on to prevent anyone from stealing it, so that he left a little chagrined at the result of his manouvrc. An exemption from customs dues and the gift of a little gold, a jar of honey, and some fish-loaves were, however, the repayment of his involuntary generosity.

Lighter of heart and of load, the caravan left Fatticonda, and as the country beyond was a perilous one, even for travellers so poor as they, a bright moonlight was chosen for traversing it. Not a word was spoken. The pitter-patter of the donkeys, the shrieks and hoots of the night-birds, and the howls of wild beasts were about the only sounds that disturbed that lonely march. Everyone was on the alert, lest they should inadvertently stumble on the camp-fire of a robber band. Even the croaking of a frog, or the din of the myriad insects, were at times startling; but except when the rustle of a prowling hyena among the bushes raised the alarm of a lurking bandit, daylight came, and the country of Kajaaga, without the explorers nreeting with any mishap. At Joag, the chief town, Park took up his residence in the house of the Duté, or judge, and was invited to attend the public dance in the evening.

He was now two hundred and forty-seven miles east of Pisania, and everything betokened a land in which there was little security for life or property. Every house was surrounded by a private wall, like the "insulie" of the ancients, and the place itself, which at that time contained 2,000 inhabitants, was circled by a lofty barricade of bakcd clay, pierced with loopholes for musketry. If, however, the traveller imagined that he had escaped the rapacity of royal personages, he was soon undcceived by the arrival of an irate party of horsemen with a message from the King of Kajaaga-a Serawuli magnate-informing him that, having entered the country without paying duties, his entire property, people, horses, donkeys, and what little remained of the original loads, were forfeited to him. Park was now in a dilemma. However, accepting the advice of his landlord, he sent one-half of his. goods to the greedy king, he and his people being forced to fast for the remainder of the stay, lest by the exhibition of what 
little of his stuff was still to the fore he might be robbed of this also. For though the custom of the country gives the invited guest house-room, it does not enjoin the necessity of feeding him. While in this woeful plight, eating a handful of nuts presented to him by a passing slave, and chewing straws for lack of anything more substantial, the nephew of the Mandingo King of Kasson, on the north bank of the Senegal, arrived from an unsuccessful mission to the potentate at whose hands Park and his people were sutfering. Hearing of their condition, this young prince -Demba Sego was his name-offered to be their guide and protector as far as his route home and theirs 'lay together. Park's companions had now had enough of it. Johnson, the English-speaking negro, was especially loth to proceed, dreading lest, in spite of all the charms he had purchased impartially from Moslem and from pagan, with so scanty a store of currency on the donkey's back; nothing but disaster awaited them. A more impartial person than the Jamaica slave might have arrived at the same opinion. Park, however, laughed away the black man's cowardice, and promptly accepted the offer of the Kasson king's nephew. Fearful of proceeding, but still more terrified to turn back, poor Johnson, who had passed the best part of his life among white men, compromised matters by tying a white chicken to a tree in the first wood through which they passed, as a sacrifice to the forest spirits-dreadful dryads-like all the black men's demons, white, with long hair, and generally as unlike themselves as possible. For some days the route had left the Fulah country, and passed through a pleasant region dotted with pasturelands and great fields of millet.* The inhabitants are Serawulis, jet-black men not to be distinguished from the Joloffs, and most of them pagans, though their judges and headmen are usually Nohammedans. All are

* Sorghum vulgare, the "dougoup" of the Joloffs, the "gaouri" of the Fulahs. Another variety, which Park calls "manio," was thought by him to be IIolcus ccrruus. "Sanio" he makes out to be Hulcus spicatus. traders, rivalling the Mandingoes in the long joumeys they undertake. When one of these far-travelled merchants returns, all the village gathers round him to hear the tale of his adventures, though mainly to share in his liberality. But if lie has been unsuccessful, his levee is a short one, for there is nothing to be made out of a nuan who, in their expressive phraseology, "brings back nothing except the hair upon his head." All of them are very superstitious, believing not only in their own fetishes, but in the Mohammedan grisgris, saphies, or charms. Among their beliefs is the ill-luck of permitting a woman to eat an egg, and it is possible that the six ostrich-eggs placed on the six minarets of a little clay mosque, among datetrees not far from the Senegal, was in some way connected with this curious belief. At Kayi, a large village, they crossed Park crosses the Senegal, not far from the the Senegal. abandoned French trading-post of St. Joseph, and entered the kingdom of Kasson, or Kassani, with the name of which the reader of Briie's narrative will be familiar.

Then the disinterestedness of Demba Sego appeared in its true light, for no sooner had he landed the traveller in his uncle's dominions than he suggested to him the propriety - which in the circumstances might be translated the necessity-of rewarding his services by a handsome present. However, though beginning to think that he had got out of the devil's grasp in Kajaaga only to get into the deep sea at Kasson, the imporerished explorer, whom the last lking's messengers had left very bare, was compelled to comply with as good a grace as might be, glad that, as the young prince had, even before landing, managed to capsize the canoe in his eagerness to rummage a tin box that attracted his fancy, he was content to take seven bar's of amber and some tobacco.

At Tisi, Park lodged with Tiggiti Sego, father of his generous young friend, who even then did not lose sight of the fact that the white man was not yet stripped quite bare; for a slave having run away, the traveller's 
horse was borrowed in order to allow Demba to join in the chase, the result of which was that the bondman was captured in half an hour, smartly flogged, and clapped into irons preparatory to being sold down the river, on a land to the west of Bondu, to the effect that, unless the people of Kasson promptly embraced Mohammedanism, war would be the consequence, the steed and its equipments were once more requisitioned in ordcr

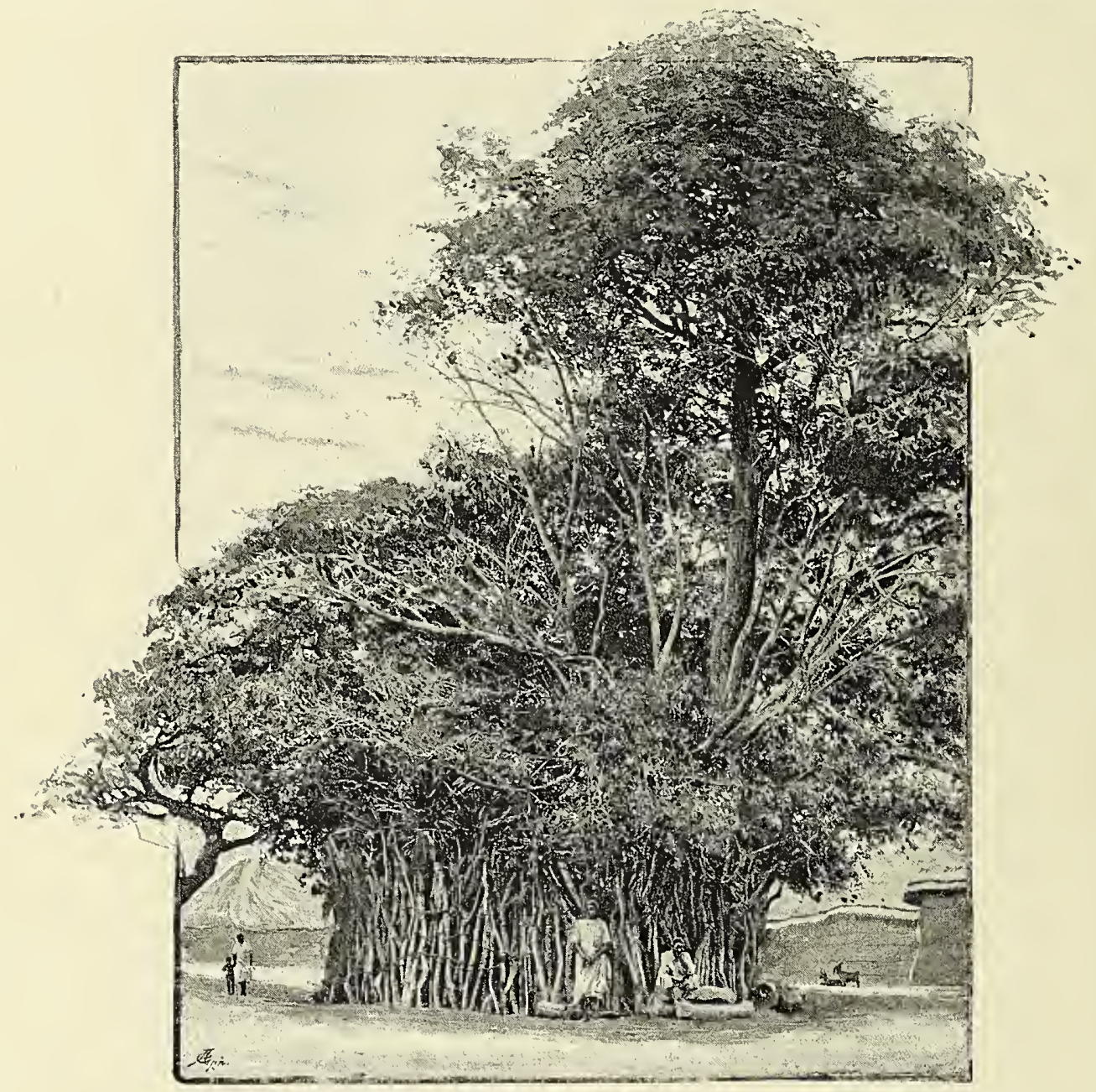

FETISH-TREE, WITH PALISADE TO GUARD IT.

(From a Photograph by Rev. J. T. F. Halligey.)

much the same principle that a refractory negro in the old days "before the War" was deported from Virginia to the extreme South, as the best way of teaching him a more contrite heart. A taste for Park's horso having grown on the young man, it was put into steady requisition for a few days. For an expedition having arrived at Tisi with a curt message from the King of Futa Larra, to send Demba on a fresh diplomatic errand. By the time the youthful Envoy had returned (the conversion of the entire inhabitants of Tisi having been accomplished in the meantime) the year 1796 had bcgun. Then Park's paticnce began to give way. In spite of the promptitude with which the threats of the King of Futa Larra* had effected a change of

* Foota Torra, according to Park's orthography. 
faith, the new creed nad not affected the old morals. Finding that the white man had still a few boxes, his host now insisted on receiving his dues, in addition to an acknowledgment of all the kindness he An avaricious had derived from him, the use of royal
family and the horse not being regarded agenerous as any set-off for the use of blacksmith, the bor'rower's roof-tree. Without waiting for a reply, Demba arrived for the present, demanding also to see father choose for himself. Before the hapless traveller had time to decide, the party began to open the baggage, Demba seizing as his special perquisite the tin box that had so much attracted his attention in crossing the Senegal. When the result of the rummage was

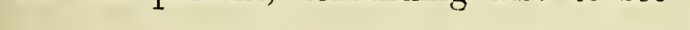

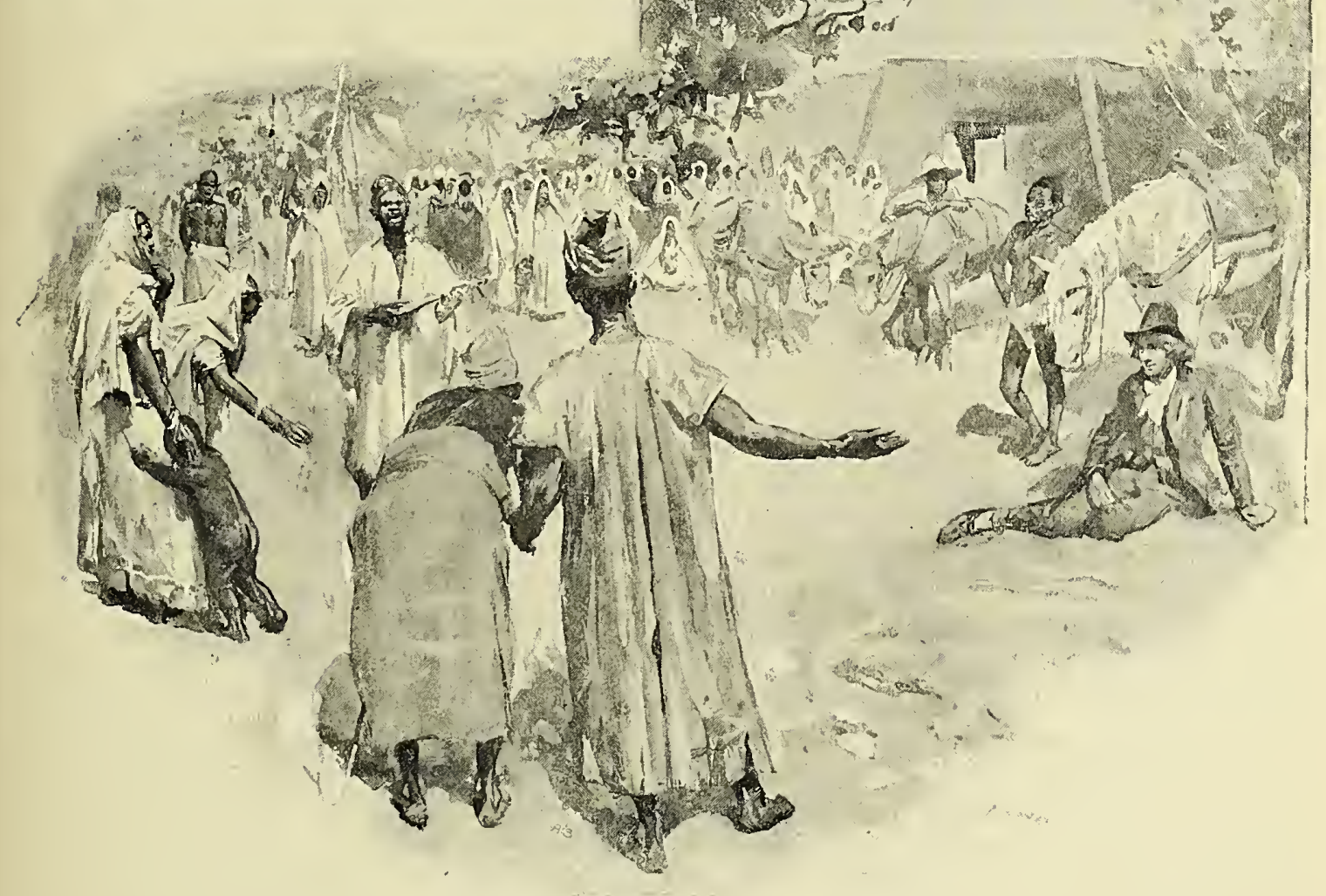

THE RETURNED BLACKS.MTH (2) 190).

what was in store. Resistance being uscless, seven bars of amber and five of tobacco were offercd. Aftcr surveying the articles for some time, the engaging youth coolly laid them down with the remark that they were no kind of gift to offer a man like Tiggiti Sego, who had it in his power to take without permission whatever he fancied, adding that, if something better was not given, it was his intention to let his over, something like half of what had escaped at Joag remained to the owner. Then began the turn of the traveller's companions. Even a blacksmith, who had accompanied the party all the way from Pisania, desirous of returning to his native country of Kasson, was exempted only on taking an oath that the articles his bundle contained were his own property. "There was, however, no remedy," Park tells us, and the meekness of the unprotected 
explorer of 1796 compares favourably with the "revolverism" of some of his successors, who, like Dr. Petcrs, can find no fault with Mr. Thomson cxecpt that he did his work without killing anybody; "and having becn under some obligation to Demba Sego for his attention towards me on the journey from Joag, I did not reproach him for his rapacity, but determined to quit Tisi the next morning. In the meanwhile, in order to raise the drooping spirits of my attendants, I purchased a fat sheep, and had it dressed for dinner."

Continuing his march over some small tributaries of the Senegal, he arrived at Jumbo, wherc the blacksmith, after four years' absence from home, was received with quite an ovation. To give dignity to the occasion, the honest fellow, who had tramped all the way from Pisania, was mounted on a horsc, and, preceded by a minstrel, entered his native village amid salvoes of musketry, to which his quondam fellow-travellers goodnaturedly contributed. His fellow-townsmen jumped with joy at seeing him, and the hired bard extcmporised to the full value of his fee in honour of the courage of the long-absent smith, while the meeting between him and his blind mother is described as imbued with that "touch of nature" which "makes the whole world kin." Even the white man was neglected. Nobody seemed to have noticed the sight which in any other circumstances would have been the first to attract attention. It was only when the blacksmith, in the midst of his narrative of all that had befell him, came to the story of how kindly he had been treated by the white man in whose company he had made so long a journey, and pointed to the place where Park sat, with the cxclamation, "Appilc ibi siring!" - "See him sitting there"- that all eyes were turned in his direction. He appeared to them like a being dropped from the clouds. Yet, in spite of the eulogium passed upon him, very few would approach too near the strange visitor. They had heard of white men before, and nothing much to their credit. It required, indecd, the blacksmith's assurance that he was perfectly inoffensive and would hurt nobody before any of them ventured to touch Park's clothes. Even then, on the slightest movement or sudden glance at anyone, the women and children would scamper off with all the timidity thcy had exhibited when Jobson and Jannequin first visited these inland regions. In a few hours, however; they became quite reconciled to him, and lavished all manner of kindness on him during the day. The blacksmith in particular never intermitted his attentions, and, when Park set out for Koniakary, insisted on escorting him so far on his journey.

On the way he called at Sulu to visit Selim Daukari, a Gambia trader of great reputation, on whom Dr. Laidley had given Park an order for the value of five slares. This, happily, was duly honoured to the extent of three bondmen, though not before messenger's arrived from the Kasson King inquiring why he had not come at once to Koniakary. Demba Sego Jalla appeared at first a better character than his relatives whose avarice had impoverished our traveller. He seemed to understand the object of his journey, and, instead of pillaging the poverty-stricken white man of what little remained, sent, in return for the trifling gift he could make him, a fine white bullock, white being the colour which in that part of the country was intended to mark particular favour. This, however, was about all that could be done for him. The route ahead was full of difficulties. Kasson and Kajaaga were at war. Kaarta, the next country he would comc to, was involved in it, and Bambarra also had threatened hostilities. While waiting the arrival of news from the disturbed districts, gossip had spread abroad rumours of the enormous sums of money which the whitc man had received from Selim Daukari, and in due time the king's messengers arrived to demand half of it from him, in addition to handsome presents for themselves. There was nothing for it but to submit. Happily, however, the more experienced "Slatee" was able to compromise the extortion for a smaller sum, and enabled 
him to set out for Kaarta, to which the war had not yet reached, not altogether bereft of warand the wherewithal to pay his way. rumours As yet the land looked peaceful of war. enough. All the vast plain was dotted with villages and eultivated fields, and so thiekly populated that by tap of drum the King of Kasson eould in those days summon 4,000 fighting men within a few hours. The country seemed to swarm everywhere with inhabitants, the native population being inereased by the inultitudes floeking in from Kaarta on aecount of the threatened Bambarra war.

Delays for guides were frequent, so that it was not until the tenth day after bidding farewell to the faithful blaeksmith (who, of all men, asked for nothing) that Kemmu, the capital of Kaarta, in the midst of a sandy plain, mostly denuded of wood, appeared at a distanee. As the little earavan neared the town the signs of eoming war were more and more evident. Many villages were quite deserted, and, though usually food is so plentiful that the eountry people deeline to aceept any payment for meal and milk, extravagant priees, in view of the unsettled eondition of affairs, were demanded for the most common neeessaries. White men seemed to be less and less known as Kaarta was approaehed, for at times the traveller was taken for a spirit, from whieh even armed hor'semen fled in terror.

Daisi Koorabori proved to be a less rapaeious prince than his brethren already met with. He not only treated the stranger well, but gare hin the best of adviee. The country was so disturbed that to proeeed meant almost eertain death, and he was unwilling to be party to any sueh misfortune as the murder of a white man who had passed through his eountry; but if go he would, Ludamar, a Moorish province whieh belonged to his friend Ali, was his safest destination; from thenee, with that sovereign's permission, he might pass to Sego, the eapital of Bambarra. If not, he must stay where he was until the war was over. As this meant losing the dry season, the only alternative was to penetrate among the Moors into a eountry where Major Houghton had already been murdered.

Then aeeordingly he set ont. He was now at the limits of a region even partially known, and was on the eve of penetrating a land where the white man was neither feared nor loved and his faith looked upon with abhorrence. How far he might go he lnew not, but that he would require to retraee his weary steps was eertain, while no explorer ever set out on a journey so long and perilous so slenderly provided with funds as this hardy Seot. For all that now remained was the balance of the gold-dust he had reeeived from Selim Daukari, whieh, at the most, eould not amount to more than between twelve and fifteen pounds, and on this sum he had to pay his way for an indefinite period.

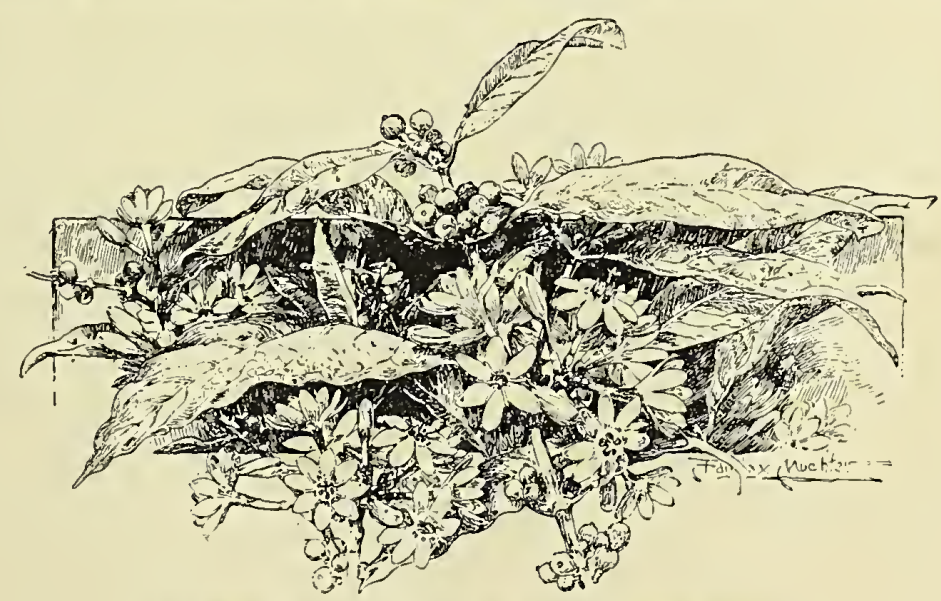

THE WEST AFRICAX COFFEE PLANT (Coffen liberica) 


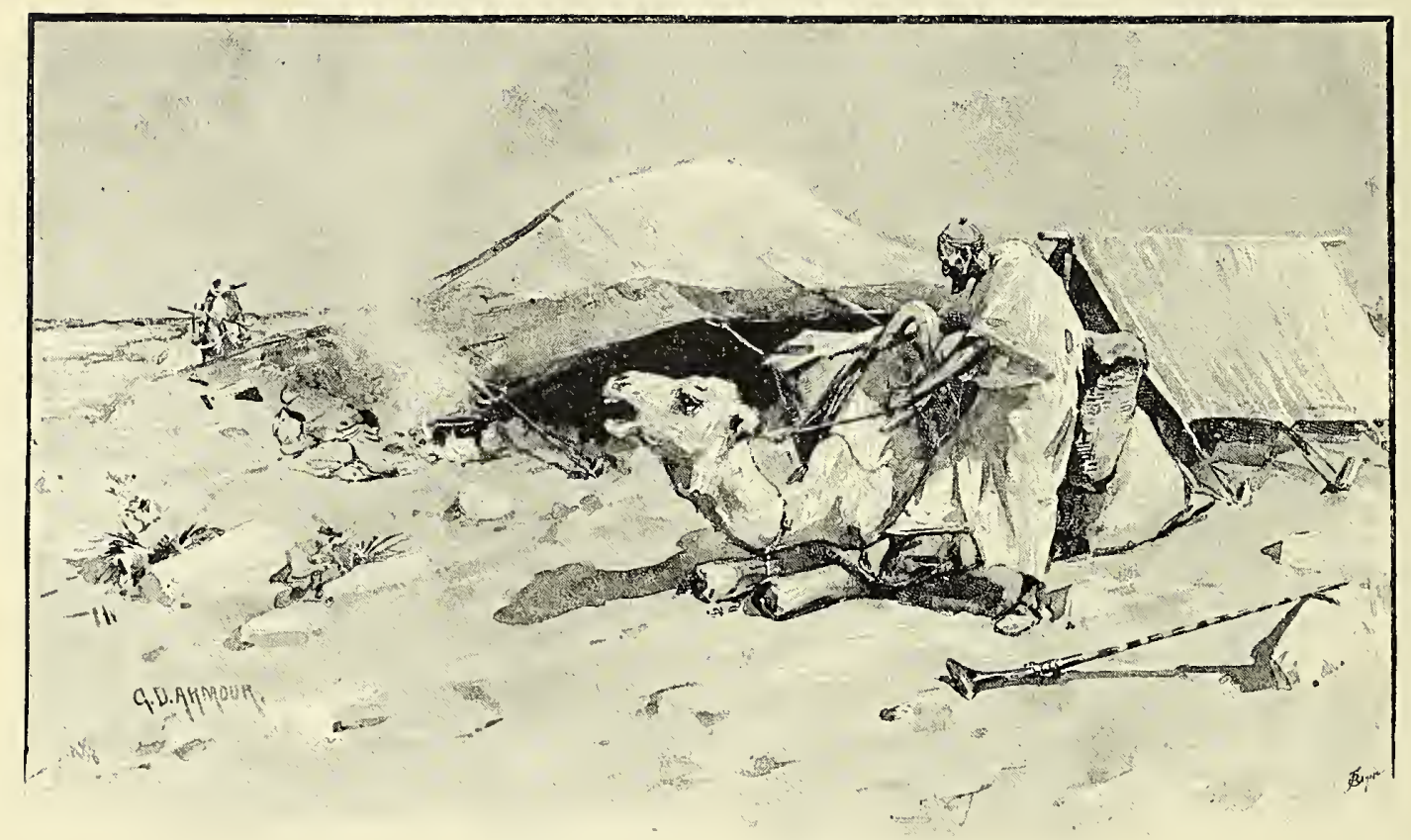

MOORISH DOUAR, OR EXCAMPMENT.

\section{CHAPTER X.}

\section{The Seekers after Thibuctoo: Muxgo Park.}

Park Enters the Country of the Moors-His Troubles Increase-New People but Old Manners-Ali's Camp-Some Unpleasant Experiences-Queen Fatima and the Shereefs-A Burst for Freedom-One Companion Deserts and Another is Sold into Slavery-Alone in the Desert-Inhospitality and Threatened Imprisonment from the Rich and Charity from the Poor-Selling Charms for a Livelihood-Traverses Bambarra-Reaches the Niger-Refused Permission to Enter the City of Sego-A Semi-civilised-looking Country-Kindness in Unexpected Quarters-A Song of Pity-Shell Money-A Forlorn Journey-Shea Butter-Park Determines to Return-The Miseries of the Homeward Route-Comfort in the Desert-A Slave Merchant Comes to the Rescue--Journey with a Slave "Coffle"-Reaches the Gambia, and Returns to England.

PARK had now arrived at the central stage of his journey, and had good reason to remember the advice tendered him by the Wuli king. He had left the land of the negroes proper -a race who, when Mohammedans at all, bear the burdens of Al Islam very lightly, and, though avaricious to the last degree, entertain no particular ill-will to the white man whom they pillage. But he was now entering the " country of the Moors "-people originally sprung from Arab ancestors, but, by long intermarrying with the black people whom they had conquered and amalgamated, mulattoes, in whom is combined all the ferocity and fanaticism of the stock by whose name they are known, with the brutality of that which has imparted to their skin its swarthy shade. A less inviting horde it would be difficult to entrust one's life to, for they hate the Christian with all the bitterness of religious fanatics, and in the vindictive expression of their looks, and their wild, strange eyes, make no pretence of concealing it. Some of them- as they still do-lived in towns, but most wandered about the country in tents, robbing caravans, or engaged in war's undertaken for the purpose of pillage. Few of them had then had any direct dealings with the whites, and, being far removed from the possibility of experiencing his power, were in 


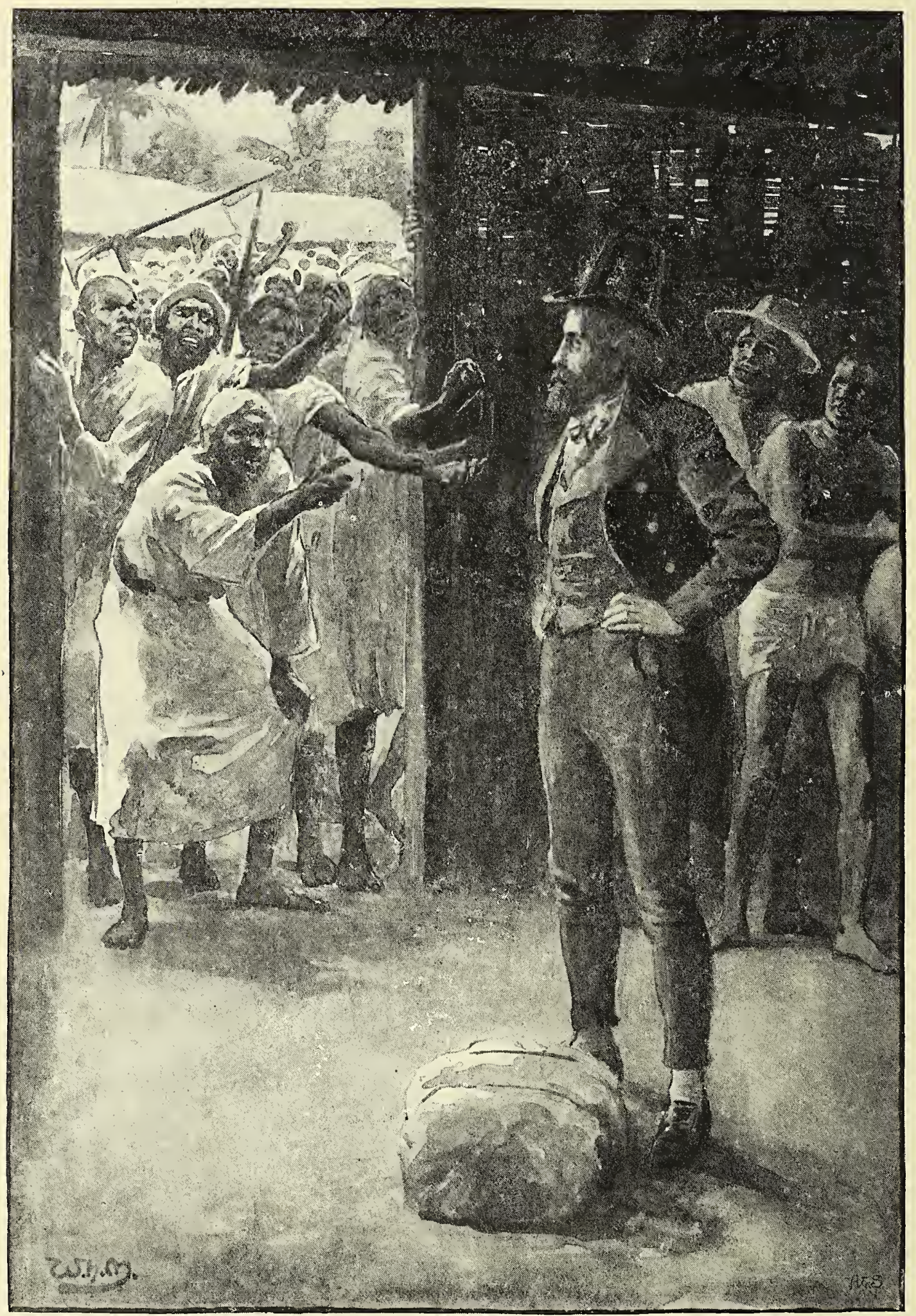


noway inclined to treat the new-comer with the good-nature seldom lacking in the negroes who had robbed him so freely all the way from Pisania to Kemmu. However, for a time all went well, three of Daisi's sons and about two hundred horsemen having convoyed him a little way on his road. Thieves there were, of course, and at the first halting-place he lost part of his now scanty baggage.

At Yarra, a large stone-built town, chiefly inhabited by negroes, he took up his residence for fourteen days in the house of Daman Jumma, a Gambia slatee, upon whom he had an order from Dr. Laidley for a debt, until permission could arrive from Ali for the creating a quarrel, which would give them an excuse for seizing his baggage. Finding that their provocation had not the desired effect, they proceeded to plunder him of everything that took their fancy, on the plea that being an Infidel he was the lawful prize of any True Believer. Already his sextant had been stolen, so that for all purposes of exact geography his future progress was useless. To add to his miseries, the people whom he had brought from Yarra, seeing that everybody could rob the white man with impunity, refused to go any further. Accordingly, he left this den of ferocious thieves next day, without any other companion except the boy Demba

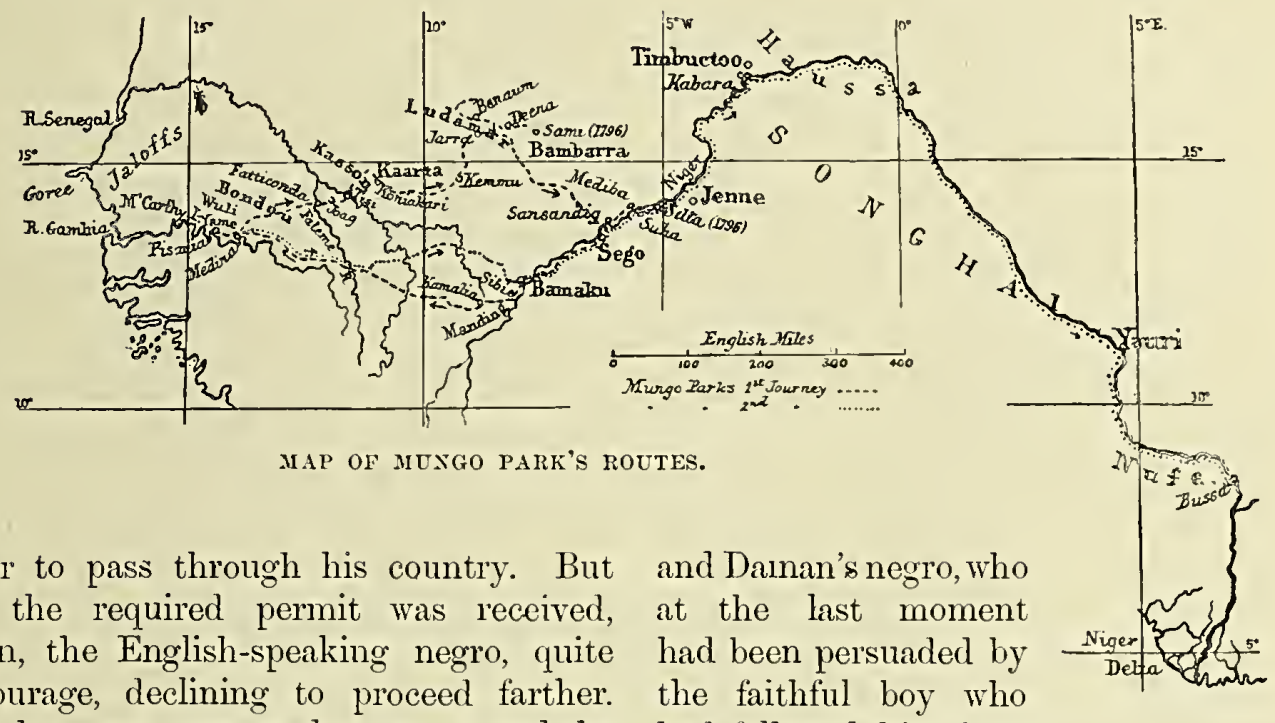

stranger to pass through his country. But before the required permit was received, Johnson, the English-speaking negro, quite lost courage, declining to proceed farther. Demba, however, consented to go on, and the trader with whom he was residing supplied the place of the recalcitrant West Indian by one of his own slaves.

It was not long before the character of the people was to be displayed. At Dina, the New people and old manners. next town, the Moors predominated, and in their rancour to the Christian forgot the precepts of their faith touching hospitality to the stranger. Gathering round the hut in which he had taken shelter, a surging mob hissed, shouted, and abused him, yelling every description of epithet in at the door, and even going so far as to spit in his face, with the object of 13 and Dainan's negro, who at the last moment the faithful boy who had followed him from

Pisania to continue true to his temporary master.

The land through which they travelled was dry and sandy, with few water-holes, and as they journeyed by moonlight to avoid the heat and the robbers, with the exception of the roaring of wild beasts, and difficulty of obtaining water, even when there were wells, by the numerous lions taking possession of these fountains, they were proceeding through Ludamar, almost to the borders of Bambarra, without any particular mishap, when messengers arrived from Ali with orders to convey him to that sovereign's camp, as his wife, 
Fatima, wished to have a look at the latest curiosity in the shape of a white man. At this news the Yarra negro's courage finally gave way; but as black men were common enough in that region, he managed to escape unperceived. The camp of Ali was reached after four days' weary journey. A less picturesque affair of the kind it would be hard to imagine. The dirty tents were scattered over a wide space, and betwecn them straggled camels, cattle, and goats, without any order or discipline being observed by the ragged horde that constituted his soldiery. On the new arrivals approaching, the people drawing water at the wells threw down their buckets, the men in the tents mounted their horses picketed hard by, and one and all alike caine running, galloping, and bawling towards them, until the crowd became so dense that it was with difficulty that Ali's tent could be approached.

On gaining admittance to that potcntate, the sight that net his eyes was not imsome un- pressive. Ali, an old man of a comfortable peculiarly sinister cast of countenin Ali's camp. ance, was engaged in the unkingly

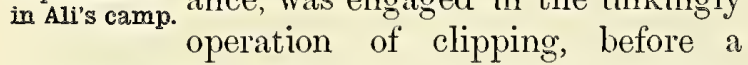
looking-glass held by a slave, the few straggling hairs on his upper lip. This operation finished, he proceeded to bestow on Park a sullen and malignant survey, expressing soine surprise when he heard that a knowledge of Arabic was not among his accomplishments, and then relapsed into silence. The ladies of his family were, however, inore curious. Nothing was too minute for their inquisitiveness, no part of his dress too trivial not to be examined by their restless fingers. His pockets were turned inside out and the contents appropriated, and his waistcoat was unbuttoned to examine the whiteness of his skin. They even counted the number of his toes and fingers, in doubt whether, in spite of their endless questions, a creature so strangely faced was really a human being.

Fatima, the fattest and fairest wife-for among the Moors fatness and fairness are synonymous-for the gratification of whose curiosity Park had been brought so far out of his way, being at a distance, he was ordered to remain until she returned, and slaves were sent to bring him food. This turned out to be a wild hog, which some boys tied to the tent-poles, inviting the Nazarene to kill and devour it. Thinking it would be unwise, in spite of his hunger, to touch an animal regarded with such extreme antipathy by the Mohammedans, he declined the insolent offer. The hog was then set free; but instead of rushing at the Christian, towards whom it was supposed to entertain an intense dislike, the irate boar ran amuck right and left, attacking without discrimination every person with whom it came in contact. However, the malicious Moors, not to be deprived of an opportunity of venting their malice on the Infidel, shut him and the pig up in the same hut. Yet even then the animal played Nemesis to its tormentors, for a thief creeping into the sty overnight to steal something from the human occupant, stumbled over the hog, and was bitten in the arm for his pains. Neanwhile, Park and his boy were treated not as guests, but as slaves. As barber to Ali's son, the Selkirk surgeon acquitted himself so badly that he was ignominiously discharged, much to his satisfaction, and ever afterwards, seeing that he hrd little chance of freedom if he proved too useful, it was his study to seem as incompetent as possible. Demba was, however, not so fortunate, for as grass-cutter he could scarcely plead ignorance; and by-and-by there arrived in the camp, much in fear of the fate that awaited him, the timid Johnson, who had been arrested at Yarra while meditating how best he could make his way back to his native Gambia.

His idleness, however, gave Park no intermission from annoyance. All day long he was kept, while parched with thirst, buttoning and unbuttoning his clothes for the satisfaction of the idle curiosity of the women, while the men would often gallop round and round him, twirling their muskets over their heads, and exhibiting feats of activity and horsemanship more for the gratification 
of their malice than for his amusement, since they never failed to vomit the foulest epithets at the hapless traveller. At times, indeed, they would call out to hin the words of the Moslem confession of faith, "La Illa ila Allah, wa Mohammed, arrasule, Allah" ("There is no God but God, and Mohammed is God's Apostle"), signifying at the same time with threatening gestures that unless he "testified" his throat would be cut. An old woman returning from a wedding in the camp told him she had brought him a present from the bride, and immediately discharged in his face the contents of a wooden bowl she carried in her hand. "Finding that it was the same sort of holy water with which among the Hottentots a priest is said to sprinkle a new-married couple, I began to suspect that the old lady was actuated by mischief or malice, but she gave me seriously to understand that it was a nuptial benediction, which on such occasions is always received by the young unmarried Moors as a mark of distinguished favour. This being the case, I wiped my face, and sent niy acknowledgment to the lady." Little in the shape of kindness was bestowed upon him, and the inquisitiveness displayed by the women savoured, to our ideas, of gross indecency. Yet the Moors were so much shocked at the white man's nankeen breeches that even Ali, who was by no means a refined personage, requested him to discontinue their use.

Hunger was added to thirst. For as he happened to arrive during the fast of Ramadan, when no Mohanmedan eats or drinks anything between sunrise and sunset, he was expected to conform to the same ascetic life. 'To beguile the tedium of his enforced leisure, Park began to learn the Arabic characters. This saved him from some annoyance, since the bystanders, seeing him industriously trying to shape letters in sand, got too interested in his 'prentice efforts to tease him. They preferred, when they were not ridiculing his clumsy attempts, to gratify their own vanity by teaching him the proper method of writing the holy tongue.
But nothing kept them from pillaging his bundles. As everywhere else, these were turned out, and his person was carefully searched to see whether he had not concealed some gold or amber, since the anrount in his bags was so small. Nothing escaped them: instruments, watch, and pocket-compass, all were equally the objects of their avarice. The compass puzzled them much, for the needle always pointed to the Great Desert. This was magic so great that they resolved not to keep it, and their dread of this "jin "-like tool of brass and iron was not allayed by learning that the reason why it pointed to the interior was that the owner's mother lived in that direction, and it guided him to her home or to her grave. Ali's sons appear to have been truculent scoundrels. They insisted on his mending muskets, which he was unable to do, and more than once snapped pistols at his head and at that of his boy on the pretence that they were attempting to escape. Escape, indeed, was ever present to the mind of the Moors. For on the night when the hog bit the robber, the entire camp turned out at the alarm, Ali, among others, appearing on horseback, preparing to give chase should the Christian have, as was thought, run away. Everyone in reality suspected everyone else, and, as the king was in hourly dread of assassination, or of poison, he was the most timid of them all-never sleeping in the same tent for two nights in succession, nor at any time permitting more than a chosen wife to know the exact spot where he was to be found.

Anxious, however, to conciliate his oppressors, Park determined to bear meekly the ills he endured rather than risk, by resentment, others still worse. With patience he bore every insult and complied with every command, and never did time pass so heavily as when he was obliged to suffer from sunrise to sunset, with an unruffled countenance, the insults of people whom he not unjustly styles "the rudest savages on earth." For, so far as he was concerned, the daily amusement of the boys was to beat the hog, and of the 
men and women to plague the Christian who shared its sty.

The end seemed at one time not far off; for a eouneil was held to determine his fate. Several voices were loud for his execution; while others eonsidered that to eut off his right hand, as if he had been a thief, would be the most fitting mark of ignominy to bestow upon him; but finally the proposal to put out his eyes obtained the unanimous eonsent of the Bushreens, on the ground that they were mud from the gutters-a diet that often proved fatal to them. In these eircumstanees little fell to the captives, unless when a slave, out of pity, gave them some, or they managed to push in between the eattle at night to share the filthy eontents of the tanks.

By-and-by the long-looked-for Fatima arrived. Though, as beeame a good Moslem, shoeked at the sight of so depraved a ereature as a Christian, she showed herself, after asking

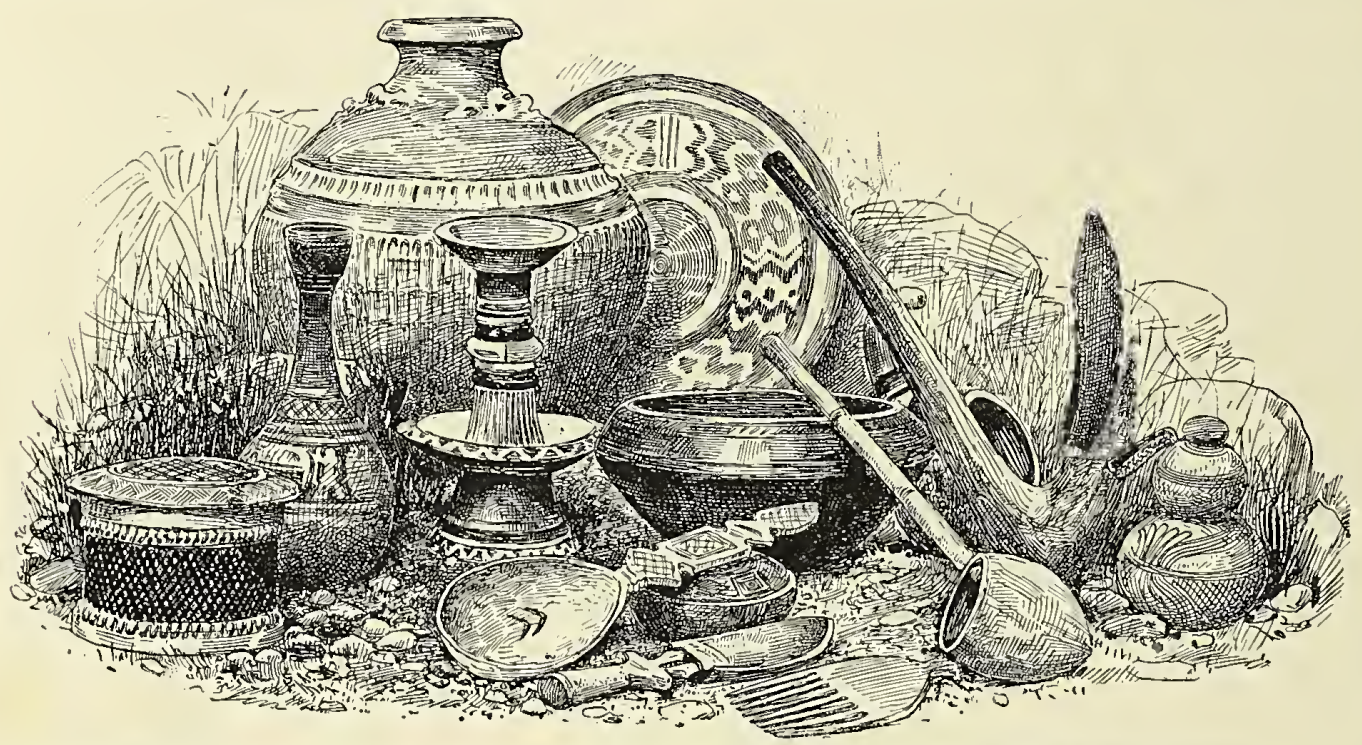

HOUSEHOLD UTENSILS FROM THE WEST COAST OF AFRICA. (From Specimens in the British Museum.)

like those of a eat. This insensate cruelty would most likely have been earried into effeet had not Ali resolved to delay the sentenee until Queen Fatima returned. Meanwhile, it seemed as if death in any form would be welcome compared with the torture the eaptives were enduring from hunger, and still more from thirst. Water was every day getting seareer and seareer, and the sand so hot that even the negroes with their horny feet found it impossible to pass, in the heat of the day, from one part to another without protecting them with sandals.

Day and night the wells were erowded with eattle, fighting to get at the troughs, or devouring in their intolerable thirst the moist black innumerable questions, not without a woman's kindly heart. For while the people of the eamp were so afraid of polluting their vessels, by permitting Ali's Queen Fatima and the shereefs. so vile a being to drink out of them, that rather than lun sueh a risk they would empty the eontents, she presented him with a bowl of inilk, and in other ways showed him almost the first kindness he had reeeived sinee coming to the Benaum eamp. As nothing: further was said about his eyes being put out, it may be inferred that in other respeets her intercession was favourable to the captives. Possibly also the arrival of an Arab merchant from Moroeeo-the Shereef Sidi Mohammed Mura Abdallah-was not without its influenee 
on these rude barbarians. This man of the Prophet's blood was a salt-trader, who, after a journey of four months across the Sus country and the sandy desert from Agadir, had cone
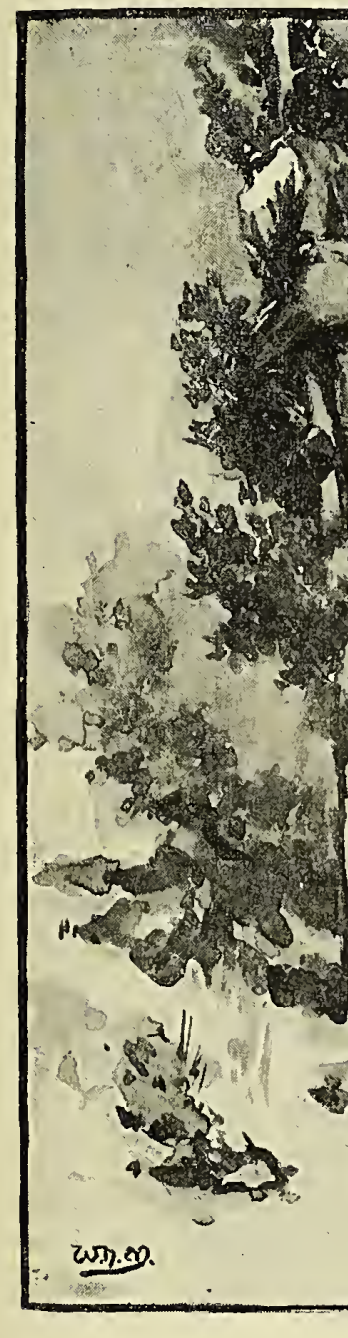

Agadir,* he had visited Gibraltar and could converse intelligibly in English. Another Shereef arrived about the same time; hc also was a man of great intelligence, who had travelled extensively through many of the interior kingdoms, and had lived for some years in Timbuctoo. But he gave Park no encouragement to follow in his footsteps; for though he supplied very accurate information regarding the route to and position of the city, his assurance was that "it would not do " to travel thither, since Christians werc looked upon " as the Devil's chidren, and enemies to the Prophet."

Conversing with these links bctween savagedom and civilisation relieved the tedium of the captive's life, and secmed also to have to trade for gold and slaves and ostrich-feathers with the inland parts of Africa, just as his countrymen had done for centuries, and as they still do after exactly the same fashion that they followed in former days. $\mathrm{He}$ was a person of much greater refinement than the people in the camp: since, apart from the fact that he was familiar with white merchants in Mogador and impressed the fanatics around him with an idea that, if men of their holy ancestry could stoop to treat him with friendliness, he could not be quite so vile as they had hitherto concluded.

* Swera (Sueira), and Santa Cruz, of Park's narrative, the first being the native name for Mogador, the second, the old Portuguese name of a place at one time a seat of considerable commerce with Europe, but now a tumbledown town without any resident whites. 
Food, however, was no more plentiful than before: for, as Ali's slaves were left to supply the stranger's wants, they not infrequently negleeted the task altogether, and in no instanee performed it lavishly. On one oeeasion nothing was brought for two whole days, and a house-to-house begging by Deinba, in the little negro village hard by, resulted in obtaining no better alms than a few handfuls of ground-nuts, which the lad readily shared with his master. The heat was so terrible that it was sometimes diffieult to keep the hand inore than a few seeonds in the hot breeze whieh swept from the desert. The Moors themselves would he all day on the sand in a semi-torpid eondition, while Demba and Johnson, aecustomed to the damp heat of the West Coast, beeame in time so dejeeted that even the ery of "kous-kousso" would fail to awaken them out of their heavy, uneasy slumbers. Park himself did not suffer in this way: his troubles were dim eyesight and laboured breathing, with tantalising dreams of rumning fountains of whieh he was about to partake, when suddenly he would awake to find himself still a thirsty sharer of the Benaum pig-sty.

The rainy season was now approaching, when the Moors retreat to the far interior. Park, A burst for seeing that there was no opportunity freedom. of escaping, obtained permission, through the intereession of Fatima, to aecompany Ali to Yarra, whence he went to treat with the fugitive Kaartans who had solieited his assistance against Daisi, their native prinee. This was better than being taken with them into the Great Desert. Demba, whose fidelity had deserved a better reward, was now seized by Ali as his own slave, on the plea that, being the interpreter of the Christian, he night perhaps conduet him to Bambarra. It was in vain that Park remonstrated against this high-handed conduet. All that he obtained was a signifieant hint, with a look that meant more, that if the white man did not instantly mount his horse he would share the same fate. The "old fool," as they ealled Johnson, might, however, if he pleased, stay with him, and, possibly, when the danger that was apprehended had passed away, the boy would be sold, at the price of a eommon slave, to the slatee in whose house Park lived on his former visit. That good fortune does not seem to have been poor Demba's lot. His master shared his tears at parting and neither ever saw the other again.

Johnson, again a free man, made what preparations he eould for returning to the Gambia, and Park, fearing that he would be taken to the eamp, devised plans also for eseaping, though in the opposite direetion. Bereft of every article that eould serve him as money, his entire baggage eonsisting of two shirts, two pairs of trousers, two pocket-handkerehiefs, an upper- and under-waisteoat, a hat, a pair of boots, and a eloak, this intrepid man determined to eontinue his course to the Niger. To go on seemed like eourting certain death; to remain was even worse, since it meant a lifelong captivity. He therefore chose the lesser of two evils: to return without aeeomplishing his errand would appear to have been the only thought that he eould not for a moment entertain. The ehanee oceurred one dark night when the Moors were all asleep. Telling Johnson to take good eare of his papers, he stepped gently over the sleeping guards, and, mounting his old horse, started alone for Bambarra. Relieved of every encumbranee, as nearly a beggar as a man without more than a change of clothing ean be, the dauntless explorer trotted away into the night with the lightest heart he had felt for many a day. For, having nothing to steal, he eould now not be robbed, and death was the worst that could befall him. "I felt," he tells us, "lilke one reeovered from siekness. I breathed freer. I found unusual lightness in my limbs; even the desert looked pleasant, and I dreaded nothing so much as falling in with some wandering parties of Moors, who might convey me baek to the land of thieves and murderers from whieh I had just escaped."

This pleasing reverie was, however, rudely interrupted by three horsemen overtaking 
him before he had ridden a couple of miles. 'They were messengers, they said, from Ali, whose orders were that he should inmediately return. How far this was the truth is doubtful. At all events, finding that the traveller, schooled in adversity, submitted to their demands with the apathy of despair, they took him aside into some bushes, stripped him of his cloak, as the only article worth taking, and then let him go. Again he turned his head towards the East, directing his course over the sandy desert through which it lay by means of the compass. The heat of the sun was often intolerable, water was not to be had, and his horse, hitherto as patient under hardships as his master, began to grow restive by reason of Alone in fatigue. Often did the traveller the desert. ascend the tallest tree(p. 197) to look for the smoke of village or the trace of human habitation, but nothing appeared on the level horizon except ridges of sandy waves that seemed to fluctuate like the sea in the ascending haze, dotted here and there with thick underwood. In rain did he and his horse chew the bitter leaves of the shrubs: they afforded no refreshment. Fearing that his fate was now settled, Park removed the bridle from the poor brute, and sank insensible on the white sand. When he recovered, the sickness and giddiness still continued, but the sun now sinking below the horizon he felt less exhausted, and prepared to make another effort to reach succour. By-and-by, as the darkness increased, the wind rose and a welcome shower laid for a time the drifting clouds of sand. Then, spreading out his clothes to catch the rain, he, by wringing and sucking them, quenched his thirst and continued his journey by the guidance which the flashes of lightning supplied; until about midnight, hearing what he calls "the heavenly music of frogs," he was directed to a wateringplace, at which, avoiding the huts hard by, he took large draughts of a muddy liquid on the surface of which the musicians lay in a thick sheet.

Next day he arrived at a Fulah village subject to Ludamar. Here, not only did the headman refuse to supply his necessities, but threatened to convey him back to Ali, and had it not been for the kindness of an old woman, who fed both him and his horse, it is not unlikely that he might have been compelled from absolute necessity to submit to this cruel decision. However, fortified by the food he had received, he managed to give these inhospitable villagers the slip and, with varying fortune, continued his journey.

The country, however, was now fertile, and the people hospitable, supplying him readily with food and asking nothing in return except a few hairs from his beard, under the notion that such a "saphie," or charm, might possess uncommon virtue. Warned, nevertheless, by bitter experience, the lonely traveller journeyed at night, when he would often sit for hours holding his horse by the nose, in equal danger from wild beasts in the bushes around and wild men in the open country beyond. In three days, nevertheless, he reached, without mishap, the frontier of Bambarra, and was out of the power of Ali. The people, moreover, were now negroes, and among them there was little danger from religious fanaticism, and. as he had nothing worth stealing, even less peril from cupidity. In those years beards were unknown among "Christians" - that is, among Europeans, the two words being synonymous in Mohammedan Africa. Accordingly the long beard of Park led him to be everywhere mistaken for a Moor. "He has been to Ylecca," was the ironical remark, "you may see that by his clothes." Another would break jokes upon the sorry condition of his horse, and ask whether he did not wish to sell so valuable an animal. Day after day the country grew more populous and the routes of travels more thronged. The people also became less kindly, more niggard in supplying his wants, less courteous, and more inclined to indulge in rough badinage, though in no other way interfering with his progress. It was clear he was approaching some large town. On the morning of the 20th July, 1796, this expectation was fulfilled, 
for on that memorable day he saw glistening in the morning sun the long-sought-for Niger, Park reaches a great river, as broad' as the the Niger. Thames at Westminster, and flowing to the eastward, and on the opposite bank the populous Mohammedan city of Sego. "I hastened to the brink," he tells us, "and

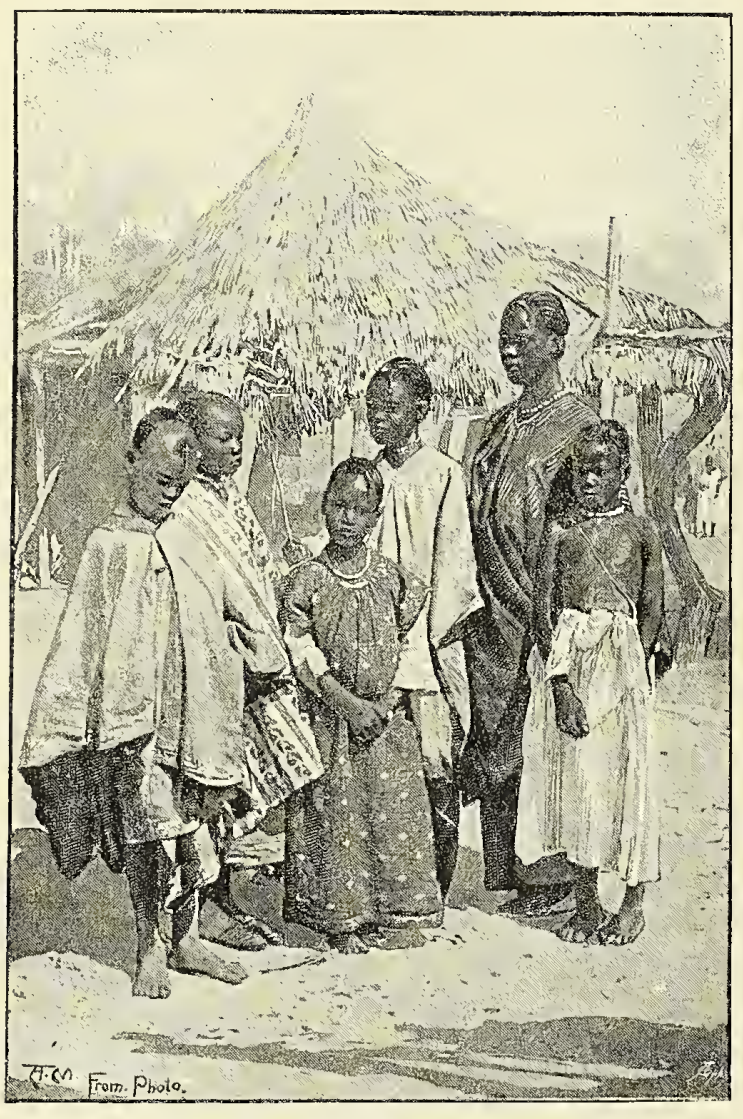

YOUNG GIRLS OF BAMBARRA.

(From a Photograph by the Paris Society for Erangelical Missions.)

having drunk of the water, lifted up nuy fervent thanks in prayer to the Great Ruler of all things for having thus crowned my endeavours with success."

It was market-day, and throngs of laughing villagers were hurrying towards the capital, eager to buy and sell and gossip. Among them he recognised some fugitive Kaartans whose benevolence he had already experienced during his journey through Bambarra, and by them he was procured an introduction to the king, though, in trutl, as the very slaves were ashamed of being seen in the company of so ragged a vagabond, it required no small moral courage on the part of these good people to become sponsor for a person of such disreputable appearance (p. 204).

The scene that now presented itself was a busy one. Scores of canoes were crossing and recrossing with passengers, the ferry, which was carried on by the king's slaves, being a royal nionopoly; while the crowded roads, the well-dressed people, and the highly cultivated country around the capital, betokened a state of civilisation which his travels up to this point had not led him to expect in the very heart of Africa. He found, however, to his nortification, that he was again in a centre of Moslem bigotry. For, to the chagrin of the kindly Kaartans, who expected no such obstacles, he was ordered to take up his residence in a village in the distance, the king having issued orders that, until he knew the errand of the white man, he was not to be permitted to cross the river. At the village, however, nobody would receive him. White men were, in those days, unfamiliar personages on the Upper Niger and not to be lightly entertained for the asking.

All day long he had to sit under the shade of a tree, and, as the wind began to rise and the rain to fall, his prospects for Hospitality the night seemed anything but in unexpleasant. Then as darkness closed quarters. in the staring crowd moved away, and left him to the society of his horse. Just then a wonan, returning from the labours of the field, noticed him and inquired why he sat there weary and dejected. On hearing his tale, she took up his saddle and bridle and beckoned him to her hut, where she lighted a lamp and spread a mat for him to lie on. In a few minutes she broiled a fish for his supper, and then, as the females of the little household spun cotton far into the night, one of them sang a song, the rest joining in the chorus (p. 205). The air, Park tells us-though, no doubt, he was a very partial critic-was sweet ana 
plaintive, and the words, literally translated, ran-

"The winds roared, and the rain fell;

The poor white nan faint and weary came,

And sat beneath the tree:

He has no mother to bring him milk,

No wife to grind his corm."

Chorus :

"Let us pity the poor white man :

No mother has he to bring him milk,

No wife to grind his corn."

Then they ended a simple song (which, unknown to them, an English duchess set to music in after-days), and made a bed for the weary inan on their earthen floor. After the toil he had endured, sleep ought to have been welcome; but the kindness he had received from these simple negroes was even greater than his weariness, so that he lay all night awake, thinking of the past and the future, bestowing in the morning upon his compassionate hostess, as almost the only compensation in his power, two of the four brass buttons still remaining on his well-worn waistcoat.

In this forlorn condition, it was ahmost sublimely ridicuA feeble lous for a messenger king and an
unkingly to arrive from the welcome. king with an inquiry whether he was going to send him a present. The answer was that the Moors had robbed the traveller of everything. It turned out afterwards that in Sego the Moors were, as in most parts of the kingdom of Bambarra,

so influential that the nominal sovereign, Mansong by name, despaired of being able to protect the traveller. This, however, Park only learned at a later date. Meanwhile, another messenger arrived with a gift of 5,000 cowries, and a message from the king that it was his earnest wish for him to depart immediately, the messenger being at the same time directed to accompany him as far as Sansanding, if he intended to visit Jenné.

For Jenné, therefore, the weary traveller set out, in a state of greater affluence than he had been for many days past. For, with 5,000 cowries of currency, he reckoned, at the rate of 250 for a shilling, he coukd support himself and his horse for twenty days. This cowry* (p. 201) is a small shell, two species of which are found on the British coast. But the one which then formed, and, to some extent, still forms, the ordinary moncy of the Soudan Basin, is Shell money. obtained chiefly from the Indian Ocean, and

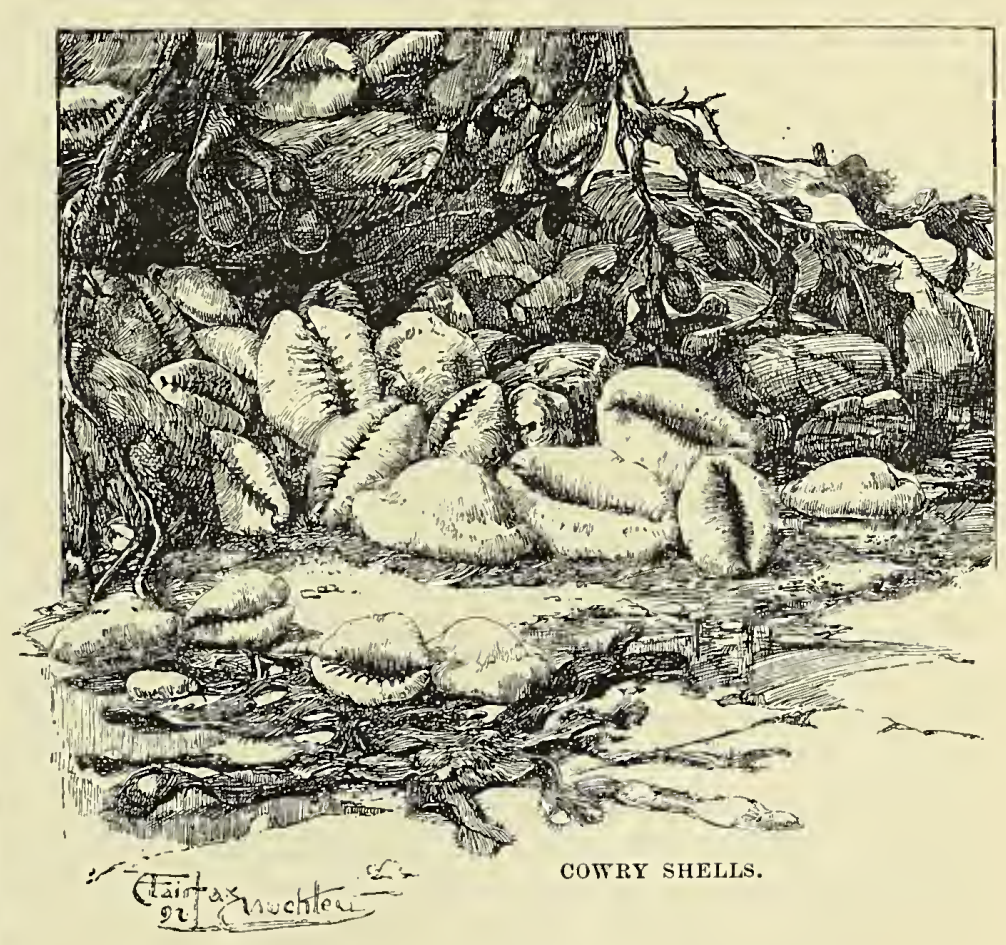

is employed as a medium of exchange not only in Africa, but in Southern India. In the latter country its value has within the last century fluctuated between 2,400 and 3,800 to the rupee. In former days it was more generally used than at present.

* cyprea moneta. 
At Cuttack, a bungalow that cost $£ 400$ was entirely paid for in these shells; and to this day tons are exported from Liverpool for use on the upper parts of the Niger and other West African rivers, the supplies being obtaincd from the Maldive Islands, Ceylon, the Malabar Coast, Borneo, and other East Indian islands, in addition to considcrable quantitics imported from various parts of the East African Coast, from Ras Hafun to Mozambique. Bengal at one time importcd about $£ 30,000$ worth, and even yet, in Siam, 6,400 cowries are on an arerage equal to a ficul, about 1s. 6d. Before the abolition of the slave trade, and the introduction of other standards of valuc, including coin and "bars," it was almost the only money used along the entire Guinea Coast, and far into the interior. Indeed, so rapidly did it penctrate the contincnt that, forty years ago, it was a quite recognised currency in Kanó, Kukawa, Gondo, and Timbuctoo; and in Muniyona the king's revenue was assessed at 30,000,000 cowries, every adult male being required to pay an annual poll-tax of 1,000 shells for himself, 1,000 for each pack-ox, and 2,000 for each slave owned by him. Nearer the coast, the shells are usually fastened in strips of forty or a hundred, a certam number of strips having, according to the locality, a recogniscd value, though in the interior, where they are hold at a higher ratc, the "Kurdi" are counted out one by one. Even those tribes who, like the Niam-Niam, do not bestow on them a monetary value, estcem the shells so highly as ornaments that the Zanzibar traders find it convenient to carry them into the interior, though it is not likely that any exploring expedition of our times will fall into the blunder which, it is said, one despatched by the British Government some years ago was requested to commit, by the Foreign Office clerks despatching a cargo of cowrics as the means wherewithal to defray its expenses in the Lake Regions. These sapient officials might as lief have consigned to the travellers a shipload of warining-pans.

Provided, thereforc, with a pound's worth of this bulky currency, Park set forth again in the hope of reaching 'Timbuctoo, the roal that he always kept journey. fixed in his memory as the one to which, if possible, he should attain. It is not necessary to remark that with the objects of his journey no one sympathised. When he told them that he had come so far to see the great Niger, or Joliba, the rejoinder was, "Were there no rivers in his own country, and was not one river just like another?" Undeniably, the appcarance the traveller now presented was not what the black folk had been accustomed to associate with a white man, and, apart from rcligious fanaticism, the Moors and those under their influence were not unjustified in setting him down as a suspicious charactera rascal most likely, a spy of some sort very probably. It is therefore not surprising that he received scant courtesy in his lonely journey.

All along his route, the country people were collecting the kernels of the shea-tree * fruit, from which is extracted the celebrated sheabutter, which is fragrant, white, firmer, and bettcr-flavoured than that of milk, while every other tropical crop was in abundance: It was, however, little that the ever-waning funds of the explorer profited by the pervading plenty. At Sansanding, a town of 10,000 inhabitants, he was mistaken by the negroes for a Moor. The Moslems, however, soon detectcd the error, and, with their usual insolence, ordered him to repeat the Mohammedan prayers after the fashion of the Jews, who, notwithstanding this conformity, are in those parts of the world regarded as inferior to Christians. In vain Park plcaded that he did not understand Arabic. A Shereef from Tuat, a chuster of oases in the desert south of Morocco, swore by the bcard of the Prophet that, unless he went to the mosque and testified, he should drag him thithcr himself; and

* Bassia Parkii, the species bearing Park's name. The butter, which is allied to that of the Bassia butyracen of India (Ghee), consists mainly of stearin and olein, and is now imported for soap- and candle-making, and for the preparation of pomades. 
not improbably would have done so had not the Duté, or magistrate, interfered on the ground that the stranger was "the lking's white man," and inust be protected. All that evening the little court-yard in which he was accoinmodated was crowded with hostile Moors, clamouring that they should see him perform his devotions " and eat eggs." With the latter of these requests poor Park expressed himself as only too happy to comply. Indeed, the inore he was asked to eat in moderation, the happier he should be; though, as they had been taught to believe that Christians subsisted solely on raw eggs, they were amazed when he asked for this welcome nourishment to be cooked. Finding, after all, that the white mian ate pretty much as he did himself, the Duté entertained him with a substantial meal of mutton and, when the Moors had departed, asked him to write him a "saphie," on the ground that, if a Moor"s charm be good, a white man's must be better. This was easily complied with, a scrap of board with the Lord's Prayer scratched on it meeting all the necessities of the case. The country beyond was less thickly peopled, but not more hospitable. At Medibu, he was forced to leave his horse, exhausted with the hardships it had undergone, and pursue his journey on foot. His altered circumstances did not, however, arouse any increase of sympathy. At Kea, a small fishing-village on the river, the Duté, on being asked for food and protection, informed him coolly that, as it was not his habit to pay any attention to fine speeches, he had better continue his journey, for no shelter should he receive from him.

This churlishness convinced Park that, though now little more than two hundred miles Park deter- from Timbuctoo, to proceed farther mines to meant for him either death or return. slavery. Every hour the hostility of the Moors and their paramount influence over the negroes increased, until, by the time he arrived at Silla-sick, exhausted, half naked, without any means of paying for provisions, clothing and shelter, with a swampy country before him, and the tropical rains beginning to inundate the rice-fields-he felt himself no longer able to face the prospect of losing all that he had accomplished by the growing fanaticism of the people.

At this point, accordingly, he wisely determined to begin his homeward journey, after accumulating from the conversation of the people all the information he could collect regarding the regions that he had been unable to visit. What was told him regarding Timbuctoo was certainly not inspiriting. For one of the tales related by an old negro was, that when he visited the city, his landlord, laying a rope down on the mat beside hin, addressed the stranger in these words: "If you are a Mussulman, you are iny friend-sit down; but if you are a Kafir, * you are nny slave, and with this rope I will lead you to market."

His homeward route was for a time even less pleasant than his outward one. At Medibu he recovered his horse. But often unable to find any guide, he was compelled to flounder for miles through morasses, to swim creeks with his bridle in his teeth and his papers in the crown of his hat; always treated with rudeness and suspicion, even when mistaken for a Moor, and often obliged to subsist on the same raw Indian corn as his horse, unless when the superstition of the negroes induced them to buy " a white man's saphie " for a meal of rice or mill.

Passing by several considerable walled towns, he reached the village of Song. But though the country round about was infested by lions, the inhabitants shut the gates in his face, under the belief that he was one of the Moors, a race for whom they entertained, not unreasonably, the most violent antipathy. As a prowling lion approached dangerously near the spot where he had lain down, Park found it necessary to climb a tree. Then the people invited him in, convinced that they had inistaken his nationality ; for, they added, with a knowledge of character that was evidently

* That is. " unbeliever," the term first applied by the Ioors to the South African tribes so widely known by that name. 
based on a wide experience, "no Moor ever waited till midnight at the gate of a city without cursing the inhabitants."

One day, wading a creek up to the neck, leading his horse by the bridle, his few rags fastened in a bundle on the saddle, a passing negro shouted to hin in the Mandingo language to conve out, or the alligators would devour him. Emerging from the strean, the black man gazed in amazement at the naked being. He had evidently never seen a brute intended to dispose of him in a more summary fashion than had yet been his lot, when the corpse of a slave was brought out of a hut and tumbled into the hole.

With varying fortune-never good, though sometimes a little worse than at other timesthe explorer passed as far up the Niger as Bamaku, intending if possible to reach the Gold Coast through Kong. Utterly penniless-or rather, cowrieless-without anything left except the rags he chose to call his

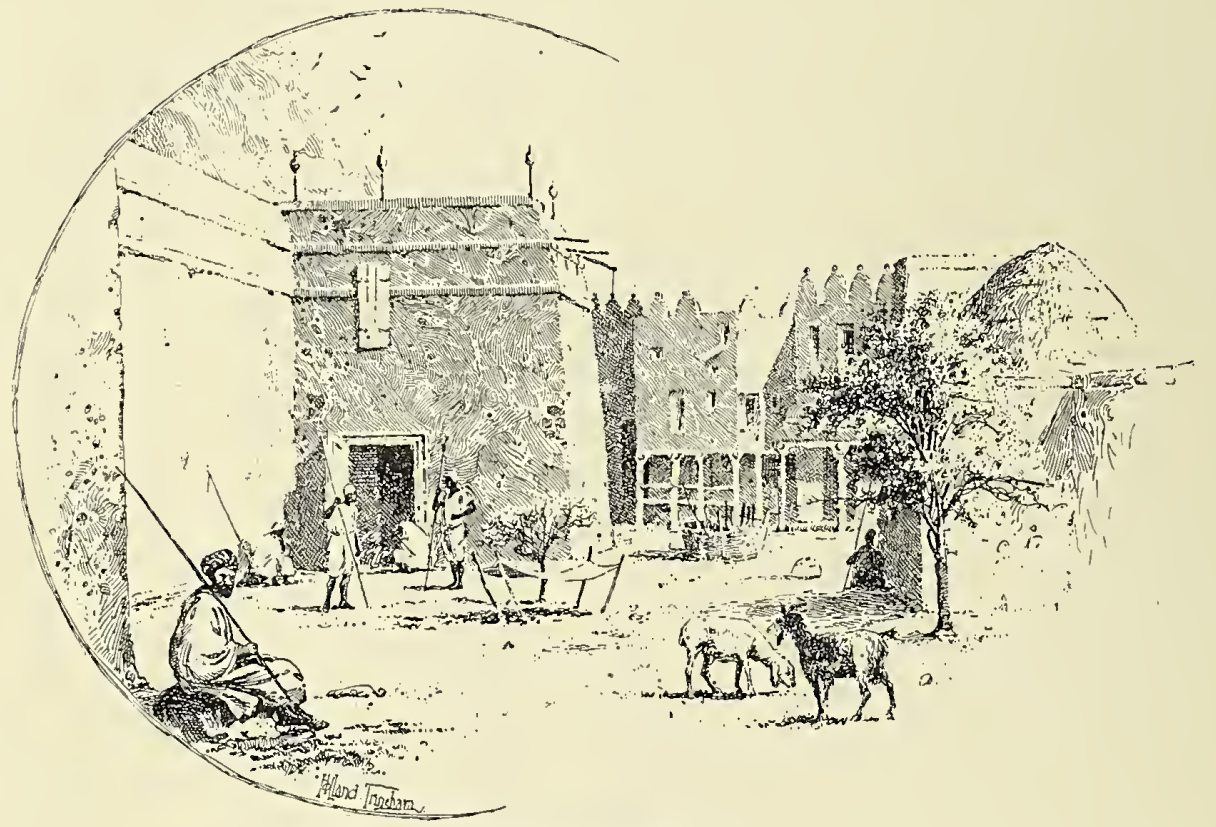

THE PALACE, SEGO.

European, and as he retreated from the apparition was heard muttering to himself, "God preserve ne! who's this?" Hearing" that the white could speak the Bambarra tongue, the good fellow became more confident, and conducted him for a few miles on his way. At Suha matters did not mend. The Duté was not hospitable-that by this time was the rule rather than the exception. He would neither give nor sell him food, and as he called to his slaves to dig a pitgrumbling all the time, "Good for nothing," "a vile plague," "money lost! money lost!"-our traveller was beginning to be afraid that the clothes, this looked a hopeless project. But when even the slender possessions mentioned were stolen from him by some Fulah robbers, who at first stripped him naked, but, finding that the garments of which they had plundered him were scarcely worth carrying, returned him the worse of his two shirts, a pair of trousers, and his hat, in the crown of which he kept his memoranda--with his only arms an old spear, he saw that it was out of the question.

He was now in the midst of a vast wilderness, without food or the means of buying any, without a horse, surrounded by savage beasts 
and still more savage men, naked and alone, and five hundred miles from the nearest European settlement. For the first time his courage began to give way, and as he lay down on the arid ground he felt that his end was drawing near. "The influence of religion, however, aided and supported me," Park wrote irresistibly caught my eye. I mention this to show from what trifling circumstances the mind will sometimes derive consolation, for though the whole plant was not larger than the top of one of nyy fingers, I could not contemplate the delicate conformation of its roots, leaves, and capsula without admiration.

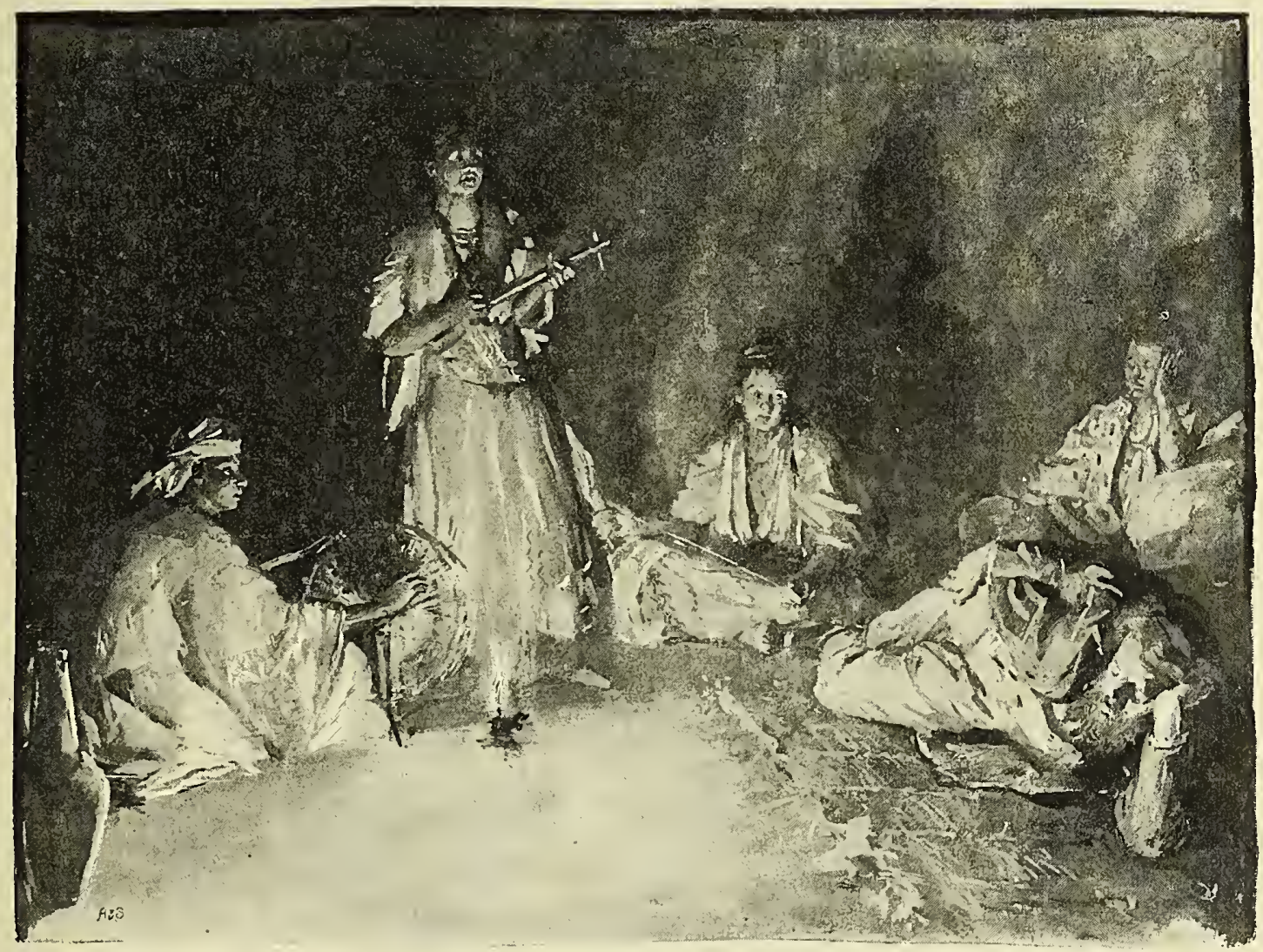

SEgo WOMEN ENTERTAINiNg PAkK (p. 201).

in a passage of his narrative which has, perhaps, been more frequently quoted than any other. "I reflected that no human prudence or foresight could possibly have averted my present sufferings. I was, indeed, a stranger Comfort in in a strange land, yet I was still misfortune. under the protecting eye of that Providence who has condescended to call Himself the stranger's friend. At this moment, fearful as my reflcctions were, the extraordinary beauty of a small moss in fructification
Can that Being (thought I) who planted, watered, and brought to perfection in this obscure part of the world a thing which appears of so small importance, look with unconcern upon the situation and sufferings of creatures formed after His own innage? Surely not! Reflections like these would not allow me to despair. I started up, and disregarding both hunger and fatigue, travelled forwards, assured that relief was at hand, and I was not disappointed." For in a short time he 
overtook two shepherds whom he had met in a former part of his journey, and with them journeyed to the kingdom of Manding, the land of those Mandingoes who, we have seen, are found all through West Africa as colonists, commercial travellers, and traders.

His route thenceforward was in even greater misery than beforc. Every bite he swallowed had to be begged, whether it was maizeflowcrs stewed in milk and watcr, or some coarser though more substantial nutriment. Yet even this was often denied him, for there was a famine in the land, and as women were selling their children to buy corn for themsclves, little could be spared to a traveller; and, to crown his miseries, at Wonda he lay ill of fever for nine days, to the uncasiness of his negro landlord, who was overheard remarking to his wife that the white man would be much cost and trouble, since, "for the sake of their good name," they would be forced to maintain him till he should recover or dic. At this place his oft-lost horse turned up, but as the roads were now unfitted for travelling on horseback, he presented the beast to his host, and the saddle and bridle to the Mansa, or chief magistrate, of Sibidulu, by whose exertions it had becn recovered.

At Kamalia his worst misfortunes came to an end; for though he had still a long journcy

A slavemerchant comes to the rescue. Park reaches reason was that here he met with the Gambia. a negro "slatec," one Karfa Taura, bound with a "coffle," or gang, of slaves to the Gambia as soon as the rains abated, who agreed to escort him to Pisania and accept payment on their arriving at his destination. With this man he stayed until the party set out, and it may be remarked that when he first visited him he found the slatee reading out of an Arabic volume, and noticed in his little library a copy of the "Book of Common Prayer." Fever now seized Park, and for four weeks it secmed as if the slatec's kindness would be of no avail. Thanks, however to the disinterested tenderness of the village schoolmastcr, while the slave-merchant was collecting his human chattels he recovered, and on the 19th of April, 1797, sct out. The travels of the next few weeks were not eventless. He passed through a country not quite unknown, though at that date not fully described, and saw much of the slave trade in all its horrors (p. 179). Among the most pitiful of these was his recognition, among the coffle with whom he journeyed to the coast, of several persons from whom only a few months before he had received such little kindnesses as lay in their power. Among them-such is the vicissitude of savage life-were the fugitive Kaartans who had offered to introduce him to the King of Bambarra at Sego; now they were on their way to a lifetime of slavery. Since then they had fallen captive to some robber's spear and bow.

At Pisania, where in due time he arrived, his friends received him as one risen from the dead. All the traders on the Gambir had been informed that he had been murdered by the Moors of Ludamar, a rumour which Johnson, like Musa when placed in a similar position towards Dr. Livingstone seventy years later, had no doubt done his best, as cover for his own cowardice, to confirm. That pusillanimous negro, however, never reached Pisania; he had either died or been enslaved, and with him disappeared the papers with which he had been entrusted. Everyone was now handsomely paid, and gifts wcre sent, as far as possible, to the few people who had befriended Park when friends meant life or death-a meal or a tightening of the traveller's belt.

Then the greatest of African explorers sailed from Goree on his way to England. In those days steamers were unknown, and, it is not necessary to add, telegraphs undreant of. For more than two years no ncws had penetrated from Inner Africa to the London Association regarding thcir agent, except, indeed, that he had met the same fate as Major Houghton at the hands of the samre ferocious fanatics. For a time, however, they had still to wait; for the usual course of commerce was, in those days, 
to load with slaves and then sail for America or the West Indies. To Antigua, therefore, the ship in which he had taken passage departed, and as the surgeon died of fever before leaving Africa, Park took his place. Yet, even on the slave-ship he was not without memories of the journey he had completed, for several of the captives he remembered having seen on various parts of his route. After all the perils he had endured it seemed that he was to perish at sea. The vessel, overladen, ill-found, and bad in itself, looked once or twice in the course of the thirty-four days' passage to the West Indies as if it would founder. That doom was, however, spared her, and, in due time, exchanging into the ordinary packet which called at Antigua, he landed at Falmouth on the 22nd of December, 1797, after a journey remarkable in any circumstances, but, considering the trifling cost at which it was performed, the terrible hardships the traveller endured, and the result to which it led, perhaps the most extraordinary in all the story of Africa and its explorers.

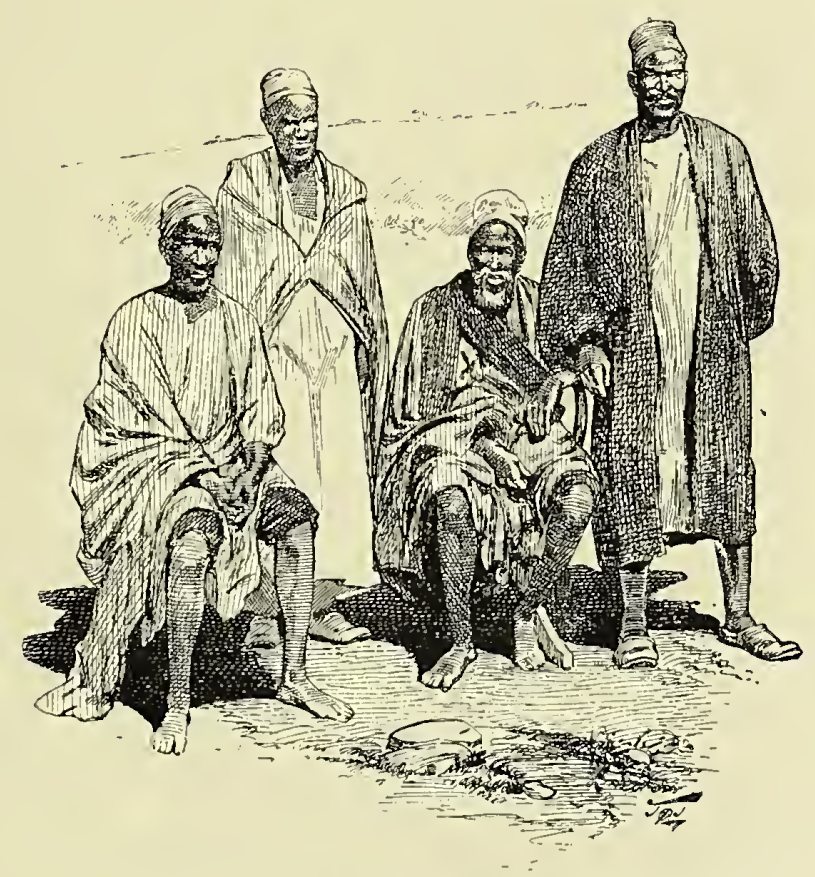

BAMBARRA TYPES.

(From a Plotograph by the Paris Society for Eungelical Missions.; 


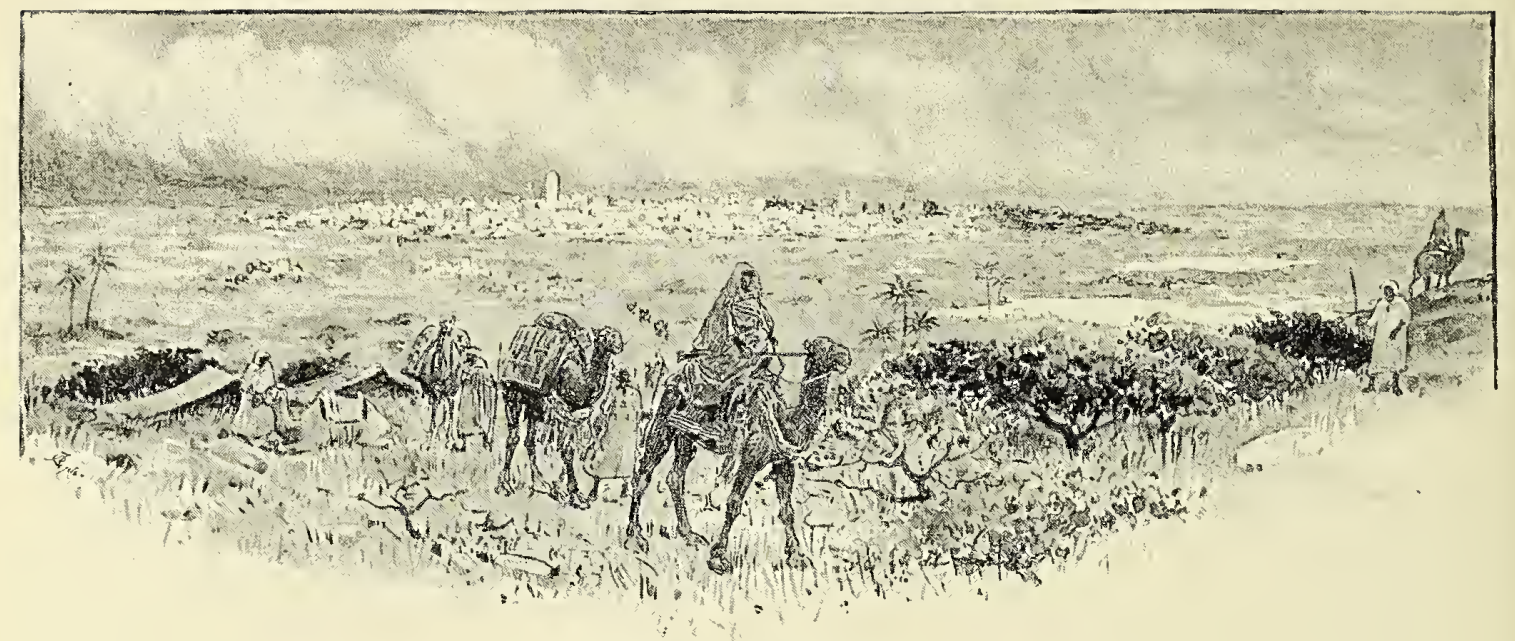

TIMBUCTOO : DISTANT VIEW

\section{CHAPTER XI.}

\section{The Seekers After Thibuctoo: A Chronicle of Fallures.}

Park's Return-A Strange Meeting-The First African "Lion" in London-Park as Author and Country Doctor-Disappointments-Second Expedition-Early Misfortunes-Hustilities with Native Thieves-Disease and Death-The Expedition Reduced to Five-Build a Boat at Sansanding-And Begin the Descent of the Niger-Their Truculent Proceedings Over a Course of One Thousand Miles-Near the River Port of Timbuctoo and yet do not Land-The Last Fight with the Natives-Death of Park and all his Companions-The Tale Told by Amadi Fatuma to Isaaco-Young Park-The Legends of the ExplorerRoentgen-The Dangers of Disguise-Caravan Tales-Adams and his Imposture-Riley-Peddie-Campbell - Gray and Dochard-A Chapter of Failures.

ExCEPT that he had met his doom in the centre of Africa, no news had reached England regarding Park since the day he set out on his travels more than two years before. Nowadays a returning traveller with half his merits is, in spite of any other course his modesty might suggest-and the age is an advertising one-fanfaronaded evcry step of his homeward journey. The telegraph tells how he has arrived here, the special correspondent what he has to say there, until by the time he lands at Liverpool or Plymouth, or steams into Charing Cross, the interviewer and the illustrated journals have taken the heart out of any tale he may have to tell. But in 1797 the world moved more slowly; telegraphs were undreamt of, and posts slow and infrequent, while the enterprise of the press did not reach so far as to tap the tale of a traveller on his way from Inner Africa vin the Gambia and Antigua. Accordingly when Park reached London by the Falmouth stagecoach early one morning in the Christmas week of 1797 , he came perfectly unheralded by any species of puff-in-advance. Having some time to spare before he could wait upon his employers, the African Association, he spent it in the gardens of Montagu House, which had then been converted into the nucleus of the British Museum. It happened that by an accident the gates had been left open all night, so that when the curator peeped out soon after dawn he was annoyed to see someone sauntering about the grounds. By a curious coincidence this official was Mr. Dickson, Park's brother-inlaw, who, since his departure for Africa, had been appointed to the post in qucstion. Their mutual astonishment at meeting in such circumstances may well be imagined, for the 
traveller was unaware of his relation being in London, while Dickson, like the rest of the world, had long mourned him as dead. In a few days, however, the faine of the home-comer was the chief attraction of Sir Joseph Banks's Sunday evening parties, and Bryan Edwards, in whose house he lived, was compelled, in order to stay the public appetite for some

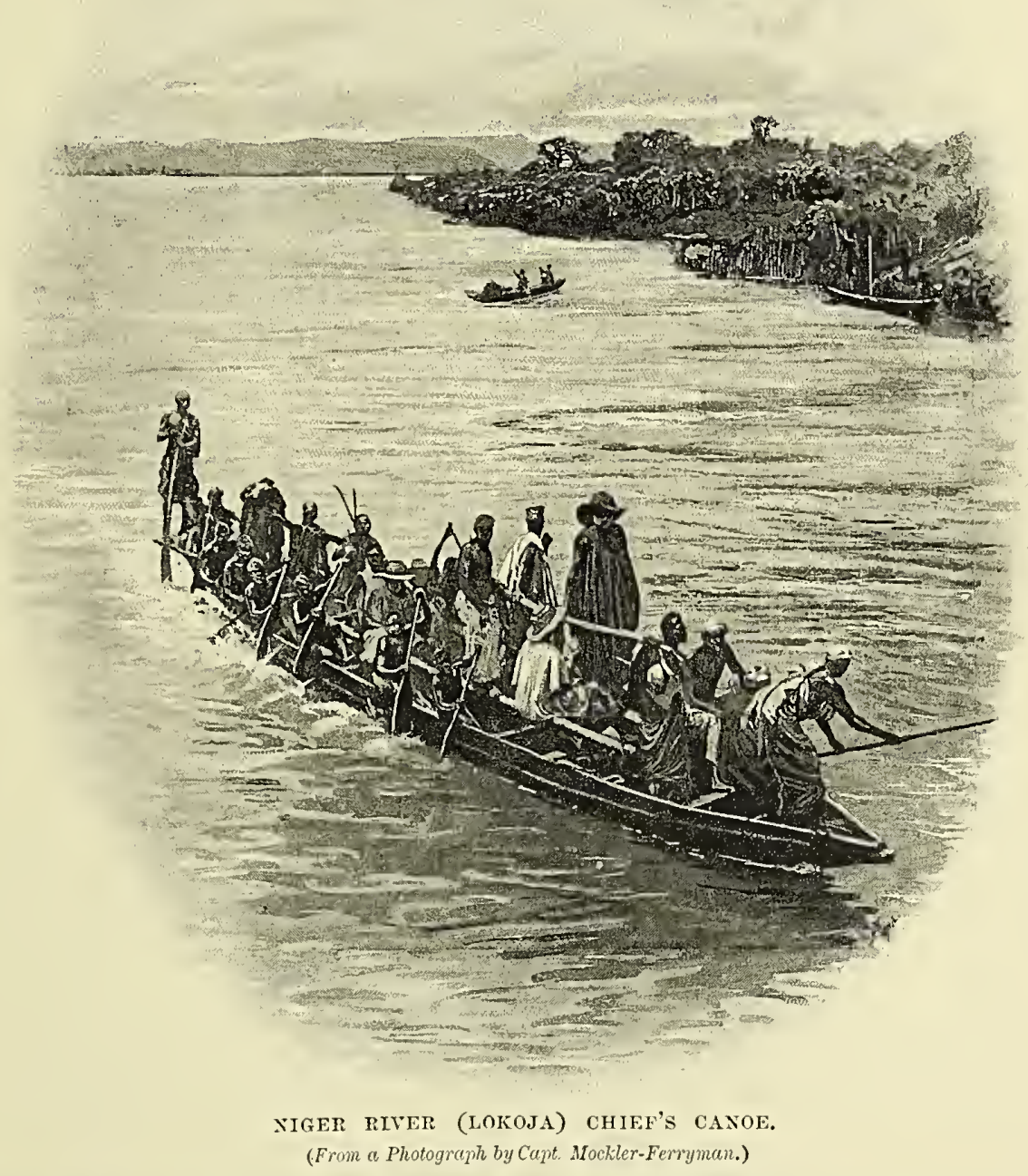

was not confined to so narrow a circle. The African "Lion" was until then unThe first African "Lion." known, and so valued accordingly that for several weeks the first captured specimen of a now familiar species account of the young Scotsman's explorations, to print a preliminary narrative for private circulation.*

* Precedings of the Association for Promoting Discovery in the Interior of Africa. (1798.) 
Meanwhile, in order to obtain greater leisurc for preparing the fuller description on which he was engaged than the whirl of fashionable London afforded, Park took up his residence with his widowed mother and his brother at Fowlshields farm-house. In consequence of the many robberies he had suffered and the loss of the papers he had despatched to the coast with Johnson, he had few materials (save what his memory had retained) out of which to write the eagerly expected volume. Some greasy scraps of paper, the jetsam and flotsam that had escaped pillage and flood and tropical showers in the lining of his hat, werc the most tangible notes on which he had to rely; while Major Rennell, the most accomplished geographer of his time, who undertook to construct the map of Park's travels, had to depend largely on dead reckonings and scattered memoranda in addition to the rough outline that Park drew from recollection. Bryan Edwards helped him much. Indeed, as the sketch that the accomplished historian of the West Indies had prepared was to a large extent incorporated in the narrative, the volume, though carefully revised by the ostensible author, was to some extent a joint production. Its success was great and immediate. In the closing years of last century the world had not the plethora of African travels it has since those days bcen asked to digest, though then, as now, it was dreaming airy dreams regarding the future of the continent that nobody believed to be either "dark" or "lost," except that its unknown wcalth left everyone to form his own conclusions regarding the possibilitics of its future.

But while writing his "Travels" Park had paid a great many visits to Dr. Anderson's surgery in Selkirk, and there renewed his friendship with the doctor's winsome daughter, whom he married on returning from London.

Disappointed in his great friends finding a "Doctor post for him, the African explorer "Park of put a brass plate on his door, and Peebles." settled down to the prosaic life of a medical practitioner, in the Byegate of
Peebles, a pleasant town which even yet does not claim to be an exciting place of residence. A century ago it must have been about as dull as Sego in the rainy season. "Paris for grandeur," the native is reported to have summed up his "Tale of Two Cities," "but Peebles for pleasure." Mrs. Park, who was a lady somewhat prone to gadding about, pronounced it, however, "silent as the grave," and her husband, a shy man, little addicted to socicty, and less to notoriety, found "a look through Mr. Oman's telescope and a glass of strong beer" quite a break in the monotony of his existence. His practice was not large nor very lucrative. Some of his patients did not and many of them could not pay, so that often, after a bleak ride for mile after mile in a dark night over the Southern hills, to attend a woman in her sorest hour of need, a piece of barley bannock and a drink of milk would be his only fee. His heart was not in his profession. He was dreaming of something less mechanical, a fact which before long was noted by the people whose grandsons reared a statue to him in the town where he led so uncongenial a life. "He was a dacent man, Dr. Park," an aged man who had been one of his unremunerative patients told the writer when a boy, "but he hadna muckle to say for himsel'."

Among the friends of those days was Sir Walter Scott, then Sheriff of the county, Park's brother Alexander serving as his deputy and general factotum. Calling on him one day, Scott found the traveller sitting by the banks of the Yarrow tossing stone after stone into a deep pool, watching with still dreamanxious attention the time the ing of the bubbles took to rise to the surface. Niger.

Asked by his friend why he indulged in so idle an amusement, he replied that it was the way he calculated the depth of the African rivers before he risked fording thenl.

For a time he was in hopes of obtaining a Government appointment in the then young colony of New South Wales; but for somic reason this, like other expectations, came to nothing, and poor Park returned from London 
in bitter disappointment to resume work so toilsome that his friend "the Shirra," * after seeing something of the Peebles doctor's life, declared that there was only one being more hardly worked than a country surgcon, "and that was his horse." No wonder that he declared to Scott when the hour of deliverance came that, rather than resume such a life as that of the years now ended, he would cross Africa with pleasure. And by-and-by, eager like so many others in similar case to find a career more congenial than that which he had adopted before knowing all that the world held in store, the opportunity came. Park was now a married man with three children, and, as we gather from the few letters that have survived, feeling the daily pinch of poverty. His African earnings were spent, and the first rush of buyers for his book had abated. It is therefore more than likely that when the Peebles surgeon yielded once more to the "demon of unrest," by accepting the command of a new African expedition, he did so as much to provide for the future of himself and his family as from any idea that Timbuctoo was the goal which it was his duty to seek. Eight years had made a great difference in his condition of life.

But, now, he was no longer to travel poor and alone. He was to be a Government official, with soldiers to guard him, educated companions to help him, and ample Government funds to pay his way, a good salary, and, if he perished, a pension to his widow. In rain his friends expostulated with him on the risks he was running. Another winter or two of country practice, he declared, would quite as effectually shorten his life as a journey into Africa. He hoped, however, to return as scatheless from its dangers as before, with a reputation that would necessarily secure the occupation for which he longcd.

The few inonths he had to spare before his departure were spent in practising astronomical observations, and in learning Arabic from Sid Ambak Bubi, of Mogador, who had

* Or Sheriff, the name by which Scott was known for many years in Selkirkshire. come from London to play the teacher in Peebles, and during his stay was the one sight of the place. Just before leaving Selkirk Park and Scott rode for several miles together, from Ashesteil over the wild, grassy hills that form the divide between the Tweed and the "dowie denes o' Yarrow," talking of many things, until on the top of Williamhope, a lofty ridge which overlooks the vallcy of the latter river, they stopped to part for the last time. It was autumm, and the inist, which to the poet's mind formed a fitting emblem of the hazy prospects that lay beforc his friend, floated slowly down the vallcy. A little ditch divided the moorland from the road which they were now to take in opposite directions. In stepping over it Park's horse stumbled. "I am afraid, Mungo," Scott remarked, "this is a bad omen." "To which the ill-fated traveller, smiling, replied: "Freits (omens) follow those who look to them," $\dagger$ and rode away into the mist for ever. But the "Shirra" was right, for a more ill-fated expedition never entered Africa. Nothing went right with it, Park experiencing what so many African travellers proved afterwards, that the man who succeeds as a solitary explorer too frequently fails when hampered by a host of many-humoured companions, and many additional troubles therefrom.

The ostensible object of the new venture which Park entered upon was to ascertain whether commercial intercourse of a profitable nature could be opened Park's up with Central Africa. This, of dition: Niger course, involved exploration, but ex-

ploration as such was not included in his programme. His own theory, formed by many conversations with George Maxwell, a Scotsman who had been much in that part of Africa, was that the Nigcr terminated in the Congo. No one dreamed of the many sluggish rivers creeping into the Bights being the mouths of that vast current, and now that it had been clearly ascertained that it was not identical

+ "Thame luiks to freits, my master dear, Then freits will follow them."

Ballad of Edom o' Gordon. 
with either the Senegal or the Gambia, this doctrine was as reasonable as those which held that it formed a branch of the Nile, or ended in the desert wastes of Wangara and Ghana. The plan which Park laid before the War Office in London* was, after passing through Bondu, Kajaaga, and Falada, to construct a boat at Sego, in the kingdom of Bambarra, and then float in it down the Niger by way of Jenné and Kabara (the port of Timbuctoo), through Houssa, Nyffé (Nufé), Kashna, and other countries along its banks to Wangara, $\dagger$ where, according to the hypothesis expressed by Rennell, the river ended in what is known in Western America as a "sink." Thence, if this supposition should prove true, he would require to reach the sea by Tripoli, or Egypt, or Abyssinia, or the Bight of Benin. If not, he would follow its course, confident that it would bring him to the Atlantic by the Congo.

Five thousand pounds were put at the disposal of the expedition, and an ample outfit of stores, donkeys, arms, and other equipments was provided. A captain's commission was given Park, and to his second in command, Dr. Alexander Anderson (Mrs. Park's brother), the rank of lieutenant, in order to enable them to exact military obedience from the soldiers who were to be taken from the garrison of Goree, at that time in the possession of England. A fellow dalesman, George Scott, was added to the party as draughtsman, and several boat-builder's and other workmen were taken in order to construct the craft in which the party were to-

\section{"Trace the Niger to its source \\ Far in its native wilds."}

At Goree the troops, wearied with the monotony of their life, would have gladly enlisted en

\footnotetext{
* Up to the year 1801 the business of the Colonies was carried on at the Home Office. After that date, up to the year 1854, it was a part of the War Office business; though in 1825 Lord Bathurst in a document before us is styled "His Majesty's Principal Secretary of State for the Colonies." Mungo Park's negotiations were with the Earl of Buckingham.

$\uparrow$ There was a confusion on Park's part in thinking the river after passing Nufé continued to Kashna (Katsena) and the kingdom of Wangara.
}

bloc; but not a negro, whose services would have been more important to the expedition, could be persuaded to face the terrors of the Moorish country in the interior. Lieutenant Martyn, thirty-five privates, and two seamen were finally selected from what was unquestionably very poor material, considering the stuff out of which the African Corps was composed, the loose discipline that prevailed, and the enervating effects of the climate. To add to their initial misfortunes, the expedition had met with so many delays that the rainy season was at hand before it could reach the Gambia, on the 27th of April, 1805.

So large a party of Europeans was a mistake from the first. They were not numerous enough to force their way if there had been any resistance, yet they were too niany not to arouse suspicion. Their considerable stores tempted marauders and cumbered their morements, while the difficulty of finding food for so large a party in health, and of attending to them when sick, soon convinced the conlmander that the task he had undertaken was very different from that which he had accomplished so successfully eight years before. However, partly by land and partly by water, over a country much the same as that which he traversed alone, Park advanced with his mixed cavalcade. For a time all went well. To most of them the life was novel, and as everybody was glad to start, even the depressing influence of the wet season did not damp their spirits. The Borderers sang the songs of their fatherland as they gaily rode to their graves (p. 216), and even the soldiers, freed from the daily dread of the cat-o'-ninetails, forgot for a time the rum they had left behind them.

But in spite of this imposing array nobody seems to have been greatly impressed by it. The black lings were as greedy, their subjects as thieving, as ever. At one place they would be compelled to pay for water, and at the next spot, the villager's, fearing that they were not strong enough to take this step, would bale out the wells in advance of their arrival. At times violent altercations between village chiefs 


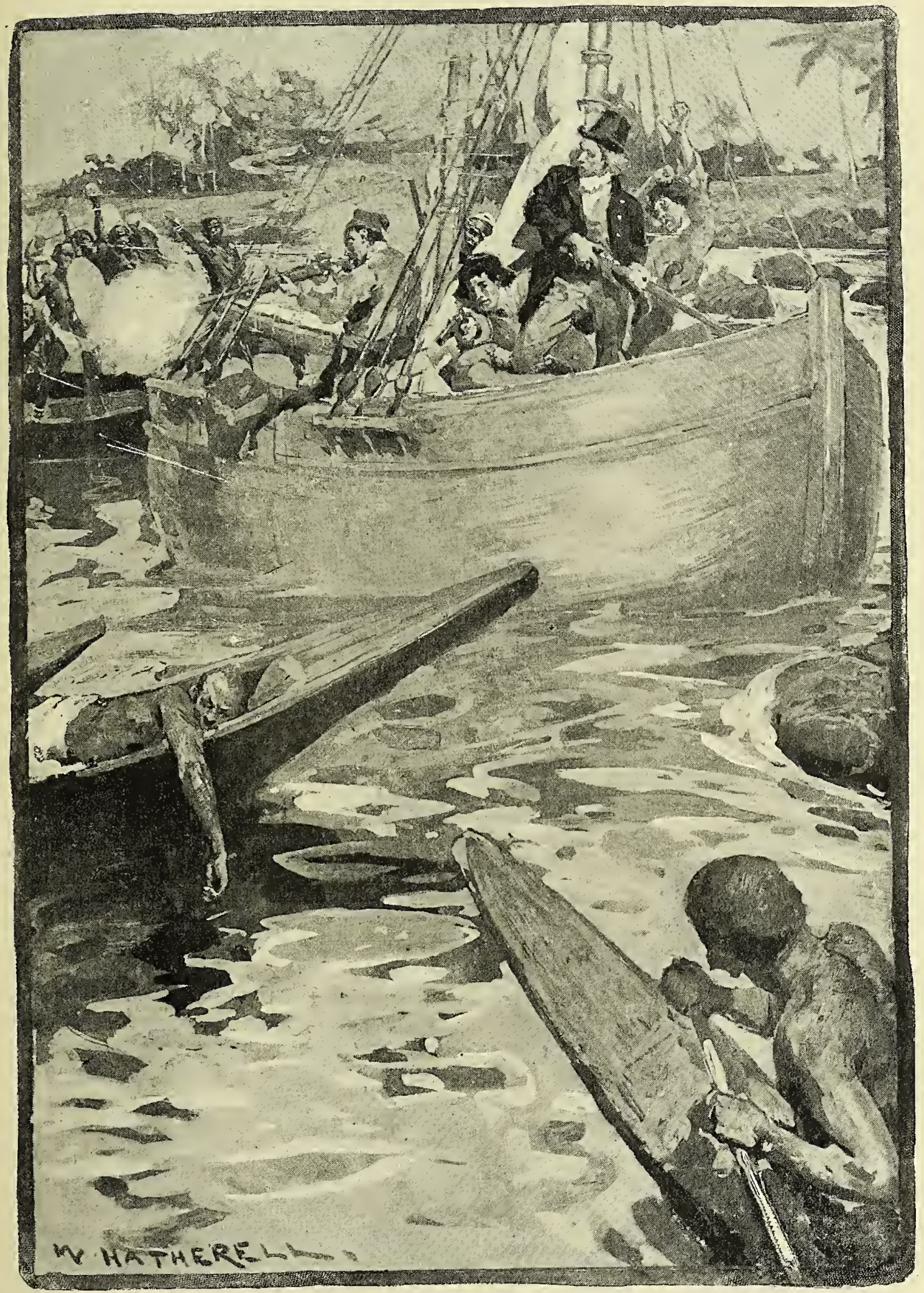

MUNGO PARK'S IdAST STAND (p. 216). 
and the camp-followers of the expedition delayed its progress, these pcople being only too Misfortunes happy to pay off old scores by multiply. misrepresenting the state of matters when it appeared that this could be done with safety. Park also appears less to advantage on this than on his former journey. Success had not improved his temper; he bore adversity with dignity: like many who have done the same, prosperity was too much for his head. Baeked by a force of armed men, he seems to have grown imperious, to have talked of burning villages, and even of shooting natives, on provocation which, remembering the provocations he had borne so meekly on his first journey, appears scarcely justifiable. Theft was unusually frequent. At Konkromo gold was being washed out of the rusty-coloured sands of the Bafing (p. 135), melted in sun-dried clay crucibles, heated by the application of bellows to a charcoal fire, and the ingots formed by pouring the melted metal into furrows, twisted by pincers into the form of rings. But it would appear that wealth had corrupted their morals, for Park, with a sweeping characterisation not usual with him, pronounced them "all thieves." At Keminum, a fortified place, the inhabitants were "thieves to a man," and, owing possibly to their strong walls, excelled in impudence also. Of all the robbers with which the place abounded, the most daring were the thirty sons of the reigning monarch. These princes, regarding themselves above all law, pursued their depredations almost openly, and with such success that in the course of two days they managed to steal four greatcoats, a large bundle of beads, a musket, a pair of pistols, and a number of other articles, some of which could be of little use to them. On resuming his journey, nearly the whole town being in the rear of the expedition, ready to pounce upon anything that lay handy, one of the gang of thieves snatched at a bag, and while Park and Martyn tried to recover it, another made off with a musket. One of the king's sons held Park in conversation while his brother decamped with a fowling-piece.
Park thereupon ordered them to be fired on, but Anderson, more prudent, thought it advisable not to rouse the king's vengeance by an act so high-handed for an offence regarded by him as venial, though soon after one of the natives, darting from a hiding-place upon some article which took his fancy, was wounded in the leg by Park himself. At Bangssi the king recognised the "poor white man" in his new capacity, and was profoundly suspicious of the eircumstances that had effected the change in his surroundings-a suspicion not even soothed by the sight of the gifts that were laid before him.

But, worse than thieves and unfriendly kings, the rainy season had no sooner set in than the men, their constitutions weakened by a long stay in and The expwealened by a long stay in an tion begins African climate and the debauchery to perish. of an African station, began to sicken. Day after day they dropped by the way, and were left to die or to recover. The novelty of the adventure had now worn off, and while the officers in command were sustained by the expectation of making great discoveries, the soldiers soon lost interest in anything. Scenery, the source of the Niger, Timbuctoo, gold-washing, weaving, all were alike idle sights to men dying of fever. Even a glimpse of the Niger at Banaku (p. 204), a visit from Park's old friend Karfa Taura, the slatee (p. 206), and a pleasant meeting with the old schoolmaster who had cared for him at Kanialia, failed to arouse them. Of the thirtyeight men who had left Goree soon only seven remained. Some were dead, others had been left behind, but as none ever reached the coast, all of thein had, no doubt, expired within a fow days of falling ill. They were now five hundred miles in the interior, and, for the first time in the history of Africa, a party of Europeans had penetrated thus far.

The Sego king was, however, as unwilling to meet Park as ever. He accepted the white inan's presents, but as Isaaco, the interpreter who had been sent with them, declared, he drew triangles and squares with his finger on 
the sand all the time he was negotiating an audience, evidently with the design of making a charm against the evil designs of the newcomers-shunning every proposal that could lead to a personal interview with him.

Continuing therefore past Sego, Park came to Sansanding, where he had permission to build a boat in which to descend the Niger. This place is a large town, full of traders, whose jealousy Park aroused by opening a sale of European goods. Indeed, so virulent was the enmity when business grew brisk that heavy bribes were offered to King Mansong either to kill the whites or to send them out of the country. On the 16th of November, the Joliba, as he called the schooner which he had patched up out of some half-rotten native boats, was ready. Meanwhile, deaths had continued, and day by day cven the stoutest of the party began to show inore and more marked symptoms of weakness under the African sun. Nor was the native beer sold in the Sansanding bazaar altogether blameless for the mortality. It was a hard-drinking age, and Lieutenant Martyn was perhaps not the most favourable specimen of the kind of soldier who served on the African coast. Even at Sansanding he seems to have found materials for a carouse. In a letter written to a comrade at Goree, we get a picture of the kind of men who were selccted to help a great geographical expedition. "Whitebread's beer," it was the opinion of this explorer, "is nothing" to what we get at this place, as I feel by uny head this morning, having been drinking all night with a Yoor, and ended by giving him an excellent thrashing." It is clear that from this sort of companion little sympathetic assistance could be expected. But it was not until his brother-in-law died that Park felt himself, as he wrote, "a second time lonely and friendless amidst the wilds of Africa."

By the time the Joliba was launched the party had been reduced to three Europeans, besides

The descent

of the the commander and Martyn, and of the three-all soldiers-one was in a state of mental derangement. On the 12th of November, 1805, the party set out on their voyage, with the object of tracing the river to its termination, and though to some of his friends Park wrote in a more desponding tone, his letters to his wife express confidence that in leaving Sansanding he was "on his way home." Here Isaaco, his interpreter, left him, carrying in safety to the Gambia his letters and journals; and then for a long time nothing more was heard of Park. Still, he had gone through so many trials, and coinmunications in those days were so infrequent, that it was not until 1806 that the rumours reaching the coast gave his friends uneasiness. Then, as these grew morc and more alarming, Isaaco was despatched to ascertain what he could regarding the tales brought from far and near by the slave-traders of the Gambia. By-and-by the messenger returned, and though something has been ascertained since then, the story brought back by Isaaco remains, be it true or only partially true, substantially all we know of the fate of Park. Leaving Sansanding with Martyn and three English soldiers-one of whom soon afterwards died-three slaves, and a inan named Ainadi Fatuma, who agreed to go as far as Houssa (p. 53), their vessel was, as night have been expected, often attacked during its downward voyage. In these encounters great numbers of natives were killed, which so incensed the people against them that they were afraid to land to buy provisions, this part of the work being effected by Amadi, whose personal acquaintance with the history of the voyage ended at Houssa, where hc left. It does not appear, from this report, that any effort was made to accomplish what so many previous explorers had longed to do. For they passed close to Kabara, the Niger port of Timbuctoo (p. 121), without landing to visit the city, only a few miles back from the river, a fight attended with the death of many of the natives having occurred off this spot.* According to Amadi's account, the

\footnotetext{
* This is the accepted tale. But it is known that in the month of March, 1806, a letter was received at Mogador, in Morocco, by Sidi El Abes Buhellal Fasi from his liberated slave at Timbuctoo, which related how a
} 
trouble began soon after leaving Houssa, by the anger of the Yauri King at not reeeiving presents from the party. 'To exaet what he considered his dues, the king sent a foree of men to a village called Bussa, whieh Park had to pass. Here he was attacked with lanees, men, and, jumping into the river, was drowned. Martyn followed his example, and met his death in trying to eseape. The only slave who remained in the The end. boat, seeing the natives persisted in throwing weapons at the eanoe without eeasing, stood

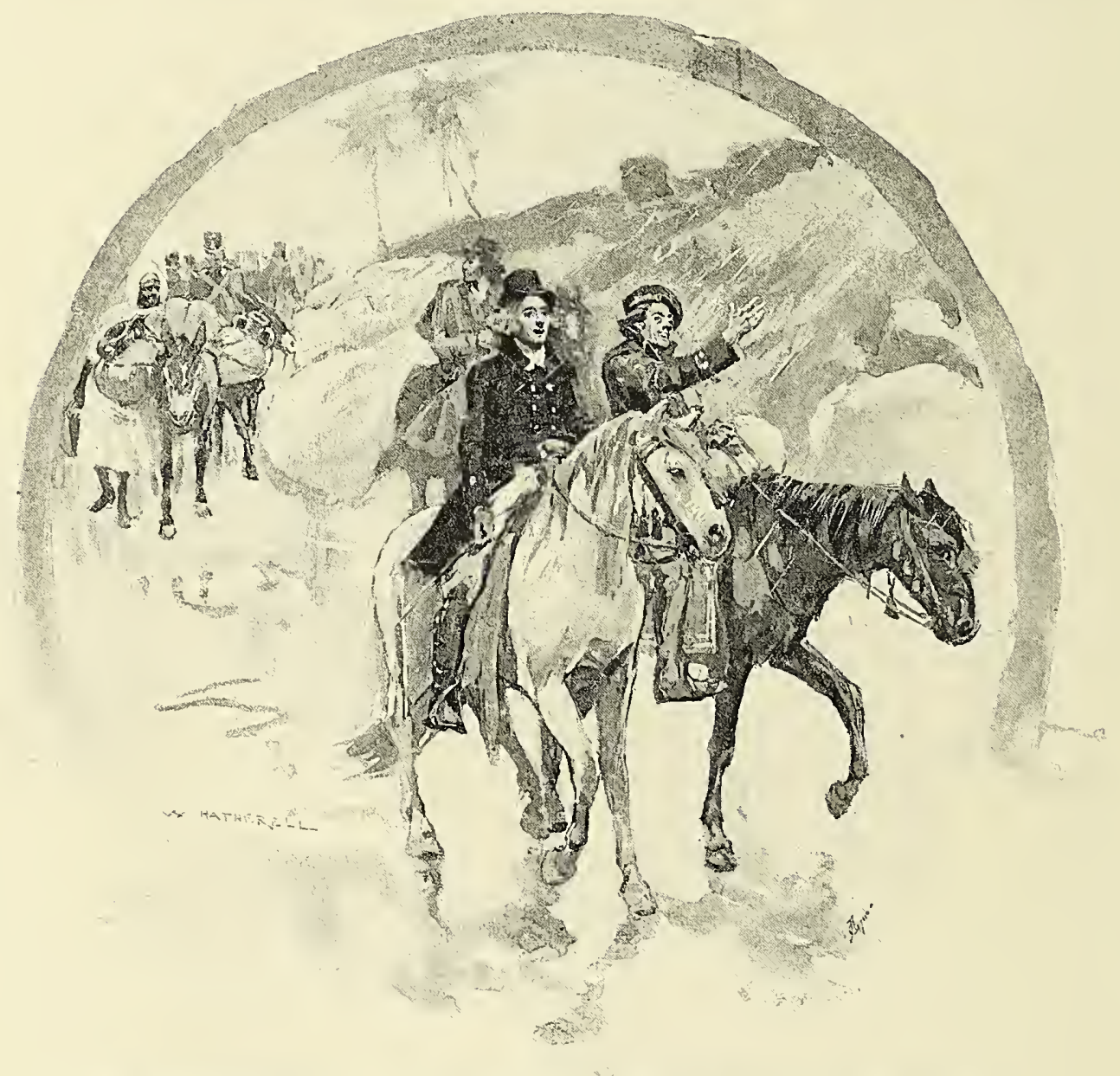

"THE BORDERERS SANG . . AS THEY GAILY RODE TO THEIR GRAVES" (p. 212).

pikes, arrows, and stones, defending himself for a long time, until, seeing that there was no eseape, Park took hold of one of the white boat with two or three Christians in it arrived from the West at Kabara. "One of them was a tall man, who stood erect in the boat, which displayed a white flag. The Kabara people did not, however, understand the signal to mean peace, and no one went to the boat, although it remained at anchor before Kabara the whole day till night. In the morning it was gonc." up and said to them, "Stop throwing now; you see nothing in the eanoe, and nobody but myself, therefore eease. Take me and the eanoe, but don't kill me!" an advice whieh they neeepted.

Some not unjustifiable doubt has been expressed as to the exaet truth of this story. But in its main details there is no reason for holding that it is not fairly aceurate. At all 
events, the little subsequent information that has been obtained does not materially alter the tale collected by Isaaco. For many years Park's widow held to the belief that her husband was a prisoner somewhere in the interior of Africa. This idea she transmitted to her three sons, the second of whom landed in 1827 on the Gold Coast, with the intention of whether the canoemen who "barred the river" were inspired by hostile intentions or simply by a very natural curiosity. In the legends this truculent fashion they shot of Park. through the country of the Moors into that of the Touaregs, a fierce Berber race, until, in the centre of the old Songhai Empire, some seventy miles south of Gogo, the former

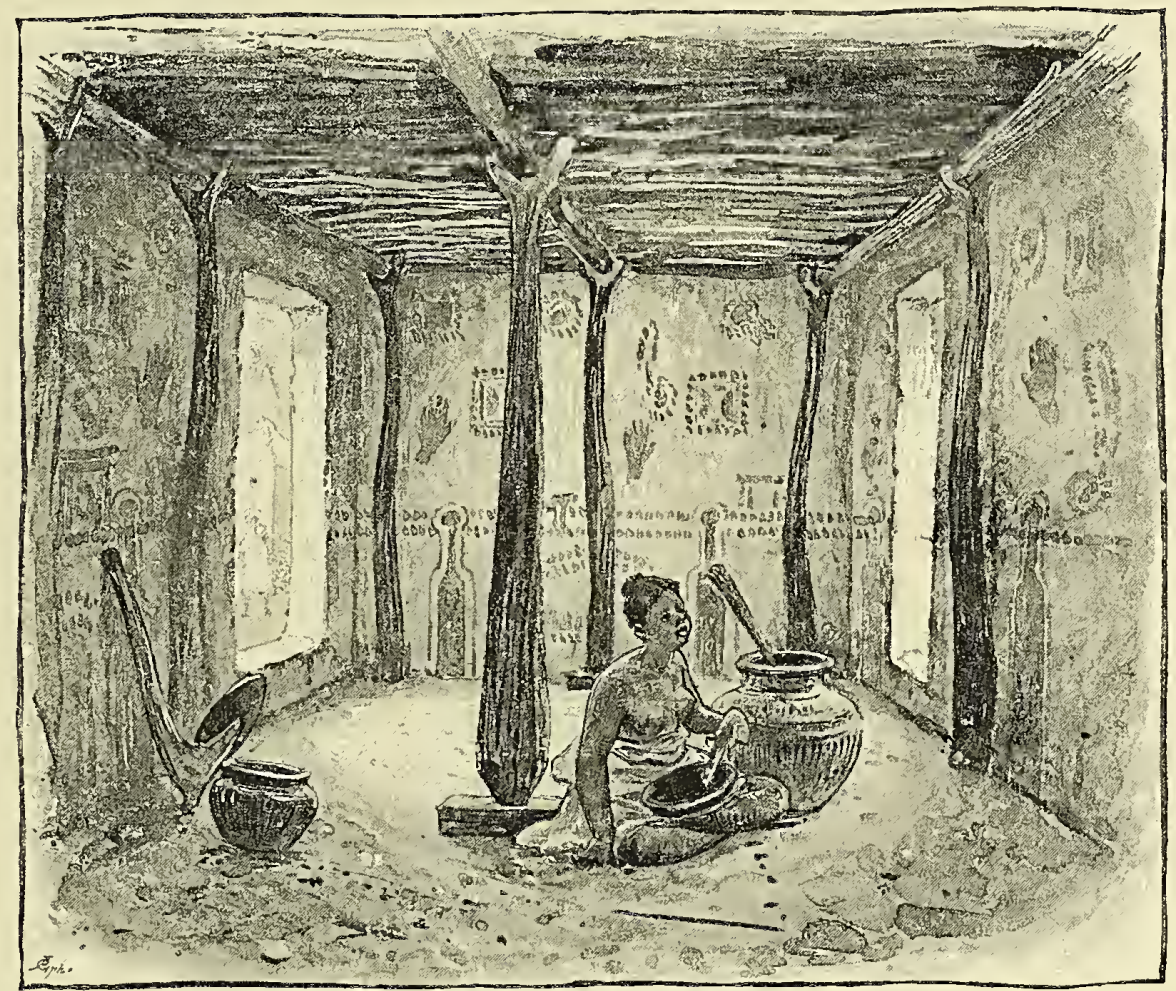

BAMBARRA INTERIOR。

ascertaining the fate of his father. But he, also hot-headed, and, it is feared, not the person best suited for such a task, disappeared in the Dark Continent soon after leaving the place from which he had set out on his illconsidered errand. Later accounts collected by travellers who have gone over this route confirm Amadi's story as told to Isaaco. During the thousand miles of the voyage, the evil counsels of Martyn-possibly also the effect of the clinate on Park's brain-had full swing. Right and left the Joliba party fired, often recklessly, and always without considering capital, the keel of the ressel, in passing through the Bussa rapids, stuck fast in a cleft rock, and they were at the mercy of the hostile crowds on the bank. There is, however, no ground for believing that robbery was the original intention of the natives. It was vengeance they wanted for the many deaths which the guns fitted at the sides of the Joliba had caused. It is idle to try to acquit Park of conduct that was at once reckless and inhuman. He paid for it with his life and the lives of his companions. Laing, one of his successors in the exploration of the 
Upper Niger, was killed near Timbuctoo by a tribe of Berabish in revenge for the slaughter inflicted ou them by "the Wild Beast," as they termed Park. Even when Barth visited the country and encountered the same people, more than fifty years later, he ran some risk of paying for the misdeeds of his predecessor. For one of the men whom Park, under evil counsels and the panic which, we are willing to believe, was duc to a disordered mind, had wounded, was still alive, and could recall to his tribesmen the lives that the guns of the first white men on the Niger had cost their village. Many years afterwards, Park's book of logarithms, long preserved by the natives, was brought down to the coast, and presented by Sir John Glover to the Royal Geographical Society, by whom it is preserved as a precious relic of a man who was the first British explorer of Central Africa, and, in many respects, one of the greatest (p. 221).

Park encountered obstacles that were then new ; he overcame difficulties that until then were not even dreamt of, and paved the way for others provided with greater resources and the experiences that he won at the cost of such toil, privation, and loss of life. We have therefore bestowed on his pioneer travels a greater space than can be afforded to explorations of wider extent. For he first familiarised the world with much that in a few years had become stale, if not unprofitable.

The death of Park, instead of dainping the ardour for African exploration, rather stimulated it. Romantic young men were eager to share in adventures of which they knew not the end, and ambitious ones anxious to succeed where others failed. Indeed, at the Nicholls. very period when Park was in Nicholls. Africa, Nicholls had been attempting to reach Houssa, on the Niger, from New Calabar, in the Bight of Benin; but he had not procecded far on his way bcfore he was seized with fever and dicd.

The narratives sent to England by merchants and consuls in Morocco, of the regular journeys made by the Moorish caravans across the desert from Mogador and Agadir to Timbuctoo and the Soudan generally, led the African Association to think whether a traveller well acquainted with Arabic might not be found capable of trying this route. A young gentlenran of gentle birth, strong constitution, good character, and many accomplishments was recommended to them by Blumenbach, the famous anatomist. For reasons connected with the plan he proposed, his real name was withheld, though it is now known to have been Roentgen. His idea was that, by passing himself Roentgen: off as a Mohammedan, he might of disguise. be enabled to journey without exciting remark. Like many others, he forgot that no man not born and bred in Islam, and speaking Arabic as his mother-tongue, can ever quite escape revealing himself by some slip in manner or by some tale-telling accent in speech. The writer is aware that there are many so-called instances to the contrary. But, apart from the fact that some of them are not authentic, in so far that the disguise never imposed on anyone, they were undertaken in circumstances that, as on a Mecca pilgrimage, which is nccessarily shared in by Moslems speaking many tongues, enable even a European, tolerably familiar with the religious forms, to pass muster in a crowd. Again, in a mosque, where the genuflexions are rigidly prescribed, and no one talks, an Oriental-looking Christian might easily enough escape detection. But it is very different when the journey is undertaken through a particular country, where every word or movement of the stranger is noticed by the population. As M. Duveyrier, an experienced North African traveller, whose opinion on such matters is worthy of every respect, declares, no man, no ordinary European traveller, can possibly deceive them. The mispronunciation of a word, a particular accent, an awkward motion, a blunder in some ccremony, or ignorance of something that he ought to have known, at once revcals the imposture, cven if no trap be laid for the sham Moslem. Then the latter fate 
of that man is worse than the first, for naturally suspicion is aroused regarding the motives of a traveller trying to disguise himself.

Yet, again and again-such is the innate vanity of even an intelligent man on the subject of his facility in speaking a particular language-the attempt has been made, almost invariably with the same result, and not unfrequently, as the fate of Davidson, and still more recently of Douls and the German explorer employed by the African Association, too abundantly testifies, ending in the death of the over-confident adventurer. Even Gerhard Rohlfs, though avowedly a renegade, was at once fixed upon as a shoe-wearer, by the corns on his toes; and I have been told by Hadjis that Burton and others who have made the Mecea pilgrimage were perfectly well known not to be what they pretended. But, as they had "testified" and performed all the prescribed forms, it was not consistent with a faith which is eager for proselytes to interfere with them and thereby bring a scandal upon religion.

All this leads up to the fact that Roentgen, who in the spring of 1809 left Mogador to join the Soudan caravan, was murdered soon after leaving that town, it is believed by his own guides. European merchants residing in Morocco collected many accounts of the route which Roentgen intended to take. One of them was from Hadji Mohammed, who had met Park in Sansanding and offered to conduct him to Timbuctoo, which, this trader declared, had since its recent conquest by the Fulahs become less fanatical than of old, while the profit of the trade to the Moors was so great that, in a year or two, five thousand dollars invested in European goods would return to the speculator twenty thousand or more.

By-and-by the interest in Timbuctoo was further aroused by the story of an AngloAdams's American sailor named Robert imposture. Adams, who professed to have actually visited the city. $\mathrm{He}$ had, like many before and many after him, been wrecked on the sandy shore between Morocco and Cape Blanco, and, with the rest of the crew, enslaved (p. 102). In the course of this captivity Adams pretended that he had made the journey to Timbuctoo with his master, and as he was an uneducated man, his information was put into volume form by the Secretary of the African Association. Its publication aroused a heated controversy, and the book was translated into various languages - some critics holding that Adams was truthful, others as decidedly declaring that he was a gross impostor. After the lapse of eighty years the world has universally arrived at the latter opinion. His narrative contains much curious information about Sus and the country south of it; but it is now certain that neither he nor Scott, a kindred pretender, was ever at Timbuctoo, that distinction, as we shall see in the course of the next chapter, being due to another Christian slave of a much earlier date, anything Adams has to say about it being derived from the talk of the Arabs annong whom he was held prisoner. In reality, this man was Benjamin Rose, a native of Hudson, near New York, but a deserter from a British man-of-war, who during the whole of his stay among the Arabs was never far from the iest of the shipwrecked crew of the Clacrles.*

Riley, the master of another American vessel wrecked on the same coast in 1815 , who endured sufferings very similar to those of his predecessor, also collected much information regarding Timbuctoo from the conversation of persons who had been there.

Captain Tuckey, in order to test Park's belief that the Congo was the seaward end of the Niger, penetrated, in 1816, past Tuckey, the falls of that river, and returned Peddie, convinced that the theory was and Gray. erroneous, only to die with most of his companions in the swamps of the lower river.

Major Peddie, who with a hundred men

* "The Narrative of Robert Adams, a Sailor who was wrecked on the Western Coast of Africa in 1810," etc. (1816). In their "Bibliography of Morocco" (R. G. S., 1892), Sir Lambert Playfair and the present writer have given the evidence convicting Adams of fraud. 
and two hundred animals had started from the mouth of the Rio Nuñez, midway between the Sierra and the Gambia, intent on solving the same problem, perished of fever before he had gone far on his road: and Captain Campbell, who sueeeeded to the
Futa-Jallon; the few whieh remained were searcely suffieient to eonvey their remaining baggage during the retreat to the coast. Even that little was plundered by the people who had refused him permission to proeeed. The expedition was obliged to pay a heavy

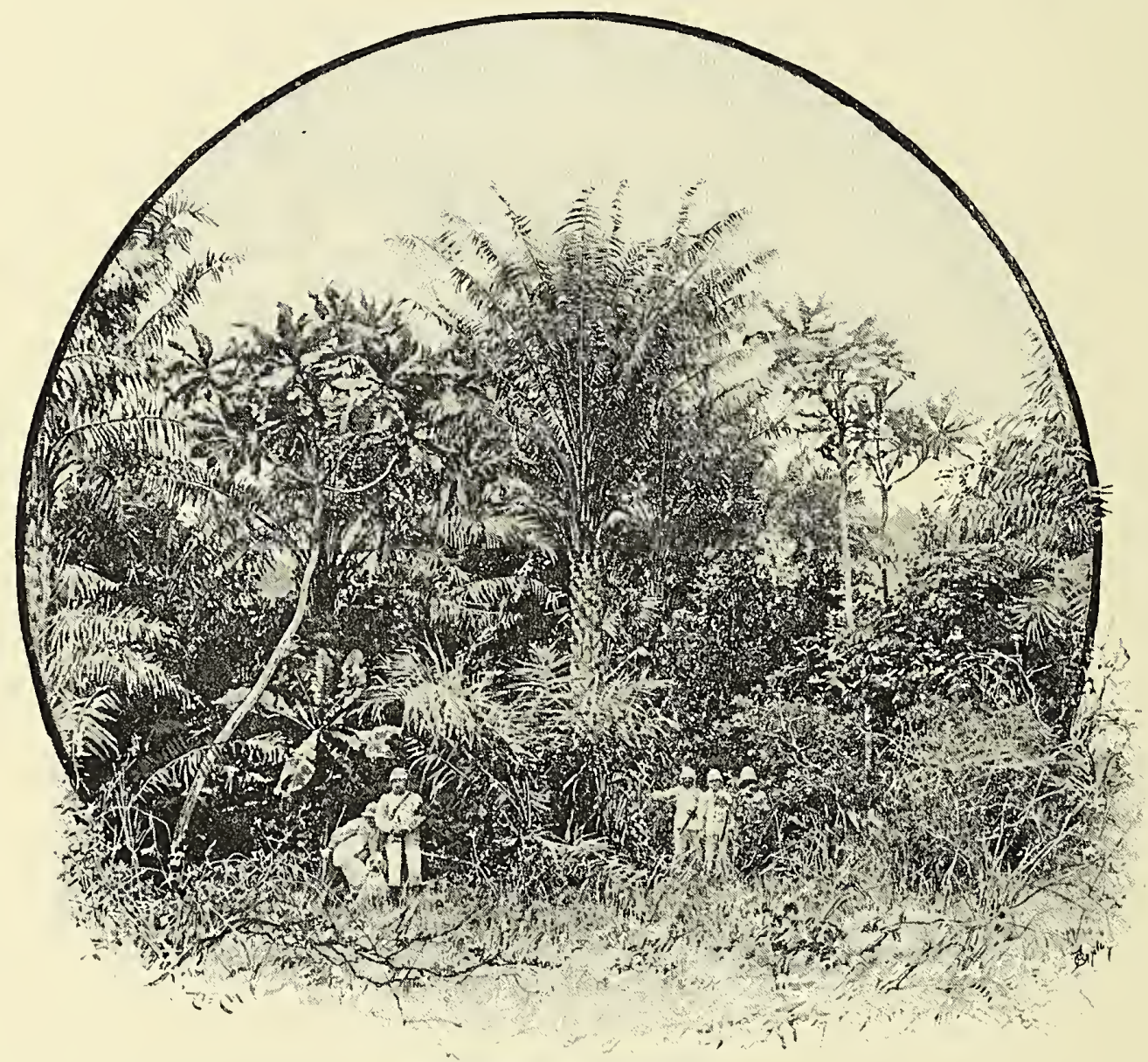

SENEGAMBIAN THICKET.

(From a Photograph by the Paris Society for Evangelical Missions.)

command, though he arrived at the Fulah eountry, met with luck seareely better. The beasts of burden perished under the climate, from bee-stings, and the unskilfulness of their attendants, in the eourse of the mareh and during the four months' detention by the suspieious Almami,* or Fulah sovereign of

* A corruption of Al-Iman, the Arabic words for Sovereign Pontiff. It is used by many of the Mohammedan people of this part of Africa. eontribution to the Almami for permission to retur'n by the way it had eome, to reeross rivers which it had passed with great diffieulty, and, in short, endured sueh persecutions that to put an end to them, and to render his mareh easier, Captain Campbell eaused the most of his goods to be burned, the muskets to be broken, and the gunpowder to be thrown into the river. The naturalist of the expedition died on the return journey. Campbell 
and several of his officers did not long survive their arrival at Kakundi, and Lieutenant Stokoe, a naval officer who assumed the cominand of the expedition thus cruelly decimated, perished as he was on the eve of making another attempt to retrieve its fortunes. They were all buried under an orange-tree at the factory of Mr. Bethmann, an English merchant residing there.

Major Gray, with Dr. Dochard, made in 1818 another effort to retrieve the fortunes of the party. Travelling by way of the Gambia, through Wuli, Bondu, and the neighbouring countries, he was forced to return without having accomplished anything in the way of exploration. To avoid Timbo, the capital of the terrible Almami, the expedition sailed up the Gambia, and traversing Wuli and Gabu arrived in Bondu. Here, however, the party fared no better than its predecessors in Timbo, for

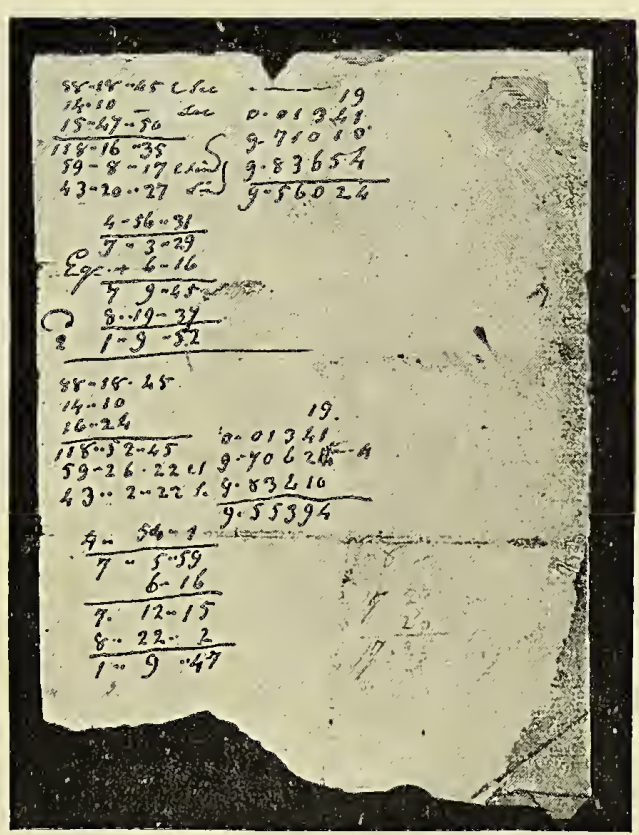

SHEET OF LOGARITHMS BY MUNGO PARK. (By permission of the R. G.S.) and intentions of the party showed that, in the course of the thirteen years since that traveller's death, the unkindly feelings of the inhabitants had not sufferer any improvement: Dr. Dochard travelled as far as Sego in order to obtain the king's permission to visit that region. But, after an endless amount of dilatoriness, he was compelled to return to die on the Senegal without having received what he had been sent to obtain. Neanwhile, the expedition had been melting away by death and disease, to which the monotony of an inactive life greatly conduced.

All of thesc parties had been at Govcrnment expense. All of them were too large, with too many Europeans; and none of them were conducted with anything like ability. They were, in short, accentuated cditions of Park's last venture, without its redceming inerits; and, if they did not meet with its tragic end, the king and people were equally malevolent, demanding from Major Gray, on the pretext of some old debt due fron the British Government, such a quantity of goods that the expedition was soon stripped, and obliged to send to Senegal for more, in the hope of being permitted, by means of these, to continue the journey thus rudely interrupted. Gray covered, indeed, to a large extent the ground which Park had made familiar, though the suspicion which was everywhere engendered regarding the objects

entailed as much cost in life and treasure, and were, even as failures, much more decided than that unfortunatc attempt to open up Africa. It is impossible cven to accord them the compliment which Charles the Fifth passed upon the disastrous defence of Rhodes. For though the journeys with which this chapter has been occupied werc, one and all, labour and lifc and money thrown away, their treasures were not "well lost." They were wasted to almost no purpose. 


\section{CHAPTER XII.}

\section{The Seekers after Timbuctoo: A Tale of Success.}

A Now Era in African Exploration-The British Government Takes It Up, and the African Association Surrenders the Self-Imposed Task-Major Laing Reaches Timbuctoo, and is Murdered on his Way BackThe Fulahs and their Conquests-The Influence of these in the Civilisation of the Upper Niger-The Rise of René Caillié-His Early Struggles-His Residence Among the Moors-Assumes the Garb and Faith of Mohammedanism-Leaves Kakundi with the Intention of Reaching Timbuctoo-His Adventures on the Way-Five Months' Illness at Timé-Reaches Jenné-Description of that City-Sails Down the Niger to Kabara-Resides in Timbuctoo-Crosses the Desert-Aruan-Tafilet-Crosses the Atlas-FezMequinez-Rabat-Tangier-France-Reception of Cailliés Tale in Europe-The Controversy that EnsuedRevival of the Story of Paul Imbert-The Last Days of Caillié.

THESE repeated failures disheartened in no way those who had charged themsclves with the opening up of Africa. The work, it is true, gradually passed out of the hands of private individuals, and, henceforth, instead of the African Association defraying the cost of the expeditions, they became a charge upon the Imperial revenue. Hence, in the new circumstances to which we have alluded, the travellers sent into the unknown were, naturally, more frequently military and naval officers than the civilians with whon in earlier days Sir Joseph Banks and his associates had to deal.

Among the new men who now appeared was Alexander Gordon Laing, born at Edinburgh in 1794, and, like his father, for a time a teacher of classics in that city. The early years of the present century were, however, stirring ones for a youth of spirit, and it so happened that, inflamed with the prevailing military ardour of the times, young Laing, deserting his pupils, made his way to Barbadoes, where a maternal uncle, Colonel Gordon, was in command. Through his intcrest he procured a commission in the York Light Infantry, and with it saw some service in the outskirts of the Empire. However, it was not as a Major Laing. soldier that his career was to be distinguished; for, in 1823, while on the West Coast of Africa, he was sent on a mission to the country of the Sulimas, and adranced as far as the source of the Rokel or Sierra Leone River, and ascertaining that the Niger was not more than 1,600 feet above the sea, dispelled the fast-vanishing notion that it was in any way connected with the Nile.

In 1825 he began the journey which was to immortalise him. Following the example set by two previous explorerswhose travels we shall for convenience' sake treat of in the next chapter-he abandoned the unhealthy route by the West Coast, the region behind which was now getting very well known, in favour of the healthier country in the North. The starting-point of his new expedition was accordingly the ancient city of Tripoli, then as now, after being disputed by many a rival Power, in the hands of the Turks (p. 23). Passing south-west to Gha: dames and the oases of Tuat, he boldly entered the desert that lay between this comparatively fertile region and the upper water of the Niger. Over this country roam the Touaregs, a section of the widespread Berbers, the aboriginal people who seem to have overrun nearly all of North Africa previous to the arrival of the Arab invaders. No wilder race of nomads exists. Ever on the move, compelled by the necessity of finding fresh green spots for their flocks and camels, they are the robbers whom Arabs and whites alike fear. Sixteen days after leaving Tripoli, Laing fell in with a party of these marauders, and, as we learn from a letter he inanaged to send to the British Consul in Tripoli, barely escaped with his life. He was left for dead, bleeding from twenty-four wounds; though, thanks to a sound constitution, and the dry, healthy desert air, he recovered so fin that he was able to 
resume his journey, and actually: to enter Timbuctoo on the 18th of August, 1826.* In this city he was permitted to remain undisturbed for a 1110nth; but by this time the fanaticism of the ruling class had been roused, and he was ordered to withdraw. In no way unwilling, as there was nothing inore to be learnt, he obeyed a mandate that he could not resist, and passed beyond its gates on the $22 \mathrm{nd}$ of September, relying upon the promise of certain Touaregs, or, as others will have it, the Arabised Berabish people, to guard him across the desert. The exact particulars regarding his fate are not known, the native accounts varying very much. But from what could be picked up from report, it is believed that he was betrayed by his own guide as the countryman of Park, who had a few years before inflicted such punishment on the people, who now took their rengeance by murdering him, near the town of Aruan-where he is still renembered as "El Raïs," the Captain--two days after leaving Timbuctoo. Every effort was made to recover his papers, $\uparrow$ but all in vain, so that the tale of the first Britonthough it now appears not the first European - to reach the long-sought-for city must for ever remain of the shadowiest description, the only substantial record of his labours being the narrative of his first expedition. $\ddagger$

Laing's death was owing largely to the disturbed condition of the country, due to the remarkable revolutions then in progress in the region through part of which he travelled. These were the Fulah conquests. In the course of the previous pages we have every now and again been coming across this remarkable race, and, at the time when Park was travelling in the same region, we gain glimpses of it in "the wars" which were so often interfering with his plans. These people (pp. 12,13), though dark, owing to

* This is known from a letter addressed from Timbuctoo to Colonel Warrington, the British Consul at Tripoli.

† Quarterly Review, vol. xlii. (1830): Oskar Lenz: "Timbuktu" (188t), vol. ii., pp. 91-93.

† "Travels in the Temanee. Kooranko, and Soolemana Countries in Western Africa." (1825.) their long residence in Africa, and frequent intermixture with the Negroes, are, however, undeniably of a different origin from the latter, though the The Fulahs origin from the latter, though the and their land they came from is always likely to remain one of the many mysteries of an old and mysterious continent. They are in all probability an Asiatic race, who, entering Africa by the narrow Isthmus of Suez, have gradually spread across their new domain until - not taking into account many border races with whom they hare, nore or less, intermixed -we find them dispersed over the entire Soudan, from Senegal in the west to Darfur in the east, and from Timbuctoo and Houssa on the Niger to Yoruba and Adamawa in the south, though invariably keeping to the open country, being a pastoral people, and for this reason also shumning the moist, forest-covered regions in the vicinity of the sea-coast. But from the very circumstances of their life they were always a wandering people $§$ (p. 224).

The first glimpse we have of them-though by that time they must have been many centuries in Africa-is in an old Arabic work of the fourteenth century, which describes bands of them as leaving the Futa-Jallon country in Senegambia and spreading over much of the region to the eastward, and

\$ Their nomadic life is well exemplified in the many names which they bear throughout the region occupied by them. The root "Ful" means red, to distinguish their colour from the prevailing black of their neighbours. Fulbe is the plural of the singular Pulo. Among the Arabs they are called Fulan. Fulata (plural), Fulani, Felati, Fulania, Felatia. The Touaregs know them as Ifellan, Afullan, Ifullan, Fulan, Ifilanen, and Afilan. Among the Houssa the terms Fillani, Fullani, and Bafillantschi are current. The Musgu of Southern Boinu call them Maplata and Maplatakai, and the Kanuri of the same kingdom Felata. Fula is the word among the Mandingoes, Agai among the Dschumu of Yoruba, Tschilmigo among the Mossi, Kambumana among the Zurescha, Folani or Fulga among the Gurma, Bale among the Bafut, Fato-that is, "the white men"among the Ham, Abati among the Dscluku, and Goi in the Nufé country; while the whites describe them variously as Fulah, Fulbe, Pouls (Peulhs), Fellata, Fulon, Futa. etc. Krause : Das Ausland (1883), p. 181, and "Ein Beitrag zur Kenntnis der fulischen Sprache in Afrika." in "Wittheilungen der Riebeckschen Niger" E.rpedition" (18st). 


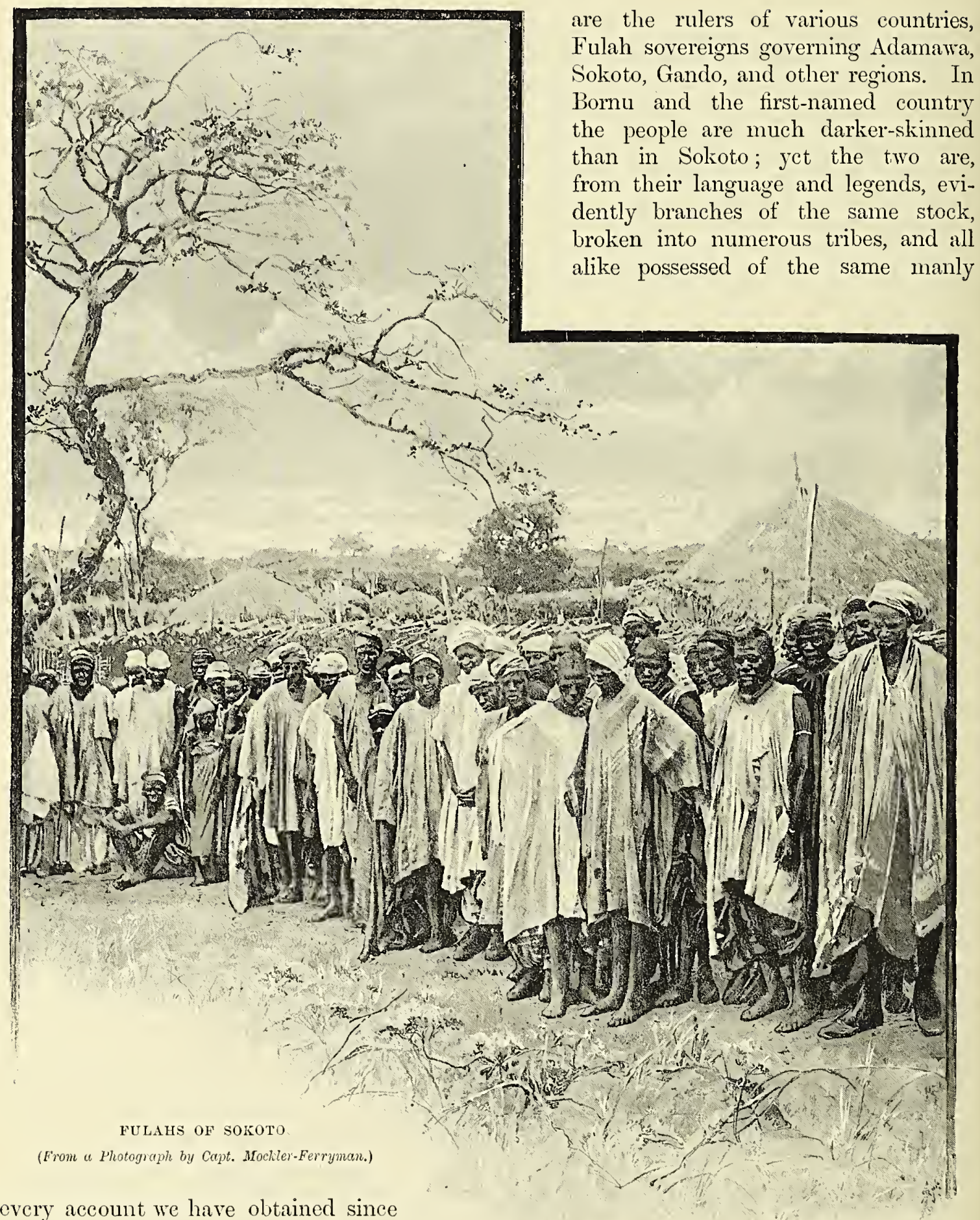

bears out this description. It thus

happens that nowhere are they a

nation. Everywhere they are scattcred races bearing, intelligence, commercial aptitude, and of conquerors, who, though in a minority, -compared with the natives around them- 
even trustworthiness. But what renders the Fulahs most remarkable anong the raees of the Soudan is that their hair is long, their features are almost European, and their eomplexion, as in the ease of the Sokoto seetion, is not much darker than olive. Their intelligence is also far above the negro stamp. They are industrious trader's, notorious for their participation in what was onee the ehief traffic of the Soudan, but now, sinee the buying and selling of human beings are redueed to smaller dimensions, equally energetic in more legitimate branches of eommeree. They are weavers of eoarse but durable fabries, and their iron-, silver-, and leather-work is famed throughout West Africa; while their droves of cattle and their well-tilled fields suggest possibilities for the Fulah whieh the most hopeful of philanthropists must sometimes despair of where the coast negroes are eoneerned.

And above all, the Fulahs are Hoslems of the strictest order. In every village there is a mosque and a sehool, and to the proselytising zeal of Othman-dan-Fodio, a Fulah teaeher, may be traeed the fact that while the Songhai Empire has now fallen in piees, and the people have relapsed into barbarism, and Bornu and the onee powerful Houssa States have either lost mueh of their former military status or sunk into a eondition little better than paganism, the Fulahs have preserved all their former influenee, and in many instanees even increased it. Nor is it to their diseredit that ever sinee their enversion to Mohammedanism they have remained steadfast to the faith which they were anong the first of the Soudan raees to aecept.

Yet up to the end of last century the Fulahs, scattered in eomparatively small bands among older and in general heathen people, had hard work to hold their own against the more homogeneous raees by whom they were surrounded. To Othman is due the movement by whieh, under the fanatieism of religious zeal, they entered npon a course of eonquest that spread their power over a wide area of Afriea. At first they met with reverses everywhere. It was only when, taught by experience, they got hammered into a semi-disciplined foree, that success attended their arms From Gober, the hone of their Mahdi Othman, they poured forth, until, from Lake Tehad to the Atlantic, most of the Soudan acknowledged their suprenacy and aecepted their creed and the approaeh of eivilisation which has everywhere been the result of the displacement of paganism by Islam. Order and what might be ealled good government prevailed until the death of Othman in 1818, when the empire he had built 1 p was divided between his son

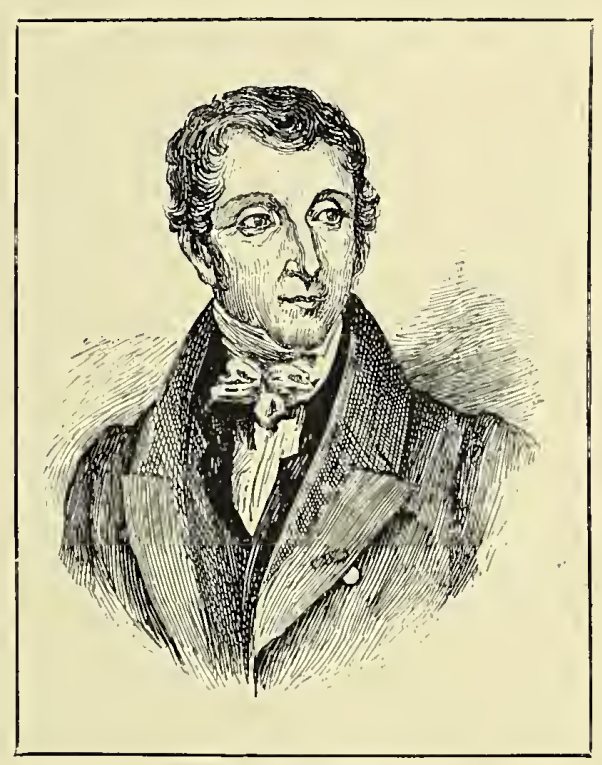

RENÉ CAILLIÉ.

Mohammed Bello-dan-Othman and his nephew Abd Allah-dan-Fodio, the former inheriting or seizing Sokoto and the country to the east, and the latter taking the Niger provinees, of whieh Gando was the capital, while IIassina and a wide region west of the Niger whieh had been eonquered shortly before the death of Othman by Ahmadu-ben-Mohammer Labbo, one of his captains, beeame the fief of that soldier. Civil war followed between Bello and his brother Atego, though the eontest was only of brief duration.* Labbo's

* De Crozals : "Les Peulhs" (1883), pp. 14う-166. 
state lay between Sego (which is still governed by his descendants) and Timbuctoo, and the latter city in the end submitted to him, though in time the Fulah rulc had to give place to that of the 'Touaregs. Between 1857 and $1861 \mathrm{El} \mathrm{Hadj}$ Omar still further extended the Fulah conquests by bringing the powerful states of Kaarta and Sego under his control. A seventh Fulah kingdom was for a time cstablished by Ahmadu Checkhu, King of Sego, the son of Omar, who compelled the Damel to evacuate Kayor, hitherto regarded as Joloff territory, and but for the intervention of the French between 1883 and 1887, which ended in his country becoming a "Protectorate," he would have absorbed all the other states owned by that peoplc. In short, at this hour the Fulahs are masters of almost all the region between Cape Verd and Lake Tchad, over thirty degrees of longitude, between the fourth and fifteenth degrees of north latitude - that is to say, about 80,000 or 90,000 square leagues of country own the Fulahs as their more or less undisputed lords; and it is by no means certain that the expansion of this remarkable people has come to a close. The old religious fervour has not yet died away, even under the damper of a Christian "Protectorate," and it may be that in time every village from the mouth of the Senegal to that of the Niger will, under their influence, possess, as does the Central Soudan, a mosque where may be "heard," to use the words of Mr. Thomson, "in the grey dawn of the tropic morning the stentorian voice of the negro Mueddin, announcing that prayer is better than sleep; bringing from out the faintly illumined houses the devout Moslems to humble their faces in the dust and acknowledge their utter faith in and dependence on Allah."

It was during this remarkable movement that Laing visited Timbuctoo, and while it was still vivid with its early zeal that the travellers whom we shall presently have to treat of made their journeys through the kingdom under the rule of Othman's descendants, of whose policy and people they have so frequently to speak.
The activity of the English in African exploration was not permitted to pass unnoticed by the French. For a some French time the long Napoleonic wars explorers. prevented any systematic attention being bestowed on such peaceful pursuits as the exploration of countries from which so little "glory" could be obtained as the regions behind the uninviting shores of West Africa. Eighty-four years after the journey of Campagnon, an official of the Senegal Company named Rubault, starting out from Saint Louis with three camels, traversed the desert of Ferlo in the direction of the Gambia. Arriving on the Niani, he turned towards the east, penetrating into Ouli, crossing the Falemé near Kenieba, from which he reached Bondu, and finally descended the Senegal from Fort Saint Joseph at the Felou cataracts (p. 157). In 1818, Gaspard Mollien, cousin of one of Napoleon's Ministers and a survivor of the disastrous wreck of the Medusa, started out from Saint Louis to discover the sources of the Senegal and the Gambia with no more sumptuous equipment than a donkey-load of stores and trading-goods and the escort of a single marabout, who spoke the language of the countries through which they intended to pass. Marching through the great forests of Ferlo, he reached Saldé, ascended the Senegal to Bondu, and, crossing the Gambia, halted at the village of Cocagné, on the borders of Futa Jallon. From this part he visited the 'Tangué mountains, discovered the sources of the Gambia and those of the Rio Grande (Comba) near Bandeïa, and arrived at Timbo, where he met with some opposition, the natives regarding the country in which the Senegal arose as so sacred that they threatened with death the impious person who attempted to penetrate the secret of the river's birthplace, though he obtained sufficient information to fix the quarter from whence it sprang. Worn out with fatigue and weakened by fever, he was forced to lic for a month at Bandeïa, surrounded by an unfriendly population, and in the hands of a treachcrous host, who endeavoured to kill him for the purpose of 
obtaining possession of what little property remained unpillaged. He was, therefore, very glad to escape and reach the coast by way of the Portuguese settlements of Geba and Bissao, after an absence of a year. MLollien, whose work deserves a larger place than it has obtained in the history of African exploration, was afterwards Consul-General in Havana, and died at Nice so recently as the year 1872.*

De Beaufort, a French naval officer who traversed Ferlo and the country bordering the Gambia as far as Kaarta in the years 1824 and 1825, is cven less known. For before he had time to write any account of his journey he was seized with an illness which proved fatal, the only records of his travels that remain being some letters and other notes. Both of these travellers intended, if possible, to reach Timbuctoo. Mollien, indeed, expressly writes that he hoped to accomplish this object by going in the guise of the slave of his guide.

It is, nevertheless, quite certain that neither reached within many leagues of that goal. It was, however, the lot of another Frenchman to do so, and to bring to Europe the first detailed information of the city which any European had obtained, since his predecessors left no descriptions behind them. This was Auguste Rcné Caillié or Caillé†-as his name The journey is variously spclt-a man of of Rene Caillie luodest station, the son of a poor to Timbuctoo. baker of Manzé in the Dcpartment of the Deux-Sèvres, whose education never passed beyond a moderate acquaintance with reading and writing. He was born in the year 1799, and brought up in the village charity-school, where a copy of "Robinson Crusoe" fell into his hands. After being apprenticed to a shoemaker, the story of the shipwrecked mariner so influenced Caillié's mind with such riews of adventure,

* "Trarels in Africa to the Sources of the Senegal and Crambia in 1818." Translated from the French. (1820.)

+ Towards the end of his life the traveller signed his name Caillé, believing that to be the proper orthography. that, contrary to the wish of his uncle (his father having died in his infancy), he proceeded, at the age of sixteen, to Rochfort, with sixty franes in his pocket, to ship on board La Loire, a tender to the unfortunate Medusa, bound for Sencgal. After remaining for a few months at Dakar, a village of Cape Verd, he set off for St. Louis, on that place being surrendered to the French. Here he heard of IIajor Gray's expedition (p. 221). 'This set him once more on the move, in order to offer his services, travelling on foot as far as Dakar and from thence in a small boat to Goree. But the misery he had suffered in his overland journey so damped his ardour that little difficulty was expericneed in inducing him to abandon his project and accept a free passage to Guadeloupe, where he remained for six months in some petty position. There, however, he fell in with the "Travels" of Mungo Park, and was once more fired with such ardour for African exploration that he quitted Pointe-à-Pitre for Bordeaux, and returned in very humble circumstances to Gorce in the end of 1818. Here he joined Adrien Partarrieu, who had been sent by Major Gray to purchase the merchandise required by the King of Bondu (p. 221). Of the later sufferings of this expedition Caillic had his full share, and on reaching Bakel he was so weakened by a fever that in order to recover he was compelled to return to France. Still cherishing his project of opening up the interior, he again made his way to Senegal, furnished, by the generosity of some friends, with a small quantity of trading-goods. Baron Roger, an enlightened friend of science, who was at that time governor of the colony, finding it impossible to check the ardour of his young countryuran, supplied him, on behalf of the Government, with some further means to enable him to live annong the Braknas, a tribe of Moors, to acquire the Arabic language and be initiated as a renegade into their religious and other ceremonies. This he duly accomplished, though, such are the abstcmious habits of these pcoplc-milk being almost the only food - that he was nearly 
famished before he found himself suffieiently Mohammedanised to return to St. Louis.

Feeling that in appearanee, as well as in capaeity to keep up his assumed charaeter of an apostate thirsting for information and " the light," he might safely venture to set out for Timbuctoo, he asked for further help from the Senegal authorities. The Govermment having already spent $\mathfrak{2} 20,000$ * on Beaufort's abortive attempt, did not eare to waste any further pounds on what they regarded as little better than the idle whim of an enthusiast, and so, in disappointment, Caillié betook himself to Sierra Leone, where, by the kindness of Sir Charles Turner, the Governor, he was set to superintend some indigo-plantations on a salary whieh enabled him to save about eighty pounds. Sir Neil Campbell, the sueeessor of 'Turner, did not, however, see fit to supplement this sum by an additional two hundred and forty, under the plea that the Govermment, having already gone to eonsiderable expense with Major Laing's venture, eould not just then incur any further outlay in the seareh for Timbuctoo. This refusal seems to have touehed the vanity of the Frenchman, who throughout his narrative displays little gratitude to the Englishmen who again and again befriended him, preferring to regard them as instigated by national jealousy, when, as was only natural, considering Caillié's slender scientifie equipment, they did not fall in with his somewhat liberal views as to their peeuniary duty to a foreigner of whom his own Government had not displayed any marked appreeiation.

Undeterred by this refusal to loose the purse-strings of perfidious Albion on his behalf, Caillié quitted Sierra Jeone in high dudgeon. Investing part of his 2,000 francs in some eommodities useful for barter in the interior, and provided, by the kindness of his English friends, with a few medicines, which might possibly prove more immediately useful

* Caillié declares that the British Gorernment expended on the expeditions of Tuckey, Peddie, Campbell, and Gray-or, as he is pleased to put it, in trying to "injure French commerce"-- $\$ 750,000$. This may be doubted. than the sovereigns which he stowed away in the Moorish girdle and turban whieh he again assumed, he determined to win the 10,000 franes which he heard that the Freneh Geographical Society had offered to the first man who reached Timbuctoo. He had, moreover, his story ready. During his stay in Sierra Leone he had assidnously cultivated the acquaintanee of some Mandingoes and Saraeelots, who for'm the eommereial travellers or wandering merchants of the interior. 'To these he entrusted the apoeryphal secret that his parents were Moslems resident in Alexandria; but that when the French invaded Egypt they took him with them to Franee and fiom thence to Senegal, where, eseaping from his master, he was now trying to reaeh his home in Northern Afriea. How far this tale served him is doubtful; he deelares it was always believed by the country folk, though the townsmen, especially in Morocco, were not so readily eonvineed of its truth. But at all erents, by being outwardly as eonsistent a Mohammedan as possible, and eonstantly reading the leaves of the Koran with whieh his travelling-poueh was filled, he eontrived to keep up the eharaeter he had assumed.

After staying for some time at Kalsundy on the Rio Nuñez, † reeeiving everywhere the greatest kindness from British and Freneh residents alike, he started, on the 19th of April, 1827, for the interior. For the first part of his journey he travelled in the company of a sinall Mandingo earavan, suffering no greater inconvenience than being pestered by stinging bees. As happened when the Sieur Briie traversed the same region, these insects would sometimes beeome masters of the situation, settling on artieles of food and on the rims of drinking-ressels, resisting, after their customary fashion, any attempts to drive them away. In plaees they were so numerous that they took possession of the huts, and unless expelled by smoke the lawful tenants were eompelled to wait at a distance till it suited their good pleasure to leave. Among the people in this region a kind of t Between Sierra Leone and the Gambia. 
institution akin to Freemasonry is said to exist, and many years ago a British offieer wrecked on the neighbouring coast deelared that he had good reason to be grateful for the benefits that he derived from it. deal. An albino child, with white, eurly hair, blue eyes, and rosy skin, was about the most novel object noted by him at Kamboya. M. Caillié was, however, not a trained observer, and the eharacter he had assumed preeluded

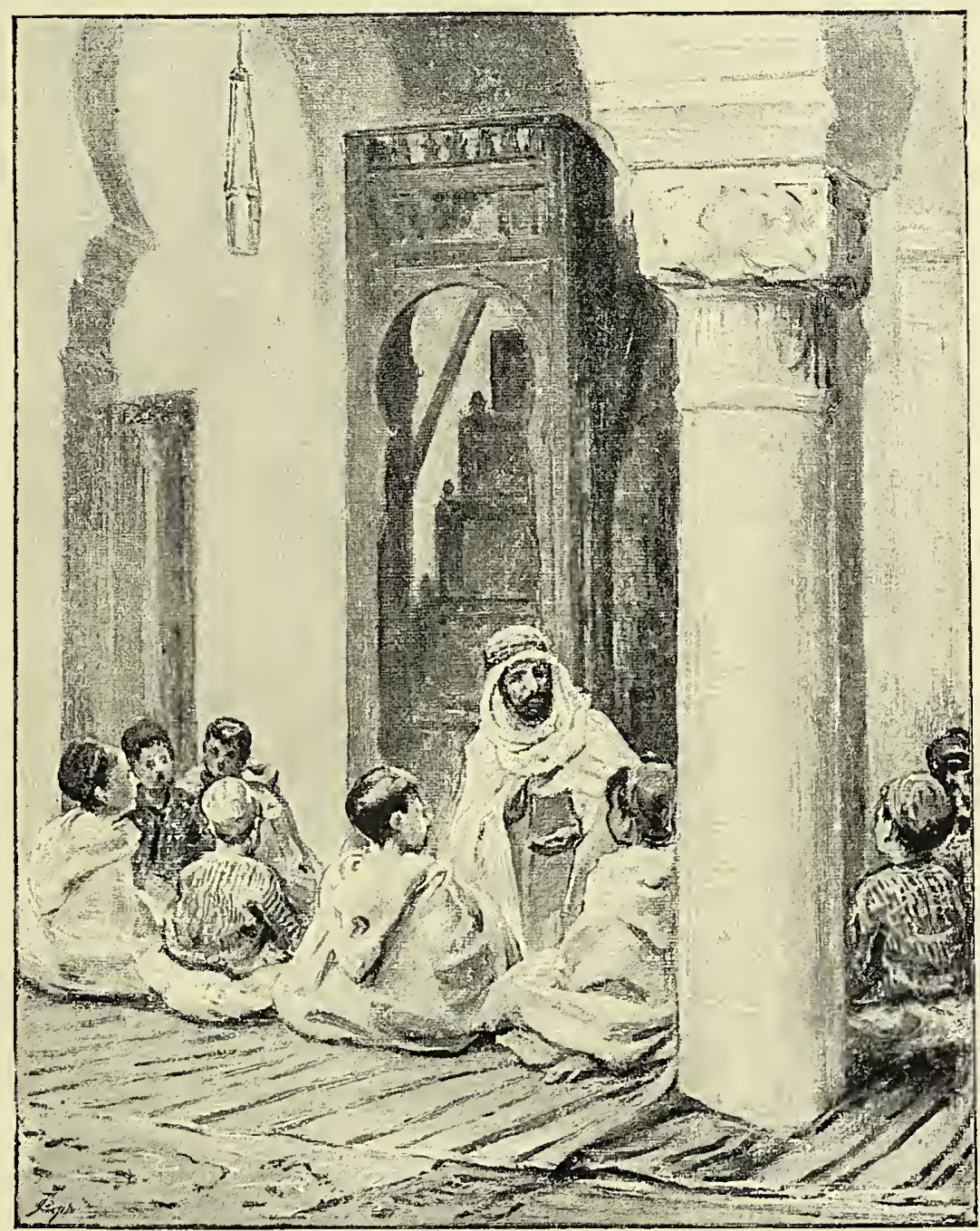

MOSQUE SCHOOL IN NORTHERN AFRICA.

However, though journeying as an Arab in the company of native tribes, Caillié and his party did not escape the extortions with whieh the reader must by this time be familiar as the invariable eoneomitant of all African travel, espeeially in the region of the great river with whieh the previous pages entirely him from taking observations or keeping anything in the shape of a diary. For in adopting Mohammedanism he was compelled to adopt its ignoranee and prejudiees also. For the same reasons, though he contrasts the merry life, the singing and the danees, the games and the joeundity of the pagan negroes 
with the dignity and even dulness of the Mohammedans, he, as a good Moslem who comes from a land not far from the birthplace of the Prophet, is bound to refrain from anything that might stamp him as an infidel.

Still journeying due east, through the FutaJallon country, he reached the Niger at Kurusa. This is a pretty village in the district of Kankon, in what is known as the Samory's Dominions, and at that time was a place of some consequence, being surrounded. with a mud wall ten or twelve feet in height, and about as many inches thick. The Niger at a part so near its headwaters was, of course, a much less remarkable current than lower down, though even here it was about eight or nine fcet deep, and nearly a quarter of a mile broad. Crossing the river in one of the canoes which constitute the four ferry-boats, he reached 'Timé, where he was detained for four months by a severe attack of scurvy, during which he was annoyed by the inpertinence of the natives. "The Arab is no good," they would cry ; "he gives nothing away to anyone." It was in vain that he told them of the long journey he had yet to perform. "All Arabs and whites are rich," they insisted and, finding it impossible to extract nore than a few beads from him, amused themselves by ridiculing a wound in his foot, and laughing immoderately when he hobbled about with difficulty.

By this time the caravan with which he had set out had left him or gone about its errand. His companion for the rest of the journey was a guide, who was accompanied by his brother and the wife of the latter to carry their little baggage. As the traveller proceeded northward he notes that the gaiety of the inhabitants diminished: he never saw them dancing or amusing themselves, and even the art of making an intoxicating drink from the juice of the oil-palm tree secmed to be unknown to them, or, at least, not practised. The country of the Wasulu was, however, well cultivated, and thickly inhabited, and so continued until he again reached the Niger opposite to the eity of Jenné, where the river was about five hundred fect broad.
Caillie was the first European* to enter this town, Park having seen it on his last journey from the river only. The city of In those days it would appear to Jenné.

have been the principal commercial town of that part of Africa, the bazaars being furnished not only with abundance of native goods, but with all kinds of European manufactures, mostly of English origin. English gunpowder in an espccial degree was highly estecmed, the native sort having little strength, and frequently going off without producing any regular detonation. Slaves entircly naked were called about the streets by the brokers and auctioneers and sold at prices varying from 25,000 to 40,000 cowries. The eity itself is about two and a half miles in cireumference, surrounded with a wall of earth badly built, ten feet high and fourteen inches thick, and entered by several small gates. The houses are of sun-dried bricks, one storey high, with terraced roofs, and windows looking into an inner court. But the environs of the town are marshy, unhealthy, and without any trees. One inark of civilisation Caillié noticed herc for the first time since he left the white settlements behind, namely, that as the inhabitants used pocket-handkerchiefs, he was, to his great relief, able to employ that implcment of civilisation without exciting lidicule or arousing suspicion of his being a different person than he had represented himself to be. Many of the citizens were then, as now, not only wealthy but refined. At the house of a Noor with whom he dined the guests were served with tea in eups of delicate porcelain, and, what for the impoverished traveller was even more important, several of the richer inhabitants not only treated him with the greatest kindness during his stay, but believing -or affecting to believe-his story, made up amongst them. a little purse to defray his expenses to Timbuctoo. The intercourse between this city and Jenné is kept up by means of large decked boats made of planks

* Leo Africanus was well acquainted with it three centuries earlier. But though born in Spain, he was by race an Arab. 
tied together with ropes twisted out of palmleaves, and manned by sixteen or eighteen sailors, their rude vessels often drifting down stream in floats of sixty or eighty. At Dibbo or Dibbie Lake, which Park had heard of, the river expands in a broad pool or sheet, dotted with islands, which the Frenchman duly named in honour of Charles X., the Duke of Bordeaux, and the Dauphin. The voyage was, however, not very eheerful, for in order not to attraet as a stranger, presumably worth plundering, the wandering Touaregs who frequent the river banks and levy contributions on passing travellers, Caillié kept for the most part below, until—on the 19th of April, nearly four weeks after leaving Jenné, exaetly one year after leaving Kakundy - they arrived at Kabara, or Kabra, the port of Timbuetoo, built on the banks of a weed-choked channel which leads from the Niger for about half a mile (p. 121). Next day, in company with : slare-merchant and his eoffle, he proceeded on horseback to Timbuctoo, which lies about nine miles north of its riverine port.

The view which lay ahead of him (pp. 121, 208) was an impressive one. For here The city of was the famed city which so many Timbuctoo. had tried to reaeh in vain. Yet the result was disappointment. He had formed inflated notions of its magnifieence, which ought to have been dissipated by a perusal of the old Moorish traveller's narrative of three centuries ago, modified by the fact that since then the place had decayed. "The speetaele before me," he tells us, "did not answer my expectations; at first sight it presents but a heap of houses badly built of earth-it is neither so large nor so well-peopled as I had been led to believe. Its commeree is less eonsiderable than is stated by publie report: a great eoncourse of strangers coming from every part of the Soudan is not seen here as at Jenné. I met in the streets only the eamels coming from Kabia. The eity is inhabited by negroes of the Kissur nation : they form the prineipal population. Many Moors are established here for eommereial purposes. They have mueh influence over the natives ; nevertheless, a king or governor, with whom we had an interview, is a negro, is named Oman,* and is mueh respected. His offiee is hereditary: his eldest son should sueeeed him. The eity may be three miles in eircumference; its form is a sort of trough; the houses are large, not lofty, and have only a ground floor. In some a small room is raised above the entranee. They are built of round brieks rolled in the hand and dried in the sun; the walls resemble in height those of Jenné. The streets are clean, and sufficiently broad for three horsemen to pass abreast; both within and without the

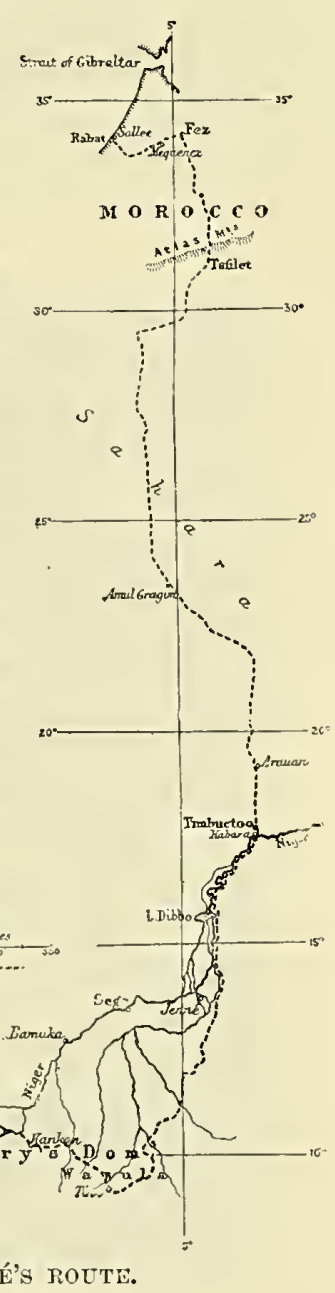

city are many straw huts almost like those of the Fulah shepherds. There are seven mosques" - in another place he says eight"of which two are large, each surmounted with a brick tower. The eity is without any walls and open on all sides, and may eontain 10,000 or 12,000 inhabitants, ineluding the Moors. All the native inhabitants are zealous Mohammedans. The commeree of the place is mueh restrained by the neighbourhood of

* This was no doubt Osman, the licutenant of Ahmadu. ben-Mohammed Labbo. 
the Touaregs, a warlike nation which renders tributary the inhabitants of this city."

When we remember that only a few years before the population of the city had been estimated from the reports of Moorish traders at 100,000 , this state of matters was rather disappointing, though it was not out of lieeping with the accounts of the only Arab traveller of credit who had deseribed it within of the desert ofiered little to invite a long stay, no one living there except the street dogs or the ravenous hyenas, gorging themselves on the offal thrown out of the town. The terrace on which it stands, at a height of some 800 feet above the sea-level, overlools a chain of "dhyas" or marshy hollows, fringed here and there with a few stunted mimosas and palmthickets, which relieve the sandy wastes around.

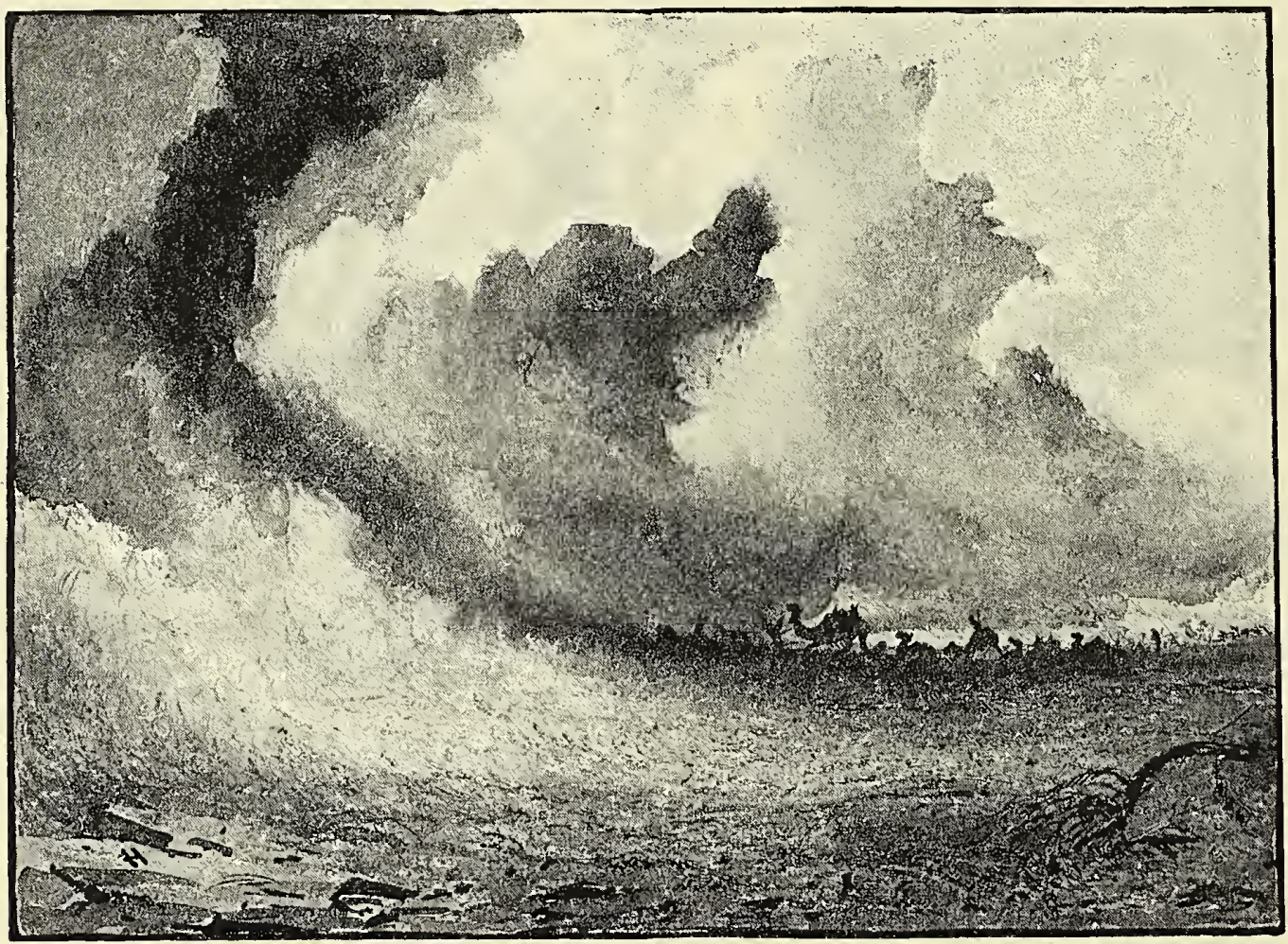

SAND STORM IN THE SAHARA ( $p .235)$.

the preceding three centuries, or, indeed, with some of much later date. Some Moors, who had resided long in the place, trying to give M. de Lesseps-father of the canalmaker-some idea of the town, used the following illustration :- " Take a heap of cabins in your hand, cast them into the air, let them fall upon the ground, and you will see Timbuctoo." Nor was Caillié more inpressed with the surroundings of this famed city. North-east and south of it the burning sands
Yet even here there were many learned men, and though Timbuctoo had fallen-and since that day it has fallen still more-from its ancient grandeur, books on devotional subjects, commentaries on the Koran, and the like, were part of the regular merchandise which the traders across the desert bore every year, as they bear still, in the caravans from Morocco.

Since Caillié's risit-as we shall learn byand-by-nuch information has been obtained 
regarding this famous place. Though the name has still a certain charm, it is no longer invested with any mystery, several travellers having been there. Yet, while some of the statements made by this unlettered Frenchman have been shown to be erroneous, briefly rehearsing what was known regarding the history of a city which for centuries formed the goal of so many journeys, and in its way has cost more valuable lives and done more to stimulate exploration than any other town on the earth's surface.

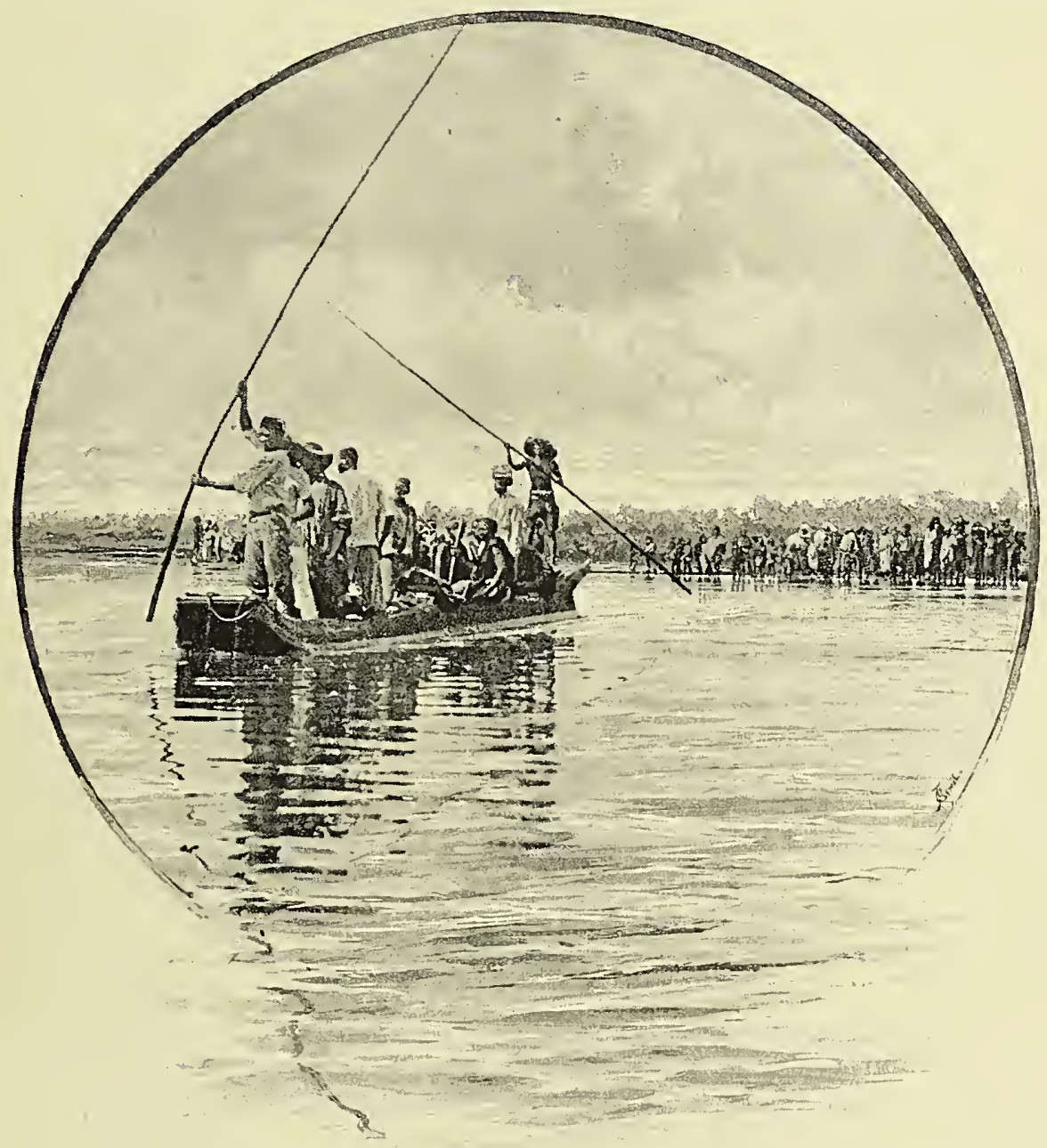

NIGER RIVER FERRY-BOAT.

(From a Photograph by Captain Mochler-Ferryman.)

subsequent inquiry has confirmed the essential truth of his narrative, his blunders being due to an imperfect recollection unaided by notes, or to defective education.

This episode in the history of Timbuctoo may therefore afford an opportunity for
Timbuctoo is situated in the now Fulah State of Moassina or Massina, and though no longer on the Niger, the "dhyas," which are flooded every three or four years, converting the lowlands at the foot of the scarp on which the city stands into a 
network of channcls and backwaters, are all that remains of a navigable creek which reached from the great river up to tho base of this terrace. Indeed, in the year 1640, the Niger forced itself during a time of flood right up the creek from Kabara to Timbuctoo, inundating the lower part of the city. It is also probable that at some carly date the Niger, before it took its present easterly curve to Burum, where it bends in the direction of the coast, occupied this channel; and some observations made by Lenz would indicate that before the increasing drought of the desert dried up the now westerly Wady Messaura, from the Tuat oases, south of Morocco, this stream joincd the Niger here.

From the data accumulated by the patient Barth, it would appear that Timbuctoo was originally a native village, captured in the eleventh century by the Touregs, and by them constituted the nucleus of what eventually became an important commercial centre. As early as 1373 it is noted on the maps as a place under the Mandingo kings of Mali much frequented by traders in gold and salt (p. 122). Its greatest glory was, however, attained in the fiftcenth century during the short-lived but extensive Songhai (Sonrhai) Empire, founded by Askia in 1492. In those days its splendour, though perhaps very modest according to European notions, was infinitcly greater than at any former or later period, and, it shared with Gogo, Fez, and Kairouan the distinction of being one of the centres of Mohammedan culture in Africa.

However, in 1591 the Songhai dynasty was overthrown by the Sultan of Morocco (p. 1.23), who up to a comparatively recent date kept a garrison here, though nowadays the Moors do not regard it as a portion of their dominions. When Caillié visited it the Fulahs were masters ; but these in 1865 seem to have been displaced by the Scnegal Toucouleurs* (p. 236), and these in turn by the Touaregs, until the town, after being for ages at the mercy

* These are a mongrel race-mixture of the Fulah and the negro races around them. of onc marauder after another, has fallen into decay. What was its condition when last visited we shall learn in a future chapter.

Secure in his disguise--or, at least, Mohammedan enough not to be suspectedCaillié remained for a fortnight in the city, occupying a house opposite the one which had been tenanted by the unfortunate Major Laing, though the account he was given of the manner of Laing's death was afterwards discovered to have been either intentionally, or through the confused rumours of the wandering merchants, by no means compatible with the more carefully sifted facts obtained by the British agents at Tripoli. $\dagger$

Like most people accustomed to mingle with strangers engaged in commerce, the Timbuctooese were hospitably inclined to the traveller whom they regarded as their coreligionist. They would fain have persuaded him to prolong his stay. But a caillie's caravan being on the eve of return from leaving for Morocco, he determined. to reach civilisation by crossing the Great Desert in preference to returning to Senegal, knowing well that in the latter case he might be accused of having simply repeated ono of the half-way journeys of his predecessors. Accordingly on the 4th of May, 1828, he set out on what was in many respects the most tedious part of his travels, and in five days reached El Aruan, a town near which Major Laing was murdered. It stands in the middle of a vast area of sand-dunes stretching as far as the eye can see, and so bare of vegetation that the only fuel used-and except for cooking none is required-are the dried droppings of camels. The houses number at present about one hundred, and in 1828 we may take it the place was in no way different from what the latest European travcller describes iteach house built in the form of a square, entered by a door at one comer, but without any windows except those looking into the little court-yard within. When the inmates want to take the air they ascend to the flat roof; but for all practical purposes every dwelling + Quarterly Review, No. Ixxvii. 
is in itself a self-containcd little fortress detached from all others in the vicinity.*

From its own resources the town had little to sell ; but, owing to its being the distributing point for the salt obtained from the mines of Taudeni, in the middle of the Sahara-near which there are the ruins of an old Arab town -which is forwarded to all parts of the Upper Niger country, the citizens enjoyed a considerable transport trade. Caravans arrived about every day from Agadir, Tafilet, Mogador, Draa, Tuat, Tripoli, and other places in the Barbary States, with European merchandise, arms, powder, tobacco, datcs, and similar articles of necessity or luxury.

In Aruan, for the first time since assuming the character of a "True Believer," Caillié became an object of suspicion. However, redoubling his zeal in the observance of his religious duties, this distrust wore away, and he was again permitted to set out with a caravan of 1,400 camels destined for Tafilet, a locality on the desert side of the Atlas, which is famous as the home whence came the present ruling family of Morocco, and the spot to which are sent any members of the Imperial stock whose prescnce in the vicinity of the throne would not be desirable. The drifting sand and the burning east winds caused intense suffering to the traveller, and water was often so scarce that Caillié, owing to the niggardliness of the Moor into whose charge he had committed himself, was often obliged to beg for a fcw drops in the name of Allah the All-merciful, while he told off on his beads the routine prayer which he had learnt. In this dreadful mass of moving sand whole caravans are often lost, either from the water.skins getting exhausted, from the wells at which they hope to refill them being found empty, or by the rast clouds of sand borne by the desert wind overwhelming the hapless traders (p. 232).

Such an experience, on a sinall scale, befell Caillie and his party. At the tine when the column of sand was carried in their dircetion by the whirlwind they were encamperl: but

\footnotetext{
* Lenz: "Timbuktu," vol. ii., pp. 96-107.
}

in a few seconds tents and everything clse within the power of the wind were spun round and tumbled together "like straws." At various oases or habitable spots in the desert there are tribes who undertake to guide travellers across it, and others who are quite as ready to undertake the plunder of a caravan not too large to render the risk unequal to the profit. Some of these guides belong to a curious race called Daggatoun, who are said to be of Jewish origin, of fairer complexion than the Arabs and Berbers around them, with whom they refuse to intermarry. Extraordinary tales are told of the skill of some of these desert pilots-of blind men who, by simply smelling a handful of the soil, can at once tell in what part of the waste the caravan happens to be.

Great, however, as the torture from hcat, sand, and thirst was, poor Caillié inet little sympathy from his heartless companions. Falling ill of scurvy, they refused to sit at meat with so unclean a person, and, notwithstanding the care with which the sham Moslem had studied their manners and habits, they remarked that he could not, like them, jerk the rice into his hand, makc it into a small ball, and pitch it into his mouth. A common insult was that, "he atc like a Kafir." Even the slaves of the party were encouraged to annoy him by cvery species of insolence, and the burthen of their opprobrium always was, "he looks like a Christian." Onc man, indeed, was so certain that he was the despised "Kafir" or Infidel, that he proposed to sell him. At the well of Amul Gragim the night was cooler, though here the visits of huge serpents rendered it impossible for the weary traveller to rest in peace. Yet, exccpt from the unsympathetic character of his fellow-travellers, the constant thirst, the plague of sand-winds, and, as in the above case, of snakes, Caillié tclls us that, in spite of his fatigue, he felt better in health than when

$\uparrow$ The story is as old as the days of Leo Africanus $(1500)$; but it is still repeated by the Morocco traders who make the journey from Mogador and Agadir to Timbuctoo-another proof of the accuracy of the old Moorish chronicler. 
traversing the more hospitable regions behind him. Food he had in abundance. In payment for writing charms for the women he was supplied with a plenitude of messes, into which had been liberally introdueed the butter used by them for greasing their hair. The object of all these anulets was to obtain husbands for them and their relatives, but, as the writer's stay was for a brief period only,

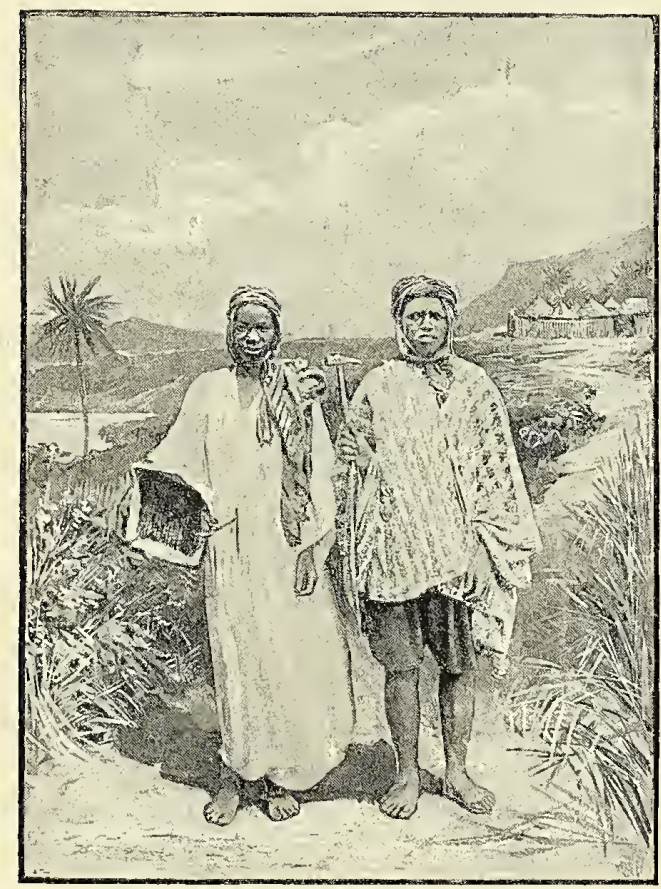

TOUCOULEURS OF SENEGAL $(p, 234)$.

(From a Photograph by the Paris Society for Evangelical Missions.)

he felt safe in promising any boon to his eager clients.

By-and-by the worst of the desert ended, and, sevcnty-five days after leaving Timbuctoo, the series of scattered Kasbahs, or large fortified plaees which constitute Tafilet-the aneient Sigelessma-was reached. Here, deseendants of the Prophet were ineonveniently numerous. So also were robbers, to guard against whom every Berber village was watchcd by a troop of feroeious dogs. On aeeount of these brutes no strangers ever approaeh a village without being in the company of a person known to the four-legged guardians. Even then they are not safe; so that the hospitality offered is seldom given in a tent, but at a distance from the clouar and from its savage canine garrison. It was, however, but little of this that Caillié reeeived. In vain he begged from the Moorish governor some help to enable hin to reach Fez, on the other side of the Atlas, still keeping to his old story of being on his way to his native town of Alexandria. A pious $\mathrm{Hadji}$ or Mecea pilgrim would at times treat him with kindness in memory of his cscape from the Christian thrall, and a trader sometimes bestowed on him a eoarse loaf of bread "for the love of God." He had a few English shillings in his possession, one of which a Jewof whom there were many at this mectingplace of the caravans-exchanged for its value in silver; and at the same time, perhaps suspeeting his real eharacter, entertained him with a politeness which eontrasted with the boorish rudeness of a people who, like the Tafilet Moors, have no links with Western eivilisation and no regard for its good opinion.

Caillié had, however, brought from Tinbuetoo some deeent pieces of native apparel, and, by selling these-everything being very cheap-he raised funds enough to hire a donkey, on whieh, in the eompany of a little earavan, he passed the fertile valleys of the still little-known Atlas, and on the 12th of August, more than three months after leaving Timbuctoo, entered the Imperial city of Fez. Built in a valley, it looks-like most Moorish towns-more pieturesque at a distanee than near at hand. The gardens of oranges and olives, in which the suburbs immediately within the walls are embosoned, impart to the place a charm in the eyes even of travellers who have not been trudging day after day through the desert sands. But the "City of the Hatchet" is never a very hospitable place for a poverty-strieken traveller, and Mequinez, another of the three Moroecan capitals, is an even less agreeable plaee of asylum for the destitute: for here, failing the mosques-which are usually plaees of 
shelter for the houseless and sometimes the village school also (p. 229)-he was left to sleep in doorways, or in the narrow, dirty lanes of the old-world metropolis of the Sultans. In three days, following the ordinary route, he reached the Atlantic at Rabat, on the
Hiring, therefore a donkey with the little which remained to him of the money brought from Goree, he in due time reached Tangier. Here his troubles came to an end, and ineans were provided for sending him to France, where he arrived 567 days after leaving Kakundy, to

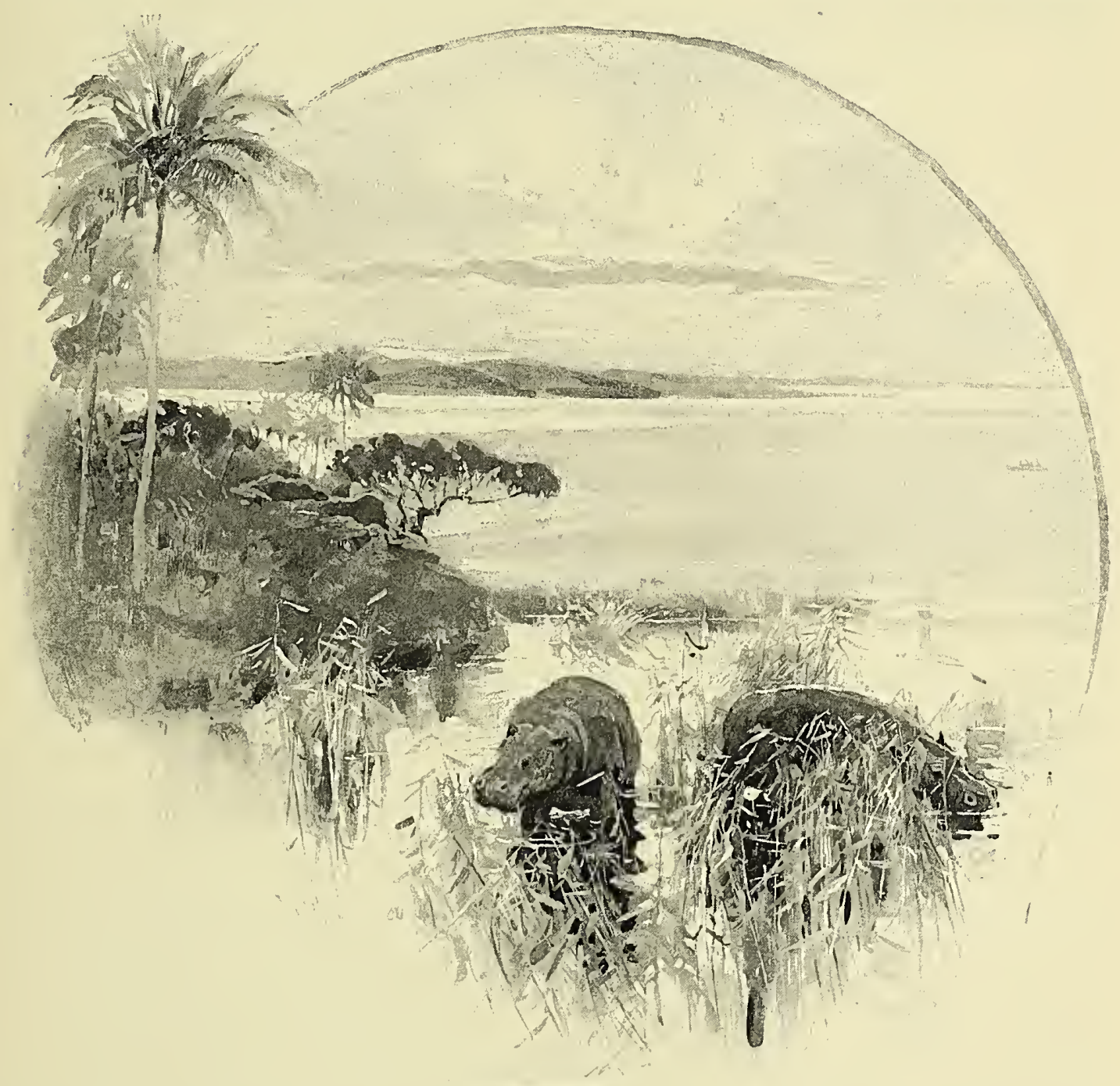

LAKE TCHAD.

Bon-ragreg River opposite Sallee, which shares its evil fame as the last of the pirate haunts of North Africa (p. 105). Here again he had the "key of the street." In Rabat the French Consular agent was a Jew, who displayed no desire to help him: and Christians in those days were fewer in that port than at present. receive the honours which he had so justly earned.* For he had redeened with success a long tale of failure.

* René Caillié : "Journal d'un Voyage à Tembuctou et à Jenné dans l'Afrique Centrale," etc. 3 vols. (1830.) There is also an English translation in two rols. The discussion which followed gave rise to a considerable 
When the disjointed story told by Caillié spread over Europe, there was at first some inclination to doubt its strict accuracy. It contained some statements that were, or seemed to be, not quite in accordance with fact, while a very superticial reader could easily point out contradictions tending to justify the scepticism with which it was received in many influential quarters. In England especially was this the case. Indeed, there were not lacking critics ready to affirm that Caillié had never been in Timbuctoo, but, derived his information either from native report or from the papers of Major Laing, of which Baron Rousseau, French Consul at Tripoli, had in some way villainously possessed himself, and used his illiterate countryman to gain for France the glory which was the Briton's due. Suspicions of this character were not a little aroused by the inflated eulogies which some indiscreet admirers of the traveller chose to bestow upon his book. This was in reality largely the work of M. Jomard, Secretary of the French Geographical Society, who may be held responsible for permitting his protégé to indulge in the many absurd reflections on the English to whom he was so much indebted, and to quote compliments to France from quarters where it is doubtful whether that country was even known.

Nor was this irritation, at a time when the old sores created by.the long Napoleonic wars had scarcely healed, in any way soothed by an attempt to make out that Caillie had becn the first European to reach Timbuctoo. This claim was, howerer, not admitted in French scientific circles, though curiously enough, the inscription on his monument in the cemetery of Pont-l'Abbé would convey that notion to the uninstructed reader.*

literature, most of which, so far as France is concerned, will be found noticed in the appendix to Jules Duval's "Un Ouvrier Voyageur, Reué Caillie " (1867), to a copy of which, annotated by the famons traveller's daughter, the writer has been indebted for many facts regarding: the joumey sketched in this chapter.

* "Renć Caillié . . . le seul Europêen qui ait vu et décrit Tembouctoo. Son nom sera placé par la posterité
But, strange to say, while the French were straining truth to obtain for La Belle France the glory of furnishing the first traveller that had entered the then almost fabulous city of Central Airica, they might, had they taken the trouble to read their own records, have found that, after all, a Frenchman, from no wish of his own, had earned that credit.

This was Paul Imbert, who in 1630 was wrecked on the sandy shore between Morocco and Sene-

The tale of Paul Imbert, the French slave. gambia, and, like so many hapless seamen since then, was enslaved by the natives and, in company with his Arab master, made a trading journey to that city. But he died a slave in Morocco, and the world has been none the wiser for his involuntary exploration. Later travellers have long ago rehabilitated the credit of René Caillié, proving that if he erred now and then through ignorance, or an insufficient memory indifferently aided by a few half-effaced pencil notes, his account was substantially correct. This meritorious man did not, unfortunately, live to rejoice in an unimpaired credit. During his lifetime nevertheless he received all honour, the reward of the French Geographical Society which had. tempted him to make his famous journey, the Legion of Honour, and a pension in the form of the office of French Consul at Bamaku on the Niger, without the obligation of residing or even visiting his post. Marrying, he retired to a small property at Beurlay (CharenteInférieure), which-after filling for a time the office of mayor-he exchanged for La Badère, where he died on the 17th of May, 1838, of a malady contracted during his African journey. A monument, erected in 1866 at Déboké, a short distance from Kakundy on the Rio Nuñez, where he set out on his inland adventure, marks the respect borne by the Senegal colonists for the menory of this deserving if ill-instructed explorer.

non loin de ceux de Brown, Hornemann, Mungo-Park, Denham et Clapperton." It will be noticed that Laing is not evell mentioned. In M. Duval's biography a similar attempt to ignore facts is exhibited. 


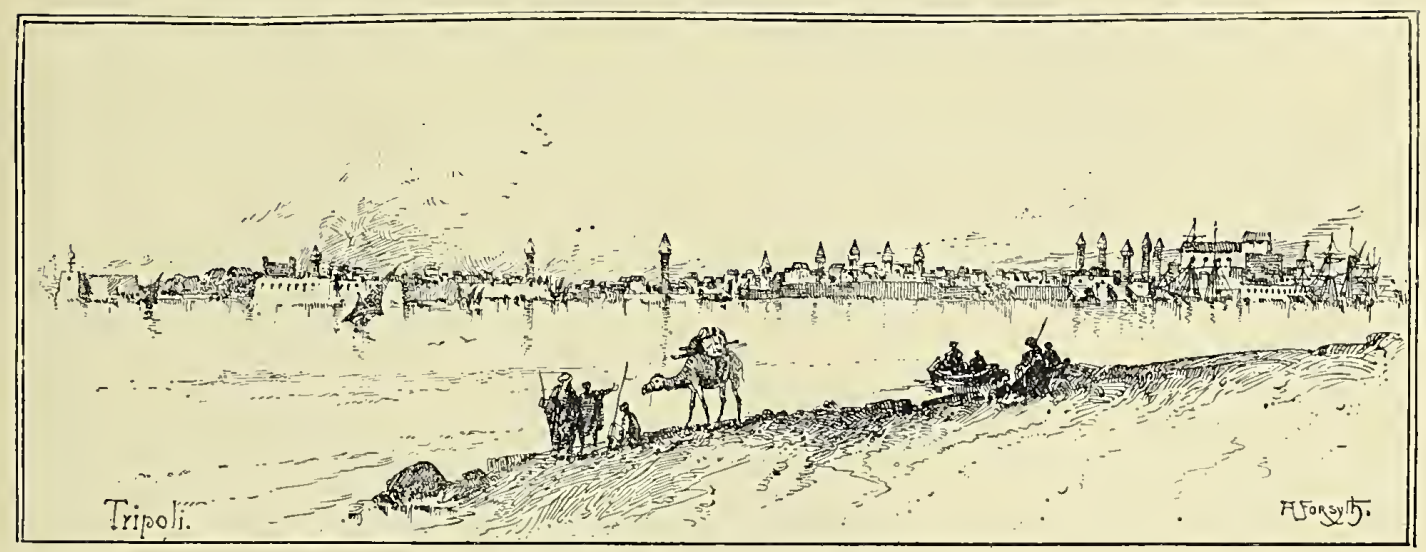

THE TOWN OF TRIPOLT, IN DARBARY.

\section{CHAPTER XIII.}

\section{The Niger Kingdons: A Half-told Tale.}

The Effects of Caillié's Story in Europe-Fictitious Travels-Timbuctoo no longer a Stimulus to African ExplorationA New Departure-The Niger Course and Termination : the Discovery aimed at-Attempts made at this after Park's Journey-Lyon's Expedition to Murzuk and Tegérri by way of Tripoli--The Ghurian MountainsFezzan-Oudney, Clapperton, and Denham's Expedition-IIurzuk-A . Tay in Peacock's Feathers-DilatorinessAn Arbitrary Gentleman-The Ghat Country-Troglodytes-Natron Lakes-A Larva Fishery-Leaves Murzuk - Hiseries of the Desert-A Pathway marked out by Skeletons-The Soudan Reached-Bornu-Its HistoryLake Tchad-A Slave Raid-Imprudence of Denham-And a Disaster-A Narch to Birni-Gambaru is Visited-A Narrow Escape-Sickness-A Journey towards Kano-Death of Oudney-Sokoto-Sultan Bello is Unfriendly, and refuses Assistance to Navigate the Niger-Zyrmi-Arrival of Mr. Toole with Stores from Tripoli-Death of Toole-Return of the Expedition to Tripoli.

THe tale told by Caillié rendered Timbuctoo no longer a stimulus for the exploration of Inner Africa. It was a point to be reached, no doubt, but now that it had ceased to possess the charm of being a city virgin to the white man's foot, it began to be regarded rather as a stage in a journey than the end of an exploration. MIen's thoughts began once more to be directed to the river near the banks of which it stood, the course it took to the sea, whether by the Nile to the Mediterranean, to some inland waste, or, what was now more generally held, to the Atlantic. Fictitious works of travel were not infrequently palmed off upon the public, of which that of the apocryphal Christian Damberger, who pretended to have journeyed from the Cape to Moroceo, which was translated into several languages, was the most notorious, and the "Voyage au Congo et dans l'intérieur de l'Afrique" of Douville the most astonishing. For though it was based on a small substratum of fact, most of it was evidently compiled from reports heard by the author, who, nevertheless, imposed not only on the French Geographical Society so far as to receive their highest honours, but upon a number of foreign savants not so likely to have their judgment warped by national predilections.

The British Government seems also to have been stimulated to fresh excrtions by the success of Caillié to continue the Ritchie work it had begun, though it and Lyon. was the Niger and not Timbuctoo which was the object of the journeys after 1828 . Several years, however, before Caillié had rcturned, British explorers had been penetrating from the north-not, however, with any immediate intcntion of reaching either the Niger or Timbuctoo, but mainly with the intention of opening up Inner Africa to commerce, though neither the course of the great river nor the famous towns in its vicinity were out of their minds. As these journeys led by 
a series of unbroken links to the discovery of the Niger mouth and to the re-discovery of some important Central African kingdoms not far from its upper course, we have reserved their description, though in reality they were antecedent to those of Laing, Caillié, and others alieady narrated.

Taking advantage of the excellent relations between the Bashaw of Tripoli (p. 239) and the British Government, it was resolved to tap the country from Northern Africa instead of, as formerly, from the West Coast. It was, in the first place, healthier, though morc dangerous, in spite of the fact that the Bashaw's power, actual or nominal, direct or indirect, extended not only throughout his own dominions far into the oases-dotted desert, but among the lingdoms near the Upper Niger, caravans from that part of Africa continually arriving with ostrich-feathers, ivory, and slaves for the Tripoli market. Lucas had already made an attempt in that direction, and in the year 1818, Mr. Ritchic, under a commission from the British Government, started from this point on a journey southward. He was to have been accompanied by Captain Marryat, afterwards famous in another department of travel tales; but the future sea-novelist failing him, Captain George Lyon, also of the Royal Navy, and better known for the share he took in Parry's Arctic Expedition immediately after his return from his African travels, was selected as his companion.

Their route has often bcen traversed since their time, but in 1818 it was unknown to the world at large, leading as it did through the sand-hills that approach almost to the gates of Tripoli, into the Ghurian Hills, famous for their semi-Judaised Berber inhabitants, who live in underground dwellings, the entrance to which is often difficult for a stranger to find. Here corn grows and shrubs again appear, and on the summit of the hills are found the crocus-fields that yield the saffion of commerce, and many groves of olives from which in good scasons large quantities of oil are produced. Beyond is a stony desert over which are scattered fossil shells, indicating that at one time it lay under the sea, though it is a inistake to suppose that the Sahara at large is of that nature; it is in reality above the sea, and the drifting sand is due to the wearing away, under the combined action of sun and wind, of the loose sandstone that forms its foundation. Olives, however, still flourish in places, and the wells, some of which are of great depth, yield such an abundance of excellent water. that the country is comparatively thickly populated by the Arab tribe to whom it belongs. At Bonjeem they passed the northern border of the kingdom of Fezzan, and even here are found fine remains of a fortress, which, according to the inscription still visible over the gates, was built by order of Septimus Scverus (p. 243). All this contry, indeed, is dotted with Roman ruins. Until Sokna was reached few inhabitants save wandering Arabs were met with. At Sokna, however, about 1,500 people lived in a walled town-most of them, judging from the fact of their speaking the Touareg language, understood only at this point, of Berber extraction. Dates of fine quality-finer even than those from the groves around the town of Tripoliare gathered from trees growing on the gravelly plain in the midst of which the town is built.

Crossing the low Soudah or Black Mountains, through a very sombre country, with villages or tent camps here and there-the black population beginning at Sebha-the party reached Murzuk, the capital of the Sultanate. In those days the place was the seat of an independent sovereign, and the meeting-place of caravans from all parts of the country around, so that here the travellers met with more civilised treatment than might have been expected so far in the wilds. Unfortunately, however, both fell ill here, and Mr. Ritchie died. Captain Lyon, nevertheless, detcrmined to push on, and reached as tar as Tegérri, the southernmost town in Fezzan, though here Arabic is little understood, the Bornu tongue being that of most 


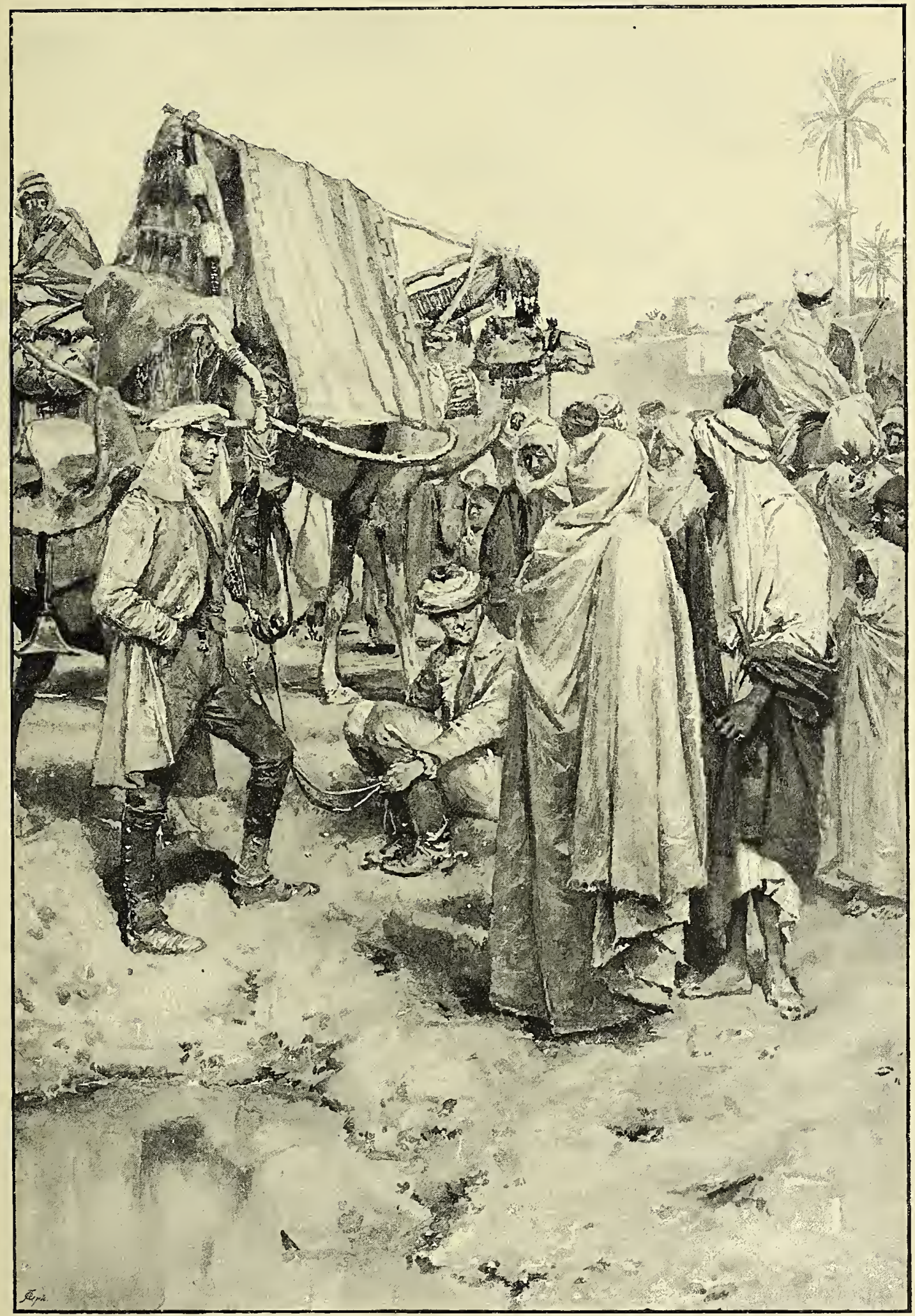

THE CLAPPERTON EXPEDITION AT MURZUK (p. 243). 
of the inhabitants, who, however, in those days did not number more than two hundred and fifty. From this point Lyon began his return journey, which he completed in the year $\mathbf{1 8 2 0}$.

This exploration was interesting from its thoroughness, though, as most of the country was already more or less known, it lacked something in novelty. It was, however, conducted with great slill, and furnished the first circumstantial account of the region through which the travellers passed at a very important period in its history.* Generally speaking, the country traversed consists of huge depressions fenced in by low ranges of hills, some over 3,000 feet in height. Barren, stony, bleak plateaus, between which lie long, shallow valleys containing fertile oases, complete the picture of a region which since lyyon's day has seen many changes. Originally a Roman province, Fezzan has seen many l11aster's, until, in 1842, it became a Turkish province, and has ever since remained nominally a part of Tripoli, though most frequently its governor acts quite independently of the Pasha of that region. Dates constitute its chief product; but most of these are consumed at home, soda obtained from the salt lake to the west being its principal, if not sole, export. At one time the slave trade was the staple trade of the country, the Fezzanees-who are mostly of Berber origin-not only raiding for prisoners on their own account, but acting as intermediaries between the merchants of Egypt and Tripoli on one side and Bornu and Timbuctoo on the other. This, however, is now, if not ended, largely curtailed, owing to the difficulty of finding a nuarket for the captives or purchases, though Murzuk is still a town of some $6,000 \mathrm{or} 7,000$ inhabitants noted for their good-nature, honesty, idleness, frivolity, immorality, and love of pleasure, taking everything as it comes with the resignation of a race who during the heat of summer are almost roasted alive, and in winter-incredible as it may seen to those

* Lyon : " $\Lambda$ Narrative of Travels in Northern Africa in the years 1818, 1819, and 1820." (1821.) not acquainted with the sudden variations of temperature in the desert-subjected at times to a cold so severe that the water. slins freeze at night, and it has happened that the flat roofs of the houses were white with snow. In short, the thermometer ranges from nine degrees below freezing to as much as ninety above it, so that the country, though healthy, except for the malarial fever which prevails in the low-lying grounds, cannot be quite commended as a retreat for invalids. It was through this country that Major Laing reachcd Timbuctoo (p. 222), though he fared worse from Touaregs and Arabs, hunger and thirst and heat, scorpions and sand storms, than did his predecessors, albeit they had enough of these familiar perils of the clesert.

Of these predecessors those immediately following Captain Lyon were Captain Clapperton, Major Denham, and Dr. Oudney. In suitability for the task they had entered upon, not one of them was perhaps so well fitted as Lyon, who, though quite unfamiliar with Africa,

Capt. Hugh Clapperton, Major Dixon Denham, and acquired a vernacular knowledge of Arabic in the course of a few months, and in other ways so completely adopted the native customs that his successors found their way smoothed by the good impression that he and his companions had made. The members of the new expedition that was to follow up Captain Lyon's were hampered by such complete ignorance of Arabic $\dagger$ and of the country that, with the exception of Dr. Oudney, who was a Naval surgeon and had been designated as Consul to Bornu $\ddagger$ with the olject of opening up a

+ Major Denham learned a little after a somewhat primitive fashion.

$\mp$ This expedition is usually associated with the names of Captain Clapperton and Major Denham, its historian, while Oudney's name is mentioned merely as that of a secondary person. In reality, he was the head of the expedition. his death depriving him of much reputation connected with it, while Denham became the historian mainly owing to Clapperton's engagement elsewhere. Oudney left little written material and Clapperton almost none, and as he died before he had time to write his narrative or to extend Denham's, the tale of this adventure will always remain only half told. 
trade with the interior, not one of them had read any book about Africa, except that of their inmediate predecessor in exploration. Like Park, Hugh Clapperton was a Scottish Borderer, the son of a surgeon at Annan in Dumfriesshire, where he was born in the year 1788. While still a boy he was apprenticed on board a ressel sailing between Liverpool and North America. Out of this service he was pressed for the Nary; but possessing some little influence and a great deal of intelligence, he was soon promoted to the rank of midshipman, and in that capacity so distinguished himself in Mauritius and on the Canadian lakes that when in 1817 he retired on half-pay he had attained the rank of lieutenant. During his enforced idleness in Edinburgh he contracted an intimacy with Dr. Walter Oudney, who was soon afterwards appointed to proceed to Bornu as British agent, the result of which was that Lieutenant Clapperton was appointed to accompany him, and at a later date Lieitenant-afterwards Major-Dixon Denlaan was permitted to form the third nember of the party, the only other European being Willian Hillman, a shipwright from the Malta Dockyard (p. 249).

Starting from Tripoli in the spring of 1822 , they were not long in reaching Murzuk, in Fezzan (p. 244). Lyon had made their path smooth thus far; and, indeed, by the constant traffic between Tripoli and this frontier town of the desert, the jealousy, the fanaticism, and the lack of summary justice which made the rest of the journey by no means easy, in those days, far less than in ours, impeded the path of travellers under the protection of the Bashaw. For whatever may be said regarding the humanity of that official's rule - and Tripoli in the early years of this century was not a model Government-no fault could be found with its firmness. And so complete was the hold which Consul Warrington had then on the esteem of the all but independent Bashaw that, as in the case of his predecessor, little was done without consulting the English representative.

The time was, therefore, auspicious for British explorers. For on a voyage of exploration the four Britons were unquestionably bound, the region for which they were making being none the less mysterious because three hundred years before Leo the African had described it in his journey from 
their camels could come up and swell the dimensions of the procession which they expected to see every minute forming in their honour. They might, however, have saved themselves the trouble; with the exception of some naked boys and a mob of 'Tibbus, Touaregs, and Fezzanees, who gaped at the party with extremely unpleasant looks, no

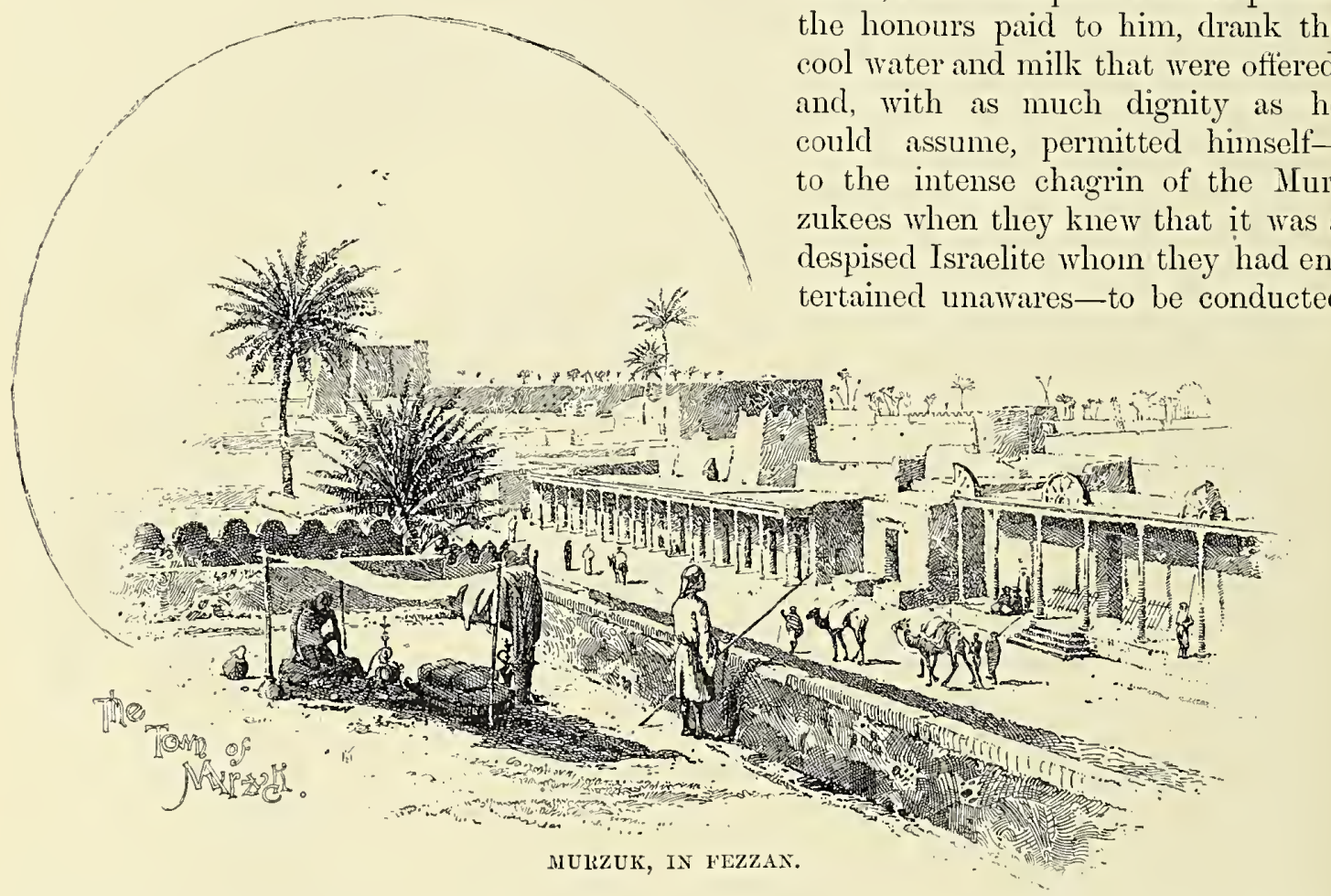

canteens being sturlded with small brass nails, the simple folk came to the conclusion that he must be an official of high rank, and, as no other except the Bornu Consul had been announced, that the Hebrew was this representative from Great Britain. Noway disinclined to be received with a respect not commonly accorded to his race in Northern Africa, Jacob accepted withont protest the honours paid to him, drank the cool water and milk that were offered, and, with as much dignity as he could assume, permitted himselfto the intense chagrin of the Murzukees when they knew that it was a despised Israelite whom they had entertained unawares-to be conducted one camle to meet them (p. 241). Nettled at such scurvy treatment, they sent Murzak: a
jay in peacock's feathers. their arrival, and in about half an hour the Sheik el bilâd, or governor of the place, came out and requested them in the Sultan's name to accompany him to the house prepared for them, adding, to their grcat surprise, "The English Consul is there already." The fact was, a very evil-countenanced Jewish servant of Major Denham, mounted on a white mule, with a pair of small canteens under him, had preceded the cannels and entered the town by himself. Struck with the fact of his to the house in the castle set apart for his master, who now took possession of it

By this time the Saharan summer had set in with its usual virulence, and the thernometer, which is seldom very low in Murzul, began to mount within an hour or two of sunrise to ninety-seven in the shade. In these circumstances even the civility of Sultan Mustafia El Akhmar did not tempt the travellers to tarry long within the walls of this stuffy town. However, no hope was given them that they could leave before next spring, the caravans haring already set out, the road not being safe, and a score of other excuses in which the Oriental is so fertile being adduced 
in support of this preposterous delay. When fiery Englishman. Tully* he had heard of, Lord Bathurst had communicated with the and Warrington he knew, but the peremptoriBashaw of Tripoli regarding the object of the expedition, he was assured that the road to Bornu was "as open as that from London to Edinburgh;" and making allowance for Eastern hyperbole, this statement, as later events proved, was not far from the mark. No time was, therefore, to be lost. ness of Denhham looked like a oriental rupture with his friends the Un- dilatoriness believers. Even in a day of swift arbitrary steamers, special trains, and tele- explorer. graphic communications, a journey from Murzuk to London would be regarded as a tolerably marked piece of energy, but so long since as

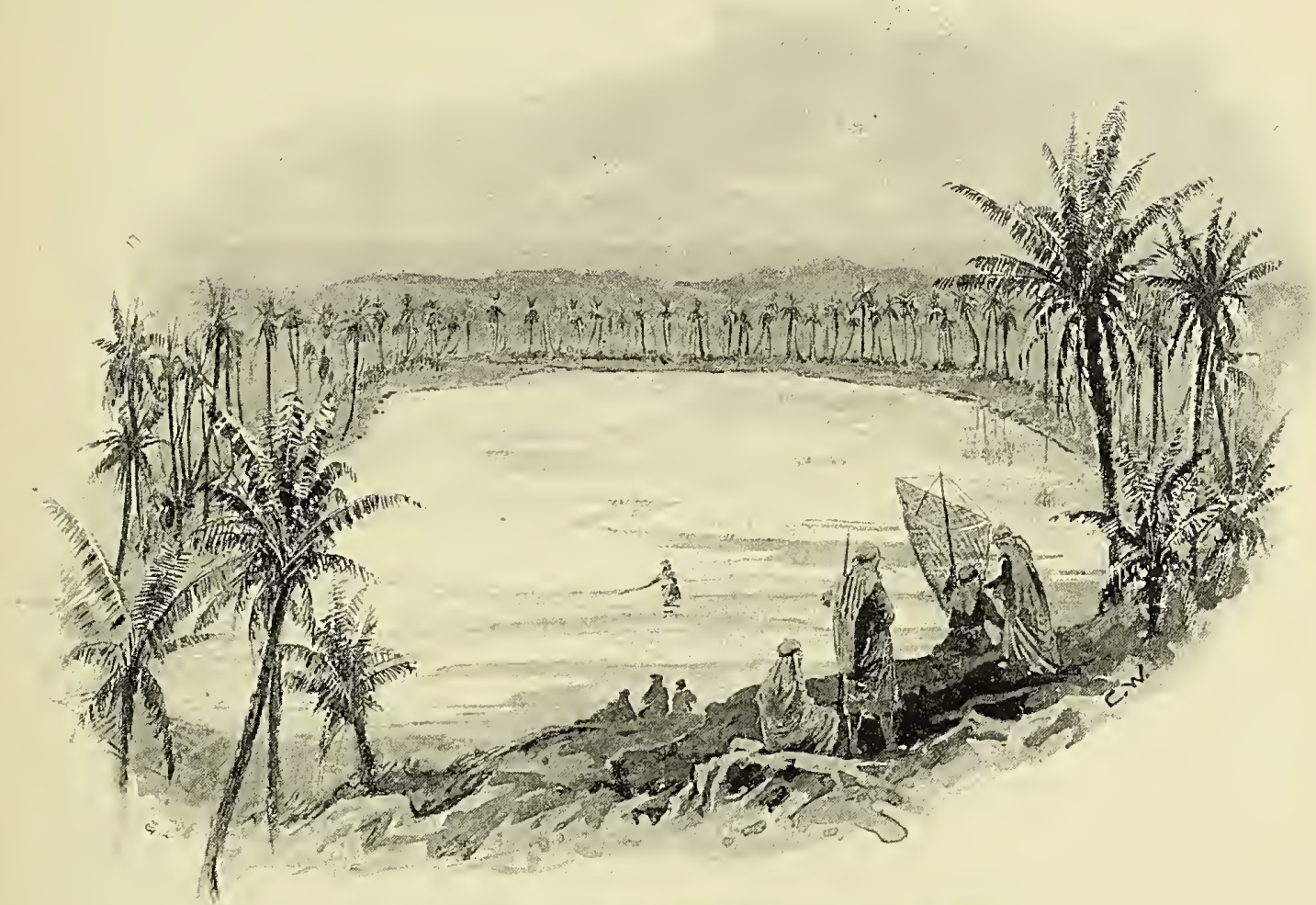

THE NATRON LAKES IN THE GHAT COUNTRY (p. 246).

Accordingly, finding the Murzuk Sultan not open to argument, Denham returned to Tripoli to lay his complaint before the Bashaw, and, finding that dignitary more lavish in promises than in acts, left for England by way of Marseilles with the first ship ready to start in order to represent the faithlessness of our ally to the British Government.

But by this time the Bashaw had grown alarmed by the unaccustomed energy of the
1822, when all modes of transit were much slower, it so impressed the sleepy Bashaw that ship after ship was sent to bring back the major. At last, he was overtaken at Marseilles and persuaded to return. Under his indomitable will all the "insurmountable" obstacles had vanished, for he had scarcely landed on the Marina of Tripoli before he was

* Richard Tully was British Consul in Tripoli. The "Letters" of his sister form a most vivid picture of the country during the despotic days of the old Bashaws. 
told that an eseort had already been provided for his party, and was by this time most likely waiting them at Sokna on the borders of the Tripolitan desert (p. 240). 'Murzuk was soon regained. But during Denham's absenee fever had seized his eompanions, and generally the town was in so insanitary a eondition that few even of the natives looked healthy. The enforeed halt had, however, been utilised by a visit to the Touareg eountry of Ghat, under the guidanee and proteetion of a powerful ehief to whom in memory of his kindness Captain Lyon had sent a sword. This region The Ghat is a mixture of desert and fertile country: the valley, salt-fields and low hills, and natron lakes, contains the town of Idrî on a hill larva fishery. three hundred feet high in the Wâdî Shâtî, the neighbourhood being studded over with basaltie eolumns and having salt plains at a short distanee and fields of eorn among palm groves in the immediate vieinity. Water flows in the shape of springs near the surfaee, and henee the fields look fresh and fertile. But though the inhabitants proved friendly, their begging propensities were troublesome. Tet many of the wonten exhibited that strange union of rags, dirt, and valuable ornanients so often found among the races of Northern Afriea. Charms were in much request for all manner of real or imaginary troubles, and one buxom widow gave the travellers no peaee until they manipulated for her a paper amulet that would ensure the possession of a seeond husband. Captain Clapperton was in espeeial demand as a neeromaneer. For his beard being red, it was innagined that he was an old and eorrespondingly wise man who had eoneealed the bleaching effeets of time by eolouring it with henna.* As is the ease with many of the raees of this region, it appeared that the former inhabitants of Idrî, before the present ones displaced them, were Troglodytes, or eave-dwellers. Their holes in the roek are still to be seen, and the eluster of huts piled one upon another on the sides of

\footnotetext{
* Derived from Lawsonia inem is, a plant widely grown in North Africa and elsewhere for dyeing purposes.
}

the eonieal hill, though then ealled the New Town, were in truth to a large extent in ruins. Wueh of the eountry seen from the summit of this hill is desert; but a great deal of it, though apparently favourable for settlement, is entirely without inhabitants. In some of the valleys are lakes eontaining natron, which forms an artiele of trade in that region. When the water is suffieiently shallow the mineral erystallises in eakes, rough on the upper side but studded on the surface next the water with beautiful vertieal erystals of "muriate of soda." + In many plaees the surfaee of these shallow lakes is eovered with large, thin sheets of salt, giving the whole the appearanee of a pond partially frozen over, and at plaees what the explorers deseribe as something like "mineral tar" was to be seen oozing out of the banks, whieh, eoupled with the diseovery of aneient beds in the valley of Rhât and of Devonian beds older than those of the oil-bearing strata, lend hope to the ehanee of petroleum being yet "struek" in this otherwise resoureeless land. The natron (elatroun or oksem of the natives) is, however, so abundant that the lakes yielding it-the Bahar-et-Troumia, to the north-west of Murzuk-are depleted to the extent of some sixteen to twenty hundredweight every year, and the sands are daily eneroaehing on the water-surfaee. Supplies are still obtained from the same souree for the use of the Touaregs, who mix it with their tobaeeo and employ it as a mordant in dyeing, while, like every other substance with which they are aequainted, it is supposed to possess eertain medieinal qualities. The lakes (p. 245) are surrounded by a fringe of stunted trees that give a eheerful appearanee to the little tarns. in the eyes of travellers emerging from the dreary region of sand-dunes and stony wastes. around, though at the time of the visit deseribed the only inhabitant of the valley was an old Fezzanzee who superintended the eolleetion of the natron and another very

+ The natron is in reality an impure sesquicarbonate of soda, which always contains sulphate of soda and chloride (muriate) of sodium. 
peculiar product of the region. This is the "worm" found in the lakes, which is in great favour as an article of food among the Fezzanees. It swarms in enormous quantity, each being about the size of a grain of rice, and enclosed in a great quantity of glutinous matter, mixed with a minute species of alga-the "danga" of the Arabs-which is also preserved as a condiment. Of the "worms" there are two varieties-the reddish brown (the "duda" proper) and the "tâkerukta" (a brownish-yellow form that is less esteemed).

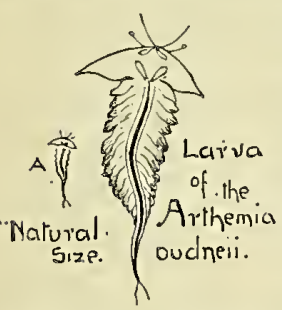

Both are, however, the larva of a species of fly, the Arthemice oudneii of M. Bocourt, who gave it this name many years later in honour of $\mathrm{Dr}$. Oudney. The lakes, at the period of the wheat and date harvests, are swept with handnets for the larva. They are then either' dried in the sun by themselves, or more frequently pounded with salt in a mortar, until they form a black paste, which is made into balls of about double the size of the fist and then dried. This paste is called "duweïdah," or wormlet. It tastes like bad caviare, and to the nose of a European has a very offensive smell. The balls are generally stored in silos, or "matamoras," and sold all through Fezzan, where they are either eaten alone or in the shape of soup, but more frequently are used for preparing a sauce to flavour the solnewhat insipid vegetable diet of the greater part of the population.* Wide, gravelly valleys full of gum acacias and enclosed by parallel ranges of sandstone and clayey hills led the travellers to Bukra, with its "Father of the Fort," a conical mound that was hopped over by the whole caravan to see who was least tired. In the Wâdy Sardalis there are ruins of an ancient Moorish building, the "hiding-place of treasurc and the haunt of ghosts," as, in the opinion of the African, all old ruins are, while the sandy cliffs, worn into the appearance of battlements,

\footnotetext{
* Duveyrier : "Les Touareg du Nord" (1864), p. 244.
}

pinnacles, towers, spires, and minarets are, according to the legends of the muffled Touareg, who passes them in haste on his swift camel, the home of demons, the loftiest being known as the especial "Kas! junuin," or the "Devil's Castle."

The Touaregs are proverbially a grave race, and the Ghatees, whose town they duly reached in charge of their guide, who was a native of it, are so eminently sober a people that the travellers were anxiously warned not to sing or giggle, or in any way play the merry man. Ghat is, moreover, a clean, wellwatered town of a thousand people; and what is most remarkable, the handsome women of the place-for the Touaregs are not negroes, or even Arabs, but members of the still fairer Berber stock-enjoy an amount of freedom unknown in most other parts of Moslem Africa.

On their return journey the travellers passed through Tesauwah and Jermah, the two most celebrated towns in Fezzan-for the latter was the ancient capital of the Roman Phazania, though the travellers seemed to have no idea that Fezzan was known to the ancients, in spite of the fact that the remains of a Roman sepulchre were seen near the lastnamed town, and both of them are mentioned by Edrisi, who wrote in the twelfth century.

The condition of Clapperton and Oudney when Denhain returned to Murzuk made it imperative that no time be lost in The expedisetting out for a healthier region. tion sets out With ant from a hearzuk: With an energy unusual with these the miseries dilatory folk, the escort and the of the desert. caravan was got into marching order, and to the number of 300, Europeans, Arab irregular cavalry, and merchants, set forth on the joulney, though in reality both Oudney and Hillman were too ill to bear the hardships of travel. Scarcely were the walls of Murzuk and the date-groves around it out of sight than the merciless desert, with its burning heat and drifting sands, lay before them. Here and there they came upon a little green oasis, where a spring imparted verdure to the hollow into which its waters ran, or 
where the rain showers did not sink so rapidly into the thirsty soil. But billowy sands or stony "hammada" were the prevailing fcatures of the country traversed, and the whitened skelctons of man and beast that marked the pathway indicated, with grave suggestiveness, the miseries that had overtaken their predecessors and might overtake then also. In one day they counted one hundred and seven poor outlines of humanity,

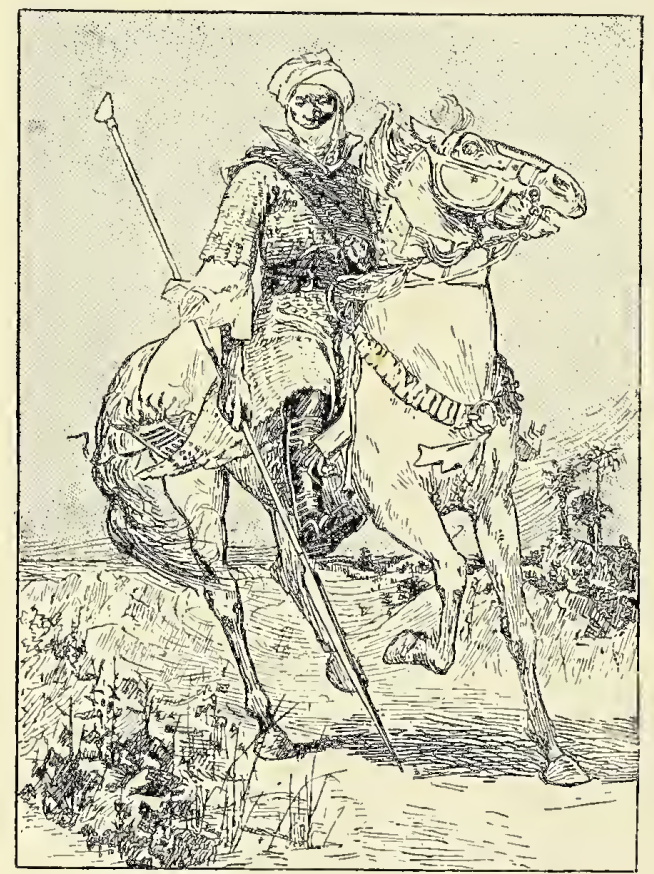

MAIL-CLAD WARRIOR FROM BORNU $(p, 250)$.

and at one well a hundred were found-the remains of slaves too exhausted to keep up with the "coffle," or of caravans that had been overwhelmed by sand-clouds just when they reached the dried-up spring.

As thcy passed southwards the wells grew scarcer, the date-trees and oases fewcr, until the wandering Tibbus and Touaregs, who prefer to pick up a precarious livelihood by plunder or nnore peaccful pursuits, became fewer and fower; and even the wild beasts, who share with them the little the land produces, vanished before the vast expanse of yellow sand beneath the rainless sky. For days at a stretch scarcely a scrap of vegetation could be seen, and the hot winds that blew across the waterless waste scorched where the pitiless sun had failed to reach. The travellers were too miserable to speak. Their tongues clave to the roofs of their mouths. Even the camels ceased their monotonous moan, that patient but ill-conditioned beast feeling, like his master, the idleness of complaining over what could not be remedied. To push on was the only alternative, in a silence broken only by the crunching of a hoof over the bleached skeletons in the path, or the flop-flop of the beasts of burden on the soft sand or the still more painful stonestrewn "hammada." A time cane when even the camels gave in, twenty or more sinking exhausted in the course of a few hours, while the welcome night, with its starlit sky and its cool breezes, was not always free from terror. Often, as the travellers sank on the soft sand ready for slecp and rest, the cry of marauders would arouse the drowsy guards; for in this arid region even the passing caravan preys like wolf upon wolf: their very fellow-travellers are regarded as fitting subjects to provide part of the poor livelihood which the robbers manage to wring from a region unfitted for the abode of honest men.

Passing Bilma, across another sandy desert, the year 1823 opened with brighter prospects. For the Sahara - the belt we have seen (p. 35) between the fertile north and the luxuriant region on each side of the equator-had been passed, and the greener Soudan reached. Trees now appeared, then green The soudan patches, and by-and-by they passed is reached. into a land of flocks and herds, tended by Tibbu herdsmen, until, as they advanced, the land far and near assumed an appearnnce unknown even to the semi-civilised country in the vicinity of Tripoli. It was like a park in Europe. Birds twittered in the shady trees, gazelles ambled in front of the caravan, and the hospitable blacks, who brought fresh meat, and milk, and juicy dates to the weary travellers, seemed in keeping with the smiling land. 
which they inhabited, just as the wild Touaregs and the savage Arabs were fitting nomads for the forbidding desert over which the travellers had passed. As misfortunes never come save in battalions, so Fortune is equally larish in her favours, for, amid this plenty, the explorers were gladdened by the sight of what at first they must have mistaken for one of those inviting mirages with which the desert pilgrim is too Iake Tchad. familiar. A sheet of water, studded with islands, its low shores surrounded by reedy marshes and clumps of white water-lilies, among which the hippopotami wallowed, and its surface brightened by the white sails of fishermen, lay before then. This was the fanous Lake Tehad, often heard of by previous travellers, and even described by Leo Africanus and the Arabic geographers, but now for the first time scen of christened men. In many respects, this is

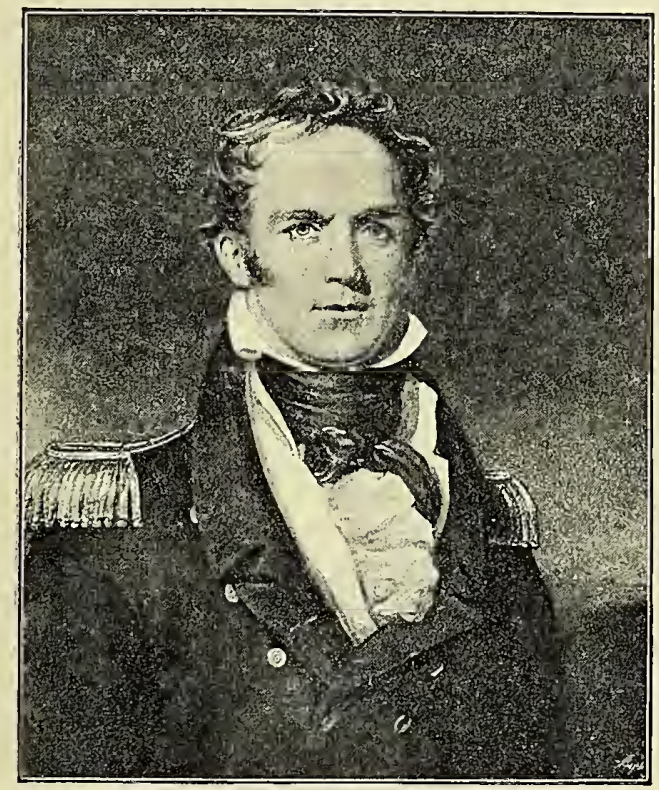

CAPTAIN CLAPPERTON. (From a Print.)

the most remarkable of all the African lakes, for, though its size is smaller than the great inland sea farther east, the basin in which it lies

* Chad. Tsad, Tsâde. is a "self-contuined hydrographical system," eight hundred feet above the Atlantic, situated in the very heart of the continent, in a trough

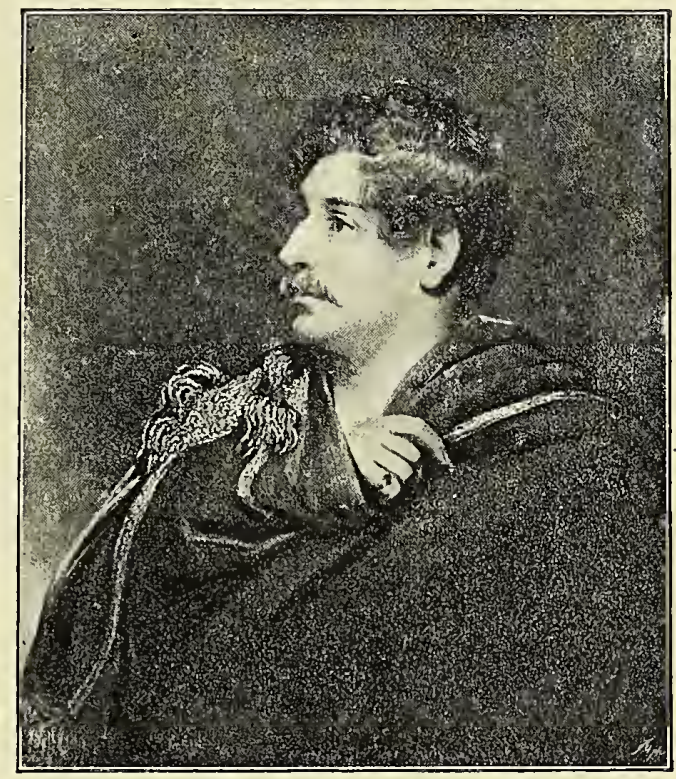

MAJOR DJXON DENHAM. (From a Print.)

between the water-sheds of the Nile, the Congo, and the Niger, with none of which it has any relations, the latest discoveries proving that the Kebbi, the most distant tributary of the Benue, the largest fceder of the latter river, has not, as was at one time believed, any connection with the Tuburi Marsh, or with the feeders of the sheet of water now under consideration. Lake T'chad itself is, indeed, at times little more than a vast marsh-bigger than the island of Sicily - for, while its tributaries, the Shari, the Komadugu Yoobe, and other sinaller streams, fill it during the tropical rains, when the dry season comes its contents sink twenty or thirty feet, and its outlet, the Bahr el Ghazâl, which at the time of grcatest fulness discharges the surplus water north-easterly for three hundred miles into the Bodeli depression, is entirely dry. This enables the contents of Lake Tchad to keep fresh, for, though the Shari is not much shorter than the Rhine, and is the largest river in Africa which does not reach the sea, its flood is, for more than half 
the year, simply evaporated without flowing through the basin.*

Not far from the western side of this remarkable lake-which is to play a considerable part in the future of Africa, The kingdom it being already the point round
of Bornu.

which some international jealousies are beginning to work-is Kuka, the capital of the Mohammedan negro kingdom of Bornu, though for the moment the sight of this realm, also described by the old Arab traveller (p. 243) exeited less interest than the lake; for, at the time when Clapperton and his eompanions sought it, they believed it to be the souree of the Niger, and therefore in a way, the solution of the longeanvasserl problem. But Kuka, nevertheless, is an interesting town, and Bornu, from many points of view, one of the most curious of the Afriean monarchies. Their welcome there was pleasant, eavalry and infantry being drawn up to do them honour, with the usual wild horsemanship which is the farourite display of the Arabs and of the tribes who have picked up the ruchuents of eivilisation from then. But the most remarkable feature of this reception was the fact that many of the Sheik's (p. 248) body-guard of negroes were clad in eoats of mail from the throat to the knees, and that some of them had, in addition, iron helnets and chin-piees, while the horses' heads were also defended by plates of iron, brass, and silver, leaving just roon enough for the eyes of the animal. This armour, so utterly unsuitable for the climate, was doubtless a reeolleetion of what they had seen on the Arab warriors when first they made their aequaintanee many centuries age, sinee it is scarcely likely that it could be an independent invention of their own. After many quibbles over etiquette, and the mode of salutation which the travellers were to aeeord to hin, they were armitted to the presence of the Sheik, and were lodged in huts near the palaee.

* Tachtigal : "Saharâ und Sûdân Eroebnisse sechs. jähriger Reisen in Afrika." (1s81), vol. ii., pp. 347-379. Barth: "Travels in Central Africa" (1857), vol. ii., pp. $148-350$, for the history of Bornu.
The Sheik, with the ignorant self-importanee: of a loeal celebrity, attributed the visit to a desire on the part of the British sovereign to see a man who had won so many victories over the Baghirmis of the neighbouring territory, and as his guests did not think it prudent to ruffle this charaeteristic piece of vanity, eaeh of his courtiers eagerly inquired, "Did he ever hear of me?" Major" Denhan-who was not regarded by his eontemporaries as burdened by many seruplesimagined that his diplomatie reply greatly helped the popularity of the expedition, forgetting that the complaeency of the Sheik, at hearing that he had to divide. his fame-which was, of eolrse, imaginarywith his captains would be so wounded as to neutralise the good effeets of the earlier pieee of invention. However, the Sheik in no way abated any of his politeness, though eager enough to reeeive the traveller's' gifts and greedy of the tales they had to tell of how tights were won in the white nuan's land, and absolutely forgot royal dignity in his astonishment when he heard of "twenty- and thirty-pounders!" Bornu has always been the Central African sovereignty which has. been fondest of pomp and eiremustanee in its sultans, $t$ and what the travellers saw among its motley people-Arabs, Berbers, Fulahs, and negroes of many tribes-surpassed anything for whieh they were prepared. In the very heart of Africa-a continent the borders of which are garrisoned by dense. arrays of savages-were found people who deserved the name of civilised, living in a fine country shut in by the desert whieh they had crossed, with large walled eities, holding weekly markets, at whieh sometimes a hundred thousand people came to sell their. produee for the cotton goods of Manehester, the red eloth of Saxony, double-barrelled guns, raw silk, Sheffield razors, China tea and West Indian sugar, Nuremberg toys, and

$\dagger$ Though the people are mostly negroes of the Kanuri stock, the ruling race is of $A \mathrm{rab}$ descent. The shores and islands of Lake Tchad are inhabited by negro pirates. called Yedina or Budduma, to use their Kanuri name. 
writing-paper bearing the watermarks of Marseilles or of London. The mail-clad warriors, in spite of their black faces, recalled a state of society long vanished from Europe, and were in curious contrast with a culture-limited, it is true, to a few "tolbas," or scholars - which went so far as to study Aristotle and Plato in Arabic translations. These books came for the most part from the Barbary States of the north, and were no doubt copies of versions made centuries ago for the book-loving Moorish kings of Spain. From the same region then as now-for though Bornu is hemmed in by "Spheres of Influence," it is still independent* -cloths, yellow slippers, and Korans beautifully written were exported just as they were in Leo the African's day, and, we may be certain, for centuries before he was born. And such was the influence of Tripoli from a religious point of view; that then-as is still the caseknotty points of the law (and the law in those lands is the letter of the Koran), were often decided on appeal by the Tripolitan Ulemas or doctors learned in the sacred book, the endless traditions, and the thousand commentaries that have been written on them.

Life in Kuka and the Bornuan towns would therefore have been fairly agreeable but for the restlessness of the ragged escort that had been. sent with them from Tripoli. These idle blades were not even nominally under the command of the travellers, and practically were scarcely controlled by their own captain, who in vain joined his remonstrances to those of the Europeans against a proposal now mooted annong them. They were unwilling to return emptyhanded to their homes, and, having no other capital than their long-barrelled muskets, determined to seek fortune in a slave raid or "ghazziah" in the mountains of Mandara to the south of Bornu. Seeing that there was no preventing them and that he might see some new country, Denham, with characteristic courage and a not too delicate

* It is, by latest accounts, rapidly decaying. Kuka, however, has a population of about 60,000 , and Ngornu to the south-east is still more populous and a very important trading centre. sense of the duty he owed to his country, which was then striving by every means to discourage the horrors of the slave trade, resolved to accompany them, and thus by his presence actually countenance the abomination these ruffians were perpetrating. In Mandara the land looked so beautiful that anyone bent on so fiendish an errand as the Arabs were might have relented in the presence of the picturesque dells, clothed with gigantic trees from which a wealth of creepers swung in flowing festoons, and cliff's on which little villages were perched like eagle-nests. But the raiders had miscalculated their strength and that of the Bornu contingent, even when aided by the Sultan of Mandara, to whom the mountaineers were objectionable. For at the very first onset they were outnumbered and repulsed, and managed to reach Kuka in a woeful plight, short of many with whom they set out, and altogether in a condition of demoralisation sorely depressing to the Bornuese, who at the time of Clapperton's visit were in a state of great jubilation over their recovery from the humiliation of the Fulah yoke under the leadership of the Sheik Mohammed el-Amin el-Kânemi, who was now the traveller's host. $\dagger$ The Mandara mountaineers $\ddagger$ belong to the Musgu stock. Several of their villages were burnt. But in return

$\uparrow$ After Bornu had been for two years under the Fulahs the Sultan Ahmed was enabled to regain power by the help of this Faki, fanatic or sheik. Dumama, who succeeded him, was unable to maintain his power, and had again to be reinstated by the aid of the powerful sheik, who as reward received half the revenues of the kingdom. The nominal sultan, however, got jealous of his powerful ally, who was in consequence compelled to dethrone him in favour of his uncle Mohammed. But this roi fainéant proving no more docile than his predecessor, Dumama was reinstated. On the death of the latter in battle with the Baghirmis, Ibraham his brother became titular sultan. This was the sultan at the time of Clapperton's visit, though the real one was the sheik who, deserting Bornu the old capital on the Yoobe, had built Kuka-now called Kukawa-the first town having been destroyed. for the seat of his sovereignty. On the death of the sheik in 1835, Omar, one of his forty-two sons, became sultan in reality, by his rooting out all of the old royal stock or Shuwas. His descendants now govern Bornu.

† "Kerdies," or Pagans, is their generic name. 
many of the Arabs and Bornuese werc slain or captured, and both leaders were severely wounded. Denham himself barely cscaped. In the rout his horse fell, and the encmy

were upon him almost before

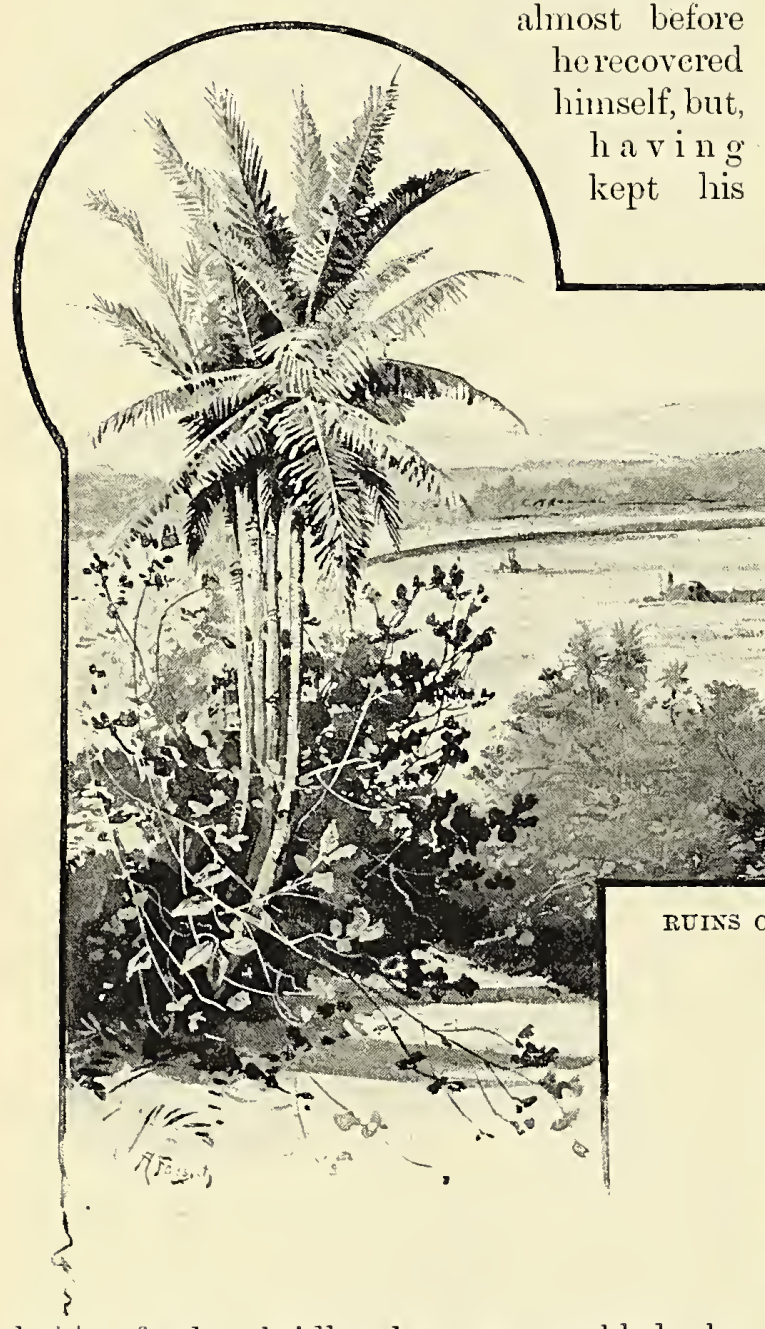

hoid of the bridle, he was enabled, by firing on his adversaries, to again mount. A second fall of the wounded animal, however, cnabled them to surround him. His fate then secmed hopeless, for he was stripped to the skin, and, preparatory to his end being discussed, his captors disputed over his arms and clothes. Taking advantage of their attention being thus distracted, the hapless prisoner crept under the belly of the nearest horse and fled as fast as his legs could carry him in the direction in which he was likely to mect with friends. Having already received several spear-thrusts, his pursters were speedily gaining upon him, and, with the loss of blood from the wounds and the torture caused by the prickly underwood not only obstrueting his way but tearing his flesh miserably, would in all likelihood have been overtaken had not a mountain stream, gliding along at the bottom of a ravine, saved him. "Mly strength," he

tells us, "had almost left me, and I seized the young branch issuing from the stump of a large trce which overhung the ravine, for the purpose of letting myself into the water, as the sides were precipitous, when under my hand, as the branch yielded to the weight of my body, a large 'liffa,' the worst kind of scrpent this country produces, rose from its coil as if in the very act of striking. I was horror-struck, and deprived for a moment of all recollection; the branch slipped from my hand and I tumbled headlong into the water beneath. 'This shock, howcver, revived me, and with three strokes of my arms I reached the opposite bank, which, with difficulty, I crawled up, and then for the first time felt myself safe from my pursuers." The hotly hunted horsemen of his troop were soon scen. Yet even then he might have 


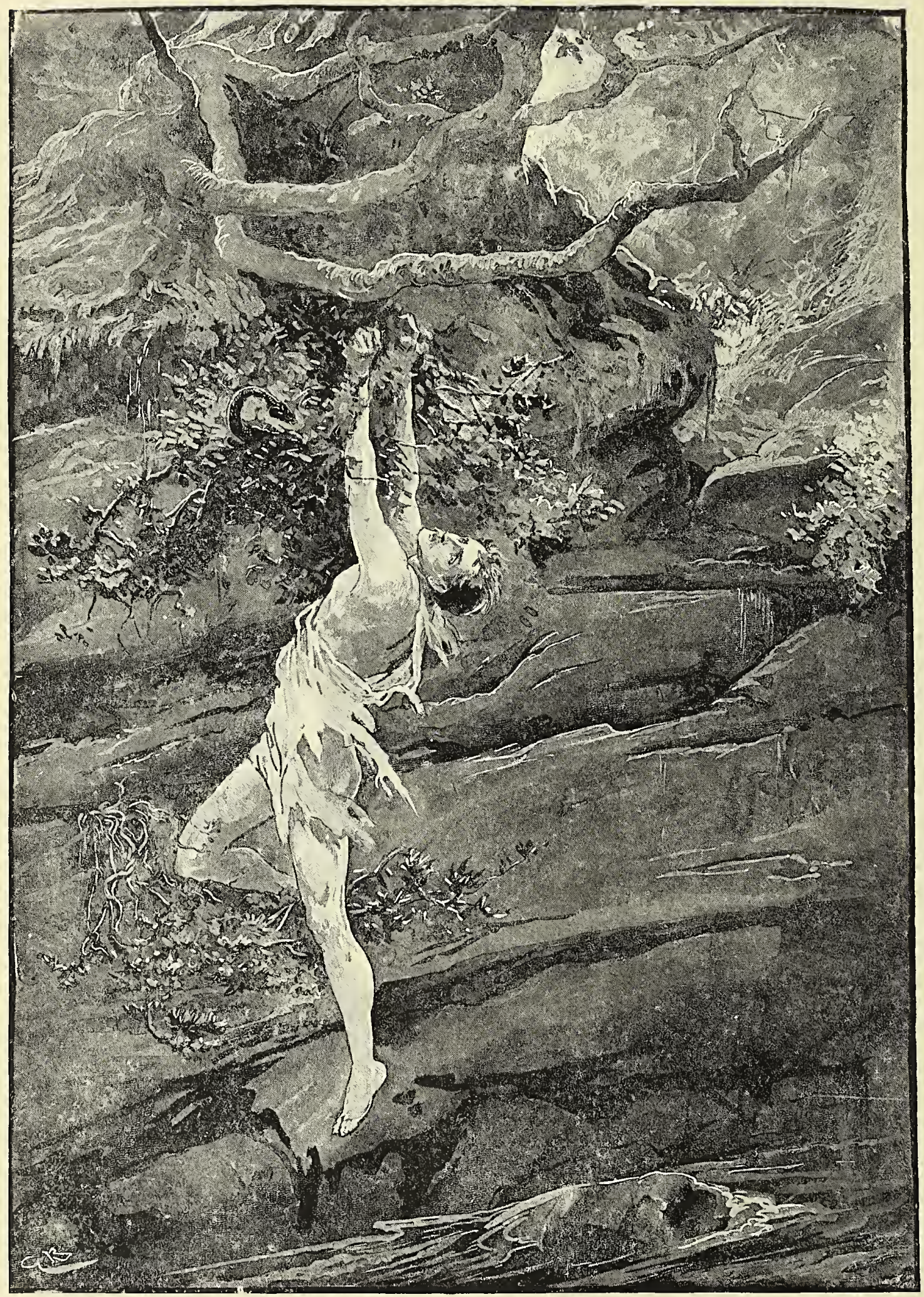


simply fallen into the hands of another Fulah party had not a negro, who had already twice saved his life, mounted him on the crupper of his own horse and galloped off with hint. On regaining the main body of the Arabs and Bornuese, Denham had his nakedness covered with a bournous or hooded cloak. Again, however, he fell from his horse and swooned, and, but for the kindness of the ncgro who had saved him from the Fulahs, would have been left to die (Plate 8).

After this discreditable episode in the history of British exploration-which created a coldness between Kajor Denham and his conlpanions, who, it is known from private information, entirely disapproved of his share in it-the expedition did little for some months. Indeed, it is open to discussion whether from that date the good fortune that had hitherto attended it did not falter. By taking part in a slaving "ghazziah" the white men had not only lowered themselves in the opinion of the natives, who had becn taught to regard the English as the cnemies of such enterprises, and incurred the displeasure of the Shcik, whose advice they had cisregarded, but roused the jealousy of the Fulah Sultan Bello (p. 225) by making' war against his subjects.

The Sheik having left Kuka on a punitive expedition against a rebellious tribe in the West, Denham and Oudney visited Bimi, the former capital, now in ruins, intending to proceed to Kabshari on the Gambaru* River, there to await his return. Travelling through a flat country, thinly strewn with acacias, they came to the river named, flowing between steep banks covered with luxuriant Birni and vegetation and abounding in game, Gambaru. especially guinea-fowl. Birni, $\uparrow$ eren in the few years which had clapsed since it had bcen deserted, was fast falling into decay.

* Also called the Yeu.

$\dagger$ Also called Ghasr-eggomo. It was founded by Ali Ghajideni about the year 1480 . When Barth visited it in 1852 the place was so utterly deserted that forest grew up to the ruined walls, and of the once teeming inhabitants not one remained. A pair of ostriches that lived among the long grass covering the site of the city were the only living things seen (p. 252).
It covered a space of five or six miles and is said to have at one time contained 200,000 inhabitants within its walls of hard red brick. The date at which they were told to expect the Sheik's arrival being still some time distant, the explorcrs visited in the meantime the town of Gambaru, which takes its nanc from the river on which it is situated. This was a favourite residence of the Sheik, and in its almost imposing buildings of brick formed a remarkable architectural contrast to the collections of humble huts that constitute the usual towns of Bornu. Around the walls were pleasant meadows, well cultivated, and on the river a service of boats, which wcre continually passing and repassing to and from the villages on the other sidc of the strcam.

On returning from this expedition the party narrowly cscaped falling into the cnemy's hands. For the rebellious tribe against whom the Sheik was marching had taken advantage of his slow progress to
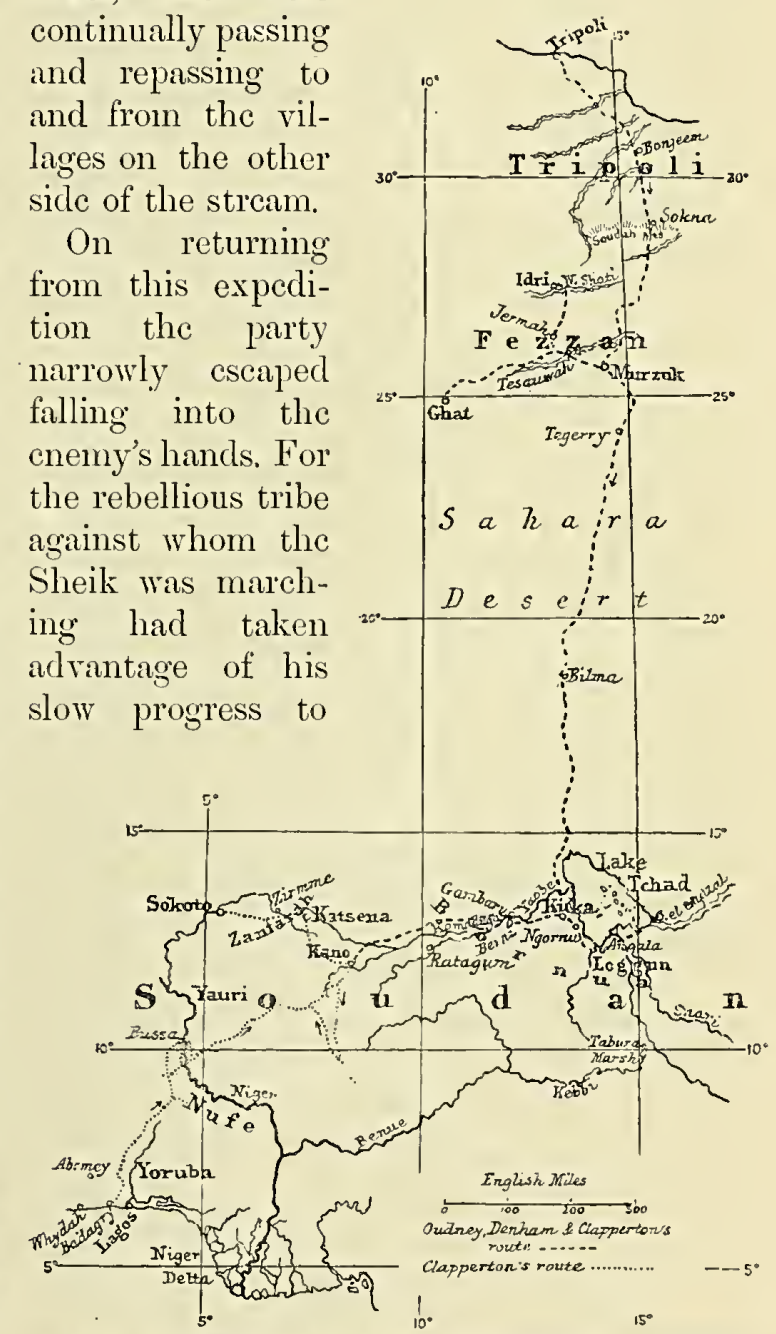

MAP OF OUDXEY, DENHAM, AND CLAPPERTON'S ROUTES. 
advanee and capture Kabshari, and were at one time quite close to them. It was therefore neeessary to make the best of their way back again, and, as the public road was inseeure, they were compelled to effect their retreat through thickets tangled with thorny climbers, and dangerous fiom the numerous pitfalls dug for the purpose of entrapping predatory Touaregs, until, at the Sheik's eamp, they met with a kind reception, and for the first tine since leaving Tripoli heard news from England, by means of a eourier from the eoast.

The rainy season setting in, the explorers were reduced very low. Clapperton and HillA journey man the carpenter were brought to Kano. near to death from repeated attacks of fever, and Dr. Oudney grew daily worse and worse. All their attendants exeept one were ill, and Denham for a time was the only member of the expedition who eould render any assistanee to the others. Dry weather again setting in, Clapperton and Oudney were able, on the 14th of December, 1823, to set oft on a journey to Kano and the Houssa States in the eompany of a trading earavan going in that direetion, leaving Major Denham to reeeive the fresh supplies for the expedition that were daily expeeted and sorely needed.

The journey on whieh they had now entered was in many respeets one of the most important of those that they had yet undertaken. For, by the observations inade upon it, they hoped to put at rest many eonflicting diseussions and reeoncile a host of warring theories. Unfortunately, Dr. Oudney was not destined to see the end of it. Conscious that the end was approaehing, he told the Sheik that, as he eould not live long, it was better that he should be travelling about, as he was never well when under a roof. Any sudden change of temperature brought back all the old fever from which he had suffered during the rainy season. Three days after Christmas the thermometer sank as low as $45^{\circ}$ at sumrise, and the eold at night was so aeute that it was neeessary to light a fire in his tent. By the 10th of January, 1824, he was unable to ride, and a fiame of wood had to be laid on the back of a eamel in order to allow him to be carried in a prostrate condition. Two days later, he died in his tent, near Nurmur, while drinking a cup of eoffee.

Proceeding alone, Clapperton reached Kano, a famous trading eentre of thirty or forty thousand inhabitants-an estimate the city confirmed by Barth, who visited the of Kano. plaee more than thirty years later, and has given the fullest aeeount of it that we possess. It is the great emporium of the Houssas, and is frequented by caravans from a long distance. The bazaar was found well filled with European goods, and among other objeets of interest Captain Clapperton beeame the owner of a green eotton umbrella for three Spanish dollarsor about twelve shillings-this and similar artieles travelling across the desert by way of Ghadames. Here also-let us hope it is so still-British eredit was so sound that several merehants pressed him to take goods to any amount, paying them simply by a bill on the British consul at Tripoli. After reeeiving all manner of hospitality from the gorernor and citizens of Kano, Captain Clapperton proeeeded to Solioto, the eapital of the new Fulah empire, being assured by The city of Bello, the Sultan, at whose in- Sokoto. vitation he came, of the lindest treatment. So far, this magnate redeemed his promise, but when he began to make preparations for a journey to Yauri and Nufé with the intention of trying to solve the worldold mystery of the Niger, the Sultan grew colder and finally refused to permit him to proeeed, exeept at his own peril, and this also finally he forbade, the clanger to his guest being too great.

Bello had heard of Denham's escapade. He had even books found in his baggage captured during the slave raid, and put some awkward questions regarding the business the white man had in the company of the raider's into the Kerdy country. These books, some of them Major Denham's manuscript journals, were, however, returned, and Bello, who is described as a man of great intelligenee and some knowledge, was good enough to declare 
that, though the gifts Clapperton gave him were wonderful, the bearer was the grcatcst curiosity of them all. And of all the things he told him the most amazing were that servants in England were hired for a limited period, and that even the king's soldiers were clothed, fed, and paid. "Allahu Akbar! God is great!" cried the Sultan, "You are a beautiful people!"

Finding it impossible to move the suspicious Sultan from his resolution, after Return waiting sevcral weeks, hoping journey to against hope, Clapperton took his Bornu. departure and returned to Bornu, visiting, on the way back, Zyrmi, the capital of Zanfarah, and Katsena, or Kashna, a city even more celebrated. The former is mentioned by Edrisi; the Arab gcographer of the twelfth century. But when Clapperton visited it-and its fortunes have not improved since his day-it was a small though still important place, noted as an asylum for thieves and vagabonds, while fields and thickets occupied a considerable portion of the area within the walls of Katsena. The Fulah conquest ruined its trade, the caravans going to Kano instead, while its local manufactures, chiefly of leather, were even then growing less and less. But the Touaregs and the merchants from Tuat and Ghadames still congregated there to buy figs, melons, ponegranates and limes, and to let and hire camels for the journey across the Sahara.

Meanwhile, during this absence a welcome supply of stores had arrived at Kuka, in charge of Mr. Toole, a young man who almost alone had traversed the long route from Tripoli to Bornu, proving to a certain extent the Bashaw's boast that the road was as open as from London to Edinburgh (p. 245). In his company Denham made an excursion to the southern and eastern shores of Lake Tchad, and Logón and to Logón on the Shari River, which Lake Tchad. discharges its waters by many mouths into the lake. Logón is a populous country, inhabited by an industrious and partially civilised race, possessing a inetallic currency, in the shape of thin plates of iron not unlike the tips with which racehorses are shod. It is not considered ctiquette to speak out; hence there is always a difficulty in catching the sound of a well-brcd gentlcman's voice. But besides the metallic currency -about three hundrcd pieces of which are equal in value to a dollar-Logón has another of the luxuries of civilisation in the shape of Stock Exchange gamblers. Every Wednesclay the value of the "circulating medium" is settled by proclamation, and speculations are nade by Bulls and Bears in anticipation of its rise and fall. It may be remarked that when the Sultan is a buyer the currency is usually announced to be high, but when his taxes are due it seems suddenly to fall below par.

An invasion of the Baghirmis forced the explorers to hasten back to Kuka. But before being able to reach that city, Mr. Toole, worn out with his exertions and the want of proper medical aid, sank and died on the 26th of February, 1824, at Angala, near the southern extrcinity of the lake. This was the last of the explorations made by this important expcdition; for in a fow days Clapperton returncd, and then, on the 16th of August, the survivors took up their return march to Tripoli, which they Return to entered on the 26th of January, Tripoli. 1825, after completing what was in somc respects the most important journey since Mungo Park's day, if, indeed, it did not surpass, both in extent and in the amount of fresh information it brought back, that famous adventurer's raid into the unknown.

Many travellers have since that day started from and returned to this old crumbling Barbary town that we have so frcquently mentioned. It is, nevertheless, perhaps more difficult at the present tine to complete the journeys which they made than it was in 1824, religious fanaticism and political jealousies-not to mention the injudicious acts of European travellers-having made the Sahara and the lands beyond it less friendly to "Christians" than they were ir more placid times. 


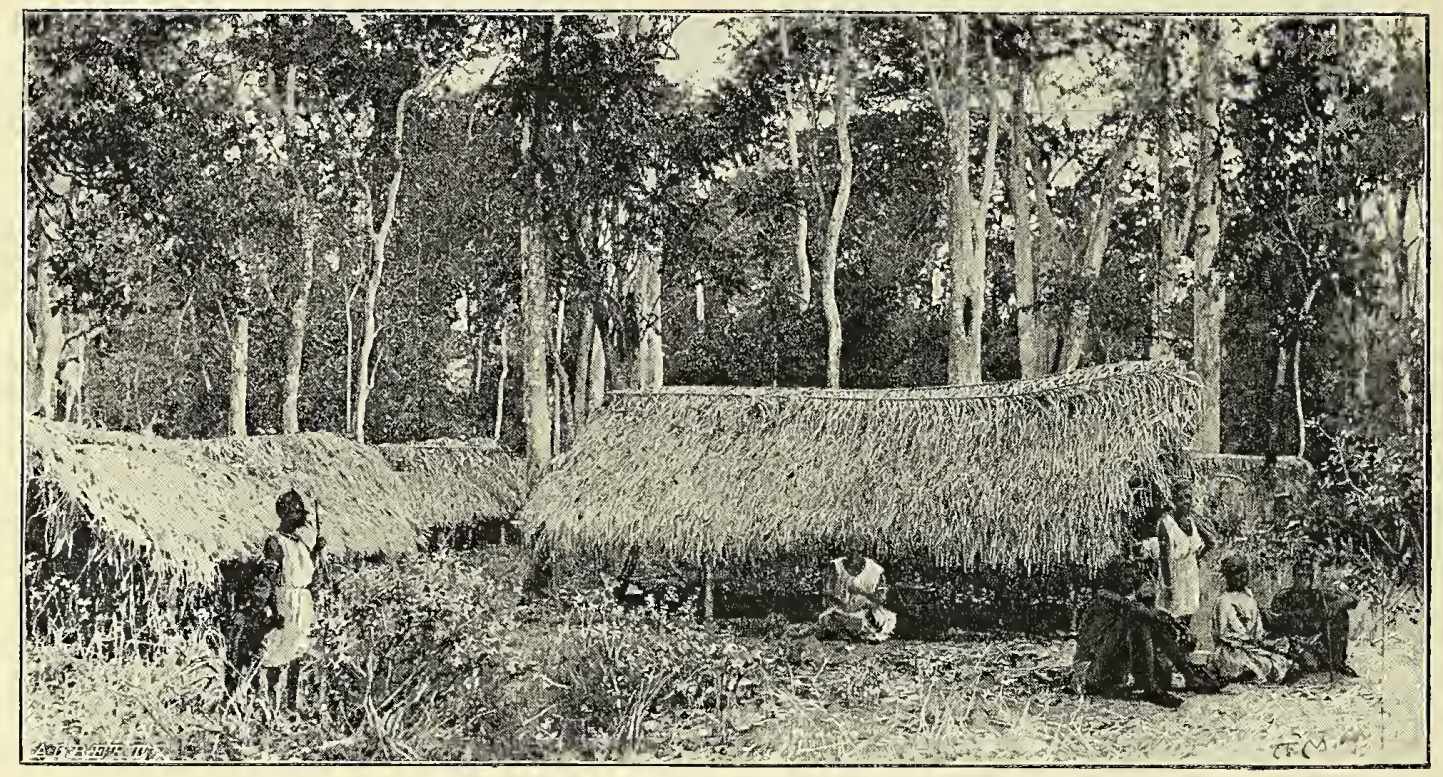

GRASS-ROOFED SLEEPING SHEDS IN MAMU FOREST, YORUBA, WEST AFRICA.

(From a Pholograph by liev. J. T. F. Halligey.)

\section{CHAPTER XIV.}

\section{The Niger Mouth: The End of a Long Story.}

Clapperton's Second Expedition-Start from Badagry-Death of Dr. Dickson-Return of Mr. James and Death at Whydah-Return and Death of Dr. Morrison-Death of Captain Pearce-The Yoruba Country-The Blandishments of the Widow Zuma-Bussa and Park's Death-Sokoto and the Sultan Bello-Death of Clapperton-Richard Lander, his Servant, makes his way to the Coast with the Stores and Records of the Expedition-The Amenities of Badagry and the Portuguese Slave Dealers-Lander is Tried by OrdealReturns to England-Second Expedition of Richard and John Lander-Richard Lander's History-The Niger Theories-Reichard's and MeQueen's Views-Reaeh Bussa-Descent of the River-A Rude ReceptionBlack Brigands and a White Ruffan-The End of an Old Story and the Beginning of a New one-The Death of Richard Lander and the Dawning of Niger Commerce.

Major Denham * and William Hillman the carpenter figure no morc in African exploration. Captain Clapperton, however, was destined to meet a more tragic end. Nettled that he should have been within five days' journey of the Niger and yet have failed to see it, he had scarcely rested from his toil in England than he determined to return and complete that part of his journey out of which the stubbornness of Bello had cheated him. He found the British Government in no way disinclined to listen to his proposals. Bello had sent the most flattering compliments to

* Denham received the customary reward of the officeseeking explorer. He was appointed Superintendent of Fernando Po, then held by the British, and there he died in 1830 . the King, with an expression of his eagerness to open up a commercial intercourse with the British traders on the West Coast, which, were it accomplished, seemed certain to end by solving the Niger problem.

Clapperton, now raised to the rank of Commander-he had been no higher than Lieutenant previously - was accordingly selected for the head of another expedition. Captain Pcarce, of the Royal Navy, was appointed second in command, and conjoined with him were Dr. Morrison, a Naval surgeon, and Dr. Dickson, a Scotsman, who had for many years practised medicine in the West Indies, while Richard Lander, a young Cornishman-who in a few ycars was to surpass all of 
them in reputation, and to die even more tragically-accompanied Captain Clapperton as his personal servant.

Sailing in August, 1825-two months after the former expedition had reached England, and while the debilitating effects of the African climate had not worn off--the Bight o: Benin was chosen as the most suitable spot in which to break new ground, under the belief, now growing into a certainty, that the Niger flowed into the Atlantic somewhere in the vicinity of the Gulf of Guinea. Badagry, a startfor few miles to the west of what is Badagry. now the British colonial town of Lagos, was the point from which they took their departure, intending to reach Sokoto; and then, after paying their respects to Bello, to return to the Niger and descend that river to its termination. Dr. Dickson had previously been lander at Whydah, on the Dahomey coast, with the intention of penetrating north to Jenné. Reaching Abomey, the capital, he was furnished by the negro king with an escort of one hundred inen as far as Shar, where the Dahomeran monarch's authority ended. Ferer had, however, already attacked him, and, it is feared, the irritating effects of the heat were not favourable to the temper of a man who had been accustomed to regard negroes simply as slaves, and not, as were those now with him, free warriors, masters of their own country. At all events, after going two days' journey from Shar, a serious misunderstanding, which has never been explained, led to his life being threatened by the chief of the escort. This so violently exasperated Dickson that he attempted to throttle the man, who, calling his followers to his assistance, fell Death and upon the unfortunate white and disease. killed him. Mr. James, an English trader from Whydah, who had accompanied him part of the way, lived to return to that place, where, after a few days, he died of dysentery, though there were long suspicions that he had been quietly put out of the way by old Antonio Da Souza, then at the height of his prosperity as a slave-merchant (p. 75), and naturally ill-disposed to British expeditions the avowed object of which was to stop the lucrative branch of commerce in which he was engaged.

Clapperton's party were scarcely more successful: for scarcely had they left the coast before the deadly climate of that portion of Africa began to claim its victims. After sleeping for a night in the open air, they were all attacked by malarious fever, which so weakened them that Morrison had to return, only to die on his way to the coast; and

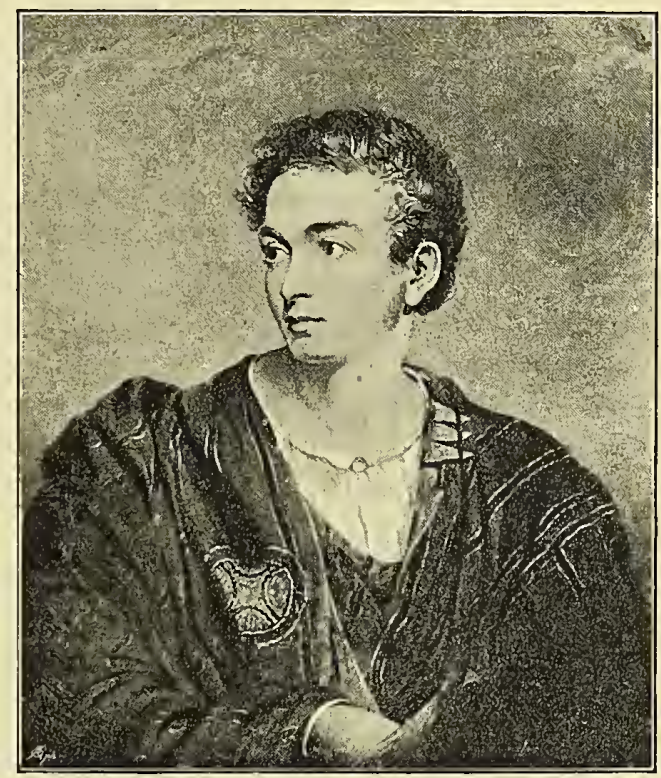

RICHARD LANDER. (From a Print.)

though Pearce struggled on, he too soon dropped by the way. Clapperton was now alone, except for the company of his intelligent servant, whose light-heartedness and devotion to his master relieved many of the sad hours that were to follow. In the populous and fertile Yoruba country they were beyond the sickly belt that encircles so much of Africa.. Here their main troubles were the anxiety of the king to keep the white men in his capital and the somewhat obtrusive attentions of a wealthy widow-fat, close on forty, but not fair-who, after in vain trying 
to induce the master to share her riches, enThe Yoruba deavoured, with no better success, country. to win the love of the man. Zuma, the lady in question, was the widow of an Arab in "the city of Wow Wow," and had been left so well off by her late lord that a thousand slares owned her as their mistress, and she had treasures besides that enabled her to live in regal splendour. She had, even before the white men's arrival, aspired to the throne by heading an armed rcbellion of her vassals, though, possibly owing to her charms-excessive corpulence being amongst the Arabs the criterion of beauty - the lady was pardoned after a couple of days' imprisonment. Yoruba is still very isolated, its traffic being not so much with the coast as with the caravans through the desert, the "tarbooshes" or red-caps of Vienna, transported no less than two thousand miles across the Sahara, finding still-as they did when Rohlfs visited Ilorin in 1867-a regular market in places not over 150 miles from the Bight of Benin. Climatc alone-as Mr. Millson remarks -and the "African colle of ethics, "so to deal with other's as thou wouldst thyself hope to avoid being dealt by," do not alone suffice to prevent the entrance of European commerce from the Atlantic; though since the British have been at Lagos, and the Niger has, through a long stretch of its lower waters, become an English river, this state of matters is likely to becomc every year less and less marked. The Dahomey war raids on the outlying towns of Yoruba, and the ceaseless "jchad" of the Mohammedan tribes on the north, paralyse the natural commercial instinct of the inhabitants and close the trade routes every now and again. But now, as in Clapperton's day, the Torubas are a race of farmcrs, in a finely cultivated country, where game is scarcc and meat and milk are comparative luxuries; and as the oil-palm does not flourish at more than 100 or 150 miles from the coast, the business that supplanted the slave tradc is not lucrative in the inland kingdom. The scarcity of milk is exemplificd in a curious custom. Children not being easily reared on the produce of their father's farm, the mother retires for two or three years to her parents' home, occupies the room in which she dwelt as a maiden, and derotes herself entirely to her child, and in many cases ceases to be maintained by her husband, who meanwhile goes on marrying and attending to the cultivation of the soil. The result of the system is, howcver, a demand for more women than the country can supply, and consequently a succession of inter-tribal raids, undertaken for the purpose of obtaining wives to replace those who arc scattered over the kingdom engaged in nursing their families of one. In those days Yoruba was pretty much what it is still. Then, as now, in that part of West. Africa, the sloping terraccs and rocky ranges that buttress up the great plateau of Central Africa for some eighty or a hundred miles inland from the Guinea Coast were, for the most part, the homes of fetish-worshipping negro pagans, who, by the aid of muskets bought from the Europeans and the rugged nature of their country, keep at bay the Mohammedan cavalry of the Soudan. Tet even they are yielding to the pressure from the North, and of late to the insidious cfforts of the followers of the Senoussia, that fanatical sect of the desert who have settled in their midst in the guise of peaceful inerchants or travelling charm-sellers. The coast tribes-thosc settled in the broken country within a hundred miles of the shores of the Gulf of Guinea, from the Scarcies River to the mouth of the Nigernumber about $12.000,000$, divided by racial and inter-tribal slave wars into almost innumerable septs ; those at a distance from the ports arc kept from trading to the sea by their brcthren who have the arlvantage of position, and they arc at the same time subjected to a steady pressurc of conquest from the North. The fertility of their land and their rapidity of increasc alonc save them from destruction.* The ancient kingdom of Toruba, through which Clapperton and his luumble friend

* Millson, Proceedings of the Royal Gengrapleicat Society, 1891, pp. 578, 579; Moloney, Ibid., 1890, pp. $596-614$. 
passed towards the Niger, was one of thosc great tribal divisions (pp. 256, 260, 261).

Rumours of war compelled them to deviate from their intended route to Nupé, and so, by

Bussa and

Park's

his companions were lilled. Instead, however, of being received with unfriendliness, or even suspicion, the people and their chiefs vied with each other in showing them kindness. The Sultan of Tauri, hearing of their advance, sent seven canoes laden with provisions for their acceptance, and a request that they would visit his capital. On the subject of Park's death they were, however, very reticent, seeming to be ashamed of the part they or their companions had taken in it, trying, of course, to shift the blame from themselves to some other tribc or people, so that it is very doubtful whether the story they told is to be accepted as even approxinately true. They declared that Park and his companions were mistaken for Fulahs, whose conquering raids were just then arousing fear all ovcr that region. If the account given to Barth (p. 218) was correct, this is not improbable, though in all essential particulars they substantiated the account given by Amadi Fatuma (p. 217): yct the fact that two of the slaves who survived the massacre wcre then at Bussa, but werc carcfully kcpt from communicating with the travellers, scarcely contirmed the favourable impression this story was intended to convey. One scquel the people addled to what was already known of the tragedy which is sufficiently striking. After Park's vessel had been pillaged and the floating property recovered by the Bussa people, there was for days and nights nothing but feasting and rejoicing. But surdenly, in the midst of these revels, a strange infectious disease broke out in the city, and spread with such virulence that the Sultan and many of his subjects perished, and it was noticed that those who had been most active in the destruction of the strangers were cut off to a man-all of them cxpiring in great agony. Naturally it was concluded that this was the vengeance of the white man's god. As such it was considered by all the neighbouring tribcs, and the Bussa people, from that day until the period of which we speak, were everywhere stigmatised as an accursed race who had been guilty of a crime heinous in the eyes of Heaven. "Do not hurt white men," had become a maxim among the Niger folk; "for if you do, you will perish like the people of Bussa!"

From Bussa, the travellers' route lay across Nupé and the Houssa States to Kano and Sokoto, where they naturally expceted to meet with a kindly reception from Clapperton's old friend Sultan Bello. At Sokoto, however, they had arrived just when the Bornuesc and the Fulahs had gone to war, and it seemcd as if the empire founded by Bcllo's father wcre on the eve of disruption. These troubles in no way inclined the suspicious Sultan to his new visitors, or rolieved his

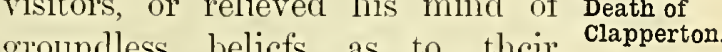
motives in entering the comtry. Irritated over the daily rebuff's he met, and disappointed at finding it impossible to obtain permission to do anything, Clapperton, who for long had been far from robust, now broke down entircly, and on the 13th of April, 1827, weakened by repeated fevers, died in the arms of his faithful scrvant. Knowing how readily poison is employed in those regions to remove inconvenient persons-arsenic among the Hoors is quite an instrument of diplomacy-it was believed in England that Bello had compassed Clapperton's death. But there is no longer any reason for holding this opinion.

Lander was now the last white man of the expedition lcft. His duty donc, he had to make the best of his way home with the papcrs and other property of the expedition. But, anxious to try to carry out the object of his master's mission, he determined, instead of taking the route across the rlesert, as Bello advised him, and indecd as Clapperton when dying thought would be safest for him, to try 
to trace the Niger from Fundah to the sea. In this, however, he failed. The rainy season lad set in and travel was difficult. Bello, moreover, displayed no anxiety to help him. Indeed, he found it hard to get away from Sokoto without being stripped of all the property of the expedition. However, in due time he reached Kano (p. 264), whence he started southwards to reach the Niger, which he believed flowed in that direction.

Being, however, disappointed in this search, sometimes indeed "howling so dreadfully" at secing him that the horse on which he rode trembled with fear. But this

was only their way of congratulat- amenities of ing the traveller on his safe return.

At Wow Wow he expected to renew his friendship with the widow Zuma. But to keep both of them out of harm's way to him, Sultan Mohammed had imprisoned the lady whose ambition in life was to marry a white man. Every day, however, she sent a slave

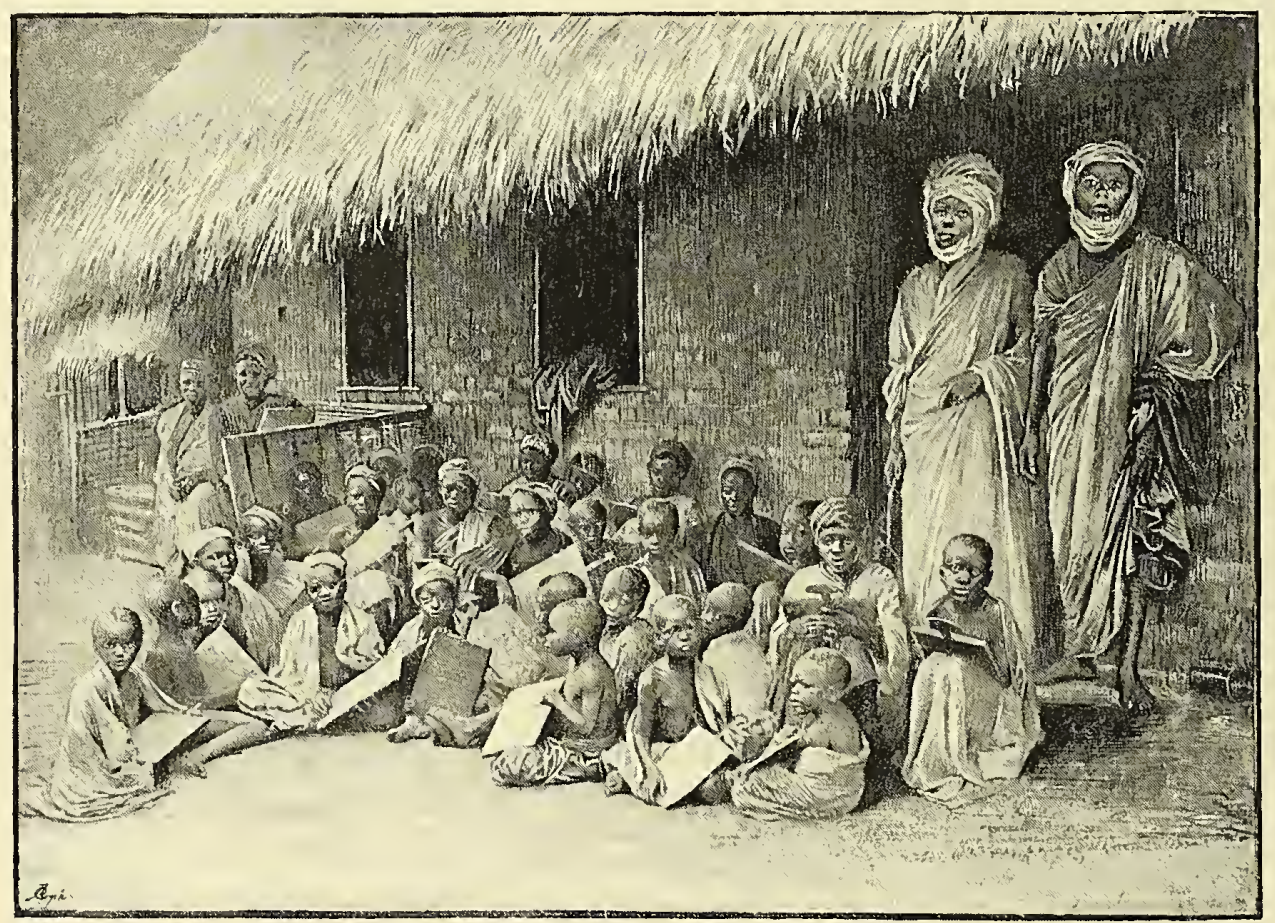

MOHAMMEDAN SCHOOL, YORUBA.

(Fron a Photograph by the Rev. J. T. F. Halligey.)

he returned to Kano, and thence made his way back to Badagry by much the same route that he and Clapperton had followed the ycar before, arriving there on the 21st of November, 1827. "The Little Christian," as Lander from his dininutive stature was called, abounded in tact and good-nature, and made friends at all points. Throughout the route to the coast he was received with kindness, the people everywhere welcoming him back with vociferous expressions of pleasure, with gifts for Lander, and every evening the messenger sang songs in her honour. The traveller was naturally gratified at these testimonies of esteem from so wealthy a clame. But his self-complacence was a little hurt by being overtaken on his road by the slave, who, in the name of her mistress, begged that, since it was not possible to wed the white man who had just left, he would send some other one-anyone-willing to become her spouse and to dethrone the villainous 
old Sultan who had treated her so despitefully.

At Badagry the native king vacated his twostorey bamboo hut in order to accommodate him. But here ended the civilities to which Lander was becoming accustomed: for the Portuguese in the place, jealous of the
Calling one day on a slave-merchant-and the incident may be related as a type of the treatment he received-he found the dealer in human flesh at breakfast. Wheaten rolls, tea, and sugar were bcfore him, all luxuries that for many months had been strangers to his visitor, who, forgetting good manners

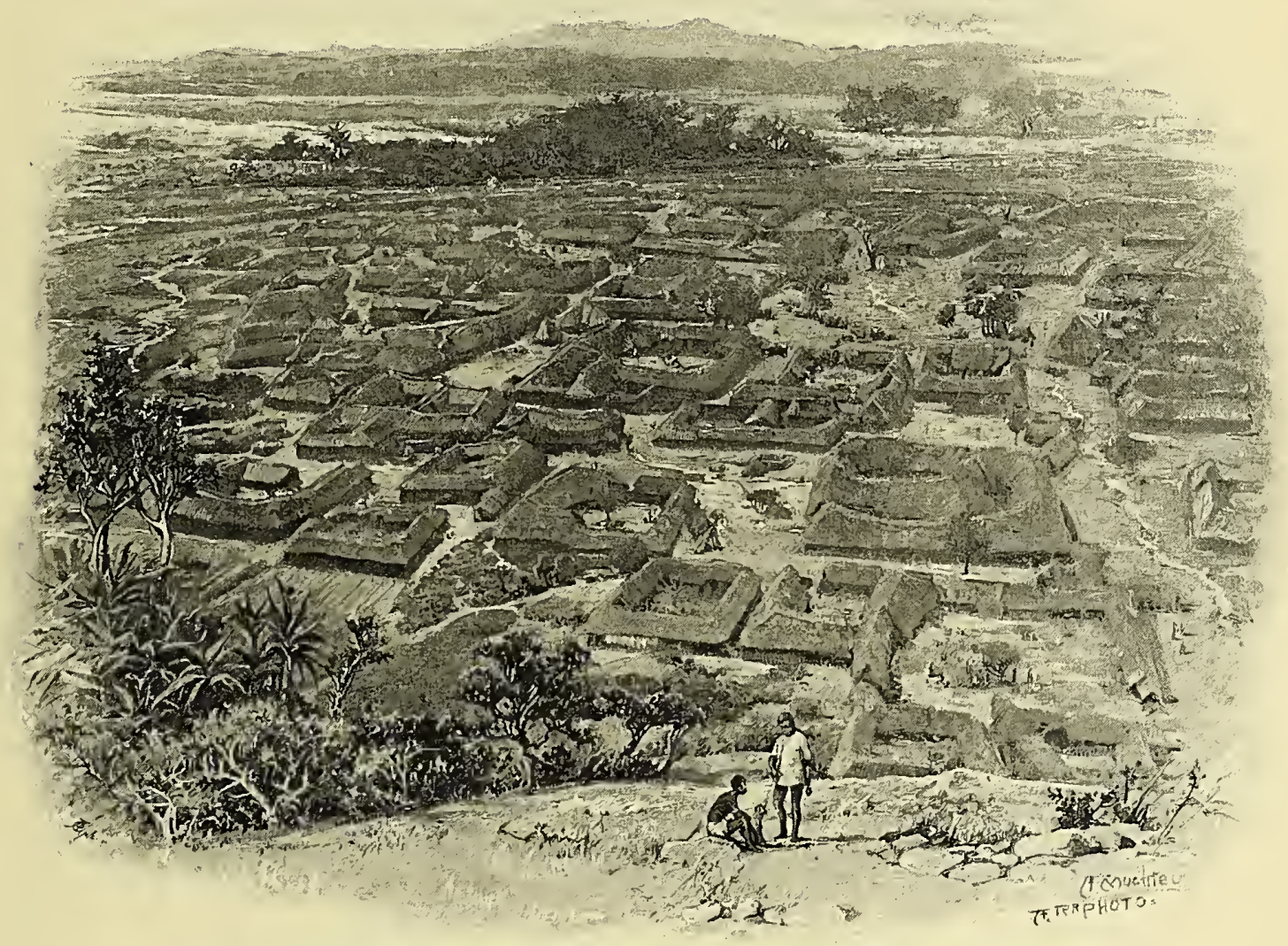

VIEW OF ESE ADO, YORUBA: TAKEN FROM A ROCK 350 FEET ABOVE THE TOWN.

(From a Photograph by the Rev. J. T. F. Halligey.)

British, who were now making the slave trade, by which everybody in Badagry lived, more and more difficult, treated the explorer with the scantest of courtesy. They tried indeed to persuade the king and his people that it would be necessary to kill Lander, asserting that he was a spy sent by the British Government and, if suffered to leave the town, would return with numbers of his countrymen and enslave its inhabitants. in the sharpness of his appetite, proceeded to help himself without being formally invited. The retort he reccived, howcver, effectually cured him of any further longing after the good things before him. "Senhor Englishman," was the stern reproof, "stay your hand for a moment, if you please. You have three fine slaves in your possession, for each of whom I will immediately pay you one hundred dollars, and also send you as many 
wheaten eakes as will serve you for a twelvemonth. But, unless you consent to this proposal, you will have neither rolls nor tea of mine, I assure you!" Unable to stay his hunger at the expense of the poor blaeks who had been the faithful eompanions of his pilgrimage, the indignant Briton bestowed on the Portuguese the most contemptuous epithets in his voeabulary, and, repairing to his own hut, broke his fast in the contentment engendered by duty done on a little boiled maize meal mixed with palm-oil. Still detcrmined to see whether Lander could not be indueed to part with the negroes, the Portuguese tradcr, affceting to regard the previous reneontre as a piece of "English phlegni," sent him a loaf of brear, a cheesc, and a bottle of English porter, articles which he had dreamt of in the interior, but never expected to partake of in Afriea. Finding, neverthcless, that the Briton was not to be persuaded to violate at onee the laws of his eountry and the dictates of his conseience, the rabble of Portuguese in this vile spot, now a town of some 13,000 people on the Lagos Lagoon, and part of the British Colony of that name, tried to ineite the fears of the native sovereign-for in those days the place was independent, the Portuguese being there solely on sufferanec-with a view to compassing his destruction. He was aecused of plotting against the king, and compclled to elear himself by the ordeal of drinking "bitter water," his innocence or guilt being indieated by the fact of whether he reeovered from the effect of the draught or, as usually happens, died under the poison. By good luek, either through the strength of his eonstitution, the eomnivance of the fetishmen, or some nore oeeult rcason, the traveller left the fetish-house nothing the worse, with the result that, in the revulsion of feeling in his favour, he, who a few hours before was accused of high crimes and mistemeanours, was now regarded as something not mueh less than a god, to whom gifts of every sort were to be offered, and favours of every deseription were duc.
Of the many forms of "trial by ordeal"which is one of the oldest and most widespread of judieial superstitions-perhaps Trial by the most characteristic is that just ordeal. indieated. It is peculiar to West Africa, and prevails to the most marked extent on the Guinea Coast. The so-ealled "red water" is a decoction of the inner bark of one of the mimosas, which, when taken in suffieient quantity, is emetic. If, on the contrary, the person condemmed to drink it gets dizzy, he is coneluded to be guilty, pelted with stoncs, and cven dragged over the roeks until he is dead. The Calabar bean (p. 275), the mbundu root, and the tanghinia nut (p. 263) are still more virulent, and, as the fetish-man who prepares them has it in his power to make the ordeal-drink strong or weak, emctic or dcadly, this individual is believed to make the most of his quasi-official position. Perhaps, when Socrates was ordered to drink the hemlock juice he was mercly submitting to one of the requirements of the ancient trial by ordeal ?

But this "proof" of Lander's innoecnce, though it acquitted him in the cyes of the natives, did not secure him favour from the Portuguese. They still reviled him and even tricd to murder him, a villainy not diffieult to perpetrate in a town where there was no law save that of the savage king, whose ideas of the sanetity of life may be gathered from this faet which the traveller witnessed during his enforced stay in this typical Guinea village. One morning he was woke up by unearthly shrieks close to the royal "palaee" in which he liver. Looking out, he found that the cries proeeeded from eight women, wives of the king, who were bcing dragged off to execution for the crime of having spoken their minds too freely to their lord, only an hour before. A few moments later their throats were cut-a mark of distinction aecorded only to the king's favourites - and next morning their bodies were secn hanging to the fetish-trec outside the village. Murder in this place was scarcely eonsidered a crimethe killing of a slave not even a misdemeanour. 


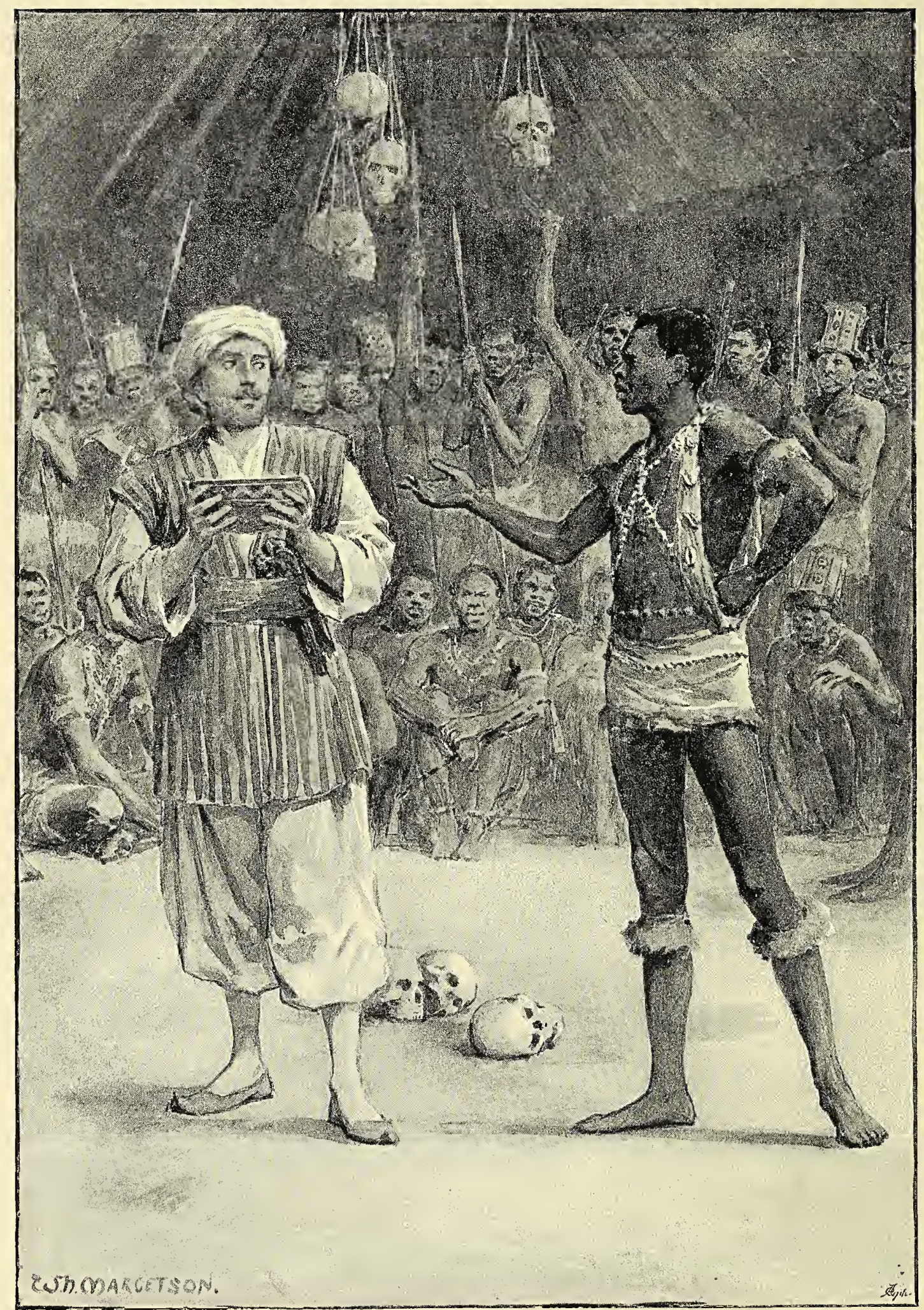

IANDER UNDER "TRIAL BY ORDEAL" (p. 262). 


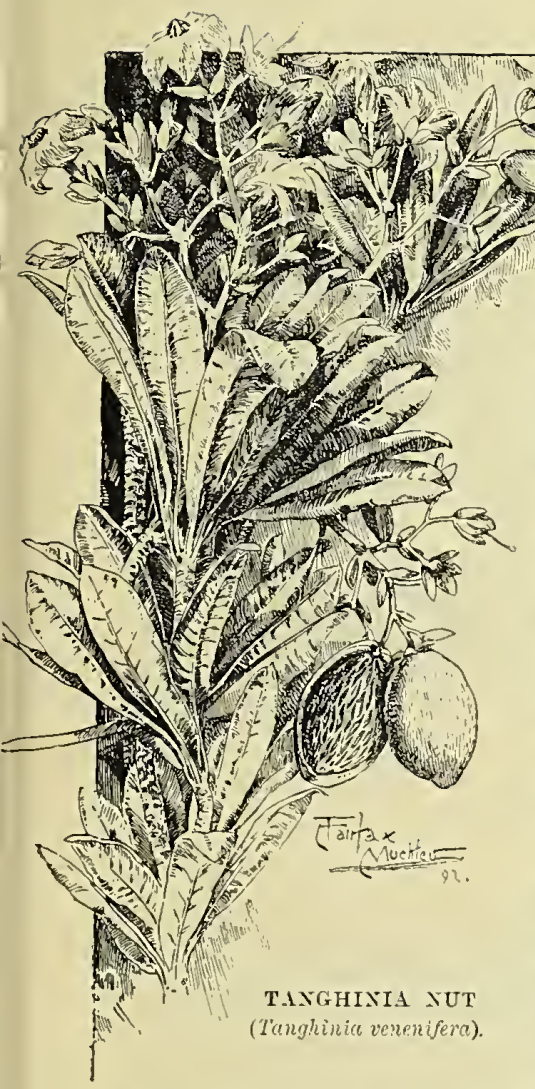
poignant torture at the saerifiees by which, as in Dahomey, hundreds of human beings were in those days destroyed every year.

The fetish-hut was deeorated with the skulls of these rietims, and around the fetish-tree where these buteheries went on the air was continually fetid with the deeaying eorpses strewn around, on which floeks of obseene vultures were gorging ravenously. Skeletons in every stage of fragmentariness swayed in the branches of the tree, and the ground was thiek with skulls and bones, silent witnesses to the abominations of what is still not the most enlightened of British eolonial towns, but less than seventy years ago was like a hundred other spots along the West Afriean shore, a lark plaee full of "the abodes of horrid eruelty."

At last Lander got off, after having a narrow escape of taking passage on board a Spanish ressel whieh he afterwards learned was a noted pirate commanded by an amiable person whose intention, after seeuring the property the Englishman was supposed to possess, was to make hin " Return of him "walk the plank." Even on Lander to board the British man-of-war by Engiand. which he eventually reached his native land the lot of the man who had endured so mueh and deserved so well was not the most agreeable. The captain, forgetting that the day Lander reeeived the heritage of his master's task had "gentled his eondition," would fain have set him to perform a menial task. But, as he puts it with playful irony, "Could I, who had so reeently shaken hands with majesty, and lodged in the palaee of kings; who had been waited on by the Queen of Bussa, and walked delighted with proud princesses of Nupé : eould I, who might have become the master of a thousand slaves, and lord of the high-minded and lovely Zuma; who had been solicited to wed the daughter of a mighty monareh, as well as become premier of his eouneils and eommander-inehief of his armies: eould I so suddenly fall from the towering elevation to whieh my eonsequenee had raised me, forget all my dignity and all my laurels, and deseend to the menial, grovelling oecupation of washing the filthy eyes of turtles?* Surely, no. But for the first time I felt that I was among my goodfor-nothing eountrymen : that the astonishing 'Nassarah Curramee' + of Afriea, the god, the prophet, the enehanter, had degenerated into the simple Richard Lander of former years; that all iny glory and all my consequenee had ranished into thin air."

Even on arriving in London he was taken for what he was not, for a Jew, seeing his long beard-then an unwonted speetacle-insisted on thinking that he was a co-religionist from Jerusalem. +

\footnotetext{
* This was the duty assigned him by the unappreciative Captain Purchase, of the Esk sloop of war.

† "Little Christian."

¥ "Records of Captain Clapperton's last Expedition to Africa, by Richard Lander, His Faithful Attendant, and the only Surviving Nember of the Expedition: with the subsequent Adventures of the Author." 2 vols. (1830.)
} 


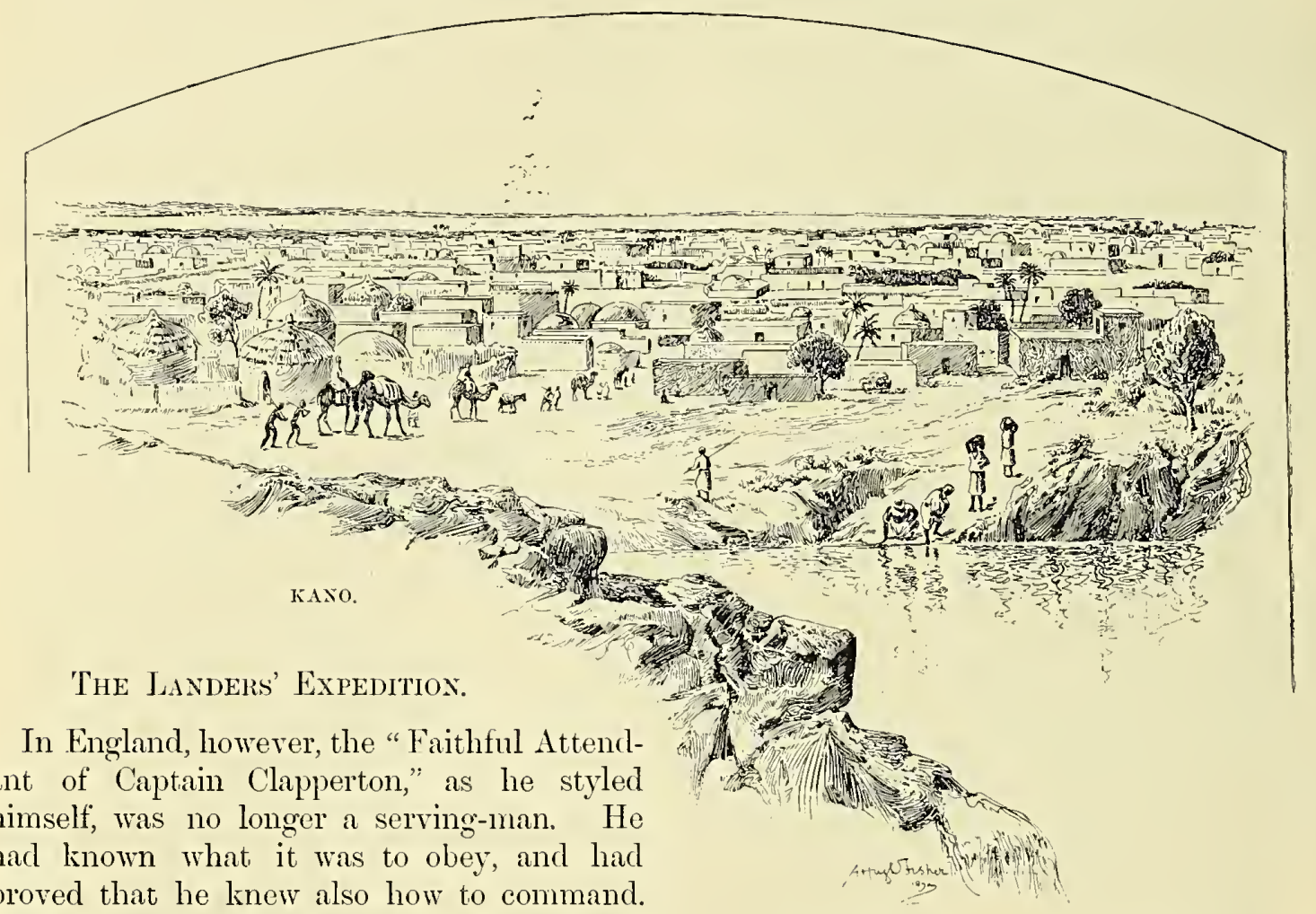

The brief career of this remarkable youth, who in the course of a few years played so notable a part in African discovery, is for its romantic incidents only equalled by that of Caillié. Born in 1804, at Truro in Cornwall, Richard Lemon Lander was one of the six children of a small tradesinan, unable to give his boys more than the slender education then considered suitable for persons in their condition. Even this the lad did not take full advantage of; being too fond of roaming about from place to place, sharing in the adventures of the village youth, and listening to the wonderful tales of foreign parts that seamen had to tell. However, by the time he was eleven Richard Lander was out in the world earning his bread; having at that age " accompanied a mercantile gentleman to the West Indies" in the capacity of page. Returning in three years, he served as footman or valet to various Englishmen in France and other Continental countries, in South Africa and in England, until he was engaged in a similar capacity by Captain Clapperton. Thus,

though not book-learned, he was not without education of a kind that schools cannot supply.

His African story, except for its pathetic aspect, did not, howerer, arouse great interest. The repeated failures, and the sacritice of many lives in making Reichard and these joumeys from: which so little armchair substantial benefit was reaped, were

bringing the country from the hot enthusiasm of a few years earlier to the cold stage at which it remained for many years afterwards. Even the nation at large were more interested in the adventures of Arctic than of African explorers, half of whom seemed to die and leave the remaining moiety to bring home their journals, which, after all, told how they were always going to but never did manage to solve the problem of the Niger mouth. Geographers, however, began to see light more clearly than before. By a process of exhaustion, the course and mouth of the river that had been so often reached and 
never traced were confined within comparatively narrow linits. Then they began to recall the theory of Herr Reichard of Weimar, an armchair geographer, who as far back as 180 s had broached the view that the Niger reached the Atlantic in the Gulf of Guinea, through a delta of which the Rio del Rey and the Rio Formosa were respectively the eastern and western branches. At the time this view-which in less than twenty-four years was proved to be substantially correct-was scouted with unwarranted unanimity by those who had adopted different opinions: Mlannert, an eminent commentator, to whose fame time has been unkindly, declaring that it was contrary to all Nature. Another geographer, who, though he had never seen the Niger, had the advantage of reading the facts about it without being under bonds to accept any of the current conclusions, arrived at much the same inferences from more extended data than his German compeer. This was James McQueen, a Scotsman, who in the course of his life as a West India planter had conversed with slaves fron the banks of the Niger-one of them, a Mandingo, having actually rowed Park across the mysterious river. Reviewing on his return home all that had been gathered since Park's day, he also showed, by a train of sound reasoning, that in the Bights of Biafra and Benin was the outlet of the Niger, and that this river was in the days to come to be one of the great highways of British commerce. The idea was then inost unreasonably regarded as the dream of a dreamer, for "the authorities" were still wrangling orer Rennell's idea that

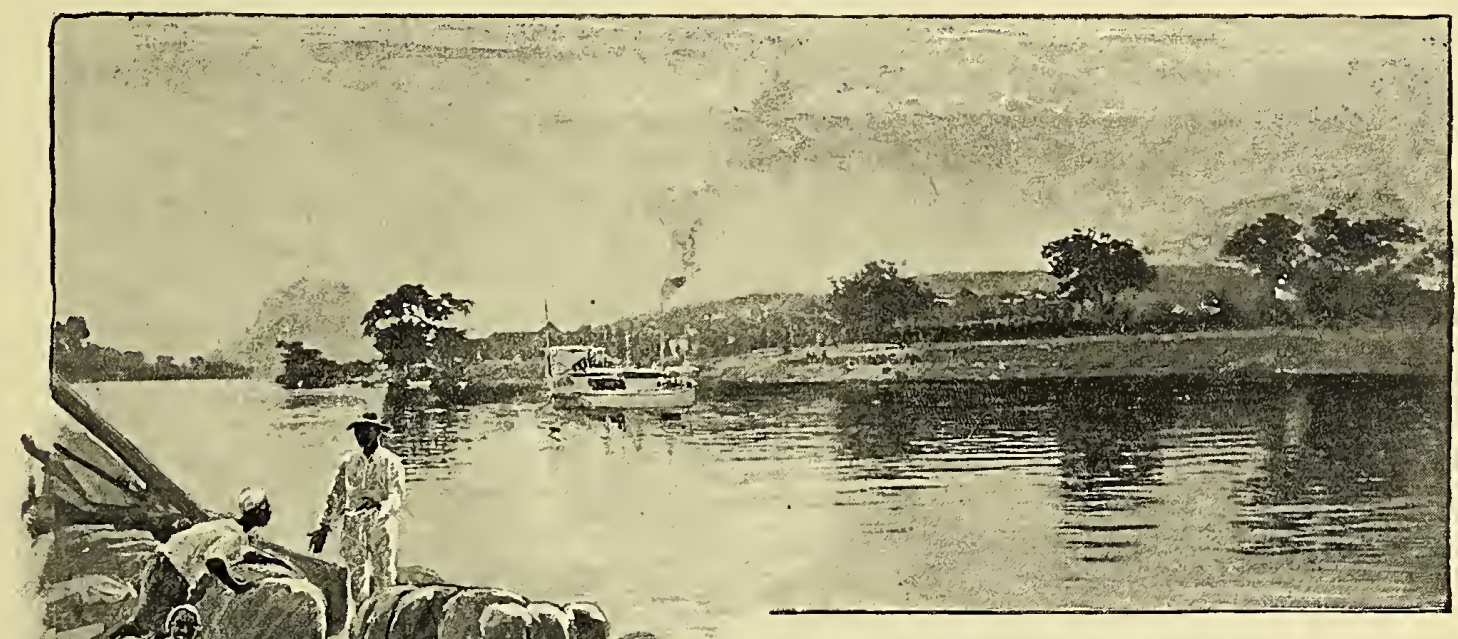

the river disappeared in some Central African "sink," evaporated under the torrid suns of the tropics; that it joined the Nile and contributed its water to the Mediterranean; or even that-all that had been said by Park and done by Tuckey notwithstanding-its actual termination was in the Congo. But as McQueen, after a chequered career, lived for half a century later, not only to see

the Niger traced to its mouth, but to

THE RIVER NIGER AT THE FOOT OF THE BUSSA RAPIDS, NEAR RABBA: "DR. BAIKIE'S SEAT" IN THE DISTANCE.

(From a Photograph taken by the Earl of Scurbnrongh during his last visit to the Niger Territories, and lindly lent by sir George Goldie.) 
weleome Livingstone, and Speke, and Grant, and Burton, and Baker, and to hear of Stanley and Cameron-most of whom were not born when he first broaehed his theory in 1820-the last of the old school of Afriean geographers deserves a higher place in the world's memory than his generation aecorded him.

But when Richard Lander came home in 1828 and offered to Government to return and complete what was still left undone, Reiehard and IcQueen were names very frequently in men's mouths. Government were, however, apathetic, and the terms they were finally induced to offer Richard and his brother John-a better-educated man than himself, whom he had smitten with a love of Afrieawere poor compared with those which had been promised to some of their predecessors. However, the Lander's were not selfseekers, and when they landed at Badagry on the 22nd March, 1830, to retrace that eourse to the Niger whieh one of them had already twiee followed, they were inspired by any feelings but those of pecuniary r'eward. They were smitten by what another Niger explorer calls the "mesmerie influence" which aftects alike those who have onee visited Africa or the Arctie regions. At Eyeo, after following much the same route as Clapperton had done and Richard Lander had taken on his return joumey, the brothers were compelled to strike more to the north, reaching the Niger at Bussa three months after leaving the eoast. At Bussa-a point now familiar as the limits of steam navigation from the seathey found some books and gums that had belonged to Park; but the traveller's papers had disappeared, and, it may be arded, have never been recovered. Why Clapperton when at Bussa three years before did not descend the river has never been fully explainer, and why he went to Sokoto in an opposite direction is equally mysterious, for the native deelaration that anyone descending the Niger would be killed was not likely to scare a man of his type. Evidently he wished to deliver the King of England's message to the Sultan Bello, and seeure his powerful aid before venturing on that voyage, and, failing to obtain it, died of fever and vexation before he had time to make the effort without that whinsical despot's perminssion.

The Landers were, however, determined not to fall into the same mistake. The "King" of Tauri, having consulted the "Dark Water," as he called the Niger,* and found the oraele farourable, the eventful royage was begum with no more imposing flotilla than two canoes. But the river, so the fetish-men had declared, promised to take care of the white men, Yauri experience of that class of personages being by this time that they would be apt to take uncommonly good care of themselves, though there was no harm in giving the river all the eredit it was capable of carrying. For a time the eourse lay through a cultivated country, where the voyagers experienced nothing except hospitality, their wants being bountifully supplied, and their parting sped with best wishes for a happy ending among their countrymen at the salt water. Sunken reefs were, however, an ever-present danger which The descent they had to exercise vigilanee to of the river. avoid; and at places the swift current often ran them perilously near those jagged rocks that reared thcir crests just above the surface of the river, now lower than during the rainy season. For two months the white men and their native followers paddled through ealm reaches, or were swept along in the swifter narrow where the river eontracted its channcl as it foreed its way through some mountain range, like that now bearing the name of Rennell. All was new then. lt is familiar enough nowadays to the student of African geography (pp. 106-7), and is likely

* So Lander puts it ; but, as we have already noted, the word "Niger" has nothing to do with the Latin for black. It is most probably a word of Berber origin. though at Bussa the river is called the Joliba. Among the many names for it (p. 106) may be mentioned Hajo, Isa, Kaki'nruwa, and N-egher-rëu, from the last of which Barth derives the word Niger. But all of them, like Joliba (Dhíliba) and Kworra (Quorra), mean sothing: more than "the river." 
before another century ends to be as well charted as the Mississippi or the Nile. For steamers now chum a large extent of the stream, abore and below Bussa, orer which its pioneer navigators skimmed little more than sixty years ago (1831) in such peril and suspense, never knowing what the next hour or the next bend might bring forth. Byand-by it seemed as if the long royage was drawing to a close. Every day the country got less bare, and the river expanded into broad reaches, flowing almost imperceptibly between banks no longer steep, $\mathrm{Ol}^{\circ}$ mountains reflected in the placid water. Vegetation became ranker and the forests larger and denser and more luxuriant. Tast stretches of rich soil were covered with huge trees grateful to shelter under, but from which a sickly miasma arose as the evening closed in. Crocodiles and hippopotami and waterfowl also grew more and more numerous, and by-and-by villages of naked black people peeped firom under the palni-trees. Instead of the stately, though sonetimes insincere, courtesy of the Ioslems of the upper river, the voyagers had now to deal with rude pagans who knew no hospitality, and-except where here and there women and slaves cultivated patches of yams and sugar-canes-scarcely any industry.

Canoes increased in number as they sailed onward, and, as it was clear that the new peoples among whom they had arrived were savages of the rudest description, and possibly cannibals in addition, every moment was now crowded with anxiety. Their paddle-men began to exhibit a fear hitherto unknown, and, but for the firmness of the whites, would fain have returned. 'That their fear' was not without foundation events soon proved too fully. They were now in a region more swamp than dry land (p. 107), the river dividing into the many branches that crawl lazily through the great delta formed by the mud it has for ages poured into the sea. Evidently they were approaching the Atlantic. One day the sign was a cocoa-nut, a tree never found far from salt water; another morning a sea-gull flew orerhead, and before many hours people were observed on the banks wearing pieces of European fabrics. At last a negro in a soldier's coatee-and nothing else-called out, "Hollo, you Englishman, you come here!" The "Little Christian" was evidently no longer a natural curiosity.

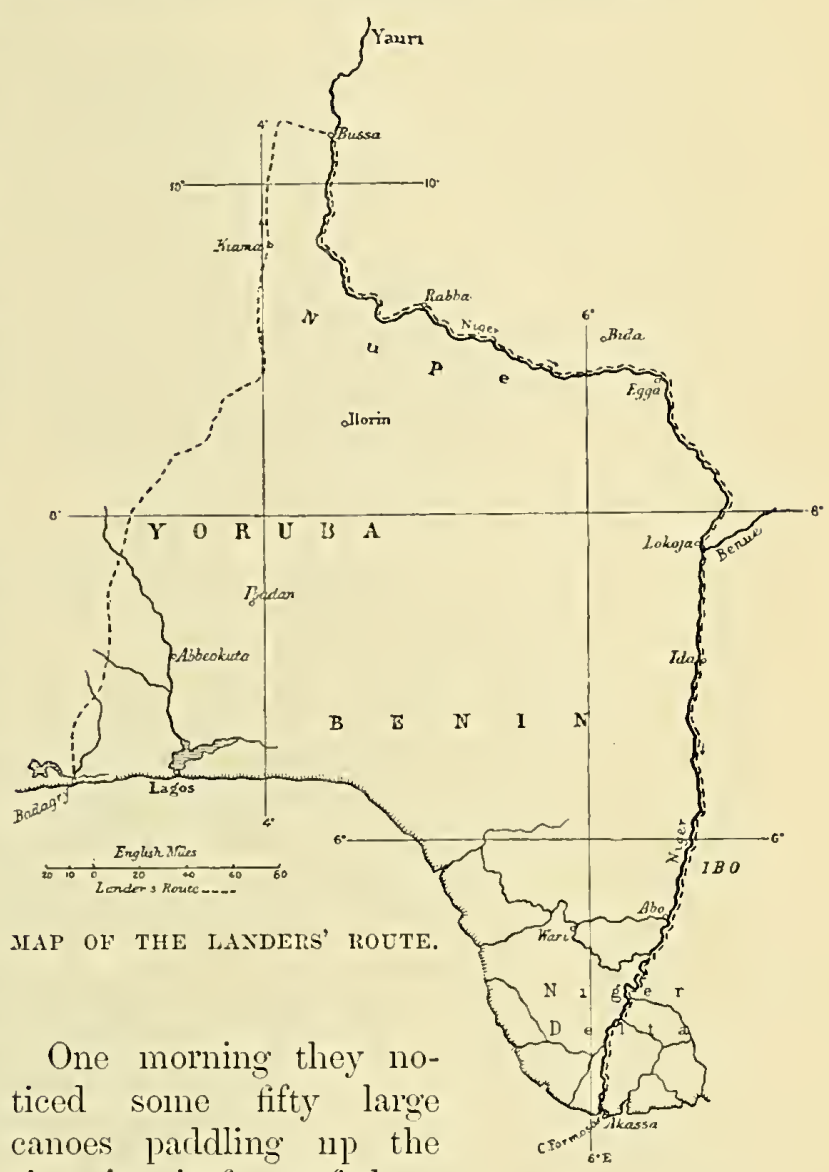
river just in front of them (p. 269), and on several of them flew the Union Jack, in addition to white flags on which were painted figures of a man's leg, The Niger chairs, tables, decanters, glasses, mouths are and f a brigands of a long familiarity with the staple $\begin{aligned} & \text { brigands } \\ & \text { and a white }\end{aligned}$ of a Guinea Coast factory. The ruffian. people on board were dressed in European clothing-trouser's excepted, these being reserved as one of the insignia of kings, common people having to be content with pockethandlierchief's as a substitute. As the canoes 
came closer it was scen that the black crews were armed to the teeth, and that mounted on little platforms was a battery of six-pounders. It was a war-party, and in a few minutes the Landers and their men were, with their baggage, in the hands of those whom a short time earlier they were so rejoiced at seeing.

The people were Eboes, and had it not been for the remonstrance of some Mohammedan marabouts who, in the midst of these rude pagans, sided with the Christians as worshippers of Allah, it might have gone badly with them. In the end, however, the prisoners were taken to the Eboe king and were ransomed from him, for the value of twenty slaves, by King Boy of Brass, who happened to be staying with his brother potentate, an advance which Lander agrecd to repay by means of a "book" or bill, and, in addition, to present King Boy with goods to the value of tifteen slaves, as some acknowledgment of his trouble. As an English trading ressel was just then lying in the Brass River, and the natives, not having been quite so frequently cheated as they were at a later date, had full confidence in British honour, they never for a inoment doubted that the bill would be duly honoured. But in this the black men were mistaken. The master of the ressel turned out to be an advanced specimen of the personage who in after years was widely known in the Niger Delta as a "P.O.R." -Palm Oil Ruffian. For just as the weary explorers heard the glad thunder of the Atlantic outside the bar and knew that they had won an immortality of fame, they sct foot on the deck of an English ship to learn that they and their mission were alike unknown. Four sailors had just died of fever, four more were sick in their hammocks, and the captain, judging from his temper, was in a very barl way indeed. It was in vain that Lander represented that, as the expedition was a Government one, no risk whatever was run in handing over to King Boy the goods promised. A tornado of oaths was the only reply. "He was no fool," was this ruffian's opinion of himself, "and, so far as lee was concernerl, the white men might go to" a locality even hotter than the Brass River, "for he was not quite so green as to advance one bar of iron on the security of the paper in question." And then the volcano opened once more and from the crater belched oaths and abuse. Seeing that it was idle to expect anything from this ruffian, Lander asked King Boy to take him to Bonny and get moncy there. But the king had been too disappointed over the transaction to risk anything further. "No, no, dis captain no pay. Bonny captain no pay; I no take you no furder." The anger of the black savage was dreadful to contemplate. He gnashed his tecth like a wild beast, and actually quivered with rage as he hissed out, "You are a thief man: English captain no will: You told me, when I took you from the Eboe country, that he would be glad to see me and give me plenty beef and rum. I got neither one nor the other. Eh! English captain no will. I gave you plenty of goods to free you. I took you into my own canoe. You were hungry, and I gave you yam and fish: you were almost naked, and I was sorry to see you so, because you were white men and strangers, and I gave each of you a red cap and a silk handkerchief. But you are no good-you are thief man. Eh! English captain no will; he no will. You told me your countrymen would do this (taking off his cap and flourishing it in circles over his head) and cry 'Hurrah! Hurrah!' when I caine on board this vessel. You promised my wife a necklace, and iny father four bars. But, eh! English captain no will; I tell you, he no will. Yes, I will satisfy your hunger with plenty more of my fish and yains, and your thirst I will quench with rum and palm-wine. Eh! you thief man, you are no good; English captain no will!" Then his sable Majesty showed his white teeth in an uncommonly nasty fashion, as he stamped on the ground and gnashed at the explorers like an enraged $\log$, and cursed them again and again in the vilest English he could command. Scraping together what little property they had left, the poor travellers 
presented it to King Boy. Instead of allaying his anger, it renewed it, and after pointing out to one of his people the beggarly reward he had received compared with what he had been promised, he refused again to speak or with raking masts of the kind that had not then quite deserted the African coast was seen making after the trader, firing shots as the stern chase continued, until the brig lay to. As the Thomas was never more heard of, it is

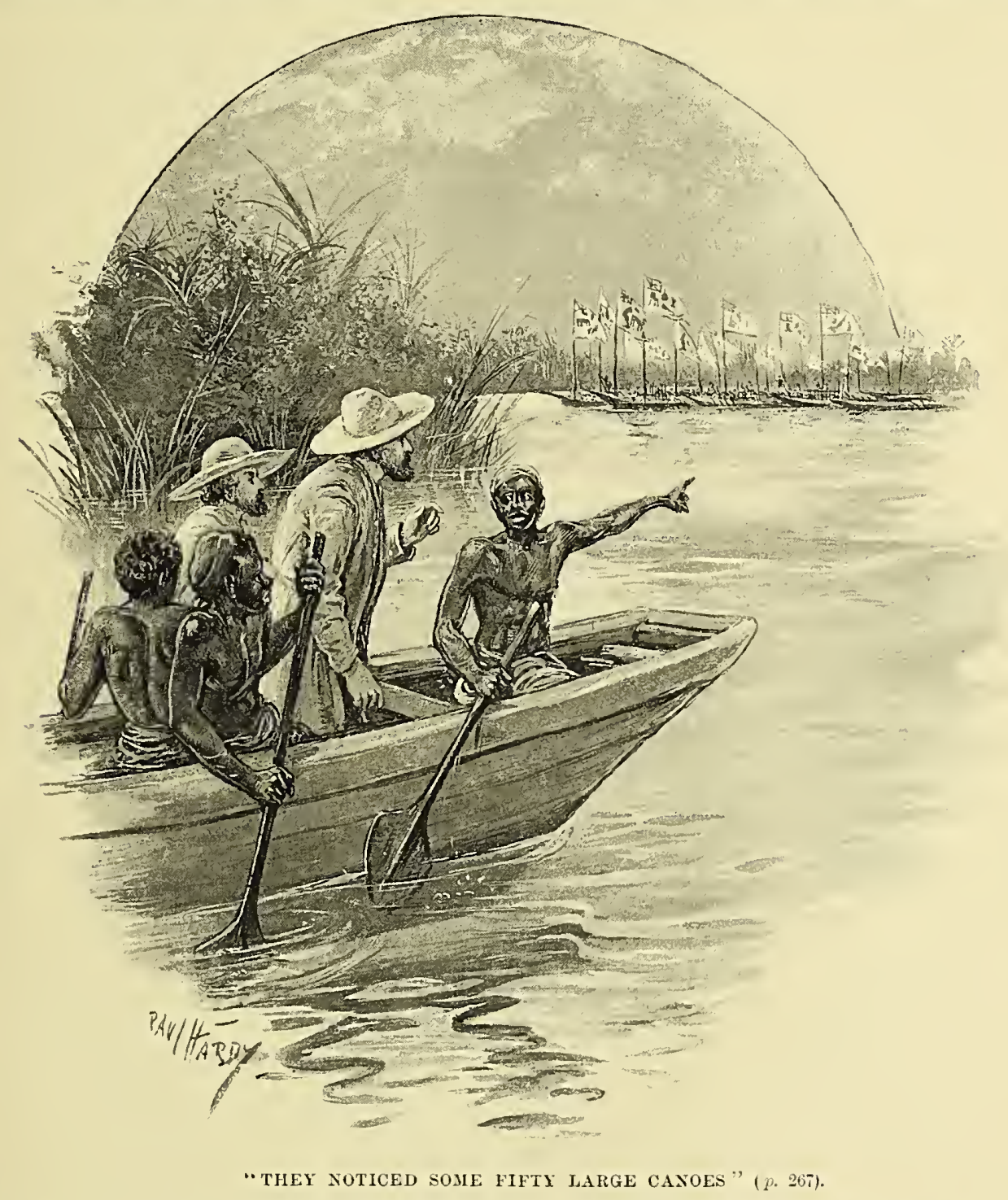

even look at those who, he considered, had so basely deceived him. However, they managed to reach Fernando Po, but, determined to have nothing more to do with this amiable mariner, declined his offer of a passage home. And it was as well that they did ; for soon after leaving the island a large vessel believed that the stranger was a pirate, who, after rifling the trader, disposed of her crew and captain on the principle expressed by the adage that " dead men tell no tales."*

* Lander, R. and J. : "Journal of an Expedition to Explore the Course and Termination of the Niger. with a Narrative of a Voyage down that River to its Termination." 3 vols. (1833.) 
Sixty years ago the doings of travellers aroused less popular interest than they do at present. Yet the return of the Landers in 1831 witl the news that at last the Niger problem had been solved was, as might have been expeeted, regarded as an epoch-making event in the Story of Africa. Nevertheless, the diseovery of the mouth of the mysterious river had been almost anticipated by the The effect of the Landers' researches of the previous twenty or thirty years. By an exhaustive process, every other likely termination of that vast stream had discoveries. been dismissed, until the broad delta along the shore of the Bights of Biafra and Benin, into which it flows by more than twenty mouths bearing names applied to them when they were supposed to be separate rivers, remained the sole spot left untonehed by destruetive critieisn. Iet Clapperton himself had eommenced his seeond expedition for the discovery of the river's mouth at the very edge of this delta, and Nicholls had actually entered at New Calabar, one of its mouths, and but for his untimely death might have passed through the deadly region into the undivided river beyond. Even Belzoni, after figuring as an acrobat and professional "strong man," was at one time on the eve of gaining, by the solution of the Niger problem, a greater fane than he won by his exeavations among the ruins of ancient Egypt. For we learn from a paper in the Public Record* Office that, resolving on a journey to Timbuetoo, he tarried in striet seclusion at Gibraltar for the purpose of letting his beard grow. This important preliminary to an African journey accomplished, he crossed the Strait to Moroceo, and actually reached Fez. But the Sultan refusing to allow hin to proceed farther, the wonld-be explorer returned to 'Tangier and sailed for the West Coast of Afriea; and there, at Gato, a village in the Bight of Benin, he met his doom on the 3rd of December, 182:3, in the shape of dy'sentery, so that Giovanni Belzoni was not destined to

* Foreign Office. Documents (Morocco), vol. xxiii. (1823) : Despatches of Consul Douglas of Tangier, etc. do more than enter upon a task that had been the death of Houghton, and Park, and Nieholls, and Peddie, which had led Burekhardt to make long journeys as a preliminary training to entering upon a Nile journey, and had at one time tempted Karsten Niebuhr, the Arabian explorer, and Leyden, the Indian philologist, though, happily for both of them, their longings never took a material form.

But among those who most eagerly foresaw in the Lander's' diseovery the potentialities of gain to British conmeree were the Liverpool merehants, who, with those of Glasgow, had for long had a praetical monopoly in the trade of West Africa. Now for the first time they had before them a great river, larger than the Senegal or the Gambia, and, unlike the Congo, not broken close to the coast by cataracts inpassable by steamers. Up this waterway vessels eould sail and carry on a trade in ivory and gold with the wealthy lingdoms of the interior, instead of having the merchandise sent down the river to be taxed by the Delta tribes who, as the Landers' experience showed, had long been familiar with slavers and palm-oil traders.

Among those pioneers of the opening up of Inner Africa to eivilised trade was Macgregor Laird, a name still familiar on the Mersey banks. Thanks to his influence, and largely also to his eapital, two well-equipped
The Macgregor Laird Niger expedition. steamers-the Quorra and the Alburlate-were built for the purpose of testing the glowing aeeounts which the explorers had brought home, and, as Richard Lander agreed to aceompany the expedition, it left Liverpool in 1832, full of high hopes, though there were wiseacres who deelared that a ressel built as was the Quorra, with the exception of the deeks, entirely of wrought iron, would meet with early and condign disaster. "The working in a sea-way would shake the rivets out of the iron," the "heat of a tropical sum bake her unhappy crew as in an oven," and the first tornado she eneountered would "hurl its lightnings upon a eonduetor evidently $\dagger$ That is, in Housa language, "Blessing." 
despatched to brave its power." But though none of these calamities happened, the venture, which Laird himself accompanied, was commercially a complete failure, and, had it gone to the bottom as the croakers prophesied, it could scarcely have fared much worse than it did. For out of forty-eight Europeans who left the Mersey, only eight returned to tell their tale of misery. From the Government no assistance of any sort had been received, except that Lieut. Allen, R.N.-who was to become in future years another victim to the African climate-accompanied the expedition with the object of making a survey of the river. The cndless branches into which it splits in the Delta were then unexanined, and indeed they are even yet only partially known. The Nun "river," or mouth-now the ordinary channcl taken by vessels-was chosen as the one that looked most promising (Maps, pp. 36, 112). King Boy, his anger over the perfidy of white men solaced by the payinent of Lander's debt with interest-though he had already sold the explorer's journal to a palm-oil trader, from whom it had to be ransomed-soon made his appearance, full of professions of friendship and endless tricks, with the object of extorting "dashes" from the new visitors in the "devil's ship," as he termed the steamer. It soon, however, became apparent that he meditated treachery, and had bribed the black pilot to run the vessel aground in a convenient place for its being plundered. But what the savages of the Delta failed to do, the vile autumn climate of their marshes soon accomplished. The palm-oil traders loading in "the rivers" looked " more like spectres than men:" and as the dank, clammy, fetid exhalation from the swamps took effect upon the languid seamen, unable to sleep at night owing to the unceasing torment of mosquitoes and sandflies, they crawled about the deck so feeble and changed that

\footnotetext{
"A mother had not known her son. Amid the skeletons of that gaunt crew."
}

By the 5th of December, entries like the following appear in the log-book: "Recovering slowly, but I hope surely. I have living, Alexander Hector, purser; John, the second steward; Harvey, Kirby,

Decimation. Belfrage, and Davies, seamen-all as weak as myself, and crawling about the decks. Dr. Briggs has been closer run than myself, and for two nights I expected every moment would be his last. He is now, thank God, doing well. Last night about ten, Johnson, a mulatto seaman, died; and in the morning Captain Robert Miller was found dead in his bed." Even this awful mortality was to be exceeded until, beginning with the captain of the Quorr $($, the expedition was reduced to so few that for a time it was doubted if a single individual would escape.

They tarried too long in "the rivers" instead of trying to enter the main strcam. But in those days the Niger navigator had to feel his way, and so six wceks were wasted at a dreadful cost among the bewildering maze of creeks and backwaters, and mangrove-fringed branches, "uninviting when dcscried, repulsive when approached, dangerous whon examined, and horrible and loathsome when their qualities and their inhabitants were known." The lattcr-or rather, their chiefs - seem to have been divided between greed to make as much as possible out of the present voyagers, and a dread that, if they once reached the upper river and dealt directly with the tribes in that quarter, the business of the middlemen in the Delta would bc gone. King Obie, who had behaved most extortionately to the Landers, seemed an cxception to the rule. He received the new-comers with much amiability, clad in his royal panoply of scarlet cloth, his person decked with coral charms, bracelets, and other ornaments, worth something like a hundred pounds. The travellers were indeed surprised at his "pleasant and gentlemanly conduct," and still more at the generosity with which he presented them with a fine bullock, five goats, and three yams. Perhaps he was conscious that his previous conduct deserved reprisals, or was anxious to get free of the necessity of selling 
his produee through the intervention of the tribes lower down. The amount of this which was obtained was demonstrated by the fleet of eanoes that started out every morning to colleet yams, palm-oil, and other " eountry

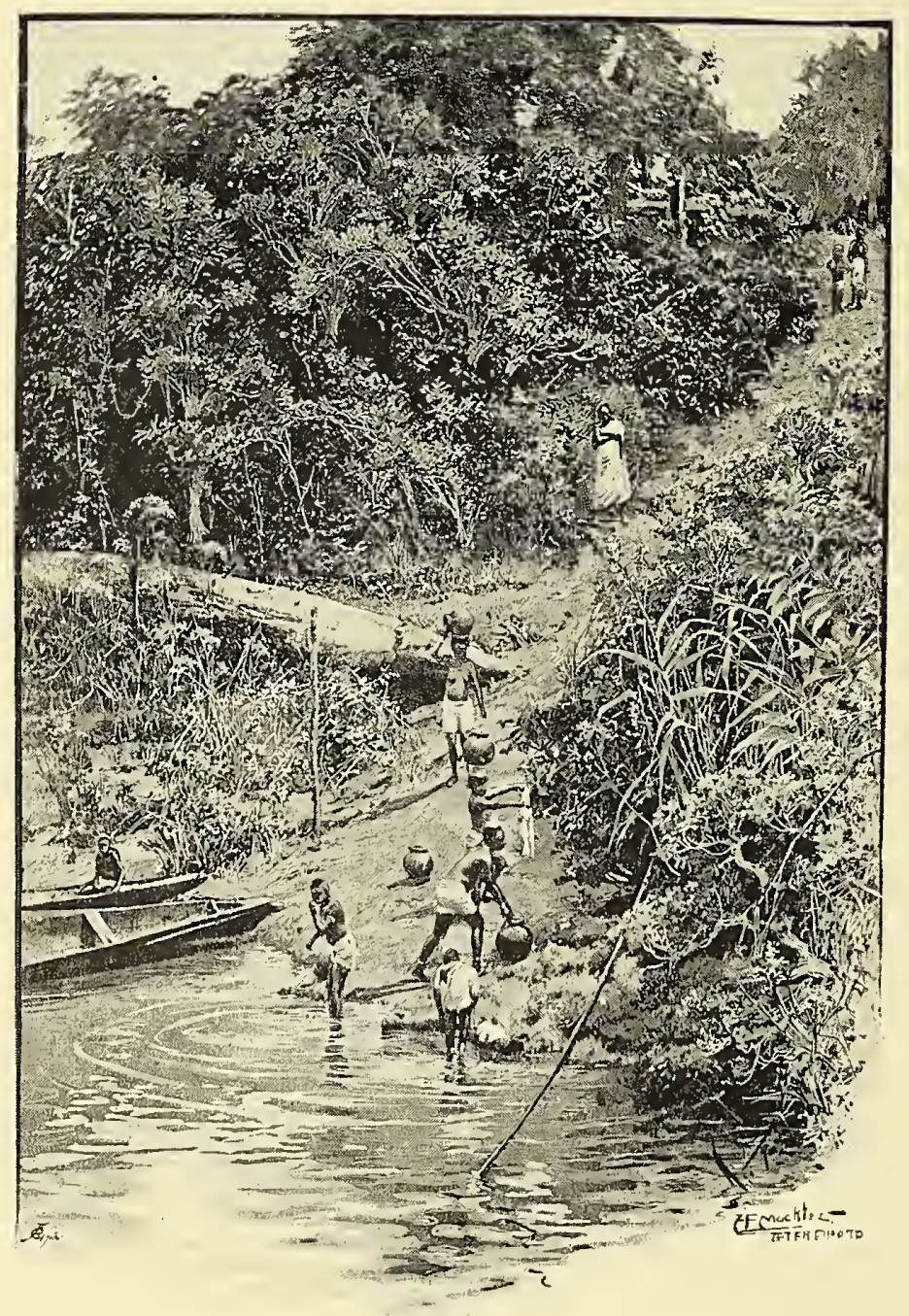

RIVER-SIDE SCENE AT ASABA, LOWER NIGER,

(From a Photograph by Capt. Mockler-Ferryman,)
Quorra grounded more than onee on sandbanks, so that the attempt to reach Rabba had to be abandoned that season, though Laird ascended the Benué or Tehad, a ehief tributary of the Niger, for some distance. Next year-the expedition meanwhile rendezrousing at Fernando Po, therì in British handsLander and Oldfield, the surviving surgeon of the expedition, and the seeond in eommand, succeeded in reaching Rabba, the eapital of Nupé (p 273), at that time eontaining a population of about 40,000 people. They also ascended the Benué for 104 miles, and, had not their provisions given out, might have steamed still farther: But even at Rabba -and they found it impossible to proeeed to the Bussa Rapids as they had antiei- Rabba. pated-they did not Rabba.
find that ready trade which they had been led to expeet. The Arabs, who here, as elsewhere, were the principal merehants, were jealous of the new-comers, while the Fulahs, to whom the eountry belonged, subsisted by plundering the weak towns and levying contributions on them by aid of an army of 5,000 cavalry and 20,000 infantry, armed with poisoned arrows, spears, knives and swords, brought from Tripoli by the Arabs. At that time they looked with dread upon firearms, and the only weapon of the kind seen among them was a double-barrelled pistol, which Lander reeognised as having beehop," and then in the evening dropped down the river with their eargoes. Unfortunately, however, when the expedition did reach the open river, with its eooler breezes and drier forest-eorered banks, the season was too late; for the water had begun to fall, and the longed to Captain Pearee. This army, however, like the country generally, was tributary to the Sultan Bello of Sokoto, and was in those days eomposed of liberated slaves, granted their freedom on eondition that, while they might work at any oceupation during the 
wet season, they should, as soon as the dry weather set in, engage in slave raids for the profit of the king, who sold his captives to the Arabs, through whose agency they reached the Spanish slavers, then almost openly pursuing their business on the coast. Among other articles seen at Rabba were a number and a costly one also, but, like all of its predecessors, it was a decided commercial failure. For on the way back Richard Lander perished. Good-natured and easy, looking upon the natires, in spite of all Death of his uncomfortable experiences, as Lander. little better than children, he grew too

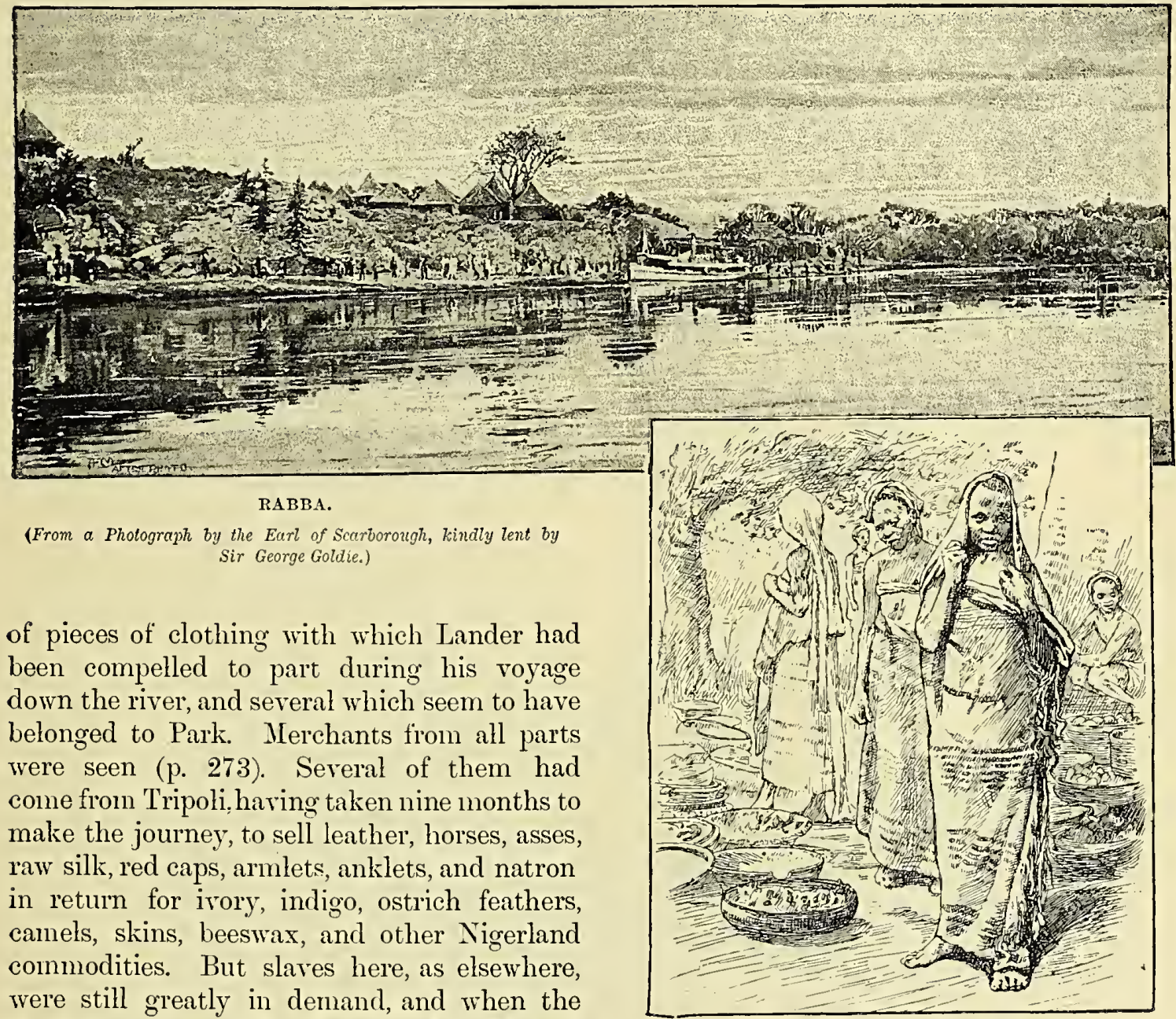

IN THE MARKET-PI,ACE, RABBA.

(From a Photograph by Capt. Mockiler-Ferryman.)

confident of their good intentions, and fully believed that, if fairly treated, they might be implicitly trusted. Like many before and after him, he forgot that a savage, even when of a higher grade than the miserable race who have their homes anid the Niger swamps, has 
all the untutored impulses without the innate generosity of a child. Coming up the river in an open boat with a cargo of cowries and dry goods, he was, while aground off their village, attacked from all quarters by the natives of Hyammah, near the fourth island from sumday Island, cighty-four miles from the Nun. Several of the party were taken prisoners, and were afterwards ransomed, and a number of others were killed and wounded. Among the latter was Lander himself, who, in addition, lost all his papers and other property. His wounds, which at first were not considercd mortal-and in a cooler climate, and with a constitution less enfeebled by a long stay in the unhealthiest part of the river, might not have been-unfortunately ender a short but remarkable carecr ; for he lived only to reach Fernando Po, where he died on the 6th of February, 1834.*

This year was the last of the Laird Expedition in Africa. It had examined the Niger as far as Rabba, and proved that, with the advantage of high water in their favour, the Bussa Rapids could be reached, as indeed they are now regularly, by steamers fitted for river navigation, whilc, in the costly school of experience, the projector had learnt much about the condition of trade, the clinuate, and the people. But from the merchants' point of view the venture had been a splendid failure. Money had been expended without any immediate return in money's worth, and life had from the first been lost so pitifully that the very day the Quorra arrived at Liverpool one of the men died from the effects of his stay in the Bight of Benin. Of all the officers, Laird and Oldfield were the only two who survived, and on thein fell the task of telling the tale of their sufferings and disappointments $†$ during a three years' expedition, in which everything

* John Lander, who shared with him the credit of discovering the lower course and mouth of the Niger, but took no part in the Laird Expedition, died on November 16 th, 1839 .

+ "Narrative of an Expedition into the Interior of Africa by the River Niger in the steam-vessels Quorra and Alburkal in 1832, 1833, 1834." 2 vols. (1837.) was lost except, perhaps, experience, honour, and hope. And hope Laird never abandoned, for, though he did not again visit Africa, he may be regarded as laying the foundation of the Upper Niger trade; and as long as he lived he helped others to be more fortunate than himself. Everything was fresh in those times, recent enough to be remembered by men still living, though so far The Niger as the Delta - the Oil River Pro- of 1834. tectorate of to-day-was concerned the natives were then pretty much what they have been cver since, a degraded race of little septs, eaten up with mutual hatreds and jealousies, filthy, covered with hideous skin-diseases, and pagans of the most pronounced description, ever in terror of their "ju-jus" or fetishes. One day clad in gorgeous cast-off finery, they would appear a littlc later in their pristine grease and nakerness. Here and there a chicf's son, who had been brought to England, was able to read books that were of no use to him, while his father confined his education to a sparse vocabulary of bad English, composed of oaths or of requests for "palaver," the end of which was invariably a "dash"for the extortion of which a most ingenious system of excuses had been devised, in the eager competition of the traders, who had not then, so much as in latcr ycars, taken to the system of doing business in stationary hulks. "Slaving" had not then becn quite abolished, Spanish and Portuguese vessels pursuing it very boldly, and the craft of other nationalities with more sccrecy. Nor was pirncy altogether extinct, as Lander had found, nearly at the cost of his life, a few years before. At that timc, indeed, slavers and pirates were getting nearly synonymous. Thus we hear of a very suspicious sail at Princess Island, the crew of which had been spending money so freely that, as usually happened in such cascs, they were suspected of not having come honestly by it, and then to have bcen going over to the mainland "to load slaves"-being a pirate on the outer passage, and a "rumer" of black bondsmen on the way to Cuba $\mathrm{Cr}^{\circ}$ 
Brazil, or perhaps to South Carolina. Every chief along the Guinea Coast dealt in "black ivory" if he had the chance, and all of them were so violent against the English for stopping the lucrative trade in men and women that when Nicholls landed at New Calabar, the "King" of the River asked him whether he came from "Mista Willyfoss," * for if he did he would kill him. And extremely trueulent personages were these palm-oil potentates. A slaver-pirate pursued by a British war-ship up the river Nazareth was blown up and her crew and captain sheltered by the "King," who refused to surrender them. Intertribal wars were as numerous as they are in our day, which has seen the interminable feuds between Oko Jumbo and $\mathrm{Ja} \mathrm{Ja}$, and for

* Mr. Wilberforce (p. 74 ), whose exertions for the suppression of the slave trade have made his name familiar along the West Coast. To this day "a Willyfoss Nigga" is, in Sierra Leone, a term of abuse for a "recaptive" "'cruit," or slave freed by a British cluiser and landed there, though the chief object in establishing that colony was to furnish a home for such people. causes almost as trifling. Thus all trade was stopped for a long time owing to a dispute between the Ibbodo people and the inhabitants of a town near Cuttum-Caraffee, which originated as follows: A boy had bought some spice balls + from a woman of the town in question, and refused to pay for them; on which the husband of the injured lady determined to be revenged. For this purpose he assembled some of his friends, and, on the Ibbodo canoes coming down the river, attacked them and killed two of the people. Thus a vendetta began, all in consequence of a dispute about four cowries' worth of negro sweetmeats.

Such was the condition of affairs when the Niger mouth was discovered, and the old life of the river haring come to an end with the veil torn from its secret places, a new era dawned for it, and for Africa, the future of which we can as yet only imagine.

$\dagger$ These are made of pounded douar corn and cayenne pepper, baked on a stone orer the fire.

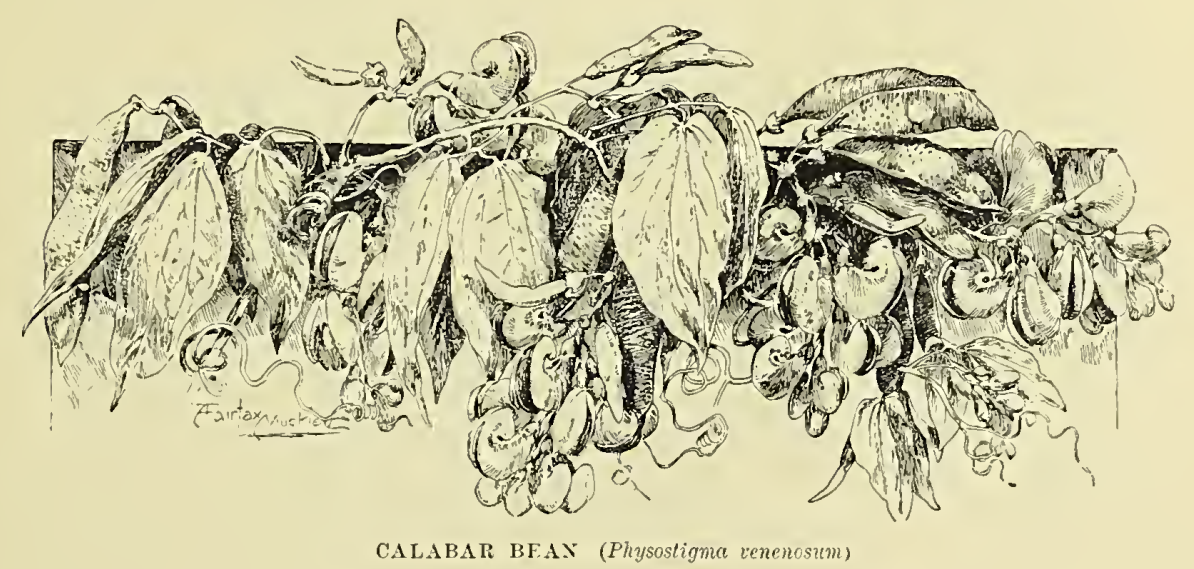




\section{CHAPTER XV. \\ The Utilisation of the Niger: An Unfinished Chapter.}

Effect of the Laird Expedition on Public Opinion-Beecroft's Voyage-The Government sends a Philanthropic Expedition, which Proves, like its Predecessor, a Complete Failure-Lull in the Exploration of the Niger-Retrospect of Fifty Years-A Few Scattered Travellers still with Longings after Timbuctoo, though the Mystery of it and of the Niger is Gone-Era of the Scientific Explorer Coincident with that of the Commercial Exploiter-Fate of the Niger-Three New Journeys to Timbuctoo-Barth-His Early Life and Travels-His Journey with Richardson and Overweg to Bornu and Lake Tchad-Death of Richardson-Overweg and Barth left alone-Barth's Journey to Timbuctoo-A Hunter's Paradise along the Shores of Lake Tchad-Koyam and Manga, a Contrast-A Land of Walled Towns-Zinder and its Commerce-Katsena-A New Land-Gando-Wars and Rumours of War-A Forest March-The Niger Tributaries-The Niger reached-Say-Along the Niger Banks-A Fanatical Folk-The "Nearer the Church, the Farther from Grace "-Embarkation for Kabara-A River Voyage-Arrival at Kabara.

The Landers' Expedition had plucked the heart out of the Niger secret, for, though there were, and are still, hosts of minor discoveries to be made and many little problems

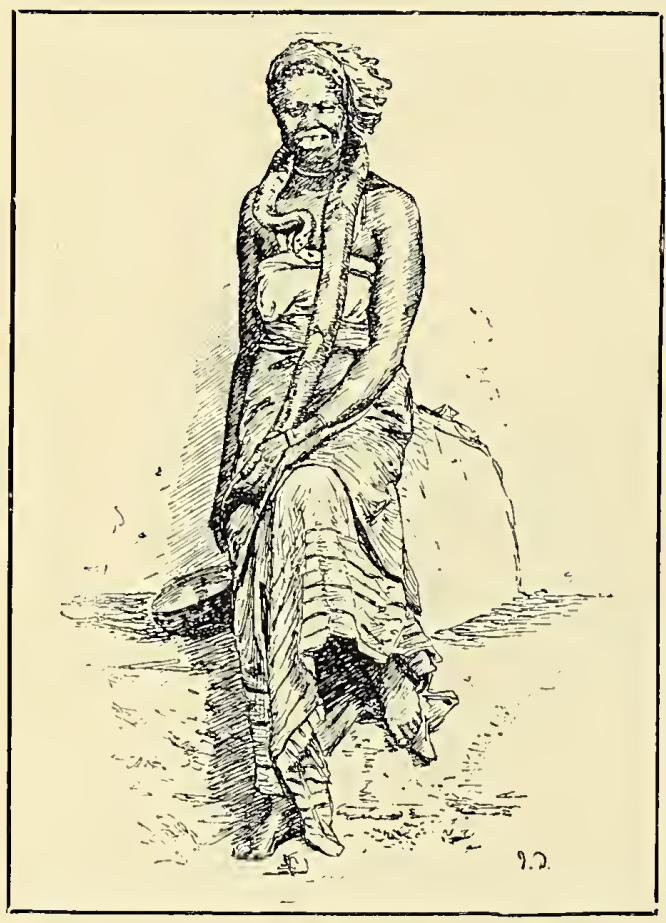

SNAKE CHARMER OF THE LOWER CONGO. (From a Photograph by the Rev. J. T. F. Halligey.)

to be solved, Timbuctoo and the up-river cities were no longer inysteries. The Hacgregor Laird experiment had, it was the opinion of many, disabused the world of the notion that there was much wealth to be won on the West African river that had for ages been rumoured to be an El Dorado. Accordingly, for some years we hear little more of the Niger, or of explorers of the Niger country. Mr. Beecroft, the Governor or Superintendent of Fernando Po, was the first to take up the broken tale by ascending, in 1840, to within thirty miles of Bussa, though not without a loss of life worth far more than the trifling additions he made to our previous knowledge of the Niger. His voyage had, however, the effect of again calling the attention of philanthropists to the teeming multitudes on the river banks; and so, in 1841, another expedition, this time with no immediate commercial or geographical aims, was despatched to A treatymaking expedition. this region of many hopes and many disappointments. It consisted of three steamers and a sailing-vessel, under the command of Captains Trotter, Bird, Allen, and William Allen, R.N.-who had as surveyor taken part in the Laird Expedition-while a good many people joined it who, so far as physique and capability of sharing in a venture that demanded something more than good intentions and a love of all mankind went, might much better have stayed at home. The moving spirit of the new enterprise was Sir (then Mr.) Thomas Fowell Buxton (p. 68), whose exertions in the suppression of slavery 


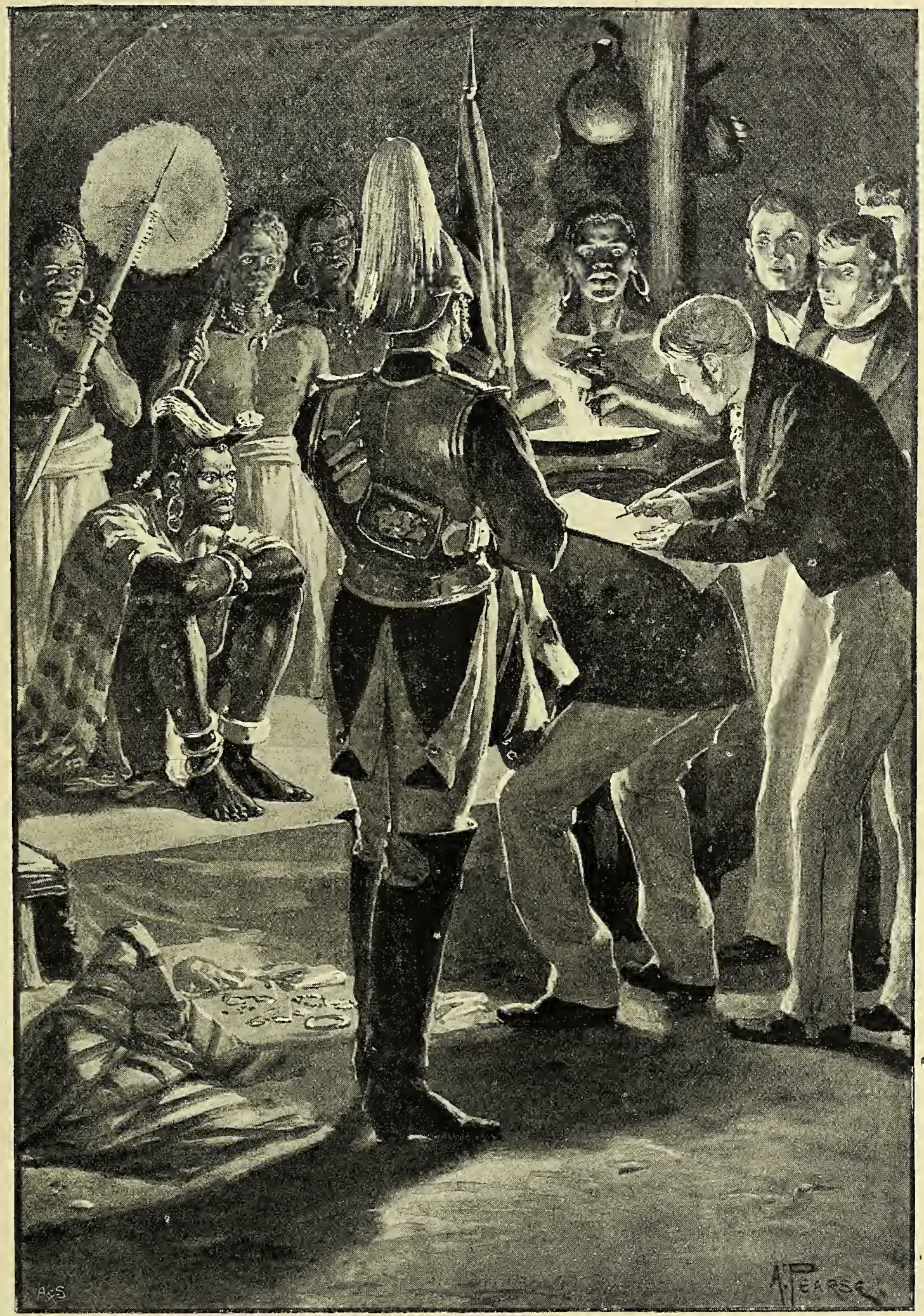

RECEPTION BY THE KING OF IDDAH ( $p .279$ ). 
and the slave trade had earned for him a prescriptive right to speak with an approach to authority wherever black Africa was concerned. Government and the Friends of Africa-who had extended no help, moral or material, to the courageous venture of Macgregor Laird-were now ready at his instigation to spend money lavishly on the new expedition, the avowed objects of which were to penetrate the river as far as Rabba, "establishing new commercial relations with those African chiefs or powers within whose dominions the internal slave trade of Africa is carried on and the external slave trade supplied with its victims; the bases of which conventions are to be: first, the abandonment and absolute prohibition of the slave trade, and secondly, the adinission for consumption in this country, on favourable terms, of goods the produce and manufacture of the territories subject to them." A model farm was, moreover, to be established at the place where the Benué joins the Niger, and therc, under skilled teachers, the natives were to be taught the merits of agriculture, the blessings of Christianity, and the curse of killing and selling each other. The archaic provision about frce trade, it must be remembered, was made in the days of a high tariff, but otherwise the project smacks of a far-away day when the morals of African chicfs were not so well understood as at present, and the notion prevailed that these potentates were to be won over to the views of European philanthropists by means less material than force or a self-interest greater than that now touched in its most vital point. But the Parliament of 1840 was still echoing with the appeals that had resulted in the abolition of slave-holding throughout the British Dominions, and kindly folk, imbued with a belief in moral pocket-handkerchiefs, had not ceased to dream the dreams that they would like to have been realities.

No expense was spared in fitting out the vessels; and if the climate of the lower Niger conld only have bcen subservient to science the expedition might have bcen successful. But, like its predecessor, it was an unredeemed failure. Only one of the steamers reached as high as Egga; and, of 145 white men, forty perished of malarious fever during the few months the vessels were in the river. The flotilla left England in Nay, 1841, and was recalled in June, 1842. It entered the Niger, therefore, at the very season that was most unhealthy, and, as Laird and others liad pointed out, the white crews were much too large for such a voyage. But as the flower of the Navy volunteered for work in which promotion seerned certain, and seamen competed with each other, as they have always done in Arctic expeditions, for employment in a service where pay and danger were both double, the remonstrances of these experienced men were disregarded as the spitefulness of interested persons. Within three weeks of the vessels rolling over the Nun "River" bar, sickness of a most malignant character broke out almost simultaneously among the ressels, and did not abate until the whole expedition was paralysed. When the confluence of the Niger and the A model Benué was reached, the materials farm. for the model farm-to be started by thirtythree negroes selected for the purposewere landed: farm-house furniture, carts, ploughs, harrows, and all sorts of agricultural implements, most of them entirely unfitted for work in such a region, or by people who had never seen them until they were taken out of the holds of the Albert, Wilberforce, and Soudan. Nor was the spot selected for what Mr. Buxton called " a city built under the protecting wings of Great Britain, to become ere long the capital of Africa," well fitted for a metropolis of any sort. It had two years before been the site of a large town destroyed by the Fulahs. But tall, rank grass now covered the streets, and from among the ruins of huts and the waste of what had once been gardens noxious reptiles glided at every step. After remaining for a couple of days on this charming spot-near which there are now busy trading-posts (p. 280) - and burying a man in that brief period, it was seen 
that the spot was unsuitable for an agricultural settlement, far less for an African metropolis of the kind built in imagination by London philanthropists with a map before them. They were therefore conıpelled, to their great mortification, to re-embark their stores. After steaming a mile higher they again landed the farming paraphernalia, including "the famous Eglinton Toumament tent as a temporary residence for the farmer and his servants." But here death speedily put an end to the plans. In a week, seven men perished and eighteen sickened, and such was the mortality that the ressel conveying the invalids down the river had only two white men on board not dead or dying.

But, ineanwhile, treaty-making went on briskly, though how far the "High Consenting Parties" had any intention of keeping their compacts inay be inferred from the fact that thirty-nine "lkings" of the Gambia region had, not long before, agrced to abolish the slave trade for a yearly subsidy of $£ 300$, or $£ 7$ 13s. 10d. apiece-that is, less than half the price of a single captive. Indeed, before the expedition started, Lord Palmerston had warned the country that if Europcan Powers like Spain and Portugal only kept their agreements to abolish a similar traffic

\section{"We, the \\ High \\ Consenting \\ Parties."} until it paid them better to wink at their infraction, the barbarians of the Niger, who never heard of the Rights of Man, and had few aspurations beyond wives and rum, could hardly be cxpected to be more virtuous. One of these potentates was the "King of Iddah," for whose reception great preparations were made. All the officers of the experlition attended to give dignity to the occasion, Mr. Duncan,* master-at-arms on board the Albert, in the full uniform of a private of the Life Guards, to which regiment he had formerly belonged, marshalling, with a Union Jack in his hand, the diplomatists into the "imperial tent" through a

* Mr. Duncan is better known for his journey to Adafoodia in 18t5-6. He perished in attempting to reach Timbuctoo through the same region. hole three and a half feet high, which the ex-Guardsman remarks, in a shor't narrative of the expedition that he wrote, was very awkward for a man of six feet three inches, with cuirass and helmet, and a boardingpike with a flag attached to it. Insidc this not very palatial shelter, they found his Majesty squatting on a bench, looking very stern, and surrounded by his court, dressed "1nuch like the Guy Fawkes' effigies in London on the 5th of November." He, however, readily accepted the gifts offered him-no African chief ever refuses them-and promised through his counsellors everything asked, on the sole condition that the white men would aid him in a difference he had on hand with the neighbouring Sultan. This was a little awkward, considering that a leading object in the negotiations in progress was to stop these native wars, which originated mainly in the desire to make prisoners to sell. He was also ready to cede a portion-any portion-of his territory to his good sister the Queen of England, and to marry her, if this would facilitate the supply of gunpowder and big guns against the potentates whom he desired to have the best of. $\dagger$ But, above all, he was anxious to exchangc Mr. Duncan's helmet for a damaged elephant's tusk. He, nevertheless, was equally pleased to become the possessor of some red nightcaps, spcctacles, and needles; and darkness coming on before the completion of this international treaty-which is not found in Herslett-it was signed and sealed by the light of a bit of calabash saturated with palm-oil, blazing in a British frying-pan, which the monarch of Iddah was in the habit of using as a candelabrum. Meanwhile, the central pcrsonage in all these negotiations never spoke a word. He only nodded his woolly head from time to time; and, after this long lapse of

+ We read, however, in the Prnceedings of the African Colonisation Society, that "the treaty with the Attah of Iddah has been ratified by Government, except that Her Majesty declines the sovereignty of any territory in Central Africa, or the proprietary interest in any land agreed to by the Attah to bc ceded to Her Majesty," which shows that in 1842 those comforting words, "Sphere of Influence," had not been invented. 


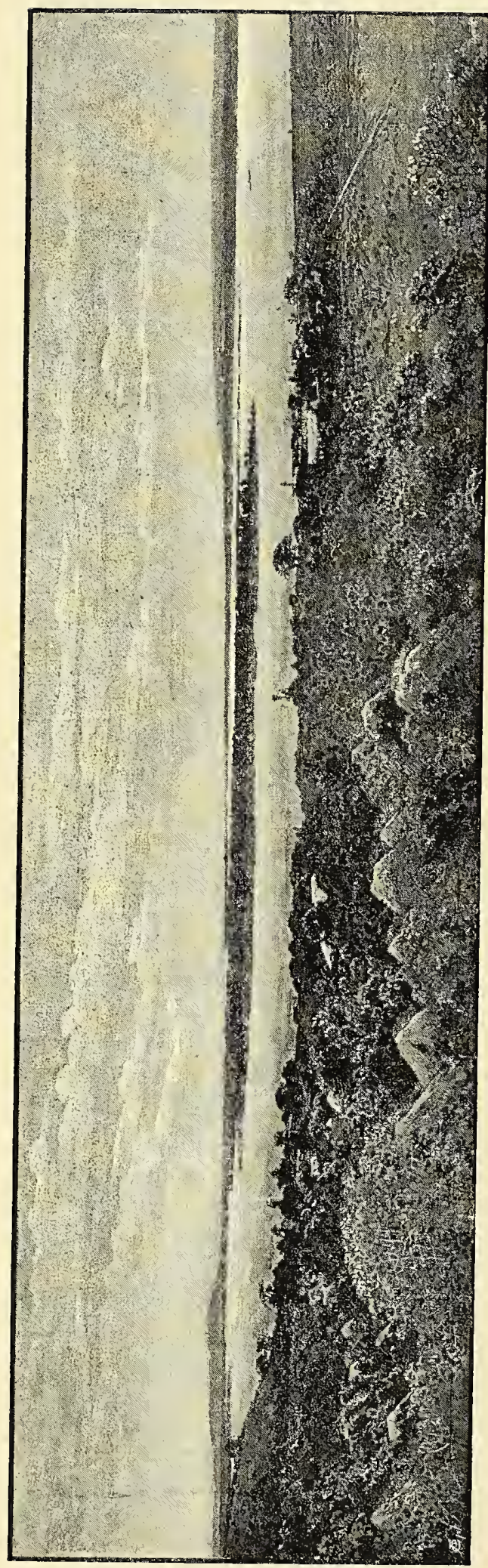

years, it may be questioned, without the risk of an indictment for minor treason, whether the dazed monarch had the most remote notion of what all the "palaver" meant. And so the farce went on all the way to Egga, as it has gone on ever since in other parts of Africa, with results about equally valuable and quite as substantial. All through three dismal months death was busy in their ranks, while the thermoneter in the coolest part of the ship stood at $92^{\circ}$. Yet these earnest men never for an hour abated the performance of the errands on which they had been sent, though perhaps, had they been endowed with a keener sense of the ridiculous, they could scarcely have performed farces like the following without laughing in each other's faces. For, a few days after the solemn treaty with the Iddah king had been signed and sealed, a son of that ally of Her Majesty came alongside "with three slaves for sale." This was the same prince who, during the Laird Expedition, had, on the occasion of his brother's death, ensured to the defunct the sincere grief of as many relatives as possible by administering to his sixty widows a dose of poison, from the effect of which thirty-one died outright, and the twenty-nine who survived were "grievously griped." $\mathrm{He}$ had, moreover, admitted having poisoned several of Laird's people. Accordingly, if the countrymen of these murdered men-some of whom were British subjects, and all of them in British pay - had promptly slung this young savage up to the yard-arm, British infiuence would have gained something by the Buxton Expedition. But Captain Trotter, in pursuance of philanthropic instructions-which applied, however, only to the black man-gravely stood in the midst of his dying comrades, and read out to this murderous scoundrel-in English, it is presumed, for the reader knew no other language- "the laws relating to slave-dealing, and also his father's treaty abolishing slaves for ever in his dominions" (pp. 277, 281).

The river falling, the danger of grounding compelled the vessels to make all speed for the coast, though even then, had it not 
been for the help of one of the traders whose counsel had been so lightly treated before the expedition left England, it is doubtful whether any member of it would have ever left the Niger. As for the model farm and the Eglinton Tournament tent, it was deserted by all save a negro sailor; the only produce of the steaming soil that the vessels brought prevented any further attempts to develop, on a large scale, the resources of this pestilential river, or to use its banks a retrospect as the starting-point for a philan- of fifty thropical departure. But neither 1892. were forgotten, and, in the fulness of time, both came in a way not widely different from what MeQueen and Laird, and even Buxton, had

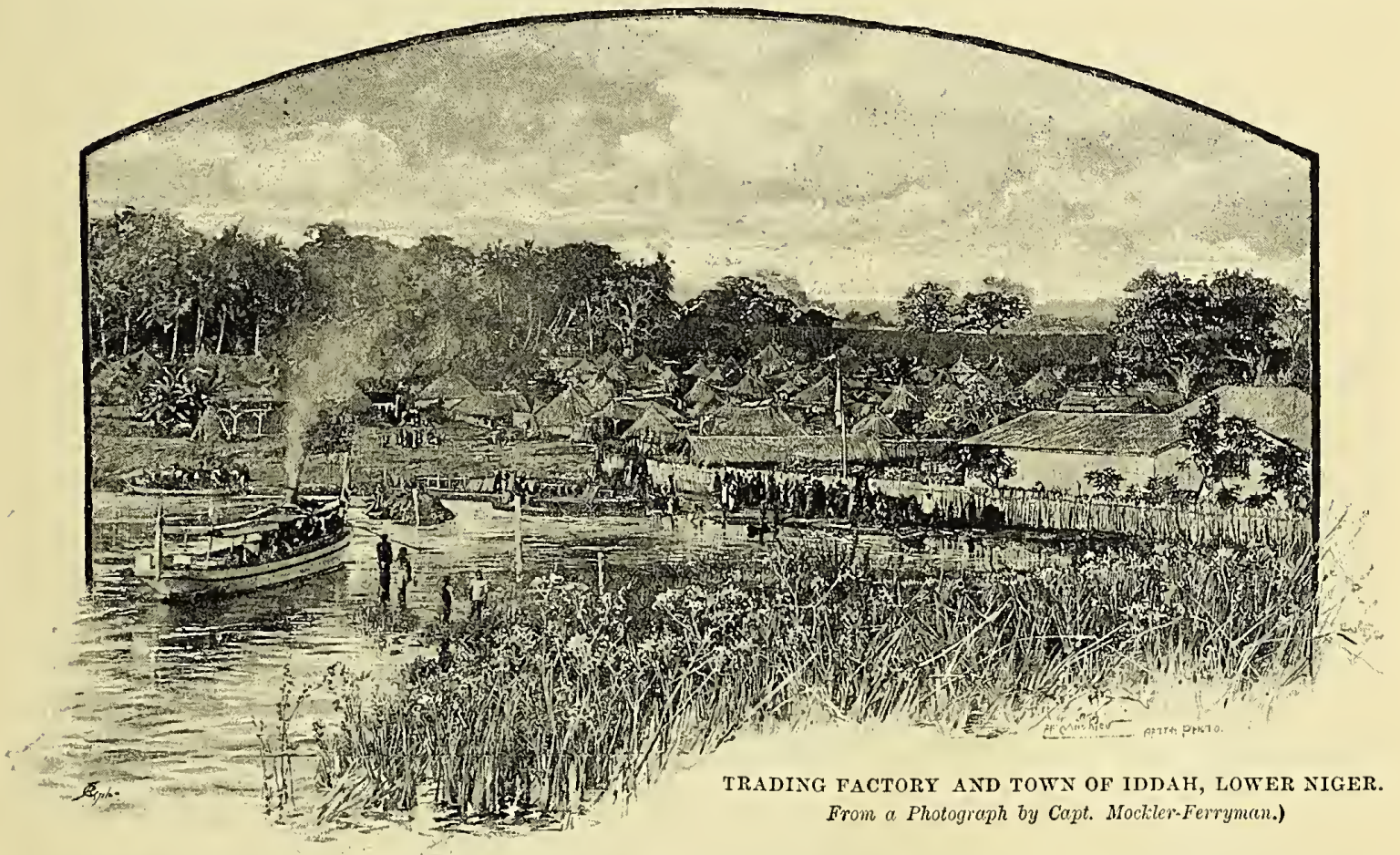

off being a boatload of wan, half-dead people, including superintendent, farmer,schoolmaster, surgeon, and gardener. When the news of the misfortunes and, it must be admitted, mismanagement also, of this philanthropic adventure reached England, the whole business was ordered to be abandoned, the diplomatic and agricultural experiments included, and the survivors removed from the river.

The disappointment, almost bordering on indignation, which the enormous loss of life caused by these two expeditions * aroused

* McWilliam : "Medical History of the Expedition to the Niger" (1843); Simpson: "A Private Journal kept during the Niger Expedition" (18t3): Duncan, in Bentley's Magazine, 1843 , etc. hoped for in their day. Little by little traders crept through the delta into the undivided river, and established trading-posts, not as high as Bussa certainly, but up to Egga, far beyond the junction of the Benué with the main stream ; and in the track of the traders came missionaries, until, in the hierarchy of the Church of England, a black man who had begun life as an Egba slave ended it as Bishop of Nigerland. Then private traders gave way to an association of larger dealers, until to-day the Royal Niger Company is one of the great leagues of merchants who, like the East India and the Hudson's Bay Companies, carry on at once the government and the commerce of vast territories as the suzerains of the Crown. 
In the case of the eompany under notiee, their territory eomprises 270,000 square miles, an empire larger than the Fulahs ever ruled. But the rise and proeeedings of this league will be eonsidered in a later volume. From the eoast, however, in the eourse of the next fifty years many travellers erept inland, until streams mheard of in Park's and Clapperton's and Lander's days were laid down on the map. But most of these explorers were intent on enlarging the bounds of Colonial trade, opening up routes to the Gambia, the Sierra Leone, the Lagos, or the Senegal settlements, and will be diseussed more fittingly when we eome to deal with the Colonisation of the Continent, in the interests of whieh their expeditions were undertaken. Gther explorers also penetrated the desert from the North, until, from 'Tripoli and Egypt, and Moroeeo and Algeria, routes to the Niger were traeed. These travels were, however, not for the exploration of the Niger. That onee romantie flood was now beeoming about as unpieturesque from a literary point of view as the Amazon or the Orinoeo. They were for purely seientifie purposes, to study the geology and ethnology of the eountry, the plants and the animals and the languages of the Sahara and the Soudan, and will be eonsidered as a whole later.

Even Timbuetoo seemed to have lost its romantie eharm. For, though that eity has been seldom visited-more seldom perhaps than any other in Afriea-in the whirligig of events, by the Freneh eutting in and obtaining the eontrol of the Upper Niger, it has eome under their Sphere of Influenee, while Sego is, as we shall see by-and-by, now the seat of a Freneh Resident, who nominally at least asserts the rule of his eountry over all the vast proteetorate of the Upper Niger beyond that under the influenee of the English Company.

Not that Timbuetoo had lost all its attraetion; for in 1836 John Davidson, a learned Englishman, was murdered at Tenduf on an expedition thither soon after he had left the Sus provinee in Southern Moroeeo; and in 1869 Alexandrine Tinné, a young and wealthy Anglo-Duteh lady who had previously travelled mueh in Northern Afriea, met the same fate at the hands of her Touareg eseort (who believed that her water-eanteens eontained loads of money) on the route from Murzuk to Rhat, while on a journey the goal of whieh it is believed was to have been Timbuetoo, though when she left Tripoli it was understood that she intended visiting: Lake Tehad, and thenee, by way of Wadui, Darfur, and Kordofan, to try to reaeh the Upper Nile.

Paul Solleilet's journeys into the Sahara from Algeria looked to Timbuetoo as their turning-point. Flatters, who fell a vietim to his zeal, was aetually engaged in surveying the route for a railway from Algeria to the same eity, a seheme that is not yet abandoned; and Camille Douls, an enterprising youth who started in 1889 in disguise with a view to reaeh the same region-though by a route already known-ended, it is believed, his love of adventure by being inurdered. At all events, from that day to this he has never been heard of. But among the mass of minor explorer's-some of whom we may have veeasion to meet again in another seetion of our studies-three stood out with greater prominenee than the rest. These are Heinrieh Barth, the Rabbi Mordokhaï Abi-Serour, and Oskar Lenz; for all three reaehed Timbuetoo, and thus eompleted the number of Europeans known to have seen that eity, and witnessed the many ehanges whieh it has undergone in reeent years. Mordokhaï was a Moroeeo Jew without any seientifie knowledge, and, exeept as a eommereial adventure, his expedition is not of great moment. Barth and Lenz were, on the other hand, men of great aeomplishments, and though the routes whieh they took were not through an entirely novel eountry, the minuteness and exaetitude of the information that they brought baek denrands for them a plaee among explorers in the strietest sense of the term.

Dr. Barth was born in Hamburg, in the year 1821, and after graduating in Berlin in 1844, 
set out on those travels which he continued with littlc intermission until his death at the age Heinrick of forty-four. In his student life Barth. he had contracted keen archæological tastes during a visit to Italy and Sicily. Hence the first long journey that he undertook was less geographical than antiquarian, for it consisted of a circuit of the Mediterranean shores of North Africa from Norocco to Cyrenaica, and down the Nile Talley, examining the sites of ancient citics, and the conclition of the races who now hold the colonics of the ancient conquerors of the world. This tour, taken entirely by land, was of the utmost value to science, though the knowledge of Arabic that Barth had acquired did not save him from molestation by robbers, in an encounter with some of whom he was wounded. After wandering through Egypt and Palestinc, Asia Minor, the Greek Islands, Greece, and Turkey, he returned to Berlin to prepare an account of his researches, and begin the sober realities of a scholar's life as a privat-docent, or "coach," in his Alma Mater. But in 1849 the British Government determined to make onc more effort to open up commercial relations with the Upper Niger and Central African countries that Denham and Clapperton had visited, and for their agent in this schemewhich it must be understood was not geographical or scientific-selected Mr. Janncs Richardson, who had already gained some experience of the dutics incumbent upon him during various journeys he had taken in the Sahara and coast-lying regions of Northern Africa. By the influence of Bunsen and Ritter, Barth and Overweg, a Prussian astronomer, were attached to the expedition, though before long the death of Richardson and of his companion left Barth to finish a task which has therefore, not unfairly, been alınost solely associated with his reputation.

The party left Tripoli in the spring of 1850 , and without any very remarkable incident

To Bornu and Lake Tchad. passed to the frontier of Bornu over ground already familiar. Here the members of the party separatcd, in order to cover a greater area than they could have done together ; but they never met again, for at Ngurutuwa-once a celebrated but now a somewhat decayed town-Richardson died, and was buried under one of the umbragcous fig-trees with which the place is shaded. The two Germians-between whom and their English chicf there had been frequent bickerings and jealousies which, but for his untimely end, might have done serious damage to the work they had in hand-wcre now left to carry out the plans of the English expedition. Barth and Overweg in their turn divided the exploration of the country around Kukawa, the Bornu capital, between them. In returning from onc of these detached trips, Barth found Ovcrweg ill and exhausted, and within a weck he followed Richardson, and lics by the shores of Lake Tchad, to which he had been carried in the hope that the cooler air of that neighbourhood would revive him (1852). As Orerweg was the first to navigate that shect of water, in a portable boat conveycd thither,* it was but fitting that he should be buried on its margin-the fourth of the European martyr's to their zeal for the exploration of the country of which it forms the centrc. During the next four ycars Barth, singlc-handed, often in sore straits for means, frequently ill, and sometimes in peril of his life, devoted himself to carrying into effect the instructions that he had inhcritcd as the official heir of Mr. Richardson.

It is impossible in the course of a brief narrative to describe all of the journeys that he pcrformed. Nor is it necessary, for though he for the first time described with minute accuracy the topography, history and resources of the country between Murzuk and Lake Tchad, and westward of that shect of water through the Sokoto Empire to the Niger, Gando, and the Songhai-land to Timbuctoo, much of it was already impcrfectly known by the less exhaustive descriptions of earlier travellers; and it was Barth's good fortune to leave littlc for his successors to glcan in his steps. Abandoning his intention of

* The sailor taken to navigate it, having proved an unfortunate choice, was sent back from Murzuk. 
journeying in the direction of Kanem and the north-east shore of the lake, which he had already partially examined before the death of Overweg, Dr. Barth now resolved to turn westward and devote himself to an exploration of the country between Bornu and the middle on the road course of the Niger, fixing upon to Tim- Say on that river (p. 108) as his buctoo. goal, though in the private mental memoranda (which he kept to himself) Timbuctoo was to be the real turning-point of his expedition. For more than twenty months he had made Kukawa his head-quarters. Here, therefore, he was so well known that he found little difficulty in persuading some men of consequence to become his companions. Of these the chief was a Shereef, or descendant of Mohammed, who had come on a trading trip from $\mathrm{Fez}$, and was bound on his own business as far as Zinder. Under this man's protection Barth was comparatively safe, though even then he found it necessary, or at least prudent, to affect-under the name of Abd-el-Kerim-conversion to the faith of his fellow-travellers. The rest of the troop were hired servants, camel-drivers and the like, who, their interest being to serve the master who paid them, were, as circunstances showed, of perhaps more value to the traveller than the holy personage who for ends of his own had attached himself to a party the leader of which he knew to be provided with influential letters to the princes on his way.

It was the cool season when they set out. In Central Africa this is at best only a comparative term, yet at times the nights were positively cold, the thermometer on one occasion rising only nine degrees above freezing, while the appetites of the party were often keener than was convenient. Between Kukawa and Kano the scenery is uninteresting, consisting for the most part of bleak, dreary hollows of black, clayey soil, but now they were waving with rich crops of corn-masakwa, ${ }^{*}$ still uncut, and fields of millet $\dagger$ in stubble. Passing by a deep well, on the gentle

\footnotetext{
* Pennisctum typhoüdeum. †Holcus cernuus.
}

slope of the rising ground towards the north great flocks of cattle, goats, sheep, and donkeys were being watered in rapid succession, though the travellers' delight at so animated a scene in the pleasant open country after being moored for weeks in the dull lanes of an African town was damped by the rapacity of the herdsmen, who thought right to sell the water to the new-eomers-a specimen of greed that we have met with more than once in that part of the continent. In Koyam, a land of straggling villages, with cultivated fields and extensive forests of stunted mimosa, which afford food to the numerous herds of camels constituting the people's wealth, the route lay through a country of wandering tribesmen. Unfortunately, it was a land of robbers also, and at night constant watch had to be kept lest their little caravan should be taken unawares, while the leader of it had in his turn to exercise continual vigilance over his drowsy men by rising at night and making the rounds to see that the guards were not asleep. However, the continual novelty of the route, and the prospect of what the next day had in store for them, beguiled the way and enabled them to forget the plague of ants that in places covered the ground, until, approaching the valley through which the drainage of that part of Bornu collects, they became entangled in a network of channels and thiek forests that are difficult to pass after heavy rains. Yet this Komádugu, in spite of the sore legs that are apt to follow frequent fordings and the sloughs into which the wariest rider sinks when he least expects, is in the cool season a kind of African Elysium. Majestic groups of tamarind-trees began to appear and flocks of Guinea-fowl enlivened the landscape, while the camels luxuriated on the rich vegetation produced in so favoured a locality. Yet even this oasis was not without its drawbacks, for, like all similar localities, it harbours immense swarms of mosquitoes that pester the wayfarer during the day and leave him little chance of a rest at night.

The route lay for part of the way along the shores of Lake Tchad, into which the 
Komádugu flows. In the rainy season this basin presents a very different aspect from what it does when the shores are dry, or reedcovered swamps and long black banks of mud appear where a few weeks before there were pleasant bays indenting the shore in the most picturesque inanner. Trees of various species and other rich vegetation fringe it, of various species of water-fowl may be had without much seeking.

The old capital of Bornu (p. 252) did not detain them long, and after fording the river at Zengiri to avoid the wide area over which it spreads during the wet season, they entered the province of Manga. Yet, notwithstanding their long circuit, every now and again the

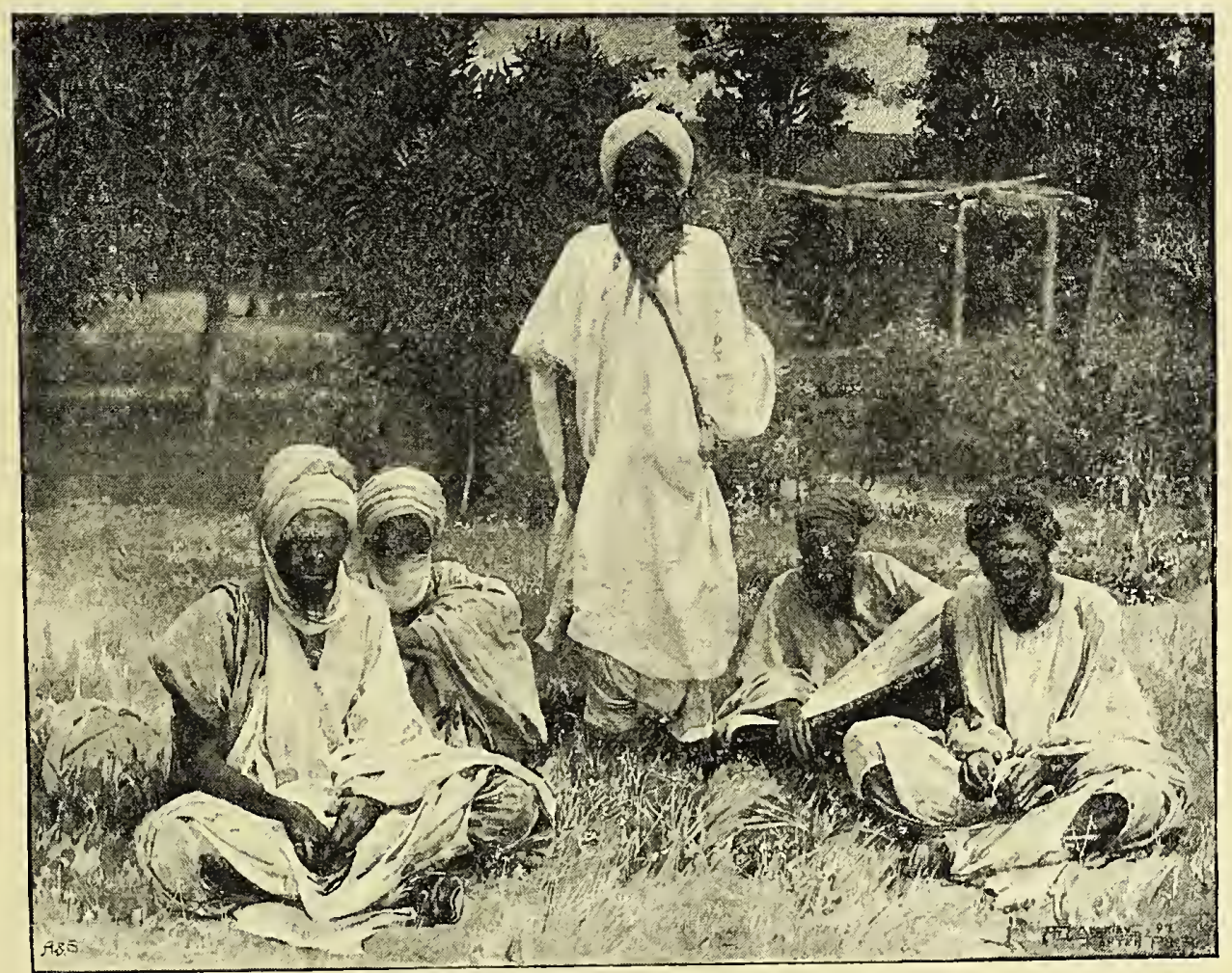

MOHAMMEDANS OF THE MIDDLE NIGER.

(From a Photograph by Capt. Mockler-Ferryman.)

while in the drier places the doom palm* rears its branched head.

Guinea-fowl + were here so numerous that one could hardly move a step without disturbing a group of these lazy birds, which constitute one of the greatest delicacies of the traveller in that part of the world. Nor is larger game lacking. Elephants, several species of antelopes, including even the oryx, or tetel, and the large addax, the wild hog, partridges, monkeys, and an unlinited supply

* Iyphane crinita. $\quad$ + Numida meleagris. march was impeded by many backwaters stretching into the deeper part of the valley amid belts of the rankest vegetation, before they reached the real channel, which wound along in a meandering course, confined between sandy banks of about twenty-five feet in elevation, and clothed with trees and shrubs that imparted a very interesting aspect to this secluded part of Africa. At every step the tetel antelope, startled by the unwonted noise, ambled from among the long grass and bush, and in places the larger 
one, or kargum, fled in terror before the caravan.

Accordingly, though the inhabitants do not culțivate much corn, and, like all the Kanuri, A hunter's or predominant race in Bornu, are paradise. not such keen hunter's as the Houssas, they cannot suffer from want if they draw on the woods alone for their daily food. Howerer, in addition to the land game, the river abounds with excellent fish, so that the English sportsman, who has now ahnost exhausted the hunting-grounds of the worldkilled off the buffaloes in America, thinned the tigers in India, ahmost exterminated the lion, the giraffe, and the quagga in South Africa, and will before long be prohibited from slaughtering the ever-diminishing number of elephants in the East African Company's territory - might do wor'se than try his luck in Bornu and the country between Lake Tchad and the Nigcr through which we are now journeying with Dr. Barth and the Shereef from Fez. For it is this beautiful region, by the luxuriant shores of the Komáchugu, from which the native in his inborn laziness, too idle to restrain the overflow by embankments or to utilise it during the dry season, has despairingly retired and allowed it to be converted into the almost impenetrable jungle where the elephant has now his principal home in Central Africa.

For the first time in Nigerland a real jungle began to appear, and wherever the tall trees or bush was thinner, there long, coarse grass, ten fect high, fed by the water which after the rainy season covers the whole of the low ground, aftorded ample pasture for the game with which it abounded.

The river-which was at one time believed to flow out of the Tchad into the Benuéduring the rainy season sweeps along in a fine current, about one hundred and twenty yards broad, into the lake. All was quiet and full of repose when Barth's caravan passed. There was no traffic with the exception of a couple of homely travellers, a man and a woman, who in simple native style were crossing it riding on a pair of yoled calabashes (p. 293) and immersed in the water up to their niddle, while they stowed away their little clothing inside the ressels that supported them above the surface. Yet, notwithstanding their energetic labours, they were carried down by the force of the current to a considerable distance. Besides these primitive voyagers a solitary spoonbill proudly swimming up and down was the only other being in sight. But the inhabitants were sufficiently extortionate in their demands, asking for cloves in payment, and when these were not to be had, raising the price to what for that part of Africa is an exorbitant figure. Finally, they accepted a Maria Theresa dollar, and for this the travellers, their horses, camels and luggage, were ferried across, each cannel being drawn by a man, mounted on a pair of calabashes, while a second man bestrode the animal close to the tail. The other prices prevailing here may be inagined from the fact that a sheep was bought for eight "gábagá," or strips of cotton cloth, which, in common with cowries, have now quite displaced the old standard pound of copper, though the term "rotl" is still used to express an equivalent value. For smaller payments cowries alone are used.

The province of Manga, which they had now entered, differed widely from that of Koyan, which they had left, the country consisting of undulating Koyam and downs of red sand famous for the contrast. cultivation of ground-nuts and beans, both of which form a large proportion of the people's food, so that millet and beans are generally sown in the same field, the latter ripening later, and constituting the richest pasture for camels and cattle. Their dwellings are also different from those on the other side of the river, the cornstack-looking huts that impart so decided a character of peace and repose to the villages of Houssaland, but which we look for in vain throughout Bornu proper, here again making their appearance under the name of "sébe" or "gusi." Though not remarkable for cleaniiness, they have at a distance a rather neat 
appearance, being covered with creepers of various species of gourd. Finally, as if pointing to a time when the river divided two branches of the Bornu people having little connection with each other, the Manga people are no longer horsemen like the Kanuri, or camel-breeders like the Koyan, but footmen with leather aprons, armed with bow and arrow and battle-axe, while, to use Barth's words, " the more slender Manga girl, scarcely peeping from under her black veil, with which she bashfully hid her face, had succeeded to the Bornu female, with her square figure, her broad features, and her open and ill-covered breast." It may be added that though the Mangas now form a considerable element in the Bornu nation, their name does not occur in the early annals of the einpire which certain of the chroniclers have preserved, and we may therefore.presume that they owe their origin to a mixture of tribes. But if the Manga girls are modest, the men have their fair share of assurance; for, heedless of the holy origin of the Morocco merchant, they stole his woollen blanket from beneath him at night, dragging the Shereef, reluctant to quit his property, until he was forced to let go.

Past the walled town of Gremari, with herds of cattle around the walls, they entered a drier and hotter country, where they were joined by troops of country pedlars bearing their wares on their heads. Yet in spite of the increased waruth, this region of Iluniyo, with its wooded hills, salt- and fresh-water lakes, towns, villages, cultivated lands and pastures, its endless herds of cattle and camels, and flocks of sheep and goats and droves of horses, was in keeping with the pleasant names "Queen of the Region of the Doom Palm," "Sweetness of the World," and so forth, by which the places on the way were known. All the wells were deep, so the crowds of boys and girls were kept busy drawing water for the animals constantly arriving, while numbers of people were met with carrying their harvest into the towns in sacks made of the leaves of the doom palm, borne on the backs of oxen. In this region natron lakes similar to those already visited (p. 245) are found, though, unlike those in the desert country farther north, the borders of the lakes arc covered with cotton-patches, kitchen-gardens where deraba* is grown, doom bush and rank grass.

In this way the travellers journeyed along, seldom molested, and indeed almost invariably treated with hospitality, and sometimes with unexpected kindness. Walled towns and villages, negro huts and clay palaces, dotted the country so thickly that it was seldom that men or the signs of human habitation were out of sight. But, as always happens in a country where communications are slow or difficult, food was plentiful in one district and scarce in another, while the calculations of the traveller as to expenses were conlplicated by the different value that money or its equivalents had in different regions. Even Barth, who had the thrifty German's art of travelling at a cost the secret of which all his successors have failed to acquire, and who when necessity compelled opened shop in order to dispose to the best advantage of the goods with which he was provided to pay his way, was sometimes puzzled to decide whether he was being cheated or simply paying the market price.

Some of the towns, like Guré, built on the lower slope of a rocky eminence, and surrounded with a wall, beyond which lay kitchen-gardens and cottonplantations, were picturesque-at a A land of walled towns. distance-and the governors men of consequence, though, like corresponding dignitarics in more civilised regions, often sorely pressed by the lack of cash. The ruler of the district of which Guré was the capital (p. 288) could, for example, put 1,500 horsemen and from 8,000 to 10,000 archers into the field, while his revenues amounted to $30,000,000$ cowries-or, according to the standard of the place, about 10,000 Spanish dollars-besides a large tribute of com, which in all provinces north-west of the

\footnotetext{
* Corclerns olitorius, or Jew's Mallow, a plant allied to the Chinese hernp or jute, now used for so many purposes. It is cultivated as a pot-herb.
} 
Komádugu, owing to these territories having preserved their independence against the Fulahs, belongs to the governors pcrsonally, and not to their sovereign lord the Sheik in Kukawa. Every adult male in the province has to pay in taxes 1,000 shells for himself, and, if he possess cattle, for every pack-ox 1,000 inore, and for every slave 2,000, which ratio. may be taken to express the relative value of master, man, and beast in the politico- just then on the eve of setting out on a foray against one of the towns that had displayed some friendliness to the Touaregs, in order to "obtain slaves to pay his debts."

Wushek is another peculiarly interesting place_-" a mixture of fertility and aridity, of cultivation and desolation, of industry and

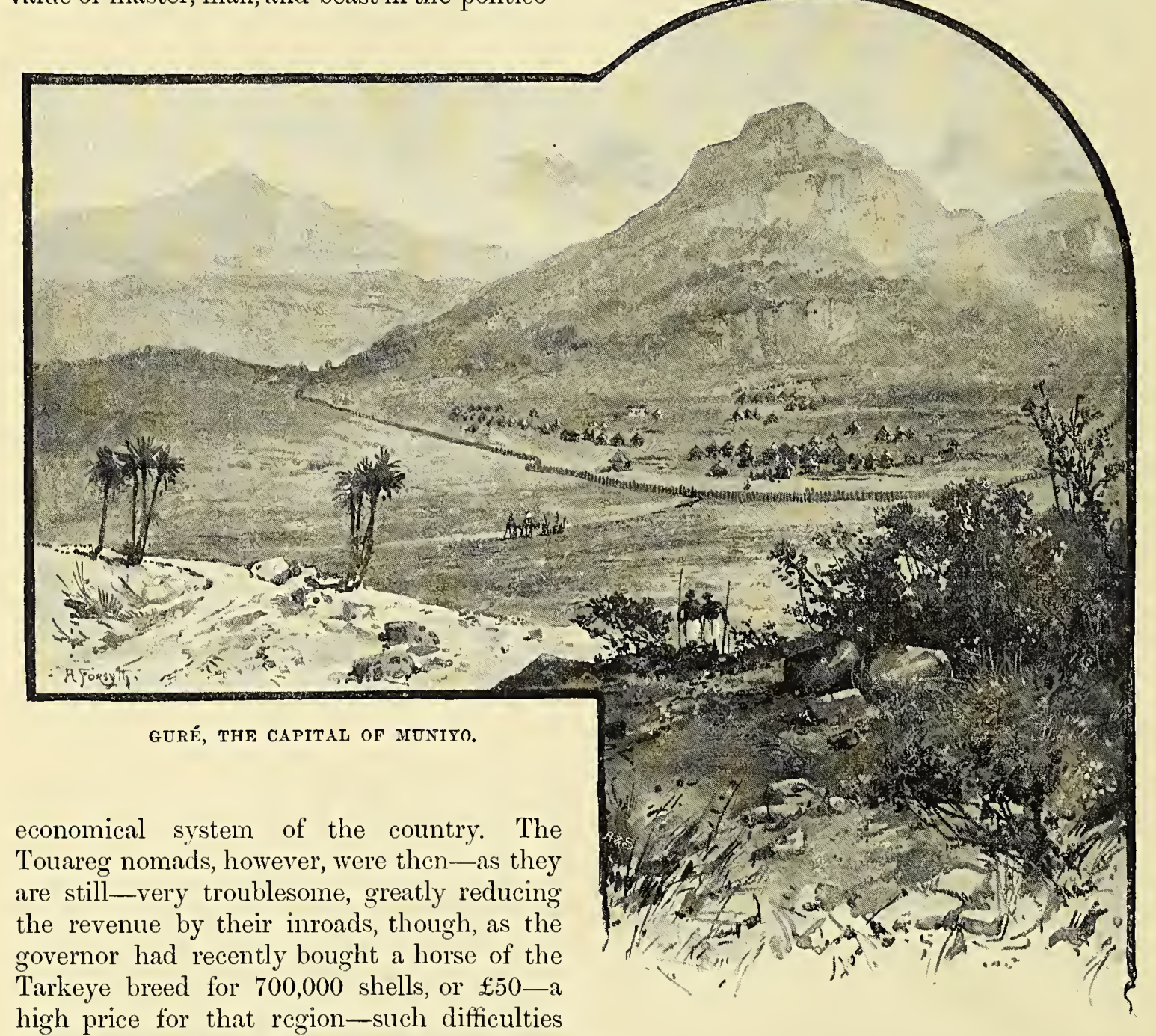
did not interfere with his personal expenditure - especially when the merchant had to wait for his money. Slave-hunting at that time was so regular an occupation that the governor -a man of exccptionally good characterbegged Barth to prolong liis stay, as he was

neglect"-being situated at some distance from the foot of a mountain-range, and scparated from it by a barren tract, whilst on the site of the town itself the springs burst out in several small dells or hollows, which 
thus yield a good crop of wheat and sereral small groves of date palms, and on the drier ground tamarind trees entwined with creepers and clothed with herbage. As might be expected, water is abundant, ponds forming in favourable places, and wells, generally full, being dug at a foot or two beneath the surface. Wushek is also the chief wheat-growing district in Bornu. Ruined holds and towers are not uncommon, the country, peaceful though it looks, having been again and again ravaged by civil war and foreign foes. Thus Gabata, the old residence of the governors, is now nothing but a heap of unsightly walls and arches, though in a recess at the foot of the mountains is standing a stone dwelling in which it was of old the custom for every ruler of the country upon his accession to the throne to retire for seven days. The natives say that there are carcs leading from the stone house into the rocks, but the governor urgently begged the white men not to visit it, for the place was-as all such eerie spots are in Moslem mythology - haunted by spirits or jinns, who would resent any such profanity from mortal men. It was on Christmas Day, 1852, that Barth arrived at the town of Zinder, a famous place for trade, and notorious also for the numerous fires that at intervals destroyed the wattle huts of which a large portion of it was composed, so that a trader might between sunrise and sunset be ruined by his merchandise being reduced to ashes. As for the ordinary citizen, he had little to lose; a few hours' toil replaced his mansion.

Here Barth had to wait for supplies that were to be sent him by an Arab caravan Zinder and its commerce. from Tripoli. This rather risky consignment duly arrived, the money portion of it being packed in two boxes of sugar, so that, happily, few people were aware that the Christian had received treasure so readily plundered. With the coin and other articles a supply of red bernouses, or cloaks, turbans, looking-glasses, clothes, razors, chaplets, and other articles was purchased at a moderate rate, all European goods, after the arrival of a caravan, falling in price. Unfortunately, another box containing English hardware and 400 dollars, which reached the town soon after he left, remained in the hands of the Shereef El Fasi, the Grand Vizier of Bornu's agent, until, in the revolution two years latcr, this man was murdered and his house plundered of all it contained.

At Katsena, farther on, another halt was made, and more goods were purchased in the shape of cotton and silk articles made at Nupé and Kano-the Katsena. "Manchester of Africa," as Barth calls it-and leather watcr-skins, for which the place is famous. Black shawls for covering the face were taken as gifts to the Touaregs, who adopt this method of protecting themselves from the grit and glare of the desert sand. Another article for which Katsena bears a good reputation is tobacco, and of this and turkedis, or women's cloths, a good supply was laid in ; so that, provided with goods in so much favour with the negro, he felt safe to pass without much trouble the countries lying beyond.

After a perilous journey, owing to the fact of civil war having broken out, and a hostile army being on the road, and also due not a little to the circumstance that the governor of Katscna had begun to look with a covetous eye on the wealth that Barth possessed, the caravan arrived at Sokoto, a spot that we have visited more than

Sokoto.

once with earlier travcllers. At that date it possessed some five thousand inhabitants, but had ceased to be the capital of the decaying Fulah Empire (p. 223), and at the time of Barth's visit was governed by a "ghaladima," or deputy. Everything bespoke decay. The Arabs, who at one time frequented the place, no longer came, and the whole trade in foreign merchandise had passed into the hands of the people of Ghat and Aghades, many of whom were wealthy. Blind beggars swarmed; and a visit to the market-always a safe test of the wealth of any town-suggested the poverty which war and turmoil had brought abont. The house in which Clapperton died (p. 259) was still in a fair state of preservation, but 
the mosque that was a-building during his stay in the town was, like many other structures, in ruins. The market, held on a rocky slope, had, however, a good many buyers and sellers of horses, cattle, oxen, and the leather goods that are extensively manufactured in Sokoto. The bridles of Negroland, and the stirrups made of the excellent iron rudely sinelted in this part of Africa, were in great demand. Some slaves were for sale at a rather high price--a "lad of indifferent appearance" bringing 33,000 cowries, while a good pony was sold for very little less. The salt caravans had just arrived with the article which, from the earliest period, has been a favourite article of commerce over Central Africa (p. 108); and among the minor merchandise that they brought with them were the desert dates, a fruit no longer a staple as it is in the drier countries farther north. Rice is another of the Sokoto crops, one valley near the town being covered with fields of it, though during the rainy season they are under water, and have to be passed in canoes, several of which were lying in halves ready to be sewn together when their services were necessary. Returning to Wurno, which had been his headquarters before the excursion to Sokoto was made, Barth met the Sultan Aliyu, who had just arrived from a warlike expedition against some hamlets that had placed themselves under the protection of his enemy, though, from the accounts received of the cowardice displayed by the Fulahs, it seemed that forty years ago the vigour of this once martial race was beginning, like the towns of the empire they had conquered, to decay.

Glad to escape from the importunate beggars of Wurno-a town that shares with Sokoto the reputation of possessing a more inveterately persistent breed of the people whom the Spaniards describe as "besonosos" ("those who want something") than any other part of Central Africa-Barth, or Abd-el-Kerim, as he found it still prudent to call himself, was glad to obtain Aliyu's acquiescence in his journey to Timbuctoo, and recommendations to its ruler, though every day the country was becoming more and more: dangerous to travel in ; for one African prince is usually so jealous of another that he will often thwart the visit to his rival of so important a personage as a white man.

Beyond Sokoto the country was entirely new to European foot, but, in spite of the disturbed state of the country, a new land: Gando was safely reached, and the Gando.

chief, Khalilú, duly waited upon. This man, a Fulah, was as powerful as the Sultan of Sokoto, and noted for his hatred of Christians. But the judicious gift of three bernouses, "one of yellow, one of red cloth, and the third of the kind called helali; a haik or jérid of the finest quality, a Stambuli carpet, two entire pieces of muslin, a red cap, four loaves of sugar, three phials of rose-oil, a pair of razors, five looking-glasses, a pound of cloves, and another of benzoin," as kingly a presenta pair of silver-mounted pistols excepted-as. the sovereign of Solioto had received, reconciled Khalilú to the dubious orthodoxy of his visitor. Possibly also the desire to stand well with his uncle, the Prince of Gando, who had sent a commendatory letter to him, had something to do with Barth's favourable reception.

By-and-by, however, an Arab named El Bakáy, who, after trying his fortune in many places, had settled down here, managed, with a view to advancing his own interest, to create trouble between Barth and the Sultan, who, leading a sort of monkish life, was easily influenced by this man and by his own brothers, to all of whom, accordingly, presents had to be made. From El Bakáy-a name Barth learned to hate, though it afterwards became dear to him as that of his protector in Timbuctoo-Khalilú learned that Aliyu of Sokoto had received silver-mounted pistols worth more than all the gifts bestowed on him, though he in reality ruled a wider territory than the prince so favoured. Accordingly, Abd-el-Kerim was given to understand that, unless this omission was promptly rectified, he should be permitted neither to proceed on his way nor to retrace his steps. 
As this was impossible to think of-though the country from this spot to the Niger was so troubled as to render it doubtful whether it wonld be wise to go on-a second pair of pistols had to be sacrificed, and, after endless bribes to the Arab who saw his chance to act as the intermediary, a letter of safe conduct was procured from the Sultan, and once more, in the first week in June, this leisurely journey was resumed.

With the great river within approachable distance, the dread that by any chance he wars and should never be able to see it rumours of oppressed the traveller's spirits, war.

while at the same time every step, being across a region that previous explorers had avoided, was full of interest. Yet it almost seemed as if he were doomed never to drink of the Niger waters. Not a day passed without signs of the ravages of war coming before the eyes of the travellers. Passing by a sheet of water that receded behind the walled town of Badda-badda, traces of the elephant, which had disappeared for a long time, now grew thick near the rice-fields and rich pastures that led down to the Faddama. A little farther on the little town of Yara was reached, and the caravan was urgently warned by the people met with to be on the outlook for an approaching raiding party. Tara was a tragic monument of the misery wrought by the war now desolating the country. Not long before it had been a busy place. But all the inhabitants were now carried into slavery, and the entire aspect of the deserted town was doleful and melancholy in the extreme. Yet immediately outside the village lay a luxuriant rice-field, where the crops were already almost three feet high, and girt by a lovely border of shade-trees, overtopped by a number of tall daleb palms, the golden fruit of which, half ripe, was starting forth from under the feathery foliage. Close by, a solitary individual, seemingly careless of the unsafe state of the country, sat quietly at the foot of one of the palm-trees stolidly enjoying its fruit. Suspecting him, not unjustly, to be a spy posted here by the enemy in order to give information of any travellers worthy of plundering, it was difficult to prevent some of the caravan from shooting the innocentlooking negro.

Still marching through a very rich country, the travellers, to their delight, met with the first evidence they had for a long time time seen of Western civilisation. from the This was a Joloff (p. 156) from the Atlantic. shores of the Atlantic, carrying his little luggage on his head, and making for the walled town of Kardi, though, from the doublebarrelled gun that he carried on his shoulder, and the short sword hanging at his side, while his shirt was tossed gallantly up and tied over his shoulder behind his neck, the far-travelled pedestrian scemed inclined to rely for safety more on his own right hand than on any man's hold. "In my joy at the sight of this enterprising native traveller," Dr. Barth tells us, "I could not forbear making him a small present in order to assist him in his arduous undertaking." At Kola, another walled " city," defended by seventy musketeers, who can, if necessary, block the great valley of Kibbi, a halt was made to conciliate the powerful governor, who, like his sister, was extremely hospitable, the lady evincing her goodwill by the gift of a goose, a bird less common than barn-door fowls in this region, and of later introduction from the European settlements on the West Coast. Well-fortified towns, additionally protected by a fence of prickly thorns, were passed every few miles, and everywhere the inhabitants doubted whether, in the turbulent condition of the country, it would be possible to reach the Niger. Many of these places were quite deserted, and remains of others only recently destroyed were frequent. Even the tribute which Nupé had to pay to Gando had, owing to the wars of the two factions that then tore the state in two, to be sent by a roundabout way. Yet close to Kola, under the protection of a couple of well-stockaded hamlets, herds of horses were grazing on the fine pastures. But the herbage was full of small venomous snakes, 
which so repeatedly, and in such unusually large numbers, crossed the paths that, to a footman, a journey in the pleasant meadows nuust be dangerous, since the wild boar is not found here, and the domestic pig, which kceps down serpents wherever it is set free, is naturally not one of the live stock round a Mohaminedan village.

By-and-by, however, leaving behind Juggara, with its groves of monkey-bread trees, Iiggi, where he was welcomed to the province by the governor's sons, and Togirma, the seat

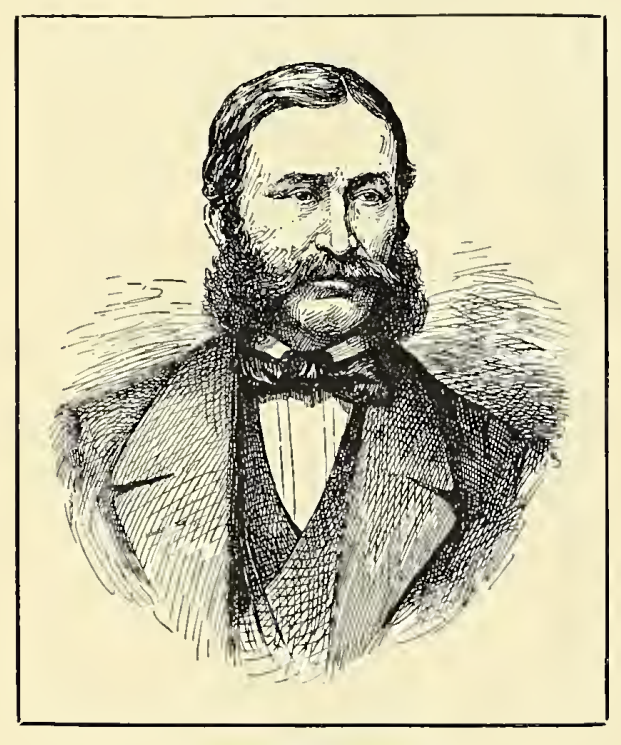

HENRY BARTH.

of government, with from 7,000 to 8,000 inhabitants, but just then suffering from a A forest scarcity of provisions, the travellers march. entered a forest-covered wilderness, pleasant to look upon, as the trees, all in blossom, diffused a delightful fragrance around, but perilous, owing to the absence of villages in which the wayfarers might take refuge after dark. Overtaking a party of Touaregs, who, with camels, bullocks, and asses, were on their way to Fogha, an unwonted treat was experienced in the shape of a night in the open country, instead of in the dirty luuts that had hitherto formed the travellers' lodgings. 'Two extensive ponds supplied delicious water, though, curiously enough, when returning by the same route little more than a year later, the same ponds had acquired-either from being meddled with or the decay of vegetation-such a pernicious character that almost the whole troop drinking of them were poisoned. But to the natives the delight of the woodland was nothing. So much terror, indeed, did its real or supposed dangers inspire, that the merc fact of Barth having spent a night in the unsafe wilderness was sufficient to secure him a reputation for courage that lasted long enough to be fresh when he passed that way in the following year.

The valley of the Fogha, which falls into the Niger one day and a half from Gaya, is one of the shallow dales that give The Niger so remarkable a feature to this tributaries. portion of the country. The water flowing through them exhibits no current, showing that the country has little inclination towards the great river, and it is also an evidence that it drains only so linited an extent of ground that it is doubtful whether, even after the plentiful rains that fall in the mountainous country of Air or Asben (of which Aghades is the best-known spot), the water-courses of that region have the slightest connection with these shallow vales that join the Niger. Salt lakes, fields of yams and tobacco, and herds of elephants-wherc the country was wooded-abounded, in spitc of the wretcherlness that the civil war then in progress between the adjoining provinces had caused, and continued until, at Garbo, the last Houssa village was reached and hurried past, since, notwithstanding the many corn-stacks standing around it, no grain was to be obtained.

Beyond this part all the country was Songhai, and at Songho-sare, a pleasant farming hamlet largely inhabited by slaves bclonging to the people of Tamkala, they found plenty of corn. The architecture-such as it was-of the houses was now markedly altered, instead of evil-smelling, unventilated clay luts, the Songhai villages consisting 
merely of reeds, so that, while the dwellings are less solid than those of Kebbi, they are better ventilated. The people of this place also seem to be more hospitable than those of the country generally, if a "jovial farmer" is to be accepted as a type of his people. For; in addition to a hearty welcome, this rendered the labours of the husbandman uncertain. Even the people were, if possible, more inhospitable than the Songhai, who, in their present degraded condition since the break-up of the old Songhai Empire, bear the reputation of bcing a sullen race; for at another village, called Tigore, inhabited by frec farmers,

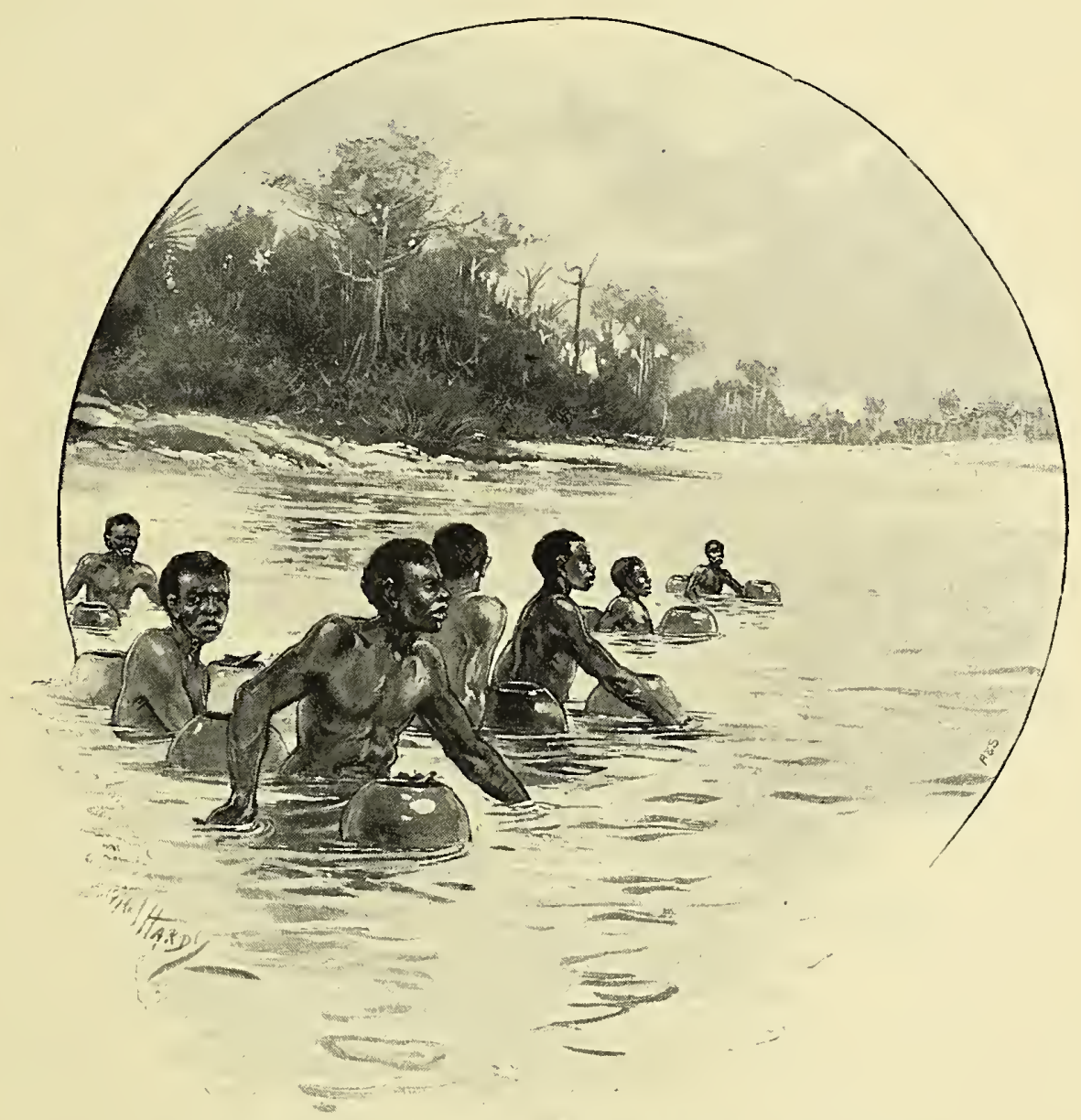

NATIVE MODE OF CROSSING A RIVER BY MEANS OF CALABASHES.

agriculturist presented the travellers with milk, corn, and a sheep. Hot weather and drought compelling short marches, the next few days were not so agreeable as their predecessors. The land was parched and untilled, except here and there, or covered with underwood which bespoke either poor soil, little security; or periodical spells of rainless seasons that difficulty was found in obtaining quarters, and at Tanna, a much larger one of the same character, "the Mayor" was so surly a functionary that he refuscd to leave his cool shed in the heat of the day, so that a hut to shelter the party could only be procured after the argument of force had been applicd.

The party was now approaching the Niger, 
and, elated with the feeling that one of the The Niger great objeets of the long journey is reached: was now over, Barth set forward town of Say. with buoyant spirits until, after a eouple of hours through a roeky wilderness covered with dense bushes, the noble river lay before them with the town of Say on the other side (p. 108). Here the stream, being hemmed in by a roeky bank, was only about 700 yards in breadth, but the opposite shore was flatter, and there the low ramparts and huts of a large town, overtopped by slender doom palins, spread out in a most pieturesque manner.

The ford was a busy one-camels, asses, paek-oxen, eorn, sheep, and their owners, with large paek-trains of merchandise, erossing and reerossing in large boats made of two trees hollowed out and sewn together in the middle. Barth's arrival was not unexpected, and the "King of the Waters"-the harbour-master, as we in our less flowery language would term him-had sent to Sinder, higher up, for the largest eorn-boats, in order that the stranger should be ferried aeross in good style. It was with strange feelings that Barth now floated on the river of so many hopes. Doubtful from the very first whether he would ever have been able to reaeh the Atlantie-though it now appears that this might have been done without greater labour than the return journey to Tripoli cost-he had determined on an even more interesting task-to survey the eourse of the Niger between the part where it had become tolerably well known by the labours of Park and Caillié, and the lower portion explored by the Landers.

In Say he reeeived a polite but by no means effusive weleome, and quarter's that were scareely to his mind. But the town itself, picturesque though it looks from the opposite bank of the river, is a poor affair when examined from the inside. It is large, but thinly inhabited, and, with the exeeption of the Governor's "palaee," all the houses are built of reeds and matting, seattered in groups like so many independent hamlets. It is, moreover, very unhealthy, the valley in whieh it is situated being at the end of the rainy season filled with water, stopping all business and, when the floods are higher than usual, eompelling the eitizens to seek safety beyond the borders of the valley, their town being then in reality, as it is geographieally at all times, on an island. The market was poor eompared with most of those Barth had seen in the great towns through which he had passed, and at the time of his visit, Say and Houssa being on unfriendly terms, provisions were searee and dear. Yet, in spite of the superabundanee of water, no riee was grown anywhere near the town. But the situation of Say as a eommereial eentre is undoubtedly great, it being the beginning of a long stretch of open water above Bussa and Yauri, a geographieal faet whieh the Freneh have already grasped, to the loss of the nation in whose interests Barth pointed it out in 1852.

It was now midsummer, and fever rampant. Nothing was to be gained by staying longer here; Timbuetoo was before him, Along the and thither aeeordingly, amid a Niger banks. storm of thunder, beginning with a terrifie sand-wind and ending in torrents of rain, the travellers set out. But to the farmers of the hilly eountry through whieh their route lay the rainfall was weleome in so far that it had rendered the soil fit for tillage and the reeeption of the seed-grain. Aeeordingly, wherever the ground was fitting for ploughing in the primitive scratehing manner praetised all over aboriginal Afrien, it was being prepared for the harrest, which in those favoured lands ripens in a month or two. Hill and dale, in general treeless and uninhabited, and at times a wilderness with only a few inhabited spots, was the general character of the country through whieh they passed, until at Champagore, a town encircled by hills, a halt was made. This place is remarkable for its eorn magazines, two of whieh are seen in every court-yard. These are towers or quadrangular' buildings, raised a few feet above the ground, in order to protect the eontents from the white ants, whieh are everywhere the pest of this region. Shaped not unlike the dove-cots of Egypt, they are from ten to fifteen feet in 


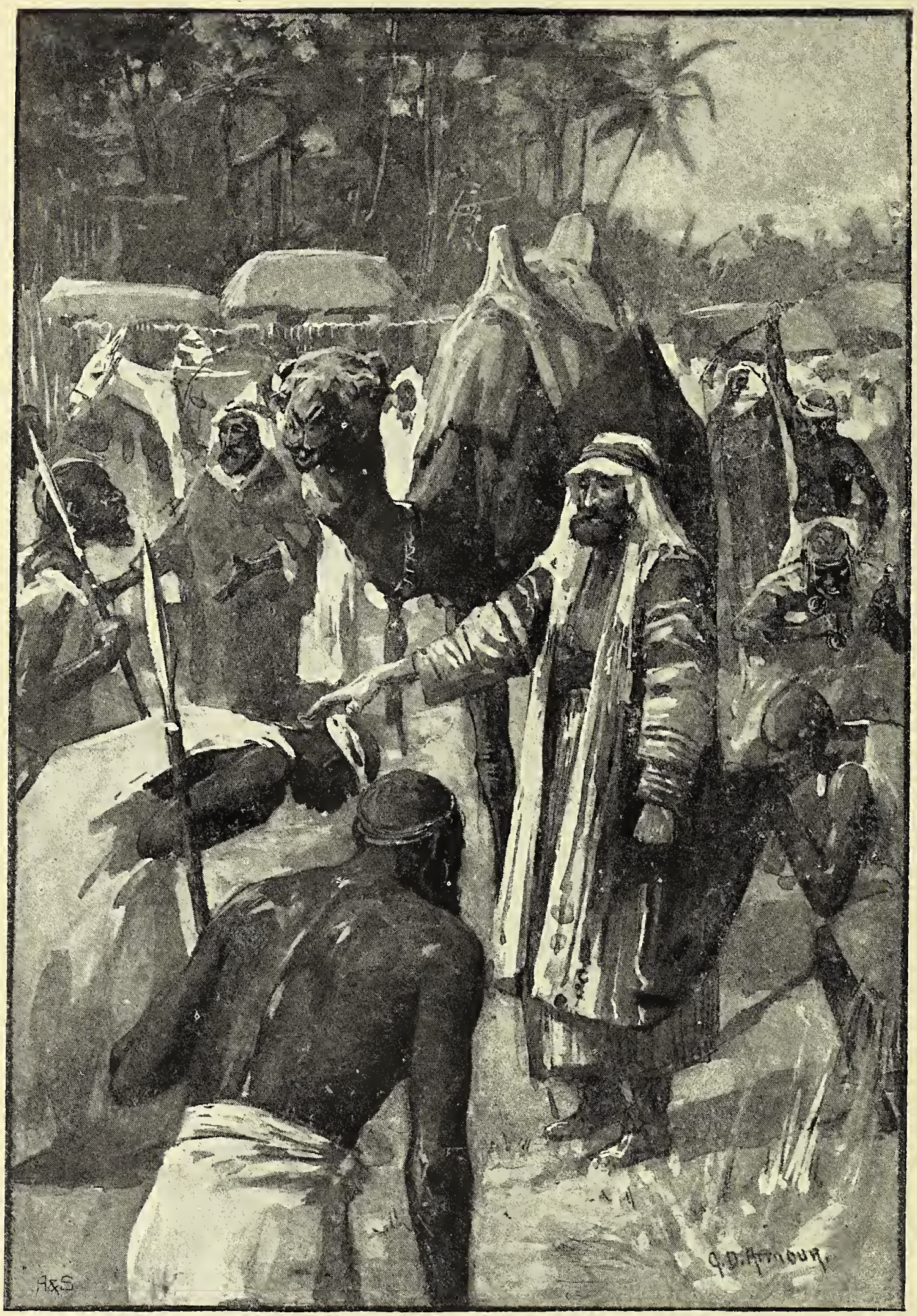

"BEGGED THE BLESSING OF THE SYRIAN PILGRIM" $(p, 295)$. 
height, without any opening at the bottom, a window-like aperture near the top serving at once for the admission of light and the putting in and taking out of the corn. Altogether, like the steeples of some village churches in England, they quite dwarf in appearance the less imposing structures built near the base.

Continuing his journey through the hilly country of Gurma, provided with an armed escort from the chief of Champagore, the party passed on the way several iron-smelting furnaces, about six feet high and a foot and a half in diameter at the base. The ironstone, of which quantities are dug out of the hills, is placed under a large amount of, wood-ashes until the metal begins to nielt, and is then,
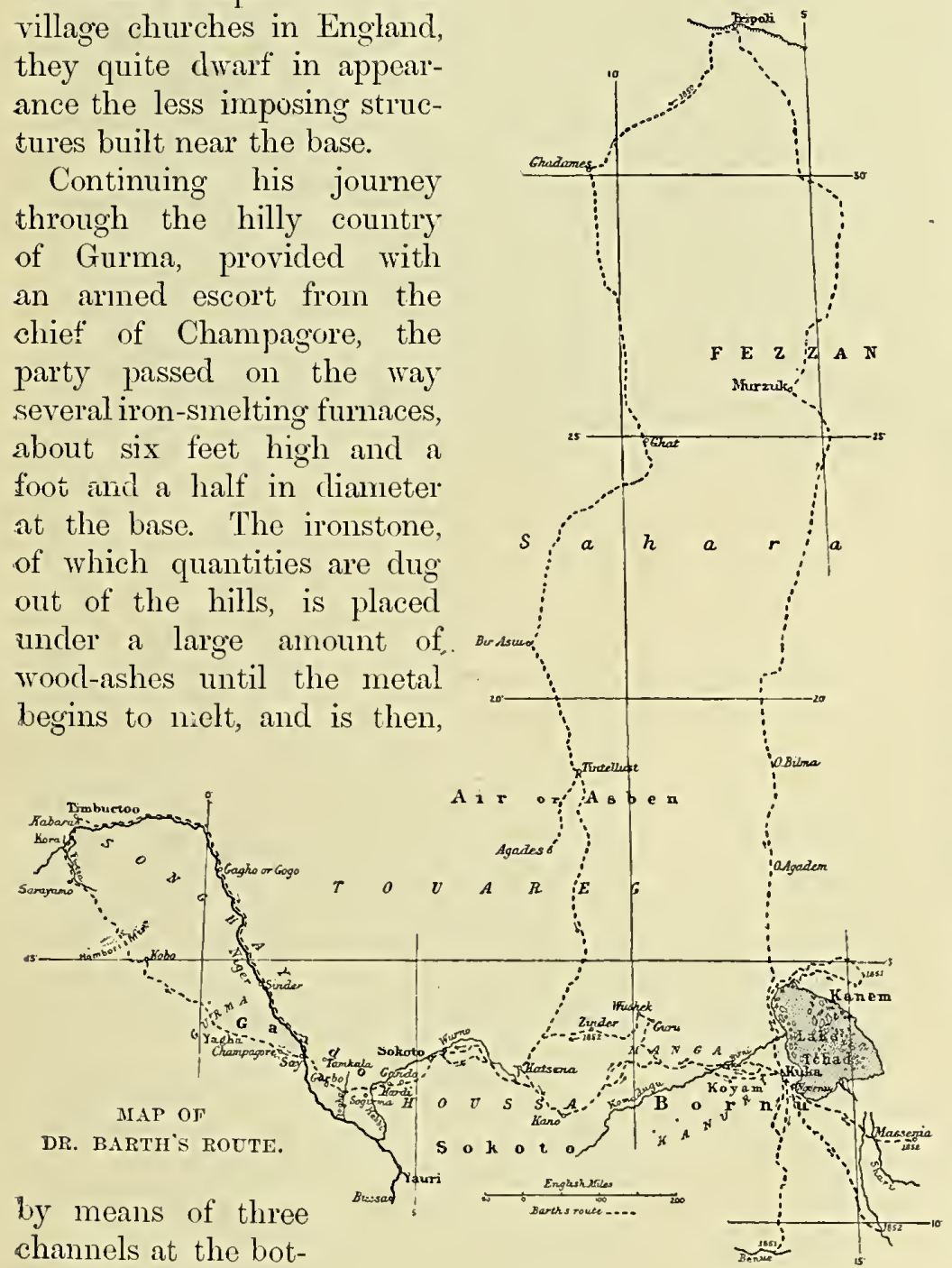

porters themselves swam beside them (p. 293). Footprints of elephants were seen, and once a large herd of buffalo were observed cropping the rich pastures by the river. In the provinces of Yagha, the weavers, the basket-makers, and the makers of leatherwork were busy at the door of every hut, though, many of their dwellings being infested by ants, it was perilous to the baggage and torture to its owner to pass a night under their roofs.

As Timbuctoo grew nearer, the fanaticism of the people became more virulent, and at one A fanatical folk: troubles. place, had not the traveller represented himself as an officer carrying books to the sheik-and therefore endowed with a special sanctity-_even Barth's profession of orthodoxy would not have saver him from the fury of these savage Moslems against anyone even suspected of nonconformity. The plea mentionerl, however, succeeded only too well, for the spears dropped from the hands of the irate mob, and each in turn begged the blessing of the Syrian pilgrim - as he called himself-a process that intom of the furnace, received in a basin. At times bends of the river had to be crossed on bundles of reeds,* or by means of calabashes in which were stowed the smaller articles of luggage, while the

* The writer has crossed rivers in Morocco in an identical fashion. Until very lecently-if not still-these bundles were the only approach to a ferry-boat across the Sebu river on the caravan route from the city of Fez to El Kassis El Kebir, half-way to Tangier. volved laying hands on a great many very dirty hearls. Poverty seemed the rule of the villages. The mayor of one was an old man in a ragged shirt, though his two fat wives were resplendent in copper armlets and bracelets, with a thin plate of tin on the under lip, like that worn by the Nlargi, $\uparrow$ though they do

$\uparrow$ This may be compared with the still more curious "ornaments" worn by the Hydah women in North-West 
not sport the nose-ring so general among the Songhai women.

At Namantugu Barth fell in with an Arab from the West, one Weled Ammer Walati, in whose company he was fated to enter Timbuctoo. Hither had Walati emigrated after leating a roving life among the louaregs and Fulahs, and, among his other accomplishments, he spoke with the greatest flucncy almost all of the languages between the Atlas and the Niger. In spite, however, of his grave appearance-his long dark gown and the black shawl about his head giving him somc resemblance to a servant of the Inquisition-El Walati was much too clever for Barth and, before the traveller had done with him, played him many a scurvy trick.

The greed of the people secmed to increasc as the great town was neared-even the governors, after being presented "The church, with gifts, begging the clothes the the farther , traveller wore. English darningfrom grace." needles were, however, held in much esteen, though the oidinary sewing ones were not reeeived with much gratitude. In the 'Touareg country the situation bccame more dangerous, for those nomads arc a fanatical raee, and as Barth had been represented to them as a great "Shereef,"-or deseendant of the Prophet-his Arab companion, "one of the clevercst men" he had ever mct with, suggested that Barth should keep up his eharacter by largess on a more than usually lavish seale, and as his counscllor aeted as the interpreter and go-betwcen, he managed to sell to the tribesmen the traveller's prescnts as his own goods!

As they approaehed 'Timbuctoo, the eagerness of the people to buy, or to be given, tea"the water of Simsim" (the holy well of Meeea), as they ealled it-grew more and morc keen, and by-and-by even the women plagued the traveller for tobaceo, whieh seemed not to be grown in that part of the eountry. Impeded by heavy rains and end-

America, and by the Botoeudos of South America, for which see "The Peoples of the World," vol. i., pp. 48 , 90, and "The Countries of the World," vol, iii., p. 160. less flooded rivers and swamps, progress along the banks was slow and tedious.

On the 27 th of August, after passing through a country full of Fulah eattle-breeders and rocks worn into fantastic shapes

by the pain they rached the Barth emtown of Sarnyamo, not without Niger for Tl WTa Kabara. El Walati trying once or twice quietly to dispose of Barth in order to inherit his property; and here the land journey cnded and the Niger voyage began. By this time, not improbably owing to the knavery of this man, suspieions as to the religion of the Syrian pilgrim again took sueh shape that he was glad to repeat the opening prayer of the Koran, which concludes with "God may give water." And as it so happened that next day rain fell, the stranger's petitions were in great favour. The governor-who asked for a blessing and an crnetic-was, however, less plcased. For, though the latter acted like a charm, he was shoeked in afterdays to learn that the former had been bestowed by an Infidel. At Kora Island, where the Fatta joins the main branch of the Niger, and forms a network of baekwaters and channels that spread over a large area of country, the party embarked in a large boat hired for their exclusive use. Croeodiles, hippopotami, and tishes were abundant, and huge lizards basked on the dry spots amid this archipelago of low islets until the open river was reached, under the name of the Isa or Mayo Balleo. During the palmy days of the Songhai Empire, fleets of boats eontinually passed and repassed up and down the river to Gagho and Jenné. But in the course of their voyage they met with scarcely one, and now, close to the great commercial city, the vast flood was as solitary as if it did not exist. Then, on the 7 th of September, 1853, six days aftcr sctting out, the boat crossed the river and entered a crcek, whieh grew shallower until it anehored off' a town on the slope of a sandy cminenee. Then the traveller knew that for the present his journey was nearing its end, for the town of dome-shaped houses was Kabara, the port of 'Timbuctoo (p. 121). 


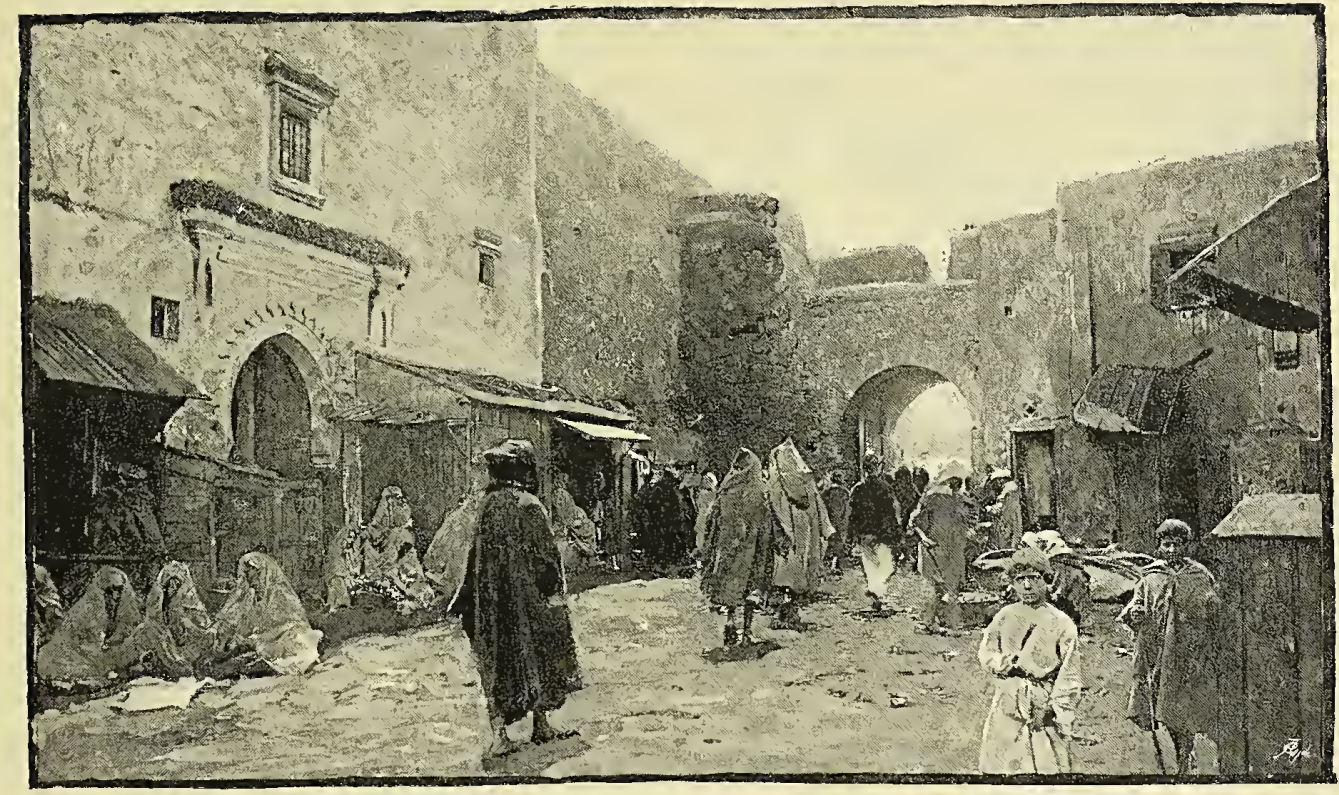

TOP OF THE MIIN STREET OF TANGIER, MOROCCO,

(From a Photograph by Mr. Consul H. E. White of Tangier.)

\section{CHAPTER XVI.}

\section{The Last Seekers after Thmbuctoo: Bartu ; liordokhä̈ Abi-Serour; Lenz.}

Barth in Timbuctoo-Timbuctoo in 1854-Barth's Homeward Journey-His Arrival in England and Later Career-His Merits as an Explorer-The Rabbi Mordokhaï Abi-Serour-His Early Life-Ventures to try his Fortune in Timbuctoo-His First Journey across the Desert-His Stay in Aruan-Reaches Timbuctoo -Troubles there, and Eventual Success-His First Caravan of Goods gets through safely, and he Returns with another and four of his Friends-Plunder of his Caravans by Desert Robbers-His Commercial WreckHis Work as a Geographical Explorer-Desert Ruins and Sculptures-The Daggatouns-The Jewish Colony in Timbuctoo-Oskar Lenz-Travels in Morocco-Crosses the Sahara by the same Route that Mordokhaï did-His Stay and Courteous Treatment in Timbuctoo-Returns to Senegal-A Last Word on Timbuctoo -Its Present Condition and Future.

THERE was a time in the history of the Soudan when Kabara was an even more important place than Timbuctoo. But at the date of Barth's visit its glory as a river port had sunk so low that its inhabitants did not number more than two thousand, in no way distinguished by wealth or intelligence. Having, in his character as a Syrian pilgrim under the special protection of the Sultan of Turkey, secured quarters in the town, he was soon visited by a truculent Tarki chief, who demanded a gift, which being refused, he left, and Barth's quarters were immediately filled by armed men. He was, however, glad to learn that these were merely herds- men who had come to protect their cattle from the very man who had just gone, he and his followers, in addition to some Touaregs, having arrived on a raiding expedition. This incident was the key to the situation, Timbuctoo and its neighbourhood being alternately under the domination of one tribe or another, and the whole country for miles around at the mercy of robber chiefs, without any power strong enough to keep them from pillaging the residents or the strangers who came here to do business. Meanwhile El Walati saw that he was master of the situation, and at once began to impoverish Barth by asking him for goods 
not only for himself, but for a great many individuals whom he represented to be his friends and brothers, before he set out for Timbuctoo to seek protection for Barth from the Sheik El Bakhay, chief of the Arabs, on whom Barth had all along been relying. Next day he returned, not with El Bakhay, who was from home, but with his brother, Sidi Alwati, and some of his followers, all of whom were very anxious to know what was the kind of protection the Turkish Sultan had given, since it leaked out that El Walati had told them that the traveller was really a Christian in disguise. As Barth had parted with his firman from the Bashaw of Tripoli, and did not possess any paper bearing upon his present situation, it became urgent to reach Timbuctoo at once and obtain the favour of $\mathrm{El}$ Bakhay, since in his present situation he was practically an outlaw, to kill whom, as an Infidel, would not entail any punishment on the murderer.

Next day accordingly he left Kabara amid a crowd of people attracted by the news that a stranger of distinction had arrived. Between the port and the city lies a desert tract covered with thorny acacias and stunted trees. Yet these five miles are so dangerous, owing to the Touareg robbers that haunt them, that in the language of the country they are known as "Ur-immandes"- "He (God) does not hear" - from the fact that people are constantly killed in this little desert without their cries reaching the ear of anyone able to succour them (p. 208).

Near the town Barth was met by a crowd of people who had come out to welcome him.

Entrance into Timbuctoo.

Among these polite 'Timbuctooese he was so unfortunate as to meet with a man who addressed him in Turkish, a language in which the pseudoSyrian traveller had some difficulty in framing an intelligent reply, in spite of his being supposed to be a subject of the Caliph, who in this part of Africa is held in higher esteem than elsewhere (p. 301). Glad to leave so compromising a company, he traversed several narrow streets of dirty reed-huts which form the suburbs, into a quarter where many of the houses were two storeys in height, until the dwelling apportioned to him was reached. Here for a time he could rest in safety. But the safety was only temporary; for El Walati, who had counselled Barth to pass as a Mohammedan, had as usual played the traitor, and, by telling that he was a Christian, roused the fanaticism of a city which is in many respects-or, at least, was in those days-as bigoted as Mecca. In the absence of El Bakhay, he considered it prudent to keep in-doors, only ascending now and then for fresh air to the flat roof of his house, from which he could survey the mixture of clay huts, big and little, the narrow lanes, in which it was difficult for two horsemen to ride abreast, and the market, glimpses of which he could obtain owing to its situation on the slope of the sand-hills that in course of time have accumulated round the principal mosque. To obtain the means of support, goods were every now and again sent into the market for sale; but, in the face of orders not to admit anyone, his retirement was continually interrupted by visitors attracted either by curiosity or by a desire to obtain information from the learned stranger.

At last, on the 26th of September, nearly three weeks after his entrance into Timbuctoo, El Bakhay arrived, and from that time the traveller's position was improved, since, apart from Barth having been recommended to this powerful man's protection, the Sheik himself was notoriously large-minded, and even liberal, beyond any of his countrymen in the city. Even in the matter of gifts, a question in which an Arab seldom shows any conscience, El Bakhay, after receiving articles worth about thirty pounds, desired to be given nothing more, only intimating that when the traveller returned home he hoped the British Govermment would send him some Arabic books and good firearms. From that time, during the nine months Barth passed in Timbuctoo, El Bakhay seldom intermitted his kindness, and but for his influence it is doubtful whether the traveller would ever have been permitted to leave the 
city alive. The feelings of the people to him were naturally not warm, and the Morocco traders, who dreaded any action that might cut off their lucrative caravan business, were to a man unfriendly; while the ungenerous conduct of Alwati, the Sheik's brother, caused him some annoyance. Add to this the fact that there were still in or about Timbuctoo men who remembered, and had been wounded by, Nungo Park, and were ready to revenge themselves and their kindred on the countryman and co-religionist of that traveller, and the constant peril that Barth underwent may be imagined. Though the government of the town was virtually in the hands of the Sheik El Bakhay, a nember of a powerful Shereefian family revered throughout the Soudan, the nominal ruler was a deputy of Ahmedu ben Ahmedin, the Fulah sovereign (p. 224), whose countrymen had conquered it in 1826. From this potentate there arrived one day an order, backed up by a troop of armed men, to drive Barth out of the city. El Bakhay was a kind but not a strong 1nan, and in his nephew, Hammadi, had long had a rival for power. Accordingly, this youth, feeling himself strengthened by the arrival of such a force, at once issued an order that the inhabitants inust attend to the orders of the Emir and, in the event of the Christian offering any resistance, not eren spare his life.

It had evidently been the intention of $\mathrm{El}$ Bakhay to send Barth out of the place at the first opportunity that offered itself. Howerer, the new position of affairs stiffened his back immediately. He loved not the Eiriri, to whose authority he was opposed, and he foresaw that if he permitted the expulsion of his protégé the position of his nephew would be materially strengthened. Barth's departure was therefore indefinitely postponed, though this fact did not improve matters so far as he was concerned; for El Walati now renewed his intrigues, and the agent whom Barth had einployed, seeing the difficulties of the situation he was placed in between rival powers, refused any longer to transact business for him. The influence of El Walati was also felt in many other ways. Continual demands were made by the Sheik's brother, and even the Sheik himself, who was a person of an entirely different character, suggested that Barth should send a letter to Tripoli for certain articles desired by him and remain a hostage in Timbuctoo until they were received. Being told most distinctly that not the value of a needle could be received until the traveller himself returned, he resumed his old relations, and even checked the knavery. of El Walati, to whose true character he gradually became alive. Determined also to show the townsfolk that he was not afraid either of them or the Fulah Emir, El Bakhay pitched his camp outside the city, and kept Barth with him during the few days he remained. Time, however, only increased the number of the Christian's enemies. In the streets he was in constant danger of attack, and scarcely a day passed without attempts being made to seize or to kill him. One party actually attacked the Sheik's camp for that purpose. The whole place seemed to have been upset on his account, until one day, close on Christmas, the leader of a large body of Berabish, who had arrived arowedly with the object of killing Barth, fell ill and died before he had time to accomplish his design. The sudden death of this chief made a profound impression not only upon his followers but upon the townspeople and the Sheik himself. For it was known that he was the son of the man who had murdered Major Laing-El Raïs, "the Captain," as he was still called-the first European traveller who had visited Timbuctoo (p. 223), and for some reason generally regarded as the father of Barth, who no doubt was considered by many of them to have come to Timbuctoo with the object of obtaining the punishment of the assassins. Others, however, were suspicious that conquest was his object; though El Bakhay questioned this much, since in his opinion it could scarcely be possible that there were any poor people among the Christians. This view, however, Barth did not confirm; 
but he added that when his sovereign heard that in Central Africa there were people who could extract a living from sand, he had despatched him to fathom the secret of this art. At all events, after the death of the Berabish chief, the Sheik seemed anxious for Barth to leave, intimating that nothing would please him better than to learn that he had reached home in safety. But this he was not fated to do until the 18th of May, 1854, for illness and other reasons kept him lingering in the city long after he had outlived the very moderate welcome he had ever received, and many months over the date when he had satistied any curiosity which a few visits to the lanes of the dirty town had aroused.

Timbuctoo was indeed a disappointment. It was by no ineans so large as rumour had Timbuctoo described, though the ruins found in 1854. beyond the present limits of the town would indicate that, before civil war and conquest had ruined it, the metropolis of Central Africa had been really an extensive city. Its circumference at present is little more than two and a half miles, though without walls, its former rampart having been destroyed by the Fulahs in 1826, and never rebuilt. Yet all the houses occupied were at that period in tolerable repair, some nine hundred and eighty being of clay, and a couple of hundred conical huts of matting, the latter, with a few exceptions, on the outskirts of the place. The three large mosques are the only remarkable public buildings in the town, the royal palace in which the Kings of Songhai used to reside having disappeared. The whole number of settled inhabitants was estimated by Barth at 13,000, while the floating population during the months of the greatest traffic and intercourse-especially from November to January-would amount on an average to 5,000, and in very farourable circumstances to as many as 10,000 .

The position of the place, at the point where the Niger in its serpentine winding approaches most closely to the Tuat oases, will always make it the link between the commercial life of the fertile North and the even more productive and populous South and the desert that lies to the west of it. But except as an entrepot for merchandise the city has few resources. The vicinity yields little, the trees even-which were plentiful before the Moroccan conquest, having at that date been cut down to rebuild the fleet with which the harbour master fled from Kabara-being now almost absent; so that the town is reduced to absolute want if any trouble with the up-river country prevents the corn-boats from coming down. As soon as the river risesand the stream attains its inaximum about the end of January, though about every third year the southern part of the town is flooded - these grain-boats arrive in large fleets, and the cost of provisions, which before was high, immediately falls to a moderate figure. The manufactures of the place are trifling, iron-work and saddlery being the principal; some of the leather pouches and luggage-bags made by the Touareg women being very neat. Even the Timbuctooese clothes are imported from other places, though in the surrounding districts good carpets are made, and occasionally silk embroidery of a tasteful character may be seen. Tet, generally speaking, the goods sold in the town come across the desert, either from the French and other European settlements on the West Coast, or from Algeria, Morocco, Tunis and Tripoli in the North, on the backs of long trains of camels. Of these goods, in Barth's day-and the course of commerce has not much altered since-the greater part were of English manufacture. All the cutlery and calico that he saw were British, and the tea sold to the Arabs, though still too dear for the natives, was derived from British merchants in Tripoli. Tobacco, red cloth, sashes, and looking-glasses were also in active demand. In payment for these goods, ostrich-feathers, ivory, gold-dust, gum, and wax were collected, and occasionally a fer slaves were exported, though the number sent to Noroce from this part of the Soudan, and indeed from any part of Africa, was then, as it is still, much exaggerated. The great difficulty in the way 


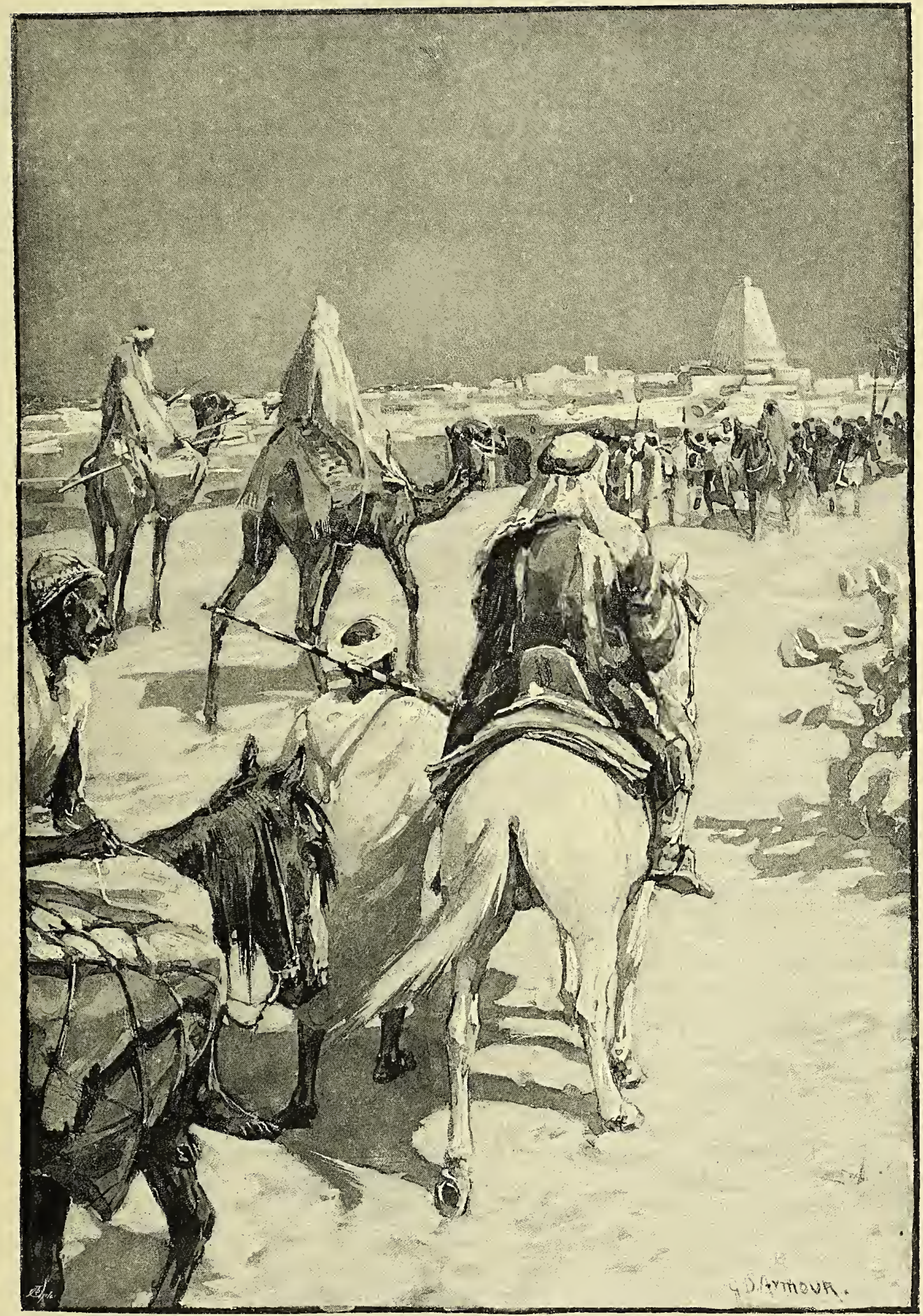

BARTI MET BY A CROWD NEAR TIMBUCTOO (p. 298). 
of European trade is its distance from the coast and the centres of civilisation in the North, while the position of the town on the borders of the desert, and in the vicinity of various warring and predatory tribes, renders good government and the security that merchants require very hard to obtain. In 1854 Barth looked to England as the country destincd to open up dealings with this commercial centre. Since that day, as we shall see, British connection with Timbuctoo has become less and less, until to-day it is the Frenclr who are striving to obtain possession of this miarket; and, in spite of the English settlements on the Niger, they run every chance of obtaining it, either by a railway from the Scnegal or, still more boldly, by one through the Sahara from Algeria.

After several false starts, the courageous German was glad to turn his back on this Barth's once mysterious city of many nomeward hopes. His later adventures and journey. observations, though full of interest, pale in importance alongside of those of which a brief outline has been given. For Timbuctoo, in spite of the exaggerated accounts that had up to that date been the staple information about it, dwarfs all other African towns into insignificance. At Gogo, once the most splendid city of Negroland, now the desolate abode of a small and miserable population, the ruined tower of the chief noosque being almost the last remnant of its former grcatness, Barth was conducted to a long clay building, into which he was, however, refused admittance, though it is by no means clear that it had anything to do with Mungo Park, far less is his burial-place, as lias been suggested.

At Gogo, the Slieik El Bakhay, who had accompanied him thus far, parted with his uninvited guest, and at Sokoto, after a long journey, during which hunger, robbery, threatened death, fever, extortion, danger from flooded rivers and treacherous swamps, were all prescnt in their turn, and sometimes all at once, he again arrived in Sokoto. Herc, however, a pleasant surprise waited him. For at this point he learnt that Dr. Vogel, a German astronomical observer and naturalist, and two non-commissioned officers of the Royal Engineers, who had been sent to his succour, were at Kukawa, where in due time he met them. Unfortunately, however, a rebellion having broken out, the new arrivals had been treated very badly by the Bornu usurper, Abd er Rahman, and what goods they had brought with them were spent. Add to this the fact that the English soldicrs and their German leader did not get along very well, and the condition of affairs. may be imagined not to have been of the pleasantest. At Kukawa Barth was detained. for four inonths, no longer, as of old, on the best of terms with the authorities, though on Christmas Day he feasted the citizens at the cost of fourteen roasted oxen. Dr. Togel secms to have been pre-eminently unfitted for the duties assigned him. He had absolutely no experience of travel, no knowledge of men, was pelantic and opinionated after the German student fashion, and of so feeble a digestion that the mere sight of flesh made him sick, a peculiarity that was also obscrved in Corporal Macguire, one of his military companions. However, he set out in the spring of 1855 to complete Barth's discoveries. and researches, first in a south-westerly direction towards the Benué, which Barth had struck 415 miles east of its confluence with the Niger, and then eastwards in the direction of the Nile. On part of this journcy he was accompanied by Macguire. But how far they succeeded is never likely to be known, for he was not seen again, having most probably been murdered.* Macguire, it seems, deserted this ill-fated traveller, whom only the passion for everything Teutonic, which at this period afflicted English science, could have induced Government to send on such a mission, and it is believed met the same fate at the well of Bedwaram in trying to make his way back.

Corporal Church returned with Dr. Bartli,

* Gerhard Rohlfs made a special journey towards Waday with the object of rescuing Vogel's papers, but failed to obtain admittance to that territory. 
who, amid endless delays, caused by the disturbed condition of the eountry, consequent on the half-suppressed revolt against the Sheik's authority, and the absenee of means, managed to get beyond the Bornu bounds. Rumours having reaehed Europe that he was dead, the funds that arrived from Tripoli were addressed to Dr. Togel, a eiremnstance that led the ever-suspicious people to imagine that Barth had fallen into disgrace and was replaeed by another man. However, after many weary days' marches with a Tebu caravan, he and Chureh arrived at Murzuk. Herc Frederick Warrington (the consul's son), whose brother had aceompanied Togel to Kukawa, but had died of dysentery on his way back, met them. From this outpost of comparative civilisation the journey to Tripoli is easy, and there in due time the long journey of fivc years ended.

Barth's later eareer was sufficiently placid. After publishing the voluminous narrative of his travels, * which, for fulness of detail has never been equalled by that of any other African traveller, he returned to Berlin, where he bccame Professor of Geography in the University and President of the Geographical Society. But, with the exeeption of somc journeys in Asia Minor and Turkey, he did not roain far from home, dying in 1865 from a weakness due to the hardships of his African journeys acting on a constitution never very strong. A residence in the South might have saved him. But though the Queen created him a C.B., her Majesty's Government, much to Barth's disappointment, who considered that his services merited some such position, did not see their way to appoint the German scholar to a consular post. Barth's researches were, nevertheless, of the utmost value, and perhaps the most extraordinary fact about

* "Reise und Entdeckungen in Nord- und Centralafrika." 5 vols. (1855-58.) There are also English and French editions of this work. But the German is, on the whole, the preferable version, Barth being occasionally a little obscure in a language which was not his mother tongue. Richardson's journals were published in 1853 under" the title of "Narrative of a Mission to Central Africa, performed in the years 1850-ol." (2 vols.) them was that the entire cost of these five and a half years' fruitful explorations was only $£ 1,600$, of whieh the Government were called upon to pay no more than $£ 1,400$, the remainder being contributed by the explorer's friends. One result of Barth's journeys was the despatch some years later of what may be described as the last expedition at the national expense for opening up the Niger. This was under the command of Dr. Baikie, R.N., who explored the Benué for 340 miles. But though it elosed the efforts of the British Government in the cxploration of Afriea in that direetion, it aetually opened a ncw era in the exploration of the Niger by private individuals and great eompanies, the history of whieh will be recorded in a later section.

When we speak of the visitors to Timbuctoo consisting of so-and-so, we do not, of course, take into account the Arabs who Mordoknai have traded there for hundreds of Abi-Serour. years, $\uparrow$ and to this hour pass and repass the desert with their caravans: so that the wonder is how the world remained so long in ignoranee of the true naturc of this mysterious semi-mythieal city. 'The Arabs, howcver, take - at least in modern times - little interest in gcographieal scienee, so that mankind has benefited nothing by thcir journeys. And, as likely as not, geographers would never have heard of those we are about to describe had not M. Beaumier, the French Consul at Mogador, met with the traveller and obtained from him a narrative of the expeditions which he made.

The hero of this adventure (p. 304) was the son of a poor Jew living at Akka, the first oasis beyond Agadir, in the Sus Province of Moroceo. Endowed with the intelligence of his race, and eager, like so many of themeven in an empire where they are regarded with such contempt as in that of Mulai El Hassan -to learn, young Mordokhaï Abi-Serour $\ddagger$ from an early age was consumed with an

+ Ebn Batuta visited it in 1352-53, and sailed on the Niger from Kabara to Gogo.

\pm Ben, or es Serour, as the Arabs call him. He is Mardochée in French, but I accept his own orthography. 
anxious desire to see strange lands. After reeeiving what edueation eould be obtained in the sechuded spot where he was born and brought up, he managed, without resources and without help from anyone, to make his way from Tangier (p. 297) to Spain. Thenee he travelled in various humble eapaeities through Franee, Turkey, Greee, and Asia Minor, until he reached Jerusalem, where, aided by his eo-religionists, he applied himsclf with sueh ardour to study that in five years he attained the rank of Rabbi. Another year was passed in Aleppo, three more were spent in Syria and Egypt, other three in Tunis and Algeria, and four in the city of Algiers as a teaeher of Hebrew. He then returned home

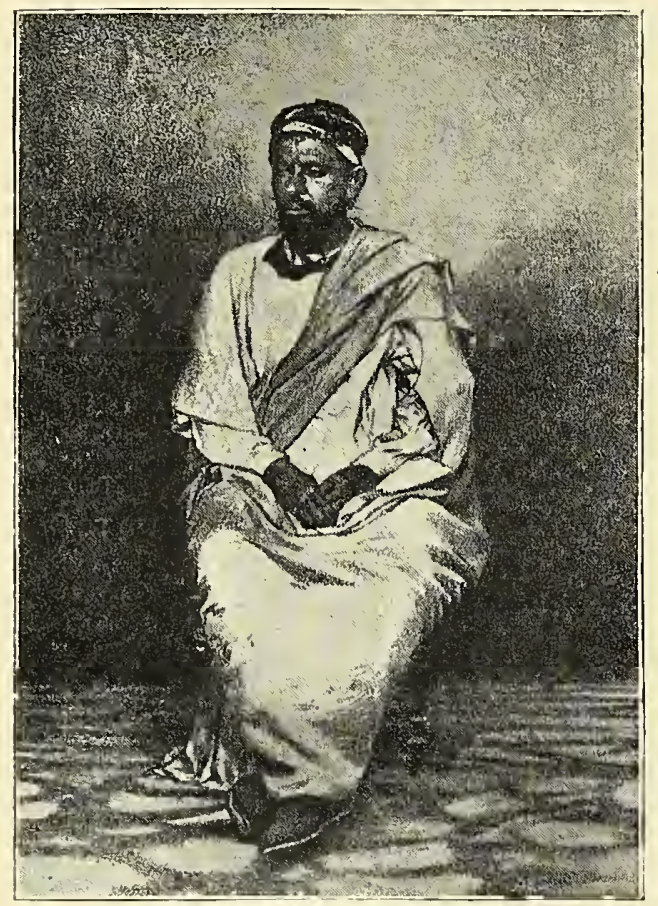

MORDOKHAÏ ABI-SEROUR.

(From Bulletin de la Soc. Géog., Paris.)

with a Freneh passport, only to find his family in Akka poorer than ever.

But by this time Mordokhai, gifted with the amazing instinets of his raee for business, had managed to aeeumulate some money.
This he determined to venture in the Timbuctoo trade, the large profits of whieh he had often heard the Arabs speak of, though hitherto that city had been as rigorously closed to Jews as to Christians. This was in the year 1858. Mounted on camels, he and his brother Isaae started, taking water enough to last them for six days, at the end of whieh period they had journey to arrived at the oasis of Tenduf, after Aruan. having traversed a great many mounds and plains of sand, in addition to "Hamada," or arid upland deserts without vegetation. During the entire journey they did not meet with water, and were in eontinual danger from the robbers who infest this region with the objeet of falling on the earavans to and from Timbuctoo. After other ten days' journey they arrived at Yguidy (Igidi), a zone of red sanddunes, but containing inany date-trees and some good though shallow wells. Here, in 1852, Bel Hamcdj, a marabout, or saint,* desiring to end his days in peace, took up his abode. His fame, howcver, speedily attraetcd to him disciples, and now a eonsiderable town of holy wien and merchants has grown up in the desert. From Yguidy-near which Davidson (p. 282) was killed in 1837-to Sefya (seventeen days) there is little exeept rolling sands. The latter spot is a high plateau covered with stones and seanty vegetation, but with no certainty of water. Three days more over plains, sand-duncs, and gravel brought them to Telyg (Areg), where is good water in many wells. From here to Taudeni is a very short distanee, but the water is braekish, and what little business is done among the few people who live among the ruins of an old Arab town, surrounded by an ancient wall, is in salt.

Another twelve days' mareh brought the Jewish travellers to Aruan, where Major Laing was murderer. At this town, in the midst of a sea of sand, their progress was arrested by the Berabish Arab Sheik deelaring that no Jew or Christian would be permitted to live among the

\footnotetext{
* "Lettré et lépreux"-lettered and leprous-is M,
} Beaumier's epigrammatic description of this personage. 


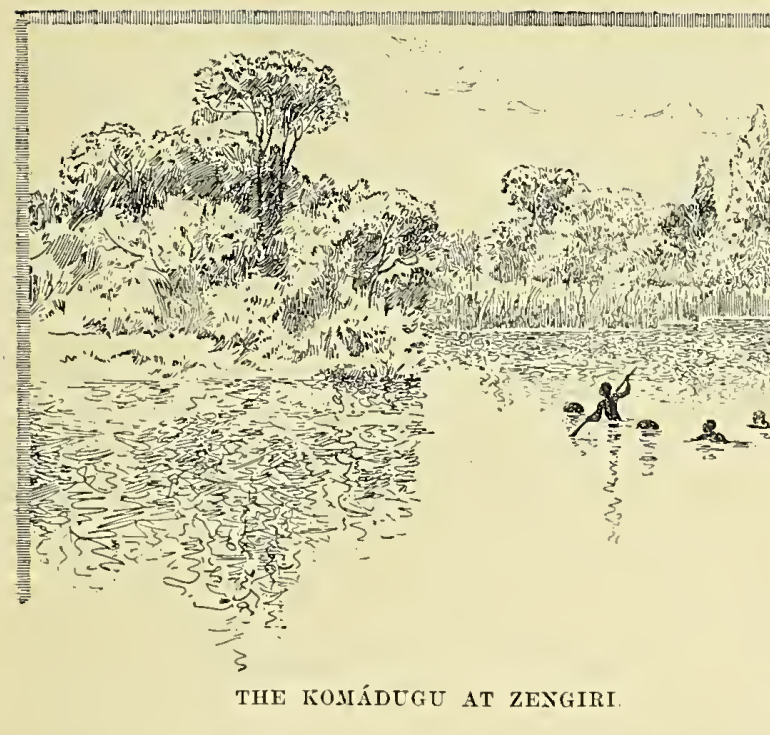

Faithful. "He would kill them as he had ce killed in times past a Christian." Thanks however, to his finesse, Mordokhai and his brother were saved. For, as he pleaded before the Tolbas, or Doctors of the Law, the Cherâa, or religious law, enjoined the Mussulinans to take tribute from Jews, not to slay them. The result was, that they received permission to trade here on giving to the Sheik a portion of their merchandise, and promising him an annual tribute of "five mizen of gold an ear," that is to say, ten mizen, or five pounds, a head. It was, however, not until the year 1859 that, by paying him a bribe of fifty pounds, they obtained permission to go to Timbuctoo. Even then it was only by tempting offers that Mordokhaï could persuade a camel-driver to accept the risk of taking a Jew to a town so fanatical, from which the Arab merehants had hitherto managed jealously to debar any Israelites, of whose eommercial abilities they were well aware.

Hoping that a Morocco trader whom he knew would protect him, Mordokhaï proceeded, in His first Arab disguise, to his house. Howvisit to Tim- ever, the ILoor, so far from helping buctoo.

him, instigated the Fulahs either to kill or compel him to turn Mussulman. But here his knowlerlge of the Koran stood him in good stead. For when it seemed as if he had

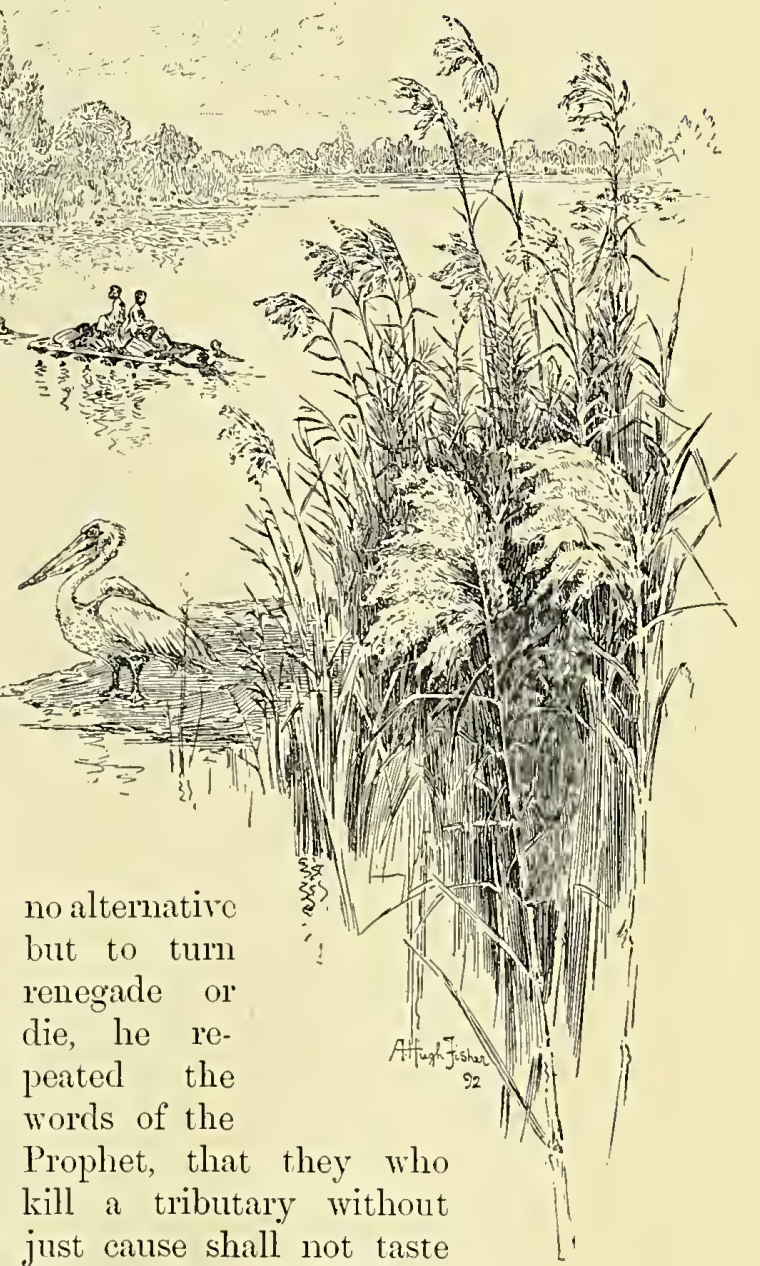
just cause shall not taste of the joys of Paradise.

The result was, that a messenger was sent to the Emir Ahmed ben Ahmedu to learn his will; when, to the Jew's delight, the order came that he was to be permitted to reside on payment of the usual lieence exacted fiom foreign merehants, whom the Prophet enjoins the Faithful to protect. Accordingly, in spite of various efforts to "squeeze" them, Mordokhai and his brother abode in Timbuctoo "with great tranquillity" and mueh profit, all through 1860, 1861, and 1862. Having aeeumulated a considerable fortune, they returned to Akka, making a second expedition with a large amount of merchandise in the course of the next, year. On this occasion he was 
aceompanied by four other Jews, all exeept one near relations, accomplishing the return journey in twenty-three days. By the end of 1863, the traffic had been so suceessful that the younger brother set out for Mlorocco with ostrich-feathers, ivory, and other produets to

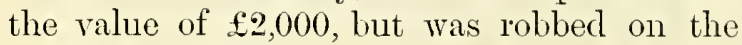
way of his entire venture, and nearly killed by the bandits.

In 1864, Mordokhaï was more lueky, having reaehed Mogador with a large earavan, whieh he disposed of, and bought extensively in Genoa and Venice glass-ware and other artieles valued by the negroes. Again, however, he was plundered by the Riguibet, Ait-el-Hassen, and Ygout tribes. But he was not penniless, for at Timbuctoo he had put out at interest twelve serrats of gold-equal to 1,200 mizen, that is about $£ 600$-which he employed in buying ostrieh-feathers. Once more, however, the Rguibet and Ouled BouSebah tribes relieved hin of the last of his wares. Finding, however, in Timbuetoo three of the latter tribe, he had them arrested by the Sheik El Bakhay-who befriended the Jew as he had befriended the Christian a few years before-and held as seeurity for the debts of their eompatriots. But during the night they broke their fetters and eseaped. Then the Sheik remonstrated with the tribe, but the only reply he got was that they His commer- were "Sheurfa,"--that is Shereefs, cial ruin. or descendants of the Prophetand therefore not answerable for such trifling peccadilloes as lifting the property of Unbeliever's. At last the good Sheik wrote to Sidi Mohammed, Sultan of Moroeeo, whose subjeets the robbers were supposed to be, with a request that he would punish them and eompensate their victim, signing the letter with the signet that Barth, on his return to England, had sent to his friend "Ahmedel-Bakhay, ben Mohamed ben Moktar ben Ahmed." Considering, however, that though it was quite possible the Sultan might try to punish the eulprits for these and other manifold offences, it was extremely unlikely that their vietim would be compensated, Mordokhaï thought it prudent not to deliver a letter that might in the end do him more harm than good. Previous to this last misfortune he had formed a partnership with another Jew. But neither of them now cared to continue business with Timbuctoo. Aeeordingly, after settling up his affairs, he quitted the Soudan in the year 1869 , about as poor as when he had sought fortume in it ten years before, resolved to devote his experienee and abilities to work in a eountry where life and property were safer than in that which he had left.

The love of travel was, nevertheless, too strong for him, and by 1875 he was in Paris getting some training in the use of seientific instruments, in order to undertake an exploring expedition under the auspices of the Geographieal Society of France. A journey through the remoter parts of the Provinee of Sus, during whieh he diseovered many ancient ruins, and seulptures, with an itinerary written in Hebrew, was the result His geoof this new departure. He de- $\begin{gathered}\text { graphical } \\ \text { achieve- }\end{gathered}$ seribeda region then quite unknown, ments. and the remains of a long-vanished civilisation of whieh history had not preserved any reeord.* The sculptures represent the elcphant (not at present inhabiting the eountry north of the Sahara, though even in Pliny's day plentiful north of the Atlas), the rhinoceros, giraffe, and other animals, many of them not now known in that part of Afriea. They are supposed to have been the work of the Djoûli raee, who are mentioned by the Romans under the name of Daratites. In the Daggatouns, a semi-Berber people who guide travellers across the Sahara, Mordokhaï believed that he had eome across a degenerate settlenent of Jews. But though these people

* Beaumier : "Premier Établissement des Israélites à Timbouktou" (Bulletin de la Soe. de Géographie, AprilMay, 1870); Duveyrier : "De Mogador au Djebel Tabayoudt par le Rabbin Mardochée Abi Serour " (Ilid., Oct., 1s75, p. 561) ; Duveyrier : "Sculptures Antiques de la Province de Sous, découvertes du Rabbin Mardochće" (Ibid., 1876, p. 129); "Mordokkhai Abi Serour de Akka : Les Daggatoun, tribu d'origine Juive demeurant dans le Sahara" (Bull. Allianee Istaélite, 1582) ; Cosson : "Compendium Flore Atlanticx," vol. i., pp. 66-68, etc. 
have some Jcwish traits-and Jews are among the oldest colonists in Mrorocco-it is doubtful whether his conclusions werc correct. Among other services to science, MLordokhaï made large collections of South Moroceo plants, though his claims to reputation rest on his journeys to and from Timbuctoo, and the courage with which he managed to obtain a footing for his race therc, a footing they have never lost, as there is still a little colony of Jews in the city, among whom the pioneer's family are the most prominent members. But they do not now trust their ventures to isolated caravans, having managed to obtain permission to travel with the great cavalcades that can defy the desert robbers.

More than a quarter of a century passed away, and little was heard of Timbuctoo.

\section{oskar Lenz.}

Commercially, the city's importance had been greatly exaggerated; in truth, not only in Central Africa, but in Morocco, there wcre towns in which no European lived twice as big as the one on the Niger. Still the place did not lose all of the old romance it possessed when Tennyson and Hallam were competitors * for the Cambridge Chancellor's prize poem, of which the thenc was the African metropolis; and Thackcray made it the subject of one of lis lightsome dittics. Still, though geographers were well aware, after the journeys of Barth and Moldokhaï, that Timbuctoo was in many respects what in America is known as "a fraud," there were plenty of people whose incmorics were retentive of the old idcas regarding it and oblivious of everything which concerned the revelations that had prover them erroncous. Even men of science had not, in 1880 , quite disillusionised themselves of the glamour that surrouncled the white houses of the ever-dwindling city of the Southern Sahara. Among thein was Dr. Oskar Lenz (p. 309), an Austrian naturalist who had been engaged, under the auspices of the German African Society, in a geological cxamination of the Lower Ogowé, in West Africa. Again

* In 1829 Tennyson won it; the poem is printed in the Prolusiones Academice. commissioned by the same body, he left for Morocco in the year 1879, with the intention of penetrating the valleys of the Atlas, which were then, as they are to a large extent still, among the least-known portions of Africa, often though they have bcen touched here and there, and even crossed, by certain caravan routes. In pursuance of that design, he travelled over various parts of the Empire, though for the most part by routes already known, which he described with a minute accuracy to which that region had hitherto been a stranger. Some of these journeys were made in the company of Hadj Ali, a nephew of the celebrated Abd-el-Kader, who had made many trading trips to Timbuctoo and was on the erc of undertaking another. Meeting the Rabbi Mordokhaï, Lenz's wavering resolution in favour of subing route stituting the route to 'T'imbuctoo through for the Atlas was strengthened by Morocco. the conversation of that remarkable man.

Accordingly he joined Hadj Ali, in the disguise of a Turkish doctor, in order to make a journey which, however interesting scientifically, could not result in any great accession to geographical information, since it was nccessarily over the caravan route which, we have scen, had been frequently traversed only a very few years before by the Jew merchant whose adventures have been already noted. As far as Terudant there was no real danger, for a Moorish guard accompanied him. But at this spot the Sultan's orders were that they should return, his letter of safe conduct (p. 309) $\uparrow$ intimating that farther on he could

* The autograph Firman, Passport, or Safe Conduct figured was, in 1884 (1302 of the Hegira), granted, as a special mark of favour, by the present Sultan of Morocco, to the late Captain F. P. Warren, R.N., Mr. T. Graham, R.S.A., and Dr. R. Brown, while resident in Fez. It authorises them to travel in any part of his dominions, and commands his officers to grant the "three Nazarene gentlemen " all assistance and protection, so long as they do not run themselves into danger by going into parts where the Sultan's authority is imperfectly established. It was invariably found more hampering than otherwise, the local authorities being so terrified lest they transgressed the letter of "Our Lord's" commands that they managed to import into it hidden meanings never intended by the Imperial writer ! 


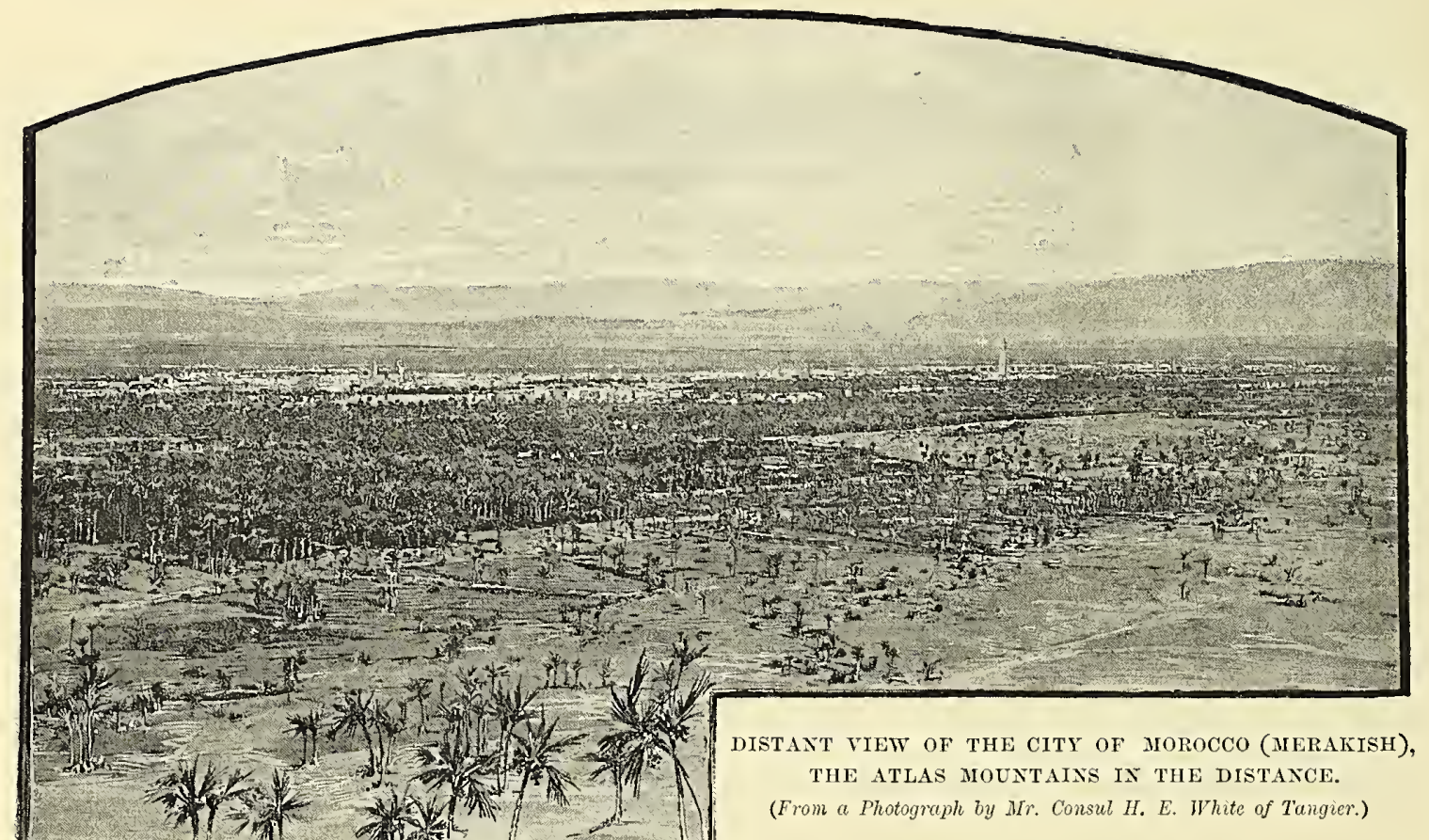

6,000 or 7,000 inhabitants, including a few Jews-who, however, enjoy greater liberty than in most other parts of the empire, being permitted to bear arms and ride on horseback -live in great poverty on the produce of

not be responsible for the safety of anyone, far less a European of whose orthodoxy there were well-founderl suspicions. Terudant was at one time a semi-royal town, and in the Viddle Ages merchants from the coast traded regularly with it. Previous to the fourteenth century, the River Sus, which waters its crumbling walls, was navigable thus far-a distance of firty iniles from the sea-and there are said to be seen even yet large, massive rings to which the cables of vessels were formerly attached. Nowadays it is a crumbling, fanatical place, in which Europeans are never found, and, indeed, would be in mortal peril were they recognised. Since Agadir ceased to be an open port the place has lost what trade it ever possessed, and the Berbers, who are its principal inhabitants, swagger about the narrow, dirty lanes, armed to the teeth, glaring at any stranger with a ferocious air. Murders are frequent in the full glare of publicity, and the the olive, date, and orange gardens that embosom the place; or on the "semsars," or native agents of the English and other merchants in Mogador who come here, and to other places on the Timbuctoo route, to intercept the caravans in the interest of their employer's.

At 'Terudant, Lenz accordingly found his troubles beginning. For the Kaïd, or governor, fearing that he might be held responsible for any mishap that might befall the Sultan's protégé, and perhaps not unwilling to have an excuse for hampering his journey, declined to permit him to pass through the territory of the Howara Berbers or Shluhs.

Several attempts that he made to join a large caravan of Terudant traders about to start for Hamed ben Musa, in the territory of Sidi Hussein - one of the semiindependent religious chiefs, of whom there are several in Norocco-failed owing to the fanatical opposition of the people. At 
last, in return for handsome gifts, some of the robber chiefs of the Howaras conducted him

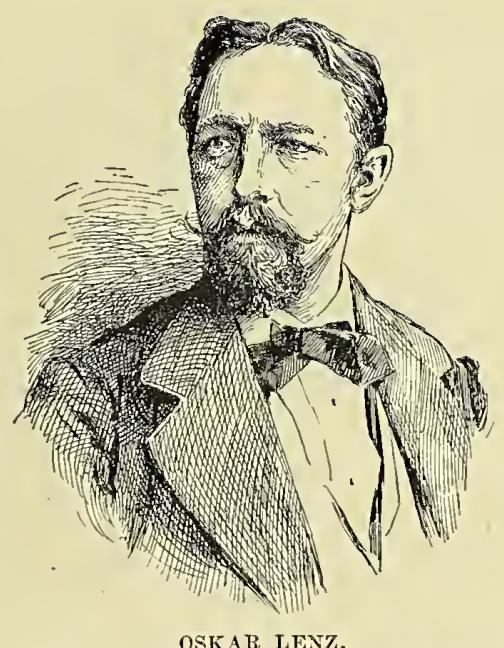

(From a Photograph by Aclolph Halwas, Berlin.) the treacherous pursuit of Sidi Hussein ben Hescham, who had enjoined the various sheiks to murder the traveller as soon as he entered the territory of any one of them. From this place he obtained a guide to Aruan, where he arrived after the usual perils from sanddunes, robbers, and thirst. 'The salt-mines of Taudeni, from which formerly thousands of camel-loads of salt were yearly sent to Timbuctoo, he found entirely deserterl.

The Sahara, which had hitherto been considered the bed of an ancient sea, beneath the level of the Atlantic, and therefore Nature of possible to be flooded, Lenz dis- the Sahara. covered to be in most places much above the sea-level, and in all likelihood never, within recent geological times, covered by salt water. It is a waste of sand and stone, of a flat or rolling character generally, but not without hills from

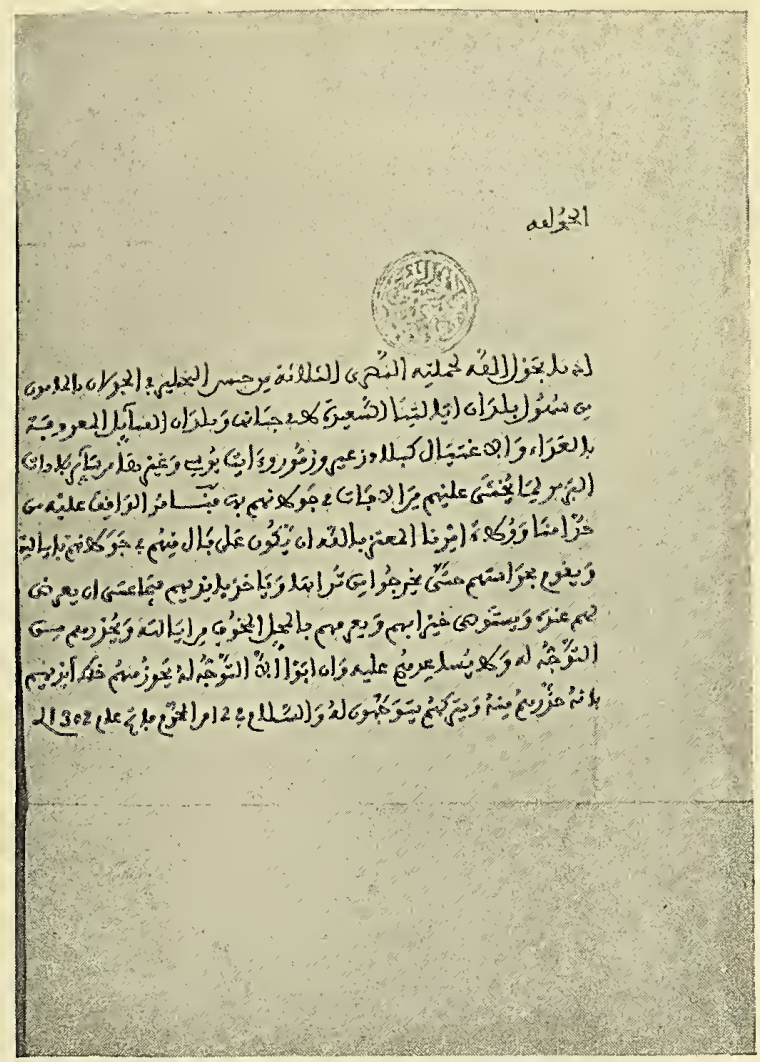

LETTER OF SAFE CONDUCT GRANTED BY THE SULTAN OF MOROCCO. (Reduced about one-half.) through their country into Ilerh, in the principality of Sidi Hussein ben Hescham, where for the time being he was in comparative safety. Here the country, though dry, was populous and well cultivated. After a halt of four days at Ilerh, the journey was continued over a stony Hamada, or plateau (p. 304), and through a river valley, until he reached the foot of a range of mountains from 4,000 to 5,000 feet high, a spur of the Atlas, the descent of which was abrupt and tedious, as no water was to be had, and the region was unsafe from robber tribes, Lower down, the country was a large plain covered with date forests, annong which the little town of Temenet lies concealed. Farther on the first glimpse of the Sahara is afforded, after the town of Ijit, sheltered belind a mountain, is passed. A little farther is Akka, the old home of the Rabbi whose name must by this time be familiar to the reader. At Fum el Hossan, the residence of the Sheik Ali, of the Berber tribe of Maribda, on the road the traveller was hospitably reto Timbuc- ceived by the sheik, who for many too.

years had carried on a considerable trade with Timbuctoo, where he had a brother At Tenduf he arrived in safety, in spite of 
five hundred to a thousand feet high, with great masses of rock, and quarries out of which porphyry might be mined, while wells are frequent. The aridity Dr. Lenz considered to be comparatively recent, being largely due to the felling of the forests on the mountains. This improvidence here, as elsewhere, has had the effect of drying up the springs of the rivers that had their origin in these heights, and flowed through plains where their old courses are now only dried-up "wadis," in which after rains a little muddy water flows. The drifting sands are the result of the crumbling down of the sandstone that forms the foundation of the Sahara, under atmospherie influences-hot sun during the day, sudden cold at night, and heavy sub-tropical rains at intervals - without the roek obtaining any protection from vegetation. In these shifting dunes, which are often vast mounds, travel is extremely tedious; even the experienced leader of the caravan was not always able to find his way, and the difficulty was increased in the southern part of the desert, where the hot sand storms and a temperature of 113 degrees during the day made marching almost impossible, the hours of night being therefore utilised for this purpose.

At Aruan there was something of the old fanaticism still remaining, though the visits of previous travellers, and the death of the ferocious Berabish ehiefs who had murdered Laing and threatened Barth, rendered the place less dangerous than of old. But at the date of Lenz's visit there was living in Aruan one of the instigators of the murder of Alexandrine Tinné (p. 282), and it is said that all the effeets belonging to Major Laing, who was assassinater fifty-five years before, were up to that period preserved there, though Lenz in vain attempted to see them.

Hitherto, the Austrian traveller's route was virtually the same as Mordokhaï's. At Aruan, however, that of Caillié branched off farther to the north; but from Aruan to Timbuctoo the road travelled for five days was that of all previous explorers. It is the caravan path, over which some 40,000 camels pass cvery year, laden with produce, from Central to Northern Africa.

Dr. Lenz arrived in Timbuetoo on the 1st of July, 1880, and during a stay of twenty days was received with the utmost kind- Timbuctoo ness by the eitizens and their ruler. in 1880.

The old fear or the old fanaticism seems to have passed away; though, if the French attempt to build a railway through the desert to this point, it is certain that the jealousy of the tribes who live by the caravan trade will be roused to a dangerous pitch, as the Flatters' party engaged in the exploration for this wild scheme learned to their cost. From Timbuctoo Lenz travelled westward by way of Basikunnu, Sokoto, Bachuinit, Nioro, and Kumiahari, and the country of the desert Moors, to the French post of Medina (p. 183) on the Senegal, whence he easily reached the coast, having been the first European to traverse the entire country between Senegambia and the great city of the Niger.

His visit is the last to Timbuctoo of which we possess any knowledge, though it is needless adding that native merchants still traffic there. Yet, even in Lenz's day, its trade was on the decrease, and at that time consisted chiefly of ostrich feathers and ivory. This was due to the incessant hostilities of the Touareg and Fulah tribes, who had inade security impossible, both for the resident traders and for the caravans. However, he concluded either that Barth had under-calculated the population, or that it had increased of late years, for, instead of 13,000 -his predecessor's estimate (p. 300)- he put the entire citizenship of Timbuetoo at $20,000, *$ to which must be added several thousand traders during the earavan season.

He agreed, however, that its importance had been grossly exaggerated. At no time was it the eapital of an empire, and even yet its market, and the fact that the various Arab tribes, the Fulahs and the Touaregs, recognise in it a stratcgical position in which to establish their supremacy are the principal reasons for

\footnotetext{
* There are over fifty thousand in Fez in Morocco.
} 
the never-ending anarchy of which it is the centre. These struggles we have already sketched (p. 234). Being thus at the mercy of the first tribe strong enough to master the others, the citizens live apathetically within the dismantled walls, paying tribute to whomsoever is master, or sometimes, for the sake of peace, to two tyrants simultaneously, taking compensation in the profits of trade whenever the river is clear of pirates or the land free from robbers. Salt exchanged for gold-dust, kola nuts, Manchester goods, tea, arms, and other articles, forms the principal commerce, and already cowries are gradually giving place to European coin, and Winchester rifles to the old long-barrelled flint-locks of Morocco. The local administration is in the hands of a " Khaia," selected from one of the "Reema,"* or "shooting" families, so called because they form the mongrel descendants of the Moorish army who took the town with the aid of firearms (p. 231), and remained as its masters after the Sultans of Morocco had left it alone. But, as in Barth's time, the Khaia was a mere creature in the hands of a neighbouring Touareg chief, and of a sheik of the powerful family of El Bakhay, the representative of which was in Lenz's time Abidin, a nephew of Barth's friend (who died in 1865), but not the individual who played such mischief to that traveller. The town possesses several libraries containing valuable Arabic manuscripts, and, besides being a centre of Moslem learning, will continue to be the converging point of all the tribes of that part of the Sahara-Arabs or Arabised Berber's, Sonhrais, Ireghenaten, or "mixed " Touaregs, Fulahs, Mandingoes, Bambarras, and Imósharh Touaregs, who belong to the Awellimiden confederation, to the country north and east of the city.

But Timbuctoo is really-with intervals of interregnum - in the hands of a commercial aristocracy like the Italian Republics of the Middle Ages. The chief members of this "Djema" form a municipal council and the

$$
\text { * Also called "Arma" or "Deraba." }
$$

"Chamber of Commerce" of the place. The Sheik is a kind of Doge, who possesses great though undefined authority in the city, and is always at enmity with the Khaia, the tendency all over Mohamnedan Central Africa being to concentrate power in the hands of religious chiefs. The present Khaia, or Emir, as he now affects to call himself, is Muhammed Er-Reemi, whose negroid features are the result of long alliances with the surrounding Sonhrai population. He commands little influence, and is practically a mere puppet in the hands of whichever of the rival Arab -Touareg or Fulah-factions happens for the time being to have the upper hand. The Imósharhs (Touraregs) command the whole district between Timbuctoo and Aruan, and their Sheik or Sultan, Eg-Tandagumu, scems to draw his chief supplies from the plundered caravans passing through his territory. The Arabs, as in the time of Barth, are still ruled by the head of the illustrious El Bakhay family, a branch of the Kuntza tribe. But the policy of the present Sheik Abidin has long been to side with the Fulahs, whose power here, as elsewhere in the Western Soudan, is constantly on the increase, and who threaten to become absolute masters of Timbuctoo unless the place falls into the hands of some Europcan Power advancing from the west, or penetrating up the Niger valley from the south.

This Power is likely to be the French, within whose "sphere of influence" the city now is, though French traders have not Timbuctoo yet attempted to settle in, or even in 1892 . to visit the place, the route from the Senegal being even more dangerous than that from the north. Yet in 1887 the French built two little steamers in Bamaku, in the Sultanate of Sego, on the Niger (p. 214); and that year Lieutenant Caron went down the Niger with the small gunboat Niger till he reached Koriumé, near Kabara, though he did not venture to visit the city. Still more recently Lieutenant Jaimé made a second visit with two gunboats, the Niger and the Magé, starting from Kuliman, close to Bamaku, and 
reached near Kabara without any difficulty.* At that time the town was again in anarchy.

Enroys from Timbuctoo have even visited Paris. In 1885, after Captain Gallieni had made his treaty-signing expedition to the Upper Nile, an envoy, purporting to be the representative of the Sheik of Timbuctoo, arrived on the Senegal, and was duly despatched to France without too rigid inquiries being made whether he and his master were what they affirmed theniselves to be. This ambassador was addressed as "His Excellency," presented to President Grévywhose grey beard sensibly impressed him-and had a grand reception from the Paris Geographical Society. This so-called Envoy, Si ElHadj Abd-el-Kader, was about thirty years of age, tall, thin, spare, with strongly marked features and eager eyes-a good type of a Soudanese. He belonged to one of the best families of 'Timbuctoo, and was well educated according to the prevailing notions of his native city. He had heard, so it was said, of French progress towards the Niger, of the French establishment at Bamaku on that river, and of the power of the French arms, and he wanted to see it all for himself. Yet, on his journey towards St. Louis and Senegal, he carefully avoided the intermediate French posts, and on his arrival at St. Louis at once sent to the Governor a letter written by the "Sheikh El-Khaer-Hadj-Ibrahim." This document stated that "we have heard of your wish to cone to us," and that the bearer of the letter is Alladhi, son of Bakar Ghuieri, a Moor, who has travelled much by land and water, and who is still alive, "praise God." The bearer was instructed to give all information about

* Caron, "De Sant-Louis au port de Timbouktou royage d'une cannonière française suivi d'un vocabulaire Sonrai" (1891); Lenz, "Timbuktu," 2 vols. (1884), and numerous papers in the Proceedings of the Berlin, Vienna, Paris, and other Geographical Societies. Deporter, "Extrême-Sud de l'Algérie" (1890), etc. the country. If the French, the letter went on to say, wish to trade with the merchants of Timbuctoo, they will be welcome; but if they wish to make treaties, then they ought to know that the country belongs to many tribes-Touaregs, Geulados, Berbers, Landsahrs, Bambarras, Fulahs-and that the merchants can do nothing without treaties. "Come only," the letter concludes, "to make trade." +

Abr-el-Kader returned with Lieutenant Caron. But he was of little use to the French. For, as his letter might have indicated, he was not the envoy of the actual ruler, but of one of the claimants to that dignity, and had been despatched in order to obtain French help against the galling yoke of the Touaregs, then masters of the city. Caron was not even permitted to visit the place, and the "Ambassador" did not venture to do so. It is still difficult to obtain any accurate information regarding the present condition of affairs, except that it is anarchy, tempered by the temporary mastership of one of the several factions always struggling for power, and that the population is steadily decreasing.

So ends one of the stages in the history of African exploration-the seeking after Timbuctoo. But long before the mysterious city on the Niger had ceased to possess attractions for the adrenturous, explorers were beginning to look to another and an even earlier field of distinction in Northern Africa. So pronounced was this change in the tendency of men's thoughts that, in 1872, Winwood Reade wrote, with the regret of a man who had passed all his travel-life in that region :- "The days of discovery in this part of Africa are over; the Niger has gone out of fashion, and the present generation has been interested only in the story of the Nile." To the River of Egypt, therefore, we shall next tum.

† The Times, January 23rd, 1885.

END OF VOL. I. 

.
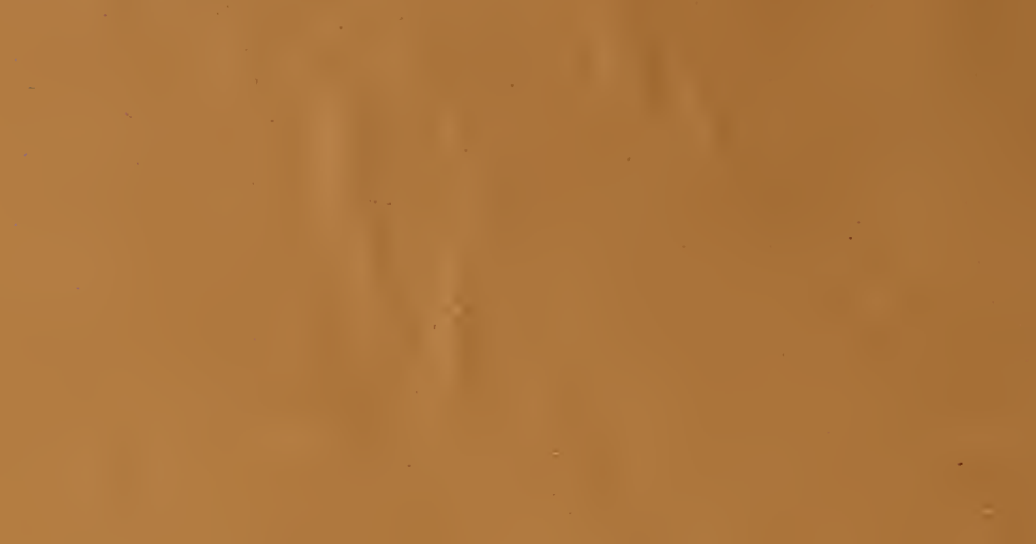

cet
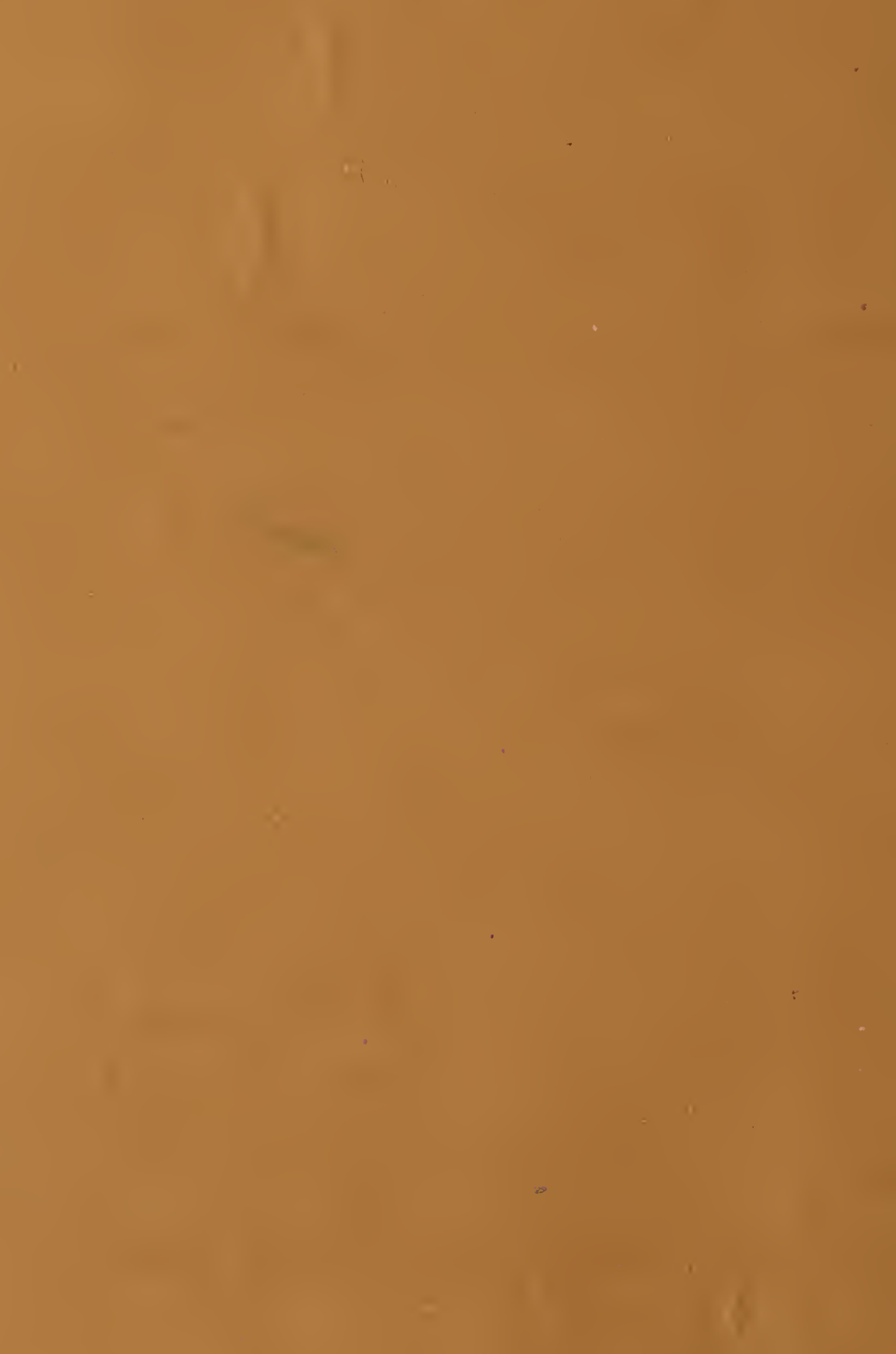



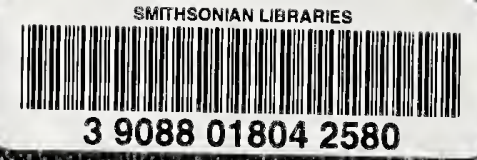

